


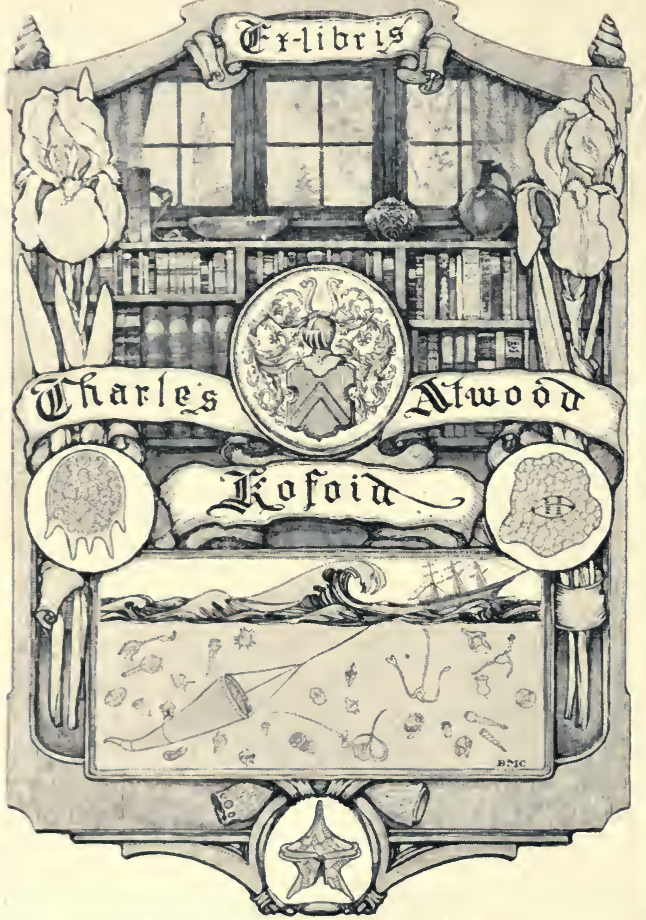




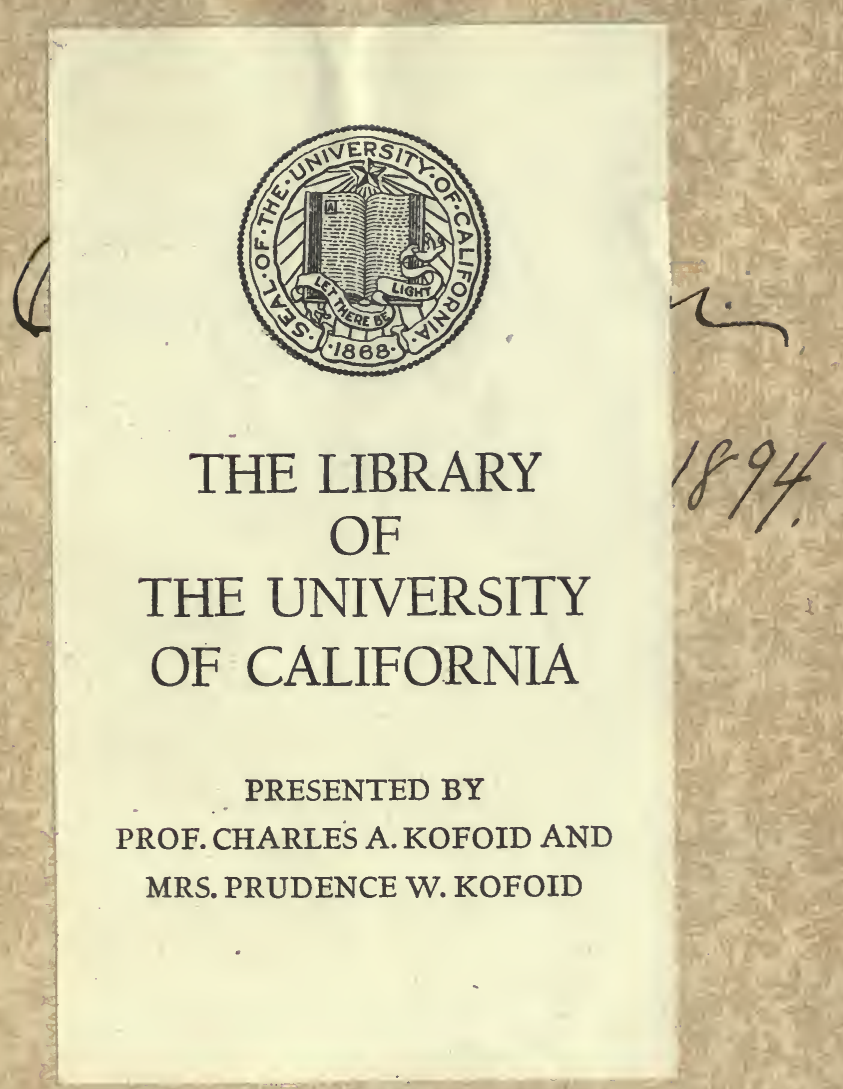




Digitized by the Internet Archive in 2007 with funding from Microsoft Corporation 


\section{TALKS ON MANURES.}

A SERIES OF FAMILIAR AND PRACTICAL TALKS BETWEEN THE AUTHOR AND THE DEACON, THE DOCTOR, AND OTHER NEIGHBORS, ON THE WHOLE SUBJECT OF M NURES AND FERTILIZERS.

BY

JOSEPH HARRIS, M. "S.

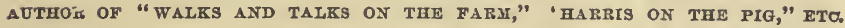

NEW'AND ENLARGED EDITION,

INCLUDING A CHAPTER SPECIALLY WRITTEN FCR IT BY SIR JOHN BENNET LAWES, OF ROTHAMSTED, ENGLAND.

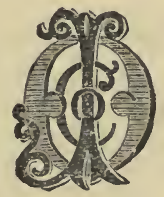

NEW YORK:

ORANGE JUDD COMPANY,

1893 . 
Fintered. according to Act of Congress, in the year 1883, by the ORANGE JUDD COMPANY,

Ine Office of the Librarian of Congress, at Washington. 


\section{3 435 1883}

\section{ONTENTS.}

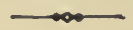

\section{CHAPTER I.}

Farming as a Business.-High Farming and Good Farming.-Summer-fallowing and Plowing under Clover. - We must raise larger Crops per Acre.Destruction of Weeds.-Farming is Slow Work.-It requires Personal Attention...................................................

CHAPTER U.

What is Manure ?-The defnitions given by the Deacon and the Doctor.....

CHAPTER III.

Something about Plant-food.-All soils on which plants grow contain it.The Season. - W Tater, Shade, Light, and Mulch, not Manures.-Several Definitions of Manure......................................... 21

CHAPTER IV.

Na:ural Manure. -Accumulated Plant-food in the Soil.-Exhaustion of the Soil.-Why our Cro's are so Poor.-How to get Laryer Crops.-We must Drain, Cultivate thoroughly, and Make Richer Manure.............. 23

CIIAPTER V.

Swamp-muck and Peat as Manure.-Draining Swamp-land.-Composition of

Peat and Muck................................................

CHAPTER VI.

What is Potential Ammonia. 31

CHAPTER VII.

Tillage is Manure.-The Doctor's Lecture on Manure.

CHAPTER VIII.

Summer-fallowing.-Mr. Lawes' crop every other ycar.-Wheat after Barley.-For Larger Crops raise less frequently, and Manure Higher; also keep better Stuck, and Fced Higher ............................ 34

CHAPTER IX.

How to Restore a Worn-out Farm-The Author's Farm. - Tillage renders the Plant-food stored in the soil available.-Cultivated Lands contain less Plant-food, but are more productive.-Grass alone will not make rich lanc. 37

CHAPTER $\mathbf{x}$.

How to Make Manure.-We must get it out of the Land.

CHAPTER XI.

The Value of the Manure depends upon the Food $\rightarrow$ rot upon the Animal..... 43

\section{CHAPTER XII.}

Foods which Make Rich Manure.-Tab!e giving the composition of 31 kinds of Food. and the value of the Manure they yield.-Cotton-seed Cake.English and German Clover.-Nitrogenous matter in Rich and Poor Foods. Manure from Corn compared with that from Straw................. 4 


\section{CHAPTER XIII.}

Horse-manure and Farm-yard Manure.-Why the one is richer than the other.-Amout of Manure from a Horse.-Composition of Farm-yard Manure.-We draw and spread a ton to get $33 \mathrm{lbs}$. of Nitrogen, Phosphoric Acid, and Potash...........................................

\section{CHAPTER XIV.}

Fermenting Manure.-Composition of Manure when Fresh and in its stages of Fermentation.-Loss in Fermentation and from Leaching.-T'ables showing the composition of Mauure at different stages.-Fermentıng makes Manure more Soluble.

\section{CHAPTER XV.}

Keeping Manure under Cover.-Dr. Vœlcker's Experiments.-Manure Fermented Outside and Under Cover.-Loss from keeping Manure spread in the Barn-yard.-Keeping well-rotted Manure in a Heap.-Conclusions from Dr. Vølcker's Experiments......... . ..........................

\section{CHAPTER XVI.}

An English Plan of Keeping Mannre.-Box-feeding of Cattle.-Spreading Manure at once.-Piling in Heaps in the Field.-Old Sods and Ashes from Charred Sods.

\section{CHAPTER XVII.}

Soluble Phosphates in Farm yard Manure.-Fermented, the Manure has the most.-Over 40 per cent. of the Phosphoric Acid is Soluble ............

\section{CHAPTER XVII.}

How the Deacon makes Manure.-A good plan for making poor Manure.....

CHAPTER XIX.

How John Johnston Manages His Manure.-Summer-fallows for Wheat.Does not plow under Clover.-Valne of Manure from different foods.Piling Manure.-Applies Manure to Grass-land in Fall, and Plows under in Spring for Corn.-His success due to the Eftect of Manure on Grass-It brought in Red Clover......................................

CHAPTER XX. .

The Anthor's Plan of Managing Manure.-Piles as fast as it is Made.-What it is Made of.-Horse anl Cow Manure Together.-Horse Manure for Bedding Pigs.-To Prevent Freezing.-Liqnid Mannre from Pigs.-Bedding Shep.-Piling in the Field.-Where the Piles should he Marle.-Mannre in a Basin.-Reasons for Piling.-What we Gain by Fermenting Mannre.....

\section{CHAPTER XXI.}

'Management Contiuned.-Why We Ferment Manur.,-Dr. Vœlcker's Experiments showing the Loss when Mannre is spread in Yarls.-Fermenting adis Nothing to Manure, bnt makes it more avallahle.-Mr. Lawes' Experiments on Wheat and Barley.-Dr. Vœlcker's Resnlts._Ellwanger \& Barry's Experience.-Loss of Ammonia hy Fermenting.-Waste from Leaching.How to Save the Liquid Manure from Cows........................

\section{CHAPTER XXII.}

Mannre on Dairy Farms.- Wheat removes much more Nitrogen than Cheese.Manures for Dairy Farms.-Letter from IIon. Harris Lewis.-How to make more and betier Manure on Dairy Farms.-How to save and apply it.-Letter from T. L. Harison, Esq... ................................ 101 


\section{CHAPTER XXIII.}

Management of Mauures on Grain Furuts,-Letter from Hon. Geo. Geddes.Gran on Dairy Farins.-Dheep on Gra.n Farms. - Visit to Johu Juhnston. Mr. Lawes' Wheat-ficld.-Mr. Geddes and Clover.-Gypsum and Clover as Mlanures............................................... .11

\section{CHAPTER XXIV.}

The Cheapest Manure a Farmer can use.-Clover vs. Tillage.-As PlantFood.-Coustituents of a Crop of Clover, as compared with oue of Wheat.Making a Furm Rich by Growing Clover..............................

\section{CHAPTER XXV.}

Dr. Vœelcker"s Experiments on Clover.-Lawes and Gilbert's on WheatoClover Roots per Acre.-Manures for Wheat.-Liebin's Manure Tueory.Peruvian Guano on Wheat.-Manures and the Quality of Wheat.-Ammonia. -Ovar 50 Busheis of Wheat to the Acre ...............................

\section{CHAPTER XXVI.}

Experiments on Clover Soils from Burcott Lodge Furm, Leighton Buzzard.Soil from Part of 11-acre Field twice Mown for Hay.-Soil from do. once Muwu for Hay and left for Seed.-Amount of Roots left in the Soil by different Crops.-Mauures for Wheat...................................... 149

\section{CHAPTER XXVII.}

Lawes and Gilbert's Experiments on Wheat.-Most Valuable and Instrinctive Tables now first made accessible to the American Furmer.-The frowth of Wheat Year after Year on the same Land, unmanured, with Farm-yard Manure, aud with rarious Organic and Inorganic Fertilizers..............170

\section{CHAPTER XXVIII.}

Lime as a Mannre.--Prof. Way's Experiments.-The uses of Lime in the Soil.-Lime in this Country.-Composts with Lime.

\section{CHAPTER X:XIX.}

Manures for Barley.-Composition of Barley, grain and straw.-Valuable Tables giving the Results of Lawes and Gilbert's Experiments on the growth of Barley, Year after Year, on the eame Land, withont Manure, and with different kinds of Manure.-Manure and Rotation of Crops ............2.27

\section{CHAPTER XXX.}

Manures for Oats.-Experiments at Rothamsted.-Experiments of Mr. Batlı of Virginia.-At Moreton Farm......................................

\section{CHAPTER XXXI.}

Manures for Potatoes.-Pernvian Giano for Potatoes.-Manure from different Foods.-Eperiments at Moreton Farm.-Mr. Hunter's Experiments....... 255

\section{CHAPTER XXXII.}

What Crops should Manure he Appliesl to?-How, and When ?-John J. Thomas' manner of Applying Mauure.-Top Dressing.-Doct. Vœlcker's Experiments. 


\section{CHAP'TER XXXIV.}

Manures for Special Crops.-Hops.-Indian Corn,-Turnips,-Mangel-Wurzel or Sugar-Bects。-Cabbages, Parsuips, Lettuce, Onious, etc.............274

CHAPTER XXXV.

Manures for Gardens and Orcliards.--Market Gardens.-Seed-growing Farms. -Private Gardens.-Hot-Deds.-Manure for Nurserymen.-Fruit Growers.

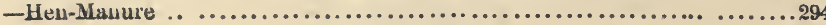

\section{CHAPTER XXXVI.}

Different Kinds of Manures.-Cow Manure.-Slieep Manure.-Buying Manure. -Liquid Mannre.-Nightsoil and Seware.-Peruvian Guano.-Salts of Ammonia and Nitrate of Soda......................................

\section{CHAPTER XXXVII.}

Bone-Dust and Snperphosphate of Lime.-Bonc furnishes Nitrogen as well as Phosphate of Lime.-Increasing the Availability of Bone with Sulphuric Acid....................................................... 314

\section{CHAPTER XXXVIII.}

Special Manures.-Liebig's Views.-Special Manure for Wheat and Turnips. -Rothamsted Experinents ................ ............. 320

\section{CHAPTER XXXIX.}

Value of Fertilizers.-Cost per pound of the Essential Constitnents of Fertilizers.-Value of Guanos.-Potash as a Manure............................. 324

\section{CHAPTER XL.}

Restoring Fertility to the Soil, a Chapter by Sir John Bennet Lawes.-The Treatment of a Poor Farm, 10 Restore it must Profitably.-Meat-making the Back-bone of the System.- The Use of Sheep to Manure the Soil.The Feeding of Cotton-seed Cake-Artificial Manures not Profitable on Poor Laud.-The Loss of Nitrogen.-The Formation of Nitric Acid... . . .342

\section{APPENDIX.}

Letter from Edward Jessop.-From Dr. E. L. Sturtevant.-From M. C. Weld. -From Peter Henderson.-From J. B. M. Anderson.-Manure statistics of Lone Island.-Letter from J. H. Rushmore.-Letter from John E. Backus. - Manure in Philadelphia.-Various other Letters.. ................. 332 


\section{INTRODUCTION TO NEW AND ENLARGED EDITION.}

Sir John Bennet Lawes kindly consented to write a Chapter for the new edition of this work. The Deacon, the Doctor, the Squire, Charlie and myself all felt flattered and somewhat bashful at tinding ourselves in such distinguished company. I need not say that this new Chapter from the pen of the most eminent English agricultural investigator is worthy of a very careful study. I have read it again and again, and each time with great and renewed interest. I could wish there was more of it. But to the intelligent and well-informed reader this Chapter will be valued not merely for what it contains, but for what it omits. A man who knew less would write more. Sir John goes straight to the mark, and we have here his mature views on one of the most important questions in agricultural science and practice.

Sir John describes a tract of poor land, and tells us that the cheapest method of improving and enriching it is, to keep a large breeding flock of sheep, and feed them American cottonseed cake. We are pleased to find that this is in accordance with the general teaching of our "Talks," as given in this book several years ago.

When this work was first published, some of my friends expressed surprise that I did not recommend the more $\epsilon$ xtended use of artificial manures. One thing is certain, since that time the use of superphosphate has been greatly on the increase. And it seems clear that its use must be profitable. Where I live, in Western New York, it is sown quite generally on winter wheat, and also on barley and oats in the spring. On corn and potatoes, its use is not so common. Whether this is because its application to these crops is not so easy, or because it does not produce so marked an increase in the yield per acre, I am unable to say.

Our winter wheat is sown here the first, second, or (rarely) the third week in September. We sow from one and a half to two and a quarter bushels per acre. It is almost invariably sown with a drill. The drill has a fertilizer attachment that distributes the superphosphate at the same time the wheat is 
sown. The superphosphate is not mixed with the wheat, but it drops into the same tubes with the wheat, and is sown with it in the same drill mark. In this way, the superphosphate is deposited where the roots of the young plants can immediately find it. For barley and oats the same method is adopted.

It will be seen that the cost of sowing superphosphate on these crops is merely nominal. But for corn and potatoes, when planted in hills, the superphosphate must be dropped in. the hill by hand, and, as we are almost always hurried at that season of the year, we are impatient at anything which will delay planting even for a day. The boys want to go fishing!

This is, undoubtediy, one reason why superphosphate is not used so generally with us for corn as for wheat, barley, and oats. Another reason may be, that one hundred pounds of corn will not sell for anything like as much as one hundred pounds of wheat, barley, and oats.

We are now buying a very good superphosphate, made from Carolina rock phosphate, for about one and a half cents per pound. We usually drill in about two hundred pounds per acre at a cost of three dollars. Now, if this gives us an increase of five bushels of wheat per acre, worth six dollars, we think it pays. It often does far better than this. Last year the wheat crop of Western New York was the best in a third of a century, which is as far hack as I have had anything to do with farming here. From all I can learn, it is doubtful if the wheat crop of Western New York has ever averaged a larger yield per acre since the land was first cultivated after the removal of the original forest. Something of this is due to better methods of cultivation and tillage, and something, doubtiess, to the general use of superphosphate, but much more to the favorable season.

The present vear our wheat crop turned out exceedingly poor. Hundreds of acres of wheat were plowed up, and the land resown, and hundreds more would have been plowed up had it not been for the fact that the land was seeded with timothy grass at the time of sowing the wheat, and with clover in the spring. We do not like to lose our grass and clover.

Dry weather in the autumn was the real cause of the poor yield of wheat this year. True, we had a very trying winter, and a still more trying spring, followed by dry, cold weather. The season was very backward. We wcis not able to sow anything in the fields before the first of May, and our wheat ought to have been ready to harvest in July. On the first 
of May, many of our wheat-fields, especially on clay land, looked as bare as a naked fallow.

There was here and there, a good field of wheat. As a rule, it was on naturally moist land, or after a good summer-fallow, sown early, I know of but one exception. A neighboring nursery firm had a very promising field of wheat, which was sown late. $\mathrm{Bu}$ their land is rich and unusually well worked. It is, in fact, in the very highest condition, and, though sown late, the young plants wore enabled to make a good strong growth in the autumn.

In such a dry season, the great point is, to get the seed to germinate, and to furnish sufficient moisture and food to enable the young plants to make a strong, vigorous growth of roots in the autumn. I do not say that two hundred pounds of superphosphate per acre, drilled in with the seed, will always accomplish this object. But it is undoubtedly a great help. It does not furnish the nitrogen which the wheat requires, but if it will stimulate the production of roots in the early autumn, the plants will be much more likely to find a sufficient supply of nitrogen in the soil than plants with fewer and smaller roots.

In a season like the past, therefore, an application of two hundred pounds of superphosphate per acre, costing three dollars, instead of giving an increase of five or six bushels per acre, may give us an increase of fifteen or twenty bushels per acre. That is to say, owing to the dry weather in the autumn, followed by severe weather in the winter, the weak plants on the unmanured land may either be killed out altogether, or injured to such an extent that the crop is hardly worth harvesting, while the wheat where the phosphate was sown may give us almost an average crop.

Sir John B. Lawes has somewhere compared the owner of land to the owner of a coal mine. The owner cf the coal digs it and gets it to market in the best way he can. The farmer's coal mine consists of plant food, and the object of the farmer is to get this food into such plants, or such parts of plants, as his customer's require. It is hardly worth while for the owner of the coal mine to trouble his head about the exhaustion of the supply of coal. His true plan is to dig it as econcmically as he can, and get it into market. There is a good deal of coal in the world, and there is a good deal of plant food in the earth. As long as the plant food lies dormant in the soil, it is of no value to man. The object of the farmer is to convert it into products which man and animals require. 
Mining for coal is a very simple matter, but how best to get the greatest quantity of plant food out of the soil, with the least waste and the greatest profit, is a much more complex and difficult task. Plant food consists of a dozen or more different substances. We have talked about them in the pages of this book, and all I wish to say here is that some of them are much more abundant, and more readily obtained, than others. The three substances most difficult to get at are: nitric acid, phosphoric acid and potash. All these substances are in the soil, but some soils contain much more than others, and their relative proportion varies considerably. The substance which is of the greatest importance, is nitric acid. As a rule, the fertility of a soil is in proportion to the amount of nitric acid which becomes available for the use of plants during the growing season. Many of our soils contain largo quantities of nitrogen, united with carbon, but the plants do not take it up in this form. It has to be converted into nitric acid. Nitric acid consists of seven pounds of nitrogen and twenty pounds of oxygen. It is produced by the combustion of nitrogen. Since these "Talks" were published, several important facts have been discovered in regard to how plants take up nitrogen, and especially in regard to how organic nitrogen is converted into nitric acid. It is brought about through the action of a minute fungoid plant. Ther 3 are several things necessary for the growth of this plant. We must have some nitrogenous substance, a moderate degree of heat, say from seventy to one hundred and twenty degrees, a moderate amount of moisture, and plenty of oxygen. Shade is also favorable. If too hot or too cold, or too wet or too dry, the growth of the plant is checked, and the formation of nitric acid suspended. The presence of lime, or of soms alkali, is also necessary for the growth of this fungus and the production of nitric acid. The nitric acid unites with the lime, and forms nitrate of lime, or with soda to form nitrate of soda, or with potash to form nitrate of potash, or salt-petre. A water-logged soil, by excluding the oxycen, destroys this plant, hence one of the advantages of underdraining. I have said that shade is favorable to the growth of this fuugus, and this fact explains and confirms the common idea that shade is manure.

The great object of agriculture is to convert the nitrogen of our soils, or of green crops plowed under, or of manure, into nitric acid, and then to convert this nitric acid into profitable products with as little loss as possible. Nitrogen, or rather 
nitric acid, is the most costly ingredient in plant food, and unfortunately it is very easily washed out of the soil and lost. Perhaps it is absolutely impossible to entirely prevent all loss from leaching; but it is cortainly well worth our while to understand the subject, and to know exactly what we ars doing. In a new country, where land is cheap, it may be more profitable to raise as large crops as possible without any regard to the loss of nitric acid. But this condition of things does not last long, and it very soon becomes desirable to adopt less wasteful processes.

In Lawes and Gilbert's experiments, thers is a great loss of nitric acid from drainage. In no caze has as much nitrogen been obtained in the increased crop as was applied in the manure. There is always a loss and probably always will be. But we should do all we can to make the ' $\mathrm{O}$ ss as small as possible, consistent with the production of profitable crops.

There are many ways of lessening this loss of nitric acid. Our farmers sow superphosphate with their wheat in the sutumn, and this stimulates, we think, the growth of roots, which ramify in all directions through the soil. This increased growth of root brings the plant in contact with a larger fecding surface, and enables it to take up more nitric asid from its solution in the soil. S'tch is also the case during t'ie winter and early spring, when a good deal of water permeates through the soil. The application of superphosphate, unquestionably in many aases, prevents much loss of nitric acid. It does this by giving us a much greater growth of wheat.

I was at Rothamsted in 1879 , and witnessed the injurious effect of an excessive rainfall, in washing out of the soil nitrate of soda and salts of ammonia, which were sown with the wheat in the autumn. It was an exceedingly wet season, and the loss of nitrates on all the different plots was very great. But where the nitrates or salts of ammonia were sown in the spring, while the crops were growing, the loss was not nearly so great as when sown in the autumn.

The sight of that wheat field impressed me, as nothing else could, with the importance of guarding against the loss of available nitrogen from leaching, and it has changed my practice in two or three important respects. I realize, as never before, the importance of applying manure to crops, rather than to the land. I mean by this, that the object of applying manure is, not simply to make land rich, but to make crops grow. Manure is a costly and valuable article, and we want to convert 
it into plants, with as little delay as possible, which will, directly or indirectly, bring in some money.

Our climate is very different from that of England. As a rule, we seldom have enough rain, from the time corn is planted until it is harvested, to more than saturate the ground on our upland soils. This year is an exception. On Sunday night, May 20, 1883, we had a northeast storm which continued three days. During these three days, from three to five inches of rain fell, and for the first time in many years, at this season, my underdrains discharged water to their full capacity. Had nitrate of soda been sown on bare land previous to this rain, much of it would, doubtless. have been lost by leaching. This, however, is an exceptional case. My underdrains usually do not commence to discnarge water before the rirst of December, or continue later than the first of May. To guard against loss of nitrogsiu by leaching, therefore, we should aim to keep rich land occupied by some crop, during the winter and early spring, and the earlier the crop is sown in the autumn or late summer, the better, so that the roots will the more completely fill the ground and take up all the available nitrogen within their reach. I have said that this idea had modified my own practice. I grow a considerable quantity of garden vegetables, principally for sead. It is necessary to make the land very rich. The plan I have adopted to guard against the loss of nitrogen is this: As soon as the land is cleared of any crop, after it is too late to sow turnips, I sow it with rye at the rate of one and a half to two bushels per acre. On this rich land, especially on the moist low land, the rye makes a great growth during our warm autumn weather. The rye checks the growth of weeds, and furnishes a considerable amount of succulent food for sheep, during the autumn or in the spring. If not needed for food, it can be turned under in the spring for manure. It unquestionably prevents the loss of considerab?e nitric acid from leaching during the winter and early spring.

Buckwheat, or millet, is sometimes sown on such land for plowing under as manure, but as these crops are killed out by the winter, they cannot prevent the loss of nitric acid during the winter and spring months. It is only on unusually rich land that such precautions are particularly necessary. It has been thought that these experiments of Lawes and Gilbert afford a strong argument against the use of summer-fallows. I do not think so. A summer-fallow, in this country, is usually a piece of land which has been seeded down one, two, and 
sometimes three years, with red clover. The land is plowed in May or June, and occasionally in July, and is afterwards sown to winter wheat in September. The treatment of the summerfallow varies in different localities and on different farms.

Sometimes the land is only plowed once. The clover, or sod, is plowed under deep and well, and the after-treatment consists in keeping the surface soil free from weeds, by the frequent use of the harrow, roller, cultivator or gang-plow. In other cases, especially on heavy clay land, the first plowing is done early in the spring, and when the sod is sufficiently rotted, the land is cross-plowed, and afterwards made tine and mellow by the use of the roller, harrow, and cultivator. Just before sowing the wheat, many good, old-fashioned farmers, plow the land again. But in this section, a summer-fallow, plowed two or three times during the summer, is becoming more and more rare every year.

Those farmers who summer-fallow at all, as a rule, plow their land but once, and content themselves with mere surface cultivation afterwards. It is undoubtedly true, also, that summer fallows of all kinds are by no means as common as formerly. This fact may be considered an argument against the use of summer-fallowing; but it is not conclusive in my miad. Patient waiting is not a characteristic of the age. We are inclined to take risks. We prefer to sow our land to oats, or barley, and run the chance of getting a good wheat crop after it, rather than to spend several months in cleaning and mellowing the land, simply to grow one crop of wheat.

It has always seemed to me entirely unnecessary to urge farmers not to summer-fallow. We all naturally prefer to see the land occupied by a good paying crop, rather than to spend time, money, and labor, in preparing it to produce a crop twelve or fifteen months afterwards. Yet some of the agricultural editors and many of the agricultural writers, seem to take delight in deriding the old-fashioned summer-fallow. The fact that Lawes and Gilbert in England find that, when land contains considerable nitric acid, the water which percolates through the soil to the underdrains beneath, contains more nitrate of lime when the land is not occupied by a crop, than when the roots of growing plants fill the soil, is deemed positive proof that summer-fallowing is a wasteful practice.

If we summer-fallowed for a spring crop, as I have sometimes done, it is quite probable that there would be a loss of nitrogen. But, as I have said before, it is very seldom that any 
water passes through the soil from the time we commence summer-fallow until the wheat is sown in the autumn, or for many weeks afterwards. The nitrogen, which is converted into nitric acid by the agency of a good summer-fallow, is no more liable to be washed out of the soil after the field is sown to wh at in the autumn, than if we applied the nitrogen in the form of some readily available manure.

I still believe in summer fallows. If I had my life to live over again, I would certainly summer-fallow more than I have done. I have been an agricultural writer for one-third of a century, and have persistently adrocated the more extended use of the summer-fallow. I have nothing to take back, unless it is what I have said in reference to "fall-fallowing." Possibly this practice may result in loss, though I do not think so.

A good summer-fallow, on rather heavy clay land, if the conditions are otherwise favorable, is pretty sure to give us a good crop of wheat, and a good crop of clover and grass afterwards. Of course, a farmer who has nice, clean sandy soil, will not think of summer-fallowing it. Such soils are easily worked, and it is not a diffsult matter to keep them clean without summer-fallowing. Such soils, however, seldom contain a large store of unavailable plant food, and instead of summerfallowing, we had better manure. On such soils artificial manures are often very profitable, though barn-yard manure, or the droppings of animals feeding on the land. should be the prime basis of all attempts to maintain, or increase, the productiveness of such soils.

Since this book was first published, I do not know of any new facts in regard to the important question of, how best to manage and apply our barn-yard manure, so as to make it more immediately active and available. It is unquestionably true, that the same amount of nitrogen in barn-yard manure, will not produce so great an effect as its theoretical value would in dicate. There can be no doubt, however, that the better wf feed our animals, and the more carefully we save the liquids the more valuable and astive will be the inanure.

The conversion of the inert nitrogen of manures and soils, into nitric acid, as alreaciy statcd, is now known to be produced by a minute fungus. I hope it will be found that we can introduce this bacterium into our manure piles, in such a way as to greatly aid the conversion of inert nitrogen into nitrates.

Experiments have been made, and are still continued, at Yoburn, under the auspices of the Royal Agricultural Suciety 
of England, to ascertain, among other things, wlether manure from sheep receiving an allowance of cotton-seed cake is any richer than that from sheep, otherwise fed alike, but having, instead of cotton-seed cake, the same amount of corn meal. We know that such manure contains more nitrogen, and other plant food, than that from the corn meal. But the experiments so far, though they have been continued for several years, do not show any striking superiority of the manure from cottonseed cake over that from corn meal. I saw the wheat on these differently manured plots in 1879. Dr. Voelcker and Dr. Gilbert, told me that, one of two plots was dressed with the cotton-seed manure, and the other with "the corn meal manure, and they wanted me to say which was the most promising crop. I believe the one I said was the better, was the cottonseed plot. But the difference was very slight. The truth is that such experiments must be continued for many years before they will prove anytining. As I said before, we know that the manure from the cotton-seed cake is richer in nitrogen than that from the corn meal ; but we also know that this nitrogen will not produce so great an effect, as a much smaller amount of nitrogen in salts of ammonia, or nitrate of soda.

In going over these experiments, I was struck with the heal'shy and vigorous appearance of one of the plots of wheat, and asked how it was manured. Dr. Volcker called out, "clover, Mr. Harris, clover." In England, as in America, it requires very little observation and experience to convince any one of the value of clover. After what I have said, and what the Deacon, the Doctor, Charley and the Squire have said, in the pages of this book, I hope no one will think that I do not appreciate the great value of red clover as a means of enriching our land. Dr. Vœlcker evidently thought I was skeptical on this point. I am not. I have great faith in the benefits to be derived from the growth of clover. But I do not think it originates fertility ; it does not get nitrogen from the atmosphere. Or at any rate, we have no evidence of it. The facts are all the other way. We have discussed this question at considerable length in the pages of this book, and it is not necessary to say more on the subject. I would, however, particularly urge farmers, especially those who are using phosphates freely, to grow as much clover as possible, and feed it out on the farm, or plow it under for manure.

The question is frequently asked, whether the use of phosphates will ultimately impoverish our farms. It may, $o_{i}$ it may 
not. It depends on our general management. Theoretically, the use of a manure furnishing only one element of plant food, if it increases the growth of crops which are sold from the farm, must have a tendency to impoverish the land of the other elements of plant fooi. In other words, the use of superphosphate furnishing only, or principally, phosphoric acid, lime and sulphuric acid, must have a tendency to impoverish the soil of nitrogen and potash. Practically, however, it need do nothing of the kind. If the land is well cultivated, and if our low, rich, alluvial portions of the farm are drained, and if the hay, grass, clover, straw and fodder crops are retained, the more phosphates we use, the richer and more productive will the farm become. And I think it is a fact, that the farmers who use the most phosphates, are the very men who take the greatest pains to drain their land, cultivate it thoroughly, and make the most manure. It follows, therefore, that the use of phosphates is a national benefit.

Some of our railroad managers take this view of the subject. They carry superphosphate at a low rate, knowing that its use will increase the freight the other way. In other words, they bring a ton of superphosphate from the seaboard, knowing that its use will give them many tons of freight of produce, from the interior to the seaboard. It is not an uncommon thing for two liundred pounds of superphosphate, to give an increase of five tons of turnips per acre. Or, so to spenk, the railroad that brings one ton of superphosphate from the seaboard, might, as the result of its use, have fifty tons of freight to carry back again. This is perbaps an exceptionably favorable instance, but it illustrates the principle. Years ago, before the abolition of tolls on the English turnpike roads, carriages loaded with lime, and all other substances intended for manure, were a'lowed to go free. And our railroads will find it to their int?rest to transport manures of all kinds, at a merely nominal rate.

Many people will be surprised at the recommendation of Sir Joln B. Lawes, not to waste time and money in cleaning poor lazd, before seeding it down to grass. He thinks that if the land is made rich, the superior grasses overgrow the bad grasses and weeds. I have no doubt he is right in this, though the principle may be pushed to an extreme. Our climate, in this country, is so favorable for killing weeds, that the plow and the cultivator will probably be a more economical means of making our land clean, than the liberal use of expensive 
manures. It depends, doubtless, on the land and on circumstances. It is well to know that manure on grass land, will so increase the growth of the good grasses, as to smother the weeds. Near my house was a piece of land that I wanted to make into a lawn. I sowed it with grass seed, but the weeds smothered it out. I plowed it, and hoed it, and re-seeded it, "but still the weeds grew. Mallows came up by the thousand, with other weeds too numerous to mention. It was an eyesore. We mowed the weeds, but almost despaired of ever making a decent bit of grass land out of it. It so happened that, one year, we placed the chicken coops on this miserable weedy spot. The hens and chickens were kept there for several weeks. The feed and the droppings made it look more unsightly than ever, but the next spring, as if by magic, the weeds were gone and the land was covered with dark green luxuriant grass.

In regard to the use of potash as a manure, we have still much to learn. It would seem that our grain crops will use soda, if they cannot get potash. They much prefer the potash, and will grow much more luxuriantly where, in the soil or manure, in addition to the other elements of plant food, potash is abundant. But the increased growth caused by the potash, is principally, if not entirely, straw, or leaves and stem. Nature makes a great effort to propagate the species. A plant of wheat or barley, will produce seed if this is possible, even at the expense of the other parts of the plant.

For grain crops, grown for seed, therefore, it would seem to be entirely unprofitable to use potash as a manure. If the soil contains the other elements of plant food, the addition of potash may give us a much more luxuriant growth of leaves and stem, but no more grain or seed. For hay, or grass or fodder crops, the case is very different, and potash may often be used on these crops to great advantage.

I am inclined to think that considerable nitrate of soda will yet be used in this country for manure. I do not suppose it will pay as a rule, on wheat, corn and other standard grain crops. But the gardener, seed grower, and nurseryman, will find out how to use it with great profit. Our nurserymen say that they cannot use artificial manures with any advantare. It is undoubtedly true that a dressing of superphosphate, sown on a block of nursery trees, will do little good. It never reaches the roots of the plants. Superphosphate can not be washed down deep into the soil. Nitrate of soda is readily carried down, as 
deep as the water sinks. For trees, therefore, it would seem desirable to apply the superhosphate before they are planted, and plow it under. And the same is true of potash; but nitrate of soda would be better applied as a top-dressing every year, early in the spring.

The most discouraging fact, in Lawes' and Gilbert's experiments, is the great loss of nitrogen. It would seem that, on an average, during the last forty years, about one-half the nitrogen is washed out of the soil, or otherwise lost. I can not but hope and believe that, at any rate in this country, there is no such loss in practical agriculture. In Lawes' and Gilbert's experiments on wheat, this grain is grown year after year, on the same land. Forty annual crops have been removed. No clover is sown with the wheat, and great pains are taken to keep the land clean. The crop is hoed while growing, and the weeds are pulled out by hand. The best wheat season during the forty years, was the year 1863 . The poorest, that of 1879 ; and it so happened, that after an absence of thirty years, I was at Rothamsted during this poor year of 1879 . The first thing that struck me, in looking at the experimental wheat, was the ragged appearance of the crop. My own wheat crop was being cut the day I left home, July 15 . Several men and boys were pulling weeds out of the experimental wheat, two weeks later. Had the weeds been suffered to grow, Sir John Bennet Lawes tells us, there would be less loss of nitrogen. The loss of nitrogen in 1863, was about twenty-four pounds per acre, and in 1873 fifty pounds per acre-the amount of available nitrogen, applied in each year, being eighty-seven pounds per acre. As I said before, the wheat in 1879 had to me a ragged look. It was thin on the ground. There were not plants enough to take up and evaporate the large amount of water which fell during the wet season. Such a condition of things rarely occurs in this country. We sow timothy wit' our winter wheat, in the autumn, and red clover in the spring. After the wheat is harvested, we frequently have a heavy growth of clover in the autumn. In such circumstances I believe there would be compuratively little loss of nitrogen.

In the summer-fallow experiments, which have now been continued for twenty-seven years, there has been a great loss of nitrozen. The same remarks apply to this case. No one ever advocates summer-fallowing land every other year, and sowing nothing but wheat. When we summer-fallow a piece of land for wheat, we sced it down with grass and clover. 
There is, as a rule, very little loss of nitrogen by drainage while the wheat is growing on the ground, but after the wheat is cut, the grass and clover are pretty sure to take up all the available nitrogen within the range of their roots. This summer-fallow experiment, instead of affording an argument against the use of summer-fallowing, is an argument in its favor. The summer-fallow, by exposing the soil to the decomposing influences of the atmosphere, converts more or less of the inert nitrogenous organic maiter into ammonia and nitric acid. This is precisely what a farmer wants. It is just what the wheat crop needs. But we must be very careful, when we render the n:trogen soluble, to have some plant ready to take it up, and not let it be washed out of the soil during the winter and early spring.

We have much poor land in the United States, and an immense area of good land. The poor land will be used to grow timber, or be improved by converting more or less of it, gradually, into pasture, and stocking it with sheep and cattle. The main point is, to feed the sheep or cattle with some rich nitrogenous food, such as cotton-seed cake, malt-sprouts, bran, shorts, mill-feed, refuse beans, or bean-meal made from beans injured by the weevil, or bug. In short, the owner of such laad must buy such food as will furnish the most nutriment and make the richest manure at the least cost-taking both of these objects into consideration. He will also buy more or less artificial manures, to be used for the production of fodder crops, such as corn, millet, Hungarian grass, etc. And, as soon as a portion of the land can be made rich enough, he will grow more or less mangel wurzels, sugar beets, turnips, and other root crops. Superphosphate will be found admirably adapted for this purpose, and two, three, or four hundred pounds of cheap potash salts, per acre, can frequently be used on fodder crops, in connection with two or three hundred pounds of superphosphate, with considerable profit. The whole subject is well worthy of careful study. Never in the history of the world has there been a grander opportunity for the application of science to the improvement of agriculture than now.

On the richer lands, the aim of the farmer will be to convert, the plant food lying dormant in the soil into profitable crops. The main point is good tillage. In many cases weeds now run away with half our crops and all our profits. The weeds which spring up after the grain crops are harvested, are not an unmixed evil. They retain the nitrogen and other plant food, and 
vhen turned under make manure fcr the succeeding crops. But weeds among the growing crop are evil, and only an evil. Thorough plowing is the remedy, accompanied by drainage where needed.

We have an immense number of farms on which there are both good and poor land. In such cases we must adopt a com* bined system. We zaust grow large crops on the rich land and use them, at least in part, to make manure for the poorer portions of the farm. Drainage and good tillage will convert much of our low, nlluvial lands into a perfect mine of wealth. And much of our high, rolling land consists of strong loam, abounding in plant food. Such land requires little more than thorough tillage, with perhaps two hundred pounds of superphosphate per acre, to enable it to produce good grain crops.

After all is said and done, farming is a business that requires not merely science, but industry, cionomy, and common sense. The real basis of success is faitll, accompanied with good works. I cannot illustrate this better than by alluding to one of my neighbors, a strong, healthy, intelligent, observing and enterprising German, who commenced life as a farm lab:rer, and is to-day wortin at least one hundred thousand dollars, that he has made, not by the advance of suburban property, but by farming, pure and simple. He first rented a farm. and then bought it, and in a few years he bought another farm adjoining the first one, and would to-day buy another if he found one that suited him. He has faith in farming. Some people think he "runs his land," and, in iact, such is the case. He keeps good teams, and good plows, and good harrows, and good rollers, and good cultivators, and good grade Shorthorn cows. He acts as though he believed, as Sir John B. Lawes says, that "the soil is a mine," out of which he digs money He runs his land for all it is worth. He raises wheat, barley, oats, corn, pctatoes, and hay, and when he can get a good price for his timothy hay, he draws it to market and sells it. Thorough tillage is the basis of his success. He is now using phosphates for wheat, and will probably increase his herd of cows and make more manure. He has great faith in manure, but acts as though h? had still greater faith in good plowing, early sowing, and thorough cultivation. 


\section{PREFACE TO FIRST EDITION.}

The Prirters have got our "Talks on Manures" in type; and the publishers want a Preface.

The Deacon is busy hoeing his corn; the Doctor is gone to Rice Lakə, fishing; Charley is cultivating mangels; the Squire is haying, and I am here alone, with a pencil in hand and a sheet of blank paper before me. I would far rather be at work. In fact, I have only just, come in from the field.

Now, what shall I say? It will clo no good to apologize for the deficiencies of the booz. If the critics condescend to notice it at all, nothing I can say will propitiate tieir favor, or moderate their censurc. They are an independent set of fellows! I lizow them well. I am an old editor myseli, and nothing would plansa me better than to sit down and write a slashing criticism of these "Talks un Manures."

But I am denied that plessure. The critics have the floor.

All I will say here, is, that the book is what it pretends to be. Some people seem to think that the "Deacon" is a fictitious character. Nothing of the kind. He is one of the oldest farmers in town, and lives on the farm next to me. I have the very highest respect for him. I have tried to report him fully and correctly. Of my own share in the conversations I will say little, and of the Doctor's nothing. Hy own views are honestly given. I hold myself responsible for them. I may contradict in one chapter what I have asserted in another. And so, probably, has the Deacon. I do not know whether this is or is not the case. I know very well that on many questions "much can be said on both sides"-and very likely the Deacon is sometimes on the south side of the fence and $I$ on the north side; and in the next chapter you may find the Deacon on the north side, and where would you have me go, except to the sunth side? We cannot see both sides of the fence, if both of us walk on the same side!

I fear some will be disappointed at not finding a particular subject discussed.

I have talkec. about those things which occupy my own thoughts. 
There are some things not worth thinking about. There are others beyond my reach.

I have said nothing about manures for cotton or for the sugarcane-not because I feel no interest in the matter, but becuuse I have had no experience in the cultiration of these import.nt crops. I might have told what the crops contain, and could have given minute directions for furnishing in manure the exact quantity of plant-food which the crops remove from tise soil. But $I$ have no faith in such a system of farmins. The few cotton-planters I have had the pleasure of seeing were men of education and rare ability. I cannot undertake to offer them advice. But I presume they will find that, if they desire to increase the growth of the cotton-plant, in nine cases out of ten they can do it, provided the soil is properly worked, by supplying a manure containing available nitrogen, phosphoric acid, and potash. But the proper proportion of these ingredients of plant-food must be ascertained by experiment, and not from a mere analysis of the cotton-plant.

I have much faith in artificial manures. They will do great things for American agriculture-directly, and indirectly. Their general use will lead to a higher system of farming - to better cultivation, more root and fodder crops, improved stock, higher feecling, and richer manure. But it has been no part of my object to uncluly extol the virtues of commercial manures. That may be left to the manufacturers.

My sympathy is with the farmer, and especially with the farmer of moderate means, who finds that improved farming calls for more and more capital. I would like to encourage such a man. And so, in point of fact, would the Dexcon, though he often talks as though a mon who tries to improve his farm will certainly come to poverty. Such men as the Deacon are useful neighbors if their doubts, and head-shakings, and shoulder-shruggings lead a young and enthusiastic farmer to put more energy, industry, and economy into his business. It is well to listen to the Deacon - to hear all his objections, and then to keep a sharp look-out for the dangers and difficulties, and go-ahead. 


\section{TALKS ON MANURES.}

\section{H A P T E R I.}

\section{FARMING AS A BUSINESS.}

"Farming is a poor business," said the Deacon. "Take the corn crop. Thirty bushels per acre is a fair average, worth, at 75 cents per bushel, $\$ 22.50$. If we reckon that, for eack bushel of corn, we get 100 lbs. of stalks, this would be a ton and a half per acre, worth at $\$ 5$ per ton $\$ 7.50$."

Total receipts per acre for corn crop.................

Expenses.-Preparing the land for the crop............ \$5 00

Planting and seed.................... 150

Cultivating, three times, twice in a row both

ways.......................... 500

Hoeing twice........................ 300

Cutting up the corn................... 150

Husking and drawing in the corn........... 400

Drawing in the stalks, etc............... 100

Shelling, and drawing to market.......... 200

Total cost of the crop.

Prefit per acre

$\$ 2300$

$\$ 700$

"And from this," said the Deacon, "we have to deduct interest on land and taxes. I tell you, farming is a poor business."

"Yes," I replied, "poor farming is a very poor business. But good farming, if we have good prices, is as good a business as I want, and withal as pleasant. A good farmer raises $\%$ bushels 
of corn per acre, instead of 30 . He would get for his crop, including stalks......................... $\$ 1500$ Expenses.-Preparing land for the crop.............. \$5 00

Plantirgg and seed...................... 1 50

Cultivating........................... $5 \mathrm{CO}$

Hloeing............................. $3 \mathrm{CO}$

Cutting up the corn.................... 150

Husking and drawing................... 1000

Drawing in the stalks................... 300

Shelling, etc........................... 600

Profit per acre

Take another case, which actually occurred in this neighborhood. The Judge is a good farmer, and particularly successful in raising potatoes and selling them at a good price to hotels and private families. He cultivates very thoroughly, plants in hills, and puts a handful of ashes, plaster, and hen-manure, on the hill.

In 1873, his crop of Peachblows was at the rate of 208 bushels per acre. Of these, 200 bushels were sold at 60 cents per bushcl. There were 8 bushels of small potatoes, worth say $12 \frac{1}{2}$ cents per bushel, to feed nut to stock.

Mr. Sloc, who lives on an aljoining farm, had three acres of Peachblow potatoes the same year. The yield was 100 bus'zels per acre-of which 25 bushels were not large enough for market, he got 50 cents per bushel for tie others.

The account of the tivo crops stands as follows:

\begin{tabular}{|c|c|c|}
\hline Expenses Fer Acre: & Mr.S.oo & Judge. \\
\hline 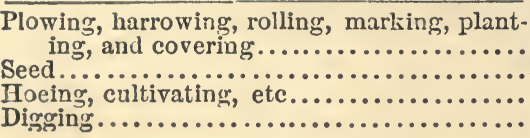 & 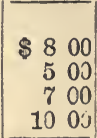 & $\begin{array}{rl}\$ 8 & 00 \\
5 & 00 \\
1000 \\
1000\end{array}$ \\
\hline 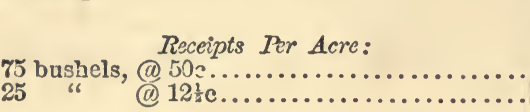 & $\begin{array}{rr}30 & 00 \\
37 & 50 \\
3 & 12\end{array}$ & 3300 \\
\hline $\begin{array}{l}200 \text { bushels, @ } 69 \mathrm{c} . . . \\
8 \text { @ } 12 \frac{1}{2} \mathrm{c} . .\end{array}$ & $\overline{\$ 106.3}$ & $\begin{array}{r}12000 \\
100 \\
1210 J \\
59300\end{array}$ \\
\hline
\end{tabular}

Since then, Mr. Sloe has been making and using more manure, and the year before last (1875) his crop of potatoes averaged over 
200 bushels per acre, and on the sandy knolls, where more manure was applied, tie yield was at least 250 bushels per acre.

"Nevertheless," suid the Deacon, "I do not believe in "high farming.' It will not pay."

"Possibly not," I replied. "It dzpends on circumstances; and these we will talk about presently. High farming aims to get large crops every year. Good farming pro luces equally large crops per acre, but not so many of them. 'Tuis is what I am trying to do on my own farm. I am aiming to get 35 bushels of wheat per acre, 80 bushels of shelled corn, 50 bushels of barley, 90 bushels of oats, 300 bushels of potatoes, and 1,200 bushels of mangel-wurzel per acre, on the average. I can see no way of paying higil viages exccpt by raising large crops per acre. But if I get these large crops it does. not necessirily follow that I am practising 'high farming.'"

To illustrate: Suppose I should succeed in getting such crops by adopting the following plan. I have a farm of nearly 300 acres, one quarter of it being low, alluvial land, too wet for cultivation, but when drained excellent for pasturing cars or for timothy meadows. I drain this land, and after it is clrained I dam up some of the streams that flow into it or through it, and irrigate wherever I can make the water flow. So muci for the low land.

The upland portion of the farm, containing say 200 acres, exclusive of fences, roads, buillings, garden, etc., is a naturally fertile loam, as good as the average wheat land of Western New York. But it is, or was, badly " run down." It had been what people call "worked to death;" although, in point of fact, it had not been half-worked. Some siil it was "wheated to cleath," others that it had been "oated to death," others that it had been " grassed to death," and ons man said to me, "Thut field has had sheep on it until they have gnawed every particle of vegetable matter out of the soil, and it will not now produce enough to pasture a flock of grose." And he was not far from right-notwithstanding the fact that sheep are thought to be, and are, the best animals to enrich land. But let me say, in passing, that $I$ have since raised on that same field 50 bushels of barley per acre, 33 bushels of Dieh] wheat, a great crop of clover, and last year, on a part of it, over 1,000 bushels of mangel-wurzel per acre.

But this is a digression. Les us carry out the illustration. What does this upland portion of the farm need? It needs underdraining, thorough eultivation, and plenty of manure. If I has plenty of manure, I could adopt high farming. But where am I to get plenty of manure for 200 acres of land? "Make it," says the 
Descoa. Very good; but what siall I make it of ? "Make it out oî your straw and stalks and hay." So I do, but all the straw and stalks and hay raised on the furm when I bought it would not make as much manure as "higi farming" requires for five acres of land. And is this not true of half the farms in the United States to day? What then, shall we do?

The best thing to do, theoretically, is this: Any land that is producing a fair crop of grass or clover, let it lic. Pasture it or mow it for hay. If you have a field of clayey or stiff loamy land, break it up in the fall, and summer-fallow it the next year, and sow it to wheat and seed it down with clover. Let it lie two or three years in clover. Then break it up in July or August, "fall-fallow" it, and.sow it with barley the next spring, and seed it down again with ciover.

Sandy or lig'st land, that it will not pay to summer-fallow, should have all the manure you can make, and be plowed and planted with corn. Cultivate thoroughly, and either seed it down with the corn in August, or sow it to barley or oats next spring, and seed it down with clover. I say, theoretically this is the best plan to adopt. But practically it may not be so, because it may be absolutely necessary that we should raise something that we can sill at once, and get money to live upon or pay interest and taxes. But the gentlemen who so strenuously advocate high farming, are not perhaps of ten troubled with considerations of this kind. Mecting them, therefore, on their own ground, I contend that in my case "high farming" would not be as profitable as the plan hintcd at above.

The rich alluvial low land is to be pastured or mown ; the upland to be broken up only' when necessary, and when it is plowed to be plowed well and worked thoroughly, and got back again into clover as soon as possible. The hay and pasture from the low land, and the clover and straw and stalks from the upland, would enable us to keep a good many cows and sheep, with more or less pigs, and there would be a big pile of manure in the yard every spring. And when this is once obtained, you can get along much more pleasantly and profitably.

"But," I may be asked, "when you have got this pile of manure can not you adopt high farming?" No. My manure pile wouid contain say : 60 tons of clover-hay; 20 tons wheat-straw; 25 ton 3 oat, bırley, and pea-straw; 40 tons meadow-l1ay; 20 tons cornstalis; 20 tons corn, oats, and other grain ; 120 tons mangel-wurzel and turnips. 
This wou'd give me about 500 tons of well-rotted manure. 1 should want 200 tons of this for the mangels and turnips, and the 300 tons I should want to top-clress 20 acres of grass land intended for corn and potatoes the next year. My pile of manure, therefore, is all used up on 25 to 30 acres of land. In other words, I use the unsold proluce of 10 acres to manure one. Is this "high farming?" I think in my circumstances it is good furming, but it is not high farming. It gives me large crops per acre, but I have comparatively few acres in crops that are sold from the farm.

"High farming," if the term is to have any definite meaning at all, should only be used to express the idea of a farm so managed that the soil is rich enough to produce maximum crops every year. If you adopt the system of rotation quite general in this sectionsay, 1st year, co:n on sod; $2 \mathrm{~d}$, barley or oats; $3 \mathrm{~d}$, wheat; 4 th, clover for hay and afterwards for seed; 5th, timothy and clover for hay; and then the 6th year plowed up for corn again-it would be necessary to make the land rich enough to produce say 100 bushels shelled corn, 50 bushels of barley, 40 bushels of wheat, 3 tons clover-hay, and 5 bushels of clover-seed, and 3 tons clover and timothy-hay per acre. This would be moderate high farming. If we introduced lucern, Italian rye-grass, corn-fodder, and mangelwurzel into tile rotation, we should need still richer land to proluce a maximum growth of these crops. In other words, we should need more manure.

The point I am endeavoring to get at, is this: Where you want a farm to be self-supporting-where you depend solely on the produce of the farm to supply manure-it is a sheer impossibility to adopt high farming on the vohole of your land. I want to raise just as large crops per acre as the high farmers, but there is no way of doing this, unless we go outside the farm for manure, without raising a smaller area of such crops as are sold from the farm.

I do not wish any one to suppose that I am opposed to high farming. There is occasionally a farm where it may be practised with advantage, but it seems perfectly clear to my mind that as long as there is such an unlimited supply of land, and such a limited supply of fertilizers, most of us will find it more profitable to develop the latent stores of plant-food lying dormant in the soil ratner than to buy manures. And it is certain that you can not adopt high farming without either buying manure directly, or buying food to feed to animals that sball make manure on the farm.

And you must recollect that high farming requires an increased 
supply of labor, and bired help is a luxury almost as costly as artumcial fertilizers.

We have heard superficial thinkers object to agricultural papers on the ground that they were urging farmers to improve their land and jroduce larger crops, "while," say they, "we are producing so much already that it will not sell for as much as it costs to produce it." My plan of improved agriculture does not necessarily imply the production of any more wheat or of any more grain of any kiad that we sell than we raise at present. I would simply raise it on fewer acres, and thus lessen the expense for seed, cultivation, harvesting, etc. I would raise 30 bushels of wheat per acre every third year, instead of 10 bushels every year.

If we summer-fallowed aud plowed under clover in order to produce the 30 bushels of wheat once in three years, insteal of 10 bushels every year, no more produce of any lind would be raiscd. But my plan does not contemplate such a resuit. On my own farm I seldom summer-fallow, and never plow under clover. I think I can enrich the farm nearly as much by feeding the clorer to a.imals and returning the manure to the lind. The animals do not take out more than from five to ten per cent of the more valuable elements of plant-food from the clover. And so my plan, while it produces as much and no more grain to scll, adds grcatly to the fertility of the land, and gives an increased production of beef, mutton, wool, butter, cheese, and pork.

"But what is a man to do who is poor and has poor land?" If he has good health, is industrious, economical, and is possessed of a fair share of good common sense, he need have no doubt as to being able to renovate his farm and improve his own fortune.

Faith in good farming is the first requisite. If this is weak, it will be strengthened by exercise. If you have not faith, act as thoug's you had.

Work hard, but do not be a drudge. A few hours' vigorous labor will accomplish a great deal, and cncourage you to continued effort. Be prompt, systematic, cheerful, and enthusiastic, Go to bed early and get up when you wake. But take sleep cnough. A man had better be in bed than at the tavern or grocery. Let not friends, even, keep you up late; "manners is manners, but still your elth's your elth."

"But what has this to do with good farming?" More than chemistry and all the science of the schools. Agricuiture is an art and must be followed as such. Science will help-help enormously -but it will never enable us to dispense with industry. Chemistry 
throws great light on the art of cooking, but a farmer's wife will roast a turkey better than a Liebig.

When Mr. James O. Sheldon, of Geneva, N. Y., bought his farm, his entire crop of hay the first year was 76 loads. He kept stock, and bought more or less grain and bran, and in eleven years from that time his farm produced 430 loads of hay, afforded pasture for his large herd of Shorthorn cattle, and produced quite as much grain as when he first took it.

Except in the neighborbood of large cities, "high farming" may not pay, owing to the fact that we have so much land. But whether this is so or not, there can be no doubt that the only profitable system of farming is to raise large crops on such land as we cultivate. High farming gives us large crops, and many of them. At present, while we have so much land in proportion to population, we must, perhaps, be content with large crops of grain, and few of them. We must adopt the slower but less expensive means of enriching our land from natural sources, rather than the quicker, more artificial. and costly means adopted by many farmers in Englan 1, and by market garleners, seed-growers, and nurserymen in this country. Labor is so high that we can not affort to raiso a small crop. If we sow but half the number of acres, and double the yiell, we should quadruple our profits. I have made up my mind to let the land lie in clover thrce years, insteal of two. This will lessen the number of acres under cultivation, and enable us to bestow more care in plowing and cleaning it. And the land will be richer, and produce better crops. The atmosphere is capable of supplying a certain quantity of ammonia to the soil in rains and dews every year, and by giving the wheat crop a three years supply instead of two years, we gain so much. Plaster the clover, top-dress it in the fall, if you have the manure, and stimulate its growth in every way possible, and consume all the clover on the land, or in the barn-yard. Do not sell a single ton; lct not a weed grow, and the land will certainly improve.

The first object should be to destroy wceds. I do not know how it is in other sections, but with us the majority of farms are com. pletely overrun with weeds. They are eating out the life of the land, and if something is not done to destroy them, even exorbitantly high prices can not make farming protitable. A farmer yesterday was contenciing that it did not pay to summer-fallow. $\mathrm{He}$ has taken a run-down farm, and a year ago last spring he plowed up ten acres of a field, and sowed it to barley and oats. The remainder of the field he summer-fallowed, plowing it four times, and rolling and harrowing thoroughly after each plowing. After 
the barley and oats were off, he plowed the land once, harrowed it: and sowed Medterranean wheat. On the summer-fallow he drilled in Diehl wheat. He has just threshed, and got 22 bushels per acre of Kiediterranean wheat after the spring crop, at one plowing, and 26 bushels per acre of Diehl wheat on the summerfallow. T'uis, he said, would not pay, as it cost him $\$ 20$ per acre to summer-fallow, and he lost the use of the land for one season. Now this may be all true, and yet it is no argument against summer-fallowing. Wait a few years. Farming is slow work. Mr. George Geddes remarked to me, when I told him I was trying to renovate a run-down farm, "you will find it the work of ycur life." We ought not to expect a big crop on poor, run-down land, simply by plowing it three or four times in as many months. Time is required for the chemical changes to take place in the soil. But watch the effect on the clover for the next two years, and when the land is plowed again, sce if it is not in far bettcr condition than the part not summer-fallowed. I should expect the clover on the summer-fallow to be fully one-third better in quantity, and of better quality than on the other part, and this extra quantity of clover will make an extra quantity of cood manure, and thus we have the means of going on with the work of inproving the farm.

"Yes," said the Dostor, "and there will also be more cl=verroots in the sjil."

"But I can not afford to wait for clover, and summer-fallowing," writes an intelligent New York gentleman, a dear lover of good stock, who has bought an exhausted New England farm, "I must have a portion of it producing good crops right off." Very well. A farmer with plenty of money can do wonders in a short time. Set a gang of ditchers to work, and put in underdrains where most needed. Have teams and plows cnourh to do the work rapidly. As soon as the land is drained and plowed, put on a heavy roller. Then sow 500 lbs. of Peruvinn guano per acre broadcast, or its cquivalent in some other fertilizer. Follow with a Sharcs' harrow. This will mellow the surface and cover the guano without disturbingु the sod. Foilow with a forty-toothed harrow, and roll agrain, if needed, working the land until there is three or four inches of fine, mellow surface soil. Then mark off the land in rows as straight as an arrow, and plant corn. Cultivate thorcughly. and kill every weed. If the ditchers can not get through until it is too late to plant corn, drill in beans on the last draincd part of the field.

Another good crop to rais? on a stock farm is corn-fodier. This can be d:illed in from time to time as the land car, he got 
ready. Put on half a ton of guano per acre and harrow in and then maris off the rows three feet apart, and drill in four huslcls of corn per acre. Cultivate thoroughly, and expect a great crop. By the last of July, the Ayrshire cows will take kindly to the succulent corn-fodder, and with three or four quarts of meal a day, it will enable each of them to make $10 \mathrm{lbs}$. of butter a week.

For the pigs, sow a few acres of peas. These will do well on sod-land, sown early or late, or a part early and a part late, as most convenient. Sow broadcast and harrow in, $500 \mathrm{lbs}$. of Peruvian guano per acre and 200 lbs. of gypsum. Drill in three bushels of peas per acre, or sow broadcast, and cover them with a Shares' harrow. Commence to feed the crop green as sonn as the pods are formed, and contiau s to fced out the crop, threshed or unthreshed, until the midale of November. Up to this time the bugs do comparatively little damage. The pigs will thrive wonderfully on this crop, and make the richest and best of manure.

I have little faith in any attempt to raise root crops on land not previously well prepared. But as it is necessary to have some mangel-wurzel and Swede turnips for the Ayrshire cows and long-wool sheep next winter and spring, select the cleanest and richest land that can be found that was under cultivation last season. If fall plowed, the chances of success will be doubled. Plow the land two or three times, and cultivate, harrow, and roll until it is as mellow as a garden. Sow $400 \mathrm{lbs}$. of Peruvian guano and $300 \mathrm{libs}$. of good superphosphate per acre broadcast, and harrow them in. Ridge up the land into ridges $2 \frac{1}{2}$ to $3 \mathrm{ft}$. apart, with a double mould-board plow. Roll down the ridges with a light roller, and drill in the seed. Sow the mangel-wurzel in May-the earlier the better-and the Swedes as soon afterwards as the land can be thoroughly prepared. Better delay until June rather than sow on rough land.

The first point on such a farm will be to attend to the grass land. This affords the most hopeful chance of getting good. returns the first year. But no time is to be lost. Sow $500 \mathrm{lbs}$. of Peruvian guano per acre on all the grass land and on the clover, with 200 lbs. of gypsum in addition on the latter. If this is sown early enough, so that the spring rains dissolve it and wash it into the soil, great crops of grass may be expected.

"But will it pay?" My friend in New York is a very energetic and successful business man, and he has a real love for farming, and I have no sort of doubt that, taking the New York business and the farm together, they will afford a very handsome profit. Furthermore, I have no doubt that if, after he has drined it, he 
would cover the whole farm with $500 \mathrm{lbs}$. of Peruvian guano per acre, or its equivalent, it would pay him better than any other agricultural operation he is likely to engage in. By the time it was on the land the cost would amount to about $\$ 20$ per acre. If he sells no more grass or hay from the farm than he would sell if he did not use the guano, this $\$ 20$ may very properly be added to the permanent capital invested in the farm. And in this aspect of the case, I have no hesitation in saying it will pay a high rate of intcrest. His bill for labor will be as much in one case as in the other; and if he uses the guano he will probably double his crops. His grass lands will carry twenty cows instead of ten, and if he raises the corn-fodder and roots, he can probably keep thirty cows better than he could otherwise keep a dozen; and, laving to keep a herdsman in either case, tha cost of labor will not be much increased. "But you think it will not pay?" It will probably not pay him. I do not think $h: s$ business would pay me if I lived on my farm, and went to New York only once or twice a week. If there is one business above all others that requires constant atiention, it is farming-and especially stock-farming. But my friend is right in saying that he cannot afford to wait to enrich his land by clover and summer-fallowing. His land costs too much; he has a large barn and everything requisite to keep a large stock of cattle and sheep. The interest on farm and buildings, and the money expended in labor, would run on while the dormant matter in the soil was slowly becoming available under the influence of good tillinge. The large barn must be filled at once, and the only way to do this is to apply manure with an unsparing hand. If he lived on the farm, I should have no doubt that, by adopting this course, and by keeping improved stock, and feeding liberally, he could make money. Perhaps he can find a man who will successfully manage the farm under his direction, but the probabilities are that his present profit and pleasure will come from the gratification of his early love for country life. 


\section{H A P T E R I I.}

\section{WHAT IS MANURE?}

"What is the good of asking such a question as that ?" said the Deacon; "we all know what manure is."

"Well, then," I replied, "tell us what it is?"

"It is anything that will make crops grow better and bigger," replied the Deacon.

"That is not a bad definition," said I; " but let us see if it is a true one. You have two rows of cabbage in the garden, and you water one row, and the plants grow bigger and better. Is water manure? You cover a plant with a hand-glass, and it grows bigger and better. Is a hand-glass manure? You shelter a few plants, and they grow bigger and better. Is shelter manure? You put some pure sand round a few plants, and they grow biggor and hetter. Is pure sand manure? I thinis we shall ha re to reject the Deacon's definition."

Let us hear what the Doctor has to say on the subject.

"Manure," replied the Doctor, "is the food of plants."

"That is a better definition," said I; "but this is really not answering the question. You say manure is plant-food. But what is plant-food ?"

"Plant-food," said the Doctor, "is composed of twelve elements, and, possibly, sometimes one or two more, which we need not here talk about. Four of these elements are gases, oxygen, hydrogen, carbon, and nitrogen. When a plant or animal is burnt, these gases are driven off. The ashes which remain are composed of potash, soda, lime, and magnesia; sulphuric acid, phosphoric acid, chlorine, and silica. In other words, the 'food of plants' is composed of four organic, or gaseous elements, and eight inorganic, or mineral elements, of which four have acid ant four alkaline properties."

"Thank you, Doctor," said the Deacon, "I am glad to knnw what manure is. It is the food of plants, and the food of plants is composed of four gases, four acid and four alkaline elements. I seem to know all about it. All I have wanted to make my land rich was plenty of manure, and now I shall know where to get it-oxygen, hydrogen, carbon, and nitrogen; these four atmospheric elements. Then potash, soda, magnesia, and lime. I know what these four are. Then sulphur, phosphorous, silica 
(sand,) and chlorine (salt). I shall soon have rich land and big crops."

Charley, who has recently come home from college, where he has been studying chemistry, looked at the Deacon, and was evidently puzzled to understand him. Turning to the Doctor, Charley asked modestly if what the Doctor had said in regard to the composition of plant-food could not be said of the composition of all our animals and plants.

"Certainly," replied the Doctor, "all our agricultural plants and all our animals, man included, are composed of thise twelve elements, oxygen, hydrogen, carbon, and nitrogen; phosphorus, sulphur, silica, chlorine, potash, soda, magnesia, and lime."

Charley said something about lime, potash, and soda, not being "elements;" and something about silica and chlorine not being found in animals.

"Yes," said I, " and be has left out iron, which is an important constituent of all our farm crops and animals." Neither the Doctor nor the Deacon keard our remarks. The Deacon, who loves an argument, exclaimed: "I thought I knew all about it. You told us that manure was the food of plants, and that the food of plants was composed of the above twelve elements; and now you tcll us that man and beast, fruit and flower, grain and grass, root, stem, and branch, all are composed or made up of these same dozen elements. If I ask you what bread is made of, you say it is compused of the dozen elements aforesaid. If I ask what whicatstraw is made of, you answer, the dozen. If I ask what a thistle is made of, you say the dozen. There are a good many milk-weeds in my strawberry patch, and I am glad to know that the milk-weed and the strawberry are both composed of the same dozen elements. Manure is the food of plants, and the food of plants is composed of the above dozen elements, and every plant and animal that we eat is also composed of these same dozen clements, and so I suppose there is no difference between an onion and an omelet, or between bread and milk, or between mangel-wurzel and manure."

"The difference," replied the Doctor, "is one of proportion. Mangels and manure are both composed of the same elements. In fact, mangels make good manure, and good manure makes good mangels."

The Deacon and the Doctor sat down to a game of backgammon, and Charley and I continued the conversation more seriously. 


\section{H A P T E R I I I. \\ SOMETHING ABOUT PLANT-FOOD.}

"The Doctor is in the main correct," said I; " but he does not fully answer the question, 'What is manure ?' To say tnat manure is plant-food, does not cover the whole ground. All soils on which plants grow, contain more or less plant-food. A plant can not create an atom of potash. It can not get it from the atmospherc. We find potash in the plant, and we know that it got it from the soil, and we are certain, therefore, that the soil coatains potash. And so of all the other mineral clements of plants. A suil that will produce a thistle, or a pig-weed, contains plant-food. And so the definition of the Doctor is defective, inasmuch as it makes no distinction between soil and manure. Both contain plant-food."

"What is your definition of manure?" asked Charley; "it would seem as though we all knew what manure was. We have got a great heap of it in the yard, and it is fermenting nicely."

"Yes," I replied, "we are making more manure on the farm this winter than ever before. Two hundred pims, 120 large sheep, 8 horses, 11 cows, and a hundred head of poaltry make considerable manure; and it is a good deal of work to clean out the pens, pile the manure, draw it to the field, and apply it to the crops. We ought to know something about it ; but we might work among manure all our lives, and not know what manure is. At any rate, we might not, be able to define it accurately. I will, however, try my hand at a definition.

"Let us assume that we have a ficld that is free from stagnant water at all seasons of the year; that the soil is clean, mellow, and well worked seven inches deep, and in good order for putting in a crop. What the coming 'season' will bo we know not. It may be what we call a hot, dry summer, or it may be cool and moist, or it may be partly one and partly the other. The 'season' is a great element of uncertainty in all our farming calculations; but we know that we shall have a season of some kind. We have the promise of səed-time and harvest, and we have ncrer known t'ie promise to fail us. Crops, however, vary very much, accoriing to the season; and it is necessary to bear this fact in mind. Let us say that the sun and heat, and rain and dews, or what we call 'the season,' is capable of producing 50 bushels of wheat per acre, but that the soil $I$ have described above, does not produce over 20 bushels per acre. There is no mechanical defect in the s.il. The seed is good, it is put in properly, and at the right time, 
and in the best manner. No weeds choke the wheat plants or rob them of their food; but that field does not produce as much wheat by 30 bushels per acre as the season is capable of producing. Why? The answer is evident. Because the wheat plants do not find food enough in the so.l. Now, anything that will furnish this food, anything that will cause that field to produce what the climate or season is capable of producing, is manure. A garlener may increase his crops by artíicial heat, or by an increased supply of water, but this is not manure. The effect is due to improved climatic conditions. It has nothing to do with the question of manure. We often read in the agricultural papers about 'shade as manure.' We might just as well talk about sunlight as 'manure.' The effects observed should be-referred to modifications of the climate or season; and so in regard to mulching. A good mulch may often produce a larger incresse of growth than an application of manure. But mulch, proper, is not manure. It is climate. It checks evaporation of moisture from the soil. We might as well speak of rain as manure as to call a mulc' manurc. In fact, an ordinary shower in summer is little more than a mulch. It does not reach the roots of plants; and yet we see t'se effect of the shower immediately in tha increased vigor of the plants. They are full of sap, and the drooping leaves look refreshed. We say the rain has revived them, and so it has; but probably not a particle of the raiz has entered into the circulation of the plant. The rain checked evaporation from the soil and from the leaves. A cool night refreshes the plants, and fills the loaves with sap, precisely in the same way. All these fertilizing effects, however, belong to climate. It is inaccurate to associats either mulching, sunshine, shade, heat, dews, or rain, with the question of manure, though the effect may in certain circumstances be presisely t'xe same."

Charley evidently thought I was wandering from the point. "You think, then," said he, "manure is plant-food that the soil necds?"

"Yes," said I, "that is a very good dofinition-very gool, indeed, though not absolutely accurate, because manure is manure. whether a particular soil needs it or not." Unobserved by us, tho Deacon and the Doctor had been listening to our talk.- "I would like," said the Deacon, "to hear you give a better definition than Charley has given."- M inure," said I, " is anything containing an element or elements of plant-foor, which, if the soil needed it, would, if supplied in sufficient quantity, and in an available condition, produce, accorling to soil, saason, climate, and variety, a maximum crop." 


\section{II A P T E R I V.}

\section{NATURAL MANURE.}

We often hear about "naturll" manurs. I do not like the term, though I believe it originated with me. It is not accurate; not definite enough.

"I ào not know what you mean by natural manure," said the Dearo:, "unless it is the droppings of animals." - "To distinguish tiem, I suppose," said the Doctor, "from artificial manures, such as superphosphate, sulphate of ammonia, and nitrate of soda." "No; that is not how I used the term. A few years ago, we used to hear muc's ia regard to the 'exhaustion of soils.' I thought this phras conveyed a wrong ilea. When new land produces large crops, and when, after a few years, the crops get less and loss, we were toll that the farmcrs were exhausting thcir land. I said, no; the farmers are not exhausting the soil ; they are merely exhausting the accumulated plant-food in the soil. In other words, they are using up the natural mxnure.

"Take my own farm. Fifty years ago, it was covered with a heavy growth of maple, bəech, black walnut, oak, and other trees. These trees had shel annual crops of leaves for centuries. The leaves rot on the grould; the tress also, age after age. These leaves and other organiz matter form what I have called natur 1 manure. When the land is cleared up and plowed, this natural manure decays more rapidly than when the land lies undisturbed; precisely as a manure-pile will ferment and decay more rapidly if turaed occasionally, and exposed to the air. The plowing and cultivating renders this natural manure more readily availalle. The leaves decompose, and furnish food for the growing crop."

\section{EXHAUSTION OF THE SOIL.}

"You think, t'ien," said the Doctor, "that when a piece of land is cleared of the forest, harrowed, and sown to wheat; plowed and planted to corn, and the process repeated again and again, until the land no longer yields profitable crops, that it is the 'natural manure,' and not the soil, that is exhauste 1 ?"

"I think t'le soil, at any rate, is not exhausted, and I can casily conceive of a case where even the natural manure is very far from being all used up."

"Why, then," asked t'ie Dexcon, "is the land so poor t'zat it will searcely sup'ort a slicep to the acre?" 
"Si.nply because the natural manurs and ot'ser plant-food which the soil contains is not in an available condition. It lies dead and inert. It is not soluble, and the roots of the plants cannot get enough of it to enable then to thrive; and in addition to this, you will find as a matter of fact that these poor ' exhausted' farms are infested with weeds, which rob the growing crops of a large part of the scanty supply of available plant-food."

"But these weeds," suid the Deacon, "are not removed from the farm. They rot on the land ; nothing is lost."

"True," said I, " but they, nevertheless, rob the growing crops of available plant-food. The annual supply of plant-food, instcad of being used to grow useful plunts, is used to grow weeds."

"I underst ind that," siid the Deacon, "but if the weeds are left on the land, and the useful plants are sold, the farmor who keeps his land clean would exhaust his land faster than the carcless farmer who lets his land lie until it is ovcrrun with thistles, briars, and pig-weed. You agricultural writers, who are constuntly urging us to farm better and grow larger crops, seem to overlook this point. As you know, I do not take much stock in chemical theories as applied to agriculture, but as you do, here is a little extract I cut from an agricultural paper, that secms to prove that the better you work your land, and the larger crops you raise, the sooner you exhaust your land."

The Deacon put on his spectacles, drew his chair nearer the lamp on the table, and read the following:

"There is, on an average, about one-fourth of a pound of potish to every one hundred pounds of soil, and about one-cighth of a pound of phosphoric acid, and one-sixteenth of a pound of sulplruric acid. If the potatoes and the tops are continually remored from the soil, it will soon exhaust the potash. If the wheat and straw ar 3 removed, it will soon exhaust the phosphate of lime; if coril and the stalks, it will soon exhaust the sulphuric acid. Unless there is a rotation, or the material the plant requires is supplied from abroad, your crops will soon run out, though the soil will continue rich for other plants."

"That extract," said I, "carries one back twenty-five years. We used to have article after article in this strain. We were told that "always taking meal out of the tub soon comes to the bottom, and always taking potash and phosphoric acid from the soil will soon exhaust the supply. But, practically, there is really litt:o danger of our exhausting the land. It doss not pay. The farmer's resources will be exhausted long befor? he can e:-hust his farm." 
"Assuming," said the Doctor, who is fond of an argument, "that the above statement is true, let us loo' $\mathrm{z}$ at tise facts. An acre of soil, 12 inches deep, would weigh about 1,600 tons; and if, as the writer quoted by the Deacon states, the soil contains 4 ozs. of potash in every $100 \mathrm{lbs}$. of soil, it follows that an acre of soil, 12 inches deep, contains 8,000 lbs. of potash. Now, potatoes contain about 20 per cent of dry matter, and tisis dry matter contains, say, 4 per cent of as'., half of which is potash. It follow, therefore, that 250 bushels of potatoes contain about $60 \mathrm{lbs}$. of potash. If we reckon that the tops contain $20 \mathrm{lbs}$. more, or 80 lbs. in all, it follows that the acre of soil contains potash enough to grow an annual crop of 250 bushels of potatoes per acre for one hundred years."

"I know farmers," said Charley, "who do not get over 50 bushels of potatoes per acre, and in that case the potash would last five hundred years, as the weeds grown with the crop are left on the land, and do not, according to the Dcacon, exhaust the soil."

"Good for you, Charlcy," sail the Doctor. "Now let us see about the phosphoric acid, of which the soil, according to the above statement, contains only balf as much as it contains of potash, or 4,000 lbs. per acre.

"A crop of wheat of 30 bushels per acre," continucd the Doctor, "contains in the grain about 26 lbs. of as', and we will say that half of this ash is phosphoric acid, or $13 \mathrm{lbs}$. Allowing that the straw, chaff, etc., contain 7 lbs. more, we remove from the soil in a crop of wheat of 30 bushels per acre, $20 \mathrm{lbs}$. of phosphoric acid, and so, according to the above estimate, an acro of soil contains phosphoric acid to produce annually a crop of wheat and straw of 30 bushels per acre for two hundred years.

"The writer of the paragraph quoted by the Deacon," continued the Doetor, "selected the crops an 1 elemen's best suited to his purpose, and yct, according to his own estimate, there is sufficient potash and phosphoric acid in the first 12 inches of the soil to enablc us to raise unusually large crops until the next Centenni.l in 1976 .

"But let us taks another view of the subject," continued t'se Doctor. "No intelligent farmcr removes all the potatoes and tops, all the wheat, straw, and chaff, or all the corn and stalks from his farm. According to Dr. Sulisbury, a crop of corn of 75 bushels per aere removes from the soil $600 \mathrm{lbs}$. of ash, but the grain contains only $46 \mathrm{lbs}$. The other $554 \mathrm{lbs}$. is contained in the stalls, etc., all of which are usually retained on the farm. It.follows 
trom this, that when only the grain is sold off the farm, it takes more than thirteen crops to remove as much mineral matter from the soil as is contained in the whole of one crop. Again, the ash of the grain contains less than 3 per cent of sulphuric acid, so that the $46 \mathrm{lbs}$. of ash, in 75 bushels of corn, contains less than $1 \frac{1}{2}$ lbs. of sulphuric acid, and thus, if an acre of soil contains 2,000 lbs. of sulphuric acid, we have sufficient for an annual crop of $i 5$ bushels per acre for fifteen hundred years!

"As I said before," continued the Doctor, "intelligent farmers sel.lom sell their straw, and they frequently purchase and consume on the farm nearly as much bran, shorts, etc., as is sent to market with the grain they sell. In the 'Natural History of New York,' it is stated that an acre of wheat in Western New York, of 30 bushels per acre, including straw, chaff, etc., removes from the soil 144 lbs. of mineral mattor. Ganesee wheat usually yields about 80 per cent of flour. This flour contains only 0.7 per cent of mineral matter, while fine middlings contain 4 per cent; coarse middlings, $5 \frac{1}{2}$ per cent; shorts, 8 per cent, and bran $8 \frac{1}{2}$ per cent of mineral matter or ash. It follows from this, that out of the 144 ibs. of mineral matter in the crop of wheat, less than $10 \mathrm{lbs}$. is contained in the flour. The remaining $134 \mathrm{lbs}$. is found in the straw, chaff, bran, shorts, etc., which a good farmer is almost sure to feed out on his farm. But even if the farmer feeds out none of his wheat-bran, but sells it all with his wheat, the 30 bushels of wheat remove from the soil only $26 \mathrm{lbs}$. of mincral matter; and it would take more than five crops to remove as much mincral matter as one crop of whcat and straw contains. Allowing that half the asis of wheat is phosphoric acid, 30 bushels remove only 13 lbs. from the soil, and if the soil contains $4,000 \mathrm{lbs}$., it will take three hundred and seven crops, of 30 bushels each, to exhaust it."

"That is to say," said Charley, "if all the straw and chaff is retained on the farm, and is returned to the land without loss of phosphoric acid."

"Yes," said the Doctor, " and if all t'xe bran and shorts, etc., were retained on the farm, it would take eight hundred crops to exhaust the soil of phosphoric acid; and it is admitted that of all the elements of plant-food, phosphoric acid is the one first to be exhausted from the soil."

I have sold some timothy hay this winter, and propose to do so whenever the price suits. But some of my neighbors, who do not hesitate to sell their own hay, think I ought not to do so, because I "write for the papers"! It ought to satisfy them to know that I bring back $\mathrm{E} 0 \mathrm{cwt}$. of bran for every ton of hay I 
sell. My rulo is to sell nothing but wijeat, barley, beans, potatoes, clover-seed, apples, wool, mutton, beer, pork, and butter. Every. thing else is consumed on the farm-corn, peas, oats, mustard, rape, mangels, clover, straw, stalks, etc. Let us make a rough estimate of how much is sold and how much retained on a hundred-acre farm, leaving out the potatoes, beans, and live-stock. We have say :

Sold.

15 acres wheat, @ 40 bushels per acre.....................18 tons

5 “ barley, @ 50 " "

15 " clover seed, 4 " "

Total sold...................................25? tons.

Retained on the farm.

15 acres corn, @ 80 bushels per acre..................... 33 tons.

Corn stalks from do................................ 40 "

5 acres barley straw.............................. 8

10 " oats and peas, equal 80 bushels of oats............ 127

Straw from do....................................

15 acres wheat-straw................................25 "

15 " clover-hay................................ 25

Clover-seed straw..................................

15 acres pasture and meadow, equal 40 tons hay........... 40 "

5 " mustard, equal 10 tons hay. ................... 10 "

5 " rape, equal 10 tons hay........................ 10 "

5 " mangels, 25 tons per acre, equal to 3 tons dry....... 15 "

Leaves from do................................ 3 "

Total retained on the farm .................... $252 \frac{1}{4}$ tons.

It would take a good many years to exhaust any ordinary soil by such a course of cropping. Except, perhaps, the sandy knolls, I think there is not an acre on my farm that would be exhausted in ten thousand years, and as some portions of the low alluvial soil will grow crops without manure, there will be an opporturity to give the poor, sandy knolls more than their share of plant-food. In this way, notwithstanding the fact that we sell produce and bring nothing back, I believe the whole farm will gradually increase in productiveness. The plant-food annually rendered available from the decomposition and disintegration of the inert organic and mineral matter in the soil, will be more than equal to that exported from the farm. If the soil becomes deficient in anything, it is likely that it will be in phosphates, and a little superphosphate or bone-dust might at any rate be profitably used on the rape, mustard, and turnips.

The puint in good farming is to devalop from the latent stores 
in tise soil, and to accumulate cnough available plaut-food for the production of the largest possible yield of those crops which we sell. In other words, we want enough arailable plant-food in the soil to grow 40 bushels of wheat and 50 bushels of barley. I think the farmer who raises 10 tons for every ton he sells, will soon reach this point, and when once reached, it is a comparatively easy matter $t \mathrm{~s}$ maintain this degree of fertility.

\section{WHY OUR CROPS ARE SO POOR.}

"If the soil is so rich in plant-food," said the Deacon, "I again ask, why are our crops so poor?"

The Deacon said this very quietly. He did not seem to know that he had asked one of the most important questions in the whole range of agricultural science. It is a fact that a soil may contain enough plant-food to produce a thousand large crops, and yet the crops we obtain from it may be so poor as hardly to pay the cost of cultivation. The plant-food is there, but the plants cannot get at it. It is not in an available condition; it is not soluhle. A case is quoted by Prof. Johnson, where a soil was analyzed, and found to contain to the deptl of one foot $4,652 \mathrm{lbs}$. of nitrogen per acre, but only $63 \mathrm{lbs}$. of this was in an available condition. And this is equally true of phosphoric acid, potash, and other elements of plant-food. No matter how much plant-food there may be in the soil, the only portion that is of any immediate value is the small amount that is annually available for the growth of crops.

\section{HOW TO GET LARGER CROPS.}

"I am tired of so much talk about plaut-food," said the Deacon; "what we want to know is how to make our land produce larger crops of wheat, corn, oats, barley, potatoes, clover, and grass."

'This is precisely what I am trying to show. On my own farm, the three leading objects are (1) to get the land clrained, (2) to make it clean and mellow, and (3) to get available nitrogen for the cereal crops. \& "ter the first two ohjects are accomplished, the measure of productiveness will be determined by the amount of available nitrogen in the soil. How to get available nitrogen, thereforc, is my chief and ultimate ohject in all the operations on the farm, and it is here that science can help me. I know how to get nitrogen, but I want to get it in tho cheapest way, and then to be sure that I do not waste it.

There is one fact fully est ıblishel by repeated experiment and general experience-that 80 lbs. of available nitrogen per acre, 
applied in manure, will almost invariably give us a greatly increased yield of grain crops. I should expe:t, on my farm, that on land which, without manure, would give me 15 busheis of wheat per acre, such a dressing of manure would give me, in a favorable season, 35 or 40 bushels per acre, with a proportional increase of straw ; and, in additio. to this, there would be cossidcrable nitrogen left for the following crop of clover. Is it not worth whila making an earnest effort to get this $80 \mathrm{lbs}$. of available nitrogen ?

I have on my farm many acres of low, mucky land, bordering on the creek, that probably contain several thousand pounds of nitrogen per acre. So long as the land is surcharged with watcr, this nitrogen, and oth?r plant-food, lies dormant. But drain it, and let in the air, and the oxygen decomposes the organic malter, and ammonia and nitric acid are produced. In other words, we get available nitrogen and other plant-food, and the land becomes capable of produciang large crops of corn and grass; and the crops obtained fro:n this low, rich land, will make manure for tise poorer, upland portions of the farm.

\section{- \\ C II $\triangle \mathrm{P} T \mathrm{~T} \Gamma \mathrm{V}$.}

\section{SIVAMP-MUCK OR PEAT AS MANURE.}

"It would pay you," suid the Deacon, "to draw out 200 or 300 loads of muck from the swamp every year, and compost it with your manure."

This may or may not be the cass. It depencs on the composition of the muck, and how much labor it takes to handle it.

"What you should do," said the Doctor, "is to commence s.t the creek, and straighten it. Take a gang of men, and be with them wit's yourself, or get a good foreman to dire:t operations. Commence at $a$, and straighten the creek to $b$, and from $b$ to $c$ (see map on next pag ). Throw all the rich, black mack in a hcap by itself, separate from the sand. You, or your foreman, must be there, or you will not get this done. A good ditcher will throw out a great mass of this loose muck and sand in a day; and you want him to dig, not think. You must do the thinking, and tcll him which is muck, and which is only sand and dirt. When thrown up, this muck, in our dry, hot climate, will, in the course of a few 
months, part with a large amount of water, and it can then be drawn to the barns and stables, and usad for bedding, or for composting with manure. Or if you do not want to draw it to the barn, get some refuse lime fro.n tile lime-kiln, and mix it with the muck after it has been t'urown up a few weeks, and is partially dry. Turn over the heap, and put a few bushels of lime to every cord of the muck, mixing the lime and muck together, leaving the heip in a compact form, and in good shape, to shed the rain.

"When you have straightened, and cleaned out, and deepenc.l the creek," continued the Doctor, "commence at $z$ on the new creek, and cut a ditch through the swamp to $y$. Throw the muck on one side, and the sand on the other. This will give you some

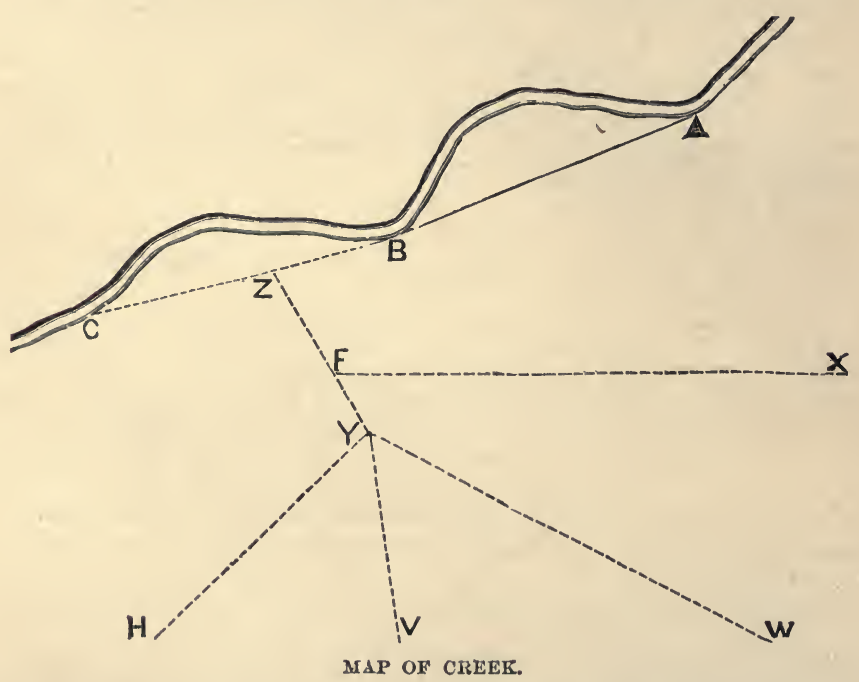

good, rich muck, and at the same time drain your swamp. Then cut some under-drains from $y$ towards the higher land at $w, v$, aud $h$, and from $f$ to $x$. These will drain your land, and set free the inert plant-food, and such crops of timothy as you will get from this swamp will astonish the natives, and your bill for medical attendance and quinine will sink to zero."

The Doctor is right. There is money and health in the plan.

Prof. S. W. Johnson, as chemist to the Conn. State Ag. Society, made accurate analyses of 33 samples of peat and muck sent him by gentlemen from different parts of the State. The amount of 
potential ammonia in the chemically dry peat was found to vary from 0.58 in the poorest, to 4.06 per cent in the richest samples. In other words, one deposit of muck may contain seven times as much nitrogen as another, and it would be well before speiding much money in drawing out muck for manure to send a sample of it to some good chemist. A bed of swamp-muck, easily accessibic, and containing 3 per cent of nitrogen, would be a mine of weaith to any farmer. One ton of such muck, dry, would contain more nitrogen than 7 tons of straw.

"It would be capital stuff," said the Deacon, "to put in your pig-pens to absorb the urine. It wou!d make rich manure."

"That is so," said I, "and the weak point in my pig-breeding is the want of sufficient straw. Pigs use up more bedding than any nther animals. I have over $200 \mathrm{pi}$ rs , and I could use a ton of cry muck to each pig every winter to great advantage. The pens would be drier, the pigs healthier, and the manure richer."

The Doctor here interrupted us. "I see," said he, "that the average amount of ammonia in the 33 samples of dry peat analyzed by Professor Johnson is 2.07 per cent. I had no iclea that muck was so rich. Barn-yard manure, or the manure from the horse stables in the cities, contains only half a per cent (0.5) of ammonia, and it is an unusually rich manure that contains one per cent. We are safs in saying that a ton of dry muck, on the average, contains at least twice as much potential ammonia as the average of our best and richest stable-manure."

\section{H A P T E R V I.}

\section{WHAT IS POTENTIAL AMMONIA ?}

"You say," said the Deacon, "that dry muck contains twice as much 'potential ammonia' as manure?"

"Yes," said the Doctor, "it contains three or four times as much as the half-rotted straw and stalks you call manure."

"But what do you mean," asked the Deacon, "by "potential ammonia?",

"It is a term," said the Doctor, "we used to hear much more frequently than we do now. Ammenia is composed of $14 \mathrm{lbs}$. of nitrogen and $3 \mathrm{lbs}$. of hydrogen; and if, on analysis, a guano or 
other manure was found to contain, in whstever form, 7 per cent of nitrogen, the chemist reported that he found in it $8 \frac{1}{2}$ per cent of 'potential' ammonia. Dried blond contains no ammonia, but if it contained 14 per cent of nitrogen, the chemist would be justified in s.yying it contained 17 per cent of potential ammonia, from the fact that the dried blood, by fermentation, is capabie of yielding this amount of ammonia. We say a ton of common horsemanure contains 10 or $12 \mathrm{lbs}$. of potential ammonia. If perfectly fresh, it may not contain a particle of ammonia; but it contains nitrogen enough to produce, by fermentation, 10 or $12 \mathrm{lbs}$. of ammonia. And when it is said that dry swamp-muck coutains, on the average, 2.07 per cent of potential ammonia, it simply mcans that it contains nitrogen enough to produce this amount of ammonia. In point of fact, I suppos? muck, when dug fresh from the swamp, contains no ammonia. Ammonia is quite soluble in water, and if there was any ammonia in the swamp-muck, it would soon be washed out. The nitrogen, or 'potential ammonia,' in the muck exists in an inert, insoluble form, and before the muck will yield up this nitrogen tu plants, it is necessary, in some way, to ferment or decompose it. But this is a point we will discuss at a future meeting."

\section{$\rightarrow \infty$

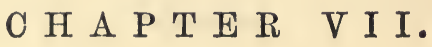

\section{TILLAGE IS MANURE.}

The Doctor has been invited to deliver a lecture on manure before our local Farmers' Club. "The etymological meaning of the word manure," he said, "is hand labor, from main, hand, and ouvrer, to work. To manure the land originally meant to cultivate it, to hoe, to dig, to plow, to harrow, or stir it in any way so as to expose its particles to the oxygen of the atmosphere, and thus render its latent elements assimilable by plants.

"When our first parent," he continued, "was sent forth from the Garden of Eden to till the ground from whence he was taken, he probably did not know that the means necessary to kill the thorns and thistles enhanced the productireness of the soil, yet such was undoubtedly the case. 
"The farmer for centuries was simply a 'tiller of t'ac ground.' Guano, though formed, according to some eminent authorities, long ages before the creation of man, was not then known. The coprolites lay undisturbed in countless numbers in the lias, the greensand, and the Suffolik crag. Charleston p'osphates were unknown. Superphosphate, sulphate of ammonia, nitrate of soda, and kainit were not dreamed of. Nothing was said about the mineral manure theory, or the exhaustion of the soil. There were no frauds in artificial fertilizers; no Experiment Stations. The carth, fres'ı from the hands of its Creator, nee.ed only to be 'tickled with a hoe to laugh with a harvest.' Nothing was said about the value of the manure obtained from the consumption of a ton of oil-cake, or malt-combs, or bran, or clover-hay. Fur many centuries, the hoe, the spade, and the rake constituted Adram's whole stock in trate.

"At length," continued the Doctor, "a great discovery was made. A Roman farmer-probably a prominent Granger-stumbled on a mighty truth. Manuring the land-that is, hoeing and cultivating it-inste.ssed its fertility. This was well known-had been known for ages, and acted upon; but tis Roman farmcr, Stercutius, who was a close observer, discovered that the dioppings of animals had tho same effect as hoeing. No wonder these idolatrous people voted him a got. They thought there would be no more oll-fas'hioned manuring; no more hoeing.

"Of coirse they were mistaken," continued the Doctor, "our arable land will always need plowi"g and cultivating to kill weeds. Manure, in the sense in which we now use the term, is only a partial substitute for tillage, and tillage is only a partial substitute for manure; but it is well to bear in mind that the worls mean the same thing, and the effects of both are, to a certain cxtent, identical. Tillage is manure, and manure is tillage." 


\section{H A P T E R V I I.}

SUMMER-FALLOWING.

This is not tic place to discuss the merits, or demerits, of fallow. ing. But an intelligent Ohio farmer writes me:-"I see thut you recommend fallow plowing, what are your reasons? Granting that the immediate result is un increased crop, is not the land impoverished? Will not the thorough cultivation of corn, or potatoes, answer as well ?" And a distingu shed farmer, of this State, in a recent communication expressed the same idea-that summerfallowing would soon inpoverish the land. But if this is the case, the fault is not in the practice of summcr-fallowing, but in growing too many grain crops, and selling them, instead of consuming them on tie farm. Take two ficlds; summer-fallow one, and sow it to wheat. Plant the other to corn, and sow wheat after it in the fall. You get, say 35 bushels of wheat per acre from the summer-fallow. From the other ficld you get, say, 30 bushels of shelled corn por acre, and 10 bushels of wheat afterwards. Now, where a farmcr is in the habit of selling all his wheat, and consuming all his corn o: the farm, it is evident that the practice of summer-fallowing will impoverish the soil more rapidly than the system of growing corn followed by wheat-and for the simple reason that more wheat is sold from the farm. If no more grin in sold in one case than in the other, the summer-fallowing will not impoverish the soil any more than corn growing.

My idea of fallowing is this:-The soil and the atmosp.ere furnish, on good, well cultivated land, plant-food sufuciert, say, for 15 cushels of wheat pcr acre, every year. It will be sometimes mere, and sometimes less, according to the season and the character of the soil, but oz good, strong liniestone land this may be taken as about the averare. To grow wheat every year in crops of 15 bushels per acre, would impoverish the soil just as much as to summer-fallow and get 30 bushels of wheat every other year. It is the same thing in either case. But in summer-fallowing, we clean the land, and the profits from a crop of 30 bushels per acre every other year, are much more t'inn from two crops of 15 bushels every year. You know that Mr. Lawes has a field of about thirteen acres that he sows with wheat every year. On the plot that receives no manure of any kind, the crop, for twenty years, averaged $16 \frac{1}{4}$ bushels per acre. It is plowed twice every year, and 
the wheat is hand-hoed in the spring to keep it clean. A few years ago, in a field adjoining this experimental wheat field, and that is of the same character of land, he made the following experiment. The land, after wheat, was fallowed, and then sown to wheat; then fallowed the next year, and again sown to wheat, and the next year it was sown to wheat after wheat. The following is the result compared with the yield of the continuously unmanured plot in the experimental field that is sown to wheat every year:

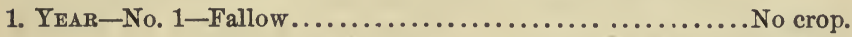

No. 2-Wheat after wheat........15 bushels $3 \frac{2}{\frac{2}{3}}$ pecks per acre.

2. YEAR-No. 1-Wheat after fallow.......37

No. 2-Wheat after wheat.......13 " $"$ " " " "

3. YEAR -No. 1-Fallow after wheat....................... No crop.

No. 2-Wheat after wheat........15 bushels $3 \frac{1}{4}$ pecks per acre.

4. YEAR-No. 1-Wheat after fallow.......42

No. 2-Wheat after wheat........21

5. YEAR-No. 1-Wheat after wheat........17

No. 2-Wheat after wheat........17

$\begin{array}{llll}\text { 6 } & - & 6 & 66 \\ 6 & 0 \frac{1}{4} & 6 & 6 \\ 6 & 1 \frac{1}{8} & 6 & 66\end{array}$

Taking the first four years, we have a total yield from the plot sown every year of 66 bushels $2 \frac{1}{4}$ pecks, and from the two crops alternately fallowed, a total yield of 79 bushels. The next year, when wheat was sown after wheat on the land previously fallowed, the yield was almost identical with the yield from the plot that has grown wheat after wheat for so many years.

So far, these results do not indicate any exhaustion from the practice of fallowing. On the other hand, they tend to show that we can get more wheat by sowing it every other year, than by cropping it every year in succession. The reason for this may be found in the fact that in a fallow the land is more frequently exposed to the atmosphere by repeated plowings and harrowings; and it should be borne in mind that the effect of stirring the land is not necessarily in proportion to the total amount of stirring, but is according to the number of times that fresh particles of soil are exposed to the atmosphere. Two plowings and two harrowings in one week, will not do as much good as two plowings and two harrowings, at different times in the course of three or four mont.hs. It is for this reason that I object, thenretically, to sowing wheat after barley. We often plow the barley stubble twice, and spend considerable labor in getting the land into good condition; but it is generally all done in the course of ten days or two weeks. We do not get any adequate benefit for this labor. We can kill weeds readily at this season, (August), but the stirring of the soil does not develope the latent plant-food to the extent it would if the 
work was not necessarily done in such a limitad period. I say theoretically, for in point of fact I do sow wheat after barley. I au so because it is very convenient, and because it is more immediately profitable. I am satisfied, however, that in the end it would be more profitable to seed down the barley with clover.

We musi raise larger crops; and to co this we must raise them less frequently. This is the key-note of the coming improved system of American agriculture, in all sections where good land is worth less than one hundred dollars per acre. In the neighborhood of large cties, and wherever land commands a high price, we must keep our farms in a high state of fertii:ty by the purchase of manures or cattle foods. Those of us in the interior, where we can not buy manure, must raise fewer grain crops, and more clover. We must aim to raise 40 bushels of wheat, 50 bushels of barley, 80 bushels of oats, and 100 bushels of shelled corn, and 5 bushels of clover-seed per acre. That this can be done on good, well-dr.ined land, from the unaided resources of the farm, I have no doubt. It may give us no more giain to sall than at present, but it will enable us to proluce much more mutton, wool, beef, cheese, butter, and pork, than at present.

"But, then, will there be a demand for the meat, wool, etc.?" The present indications are highly favorable. But we must aim to raise gcod meat. The low-priced beef and mutton sold in our markets are as unprofitable to the consumer as they are to the producer. We must feed higher, and to do this to advantage we must bave improved stock. There is no profit in farming without good tillage, larger crops, improved stock, and higher feedins. The details will be modified by circumstances, but the principles are the same wherever agri-culture is practised. 


\section{H A P T E R I X.}

\section{HOW TO RESTORE A WORN-OUT FARM.}

I have never yet seen a "worn-out" or "exhausted farm." I know many farms that are "run down." I bougut just such a farm a dozen or more years ago, and I liave been trying hard, ever since, to bring it up to a profitable standaru of productiveness-and am still trying, and expect to have to keep on trying so long as I keep on farming. The truth is, there never was a farm so rich, that the farmer did not wish it was richer.

I have succeeded in making the larger part of my farm much more productive than it ever was before, silce it was cleared from the original forest. But it is far from being as rich as I want it. The truth is, God sent us into this world to work, and He his given us plenty to do, if we will only do it. At any rate, this is true of farming. He has not given us land ready to our hand. The man who first cleared up my farm, had no easy task. Ho fairly earned all the good crops he ever got from it. I have nevcr begrudged him one particle of the "natural manure" he took out of the land, in the form of wheat, corn, oats, and hay. On the dry, sandy knolls, he probably got out a good portion of this natural manure, but on the wetter and heavier portions of the farm, he probably did not get uut one-hundredth part of the natural manure which the land contained.

Now, whcn such a farm came into my possession, what was I to do with it ?

"Tell us what you did," said the Doctor, "and then, perhans, we can tell you what you ought to have done, and what you ought to have left undone."

"I made many mistakes."

"Amэn," said the Daacon; "I am gुlad to hear yo" acknowledge it."

"Well," said the Doctor, " it is hetter to make mistakes in trying to do something, than to hug our self-esteem, and fold our hands in indolence. It has been sa $d$ that critics are men who have failed in their undertakings. But I rather think the most disagreeable, and self-satisfied critics, are men who have rever done anything, or tried to do anything, themselves."

The Deacon, who, though something of an old fogy, is a good deal of a man, and possessed of good common sense, and much cx- 
perience, took these remarks kindly. "Well," said he to me, "I must say that your farm bas certainly improved, but you did things so differently trom what we expected, that we could not see what you were driving at."

"I can tell you what I have been aiming at all along. 1st. To drain the wet portions of the arable land. 2d. To kill weeds, and make the soil mellow and clean. 3d. To make more manure."

"You have also bought some bone-dust, superphosphate, and other artificial manures."

"True; and if I had had more money I would have bought more manure. It would have paid well. I could have made my land as rich as it is now in half the time."

I had to depend principally on the natural resources of the land. I got out of the soil all I could, and kept as much of it as possible on the farm. One of the mistakes I made was, in lireaking up too much land, and putting in too much wheat, barley, oats, peas, and corn. It woula have been better for my pockct, though possibly not so good for the farm, if I had left more of the land in grass, and also, if I had summer-fallowed more, and sown less barley ard oats, and planted less corn.

"I do not see how plowing up the grass land," said the Deacon, "could possibly be any better.for the farm. "You agricultural writers are always telling us that we plow too much land, and do not raise grass and clover enough."

"What I meant by saying that it would have been bettcr for my pocket, though possibly not so good for the farm, if I had not plowed so much land, may need explanation. The land had been only half cultivated, and was very foul. The grass and clorcr fields did not give more than half a crop of hay, and the hay was poor in quality, and much of it half thistles, and other weedis. I plowed this land, planted it to corn, and cultivated it thoroughly. But the labo" of keeping the corn clcan was costly, s.nd absorbel a very large slice of the profits. But the corn yielded a far larger produce per arre than I should have got had the lard lain in grass. And as all this produce was constimed on the farm, we made more manure than if we had plowed lcss land."

I have grent faith in the benefits of thorough tillage-or, in othc $r$ words, of hreaking up, pulverizing, and exposing the soil to the decomposing action of the atmosphere. I look upon a good, strong soil as a kind of strrchous of plant-ford. But it is not an easy matter to rencler this plant-food soluble. If it were any less soluble than it is, it would have all leached out of the land center:es ago. Turning over, and fining a manure-heap, if other concitions 
are favorable, cause rapid fermentation with the formation of carbonate of ammonia, and other soluble salts. Many of our soils, to the depth o? eight or ten inches, contain enough nitrogenous mat. ter in an acre to produce two or three thousand pounds of ammonia. By stirring tre soil, and exposing it to the atmosphere, a small portion of this nitrogen becomes annually available, and is taken up by the growing crops. And it is so with the other eleme ts of plant-food. Stirring the soil, then, is the basis of agriculture. It has been said that we must return to the soil as much plant-food as we take from it. If this were true, nothing could be sold from the farm. What we should aim to do, is to develop as much as possible of the plant-food that lies latent in the soil, and not to sell in the form of crops, cheese, wool, or animals, any more of this plant-food than we annually develop from the soil. In this way the "condition" of the soil would remain the same. If we sell less than we develop, the condition of the soil will improve.

By "condition," I mean the amount of available plant-food in the soil. Nearly all our farms are poorer in plant-food to-day than when first cleared of the original forest, or than they were ten, fifteen, or twenty years later. In other words, the plants and animals that have been sold from the farm, have carried off a considerable amount of plant-food. We have taken far more nitrogen, phosphoric acid, potash, etc., out of the soil, than we have returned to it in the shape of manure. Consequently, the soil must contain less and less of plant-food every year. And yet, while this is a self-evident fact, it is, nevertheless, true that many of these sclf-same farms are more productive now than when first cleared, or at any rate more productive than they were twenty-five or thirty years ago.

Sometime ago, the Deacon and I visited the farm of Mr. Dewey, of Monroe Co., N. Y. He is a good farmer. He does not practice "high farming" in the sense in which I use that term. His is a good example of what I term slow farming. He raises large crops, but comparatively few of them. On his farm of 300 acres, he raises 40 acres of wheat, 17 acres of Indian corn, and 23 acres of oats, barley, potatoes, roots, etc. In other words, he has 80 acres in crops, and 220 acres in grass $-\mathrm{no}$. permanent grass. He lets it lie in grass five, six, seven, or eight years, as he deems best, and then breaks it up, and plants it to corn. The land he intends to plant to corn next year, has been in grass for seven years. He will put pretty much all his manure on this land. After corn, it will be sown to oats, or barley; then sown to wheat, and seeded down again. It will then lie in grass three, four, five, six, or seven 
years, until he needs it again for corn, etc. This is "slow farming," but it is also good farming-that is to say, it gives large yields per acre, and a good return for the labor expended.

The soil of this farm is richer to-day in available plant-fooil than when first cleared. It produces larger crops per acre.

Mr. D. called our attention to a fact that establishes this point. An old fence that had occupied the ground for many years was removed some years since, and the two fields thrown into one. Every time this field is in crops, it is easy to see where the old fence was, by the short straw and poor growth on this strip, is compared with the land on each side which had been cultivated for years.

This is precisely the result that I should have expected. If $\mathrm{Mr}$. D. was a poor farmer-if he cropped his land frequently, did not more than half-cultivate it, sold everything he raised, and drew back no manure-I think the old fence-strip would have given the best crops.

The strip of land on which the old fence stood in Mr. Dewey's field, contained more plant-food than the soil on either side of it. But it was not available. It was not developed. It was latent, inert, insoluble, crude, and undecomposed. It was so much dead capital. The land on either side which had been cultivated for years, produced better crops. Why ? Simply because the stirring of the soil had developed more plant-food than had been removed by the crops. If the stirring of the soil developed $100 \mathrm{lbs}$. of plantfood a year, and only $75 \mathrm{lbs}$. were carried off in the crops-25 lbs. being left on the land in the form of roots, stubble, etc.-the land, at the expiration of 40 years, would contain, provided none of it was lost, 1,000 lbs. more available plant-food than the uncultivated strip. On the other hand, the latter would contain $3,000 \mathrm{lbs}$. more actual plant-food per acre than the land which had been cultivated -but it is in an unavailable condition. It is dead capital.

I do not know that I make myself understood, though I would like to do sc, because I am sure there is no point in scientific farming of greater importance. Mr. Geddes calls grass the "pivotal crop" of American agriculture. He deserves our thanks for tho word and the idea connected with it. But I am inclined to think the pivot on which our agriculture stands and rotates, lies deeper than this. The grass crop creates nothing-developes nothing. The untilled and unmanured grass lands of Herkimer County, in this State, are no richer to-day than they were 50 years ago. The pastures of Cheshire, England, except those that have been topdressed with bones, or other manures, are no more productive than 
thcy wcre centuries back. Grass alone will not make rich land. It is a good "savings bank." It gatiers up and saves plant-food from running to waste. It pays a good interest, and is a capital institution. But the real soarce of fertility must be looked for in tirs stores of plant-food lying dormant in the soil. Tillage, underaraining, and 'thorough cultivation, are the means by which we develop and render this plant-foo $d$ available. Grass, clover, peas, or any other crop consumed on the farm, merely affords us the means of saving this plant-food and making it pay a good interest.

\section{CHAPTER X.}

\section{HOW TO MAKE MANURE.}

If we have the necessary materials, it is not a difficult matter to make manure; in fact, the manure will make itself. We sometimes need to hasten the process, and to see t'iat none of the fertilizing matter runs to waste. This is about all that we can do. We cannot create an atom of plant-food. It is ready formed to our hands; but we must know where to look for it, and how to gat it in the easiest, cheapest, and bast way, and how to save and use it. The science of manure-making is a profound study. It is intimately connected with nearly every branch of agriculture.

If weeds grow and decay on the land, they make manure. If we grow a crop of buckwheat, or spurry, or inustard, or rape, or clover, and mow it, and let it lie on the land, it makes manure; or if we plow it under, it forms manure; or if, after it is mown, we rake up the green crop, and put it i to a heap, it will ferment, heat will be produced by the slow combastion of a portion of the carbonaceous and nitrogenous matter, and the result will be a mass of material, which we should all rerognize as "manure." If, instead of putting the crop into a heap and letting it ferment, we feed it to animals, the digestible carbonaceous and nitrogenous matter will be consumed to produce animal heat and to sustain the vital functions, and the refuse, or the solid and liquid droppings of the animals, will be manure.

If the crop rots on the ground, nothing is added to it. If it ferments, and gives out heat, in a heap, nothing is added to it. If it 
is passed through an animal, and produces heat, ncthing is addec to it.

I have heard people say a farmer could not make manure unless he kept animals. We might with as much truth say a farmer cannot make ashes unless he keeps stoves; and it would be just as sensible to take a dot of stoves into the wools to make ashes, as it is to keep a lot of animals merely to make manure. You can make the ashes by throwing the wood into a pile, and burning it; and you can make the manure by throwing the material out oi which the manure is to be made into a pile, and letting it ferment. On a farm where noither food nor manure of any kind is purchased, the only way to make manure is to get it out of tice land.

"From the land and from the atmosphere," remarked the Doctor. "Plants get a large portion of t'se material of which they are composed from the atmosphere."

"Yes," I replied, "but it is principally carbonaceous matter, which is of little or no value as manure. A small amount of ammonia and nitric acid are also brought to the soil by rains and dews, and a freshly-stirred soil may also sometimes absorb more or less ammonia from the atmosphere; but while t'is is true. so far as making manure is concerned, we must look to the plantfood existing in the soil itself.

“Take such a farm as Mr. Dewey's, that we have already referred to. No manure or food has been purchased; or at any rate, not one-tenth as much as has been sold, and yet the farm is more productive to-day than when it was first cleared of the forest. He has developed the manure from the stores of latent plant-food previously existing in the soil and this is the way farmers gen. erally make manure." 


\section{H A P T E R X I.}

\section{THE VALUE OF MANURE DEPENDS ON THE FOOD- NOT ON THE ANIMAL.}

"If," said I, "you should put a ton of cut straw in a heap, wet it, and let it rot down into manure; and should place in another heap a ton of cut corn-fodder, and in another heap a ton of cut cloverhay, wet them, and let them also rot down into manure; and in another heap a ton of pulped-turnips, and in another heap a ton of corn-meal, and in another heap a ton of bran, and in another a ton of malt-sprouts, and let them be mixed with water, and so treated that they will ferment without loss of ammonia or other valuable plant-food, I think no one will say that all these diffcrent heaps of manure will have the same value. And if not, why not?"

"Because," said Charley, "the ton of straw does not contrin as much valuable plant-food as the ton of corn-fodder, nor the ton of corn-fodder as much as the ton of clover-hay."

"Now then," said I, "instead of putting a ton of straw in one heap to rot, and a ton of corn-fodder in another heap, and a ton of clover in another heap, we feed the ton of straw to a cow, and the ton of corn-fodder to another cow, and the ton of clover to another cow, and save all the solid and liquid excrements, will the manuro made from the ton of straw be worth as much as the manure made from the ton of corn-fodder or clover-hay?"

"No," said Charley._- Certainly not," said the Doctor._-"I am not so sure about it," said the Doacon; "I think you will get more manure from the corn-fodder than from the straw or clover-hay."

"We are not talking about bulk," said the Doctor, "but value." "Suppose, Deacon," said he, "you were to shut up a lot of your Brahma hens, and feed them a ton of corn-meal, and should also feed a ton of corn-meal made into slops to a lot of pigs, and should save all the liquid and solid excruments from the pigs, and all the manure from the hens, which would be worth the most ?"- "The hen-manure, of course," said the Deacon, who has great faith in this kind of "guano," as he calls it.

"And yet," said the Doctor, "you would probably not get more than half a ton of manure from the hens, while the liquid and solid excrements from the pigs, if the corn-meal was made into a thin slop, would weigh two or three tons." 

pigs."

"More, too," sail the Deacon, "the way you feel your store

"Very well; and yet you say that the half ton of hen-manure made from a ton of corn is worth more thin the two or three tons of pig-manure made from a ton of corn. You do not seem to think, after a!l, that mere bulk or weight adds anyihing to the value of tue manure. Why then should you say that the manure from a ton of corn-fodder is worth more than from a ton of straw, because it is more bulky?"

"You, yourself," said the Deacon, "also say the manure from tise ton of corn-fodder is worth more than from the ton of straw." - "True," said I " but not because it is more bulky. It is worth more bccause the ton of corn-fodder cortains a greater quantity of valuable plant-food than the ton of straw. The clover is still richer in this valuable plant-food, and the manure is much more valuable ; in fact, the manure from the ton of clover is worth as much as the manure from the ton cf straw and the ton cf cornfodder together."

"I would like to see you prove that," said the Deacon, "for if it is true, I will sell no more clover-hay. I can't get as much for clover-hay in the market as I can for rye-straw."

"I will not attempt to prove it at present," said the Doctor; "but the evidence is so strong and so conclusive that no rational man, who will study the subject, can fail to be thoroughly convinced of its truth."

"The value of manure," sail I, " does not depend on the quantity of watcr w'ich it contains, or on the quantity of sand, or silica, or on the amount of woody fibre or carbonaceous matter. Tisese things add little or nothing to its fertilizing value, except in rare cases; and the sulphuric acid and lime are worth no more than the same quantity of sulphate of lime or gypsum, and the chlorine and soda are probably worth no more than so much common salt. The real chemical value of the manure, otler things being equal, is in proportion to the nitrogen, phosphoric acid, and potash, that the manure contains.

"And the quantity of nitrogen, phosphoric acid, and potash found in the manure is determined, other things being cqual, by the quantity of the nitrogen, phosphoric acid, and potash contained in the food consumed by the animals making the manure." 


\section{H A P T E R X I I .}

\section{FOODS WHICH MAKE RICH MANURE.}

The amount of nitrogen, phosphoric acid, and potash, contained in different foods, has been accurately determined by many able and reliable chemists.

The following table was prepare.1 by Dr. J. B. Lawes, of Rothamsted, England, and was first published in this country in the "Genesee Farmer," for May, 1860. Since then, it has been repeatedly published in nearly all the leading agricultural journals of the world, and has given rise to much discussion. The following is the table, with some recent additions:

\begin{tabular}{|c|c|c|c|c|c|c|}
\hline & \multicolumn{5}{|c|}{ PER CENT. } & \multirow{2}{*}{ 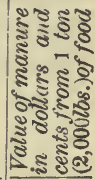 } \\
\hline & 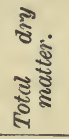 & 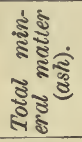 & 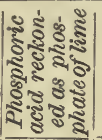 & 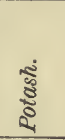 & 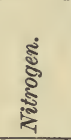 & \\
\hline 1. Linseed cake............. & 88.0 & 7.00 & 4.92 & 1.65 & 4.75 & 19.72 \\
\hline 2. Cotton-seed cake*.. . . & 89.0 & 8.00 & 7.00 & 3.12 & 6.50 & 27.83 \\
\hline 3. Rape-cake............... & 89.0 & 8.00 & 5.75 & 1.76 & 5.00 & 21.01 \\
\hline 4. Linseed.............. & 90.0 & 4.00 & 338 & 1.37 & 3.80 & 15.65 \\
\hline 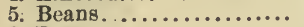 & 81.0 & 3.00 & 2.20 & 1.27 & $4.00=$ & 15.75 \\
\hline 6. Peas................... & 84.5 & 2.40 & 1.84 & 0.96 & 3.40 & 13.38 \\
\hline 7. Tares... & 84.0 & 2.00 & 1.63 & 0.66 & 4.20 & 16.75 \\
\hline 8. Lentils.. & 88.0 & 3.00 & 1.89 & 0.96 & 4.30 & 16.51 \\
\hline 9. Malt-dust. $\ldots \ldots \ldots \ldots \ldots$ & 94.0 & 8.50 & 5.23 & 2.12 & 4.20 & 19.21 \\
\hline 10. Locust beans.............. & 85.0 & 1.75 & & & 1.25 & 4.81 \\
\hline 11. Indian-meal. ............ & 88.0 & 1.30 & 1.13 & 0.35 & 1.80 & 6.65 \\
\hline 12. Wheat. ............... & 85.0 & 1.70 & 187 & 0.50 & 1.80 & 7.08 \\
\hline 13. Barley..................... & 84.0 & 2.20 & 1.35 & 0.55 & 1.65 & 6.32 \\
\hline 14. Malt........ & 95.0 & 2.60 & 1.69 & 0.65 & 1.70 & 6.65 \\
\hline 15. Oats.. & 86.0 & 2.85 & 1.17 & 0.50 & 2.00 & 7.70 \\
\hline 6. Fine pollard $+\ldots .$. & 86.0 & 5.60 . & 6.44 & 1.46 & 2.60 & 13.53 \\
\hline 17. Coarse pollard $\neq \ldots \ldots \ldots \ldots$ & 86.0 & 6.20 & 7.52 & 1.49 & 2.58 & 14.36 \\
\hline 18. Wheat-bran. & 86.0 & 6.60 & 7.95 & 1.45 & 2.55 & 14.59 \\
\hline 19. Clover-hay........ & 84.0 & 7.50 & 1.25 & 1.30 & 2.50 & 9.64 \\
\hline 20. Meadow-hay.... & 81.0 & 6.00 & 0.88 & 1.50 & 1.50 & 6.43 \\
\hline 21. Bean-straw................ & 82.5 & 5.55 & 0.90 & 1.11 & 0.90 & 3.87 \\
\hline 22. Pea-straw........ & 82.0 & 5.95 & 0.85 & 0.89 & & 3.74 \\
\hline 23. Wheat-straw.... & 81.0 & 5.00 & 0.55 & 0.65 & 0.60 & 2.68 \\
\hline 24. Barley-straw............ & 85.0 & 450 & 0.37 & 0.63 & 0.50 & 2.25 \\
\hline 2.5. Oat-straw. & 83.0 & 5.50 & 0.48 & 0.93 & 0.60 & 2.90 \\
\hline 26. Mangel-wur & 12.5 & 1.00 & 0.09 & 0.25 & 0.25 & 1.07 \\
\hline 27. Swedish turnips.......... & 11.0 & .68 & 0.13 & 0.18 & 0.22 & 91 \\
\hline 28. Common turnips ....... & 8.0 & .68 & 0.11 & 0.29 & 0.18 & .86 \\
\hline 29. Potatoes............ & 24.0 & 1.00 & 0.32 & 0.43 & 0.35 & 1.50 \\
\hline 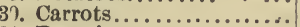 & 13.5 & .70 & 0.13 & 0.23 & 0.20 & .80 \\
\hline 31. Parsnips............. & 15.0 & 1.00 & 0.42 & 0.36 & 0.22 & 1.14 \\
\hline
\end{tabular}

* The manure from a ton of undecorticated cott on-seed cake is worth \$15.74; that from a ton of cottun-seed. after being ground and sifted, is worth \$13.25. The grinding an: sifting, in Mr. Lawes' experiments, removed about 8 percent of husk and cotton. Cotton-seed. so treated, proved to be a very rich and cconomical food. 
Of all vegetable substances used for food, it will be seen that decorticated cotton-seed cake is the richest in nitrogen, phosphoric acid, and potash, and consequently makes the richest and most valuable manure. According to Mr. Lawes' estimate, the manure from a ton of decorticated cotton-seed cake is worth $\$ 27.86$ in gold.

Rape-cake comes next. Twenty-five to thirty years ago, rapecake, ground as fine as corn-meal, was used quite extensively on many of the light-land farms of England as a manure for turnips, and not unfrequently as a manure for wheat. Mr. Lawes used it for many years in his experiments on turnips and on wheat.

Of late years, however, it has been fed to sheep and cattle. In other words, it has been used, not as formerly, for manure alone, but for food first, and manure afterwards. The oil and other carbonaceous matter which the cake contains is of little value for manure, while it is of great value as food. The animals take out this carbonaceous matter, and leave nearly all the nitrogen, phosphoric acid, and potash in the manure. Farmers who had found it profitable to use on wheat and turnips for manure alone, found it still more profitable to use it first for food, and then for manure afterwards. Mr. Lawes, it will be seen, estimates the manure produced from the consumption of a ton of rape-cake at $\$ 21.01$.

Linseed-oil cake comes next. Pure linseed-cake is exceedingly valuable, both for food and manure. It is a favorite food with all cattle and sheep breeders and feeders. It has a wonderful effect in improving the appearance of cattle and sheep. An English farmer thinks he cannot get along without "cake" for his calves, lambs, cattle, and sheep. In this country, it is not so extensively used, except by the breeders of improved stock. It is so popular in England that the price is fully up to its intrinsic value, and not unfrequently other foods, in proportion to the nutritive and manurial value, can be bought cheaper. This fact shows the value of a good reputation. Linseed-cake, however, is often adulterated, and farmers need to be cautious who they deal with. When pure, it will be seen that the manure made by the consumption of a ton of linseed-cake is worth $\$ 19.72$.

Malt-dust stands next on the list. This article is known by different names. In England, it is often called " malt-combs ;" here it is known as "malt-sprouts," or " malt-roots." In making barley into malt, the barley is soaked in water, and afterwards kept in a warm room until it germinates, and throws out sprouts and roots. It is then dried, and before the malt is used, these dried sprouts and roots are sifted out, and are sold for cattle-food. They weigh 
Irom 22 to $25 \mathrm{lbs}$. per bushel of 40 quarts. They are frequently mixed at the breweries with the "grains," and are sold to milkmen at the same price--from 12 to 15 cents per bushcl. Where their value is not known, they can, doubtless, be sometimes obtained at a mere nominal price. Milkmen, I believe, prefer the "grains" to the malt-dust. The latter, however, is a good food-for sheep. It has one advantage over brewer's "grains." The latter contain 76 per cent of water, while the malt-clust contains only 6 per cent of water. We can afford, therefore, to transport malt-dust to a greater distance than the grains. We do not want to carry vater many miles. There is another advantage: brewer's grains soon ferment, and become sour; while the malt-dust, being dry, will keep for any length of time. It will be seen that Mr. Lawes estimates the value of the manure left from the consumption of a ton of malt-dust at $\$ 18.21$.

Tares or vetches, lentils, linseed or flaxseed, beans, wheat, bran, middlings, fine mill-feed, undecorticated cotton-seed cake, peas, and cotton-seed, stand next on the list. The value of these for manure ranging from $\$ 13.25$ to $\$ 16.75$ per ton.

Then comes clorer-hay. Mr. Lawes cstimates the value of the manure from the consumption of a ton of clover-hay at $\$ 9.64$. This is from early cut clover-hay.

When clover is allowed to grow until it is nearly out of flower, the hay would not contain so much nitrogen, and would not be worth quite so much per ton for manure. When mixed with timothy or other grasses, or with weeds, it would not be so valuable. The above estimate is for the average quality of good pure English clover-bay. Our best farmcrs raise clover equally is good; but I have seen much clover-hay that certainly would not come up to this standard. Still, even our common clover-hay makes rich manure. In Wolft's Table, given in the appendix, it will be scen that clover-hay contains only 1.97 per cent of nitrogen and 5.7 per cent of ash. Mr. Lawes' clover contains more nitrogen and ash. This means richer land and a less mature condition of the crop.

The cereal grains, wheat, barley, oats, and Indian corn, stand next on the list, being worth from $\$ 5.32$ to $\$ 7.70$ per ton for manure.

"Meadow-hay," which in the tablc is estimated as worth $\$ 6.43$ per ton for manure, is the hay from permanent meadows. It is a quite different article from the "English Meadow-hay" of New England. It is, in fact, the perfection of hay. The meadows are frequently top-dressed with composted mazure or artificial fertilizcrs, 
and the hay is composed of a number of the best grasses, cut early and carefully cured. It will be noticed, however, that even this choice madow-hay is not as valuable for manure as clover-hay.

Englisic bean-straw is estimated as worth $\$ 3.87$ per ton for manure. The English " horse bean," which is the kind here alluded to, has a very stiff, coarse long straw, and looks as though it was much inferior as fodder, to the straw of our ordinary white baans. See Wolff's table in the appendix.

Pea-straw is cstimated at $\$ 3.74$ per ton. When the peas are not allowed to grow until dead ripe, and when the straw is carefully cured, it makes capital food for sheep. Taking the grain and straw together, it will be seen that peas are an unusually valuable crop to grow for the purpose of making rich manure.

The straw of oats, wheat, and barley, is worth from $\$ 2.25$ to $\$ 2.90$ per ton. Barley straw being the poorest for manure, and oat straw the richest.

Potatoes are worth $\$ 1.50$ per ton, or nearly 5 cents a bushel for manure.

The manurial value of roots varies from 80 cents a ton for carrots, to $\$ 1.07$ for mangel-wurzel, and $\$ 1.14$ for parszips.

I am very anxious that there should be no misapprehension as to the meaning of these figures. I am sure they are well worth the careful study of every intelligent farmer. Mr. Lawes has been exgaged in making experiments for over thirty years. There is no man more competent to speak with authority on such a subject. The figures showing the money value of the manure made from the different fools, are based on the amount of nitrogen, phosphoric acid, and potash, which they contain. Mr. Lawes has bee: buying and using artificial manures for many ycars, and is quite competent to form a correct conclusion as to the chcapest sources of obtaining nitrogen, phosphoric acid, and potash. Hc has certxinly not overestimated t'xeir cost. They can not be bought at lower rates, either in England or America. But of course it docs not follow from this that these manures are worth to the farmer the price charged for them; that is a matter dcpending on many conditions. All that can be said is, that if you are going to huy commercial manures, you will have to pay at least as much f $r$ the nitroyen, phosphoric acid, and potash, as the pricc fixed upon by Mr. Lawes. And you should recollect that therc are other ingredients in the manure obtained from the food of animals, which are not cstimated as of any valu? in the table. For instance, there is a large anount of carbonacsous matter in t'xc manure of animals, 
which, for some crops, is not without value, but which is not here taken into account.

Viewed from a farmer's stand-point, the table of money values must be taken only in a comparative sense. It is not claimed that the manure from a ton of wueat-straw is worth $\$ 2.68$. Tuis may, or may not, be the cuse. But if the manure from a ton of wheatstraw is worth $\$ 2.68$, then the manure from a tod of pea-straw is worth $\$ 3.74$, and the manure from a ton of corn-meal is worth $\$ 3.6 \tilde{5}$, an $l$ the manure from a ton of clover-hay is worth $\$ 9.64$, and the manure from a ton of wheat-bran is worti $\$ 14.59$. If the manure from a ton of corn meal is not worth $\$ 6.65$, then the manure from a ton of bran is not worth $\$ 14.59$. If the manure from the ton of corn is worth more than $\$ 3.65$, then the manure from a ton of bran is worth more than $\$ 14.59$. There necd be no doubt on this point.

Settle in your own mind what the manure from a ton of any one of the foods mentioned is worth on your farm, and you can easily calculate what the manure is worth from all the others. If you say that the manure from a ton of wheat-straw is worth $\$ 1.34$, then the manure from a ton of Indian corn is worth $\$ 3.33$, and the mzinure from a ton of bran is worth $\$ 7.30$, and the manure from a ton of clover-hay is worth $\$ 4.82$.

In this section, however, few good farmers are willing to sell straw, though t'ey can get from $\$ 8.00$ to $\$ 10.00$ per ton for it. They think it must be consumel on the farm, or used for bedding, or their land will run down. I do not say they are wrong, but I do say, that if a ton of straw is worth $\$ 2.68$ for manure alone, then a ton of clover-hay is worth $\$ 9.64$ for manure alone. This may b3 accepted as a general truth, and one which a farmer can act upon. And so, too, in regard to the value of corn-meal, bran, an l all the other articles miven in the table.

There is azother point of great importance which should b3 meztioned in t'is connection. The nitroy $n$ in the better class of foods is worth more for manure than the nitrogen in straw, cornstalks, and other coarse fodder. Nearly all the nitrogen in grain, and other rich foods, is digested by the animals, and is voided in solution in the urine. In other words, the nitrogen in the manure is in an actire and availoble condition. On the other hand, only about half the nitrogen in the coarse fodders and straw is digestible. The other half passes off in a crude and comparatively unavailable condition, in the solid excrement. In estimating the value of the manure from a ton of food, these facts should be remembered. 
I have said that if the manure from a ton of straw is worth $\$ 2.68$, the manure from a ton of corn is worth $\$ 6.65$; but I will not reverse the proposition, and say that if the manure from a ton of corn is worth $\$ 6.65$, the manure from a ton of straw is worth $\$ 2.68$. The manure from the grain is nearly all in an available condition, while that from the straw is not. A pound of nitrogen in rich manure is worth more than a pound of nitrogen in poor manure. This is another reason why we should try to make rich manure.

\section{$\longrightarrow+\infty$ \\ C H A P T E R X I I I.}

\section{HORSE MANURE AND FARM-YARD MANURE.}

The manure from horses is generally considered richer and better than that from cows. This is not always the case, though it is probably so as a rule. There are three princip.l reasons for this. 1st. The horse is usually fed more grain and hay than the cow. In other words, the food of the horse is usually richer in the valuable elements of plant-food than the ordinary food of the cow. 21 . The milk of the cow abstracts considerable nitrogen, phosphoric acid, etc., from the food, and to this extent there is less of these valuable subst.ances in the excrements. $3 \mathrm{~d}$. The excrements of the cow contain much more water than those of the horse. And consequently a ton of cow-dung, other things being equal, would not contain as much actual manure as a ton of horse-dung.

Boussingauit, who is eminently trustworthy, gives us the following interesting facts :

A horse consumed in 24 hours, $20 \mathrm{lbs}$. of hay, $6 \mathrm{lbs}$. of oats, and $43 \mathrm{lbs}$. of water, and voided during the same period, $3 \mathrm{lbs} .7 \mathrm{ozs}$. of urine, and 38 lbs. 2 ozs. of solil excrements.

The solid excrements contained $23 \frac{1}{1 b s}$. of wa'er, and the urine 2 lhs. 6 ozs. of water.

According to this, a horse, eating $20 \mathrm{lbs}$. of hay, and $6 \mathrm{lbs}$. of oats, per day, voids in a year nearly seven tons of solid excrements, and $1,255 \mathrm{lbs}$. of urine.

It would seem that there must have been some mistake in collecting the urine, or what was probably the case, that some of it must have been absorbed by the dung; for $3 \frac{1}{3}$ pints of urine per day is certainly much less than is usually voided by a horse. 
Stockard gives the amount of urine voided by a horse in a year at 3,000 lbs.; a cow, 8,000 lbs.; sheep, $380 \mathrm{lbs}$; pig, 1,200 lbs.

Dr. Vœlcker, at the Royal Agricultural College, at Cirencester, England, made some yaluable investigations in regard to the composition of farm-yard manure, and the changes which take place during fermentation.

The manure was composed of horse, cow, and pig-dung, mixed with the straw used for bedding in the stalls, pig-pens, sheds, etc.

On the $3 \mathrm{~d}$ of November, 1854 , a sample of what Dr. Vœlcker calls "Fresh Long Dung," was taken from the "manure-pit" for analysis. It had lain in the pit or heap about 14 days.

The following is the result of the analysis :

FRESH FARM-YARD MANURE.

HALF A TON, OR 1,000 LBS.

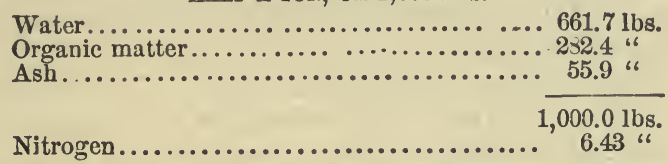

"Before you go any farther," said the Deacon, "let me understand what these figures mean ? Do you mean that a ton of manure contains only $12 z_{1} \mathrm{lbs}$. of nitrogen, and $111 \mathrm{lbs}$. of ash, and that all the rest is carbonaccous matter and water, of little or no value"?-" That is it precisely, Deacon," said I, "and furthermore, a large part of the ash has very little fertilizing value, as will be seen from the following:

DETAILED COMPOSITIOY OF THE ASH OF FRESH BARN-YARD MANORE.

Soluble silica........................... 21.59

Insoluble silicious matter (sand) $\ldots \ldots \ldots \ldots \ldots \ldots \ldots, 10.04$

Phosphate of lim $\ldots . . . \ldots \ldots \ldots \ldots \ldots \ldots \ldots \ldots \ldots, 5.3 . \ldots \ldots$

Oxide of iron, alumina, with phosphate............ 8.47

Containing phospheric acid.................... 3.18

Lime......................................... 21.31

Magnesia...................................... 2.76

Potash........................................ 12.04

Soda..................................... 1.30

Chloride of sodium........................... 0.54

Sulphuric acid $\ldots \ldots \ldots \ldots \ldots \ldots \ldots \ldots \ldots \ldots \ldots \ldots, 1.49$

Carbonic acid and loss........................ 15.11

100.00

Nitrogen, phosphoric acid, and potash, are the most valuable ingredients in manure. It will be seen that a ton of fresh barn-yard manure, of probably good average quality, contains :

Nitrogen............................. 12 lbs.

Phosphoric acid ......................... 6 6 "6

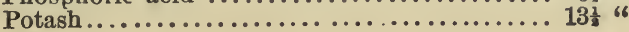


I do not say that these are the only ingredients of any value in a ton of manure. Nearly all the other ingredients are indispensable to the growth of plants, and if we should use manures containing nothing but nitrogen, phosphoric acid, and potash, the time would come when the crops would fail, froin lack of a sufficient quantity of, perhaps, magnesia, or lime, sulphuric acid, or soluble silica, or iron. But it is not necessary to make provision for such a contingency. It would be a very exceptional case. Farmers who depend mainly on barn-yard manure, or on plowing under green crops for keeping up the fertility of the land, may safely calculate that the value of the manure is in proportion to the amount of nitrogen, phosphoric acid, and potash, it contains.

We draw out a ton of fresh manure and spread it on the land, therefore, in order to furnish the growing crops with $12 \frac{8}{4} \mathrm{lbs}$. of nitrogen, $6 \frac{1}{2}$ los. of phosphoric acid, and $13 \frac{1}{2} \mathrm{lbs}$. of potash. Less than 33 lbs. in all !

We cannot dispense with farm yarl manure. We can seldom buy nitrogen, phosphoric acid, and potash, as cheaply as we can get them in home-made manures. But we should clearly understand the fact that we draw out 2,000 lbs. of matter in order to get $33 \mathrm{lbs}$. of thes fertilizing ingredients. We should try to make richer mxnure. A ton of manuro containing $60 \mathrm{lbs}$. of nitrogen, phosphoric acid, and potash, costs no more to draw out and spread, than a ton containing only $30 \mathrm{lbs}$, and it would be worth nearly or quite double the money.

Fiow to make richer manure we will not discuss at this time. It is a question of food. But it is worth while to enquire if we can not take such manure as we have, and reduce its weight and bulk without losing any of its nitrogen, phosphoric acid, and potash.

\section{$\rightarrow \infty$ \\ O II A P T E R. X I V.}

\section{FERMENTING MANURE.}

Dr. Vœlcker placed 2,838 lbs. of fresh mixed manure in a heap Nov. 3, 1854, and the next spring, April 30, it weighed 2,026 ibs., a shrinkage in weight of 28.6 per cent. In other words 100 tons of such manure would be reduced to less than $71 \frac{1}{2}$ tons.

The heap was weig'ced again, August 23 , and contained 1,994 lbs. It was again weighed Nov. 15, and contained 1,971 lbs 
The following table shows the composition of the heap when first put up, and also at the three subsequent periods :

TABLE SHOWLNG COMPOSITION OF THE WHOLE HEAP ; FRESH FARM-YARD MANUTE (NO. I.) EXPOSED-EXPIESSED IN LBS.

\begin{tabular}{|c|c|c|c|c|}
\hline & $\left|\begin{array}{cc|}\text { When } & \text { put } \\
\text { up } & \text { Nov. } \\
3,1854\end{array}\right|$ & $\begin{array}{c}\text { April } \\
1855 .\end{array}$ & $\begin{array}{c}\text { Aug. 23, } \\
1855 .\end{array}$ & $\begin{array}{l}\text { Nov. } 15 \\
1055 .\end{array}$ \\
\hline Weight of mauure in lbs......... & 2,838 & 2,026 & 1,994 & 1,974 \\
\hline $\begin{array}{l}\text { Amt. of water in the manure......... } \\
\text { Amt. of dry matter in the manure.... } \\
\text { Consisting of - }\end{array}$ & $\begin{array}{r}1.877 .9 \\
960.1\end{array}$ & $\begin{array}{r}1.3336 .1 \\
689.9\end{array}$ & $\begin{array}{r}1,505.3 \\
488.7\end{array}$ & $\begin{array}{r}1,4665 \\
507.5\end{array}$ \\
\hline $\begin{array}{l}\text { Soluble organic matter............ } \\
\text { Soluble mineral matter............ } \\
\text { Insoluble organic matter......... } \\
\text { Insoluble mincral matter....... }\end{array}$ & $\begin{array}{r}70.38 \\
43.71 \\
731.07 \\
114.94\end{array}$ & $\begin{array}{r}86.51 \\
57 . .88 \\
389.74 \\
15577\end{array}$ & $\begin{array}{r}58 . \$ 3 \\
89.16 \\
243.22 \\
147.49\end{array}$ & $\begin{array}{r}54.04 \\
36.89 \\
214.92 \\
201.65\end{array}$ \\
\hline 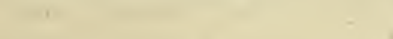 & 960.1 & 689.9 & 483.7 & 507.5 \\
\hline 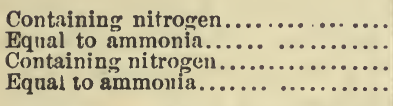 & $\begin{array}{r}4.2 .2 \\
512 \\
14.01 \\
17.02\end{array}$ & $\begin{array}{r}6.07 \\
7.37 \\
12.07 \\
14.65\end{array}$ & $\begin{array}{r}3.76 \\
4.56 \\
9.98 \\
11.40\end{array}$ & $\begin{array}{r}3.65 \\
4.36 \\
9.38 \\
11.39\end{array}$ \\
\hline $\begin{array}{l}\text { Total amount of nitrogen in mannie. } \\
\text { Equal to anmonia. .............. }\end{array}$ & $\begin{array}{l}18.23 \\
22.14\end{array}$ & $\begin{array}{l}18.14 \\
22.02\end{array}$ & $\begin{array}{l}13.14 \\
15.96\end{array}$ & $\begin{array}{l}13.03 \\
15.75\end{array}$ \\
\hline $\begin{array}{l}\text { The manure contains ammonia ir } \\
\text { free state.... } \\
\text { The manure contains ammonia in } \\
\text { form of salts, easily decomposed by }\end{array}$ & .96 & .15 & .20 & .11 \\
\hline $\begin{array}{l}\text { quicklime .................... } \\
\text { Tutal amount of organic matters... } \\
\text { Total amount of mineral matters... }\end{array}$ & $\begin{array}{r}2.49 \\
801.45 \\
153.15\end{array}$ & $\begin{array}{r}1.71 \\
476.25 \\
213.65\end{array}$ & $\begin{array}{l}.75 \\
302.05 \\
186.65\end{array}$ & $\begin{array}{r}2 f 8.87 \\
238.54\end{array}$ \\
\hline
\end{tabular}

"It will be remarked," says Dr. Vœlcker, "that in the first experimental period, the fermentation of the dung, as might have been expected, proceeded most rapidly, but that, notwithstanding, very little nitrogen was dissipated in the form of volatile ammonia; and that on the whole, the loss which the manure sustained was inconsiderable when compared with the enormous waste to which it was subject in the subsequent warmer and more rainy seasons of the year. Thus we find at the end of April very nearly the same amount of nitrogen which is contained in the fresh; whereas, at the end of August, 279 por cent of the total nitrogen, or nearly one-third of the nitrogen in the manure, has been wasted in one way or the other.

"It is worthy of observation," continues Dr. Vœlcker, "that, during a well-regulated fermentation of dung, the loss in intrinsically valuable constituents is inconsiderable. and that in such a preparatory process the cfficxcy of the mxnure becomes greatly enhanced. For certain purposes fresh dung can never take the 
place of well-rotted dung. * * The farmer will, therefore, always be compelled to submit a portion of home-made dung to formentation, and will find satisfaction in knowing that this process, when well regulated, is not atteaded with any serious depreciation of the value of the manure. In the foreguing analyses he will find the direct proof that as long as heavy showers of rain are excluded from manure-heaps, or the manure is kept in waterproof pits, the most valuable fertilizing matters are preserved."

This experiment of Dr. Vœlcker proves conclusively that manure can be kept in a rapid state of fermentation for six months during winter, with little loss of nitrogen or other fertilizing matter.

During fermentation a portion of the insoluble matter of the dung becomes soluble, and if the manure is then kept in a heap exposed to rain, there is a great loss of fertilizing matter. This is precisely what we should expect. We ferment manure to make it more readily available as plant-food, and when we have attained our object, the manure shoull be applied to the land. We keep winter apples in the cellar until they get ripe. As soon as they are ripe, they should be eaten, or they will rapidly decay. This is well understood. And it should be equally well known that manure, after it has been fermenting in a heap for six months, cannot safely be kept for another six months exposed to the weather.

The following table shows the composition of $100 \mathrm{lbs}$. of the farm-yard manure, at different periods of the year :-

COMPOSITION OF 100 LBS. OF FRESH FARM-YARD MANURE (NO. I.) EXPOSED IN NATURAL STATE, AT DIFFERENT PERIODS OF THE YEAR.

\begin{tabular}{|c|c|c|c|c|c|}
\hline & $\begin{array}{c}\text { Whenput } \\
\text { up. Nov. } \\
\text { 3, 1854. }\end{array}$ & $\begin{array}{c}F e b \quad 14 \\
1855 .\end{array}$ & $\begin{array}{c}A m \cdot .30 \\
1855 .\end{array}$ & $\begin{array}{c}\text { Aug. } 23 . \\
1855 .\end{array}$ & $\begin{array}{c}\text { Now. } 15, \\
1855 .\end{array}$ \\
\hline Wate & 66.17 & 69.83 & 65.9ลั & 75.49 & 74.29 \\
\hline Solt & 2.48 & 3.86 & 4.27 & 2.95 & 2.74 \\
\hline Solnble inorgan & 1.54 & 2.97 & 2.86 & 1.97 & 1.87 \\
\hline nic matter..... & 25.76 & 18.44 & 19.23 & 12.20 & $\cdot 10.89$ \\
\hline Insoluble mineral inatter....... & 4.05 & 4.90 & 7.69 & 7.39 & 10.21 \\
\hline & 100.00 & 100.00 & 100.00 & 100.00 & 100.00 \\
\hline Containing nitrogen. & .149 & .27 & .30 & .19 & .18 \\
\hline Equal to anmot & .181 & .32 & .36 & .23 & .21 \\
\hline ining nit & .49 & .47 & .59 & .47 & .47 \\
\hline Equal to an & $.5 !$ & .5 & $\pi 1$ & .62 & .57 \\
\hline itrogen & .61 & .74 & .89 & .66 & .65 \\
\hline Equal to an & .76 & .89 & 1.177 & .85 & .78 \\
\hline Ainmonia in a free state. & .034 & .019 & .008 & .010 & .006 \\
\hline $\begin{array}{l}\text { Anımonia in form of salts easily de } \\
\text { composed by quicklime. }\end{array}$ & & & & & \\
\hline sed by quicklir & 28.24 & 22.30 & 23.50 & 15.15 & 13.6i3 \\
\hline Total amt. of mineril substauces.. & 5.59 & 7.87 & 10.55 & 936 & 1203 \\
\hline
\end{tabular}

It will be seen that two-thirds of the fresh manure is water. After fermenting in an exposed heap for six months, it still con- 
tains about the same percentage of water. When kept in the leap until August, the percentage of water is much greatur. Of four tons of such manure, three tois are water.

Of Nitrogen, the most valuable ingredient of the manure, the fresh dung, contained 0.64 per cent ; after fermenting six months, it contained 0.89 per cent. Six months later, it contained 0.65 per cent, or about the same amount as the fresh manure.

Of mineral matter, or ash, this fresh farm-yard manure contained 5.59 per cent; of which 1.54 was soluble in water, and 4.05 insoluble. After fermenting in the heap for six months, the manure contained 10.55 per cent of ash, of which 2.86 was soluble, and 7.69 insoluble. Six months later, the soluble ash had decreased to 1.97 per cent.

The following table shows the composition of the manurc, at different periods, in the dry stxte. In other words, supposing all the water to. be removed from the manure, its composition woulil be as follows:

COMPOSITION OF FTESH FAIM YATD MANURE (No. r.) EXPOSED. CALCULATED DRY.

\begin{tabular}{|c|c|c|c|c|c|}
\hline n & $\begin{array}{l}\text { When put } \\
\text { up, Nov. } \\
\mathbf{3}, \mathbf{1 8 5 4} \text {. }\end{array}$ & $\begin{array}{c}F e b . \\
14 . \\
18.55 .\end{array}$ & $\begin{array}{l}\text { April } \\
30, \\
1855 .\end{array}$ & $\begin{array}{c}\text { Aug. } \\
23, \\
1855 .\end{array}$ & $\begin{array}{c}\text { Nov. } \\
15 \\
1855 .\end{array}$ \\
\hline 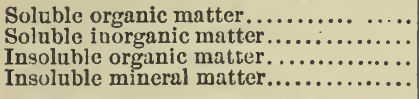 & $\begin{array}{r}7.33 \\
4.55 \\
76.15 \\
11.97\end{array}$ & $\begin{array}{r}12.79 \\
9.84 \\
61.12 \\
16.25\end{array}$ & $\begin{array}{r}12.54 \\
8.3: \\
56.49 \\
22.58\end{array}$ & $\begin{array}{r}12.04 \\
8.03 \\
49.77 \\
30.16\end{array}$ & $\begin{array}{r}10.65 \\
7.27 \\
42.35 \\
39.73\end{array}$ \\
\hline & 100.00 & 100.00 & 100.00 & 160.00 & 100.00 \\
\hline 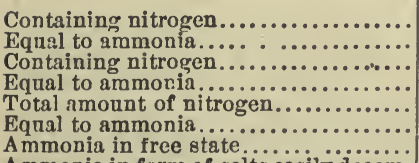 & $\begin{array}{r}.44 \\
.53 \\
1.46 \\
1.77 \\
1.90 \\
2.30 \\
.10\end{array}$ & $\begin{array}{l}.91 \\
1.10 \\
1.55 \\
1.88 \\
2.16 \\
2.98 \\
.062\end{array}$ & $\begin{array}{l}.88 \\
1.06 \\
1.75 \\
2.12 \\
2.13 \\
3.18 \\
.02 \\
.02\end{array}$ & $\begin{array}{l}.77 \\
.83 \\
1.92 \\
2.33 \\
2.69 \\
.2 .26 \\
.011\end{array}$ & $\begin{array}{l}.72 \\
.83 \\
1.85 \\
2.24 \\
2.57 \\
3.12 \\
.023\end{array}$ \\
\hline $\begin{array}{l}\text { A mmonia in form of saits easily decom- } \\
\text { posed by quicklime................. } \\
\text { Total amount of nrganic matter....... } \\
\text { Total amount of nineral substances .. }\end{array}$ & $\begin{array}{r}.26 \\
83.48 \\
16.52\end{array}$ & $\begin{array}{l}.212 \\
73.91 \\
26.09\end{array}$ & $\begin{array}{l}24^{n} \\
6.0 .03 \\
30.97\end{array}$ & $\begin{array}{r}.154 \\
61.81 \\
38.19\end{array}$ & $\begin{array}{l}.159 \\
53.00 \\
47.00\end{array}$ \\
\hline
\end{tabular}

"A comparison of these different analyses," says Dr. Vœlcker, "points out clearly the changes which fresh farm-yard manure undergoes on keeping in a heap, exposed to the influence of the weather during a period of twelve months and twelve days.

"1. It will be perceived that the proportion of organic matter steadily diminishes from month to month, until the original percentage of organic matter in the dry manure, amounting to 83.48 per cent, becomes reduced to 53 per cent.

" 2 . On the other hand, the total percentage of mincral matter rises as steadily as that of the organic matter falls. 
"3. It will be seen that the loss in organic matter affects the percentage of insoluble organic matters more than the pcrecntare of soluble organic substances.

"4. The percentuge of soluble organic matters, indeed, increased considerably during the first experimental period; it rose, namcly, from 7.33 per cent to 12.79 per ecnt. Examined again on the 30 th of April, very nearly the sume percentage of soluble urganic matter, as on February the 14th, was found. The August analysis shows but a slight decrease in the perecntage of soluble crganie matters, while there is a deerease of 2 per cent of soluble organic mattcrs when the November analysis is eompared with the February analysis.

" 5 . The soluble mineral matters in this manure rise or fall in the diffcrent experimental periods in the same order as the soluble organie matters. Thus, in February, 9.84 per cent of soluble mineral matters were found, whilst the manure contained only 4.55 per eent, when put up into a heap in November, 1854. Gradually, however, the proportion of soluble mincral matters again dimin. ished, and became reduced to 7.27 per cent, on the examination of the manure in November, 1855 .

" 6 . A similar regularity will be observed in the percentage of nitrogen contained in the soluble organic matters.

"In the insoluble organic matters, the percentage of nitrogen regularly inereased from November, 1854, up to the $23 \mathrm{~d}$ of $\mathrm{Au}$ gust, notwithstanding the rapid diminution of the pereentage of insoluble organic matter. For the last experimental period, the pereentage of nitrogen in the insoluble matter is nearly the same as on Aurust $28 \mathrm{~d}$.

" 8 . With respect to the total pereentage of nitrogen in the fresh manure, examined at different periods of the year, it will be secn that the February manure eontains about one-half per eent more of nitrogen than the manure in a perfectly fresh state. On the 30th of April, the percentage of nitrogen again slightly inereased; on August 23d, it remained stationary, and had sunk but very little when last examined on the 15 th of Norember, 1855.

"This series of analyses thus shows that fresh farm-yard manure rapidly beeomes more soluble in water, but that this desirable change is realized at the expense of a large proportion of organic matters. It likewise proves, in an unmistakable manner, that there is no advantage in keeping farm-yard manure for too long a period; for, after February, neither the percentage of suluble organic, nor that of soluble mineral matter, has beeome greater, 
and the percentage of nitrogen in the manure of April and August is only a very little higher than in February."

"Before you go any further," said the Deacon, "answer ma this question: Suppose I take five tons of farm-yard manure, and put it in a heap on the $3 \mathrm{~d}$ of November, tell me, 1st, what that heap will contain when first made; $2 d$, what the heap will contain April 30th ; and, 3l, what the heap will contain August 23d."

Here is the table:

CONTENTS OF A HEAP OF MANJBE AT DIFFERENT PERIODS, EXPOSED TO RADN, ETC.

\begin{tabular}{|c|c|c|c|c|}
\hline & $\begin{array}{c}\text { When put } \\
\text { up, Lov. } \\
3 .\end{array}$ & April 30. & Aug. 23. & Nov. 15. \\
\hline Total weight of manure in heap & 10,000 & 7,138 & 7,025 & 6.951 \\
\hline Water in the heap of manurs...... & 6,617 & 4,707 & 5.304 & 5,167 \\
\hline Total organic matter................ & 2,824 & 1,678 & 1,034 & 947 \\
\hline Total inorganic matter.............. & 559 & 753 & 657 & 840 \\
\hline Total nitrogen in heap........ & 64.3 & 63.9 & 46.3 & 46.0 \\
\hline Total soluble organis matter... & 248 & 395 & 207 & 190 \\
\hline Total insoluble organic matter... & 2,576 & 1,373 & $850^{\circ}$ & 757 \\
\hline Soluble mineral matter........ & 154 & 204 & 133 & 130 \\
\hline Insoluble mineral matter ... . & 495 & 519 & 519 & 710 \\
\hline Nitrogen in soluble matter.... & 14.9 & 21.4 & 13.2 & 12.9 \\
\hline Nitrogen in insoluble matter. & 49.4 & 42.5 & 33.1 & 33.1 \\
\hline
\end{tabular}

The Deacon put on his spectacles and studied the above table carefully for some time. "That tells the whole story," said he, "you put five tons of fresh manure in a heap, it ferments and gets. warm, and nearly one ton of water is driven off by the heat."

"Yes," said the Doctor, "you see that over half a ton $(1,146 \mathrm{lbs}$. of dry organic matter has been slowly burnt up in the heap; giving out as much heat as half a ton of coal burnt in a stove. But this is not all. The manure is cooked, and steamed, and softened by the process. The organic matter burnt up is of no value. There is little or no loss of nitrogen. The heap contained $64.3 \mathrm{lbs}$. of nitrogen when put up, and $63.9 \mathrm{lbs}$. after fe.menting six months. And it is evident that the manure is in a much more active and available condition than $i i$ it had been applied to the land in the fresh state. There was $14.9 \mathrm{lbs}$. of nitrogen in a soluble condition in the fresh manure, and $21.4 \mathrm{lbs}$. in the fermented manure. And what is equally important, you will notice that there is $154 \mathrm{lbs}$. of soluble ash in the heap of fresh manure, and $201 \mathrm{lbs}$. in the heap of fermented manure. In other words, $50 \mathrm{lbs}$. of the insoluble mineral matter had, by the fermentation of the manure, been rendered soluble, and consequently immediately avaiıable as plantfood. This is a very important fact."

The Doctor is right. There is clearly a great advantage in fermenting manure, provided it is done in such a manner as to pre. 
vent loss. We have not only less manure to draw out and spread, but the plant-food which it contains, is more soluble and active.

The table we have given shows that there is little or no loss of valuable constituents, even when manure is fermented in the open air and exposed to ordinary rain and snows during an English winter. But it also shows that when the manure has been fermented for six months, and is then turned and left exposed to the rain of spring and summer, the loss is very considerable.

The five tons $(10,000 \mathrm{lbs}$.$) of fresh manure placed in a heap on$ the $3 \mathrm{~d}$ of November, are reduced to 7,138 lbs. by the 30th of April. Of this $4,707 \mathrm{lbs}$. is water. By the $23 \mathrm{~d}$ of August, the heap is reduced to 7,025 lbs., of which 5,304 lbs. is water. There is nearly 600 lbs. more water in the heap in August than in April.

Of total nitrogen in the heap, there is $64.3 \mathrm{lbs}$. in the fresh manure, $63.9 \mathrm{lbs}$. in April, and only $46.3 \mathrm{lbs}$. in August. This is a great loss, and there is no compensating gain.

We have seen that, when five tons of manure is fermented for six months, in winter, the nitrogen in the soluble organic matter is increased from $14.9 \mathrm{lbs}$. to $21.4 \mathrm{lbs}$. This is a decided advantage. But when the manure is kept for another six months, this soluble nitrogen is decreased from 21.4 lbs. to $13.2 \mathrm{lbs}$. We lose over 8 lbs. of the most active and available nitrogen.

And the same remarks will apply to the valuable soluble mineral matter. In the five tons of fresh manure there is $154 \mathrm{lbs}$. of soluble mineral matter. By fermenting the heap six months, we get 204 lbs., but by keeping the manure six months longer, the soluble mineral matter is reduced to $138 \mathrm{lbs}$. We lose $66 \mathrm{lbs}$. of valu. able soluble mineral matter.

By fermenting manure for six months in winter, we greatly improve its condition; by keeping it six months longer, we lose largely of the very best and most active parts of the manure, 


\section{H A P T E R X V.}

\section{KEEPING MANURE UNDER COVER.}

Dr. Vœlcker, at the same time he made the experiments alluded to in the preceding chapter, placed another heap of manure under cover, in a shed. It was the same kind of manure, and was treated precisely as the other-the only difference being that one heap was exposed to the rain, and the other not. The following table gives the results of the weighings of the heap at different times, and also the percentage of loss:

\section{MANURE FERMENTED UNDER COVER IN SHED.}

TABLE BHOWING THE ACTUAL WEighiNgs, AND PERCENTAge of LOSS IN WEIGHT, OF EXPERIMENTAL HEAP (NO. II.) FRESH FARM-TARD MANURE UNDER SHED, AT DIFFERENT PERIODS OF THE YEAR.

\begin{tabular}{|c|c|c|c|}
\hline bet & $\mid \begin{array}{c}\text { Weight } \\
\text { of } \\
\text { Manure } \\
\text { in Lbs. }\end{array}$ & $\begin{array}{l}\text { Loss in } \\
\text { original } \\
\text { weight } \\
\text { in Lbs. }\end{array}$ & $\begin{array}{l}\text { Percent } \\
\text { age of } \\
\text { Loss. }\end{array}$ \\
\hline Put up on the $3 d$ of November, $1854 \ldots \ldots \ldots \ldots \ldots$ & 3,258 & & \\
\hline 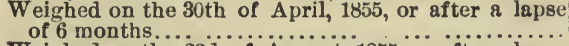 & 1,613 & 1,645 & 50.1 \\
\hline $\begin{array}{l}\text { Weighed on the } 23 d \text { of August, } 1855 \text {, or after a lapse } \\
\text { of } 9 \text { months and } 20 \text { days........................... }\end{array}$ & 1,297 & 1,961 & 60.0 \\
\hline $\begin{array}{l}\text { Weighed on the } 15 \text { th of November, } 185, \text {, or after a } \\
\text { lapse of } 12 \text { months and } 12 \text { days................... }\end{array}$ & 1,235 & 2,023 & 62.1 \\
\hline
\end{tabular}

It will be seen that 100 tons of manure, kept in a heap under cover for six months, would be reduced to $49.6-10$ tons. Whereas, when the same manure was fermented for the same length of timo in the open air, the 100 tons was reduced to only 71.4-10 tons. The difference is due principally to the fact that the heap exposed contained more water, derived from rain and snow, than the heap kept under cover. This, of course, is what we should expect. Let us look at the results of Dr. Vœlcker's analyses : 
TABLB SZOWI.G THE COMPOSITION OF EXPERIMENTAL HEAP (NO. II.) FRESH FARAYARD MANURE UNDER SHED, IN NATURAL STATE AT DIFFERENT PERIODS OF THE YEAR.

\begin{tabular}{|c|c|c|c|c|c|}
\hline & $\begin{array}{l}\text { When put } \\
\text { up, Nov. } \\
\mathbf{3}, \mathbf{1 8 5 4}\end{array} \mid$ & $\begin{array}{c}F e b .14 \\
1855 .\end{array}$ & $\begin{array}{c}A p r .30, \\
185.5 .\end{array}$ & $\begin{array}{c}\text { A ü. } 23 . \\
1855 .\end{array}$ & $\begin{array}{c}\text { Nov. } 15, \\
1855 .\end{array}$ \\
\hline 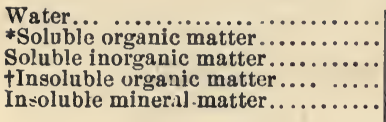 & $\begin{array}{r}66.17 \\
2.43 \\
1.51 \\
2576 \\
4.0 .5\end{array}$ & $\begin{array}{r}67.32 \\
2.63 \\
2.12 \\
20.46 \\
7.47\end{array}$ & $\begin{array}{r}56.89 \\
4.63 \\
3.38 \\
25.43 \\
9.67\end{array}$ & $\begin{array}{r}43.43 \\
4.13 \\
3.05 \\
26.01 \\
23.88\end{array}$ & $\begin{array}{r}41.66 \\
5.37 \\
4.43 \\
27.69 \\
20.85\end{array}$ \\
\hline & 100.00 & 100.00 & 100.00 & 100.00 & 100.00 \\
\hline 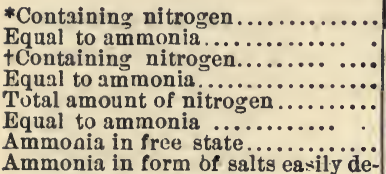 & $\begin{array}{l}.149 \\
.181 \\
.494 \\
.599 \\
.643 \\
.780 \\
.034\end{array}$ & $\begin{array}{l}.17 \\
.20 \\
.58 \\
.70 \\
.75 \\
.90 \\
.022\end{array}$ & $\begin{array}{c}.27 \\
.32 \\
.92 \\
1.11 \\
1.19 \\
1.43 \\
.055\end{array}$ & $\begin{array}{l}.26 \\
.31 \\
1.01 \\
1.23 \\
1.27 \\
1.51 \\
.015\end{array}$ & $\begin{array}{r}.42 \\
.51 \\
1.09 \\
1.31 \\
1.51 \\
1.82 \\
.019\end{array}$ \\
\hline $\begin{array}{l}\text { composed by quicklime......... } \\
\text { Total amount of or } \text { tauic matter.... } \\
\text { Total amount of mineral substance.. }\end{array}$ & $\begin{array}{c}.088 \\
28.24 \\
5.59\end{array}$ & $\begin{array}{c}.054 \\
23.09 \\
9.59\end{array}$ & $\begin{array}{l}30.06 \\
13.0 \text { j }\end{array}$ & $\begin{array}{l}30.103 \\
26.43\end{array}$ & $\begin{array}{l}.146 \\
33.06 \\
25.23\end{array}$ \\
\hline
\end{tabular}

TABLE SHOWING THE COMPOSITION OF EXPERIMENTAL HEAP (NO. II.) FRESH FARMYARD MANURE UNDER SHED, CALCULATED DRY, AT DIFFERENT PERIODS OF THE YEAR.

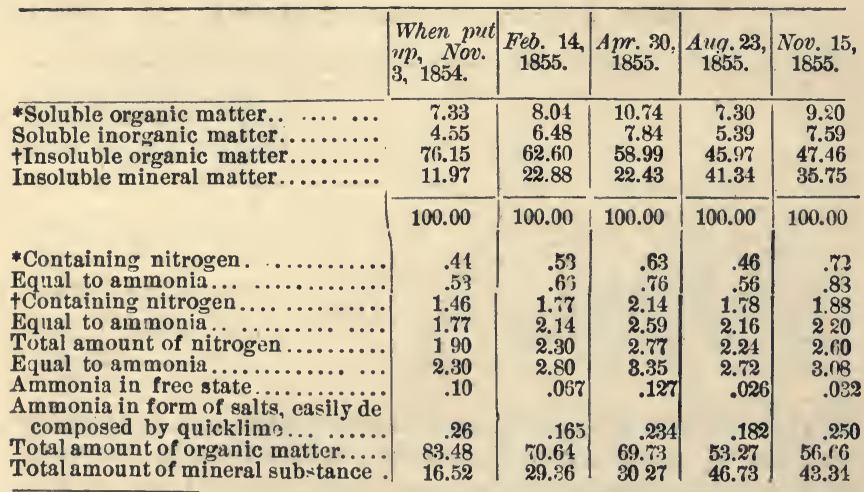

The above analyses are of value to those who buy fresh and fermented manure. They can form some idea of what they are getting. If they buy a ton of fresh manure in November, they get 12: lbs. of nitrogen, and 308 lbs. of soluble mineral matter. If 
they buy a ton of the same manure that has been kept under cover until February, they get, nitrogen, 15 lbs.; soluble minerals, $42 \frac{1}{2}$ Jbs. In April, they get, nitrogen, $23 \frac{3}{4}$ lbs. ; soluble minerals, $67 \frac{1}{2}$ 1bs. In August, they get, nitrogen, $25 \frac{1}{2}$ lbs. ; soluble minerals, 61 lbs. In November, when the manure is over one year old, they get, in a ton, nitrogen, $30 \frac{1}{4}$ lbs. ; soluble minerals, $88 \frac{1}{2}$ lbs.

When manure has not been exposed, it is clear that a purciaser can afford to pay considerably more for a ton of rotted manure than for a ton of fresh manure. But waiving this point for the present, let us see hcw the matter stands with the farmer who makes and uses the manure. What does he gain by keeping and iermenting the manure under cover?

The following table shows the weight and composition of the entirc heap of manure, kept under cover, at different times :

TABLE SHOWING CIMPOSITION OS ENTIRE EXPERIMENTAL HEAP (NO. II.) FRESH FARM-TARD MANURE, UNDER SHED.

\begin{tabular}{|c|c|c|c|c|}
\hline & $\mid \begin{array}{l}\text { When put } \\
\text { up, Nov. } \\
3, \mathbf{1 8 5 4} \text {. }\end{array}$ & April 30, & Aug. 23, & $\begin{array}{c}\text { Nov. } 15, \\
1855 .\end{array}$ \\
\hline Weight of manure.................. & $\begin{array}{l}\text { tbs. } \\
3.258 .\end{array}$ & $\begin{array}{r}\text { tos. } \\
1,613 .\end{array}$ & $\begin{array}{r}\text { fos. } \\
1,297 \text {. }\end{array}$ & $\begin{array}{r}\text { tos. } \\
1,225 .\end{array}$ \\
\hline $\begin{array}{l}\text { Amount of water in the manure........ } \\
\text { Amount of dry matter................... } \\
\text { * Consisting of soluble organic matter... } \\
\text { Solable mineral matter............ } \\
\text { tInsoluble organic matter........ } \\
\text { Insoluble mineral matier........ }\end{array}$ & \begin{tabular}{r|}
2,153 \\
$1,102$. \\
80.77 \\
50.11 \\
83.17 \\
131.92
\end{tabular} & \begin{tabular}{r|}
917.6 \\
695.4 \\
74.68 \\
54.51 \\
410.21 \\
155.97
\end{tabular} & \begin{tabular}{c|}
563.2 \\
733.8 \\
53.56 \\
39.55 \\
337.32 \\
303.37
\end{tabular} & $\begin{array}{r}514.5 \\
720.5 \\
66.28 \\
54.68 \\
341.97 \\
257.57\end{array}$ \\
\hline & $1,102$. & 695.4 & 733.8 & 720.5 \\
\hline 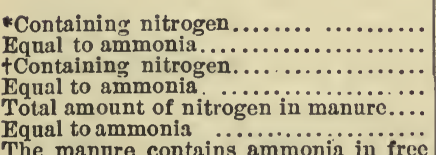 & \begin{tabular}{r|}
4.85 \\
5.83 \\
16.08 \\
19.52 \\
20.83 \\
25.40
\end{tabular} & \begin{tabular}{r|}
4.38 \\
5.33 \\
14.83 \\
17.46 \\
19.26 \\
22.79
\end{tabular} & \begin{tabular}{r|}
3.46 \\
4.29 \\
$13 . C 8$ \\
15.88 \\
16.51 \\
20.03
\end{tabular} & $\begin{array}{r}5.25 \\
6.97 \\
13.54 \\
16.44 \\
18.79 \\
22.01\end{array}$ \\
\hline 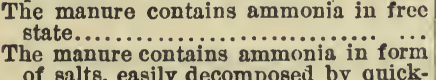 & 1.10 & .88 & .19 & .23 \\
\hline 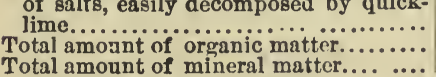 & $\begin{array}{r}2.86 \\
919.94 \\
182.06\end{array}$ & $\begin{array}{r}1.62 \\
481.92 \\
210.48\end{array}$ & $\begin{array}{r}1.33 \\
390.83 \\
342.92\end{array}$ & $\begin{array}{r}1.80 \\
403.25 \\
312.35\end{array}$ \\
\hline
\end{tabular}

This is the table, as given by Dr. Vœlcker. For the sake of comparison, we will figure out what the changes would be in a heap of five tons $(10,000 \mathrm{lbs}$.) of manure, when fermented under cover, precisely in the same way as we dil with the heap fermented in the open air, exposed to the rain. The following is the table : 
CONTENTS OF A HEAP OF MANURA AT DIFFERENT PERIODS. FERMENTED UNDKB COVER.

\begin{tabular}{|c|c|c|c|c|}
\hline & $\mid \begin{array}{l}\text { When put } \\
u p, \text { Nov.3. }\end{array}$ & April 30. & Aug. 23. & Nov. 15. \\
\hline Total weight of manure in heap. & $\begin{array}{c}\text { DDs. } \\
10.0 \hat{0} 0\end{array}$ & $\begin{array}{l}\text { to s. } \\
4,960\end{array}$ & $\begin{array}{l}\text { tos. } \\
4,000\end{array}$ & $\begin{array}{l}\text { tDs. } \\
3,790\end{array}$ \\
\hline Water in the heap of mauure... & 6,617 & 2,822 & 1,737 & $1,5 \div 9$ \\
\hline Total organic matter............ & 2.824 & 1,430 & 1,205 & 1,253 \\
\hline Total inorganic matter... ..... & 559 & 646 & 1,057 & 958 \\
\hline Total nitrogen in heap....... & 61.3 & 59 & 50.8 & 57.2 \\
\hline Total soluble organic matter..... & 248 & $2: 30$ & 165 & 203.5 \\
\hline Insoluble organic matter....... & 2,576 & 1,260 & 1,040 & 1,049 \\
\hline Soluble mineral matter....... & 154 & 167 & 122 & 168 \\
\hline Insoluble mineral matter ............. & 425 & 479 & 935 & 790 \\
\hline Nitrogen in soluble matter.... & 14.9 & 13.4 & 10.4 & 15.9 \\
\hline Nitrogen in insoluble matter. & 49.4 & 45.6 & 40.4 & 41.3 \\
\hline Total dry matter in Leap....... & 3.283 & 2,038 & 2,263 & 2,211 \\
\hline
\end{tabular}

It will be seen that the heap of manure kept under corer contained, on the 30th of April, less soluble organic matter, less soluble mineral matter, less soluble nitrogenous matter, and less total nitrogen than the heap of manure exposed to tho weather. This is precisely what I should have expected. The heap of manure in the shed probably fermented more rapidly than the heap out of doors, and there was not water enough in the manure to retain the carbonate of ammonia, or to favor the production of organic acids. The heap was too dry. If it could have received enough of the liquid from the stablez to have kept it moderately moist, the result would have becn very different.

We will postpone further consideration of this point at oresent, and look at the results of another of Dr. Vœlcker's iateresting experiments.

Dr. Vœlcker wished to ascertain the effect of three common methods of managing manure:

1st. Keeping it in a heap in the open air in the barn-yard, or field.

2d. Kreping it in a heap under cover in a shed.

3d. Keeping it spread out over the barn-yard.

"You say these are common methods of managing manıre," remarked the Deacon, "but I never knew any one in this country take the trouble to spread manure over the yard."

"Perhaps not," I replied, "but you have known a good mary farmers who adopt this very method of keeping their manure. They do not spread it-but they let it lie spread out over the yards, just wherever it happens to be."

Let us see what the effect of this treatment is on the composition and value of the manure.

We have examined the effect of keeping manure in a heap in 
the open air, and also of -keeping it in a heap under cover. Now let us see how these methols compare with the practice of leav ing it exposed to the rains, spread out in the yard.

On the 3rd of November, 1854, Dr. Vœlcker weighed out 1,652 lbs. of manure similar to that used in the preceding experiments, and spread it out in the yard. It was weighed April 30, and again August 23, and November 15.

The following table gives the actual weight of the manure at the different periods, also the actual amount of the water, organic matter, ash, nitrogen, etc. :

TABLE SHOWING THE WEIGHT AND COMPOSITION OF FNTIBH MASS OF EXPERI-

MEITAL MANURE (NO. III.), FRESH FARM-TARD MANURE, SPREAD IN OPEN

YARD AT DUFERENT PERIODS OF THE YEAR. IN NATURAL STATE.

\begin{tabular}{|c|c|c|c|c|}
\hline & $\left|\begin{array}{l}\text { When put } \\
\text { up, Nov. } \\
3,1854 .\end{array}\right|$ & $\begin{array}{l}\text { Apri? } 30 \\
18.5\end{array}$ & $\begin{array}{c}\text { Aug. 23, } \\
1855 .\end{array}$ & $\begin{array}{c}\text { Nov. 15, } \\
1855 .\end{array}$ \\
\hline Weight of manure.................. & $\begin{array}{l}\text { ths. } \\
1,65 \% \text {. }\end{array}$ & $\begin{aligned} & \text { tbs. } \text {. } \\
& 1,429 .\end{aligned}$ & $\begin{array}{l}\text { tos. } \\
1,012 .\end{array}$ & $\begin{array}{l}\text { tbs. } \\
9: 0 .\end{array}$ \\
\hline $\begin{array}{l}\text { Amount of water in the manure......... } \\
\text { Amount of dry matter .................... } \\
\text { *Consisting of soluble organic matter... } \\
\text { Soluble mineral matter............ } \\
\text { Insoluble organic matter } \ldots \ldots \ldots \ldots \\
\text { Insoluble mineral matter......... }\end{array}$ & $\begin{array}{r}1,093 . \\
559 . \\
40.97 \\
25.43 \\
425.67 \\
60.93\end{array}$ & \begin{tabular}{|c|}
1.148. \\
28.5 .5 \\
16.55 \\
14.41 \\
163.79 \\
90.75
\end{tabular} & $\begin{array}{r}709.3 \\
302.7 \\
4.96 \\
6.47 \\
106.81 \\
184.46\end{array}$ & $\begin{array}{r}622.8 \\
327.2 \\
3.95 \\
5.52 \\
94.45 \\
223.28\end{array}$ \\
\hline & $559.0 \mathrm{~J}$ & 285.50 & 302.70 & 327.20 \\
\hline 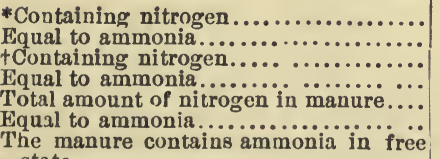 & $\begin{array}{r}3.23 \\
3.99 \\
6.21 \\
7.54 \\
9.49 \\
11.52\end{array}$ & $\begin{array}{l}1.19 \\
1.44 \\
6.51 \\
7.90 \\
7.70 \\
9.34\end{array}$ & $\begin{array}{r}.60 \\
.73 \\
3.54 \\
4.29 \\
4.14 \\
5.02\end{array}$ & $\begin{array}{r}.32 \\
.39 \\
3.56 \\
4.25 \\
3.88 \\
4.64\end{array}$ \\
\hline $\begin{array}{l}\text { state.............................................. } \\
\text { of malts, easily decomposed by quick- }\end{array}$ & .55 & 14 & .13 & $.00 \div 5$ \\
\hline 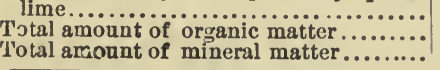 & $\begin{array}{r}1.45 \\
4 r 6.64 \\
92.36\end{array}$ & $\begin{array}{l}.62 \\
10.31 \\
105.16\end{array}$ & $\begin{array}{r}.55 \\
111.77 \\
190.93\end{array}$ & $\begin{array}{r}.28 \\
28.40 \\
228.80\end{array}$ \\
\hline
\end{tabular}

"One moment," said the Deacon. "These tables are a little confusing. The table you have just given shows the actual weight of the manure in the heap, and what it contained at different periods." - "Yes," said I. "and the table following shows what $100 \mathrm{lbs}$ of this manure, spread out in the yard, contained at the different dates mentioned. It shows how greatly manure deteriorates by being exposed to rain, spread out on the surface of the yar.. The table merits careful study." 
TABLE SHOWING COMPOSITION OF EXPERIMGNTAL HEAP (NO. III.), FRESH FARM. YARD MANURE, SPREAD IN OPLN YARD, AT DIFFERENT PERIODS OF THE YEAR. IN NATURAL STATE.

\begin{tabular}{|c|c|c|c|c|}
\hline & $\mid \begin{array}{l}\text { When put } \\
\text { up, 1.00 } \\
3,1854 .\end{array}$ & April 30, & Aug.23, & $\begin{array}{c}\text { Ncv. 15, } \\
1855 .\end{array}$ \\
\hline 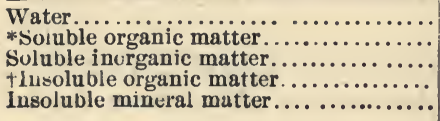 & $\begin{array}{r}6.17 \\
2.48 \\
1.54 \\
25.76 \\
4.05\end{array}$ & $\begin{array}{r}80.02 \\
1.16 \\
1.01 \\
11.46 \\
6.35\end{array}$ & $\begin{array}{r}70.09 \\
.49 \\
.64 \\
10.56 \\
18.22\end{array}$ & $\begin{array}{r}65.56 \\
.42 \\
.57 \\
9.94 \\
23.51\end{array}$ \\
\hline & 100.00 & 100.00 & 100.03 & 100.00 \\
\hline 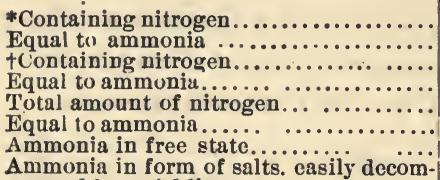 & $\begin{array}{l}.149 \\
.181 \\
.494 \\
.599 \\
.643 \\
.780 \\
.034\end{array}$ & $\begin{array}{l}.08 \\
.119 \\
.45 \\
.54 \\
.55 \\
.63 \\
.010\end{array}$ & $\begin{array}{l}.06 \\
.07 \\
.35 \\
.42 \\
.41 \\
.49 \\
.012\end{array}$ & $\begin{array}{l}.03 \\
.036 \\
.36 \\
.46 \\
.39 \\
.486 \\
.0006\end{array}$ \\
\hline 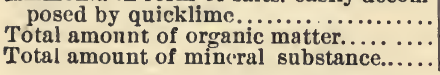 & $\begin{array}{c}.088 \\
28.24 \\
5.59\end{array}$ & $\begin{array}{c}12.045 \\
7.36\end{array}$ & $\begin{array}{l}.051 \\
11.05 \\
18.8 j\end{array}$ & $\begin{array}{l}.090 \\
10.36 \\
24.03\end{array}$ \\
\hline
\end{tabular}

The following table shows the composition of the manure, calculated dry :

IABLE SHOWING COMPOSITION OF EXP RIMENTAL IEAP (YO. MI.), FRESH FARM YARD MANURE, SPREAD IN OPEN YARD, AT DIFFERENT PERIODS OF THE YEAR. CALCULATED DRY.

\begin{tabular}{|c|c|c|c|c|}
\hline & $\left|\begin{array}{c}\text { When put } \\
\text { up, Nov. } \\
3,1854\end{array}\right|$ & $\left|\begin{array}{c}\text { April } 30 \\
1855\end{array}\right|$ & $\begin{array}{c}\text { Aug. 23, } \\
1855 .\end{array}$ & $\begin{array}{c}\text { Nov . 15, } \\
1855 .\end{array}$ \\
\hline $\begin{array}{l}\text { Soluble organic matter } \ldots \ldots \ldots \ldots \ldots \ldots \ldots \\
\text { Soluble inorganic matter................. } \\
\text { tInsoluble organic matter. } \ldots \ldots \ldots \ldots \ldots \ldots \\
\text { Insoluble mineral matter } \ldots \ldots \ldots \ldots \ldots \ldots \ldots\end{array}$ & $\begin{array}{r}7.33 \\
4.55 \\
76.15 \\
11.97\end{array}$ & $\begin{array}{r}5.80 \\
5.05 \\
57.87 \\
31.78\end{array}$ & $\begin{array}{r}1.64 \\
2.14 \\
35.30 \\
60.92\end{array}$ & $\begin{array}{r}1.21 \\
1.69 \\
23.86 \\
68.24\end{array}$ \\
\hline Insoluble mineral matter.............. & 100.00 & 100.00 & 100.00 & 100.00 \\
\hline 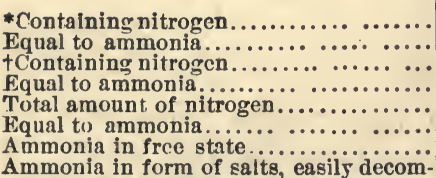 & $\begin{array}{r}.44 \\
.53 \\
1.46 \\
1.77 \\
1.99 \\
2.30 \\
.10\end{array}$ & $\begin{array}{r}.42 \\
.51 \\
2.28 \\
2.76 \\
2.70 \\
3.27 \\
.05\end{array}$ & $\begin{array}{l}.20 \\
.24 \\
1.17 \\
1.41 \\
1.37 \\
1.05 \\
.010\end{array}$ & $\begin{array}{c}.10 \\
.12 \\
1.09 \\
1.32 \\
1.19 \\
1.14 \\
.0017\end{array}$ \\
\hline $\begin{array}{l}\text { posed by quicklime...................... } \\
\text { Total amount of organic matter......... } \\
\text { Total amount of mineral substance ..... }\end{array}$ & $\begin{array}{r}.26 \\
83.48 \\
16.52\end{array}$ & $\begin{array}{l}.225 \\
69.17 \\
36.8: 3\end{array}$ & $\begin{array}{l}.171 \\
36.94 \\
6 ? 06\end{array}$ & $\begin{array}{l}30.077 \\
62.93\end{array}$ \\
\hline
\end{tabular}

I have made out the following table, showing what would be the changes in a heap of 5 tons $(10,000 \mathrm{lbs}$.) of manure, spread out in the yard, so that we can readily see the cffect of this method of 
management as compared with the other two methods of keeping tue manure in compact heaps, one exposed, the other under covcr.

The following is the table:

CONTENTS OF THE MASG OF MANURE, BPREAD OUT IN FARM-YARD, AND EXPOSED TO RAIN, ETC.

\begin{tabular}{|c|c|c|c|c|}
\hline & $\begin{array}{l}\text { When spread } \\
\text { out, Now. } 3 .\end{array}$ & April 30. & Aug 23. & Nov. 15. \\
\hline Total weight of manure. & $\begin{array}{r}\text { 10s. } \\
10,000\end{array}$ & $\begin{array}{l}\text { fos. } \\
8,650\end{array}$ & $\begin{array}{l}\text { tos. } \\
6,1: 0\end{array}$ & $\begin{array}{l}\text { tbs. } \\
5,750\end{array}$ \\
\hline W ater in the manure.............. & 6,617 & 6,922 & $4, \div 97$ & 3,771 \\
\hline Total organic matter............... & 2,821 & $1,0 \Omega 2$ & 677 & 595 \\
\hline 'Total inorgauic matter............ & 559 & 636 & 1,155 & 1,384 \\
\hline Total nitrogen in manure.......... & 64.3 & 45.9 & 25 & 82.4 \\
\hline Total soluble or gunic matter...... & 248 & 100 & 30 & $24 . x$ \\
\hline Insoluble orgauic matter........... & 2,$5 ; 6$ & 992 & 647 & 571 \\
\hline Solubl mineral matter...$\ldots \ldots \ldots$. & 154 & 87 & 39 & 38 \\
\hline Insoluble mineral matter.......... & 405 & 549 & 1,116 & 1,351 \\
\hline Nitrogen in solnble matter........ & 14.9 & 6.9 & 3.6 & 1.7 \\
\hline Nitrogen in insoluble matter...... & $4 ! .4$ & 39 & 21.4 & 20.7 \\
\hline
\end{tabular}

It is not necessary to make many remarks on this table. The facts speak for themselvcs. It will be seen that there is considerable loss even by letting the manure lie spread out until spring; but, serious as this loss is, it i3 small compared to the loss sustained by allowing the manure to lie exposcd in the yard ciuring the summer.

In the five toas of fresh manure, we have, November $3,64.3$ lins. of nitrogen; April 30, we Lare 46 lbs. ; August 23, only 25 1bs. T'is is a great loss of the most valuable constituent of the manure. Of soluble mineral matt: $r$, the next most valuable ingreäient, we have in the five tons of fresh manure, Novcmber 3, 154 lbs.; April 30, 87 lbs. ; and August 23, only 39 lbs. Of soluble nitrogen, the most active and valuable part of the manure, we have, November 3, nearly 15 lbs.; April 30, not quite 7 lbs.; August 23, $3 \frac{1}{2} \mathrm{lbs}$. ; and November 15; not quite $1 \frac{8}{4}$ lus.

Dr. Vœlcker mads still anot'ler experimcnt. He took 1,613 1bs. of well-rotted dung (mixed manure from horses, cows, and pirs,) and kept it in a heap, exposed to the weather, from December 5 to April 30, August 23, and November 15, weighing it and analyzing it at these different dates. I think it is not necessary to give the results in detail. From the 5th of December to the 30th of April, there was no loss of nitrogen in the heap, and comparatively little loss of soluble mincral matters; but from April 30 to August 23, there was considerable loss in both these valuable in. gredients, which were washzgd out of the heap by rain 
Dr. Voelcker draws tha following conclusions from his experiments :

"Having describel at length my experiments with farm-yard manure," he says, "it may not be amiss to state briefly the more prominent and practically interesting points which have beeir developed in the course of this investigation. I woull, therefore, observe:

"1. Perfectly fresh farm yard manure contaius but a small proportion of free ammonia.

" 2. The nitrogen in fresh dung exists principally in tic state of insoluble nitrogenized matters.

"3. The soluble organic and mineral constituents of dung are much more valuable fertilizers than the insoluble. Particular care, therefore, should be bestowed upon the preservation of the liquid excrements of animals, and for the same reason the manure should be kept in perfectly water-proof pits of sufficient capacity to render the setting up of dung-lieaps in the corner of ficlds, as muih as it is possible, unnecessary.

"4. Farm-yard manure, even in quite a fresh stato, contains phosphate of lime, which is much more soluble than has hitherto been suspected.

"5. The urine of the liorse, cow, and pig, does not contain any appreciable quantity of phosphate of lime, whilst the drainings of dung-heaps contain considerable quantities of this valuable fertilizer. The drainings of dung-heaps, partly for this reason, are more valuable than the urine of our domestic animals, and, therefore, ought to be prevented by all available means from running to waste.

" 6 . The most effectual maans of preventing loss in fertilizing matters is to cart the manure directly on the field whenever circumstances allow this to be done.

"7. On all soils with a moderate proportion of clay, no fear need to be entertaized of v.luabl 3 fertilizing substances becoming wasted if the manure cannot be plowed in at once. Fresh, and even well-rotten, dung contains very little free ammonia; and since active fermentation, and with it the further evolution of free ammonia, is stopped by spreading out the manure on the field, valuable volatile manuring matters can not escape into the air by adopting this plan.

"As all soils with a moderate proportion of clay possess in a remarkable degree the power of absorbing and retaining manuring matters, none of the saline and soluble organic constituents are wasted even by a heary fall of rain. It may, indeed, be questioned 
whether it is more advisable to plow in the manure at once, or to let it lie for some time on the surface, and to give the rain full opportunity to wash it into the soil.

"It appears to me a matter of the greatest importance to regulate the application of manure to our fields, so that its constituents may become properly diluted and uniformly distributed amongst a large mass of soil. By plowing in the manure at once, it appears to me, this desirable end can not be reached so perfectly as by allowing the rain to wash in gradually the manure evenly spread on the surface of the field.

"By adopting such a course, in case practical experience should confirm my theoretical reasoning, the objection could no longer be maintained that the land is not ready for carting manure upon it. I am inclined to recommend, as a general rule: Cart the manure on the field, spread it at once, and wait for a favorable opportunity to plow it in. In the case of clay soils, I have no hesitation to say the manure may be spread even six months before it is plowed in, without losing any appreciable quantity in manuring matter.

"I am perfectly aware, that on stiff clay land, farm-yard ma" nure, morc especially long dung, when plowed in before the frost sets in, exercises a most beneficial action by keeping the soil loose, and admitting the free access of frost, which pulverizes the land, and would, therefore, by no means recommend to leave the manure spread on the surface without plowing it in. All I wish to enforce is, that when no other choice is left but either to set up the manure in a heap in a corner of the field, or to spread it on the ficld, without plowing it in directly, to adopt the latter plan. In the case of very light sandy soils, it may perhaps not be advisable to spread out the manure a long time before it is plowed in, since such soils do not possess the power of retaining manuring matters in any marized degree. On light sandy soils, I would sugrest to manure with well-fermented dung, shortly before the crop intended to be grown is sown.

"8. Well-rotten dung contains, likewise, little free ammonia, but a very much larger proportion of soluble organic and saline mineral matters than fresh manure.

" 9 . Rotten dung is richer in nitrogen t'ian fresh.

"10. Weight for weight, rotten dung is more valuable than fres'.'.

"11. In the fermentation of dung, a very considerable proportion of the organic matters in fresh manure is dissipated into the air in the form of carbonic acid and other gascs. 
“12. Properly regulated, however, the fermentation of dung is not attended with any great loss of nitrogen, ror of sahue mineral matters.

"13. During the fermentation of dung, nlmic, humic, and other organic acids are formed, as well as gypsum, which fix the ammonia generated in the decomposition of the nitrugenized constituents of dung.

"14. During the fermentation of dung, the phosphate of lime which it contains is rendered more soluble than in fresh manure.

"15. In the interior and heated portions of manure-heaps, ammonia is given off; but, on passing into the external and cold laycrs of dung-heaps, the free ammonia is rctained in the heap.

"16. Ammonia is not given off from the surface of well-compressed dung-heaps, but on turning manure-heaps, it is wasted in appreciable quantities. Dung-heaps, for this reason, s'iould not be turned more frequently than absolutely necessary.

"17. No advantage appears to result from carrying on the fer mentation of dung too far, but every disadvantage.

"18. Farm-yard manure becomes deteriorated in value, when kept in heaps exposed to the weather, the more the longer it is kept.

"19. The loss in manuring mattcrs, which is incurred in kecping manure-heaps exposed to the weather, is not so much due to the volatilization of ammonia as to the removal of ammoniacal salts, soluble nitrogenizcd organic matters, and valuable mineral matters, by the rain which falls in the period during which the manure is kept.

"20. If rain is excluded from dung-heaps, or little rain falls at a time, the loss in ammonia is trifling, and no saline matters, of course, are removed; but, if much rain falls, especially if it descends in heavy showers upon the dung-heap, a serious loss in ammonia, soluble organic matter, phosphate of lime, and salts of potash is incurred, and the manure becomes rapidly deteriorated in value, whilst at the same time it is diminished in weight.

" 21 . Well-rotten dung is more readily affectcd by the deteriorating influence of rain than fresh manure.

“22. Practically speaking, all the essentially valuable manuring constituents are preserved by keeping farm-yard manure under cover.

" 23 . If the animals have been supplied with plenty of litter, fresh dung cortains an insufficient quantity of water to induce an active fermentation. In this case, fresh dung can not be properly 
fermented under cover, except water or liquid manure is pumped over the heap from time to time.

"Where much straw is used in the manufacture of dung, and no provision is made to supply the manure in the pit at any time with the requisite amount of moisture, it may not be advisable to put up a roof over the dung-pit. On the other hand, on farms where there is a de.ciency of straw, so that the moisture of the excrements of our domestic animals is barely absorbed by the litter, the advantage of erecting a roof over tie dung-pit will be found very great.

"24. The worst methol of making manure is to produce it by animals kept in open yards, since a large proportion of valuable fertilizing matters is wasted in a short time; and after a lapse of twelve months, at least two-thirds of the substance of the manure is wasted, and only one-third, inferior in quality to an equal weight of fresh dung, is left behind.

“25. The most rational plan of keeping manure in heaps appears to me that adopted by Mr. Lawrence, of Cirencester, and described by him at length in Morton's 'Cyclopædia of Agriculture,' under the head of 'Manure.' "

\section{H A P T E R X VI.}

\section{AN ENGLISH FLAN OF KEEPING MANURE.}

"I would like to know," said the Deacon, "how Mr. Lawrence manages his manure, especially as his method has received such high commendation."

Charley got the szcond volume of "Morton's Cyclopædia of Agriculture," from the book shelves, and turned to the article on "Manur3." He found that Mr. Lawrence adopted the "Box System" of feeding cattle, and used cut or chaffed straw for bediing. And Mr. Lawrence claims that by this plan " manure will have been mads under the most perfect conditions." And "when the boxes are full at those periods of the year at which manure is required for the succeeding crops, it will be most advantageously dis. pose 1 of by being transferred at once to the 1 in 1 , and covered in."

"Good, said the Deacon, "I think he is rig'st there." Charley continued, and read as follows :

"But there will be accumulations of manurz requiring removal 
from the homestead at other seasons, at which it cannot be so applied, and when it must be stored for future use. The following has been found an effectual and economical mode of accomplishing this; more particularly when cut litter is used, it saves the cost of repeated turnings, and effectually prevents the decomposition and waste of the most active and volatile principle.

"Some three or more spots are selected according to the size of the farm, in convenient positions for access to the land under tillage, and by the side of the farm roads The sites fixed on are then excavated about two feet under the surrounding surfaec. In the bottom is laid some three or four inches of earth to absorb any moisture, on which the manure is emptied from the carts. This is evenly spread, and well trodden as the heap is forming. As soon as this is about a foot above the ground level, to allow for sinking, the heap is gradually gathered in, until it is completed in the form of an ordinary steep roof, slightly rounded at the top by the final treading. In the course of building this up, about a bushel of salt, to two cart-loads of dung is sprinkled amongst it. The base lail out at any one time should not exceed that required by the manure ready for the complete formation of the hcap as far as it goes; and within a day or two after such portion is built up, and it has settled into shape, a thin coat of earth in a moist state is plastered entirely over the surface. Under these conditions decomposition does not take place, in consequence of the exclusion of the air; or at any rate to so limited an extent, that the ammonia is absorbed by the earth, for there is not a trace of it perceptible about tise heap; though, when put together without such covering, this is perceptible enough to leeward at a hundred yards' distance.

"When heaps thus formed are resorted to in the autumn, either for the young seeds, or for plowing in on the stubbles after preparing for the succeeding root crop, the manure will bo found undiminished in quantity and unimpaircd in quality; in fact, simply consolidated. Decomposition then procecds within the soil, where all its results are appropriated, and rendercd available for the succeeding cereal as well as the root crop.

"It would be inconvenient to plaster the heap, were the ridge, when settled, above six or seven feet from the ground level; the base may be formed about ten to twelve feet wide, and the ridge about nine fcet from the base, which settles down to about seven feet; this may be extended to any length as further supplics of manure require removal. One man is sufficient to form the heap, and it is expedient to employ the same man for this service, who soon gets into the way of performing the work neatly and quickly. 
It has been as'zed where a farmer is to get the earth to cover his heaps-it may be answered, keep your roads scraped when they get muddy on the surface during rainy weather-in itself good cconomy-and leave this in small heaps beyond the margin of your roads. This, in the course of the year, will be found an ample provision for the purpose, for it is unnecessary to lay on a coat more than one or two inches in thickness, which should be done when in a moist state. At any rate, there will always be found an accumulation on headlands that may be drawn upon if 1.ced be.

"Farmers who have not been in the habit of bestowing care on the manufacture and subsequent preservation of their manure, and watching results, have no conception of the importance of this. $\Lambda$ barrowful of such manure as has been described, would produce a greater weight of roots and corn, than that so graphically described by the most talented and accomplished of our agricultural authors-as the contents of 'neighbour Drychaff's dungcart, that creaking hearse, that is carrying to the field the dead body whose spirit has departed.'

"There is a source of valuable and extremely useful manure on every farm, of which very few farmers avail themsel ves-the gathering together in one spot of all combustible waste and rubbish, the clippings of hedges, scouring of ditches, grassy accumulation on the sides of roads and fences, etc., combined with a good deal of earth. If these are carted at lcisure times into a large circle, or in two rows, to supply the fire kindled in the center, in a spot which is frequented by the laborers on the farm, with a three-pronged fork and a shovel attenoiant, and each passer-by is encouraged to add to the pile whenever he sees the smoke passing away so freely as to indicate rapid combustion, a very large quantity of valuable ashes are collected between March and October. In the latter month the fire should be allowed to go out; the ashes are then t':nrown into a long ridge, as high as they will stand, and thatched while dry. This will be found an invaluable store in April, May, and June, capable of supplying from twenty to forty bushels of ashes per acre, according to the care and industry of the collector, to drill with the seeds of the root crop."

The Deacon got sleepy before Charley finished reading. "We can not afford to be at so much trouble in this country," he said, and took up his hat and left.

The Deacon is not altogether wrong. Our climate is very different from that of England, and it is seldom that farmers need to draw out manure, and pile it in the field, except in winter, anil 
then it is not necessary, I think, either to dig a pit or to cover the heap. Those who draw manure from the city in summer, may probably adopt some of Mr. Lawrence's suggestions with advantage.

The plan of collecting rubbish, brush, old wood, and sods, and converting them into ashes or charcoal, is one which we could often adopt with decided advantage. Our premises would be cleaner, and we should have less fungus to speck and crack our apples and pears, and, in addition, we should hare a quantity of ashes or burnt earth, that is not only a manure itself, but is specially useful to mix with moist superphosphate and other artificial manures, to make them dry enough and bulky enough to be easily and evenly distributed by the drill. Artificial manures, so mixed with these ashes, or dry, cliarred earth, are less likely to injure the seed than when sown with the seed in the drill-rows, unmixed with some such material. Sifted coal ashes are also very useful for this purpose.

\section{H A P T E R X V II.}

\section{SOLUBLE PHOSPHATES IN FARM.YARD MANURE.}

There is one thing in these experiments of Dr. Vœlcker's which deserves special attention, and that is the comparatively large amount of soluble phosphate of lime in the ash of farm-yard manure. I do not think the fact is generally known. In estimating the value of animal manures, as compared with artificial manures, it is usually assumed that the phosphates in the former are insoluble, and, therefore, of less value than the soluble phosphates in superphosphate of lime and other artificial manures.

Dr. Vœlcker found in the ash of fresh farm-yard manure, phosphoric acid equal to 12.23 per cent of phosphate of lime, and of this 5.35 was soluble phosphate of lime.

In the ash of well-rotted manure, he found phosphoric acid equal to 12.11 per cent of phosphate of lime, and of this, 4.75 was soluble phosphate of lime.

"That is, indeed, an important fact," said the Doctor, "but I thought Professor Vœlcker claimed that "during the fermentation of dung, the phosphate of lime which it contains is rencered more soluble than in fresh manure." " 
"He did say so," I replied, " and it may be true, but the above figures do not seem to prove it. When he wrote the sentence you have quoted, he probably had reference to the fact that he found more soluble phosphate of lime in rotted manure than in fresh manure. Thus, he found in 5 tons of fresh and 5 tons of rotted manure, the following ingredients :

\begin{tabular}{|c|c|c|c|c|c|c|c|c|}
\hline \multirow[t]{2}{*}{$\begin{array}{c}5 \text { TONS, } \\
(10,000 \text { LBS.) }\end{array}$} & \multirow[t]{2}{*}{ 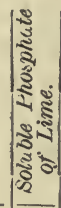 } & \multirow[t]{2}{*}{ 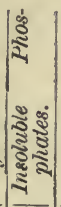 } & \multirow[t]{2}{*}{ 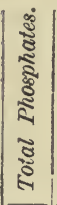 } & \multicolumn{2}{|c|}{ 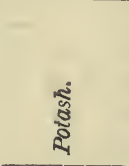 } & \multirow[t]{2}{*}{ 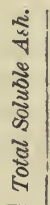 } & \multirow[t]{2}{*}{ 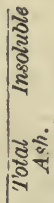 } & శై \\
\hline & & & & Sol. & Insol. & & & $\hat{~}$ \\
\hline $\begin{array}{l}\text { Fresh manure................. } \\
\text { Rotted manure.......... }\end{array}$ & $\left|\begin{array}{l}29.9 \\
38.5\end{array}\right|$ & $\left|\begin{array}{l}38.6 \\
573\end{array}\right|$ & $\begin{array}{l}68.5 \\
95.5\end{array}$ & $\begin{array}{l}57.3 \\
44.6\end{array}$ & $\begin{array}{l}9.9 \\
4.5\end{array}$ & $\begin{array}{l}154 \\
147\end{array}$ & $\begin{array}{l}105 \\
658\end{array}$ & $\begin{array}{l}5: 9 \\
805\end{array}$ \\
\hline
\end{tabular}

"It will be seen from the above figures that rotted manure contains more soluble phosphate of lime than fresh manure.

"But it does not follow from this fact that any of the insoluble phosphates in fresh manure have been rendered soluble during the fermentation of the manure.

"There are more insoluble phosphates in the rotted manure than in the fresh, but we do not conclude from this fact that any of the phosphates have been rendered insoluble during the process of fermentation-neither are we warranted in concluding that any of them have been rendered soluble, simply because we find more soluble phosphates in the rotted manure."

"Very true," said the Doctor, "but it has been shown that in the heap of manure, during fermentation, there was an actual increase of soluble mineral matter during the first six months, and, to say the least, it is highly probable that some of this increase of soluble mineral matter contained more or less soluble phosphates, and perhaps Dr. Vœicker had some facts to show that such was the case, although he may not have published them. At any rate, he evidently thinks that the phosphates in manure are rendered more soluble by fermentation."

"Perhaps," said I, "we can not do better than to let the matter rest in that form. I am merely anxious not to draw definite conclusions from the facts which the facts do not positively prove. I am strongly in favor of fermenting manure, and should be glad to have it shown that fermentation does actually convert insoluble phosphates into a soluble form."

There is one thing, however, that these experiments cleariy prove, and that is, that there is a far larger quantity of solubis 
phosphates in manure than is generally supposed. Of the total phosphoric acid in the fresh manure, 43 per cent is in a soluble condition; and in the rotted manure, 40 per cent is soluble.

This is an important fact, and one which is generally overlooked. It enhances the value of farm-yard or stable manure, as compared with artificial manures. But of this we may have more to say when we come to that part of the subject. I want to make one remark. I think there can be little doubt that the proportion of soluble phosphates is greater in rich manure, made from grainfed animals, than in poor manure made principally from straw. In other words, of $100 \mathrm{lbs}$. of total phosphoric acid, more of it would be in a soluble condition in the rich than in the poor manure.

\section{II A P T E R X V I I I.}

\section{HOW THE DEACON MAKES MANURE.}

"I think," said the Deacon, "you are talking too much about the science of manure making. Science is all well enough, but practice is better."

"That depends," said I, "on the practice. Suppose you tell us how you manage your manure."

"Well," said the Deacon, "I do not know much about plantfood, and nitrogen, and phosphoric acid, but I think manure is a good thing, and the more you have of it the better. I do not believe in your practice of spreading manure on the land and letting it lie exposed to the sun and winds. I want to draw it out in the spring and plow it under for corn. I think this long, coarse manure loosens the soil and makes it light, and warm, and porous. And then my plan saves labor. More than half of my manure is handled but once. It is made in the yard and sheds, and lies there until it is drawn to the field in the spring. The manure from the cow and horse stables, and from the pig-pens, is thrown into the yard, and nothing is done to it except to level it down occasionally. In proportion to the stock kept, I think I make twice as much manure as you do."

"Yes," said I, "twice as much in bulk, but one load of my manure is worth four loads of your long, coarse manure, composed 
principally of corn-stalks, straw, and water. I think you are wise in not spending much time in piling and working over such manure."

The Deacon and I have a standing quarrel about manure. We differ on all points. He is a good man, but not what we call a good farmer. He cleared up his farm from the original forest, and he has always been content to receive what his land would give him. If he gets good crops, well, if not, his expenses are moderate, and he manages to make both ends meet. I tell him he could double his crops, and quadruple his profits, by better farming-but though he cannot disprove the facts, he is unwilling to make any change in his system of farming. And so he continues to make just as much manure as the crops he is obliged to feed out leave in his yards, and no more. He does not, in fact, make any manure. He takes what comes, and gets it on to his land with as little labur as possible.

It is no use arguing with such a man. And it certainly will not do to contend that his method of managing manure is all wrong. His error is in making such poor manure. But with such poor stuff as he has in his yard, I believe he is right to get rid of it with the least expense possible.

I presume, too, that the Deacon is not altogether wrong in regard to the good mechanical effects of manure on undrained and indifferently cultivated land. I have no doubt that he bases his opinion on experience. The good effects of such manure as he makes must be largely due to its mechanical action-it can do little towards supplying the more important and valuable elements of plant-food.

I commend the Deacon's system of managing manure to all such as make a similar article. But I think there is a more excellent way. Feed the stock better, make richer manure, and then it will pay to bestow a little labor in taking care of it. 


\section{H A P T E R X I X.}

\section{HOW JOHN JOHNSTON MANAGES HIS MANURE.}

One of the oldest and most successful farmers, in the State of New York, is John Johnston, of Geneva. He has a farm on the borders of Seneca Lake. It is high, rolling land, but needed under draining. This has been thoroughly done-and done with great profit and advantage. The soil is a heavy clay loain. Mr. Jolnnston has been in the habit of summer-fallowing largely for wheat, generally plowing three, and sometimes four times. He has been a very successful wheat-grower, almost invariably obtaining large crops of wheat, both of grain and straw. The straw he feeds to shecp in winter, putting more straw in the racks than the sheep can cat up clean, and using what they leave for bedding. The shcep run in yards enclosed with tight board fences, and have sheds under the barn to lie in at pleasure.

Although the soil is rather heavy for Incian corn, Mr. Johnston succeeds in growing large crops ô this great American cereal. Corn and stalks are both fed out on the farm. Mr. J. has not yet practised cutting up his straw ard stalks into chaff.

The land is admirably aciapted to the growth of red clover, and great crops of clover and timothy-hay are raised, and fe 3 out on the farm. Gypsum, or plaster, is sown quite freely on the clover in the spring. Comparatively few roots are raised-not to exceed an acre-and thesc only quite recently. The main crops are winter wheat, spring barley, Indian corn, clover, and timothy-hay, and clover-seed.

The materials for making manure, then, are wheat and barley straw, In $\}$ ian corn, cora-stal'ss, clover, and timothy-hay. These are all raised on the farm. But Mr. Johnston has for many years purchased linsecd-cil cake, to feed to his sheep and cattle.

This last fact must not be overlooked. Mr. J. commenced to feed oil-cake when its value was little known here, and when he bought it for, I think, seven or eig'at dollars a ton. He continued to use it even when he had to pay fifty dollars per ton. Mr. J. has great faith in manure-and it is a faith resting on good evidence and long experience. If he had not fed out so much oil-cake and clover-hay, he would not bave found his manure so valuable.

"How much oil-cake does he use?" asked the Daacon.

"He gives his s'seep, oz the average, about 1 lb. each per day." 
If he feeds out a ton of clover-hay, two tons of straw, (for feed and bedding,) and one ton of oil-cake, the manure obtained from this quantity of food and litter, would be worth, according to Mr. Lawes' table, given on page $45, \$ 34.72$.

On the other hand, if he fed out one ton of corn, one ton of clover-hay, and two tons of straw, for feed and bedding, the manure would be worth $\$ 21.65$.

If he fed one ton of corn, and three tons of straw, the manure would be worth only $\$ 14.69$.

He would get as much manure from the three tons of straw and one ton of corn, as from the two tons of straw, one ton of cloverhay, and one ton of oil-cake, while, as before said, the manure in the one case would be worth $\$ 14.69$, and in the other $\$ 34.72$.

In other words, a load of the good manure would be worth, when spread out on t'xe land in the field or garden, more than two loads of the straw and com manure.

To get the same amount of nitrogen, phosphoric acid, and potash, you have to spend more than twice the labor in cleaning out the stables or yards, more than twice the labor of throwing or wheeling it to the manure pile, more than twice the labor of turning the manure in the pile, more than twice the labor of loading it on the carts or wagons, more than twice the labor of drawing it to the field, more than twice the labor of unloading it into heaps, and more than twice the labor of spreading it in the one case than in the other, and, after all, twenty tons of this poor manure would not produce as good an effect the first season as ten tons of the richer manure.

"Why so"? asked the Deacon.

"Simply because the poor manure is not so active as the richer manure. It will not decompose so readily. Its nitrogen, phosphoric acid, and pot:sh, are not so available. The twenty tons, may, in the long run, do as much good as the ten tons, but I very much doubt it. At any rate, I would greatly prefer the ten tons of the good manure to twenty tons of the poor-even when spread out on the land, ready to plow under. What the difference would be in the value of the manure in the yard, you can figure for yourself. It would depend on the cost of handling, drawing, and spreading the extra ten tons."

The Deacon estimates the cost of loading, drawing, unloading, and spreading, at fifty cents a ton. This is probably not far out of the way, though much depends on the distance the manure has to be drawn, and also on the condition of the manure, etc. 
The four tons of feed and bedding will make, at a rough estimate about ten tons of manure.

This ten tons of straw and corn manure, according to Mr. Lawes' estimate, is worth, in the field, $\$ 14.69$. And if it costs fifty cents a load to get it on the land its value, in the yard, would be $\$ 9.69-$ or nearly ninety-seven cents a ton.

The ten tons of good manure, according to the same estimate, is worth, in the field, $\$ 34.72$, and, consequently, would be worth, in the yard, \$29.72. In other words, a ton of poor manure is worth, in the yard, ninety-seven cents a ton, and the good manure \$2.97.

And so in describing John Johnston's method of managing manure, this fact must be borne in mind. It might not pay the Deacon to spend much labor on manure worth only ninety-seven cents a ton, while it might pay John Johnston to bestow some considerable time and labor on manure worth $\$ 2.97$ per ton.

"But is it really worth this sum?" asked the Deacon.

"In reply to that," said I, " all I claim is that the figures are com. parative. If your manure, made as above described, is worth nınety-seven cents a ton in the yard, then John Johnston's manure, made as stated, is certainly worth, at least, $\$ 2.97$ per ton in the yard."

Of this there can be no doubt.

"If you think," I continued, " your manure, so made, i3 worth only half as much as Mr. Lawes' estimate; in other words, if your ten tons of manure, instead of being worth $\$ 14.69$ in the field, is worth only $\$ 7.35$; then John Johnston's ten tons of manure, instead of being worth $\$ 34.72$ in the field, is worth only $\$ 17.36$."

"That looks a little more reasonable," said the Deacon, "John Johnston's manure, instead of being worth $\$ 2.97$ per ton in the yard, is worth only $\$ 148$ per ton, and mine, instead of being worth ninetyseven cents a ton, is worth forty-eight and a half cents a ton."

The Deacon sat for a few minutes looking at these figures. "They do not seem so extravagantly high as I thought them at first," he sald, "and if you will reduce the figures in Mr. Lawes" table one-haif all through, it will be much nearer the truth. I think my manure is worth forty-eight and a half cents a ton in the yard, and if your figures are correct, I suppose I must admit that John Johnston's manure is worth $\$ 1.48$ per ton in the yard."

I was very glad to get such an admission from the Deacon. He did not see that he had made a mistake in the figures, and so $1 \mathrm{gnt}$ him to go over the calculation again. 
"You take a pencil, Deacon," said I, "and writs down the figures :

Manure from a ton of cil cake............... \$19.72

Manure from a ton of clover-hay.............. 9.64

Manure from two tons of straw............. 5.36

$\$ 31.72$

"This would make aboit ten tons of manure. We have aqreed to reduce the estimate one-half, and consequently we have $\$ 17.36$ as the value of the ten tons of manure."

"This is John Johnston's manure. It is worth $\$ 1.73$ per ton in the ficld.

"It costs, we have estimated, 50 cents a ton to handle the manure, and consequently it is worth in the yard $\$ 1.23$ per ton."

"This is less than we made it before," said the Deacon.

"Never mind that," said I, " the figures are correct. Now write down what your manure is wort' :

Manure from 1 ton of corn ..................\$6.65

Manure from 3 tons of straw............... 8.04

$\$ 14.69$

"This will make about ten tons of manurs. In this case, as in the other, we are to reduce the estimate one-half. Consequently, we have $\$ 7.35$ as the value of this ten tons of manure in the ficld, or 173 $\frac{1}{2}$ cents a ton. It costs, we have estimated, 50 cents a ton to handle the manure, and, thercfore, it is worth in the yard, $23 \frac{1}{2}$ cents a ton."

"John Johnston's manure is worth in the yard, $\$ 1.23$ pcr ton. The Deacon's manure is worth in the yard, $23 \frac{1}{2}$ cents per ton."

"There is some mistake," exclaimed the Deacon, "you said, at first, that one load of John Johnston's manure was worth as much as two of my loads. Now you make one load of his manure worth more than five loads of my manure. This is absurd."

"Not at all, Deacon," said I, "you made the figures yourscif. You thought Mr. Lawes' estimate too high. You reduced it onehalf. The figures are correct, and you must accept the conclusion. If John Johnston's manure is only worth $\$ 1.23$ per ton in the yard, yours, made from 1 ton of corn and 3 tons of straw, is only worth $23 \frac{1}{2}$ cents per ton."

"An 1 now, Deacon," I continued, "while you have a pencil in your hand, I want you to make one more calculatio:. Assuming that Mr. Lawes' estimate is too hi wh, and we reduce it one-half, 
figure up what manure is worth when made from straw alone. Yon take 4 tons of wheat straw, feed out part, and use part for bedding. It will give you about 10 tons of manure. And this 10 tons cost you 50 cents a ton to load, draw out, and spread. Now figure:

"Four tons of straw is worth, for manure, according to Mr. Lawes' table, $\$ 2.68$ per ton. We have agreed to re.'uce the figures - oze half, and so the

10 tons of manure from the 4 tons of straw is worth...\$5.36

Drawing out 10 tons of manure at 50 cents......... 5.0J

Value of 10 tons of straw-manure in yard .......... \$0.36

“In other words, if John Johnston's manure is worth only $\$ 1.23$ per ton in the yard, the straw-made manure is worth only a little over $3 \frac{1}{2}$ cents a ton in the yard."

"That is too absurd," said the Deacon.

"Very well," I replied, " for once I am glad to arree with you. Bat if this is absurd, then it follows that Mr. Lawes' estimate of the value of certain foods for manure is not so extravagant as you supposed-which is precisely what I wished to prova."

"You have not toll us how Mr. Johnston manages his manure," said the Deacon.

"There is nothing very remarkable about it," I replied. "There are many fumers in this neighborhood who adopt the same method. I think, however, John Johnston was the first to recommond it, and subjected himself to some criticism from some of tie so-called scientific writers at the time.

"His general plan is to leave the manure in the yards, bascments, and sheils, under the sheep, until spring. He usially sells his fat sheep in March. As soon as the shecp are removed, the manure is either thrown up into loose heaps in the yard, or drawn directly to the field, where it is to ba used, and made into a heap there. The manure is not spread on the land until the autumn. It remains in the heaps or piles all summer, being usually turned once, and sometimes twice. Tye manure becomes thoroughly rotted."

Mr. Johnston, like the Deacon, applies his manure to the cor:a crop. But the Deacon draws out his fresh green manure in the spring, on sod-land, and plows it under. Mr. Johnston, on the other hand, keeps his manure in a beap through the summcr, 
spreads it on the sod in september, or the first week in October. Here it lies until next spring. The grass and clover grow up through manure, and the grass and manure are turned under next spring, and the land planted to corn.

Mr. Johnston is thoroughly convinced that he gets far more benefit from the manure when applied on the surface, and left exposed for several months, than if he plowed it under at once.

I like to write and talk about John Johnston. I like to visit him. He is so delightfully enthusiastis, believes so thoroughly in good farming, and has been so eminently successful, that a day spent in lis company can not fail to encourage any farmer to renewed efforts in improving his soil. "You must drain," he wrote to me; "when I first commenced farming, I never made any money until I began to underdrain." But it is not underdraining alone that is the cause of his eminent success. When he bought his farm, "near Genera," over fifty years ago, there was a pile of manure in the yard that had lain there year after year, until it was, as he said, "as black as my hat." The former owner regarded it as a nuisance, and a few months before young Johnston bought the farm, had given some darkies a cow on condition that they would draw out this manure. They drew out six loads, took the cow-and that was the last seen of them. Johnston drew out this manure, raised a good crop of wheat, and that gave him a start. He says he has been asked a great many times to what he owes his success as a farmer, and he has replied that he could not tell whether it was "dung or credit." It was probably neither. It was the man-his intelligence, indtstry, and good common serse. That heap of black mould was merely an instrument in his hands that he could turn to good account.

His first crop of wheat gave him "credit." and this also he used to advantage. He believed that good farming would pay, and it was this faith in a genercus soil that made him willing to spend the money obtained from the first crop of wheat in enriching tho land, and to avail himself of his credit. Had he lacked this faithhad he hoarded every sixpence he could have ground out of the soil, who would have ever heard of John Johnston? He has been liberal with his crops and his animals, and has ever found them grateful. This is the real lesson which his life teaches.

He once wrote me he had something to show me. He did not tell me what it was, and when I got there, he took me to a field of griss that was to be mown for hay. The field had been in winter wheat the year before. At the time of sowing the wheat, the 
whole field was seeded down with timothy. No clover was sown either then or in the spring; but after the wheat was sown, he put on a slight dressing of manure on two portions of the field that he thought were poor. He to.d the man to spread it out of the wagon just as thin as he could distribute it evenly over the land. It was a very light manuring, but the manure was rich, and thoroughly rotted. I do not recollect whether the effect of the manure was particularly notiecd on the wheat; but on the grass, the following spring, the effect was sufficiently striking. Those two portions of the field where the manure was spread were covered with a splendid crop of red clover. You could see the exact line, in both cases, where the manure reached. It looked quite curious. No clover-seed was sown, and yet there was as fine a crop of clover as one could desirc.

On looking into the matter more elosely, we found that there was more or less elover all over the field, but where the manure was not used, it could hardly be seen. Thз plants were small, and the timothy hid them from view. But where the manure was used, these plants of clover had been stimulated in thcir growth until they covered the ground. The leaves were broad and vigorous, while in the other case they were small, and almost dried up. This is probably the right explanation. The manure did not "bring in the clover ;" it simply inereased the growth of that already in the soil. It shows the value of manure for grass.

This is what Mr. Johnston wanted to show me. "I. might have written and told you, but you would not have got a clear iclea of the matter." This is true. Onc had to see the great luxuriance of that piece of elover to funy appreciate the effect of the manure. Mr. J. said the manure on that grass was worth $\$ 30$ an acre-that is, on the three crops of grass, before the ficld is again plowed. I have no doubt that this is true, and that the future crops on the land will also be benefited-not direetly from the manure, perhaps, but from the clover-roots in the soil. And if the field were pastured, the effect on future crops would be very decided. 


\section{II A P T E R X X.}

\section{MY OWN PLAN OF MANAGING MANURE.}

One of the charms and the advantages of agriculture is that a farmer must think for himself. He should study principles, and apply them in practice, as best suits his circumstances.

My own methol of managing manure gives me many of the advantages claimed for the Deacon's method, and John Johnston's, also.

"I do not understand what you mean," said the Deacon; "my method differs essentially from that of John Johnston."

"True," I replied, "you use your winter-made manure in the spring; while Mir. Johnston piles his, and gets it thoroughly fermented; but to do this, he has to keep it until the autumn, and it does not benefit his corn-crop before the next summer. He loses the use of his manure for a year."

I think my method secures both these advantages. I get my winter-made manure fermented and in good condition, and yet have it ready for spring crops.

In the first place, I should remark that my usual plan is to cut up all the forlder for horses, cows, and sheep. For horses, I sometimes use long straw for bedding, but, as a rule, I prefer to run everything through a feed-cutter. We do not steam the food, and we let the cows and sheep have a liberal supply of cut corn-staliks and straw, and what they do not eat is thrown out of the mangers and racks, and used for bedding.

I should state, too, that I keep a good many pigs, seldom having less than 50 breeding sows. My pigs are mostly sold at from two to four months old, but we probably average 150 head the year round. A good deal of my manure, therefore, comes from the pig-pens, and from two basement cellars, where my store hogs sleep in winter.

In addition to the pigs, we have on the farm from 150 to 200 Cotswold and grade sheep; 10 cows, anả 8 horses. These are our manure makers.

The raw material from which the manure is manufactured consists of wheat, barley, rye, and oat-straw, corn-stalks, corn-fodder, clover and timothy-hay, clover seed-hay, bean-straw, pea-straw, potato-tops, mangel-wurzel, turnips, rape, and mustard. These are all raised on the farm; and, in addition to the home-grown oats. peas, and corn, we buy and feed out considerable quantities 
of bran, shorts, fine-middlings, malt-combs, corn-meal, and a little oil-cake. I sell wheat, rye, barley, and clover-seed, apples, and potatoes, and sometimes cabbages and turnips. Probably, on the average, for each $\$ 100$ I receive from the sale of these crops, I

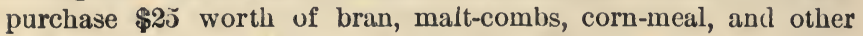
feed for animals. My farm is now rapidly increasing in fertility and productiveness. The crops, on the average, are ccrtainly at least double what they were when I bought the farm thirteen years ago; and much of this increase has taken place during the last five or six years, and I expect to see still greater improvement year by year.

"Never mind all that," sail the Deacon; "we all know that manure will enrich land, and I will concede that your farm has greatly improved, and can not help but improve if you continue to make and use as much manure."

"I expect to make more and more manure every year," said I. "The larger the crops, the more manure we can make; and the more manure we make, the larger the crops."

The real point of differezce between my plan of managing manure, and the plan adopted by the Deacon, is essantially this: I aim to keep all my manure in a compact pile, where it will slowly ferment all winter. The Deacon throws his horse-manure into a heap, just outside the stable door, and t'e cow-manure into another heap, and the pig-manure into another heap. These heaps are more or less scattered, and are exposed to the rain, and snow, and frost. The horse-manure is quite likely to ferment too rapidly, and if in a large heap, and the weather is warm, it not unlikely "fire-fangs" in the center of the heap. On the other hand, the cow-manurs lies cold and dead, and during the winter freezes into solil lumps.

I wheel or cart all my manure into one central heap. The main object is to keep it as compact as possible. There are two advaitages in this: 1st, the manure is less exposed to the rain, an.l (2d), when freezing weather sets in, only a few inches of the external portion of the heap is frozen. I have practised this plan for several years, and can keep my heap of manure slowly fermenting during the whole winter.

But in order to ensure this result, it is necessary to begin mak. ing the heap before winter sets in. The plan is this:

Having selected the spot in the yard most convenient for making the heap, collect all the manure that can be found in the sheep- 
yards, sheds, cow and horse stables, pig-pens, and hen-house, together with leaves, weeds, and refuse from the garden, and wheel or cart it to the intended heap. If you set a farm-man to do the work, tell him you want to make a hot-bed about five feet high, six feet wide, and six feet long. I do not think I have ever seen a farm where enough material could not be found, say in November, to make such a heap. And this is all that is needed. If the manure is rich, if it is obtained from animals eating clover-hay, bran, grain, or other food rich in nitrogen, it will soon ferment. But if the manure is poor, consisting largely of straw, it will be very desirable to make it richer by mixing with it bone-dust, blood, hendroppings, woollen rags, chamber-lye, and animal matter of any kind that you can find.

The richer you can make the manure, the more readily will it ferinent. A gond plan is to take the horse or sheep manure, a few weeks previous, and use it for bedding the pigs. It will absorb the liquid of the pigs, and make rich manure, which will soon ferment when placed in a heap.

If the manure in the heap is too dry, it is a good plan, when you are killing hogs, to throw on to the manure all the warm water, hair, blood, intestines, etc. You may think I am making too much of such a simple matter, but $I$ have had letters from farmers who have tried this plan of managing manure, and they say that they can not keep it from freezing. One reason for this is, that they do not start the heap early enough, and do not take pains to get the manure into an active fermentation before winter sets in. Much depends on this. In starting a fire, you take pains to get a little fine, dry wood, that will burn readily, and when the fire is fairly going, put on larger sticks, and presently you have such a fire that you can burn wood, coal, stubble, sods, or anything you wish. And so it is with a manure-heap. Get the fire, or fermentation, or, more strictly speaking, putrefaction fairly startcd, and there will be little trouble, if the heap is large enough, and frcsh material is added from time to time, of continuing the fermentation all winter.

Another point to be observed, and especially in cold weather, is to keep the sides of the heap straight, and the top level. You must expose the manure in the heap as little as possible to frost and cold winds. The rule should be to spread every wheel-harrowful of manure as soon as it is put on the heap. If left unspread on top of the heap, it will freeze; and if afterwards covered with other manure, it will require considerable heat to melt it, and thus reduce the temperature of the whole heap. 
It is far less wor's to manage a heap of manure in this way than may be supposed from my description of the plan. The truth is, I find, in point of fact, that it is not an easy thing to manage manure in this way; and I fear not one farmer in ten will succeed the first winter he undertakes it, unless he gires it his personal attention. It is well worth trying, however, because if your heap should freeze up, it will be, at any rate, in no worse condition than if managed in the ordinary way; and if you do succeed, even in part, "you will have manure in good condition for immediate use in the spring.

As I have said before, I keep a good many pigs. Now pigs, if fed on slops, void a large quantity of liquid manure, and it is not always easy to furnish straw enough to absorb it. When straw and stalks are cut into cLaff, they will absorb much more liquil than when used whole. For this reasen we usually cut all our straw and stalks. We also use the litter from the horse-stable for bedding the store hogs, and also sometimes, when comparatively dry, we use the refuse sheep bedding for the same purpose. Where the sheep barn is contiguous to the pig-pens, and when the sheep bedding can be thrown at once into the pig-pens or cellar, it is well to use bedding freely for the sheep and lambs, and remove it frequently, throwing it into the pig-pens. I do not want my sheep to be compelled to eat up the straw and corn-stalks too close. I want them to pick out what they like, and then throw away what they leave in the troughs for bedding. Sometimes we take out a five-bushel basketful of these direct from the troughs, for bedding young pigs, or sows and pigs in the pens, but as a rule, we use them first for bedding the sheep, and then afterwards use the sheep bedding in the fattening or store pig-pens.

"And sometimes," remarked the Deacon, "you use a little long straw for your young pigs to sleep on, so that they can bury themselves in the straw and keep warm."

"True," I replied, "and it is not a bad plan, but we are not now talking about the management of pigs, but how we treat our manure, and how we manage to have it ferment all winter."

A good deal of our pig-manure is, to borrow a phrase from the pomologists, "double-worked." It is horse or sheep-manure, used for bedding pigs and cows. It is saturated with urine, and is much richer in nitrogenous material than ordinary manure, and consequently will ferment or putrify much more rapidly. Usually pig-manure is considered "cold," or sluggish, but this double- 
worked pig-manure will ferment even more rapidly than sheep or horse-manure alone.

Unmixed cow-manure is heavy and cold, and when kept in a heap by itself out of doors, is almost certain to freeze up solid during the winter.

We usually wheel out our cow-dung every cay, and spread on the manure heap.

This is one of the things that neels attention. There will be a constant tendency to put all the cow-dung together, instead of mixing it with the lighter and more active manure from the horses, sheep, and pigs. Spread it out and cover it with some of the more strawy manure, which is not so liable to freeze.

Should it so happen-as will most likely be the case-that on looking at your heap some moraing when the thermometer is below zaro, you find that ssveral wheel-barrowfuls of manure that were put on the heap the day before, were not spreal, and are now crusted over with ice, it will be well to break up the barrowfuls, even if necessary to use a crowbur, and place the frozen lumps of manure on the outside of the heap, rather than to let them lie in the center of the pile. Your aim siould be always to keep the center of the heap warm and in a state of fermentation. You do not want the fire to go out, and it will not go out if the heap is properly managed, even should all the sides and top be crusted over with a layer of frozın manure.

During very severe weather, and when the top is frozen, it is a good plan, when you are about to wheel some fresh manure on to the heap, to remove a portion of the frozen crust on top of the heap, near the center, and make a hole for the fresh manurs, which should be spread and covered up.

When the beap is high enough, say five feet, we connence another heap alongside. In doing this, our plan is to clean out some of the sheep-sheds or pig-pens, where the minure has accumulated for some time. This gives us much more than the daily supply. Place this manure on the outside of the new heap, and then take a quantity of hot, fermenting, manure from the middle of the old heap, and throw it into the center of the new heap, and then cover it up with the fresh manure. I would put in eight or ten bushels. or as much as will warin up the center of the new heap, and start fermentation. The colder the weather, the more of this hot manure should you take from the old heap-the more the bettrr. Fresh manure should be added to the old heap to fill up the hole made by the removal of the hot manure. 
"You draw out a great many loads of manurs during the winter," said the Deacon, "and pile it in the field, and I have always thought it a good plan, as you do the work when there is little else to do, and when the ground is frozen."

Yes, this is an improvement on my old plan. I formerly used to turn over the heap of manure in the barn-yard in March, or as soon as fermentation had ceased.

Tine object of turaing the heap is (1st,) to mix the manure and make it of uniform quality; $(2.1$,$) to break the lumps and make the$ manure fine; and ( $3 \mathrm{~d}$,$) to lighten up the manure and make it$ loose, thus letting in the air and inducing a second fermentation. It is a good plan, and well repays for the labor. In doing the work, build up the end and sides of the new heap straight, and keep the top flat. Have an eye on the man doing the work, and see that he breaks up the manure and mixes it thoroughly, and that he goes to the bottom of the heap.

My new plan that the Dexcon alludes to, is, instead of turning the heap in the yard, to draw the manure from the heap in the yard, and pile it up in anot'zer heap in the field where it is to be used. This has all the effects of turning, and at the sa:ne time saves a good deal of team-work in the spring.

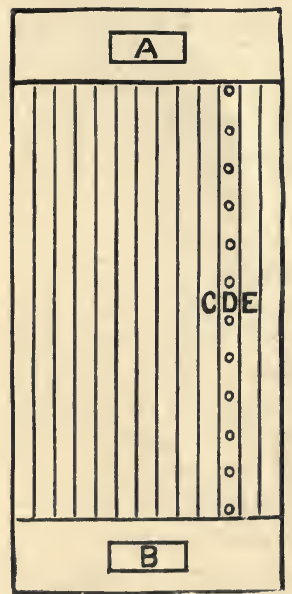

$A, B$, Manure Heaps; $C$, D, E, Ridges, $2 \frac{1}{2}$ ft. apart.

The location of the manure-heap in the field deserves some consideration. If the manure is to be used for root-crops or potatoes, and if the land is to be ridged, and the manure put in the ridges, then it wili be clesirable to put the heap on the headland, or, better still, to make two leaps, one on the headland top of the ficll, and the other on the headland at the bottom of the field,as show $n$ in the annexed engraving.

We draw the manure with a cart, the horse walking between two of the rigges (D), and the wheels of the cart going in $\mathrm{C}$ and $\mathrm{E}$. The manure is pulled ont at the back end of the cart in io small heaps, about five paces apart.

"That is what I object to with you agricultural writers," said the Doctor; "you say 'about five paces,' and sometimes 'about five paces would mean 4 yards, and sometimes 6 yards; and if you 
put 10 tons of manure per acre in the one case, you would put 15 tons in the other-which makes quite a difference in the dose."

The Doctor is right. Let us figure a little. If your cart holds 20 bushels, and if the manure weighs $75 \mathrm{Ibs}$. to the bushel, and you wish to put on 10 tons of manure per acre, or 1,500 bushels; or $13 \frac{1}{3}$ cart-luads, then, as there are 43,560 square feet in an acre, you want a bushei of manure to 29 square feet, or say a space 2 yards long, by nearly 5 feet wide.

Now, as our ridges are $2 \frac{1}{2}$ feet apart, and as our usual plan is to manure 5 ridges at a time, or $12 \frac{1}{2}$ feet wide, a load of 20 bushels of manure will go over a space $46 \frac{1}{2}$ feet long, nearly, or say $15 \frac{1}{2}$ yards; and so, a load would make 3 heaps, $15 \frac{1}{2}$ feet apart, and there would be 6 z bushcls in each heap.

If the manure is to be spread on the surface of the land, there is no necessity for placing the heap on the headland. You can make the heap or heaps.-."Where most convenient," broke in the Deacon.- "No, not by any means," I rcplied; "for if that was the rule, the men would certainly put the heap just where it happened to be the least trouble for them to draw and throw off the loads."

The aim should be to put the heap just where it will require the least labor to draw the manure on to the land in the spring.

On what we call " rolling," or hilly land, I would put the heap on the highest land, so that in the spring the horses would be going down hill with the full carts or wagons. Of course, it would be very unwise to adopt this plan if the manure was not

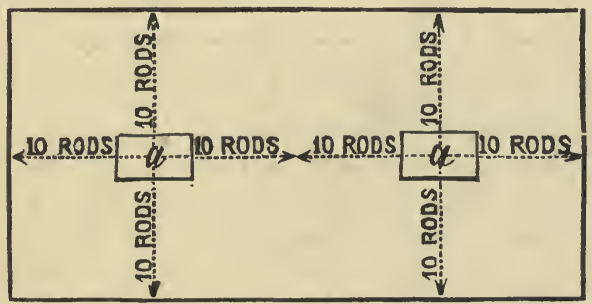

Field, 40x20 Rods, showing Position of two Heaps of Manure, $a, a$.

drawn from the yards until spring, when the land was soft; but I am now speaking of drawing out the manure in the winter, when there is sleighing; or when the ground is frozen. No farmer will object to a little extra labor for the teams in the winter, if it will save work and time in the spring: 
If the land is level, then the heap or heaps should be placed where the least distance will have to be traveled in drawing the manure from the heap to the land. If there is only one he:ap, the best point would be in the center of the field. If two heaps, and the field is longer than it is broad, say 20 rods wide, and 40 rods long, then the heaps should be made as shown on the previous page.

If the field is square, say $40 \times 40$ rods, and we can have four heaps of manure, then, other things being equal, t'ie best points for the heaps are shown in the annexed figure:

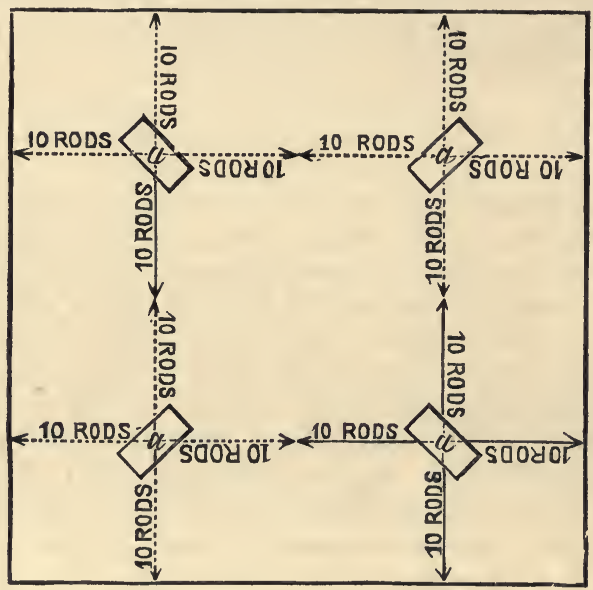

Field, 40x40 Rods, showing Position of four Heaps of Mxnure, a. a, a, a.

Having determined where to make the heaps, the next question is in regard to size. We make one about 8 fert wide and 6 feet high, the length being determined by the quantity of the manure we have to draw. In cold weather, it is well to finish the heap each day as far as you go, so that the sloping side at the end of the heap will not be frozen during the night. Build up the sides square, so that the top of the heap shall be as broad as the bottom. You will have to see that this is done, for the average farm. man, if left to himself, will certainly narrow up the heap like the roof of a house. The reason he does this is that he throws the manure from the load into the center of the heap, and he can not build up the sides straight and square without getting on to the heap occasionally, and placing a layer round the outsides. He 
should be instructed, too, to break up the lumps, and mix the manure, working it over until it is loose and fine. If there are any frozen masses of manure, place them on the east or south outside, and not in the middle of the heap.

If there is any manure in the sheds, or basements, or cellars, or pig-pens, clean it out, and draw it at once to the pile in the field, and mix it with the manure you are drawing from the heap in the yard.

We generally draw with two teams and three wagons. We have one man to fill the wagon in the yard, an 1 two men to drive and unload. When the man comes back from the field, he places his empty wagon by the side of the heap in the yard, and takes off the horses and puts them to the luaded wagon, and drives to the heap in the field. If we have men and teams enough, we draw with three teams and three wagons. In this case, we put a reliable man at the heap, who helps the driver to unload, and sees that the heap is built properly. The driver helps the man in the yard to load up. In the former plan, we have two teams and three men; in the latter case, we have three teams and five men, and as we have two men loading and unloading, instead of one, we ought to draw out double the quantity of manure in a day. If the weather is cold and wincly, we put the blankets on the horses under the harness, so that they will not be chilled while standing at the heap in the yard or field. They will trot back lively with the empty wagon or sleigh, and the work will proceed briskly, and the manure be less exposed to the cold.

"You do not," said the Doctor, "draw the manure on to the heap with a cart, and dump it, as I have seen it done in England?"

I did so a few years ago, and might do so again if I was piling manure in the spring, to be kept over summer for use in the fall. The compression caused by drawing the cart over the manure, has a tendency to exclude the air and thus retard fermentation. In the winter there is certainly no necessity for resorting to any means for checking fermentation. In the spring or summer it may be well to compress the heap a little, but not more, I think, than can be done by the trampling of the workman in spreading the manure on the heap.

"You_do not," said the Doctor, "adopt the old-fashioned English plan of keeping your manure in a basin in the barn-yard, and yet I should think it has some advantages." 
"I practised it here," said I, "for some years. I plowed and scraped a large hole or basin in the yard four or five feet deep, with a gradual slope at one end for convenience in drawing out the loads-the other sides being mueh steeper. I also made a tank at the bottom to hold the drainage, and had a pump in it to pump the liquid back on to the heap in dry weather. We threw or wheeled the manure from the stables and pig-pens into this basin, but I did not like the plan, for two reasons: $(1$,$) the manure bcing$ spread over so large a surface froze during winter, and (2,) during the spring there was so much water in the busin that it checked fermentation."

Now, instead of spreading it all over the basin, we commenced a small heap on one of the sloping sides of the basin; with a lorse and cart we drew to this heap, just as winter set in, every bit of manure that eould be found on the premises, and everything that would make manure. When got all together, it made a heap seren or eight feet wide, twenty feet long, and three or four feet high. We then laid planks on tie he ıp, and every day, as the pig-pens, cow and horse stables were cleaned out, the manure was wheeled on to the heap and shaken out and spread about. The heap soon commenced to ferment, and when the cold weather setin, although the sides and some parts of the top froze a little, the inside kept quite warm. Little chimneys were formed in the heap, where the heat and steam escaped. Other parts of the heap would ke covered with a thin crust of frozen manure. By taking a few forkfuls of the latter, and placing them on the top of the "chimneys," they checked the escape of steam, and had a tendency to distribute the heat to other parts of the heap. In this way the fermentation became more general throughout all the mass, and not so violent at any one spot.

"But why be at all this trouble?"-For several reasons. First. It saves labor in the end. Two hours' work, in winter, will save three hours' work in the spring. And three hours' work in the spring is worth more than four hours' work in the winter. So that we save half the expense of handling the manure. 2d. When manure is allowed to lie scattered about over a large surface, it is liable to have much of its value washed out by the rain. In a compact heap of this kind, the rain or snow that falls on it is not more than the manure needs to keep it moist enough for fermentation. $3 d$. There is as much fascination in this fermenting heap of manure as there is in having money in a savings bank. One is continually trying to add to it. Many a cart-load or wheel-barrowful of material will be deposited that would utherwise be allowed 
to run to waste. 4th. The manure, if turned over in February or March, will be in capital order for applying to roo crops; or if your hay and straw contains weed-seeds, the manure will be in zood condition to spread as a top-dressing on grass-land early in the spring. This, I think, is better than keeping it in the yards all summer, and then drawing it out on the grass land in September. You gain six months' or a year's time. You get a sple.ıdid growth of rich grass, and the red-root seeds will germinate next September just as well as if the manure was drawn out at that time. If the manure is drawn out early in the spring, and spread out immediately, and then harrowed two or three times with a Thomas' smoothing-harrow, there is no danger of its imparting a rank flavor to the grass. I know from repeated trials that when part of a pasture is top-dressed, cows and sheep will keep it much more closely cropped down than the part which has not been manured. The idea to the contrary originated from not spreading the manure evenly.

"But why ferment the manure at all? Why not draw it out fresh from the yards? Does fermentation increase the amount of plant-food in the manure?"-No. But it renders the plant-food in the manure more immediately available. It makes it more soluble. We ferment manure for the same reason that we dccompose bone-dust or mineral phosphates with sulphuric acid, and convert them into superphosphate, or for the same reason that we grind our corn and cook the meal. These processes add nothing to the amount of plant-food in the bones or the nutriment in the corn. They only increase its availability. So in fermenting manure. When the liquid and solid excrements from well-fed animals, with the straw necessary to absorb the liquid, are placed in a hoıp, fermentation sets in and soon effects very important changes in the nature and composition of the materials. The insoluble woody fibre of the straw is decomposed and converted into humic and ulmic acids. These are insoluble; and when manure consists almost wholly of straw or corn stalks, there would be little gained by fermenting it. But when there is a good proportion of manure from well fed animals in the heap, carbonate of ammonia is formed from the nitrogenous compounds in the manure, and this ammonia unites with the humis and ulmic acids and forms humate and ulmate of ammonia. These ammoniacal salts are soluble in water-as the brown color of the drainings of a manure heap sufficienily indicates.

Properly fermented manure, therefore, of good quality, is a much more active and immediately useful fertilizer than fresh, unc 
fermented manure. There need be no loss of ammonia from evaporation, and the manure is far less bulky, and costs far less labor to draw out and spread. The only loss that is likesy to occur is from leaching, and this must be specially guarded against.

\section{$-$ \\ C H A P T E R X X I.}

\section{THE MANAGEMENT OF MANURES.-CoNTINUED.}

\section{WHY DO WE FERMENT MANURE?}

Eowever much farmers may differ in rcgard to the advantages or disadvantages of fermenting manure, I have never met with one who contended that it was good, either in theory or practice, to leave manure for months, scattered over a barn-yard, exposed to the spring and autumn rains, and to the summer's sun and wind. All admit that, if it is necessary to leave manure in the yards, it should be either thrown into a basin, or put into a pile or heap, where it will be compact, and not much exposed.

We did not need the experiments of Dr. Vœlcker to convince us that there was great waste in leaving manure exposed to the leaching action of our heavy rains. We did not know exactly how much we lost, but we knew it must be considerable. No one ad vorates the practice of exposing manure, and it is of no use to discuss the matter. All will admit that it is unwise and wasteful to allow manure to lie scattered and exposed over the barn-yards any longer than is absolutely neccssury.

We should either draw it directly to the ficld and use it, or we should make it into a compact heap, where it will not receive more rain than is needed to keep it moist.

One reason for piling manure, therefore, is to preserve it from loss, until we wish to use it on the land.

"We all admit that," said the Deacon, "but is there anything actually gained by fermenting it in the heap ?"-In one sense, no; but in another, and very important sense, yes. When we cook corn -meal for our little pigs, we add nothing to it. We have no more meal after it is cooked than before. There are no more starch, or oil, or nitrogenous matters in the meal, but we think the pigs can digest the food more readily. And so, in fermenting 
manurı, we add nothing to it; there is no more actual nitrogen, or phosphoric acid, or potash, or any other ingredient after fermentation than there was before, but these ingredients are rundered more soluble, and can be more rapidly taken up by the liants. In this sense, therefore, there is a great gain.

One thing is certain, we do not, in many cases, get anything like as much benefit from our manure as the ingredients it con. tains would lead us to expect.

Mr. Lawes, on his clayey soil at Rothamsted, England, has grown over thirty crops of wheat, year after year, on the same land. One plot has received 14 tons of barn-yard manure per acre every year, and yet the produce from this plot is no larger, and, in fact, is frequently much less, than from a few hundred pounds of artificial manure containing far less nitrogen.

For nineteen years, 1852 to 1870 , some of the plots have received the same manure year after year. The following shows the aver age yield for the uineteen years:

\begin{tabular}{|c|c|c|}
\hline & $\begin{array}{l}\text { Wheat } \\
\text { per acie. }\end{array}$ & Straw \\
\hline lo & $\begin{array}{l}\text { 5.-Mixed mineral manure, alone } \ldots \ldots \ldots \ldots \ldots . . . \ldots . .17 \text { bus. } \\
6 .- \text { Mixed mineral manure, and } 200 \mathrm{ibs} \text {. ummo- }\end{array}$ & $15 \mathrm{cwt}$ \\
\hline & 7.-Mixed mineral manure, and $400 \mathrm{lbs}$ ammo- & $25 \mathrm{cwt}$. \\
\hline & 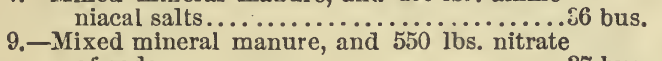 & wt. \\
\hline & 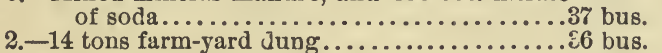 & $\begin{array}{l}41 \mathrm{cwt} . \\
34 \mathrm{cwt} .\end{array}$ \\
\hline
\end{tabular}

The 14 tons $(31,360$ lbs.) of farm-yard manure contained about 8,540 lbs. organic matter, 868 lbs. mineral matter, and 200 lbs. nitrogen. The $400 \mathrm{lbs}$. of ammoniacal salts, and the $550 \mathrm{lbs}$. nitrate of soda, each contained $82 \mathrm{lbs}$. of nitrogen; and it will be seen that this 82 lbs. of nitrogen produced as great an effect as the 200 lbs. of nitrogen in barn-yard manure.

Similar experiments have been made on barley, with even more striking results. The plot dressed with $300 \mathrm{lbs}$. superphosphate of lime, and $200 \mathrm{lbs}$. ammoniacal salts per acre, produced as large a crop as 14 tons of farm-yard manure. The average yield of barley for nineteen crops grown on the same land cach year was 48 bus. and $28 \mathrm{cwt}$. of straw per acre on both plots. In other words, $41 \mathrm{lbs}$. of nitrogen, in ammoniacal salts, produced as great an effect as 200 lbs. of nitrogen in farm-yard manure ! During the nineteen years, sne plot had received $162,260 \mathrm{lbs}$. of organic matter, $16,492 \mathrm{lbs}$. of mineral matter, and $3,800 \mathrm{lbs}$. of nitrogen; while the other had received only 5,700 lbs. mineral matter, and $779 \mathrm{lbs}$. of nitrogenand yet one has produced as large a crop as the other. 
Why this difference? It will not do to say that more nitrogt. was applied in the farm-yard manure than was needed. Mi' Lawes says : "For some years, an amount of ammonia-salts, con taining $82 \mathrm{lbs}$. of nitrogen, was applied to one series of plots (or barley), but this was found to be too much, the crop generally being too heavy and laid. Yet probably about 200 lbs. of nitrogen was annually supplied in the dung, but with it there was no overluxuriance, and no more crop, than where $41 \mathrm{lbs}$. of nitrogen was supplied in the form of ammonia or nitric acid."

It would seem that there can be but one explanation of these accurately-ascertained facts. The nitrogenous matter in the manure is not in an arailable condition. It is in the mauure, but the plants can not take it up until it is decomposed and rendered soluble. Dr. Vœlcker analyzed "perfectly fresh horse-dung," and found that of free ammonia there was not more than one pound in 15 tons ! And yet these 15 tons contained nitrogen enougia to furnish $140 \mathrm{lbs}$. of ammonia.

"But," it may be asked, "will not this fresh manure decompose in the soil, and furnish ammonia ?" In ligit, sandy soil, I presume it will do so to a considerable extent. We know that clay mixed with manure retards fermentation, but sand mixed with nianure accelerates fermentation. This, at any rate, is the case when sand is added in small quantities to a heap of fermenting manure. But I do not suppose it would have the same effect when a small quantity of manure is mixed with a large amount of sand, as is the case when manure is applied to land, and plowed under. At any rate, practical farmers, with almost entire unanimity, think well-rotted manure is better for sandy land than fresh manure.

As to how rapidly, or rather how slowly, manure decomposes in a rather heavy loamy soil, the abore experiments of Mr. Lawes afford very conclusive, but at the same time very discouraging evidence. During the 19 years, 3,800 lbs. of nitrogen, and 16,492 lbs. of mineral matter, in the form of farm-yard manure, were applied to an arre of land, and the 19 crops of barley in grain and straw removed only $3,724 \mathrm{lbs}$. of mineral matter, and $1,064 \mathrm{lbs}$. of nilrogen. 'The soil now contains, unless it has draincd away, 1,736 lbs. more nitrogen per acre than it did when the experiments commenced. And yet $41 \mathrm{lbs}$. of nitrogen in an available condition is sufficient to produce a good large crop of barley, and $\$ 2$ lbs. per acre furnished more than the plants could organize.

" Those are very interesting experiments," said the Doctor, "and show why it is that our farmers can afford to pay a higher pricc for nitrogen and phosphoric acid in superphosphate, and other ar. 
tificial manures, than for the same amount of nitrogen and phosphoric acid in stable-manure."

We will not discuss this point at present. What I want to ascertain is, whether we can not find some method of making our farm-yard manure more readily available. Plling it up, and letting it ferment, is one method of doing this, though I think other methods will yet be discovered. Possibly it will be found that spreading well-rotted manure on the surface of the land will be one of the most practical and simplcst methoc's of accomplishing this object.

"We pile the manure, therefore," said Char.ey, "first, because we do not wish it to lie exposed to the rain in the yards, and, second, because fermenting it in the heap renders it more soluble, and otherwise more available for the crops, when applied to the land.".

That is it exactly, and another reason for piling manure is, that the fermentation greatly reduccs its bulk, and we have less labor to perform in drawing it out and spreading it. Ellwanger \& Burry, who draw sevcral thousand loads of stakle-manure every year, and pile it up to ferment, tell me that it takes three loads of fresh manure to make one load of rotted manure. This, of course, has reference to buik, and not weight. Three tons of fresh barn-yard manure, according to the experiments of Dr. Vœlcker, will make about two tons when well rotted. Even this is a great saving of labor, and the rotted manure can be more easily spread, and mixed more thoroughly with the soil-a point of great importance.

"Another reason for fermenting manure," said the Squire, "is the destruction of weed-seeds."

"That is true," said I, " and a very important reason; but I try not to think about this method of killing weed-seeds. It is a great deal better to kill the weeds. There can be no doubt that a fermenting manure-heap will kill many of the weed-seeds, but enough will usually escape to re-seed the land."

It is fortunate, however, that the best means to kill weed-seeds in the manure, are also the best for rendering the manure most efficient. I was talking to John Johnston on this subject a few days ago. He told me how he piled manure in his yards.

"I commence," he said, "where the heap is intended to be, and throw the manure on one side, until the bare ground is reached."

"What is the use of that?" I asked.

"If you do not do so," he replied, " there will be some portion of 
the manure under the heap that will be so compact that it will not ferment, and the weed-seeds will not be killed."

"You think," said I, "-that weed-seeds can be killed in this way?"

"I know they can," he replied," but the heap must be carefully made, so that it will ferment evenly, and when the pile is turned, the bottom and sides should be thrown into the center of the heap."

\section{LOSS OF AMMONIA BY FERMENTING MANURE.}

If you throw a quantity of fresh horse-manure into a loose heap, fermentation proceeds with great rapidity. Much heat is produccd, and if the manure is under cover, or there is not zain enough to keep the heap moist, the manure will "fire-fang" and a large proportion of the carbonate of ammonia produced by the fermentation will escape into the atmosphere and be lost.

As I have said before, we use our horse-manure for bedding the store and fattening pigs. We throw the manure every morning and evening, when the stable is cleaned out, into an empty stall near the door of the stable, and there it remains until wanted to bed the pigs. We find it is necessary to remove it frequently, especially in the summer, as fermentation soon sets in, and the escape of the ammonia is detected by its well known pungent smell. Throw this manure into the pig-cellar and let the pigs trample it down, and there is no longer any escape of ammonia. At any rate, I have never perceived any. Litmus paper will detcet ammonia in an atmosphere containing only one seventy-five thousandth part of it; and, as Prof. S. W. Johnson once remarked, "It is certain that a hcalthy nose is not far inferior in delicacy to litmus paper." I feel sure that no ammonia escapes from this horse-manure after it is trampled lown by the pigs, although it contains an additional quantity of "potential ammonia" from the liquid and solid droppings of these animals.

Water has a strong aitraction for ammonia. One galion of icecold water will absorb 1,150 gallons of ammonia.

If the manure, therefore, is moderately moist, the ammonia is not likely to escape. Furthermore, as Dr. Vœlcker has shown us, during the fermentation of the manure in a heap, ulmic and humic, crenic and aprocrenic acids are produced, and these unite with the ammonia and "fix" it-in other words, they change it from a volatile gas into a non-volatile salt.

If the heap of manure, therefore, is moist enough and large enough, all the evidence goes to show, that there is little or no loss of ammonia. If the centre of the heap gets so hot and so dry that the ammonia is not retained, there is still no necessity for loss. 
The sides of the heap are cool and moist, and will retain the carbonate of ammonia, the acids mentioned also coming into play.

The ammonia is much more likely to escape from the top of the heap than from the sides. Tue heat and steam form little chimneys, and when a fermenting manure-heap is covered with snow, these little chimneys are readily seen. If you think the manure is fermenting too rapidly, and that the ammonia is escaping, trample the manure down firmly about the chimueys, thus closing them up, and if reed be, or if convenient, throw more manure on top, or throw on a few pailfuls of water.

It is a good plan, too, where convenient, to cover the heap with soil. I sometimes do this when piling manure in the field, not from fear of losing ammonia, but in order to retain moisture in the heap. With proper precautions, I think we may safely dismiss the idea of any serious loss of ammonia from fermenting manure.

\section{THE WASTE OF MANURE FROM LEACHING.}

As we have endeavored to show, there is little danger of losing ammonia by keeping and fermenting mauure. But this is not the only question to be considered. We have seen that in $10,000 \mathrm{lbs}$. of fresh farm-yard manure, there is about $64 \mathrm{dbs}$. of nitrogen. Of this, about 15 lbs. are soluble, and 49 lbs. insoluble. Of mineral matter, we have in this quantity of manure, $559 \mathrm{lbs}$, , of which 154 lbs. are soluble in water, and $405 \mathrm{lbs}$. insoluble. If we had a heap of five tons of fermenting manure in a stable, the escape of half an ounce of carbonate of ammonia would make a tremendous smcll, and we should at once uss means to check the escape of this precious substance. But it will be seen that we have in this five tons of fresh manure, nitrogenous matter, capable of forming over $180 \mathrm{lbs}$. of carbonate of ammonia, over $42 \mathrm{lbs}$. of which is in a soluble condition. This may be leached day after day, slowly and imperceptibly, with no heat, or smell, to attract attention.

How often do we see manure lying under the eaves of an unspouted shed or barn, where one of our heavy showers will saturate it in a few minutes, and yet where it will lie for hours, and days, and weeks, until it would seem that a large proportion of its soluble matter would be washed out of it! The loss is unquestionably very great, and would be greater if it were not for the coarse nature of the material, which allows the water to pass through it rapidly and without coming in direct contact with only the outside portions of the particles of hay, straw, etc., of which the manure is largely composed. If the manure was ground up very fine, as it would be when prepared for analysis, the loss of 
soluble matter would be still more serious. Or, iî the manure was first ferniented, so that the particles of matter would be more or less decomposed and broken up fine, the rain would wash out a large amount of soluble matter, and prove much more injurious than if the manure was fresh and unfcrmented.

"That is an argument," said the Deacon, "against your plan of piling and fermenting manure."

"Not at all," I replied; "it is a strong reason for not letting manure lie under the eares of an unspouted building-especially good manure, that is made from rich food. The better the manure, the more it will lose from bad management. I have never recommended any one to pile their manure where it would receire from ten to twenty times as much water as would fall on the sur face of the heap."

"But you do recommend piling manure and fermenting it in the open air and keeping the top flat, so that it will catch all the rain, and I think your heaps must sometimes get pretty well soaked."

"Soaking the heap of manure," I replicd, " does not wash out any of its soluble matter, provided you carry the matter no further than the point of saturation. The water may, and doubtless does, wash out the solublematter from some portions of tic mar:ur, but if the water does not filter through the heap, but is all absorbed by the manure, there is no loss. It is when the water passes through the heap that it runs away with our soluble nitrogenous and mineral matter, and with any ready formed ammonia it may find in the manure."

How to keep cows tiel up in the barn, and at the same time save all the urine, is one of the most difficult problems I have to deal with in the management of manure on my farm. The best plan I have yet tried is, to tlirow horse-manure, or sheep-manure, back of the cows, where it will receive and absorb the urine. The plan works well, but it is a question of labor; and the answer will depend on the arrangement of the buildings. If the horses are kept near the cows, it will be little trouble to throw the horselitter, every day, under or back of the cows.

In my own case, my cows are kept in a basement, with a tight barn-floor overhead. When this barn-floor is occupied with sheep, we keep them well-bedded with straw, and it is an easy matter to throw this soiled beading down to the cow-stable below, where it is used to absorb the urine of the cows, and is then wheeled out to the manure-heap in the yard.

At other times, we use dry carth as an absorbent. 


\section{H A P T E R X II.}

\section{MANURE ON DAIRY-FARMS.}

Farms devoted principally to dairying ought to be richer and cuore productive than farms largely devoted to the production of grain.

Nearly all the produce of the farm is used to feed the cors, and little is sold but milk, or cheese, or butter.

When butter alone is solit, there ought to be no loss of fertilizing matter-as pure butter or o.l contains no nitrogen, phosphoric acid, or potash. It contains nothing but carbonaceous matter, which can be removed from the farm without detriment.

Anl even in the case of milk, or cheese, the advantage is all on the side of the dairyman, as compared with the grain-grower. A dollar's worth of milk or cheese removes far less nitrogen, phosphoric acid, and potash, than a dollar's worth of wheat or other grain. Five hundred lbs. cf cheese contains about $25 \mathrm{lbs}$. of nitrogen, and $20 \mathrm{lbs}$. of mineral matter. A cow that would make this amount of cheese would eat not less than six tons of hay, or its equivalent in grass or grain, in a year. And this amount of food, supposing it to be half clover and half ordinary meadow-hay, would contain $240 \mathrm{lbs}$. of nitrogen and $810 \mathrm{lbs}$. of mineral matter. In other words, a cow eats $240 \mathrm{lbs}$. of nitrogen, and $25 \mathrm{lbs}$. are rcmoved in the cheese, or not quite $10 \frac{1}{2}$ per cent, and of mineral matter not quite $2 \frac{1}{2}$ per cent is removed. If it takes three acres to produce this amount of food, there will be $8 \frac{1}{3} \mathrm{lbs}$. of nitrogen removed by the cheese, per acre, while 30 bushels of whcat would remove in the grain $32 \mathrm{lbs}$. of nitrogen, and 10 to $15 \mathrm{lbs}$. in the straw. So that a crop of wheat removes from five to six times as much nitrogen per acre as a crop of cheese; and the removal of mineral matter in cheese is quite insignificant as compared with the amount removed in a crop of wheat or corn. If our graingrowing farmers can keep up the fertility of their land, as they undoubtedly can, the dairymen ought to bo making theirs richer and more productive every year.

"All that is quite true," said the Doctor, "and yet from what I have seen and heard, the farms in the dairy districts, do not, as a rule, show any rapid improvement. In fact, we hear it often alleged that the soil is becoming exhausted of phosphates, and that the quantity and quality of the grass is deteriorating." 
"There may be some truth in this," said I, " and yet I will hazard the prediction that in no other branch of agriculture shall we witness a more decided improvement during the next twentyfive years than on farms largely devoted to the dairy. Grain-growing farmers, like our frien i the Deacon, here, who sells his grain and never brings home a load of manure, and rarely buys even a ton of bran to feed to stock, and who sells more or less hay, must certainly be impoverishing thcir soils of phosphates much more rapidly than the dairyman who consumes nearly all his produce on the farm, and sclls iittle except milk, butter, chetse, young calves, and old cows."

"Bones had, a wonderful effect," said the Doctor," on the old pastures in the dairy district of Cheshire in England."

"Undoubtedly," I replied, "and so they will here, and so would well-rotted manure. There is nothing in this fact to prove that dairying specially robs the soil of phosphates. It is not phosphates that the dairyman needs so much as richer manure."

"What would you add to the manure to make it richer?" as'ed the Doctor.

"Nitrogen, phosphoric acid, and potash," I replied.

"But how?" asked the Deacon.

"I suppose," said the Doctor, "by buying guano and the Ger:n^n potash salts."

"That would be a good plan," said I; "but I would do it by buying bran, mill-feed, brewer's-grains, malt-combs, corn-meal, oilcake, or whatever was best and cheapest in proportion to value. Bran or mill-feed can of ten be bought at a price at which it will pay to use it freely for manure. A few tons of bran worked into a pile of cow-dung would warm it up and add considerably to its value. It would supply the nitrogen, phosphoric acid, and potash, in which ordiaary manure is d ficient. In short, it would convert poor manure into rich manure."

"Well, well," exclaimed the Deacon, "I knew you talked of mixing dried-blood and bone-dust with your manure, but I did not think you would advocate anything quite so extravagant as taking good, wholesome bran and spout-feed and throwing it on to your manure-pile."

"Why, Deacon," said I, "we do it every day. I am putting about a ton of spout-feed, malt-combs and corn-meal each week into my manure-pile, and that is the reason why it ferments so readily even in the winter. It converts my poor manure into good, rich, well-decomposed dung, one load of which is worth three loads of your long, strawy manure." 
"Do you not wet it and let it ferment before putting it in the pile?"

"No, Deacon," said I, "I feed the bran, malt-combs and cornmeal to the cows, pigs, and sheep, and let them do the mixing. They work it up fine, moisten it, break up the particles, take out the carbonaceous matter, which we do not need for manure, and the cows and sheep and horses mix it up thoroughly with the hay, straw, and corn-stalks, leaving the whole in just the right condition to put into a pile to ferment or to apply directly to the land."

"Oh ! I see," said the Deacon, "I did not think you used bran for manure."

"Yes, I do, Deacon," said I, " but I use it for food first, and this is precisely what I would urge you and all others to do. I feel sure that our dairymen can well afford to buy more mill-feed, corn-meal, oil-cake, etc., and mix it with their cow-dung-or rather, let the cows do the mixing."

\section{LETTER FROM THE HON. HARRIS LEWIS.}

I wrote to the Hon. Harris Lewis, the well-known dairyman of Herkimer Co., N. Y., asking him some questions in regard to making and managing manure on dairy farms. The questions will be unclerstood from the answers. He writes as follows:

" My Friend Harris. - This being the first leisure time I have had since the receipt of your last letter, I devote it to answering your questions :

"1st. I have no manure cellar.

"I bed my cows with dry basswood sawdust, saving all the liquid manure, keeping the cows clean, and the stable odors down to a tolerable degree. This bedding breaks up the tenacity of the cow-manure, rendering it as easy to pulverize and manage as clear horse-manure. I would say it is just lovely to bed cows with dry basswood sawdust. This manure, if left in a large pile, will ferment and burn like horse-manure in about 10 days. Hence $I$ draw it out as made where I desire to use it, leaving it in small heaps, convenient to spread.

"My pigs and calves arc bedded with straw, and this is piled and rotted before using.

"I use most of my manure on grass land, and mangcls, some on corn and potatoes; but it pays me best, when in proper condition, to apply all I do not need for mangels, on meadow and pasture.

- "Forly loads, or about 18 to 20 cords is a homœopathic dose for an acre, and this quantity, or more, applied once in three years to grass land, agrees with it first rate. 
"The land where I grow mangels gets about this dose every year

"I would say that my up-land meadows have been mown twice tach year for a great many years.

"I have been using refuse salt from Syracuse, on my mangels, at the rate of about six bushels per acre, applied broadcast in two applications. My hen-manure is pulverized, and sifted through a common coal sieve. The fine I use for dusting the mangels after they have been singled out, and the lumps, if any, are used to warm up the red peppers.

"I have sometimes mixed my hen-manure with ary muck, in the proportion of one bushel of hen-manure to 10 of muck, and received a profit from it too big to tell of, on corn, and on mangels.

"I have sprinkled the refuse salt on my cow-stable floors sometimes, but where all the liquid is saved, I think we have salt enough for most crops.

"I have abandon ad the use of plaster on my pastures for the reason that milk produced on green-clover is not so good as that produced on the grasses proper. I use all the wood ashes I can get, on my mangels as a duster, and consider their value greater than the burners do who sell them to me for $15 \mathrm{cts}$. a bushel. I have never used much lime, and have not received the expected benefits from its use so far. But wood ashes agree with my land as well as manure docs. The last question you ask, but one, is this: 'What is the usual plan of managing manure in the dairy districts?' The usual method is to cut holes in the sides of the stable, about every ten feet along the whole length of the barn behind ihe cows, and pitch the manure out through these holes, under the eaves of the barn, where it remains until too much in the way, when it is drawn out and commonly applied to grass land in lumps as big as your head. This practice is getting out of fashion a little now, but nearly one-half of all the cow-manure made in Herkimer Co. is lost, wasted.

"Your last question, 'What improvement would you suggest,' I answer by saying it is of no use to make any to these men. it would be wasted like their manure.

"The market value of manure in this county is $50 \mathrm{cts}$. per big load, or about one dollar per cord."

"That is a capital letter," said the Deacon. "It is right to t'ie point, and no nonsense about it."

"He must make a good deal of manure," said the Doctor, " to be able to use 40 loads to the acre on his meadows and 
pastures once in three years, and the same quantity every year on his field of mangel-wurzel."

"That is precisely what I have been contending for," I replied; " the dairymen can make large quantities of manure if they make an effort to do it, and their farms ought to be constantly improving. Two crops of hay on the same meadow, each year, will enable a farmer to keep a large herd of cows, and make a great quantity of manure-and when you have once got the manure, there is no difficulty in keeping up and increasing the productiveness of the land."

\section{HOW TO MAKE MORE AND BETTER MANURE ON DAIRY FARMS.}

"You are right," said the Doctor, "in saying that there is no difficulty in keeping up and increasing the productiveness of our dairy farms, when you have once got plenty of manure-but the difficulty is to get a good supply of manure to start with."

This is true, and it is comparatively slow work to bring up a farm, unloss you have plenty of capital and can buy all the artificial manure you want. By the free use of artificial manures, you could make a farm very productive in one or two years. But the slower and cheaper method will be the one adopted by most of our young and intelligent dairymen. Few of us are born with silver spoons in our mouths. We have to eara our money before we can spend it, and we are none the worse for the discipline.

Suppose a young man has a farm of 100 acres, devoted principally to dairying. Some of the land liss on a creek or river, while other portions are higher and drier. In the spring of the year, a stream of water runs through a part of the farm from the adjoining hills divin to the creek or river. The farm now supports ten head of cows, three horses, half a dozen sheep, and a few pirgs. The land is worth $\$ 75$ per acre, but does not pay the interest on half that sum. It is getting worse instead of better. Weeds are multiplying, and the more valuable grasses are dying out. What is to be done?

In the first place, let it be distinctly understood that the land is $n$ ot exhausted. As I have before said, the productiveness of a farm does not depend so much on the ansolute amount of plant-food which the soil contains, as on the amount of plant-food which is immediately available for the use of the plants. An acre of land that produces half a ton of hay, may contain as much plant-food as an acre that produces three tons of hay. In the one case the plant-fond is locked up in such a form that the crops cannot absorb it, while in the other it is in an avalable condition. I have no doubt there are fields on the farm I am alluding to, that contain 
$3,000 \mathrm{lbs}$. of nitrogen, and an equal amount of phosphoric acid, per acre, in the first six inches of the surface soil. This is as much nitrogen as is contained in 100 tons of meadowhay, and more phosphoric acid than is contained in 350 tons of meadow-hay. Tinese are the two ingredients on which the fertility of our farms mainly depend. And yet there are soils containing this quantity of plant-food that do not produce more than half a ton of hay per acre.

In some fields, or parts of fields, the land is wet and the plants cannot take up the food, even while an abundance of it is within reacli. The remedy in this case is under-draining. On other fields, the plant-food is locked up in insoluble combinations. In this case we must plow up the soil, pulverize it, and expose it to the oxygen of the atmospuere. We must treat the soil as my mother used to tell me to treat my coffee, when I complained that it was not sweet enough. "I put plenty of sugar in," she said, "and if you will stir it up, the coffee will be sweeter." The sugar lay undissolved at the bottom of the cup; and so it is with many of our soils. There is plenty of plant-food in them, but it needs stirring up. They contain, it may be, 3,0c0 lbs. of nitrogen, and other plant-food in still greater proportion, and we are only getting a crop that contains $18 \mathrm{lbs}$. of nitrogen a year, and of this probably the rain supplies 9 lbs. Let us stir up the soil and see if we cannot set $100 \mathrm{lbs}$. of this $3,000 \mathrm{lbs}$. of nitrogen free, and get three tons of hay par acre instead of half a ton. There are men. who own a large amount of valuable property in vacant city lots, who do not get enough from them to pay their taxes. If they would sell half of them, and put builcings on the other half, they might soon have a $h$ zndsome income. And so it is with many farmers. They have the elements of 100 tons of hay lying dorment in every acre of their land, while they are content to receive half a ton a year. They have property enough, but it is unproduc tive, while they pay high taxes for the privilege of holding it, and high wages for the pleasure of boarding two or three hired men.

We have, say, 3,000 lbs. of nitrogen locked up in each acre of our soil, and we get 8 or $10 \mathrm{lbs}$. every year in rain and dew, and yet, practically, all that we want, to make our farms highly productive, is $100 \mathrm{lbs}$. of nitrogen per acre per annum. And furthermore, it should be remembered, that to keep our farms rich, after we have once got them rich, it is not necessary to develope this amount of nitrogen from the soil every year. In the case of clover-hay, the entire loss of nitrogen in the animal and in the milk would not exceed 15 per cent, so that, when we feed out 
$100 \mathrm{lbs}$. of nitrogen, we have $85 \mathrm{lbs}$. left in the manure. We want to develope $100 \mathrm{lbs}$. of nitrogen in the soil, to enable us to raise a good crop to start with, and when this is once done, an annual development of $15 \mathrm{lbs}$. per acre in addition to the manure, would keep up the productiveness of the soil. Is it not worth while, therefore, to make an earnest effort to get started?-to gct $100 \mathrm{lbs}$. of nitrogen in the most available condition in the soil?

As I said before, tiis is practically all that is needed to give us large crops. This amount of nitrogen represents about twelve tons of average barn-yard manure-that is io say, twelve tons contains $100 \mathrm{lbs}$. of nitrogen. But in point of fact it is not in an immediately available condition. It would probably take at lcast two ycars before all the nitrogen it contains would be given up to the plants. We want, therefore, in order to give us a good start, 24 tons of barn-yard manure on every acre of land. How to get this is the great problem which our young dairy farmer has to solve. In the grain-growing districts we get it in part by summerfallowing, and I believe the dairyman might often do the same thing with advantage. A thorough summer-fallow would not only clean the land, but would render some of the latent plantfood available. This will be organized in the next crop, and when the dairyman has once got the plant-food, he has decidedly the advantage over the grain-growing farmer in his ability to retain it. He need not lose over 15 per cent a year of nitrogen, and not one per cent of the other elements of plant-food.

The land lying on the borders of the creek could be greatly benefited by cutting surface ditches to let off the water; and later, probably it will be found that a few underdrains can be put in to advantage. These alluvial soils on the borders of creeks and rivers are grand sources of nitrogen and other plant-food. I do not know the fact, but it is quite probable that the meadows which Harris Lewis mows twice a year, are on the banks of the river, and are perhaps flooded in the spring. But, be this as it may, there is a field on the farm I am alluding to, lying on the creek, which now produces a bountiful growth of weeds, rushes, and coarse grasses, which I am sure could easily be made to produce great crops of hay. The creek overflows in the spring, and the water lies on some of the lower parts of the field until it is evaporated. A few ditches would allow all the water to pass off, and this alone would be a great improvement. If the field was flooded in May or June, and thoroughly cultivated and harrewed, the sod would be sufficiently rotted to plow again in August. Then a thorough harrow ing, rolling, and cultivating, would make it as mellow as a garden, 
and it could be seeded down with timothy and other good grasses the list of August, or beginning of September, and produce a grood crop of hay the next year. Or, if thought better, it might bs sown to rye and seeded down with it. In either case the land would be greatly improved, and would be a productivc meadow or pasture for years to come-or until our young dairyman could afford to give it one of Harris Lewis" "homœopathic" doses of 40 loads of good manure per acre. He would then be able to cut two crops of hay a year-and such hay! But we arc anticipating.

That stream which runs through the farm in the spring, and then dries up, could be made to irrigate several acres of the land adjoining. Tuis would double, or treble, or quadruple, (" hold on," said the Deacon,) the crops of grass as far as the water reached. The Deacon does not seem to credit this statement; but I have seen wonderful effects produced by such a plan.

What I am endeavoring to show, is, that these and similar means will give us larger crops of hay and grass, and these in turn will enable us to keep more cows, and makc more manure, and the manurc will enable us to grow larger crops on other portions of the farm.

I am aware that many will object to plowing up old grass land, and I do not wish to be mis:nderstood on this point. If a farmer has a mcadow that will produce two or three tons of hay, or support a cow, to the acre, it would be folly to break it up. It is already doing all, or nearly all, that can be asked or desired. But suppose you have a piece of naturally good land that d zes not produce a ton of hay per acrc, or pasture a cow on three acres, if such land can ba plowed without great difficulty, I would break it up as early in the fall as possible, and summer-fallow it thoroughly, and sced it down again, heavily, with grass seeds the next August. If

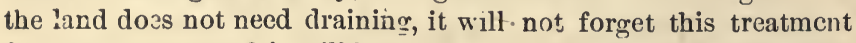
for many years, and it will bə the farmer's own fault if it ever runs down again.

In this country, where wages are so high, we must raisc large crops per acre, or not raise any. Where land is chcap, it may somctimes pay to compel a cow to travcl over three or four acres to get her food, but we cannot afford to raise our hay in half ton crops; i. costs too much to harvest them. High wages, high taxes, and high-priced land, necessitate high farming; and by high farming, I mean growing large crops every year, and on every portion of the farm; but high wages and low-priced land do rot nccessarily demand high farming. If the land is cheap we can suffer it to lie idle without mush loss. But when we raise crops, whetier on high-priced 
land or on low-priced land, we must raise good crops, or the expense of cultivating and harvesting then will eat up all the profits. In the dairy districts, I believe land, in proportion to its quality and nearness to market, commands a higher price than land in the graingrowing districts. Hence it follows that high farming should be the aim of the American dairyman.

I an told that there are farms in the dairy districts of this State worth from one hundred to one hundred and tifty dollars per acre, on which a cow to four acres for the year is considered a good average. At a meeting of the Little Falls Farmers' Club, the Hon. Josiah Shull, gave a statement of the receipts and expenses of his farm of $81 \frac{1}{2}$ acres. The farm cost $\$ 130$ per acre. He kept twenty cows, and fatted one for bcef. The receipts were as follows :

Twenty cows yielding $8,337 \mathrm{lbs}$. of cheesc, at atuut $14 \frac{1}{4}$ cents per pound...................................... $\$ 1,186.33$

Increase on beef cow ............................. 4000

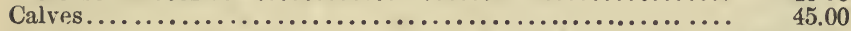

Total reccipts.............................. $\overline{\$ 1,271.33}$

EXPENSES.

Boy, fix months and board....................... \$180.00

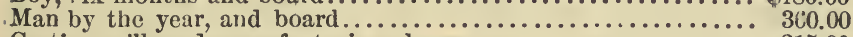

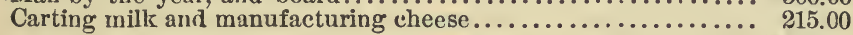

Total cost of labor ........................... $\$ 755.00$

THE OTHER EXPENSES WERE :

Fertilizers, plants, etc............................ \$ 18.00

Horse-shoeing and other repairs of farming implements, (which

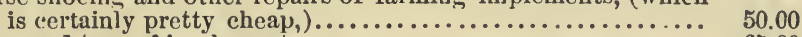

Wear and tear of implements $\ldots \ldots \ldots \ldots \ldots \ldots \ldots \ldots \ldots \ldots \ldots \ldots, \quad 65.00$

A verage repairs of place and buildings...................... 175.00

A rerage depreciation and interest on stock................... 180.00

Insurance. ........................................... $\quad 4.00$

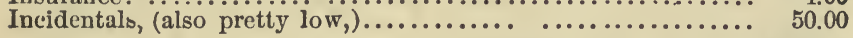

Total receipts...................... \$1,271.33.

$\overline{\$ 6: 20.00}$

Total expenses....................... 1,375.00.

This statement, it is said, the Club considered a very fair cstimate.

Now, here is a farm costing $\$ 10,595$, the receipts from which, saying nothing about interest, are less than the expenses. And if you add two cents per pound more to the price of the cheese, the profit would still be only about $\$ 50$ per year. The trouble is not so much in the low price of cheese, as in the low product per acre. I know some grain-growing farmers who have done no better than this for a few years past.

Mr. Shull places the annual depreciation and interest on stock at $\$ 180$, equal to nearly one-seventh of the total receipts of the farm. It would pay the wages and board of another man for six months 
Can not it be avoided? Good beef is relatively much higher in this State than good cheese. Some of the dairy authorities tell us that cheese is the cheapest animal food in the world, while beef is the dearest. Why, then, should our dairymen confine their attention to the production of the cheapest of farm products, and neglect almost entirely the production of the dearest? If beef is high and cheese low, why not raise more beef ? On low-priced land it may be profitable to raise and keep cows solely for the production of cheese, and when the cows are no longer profitable for this purpose, to sacrifice them-to throw them aside as we do a worn-out machine: And in similar circumstances we may be able to keep sheep solely for their wool, but on high-priced land we can not afford to keep sheep merely for their wool. We must adopt a higher system of farming and feeling, and keep sheep that will give us wool, lambs, and mutton. In parts of South America, where land costs nothing, cattle can be kept for their bones, tallow, and hides, but where food is costly we must make better use of it. A cow is a machine for converting vegetable food into veal, butter, cheese, and beef. The first cost of the machine, if a good one, is considerable-say $\$ 100$. This machine has to be kept running night and day, summer and winter, week days and Sundays. If we were running a steam-flouring mill that could never be allowed to stop, we should be careful to lay in a good supply of coal and also have plenty of grain on hand to grind, so that the mill would never have to run empty. No sensible man would keep up steam merely to run the mill. He would want to grind all the time, and as much as possible; and yet coal is a much cheaper source of power than the hay and corn with which we run our milk-producing machine. How often is the latter allowed to run empty? The machine is running night and day-must run, but is it always running to advantage? Do we furnish fuel enough to enable it to do full work, or only little more than enough to run the machinery?

"What has all this to do with making manure on dairy farms?" asked the Deacon; "you are wandering from the point."

"I hope not; I am trying to show that good feeding will pay better than poor feeding-and better food means better manure."

I cstimate that it takes from 15 to $18 \mathrm{lbs}$. of ordinary hay per day to run this cow-machine, which we have been talking about, even when kept warm and comfortable; and if exposed to cold storms, probably not less than $20 \mathrm{lbs}$. of hay a day, or its equivalent, and this merely to keep the machine running, without doing any work. It requires this to keep the cow alive, and to pre- 
vent her losing flesh. If not supplied with the requisite amount of food for this purpose, she will take enough fat and flesh from her own body to make up the deficiency; and if she cannot get it, the machine will stop-in other words, the cow will dic.

We have, then, a machine that costs say $\$ 100$; tiat will last on an average eight years; that requires careful management; that must have constant watching, or it will be liable to get out of order, and that requires, merely to keep it running, say $20 \mathrm{lbs}$. of hay per day. Now, what do we get in return? If we furnish only $20 \mathrm{lbs}$. of hay per day we get-nothing except manure. If we furnis's 25 lbs. of hay per day, or its equivalent, we get, say half a pound of cheese per day. If we furnish $30 \mathrm{lbs}$. we get one pound of cheese per day, or 365 lbs. a year. We may not get the one pound of cheese every day in the year; sometimes the cow, instead of giving milk, is furnishing food for her embryo calf, or storing up fat and flesh; and this fat and flesh will be used by and by to produce milk. But it all comes from the food eaten by the cow; and is equal to one pound of cheese per day for 30 lbs. of hay or its equivalent consumed; $20 \mathrm{lbs}$. of hay gives us nothing; $25 \mathrm{lbs}$. of hay gives us half a pound of chesse, or $40 \mathrm{lbs}$. of cheese from one ton of hay; $30 \mathrm{lbs}$. gives us one pound, or $66 \frac{2}{8} \mathrm{lbs}$. of cheese from one ton of hay; $35 \mathrm{lbs}$. gives us $1 \frac{1}{2}$ lbs., or $85^{5} / \mathrm{r}$ lbs. of cheese to one ton of hay; 40 lbs. gives us $2 \mathrm{lbs}$ of cheese, or $100 \mathrm{lbs}$. of cheese from one ton of hay; 45 lbs. gives us $2 \frac{1}{3} \mathrm{lbs}$. of cheese, or $111 \mathrm{lbs}$. of cheese from one ton of hay; $50 \mathrm{lbs}$. gives us $3 \mathrm{lbs}$. of cheese, or $120 \mathrm{lbs}$. of cheese from one ton of hay.

On this basis, one ton of hay, in excess of the amount required to keep up the animal heat and sustain the vital functions, gives us 200 lbs. of cheese. The point I wish to illustrate by these figurcs, which are of course hypothetical, is, that it is exceedingly desirable to get animals that will cat, direst, and assimilate a large amount of food, over and above that required to keep up the heat of the body and sustain the vital functions. When a cow eats only 25 lbs. of hay a day, it requires one ton of hay to produce 40 . lbs. of cheese. But if we could induce her to cat, digest, and assimilate $50 \mathrm{lbs}$. a day, one ton would produce $120 \mathrm{lbs}$. of cheese. If a cow eats $33 \mathrm{lbs}$. of hay per day, or its equivalent in grass, it will require four acres of land, with a productive capacily equal to $1 \frac{1}{2}$ tons of hay per acre, to keep ber a year. Such a cow, according to the figures given above, will produce $401 \frac{1}{2}$ lbs. of cheese a year, or its equivalent in growth $\mathbf{A}$ farm of 80 acres, on this basis, would support 20 cor3, yielding, 
say $8,000 \mathrm{lbs}$. of cheese. Increase the productive power $\mathrm{cf}$ the farm one half, (I hope the Deacon bas not gone to sleep), and ke.p 20 cows that will cat half as much again food, and we should then get $21,60 \mathrm{~J}$ lbs. of cheese. If chees: is worth 15 cents per $1 \mathrm{~b}$., a farm of 80 asres, producing $1 \frac{1}{2}$ tons of hay, or its equivalent, per acre, and supporting $20 \mathrm{cows}$, would give us a gross return of $\$ 1,204.50$. The same farm so improved as to producc $2 \frac{1}{4}$ tons of Lay or its equivalent, per acre-fed to 20 cows capable of eating, digusting, and assimilating it - would give a gross return of $\$ 3,240$.

In presenting these figures, I hope you will not think me a visionary. I do not think it is possible to get a cow to produce 3 lbs. of cheese a.day throughout the whule year. But I do think it quite possible to so breed and feed a cow that she will produce 3 lbs. of cheese per day, or its equivalent in veal, flesh, or fat. We frequently have cows that produce $3 \mathrm{lbs}$. of cheese a day for severul weeks; and a cow can be so fed that she will produce $3 \mathrm{lbs}$. of cheese a day without losing weight. And if she can extruct this amount of matter out of the food for a part of the year, why can not she do so for the whole year? Are the powers of digestion weaker in the fall and winter than in spring and summer? If not, we unquestionably sustain great loss by allowing this dizcstive power to run to waste. This digestive powcr costs us $20 \mathrm{lbs}$. of hay a day. We can ill afford to let it lie dormant. But the Deacon will tell me that the cows are allowed all the food they will eat, winter and summer. Then we must, if they have digestive power to spare, endeavor to persauce them to eat more. If they eat as much hay or grass as their stomachs are capable of holding, we must endeavor to give them richer hay or grass. Not one farmer in a thousand seems to appreciate the advantage of having hay or grass containing a high pcrcentage of nutriment. I have endeavored to show that a cow eating six tons of hay, or its equivalent, in a year, would produce 400 lbs. of cheese, worth $\$ 60$. While a cow capable of eating, digesting, and turning to good account, nine tons of hay, or ite equivalent, would produce $1,090 \mathrm{lbs}$. of cheese, or its equivalent in other products, worth $\$ 162$.

"I am sorry to interrupt the gentleman," said the Deacon with mock gravity.

"Then pray dnn't," said I ; "I will not detain you long, and the subject is one which ought to interest you and every other farmer who keeps his cows on poor grass in summer, and corn-stalks and straw in wintcr."

I was going to say, when the Daacon interrupted me, that the 
stomach of a cow may not allow her to tat nine tons of hay a year, but it will allow her to eat six tons; and if these six tons contain as much nutriment as the nine tons, what is the real difference in its value? Orcinarily we should probably stimate the one at $\$ 10$ per ton, and the cthcr at $\$ 15$. But accoraing to the above figures, one is worth $\$ 10$ per ton and the other $\$ 2 \%$. To get rich grass, therefore, should be the aim of the American dairyman. I hops the Deacon begins to see what connection this Las with a large pile of rich manure.

I do not mean merely a heavy growth of srass, but grass containing a high percentage of nutriment. Our long winters and heavy snows are a great advantage to us in this respect. Our grass in the spring, after its long rest, ought to start up like asparagus, and, under the organizing influence of our clear skies, and powerful sun, ought to be excecdingly nutritious. Comparativcly few farmers, however, live up to their priv.leges in this respect. Our climate is better than our farming, the sun richer than our neglected soil. England may be able to produce more grass $p c r$ acre in a year than wa can, but we ought to proluce richer grass, and, consequently, more cheese to a cow. And I believe, in fact, that such is often the case. The Inglish dairyman has the advantage of a longer season of growth. We have a shorter season but a brighter sun, and if we do not have richer grass it is due to the want of draining, clean culture, and manuring. The object of American dairymen should be, not only to c'otain more grass per acre, hut to increase its nutriment in a given bulk. If we could increase it one-half, making six tons ryual to nine tons, we have shown that it is ncarly t'ıree times as vauable. Whether this cun be done, I have not now time to consister; but at any rate if your land produces as many werls as do sume fields on my farm, not to say the Deacon's, and if the plant-food that these weeds absorb, could be organized by nutritious grasses, this alone would do a good deal towards accomplishing the object. Whether this can be done or not, we want cows that can eat and turn to good account as much food per annum as is contained in nice tons of ordinary meadow-hay; and we want this nutriment in a bulk not exceeding six toss of hay. If possible, we should get this amount of nutriment in grass or hay. But if we can not do this, we must feed enough concentrated food to bring it up to the desired standará.

"But will it pay?" asked the Deacon; "I have not much faith in buying feed. A farmer ought to raise wrerything he feeds out." 
"As a rule, tilis may be true," I replied, "but there are many exceptions. I am trying to show that it will of ten pay a dairyman well to buy feed rich in nitrogen and phosphates, so as to make rich manure, and give him a start. After he gets his land rich, there is little difficulty in keeping up its productiveness

"Now, I nave said-and the figures, if anything, are too low-that if a cow, eating six tons of hay, or its equivalent, a year, produces $400 \mathrm{lbs}$. of cheese, a cow capable of eating, digesting, and turning to good account nine tons of hay, or its equivalent, a year, would produce $1,090 \mathrm{lbs}$. of cheese, or its equivalent in other products."

I would like tu say much more on this subject, but I hope enough has bəวn sail to show that there is grat advantage in feeding rich food, even so far as the production of milk or beef is concerned; and if this is the case, then there is no difficuity in making rich manure on a dairy-farm.

And I am delighted to know that many farmers in the dairy districts are purchasing more and more bran and meal every year. Ta'zing milk, and beef, and manure all into the account, I feel sure that it will be found highly profitable; but you must have good cows-cows that can turn their extra food to good account.

This is not the place to discuss the merits of the different breeds of cows. All I wish to show is, that to make better manure, we must use richer food; and to feed this to advantage, we must have animals that can turn a large amount of food, over and above the amount required to sustain the vital functions, into milk, flesh, etc.

"You do not think," said the Dracon, "that a well-bred cow makes any richer manure than a common cow ?"

Of course not; but to make rich manure, we must feed well; and we can not afford to fced well unless we have good animals.

\section{HOW TO SAVE AND APPLY MANURE ON A DATRY-FARM.}

We can not go into details on this subject. The truth is, there are several good methods of saving manure, and which is best depends entirely on circumstances. The real point is to save the urine, and keep the cow-stable clean and swect. There are three prominent methods adopted :

1st. To throw all the liquid and solid excrements into a manurecellar uuderneath the cow-stable. In this cellar, dry swampmuck, dry earth, or other absorbent maierial, is mixed with the manure in sufficient quantity to keep down offensive odors. A little dry earth or muck is also used in the stable, scattering it twice a day in the gutters and under the hind legs of the cows. Where this is carried out, it has many and decided advantages. 
2d. To wheel or throw out the solid parts of the manure, and to have a drain for carrying the liquid into a tank, where it can be pumped on to the heap of manure in the yard. Where many horses ur sheep are kept, and only a few cows, this plan can often be used to advantage, as the heap of manure in the yard, consisting of horse-manure, sheep-manure, and a small por.ion of cowdung, will be able to absorb all the urine of the cows.

3d. To use sufficient bedding to absorb all the urine in the stable. In my own case, as I have said before, we usually chaff all our straw and stalks. The orts are used for bedding, and we also use a little dry earth-or, to be more exact, I use it when I attend to the matter myself, but have always found more or less trouble in getting the work done properly, unless I give it personal atten tion. To use "dirt" $t$ ( ) keep the stable clean, is not a popular plan in this neighborhood. Where there is an abundance of straw, and especially if cut into chaff, the easiest way to keep the stable clean, and the cows comfortable, is to use enough of this chaffed straw to absorb ali the liquid. Clean out the stable twice a day, and wheel the manure directly to the keap, and spread it.

In regard to the application of manure on a dairy-farm, we have seen what Harris Lewis does with his. 1 also wrote to T. L. Harison, Esq., of St. Lawrence Co., N. Y.; and knowing that he is not only a very intelligent farmer and breeder, but also one of our best agricultural writers, 1 asked him if he had written anything on the subject of manures.

"St. Lawrence Ćo.," said the Deacon, "produces capital grass, oats, and barley, but is, 1 should think, too far north for winter wheat; but what dia Mr. Harison say?"-Here is his letter:

"I never wrote anything about manure. Catch me at it! Nor do I know anything about the management of barn-yard manure worth telling. My own practice is dictated quite as much by convenience as by considerations of economy."

"Good," said the Deacon; "he writes like a sensible man."

"My rotation," he continues, "is such that the bulk of the ma nure made is applied to one crop; that is, to my hoed crops, corn, potatoes, and roots, in the second year.

"The manure from the stables is thrown or wheeled out under the sheds adjoining, and as fast as it becomes so large a quantity as to be in the way, or whenever there is an op sortunity, it is hauled out to the field, where it is to be used, and put in large riles. It is turned once, if possible, in the spring, and then spread. 
"The quantity applied, is, as near as may be, 25 loads per acre; but as we use a great deal of straw, we haul out 30 loads, and estimate that in the spring it will be about 25 loads.

"If we have any more (ind occasionally we have 100 loads over), we pile it near the barn, and turn it once or twice during the summer, ard use it as seems most profitable-sometimes to top-dress an old grass-field, that for some reason we prefer not to break for another year. Sometimes it goes on a piece of fall wheat, and sometimes is kept over for a barley field the following spring, and harrowed in just before sowing.

"I should spread the manure as it comes from the sheds, instead of piling it, but the great quantity of snow we usually have, has always seemed to be an insuperable obstacle. It is an advantage to pile it, and to give it one turning, but, on the other hand, the piles made in cold weather freeze through, and they take a provokingly long time to thaw out in the spring. I never found manure piled out of doors to get too much water from rain.

"I have given up using gypsum, except a little in the stables, because the clover grows too strong without it, and so long as this is the case, I do not need gypsum. But I sometimes have a picce of oats or barley that stands still, and looks sick, and a dose of gypsum helps it very much."

"That is a fact worth remembering," said the Deacen.

"I use sorne superphosphate," continues Mr. Harison, "and some ground bones on my turnips. We also use superphosphate cn oats, barley, and wheat (about $200 \mathrm{lbs}$. per acre), and find it pays. Last year, our estimate was, on 10 acres of oats, comparing with a strip in the middle, left for the purpose, that the $200 \mathrm{lbs}$. of superphosphate increased the crop 15 bushels per acre, and gave a gain iū quality. It was the "Manhattan," which has about three per cent ammonia, and seven to eight per cent soluble phosphoric acid.

"My rotation, which I stick to as close as I can, is: 1, oats; 2, corn, and potatoes, and roots; 3 , barley or spring wheat ; 4,5 , and 6, grass (clover or tinot'ıy, with a little mixture occasionally).

"I am trying to get to 4 , fall wheat, but it is mighty risky."

"That is a very sensible letter," said the Deacon; "but it is evident that he raises more grain than I supposed was generally the case in the dairy districts; and the fact that his clover is so heavy that he does not need plaster, indicates that his land is rich."

It merely confirms what I have said all along, and that is, that the dairymen, if they will feed their animals libcrally, and culti. 
vate their soll thoroughly, can soon have productive farms. There are very few of us in this section who can make manure enough to give all our corn, potatoes, and roots, 25 loads of rotted manure per acre, and have some to spare.

In the spring of $1877, \mathrm{Mr}$. Harison wrote: "I have been hauling out manure all winter as fast as made, and putting it on the land. At first we spread it; but when deep snows came, we put it in small heaps. The field looks as if there had been a grain crop on it loft uncut."

"That last remark," said the Doctor, "indicates that the manure looks more like straw than well-rotted dung, and is an argument in favor of your plan of piling the manure in the yard or field, instead of spreading it on the land, or putting it in small heaps."

\section{$\rightarrow \infty$ \\ C H A P TER X X I I I}

\section{MANAGEMENT OF MANURES ON GRAIN-FARMS.}

"I am surprised to find," said the Deacon, "that Mr. Harison, living as he does in the great grass and dairy district of this State, should raise so much grain. He has nearly as large a proportion of his land under the plow as some of the best wheat-growers of Western New York."

This remark of the Deacon is right to the point. Tise truth is, that some of our best wheat-growers are plowing less land, and are raising more grass, and keeping more stock; and some of the dairymen, though not keeping less stock, are plowing more land. The better farmers of both sections are approaching each other.

At all events, it is certain that the wheat-growers will keep more stock. I wrote to the Hon. Geo. Geddes, of Onondaga Co., N. Y., well known as a large wheat-grower, and as a life-long advocate of keeping up the fertility of our farms by growing clover. IIe replies as follows :

"I regret that I have not time to give your letter the consider ltion it deserves. The subject you have undertaken is truly a difficult one. The circumstances of a grain-raiser and a dairyman are so unlike, that their views in regard to the treatment of the manure produced on the farm would vary as greatly as the lines of farming they follow. 
"The grain-grower has straw in excess; he tries hard to get it into such form that he can draw it to his fields, and get it at work, at the least cost in labor. So he covers his barn-yards deep with straw, after each snow-storm, and gets his cattle, sheep, and horses, to trample it under foot; and he makes his pigs convert all he can into such form that it will do to apply it to his pasturcs, etc., in winter or early spring.

"A load of such manure is large, perhaps, but of no very great value, as compared with well-rotted stable-manure from grain-fed liorses; but it is as good as much that I have seen drawn from city stables, and carried far, to restore the worn-out hay-fields on the shores of the North River-in fact, quite like it.

"The dairyman, gencrally, has bet little straw, and his manure is mostly dung of cows, worth much more, per cord, than the straw-litter of the grain-growe:s.

"The grain-grower will want no sheds for keeping off the rain, but, rather, he will desire more water than will fall on an open yard. The milkman will wish to protect his cow-dung from all rains, or even snows; so he is a great advocate of manure-sheds. These two classes of farmcrs will adopt quite unlike mctlods of applying their manure to crops.

"I have cited these two classes of farmers, simply to show the difficulty of making any universal laws in regard to the treatment and use of barn-yard manure. * * *

"I think you and I are fully agrecd in regard to the farm bcing the true source of the manure that is to make the laad grow batter wit'. use, and still produce crops-perhaps you will go with me so far as to say, the greater the crops, the more manure they will make-and the more manure, the larger the crops.

"Now, I object to any special farming, when applied so a whole great division of country, such as merely raising grain, or devoted entircly to dairying.

"I saw at Rome, N. Y., these two leading branches of New York farming united on the Huntington tract of 1,300 acres. Three or four farms (I forgct which) had separate and distinct management, conducted by different families, but each had a dairy combined with the raising of large crops of grain, such as wheat, corn, oats, etc. These grain-crops, with suitable areas of meadow and pasture, sustained the dairy, and the cows converted much of the grain, and all of the forage, into manure. Thus was, combined, to mutual arlvantage, these two important branches of New York farming. Wheat and cheese to sell, and constant improvement in crops. 
"In our own case, sheep have bcen combined with grain-raising. So we have sold wool, wheat, and barley, and, in all my life, not five tons of hay. Clover, you know, has been our great foragecrop. We have wintered our sheep mostly on clover-hay, baving some timothy mixed with it, that was necessarily cut (to make into hay with the medium, or early clover,) when it was but grass. We have fed such hay to our cows and hors's, and have usually worked into manure the corn-stalks of about 20 acrcs of good corn, each winter, and we have worked all the straw into shape to apply as manure that we could, spreading it thickly on pastures and such other fields as were convenient. Some straw we have sold, mostly to paper-makers."

"That," said the Deacon, "is good, old-fas'ioned farming. Plenty of straw for bedding, and good clover and timothy-hay for feed, with wool, wheat, and barley to sell. No talk about oilcake, malt-combs, and mangels ; nothing about superphosphate, guano, or swamp-muck."

Mr. Geddes and Mr. Johnston are both representative firmers; both are large wheat-growers; both keep their land clean and thoroughly cultivated; both use gypsum freely; both raise large crops of clover and timothy; both keep sheep, and yet thcy rcpresent two entirely different systems of farming. Onc is the great advocate of clover; the other is the great advocate of manure.

I once wrote to Mr. Geddes, asking his opinion as to the bist time to plow under clover for wheat. He replied as follows:

"Plow under the clover when it is at full growth. But your question can much better be answered at the end of a long, free talk, which can best be had here. I have many timcs asked you to come here, not to see fine farming, for we have none to show, bit to see land that has been used to test the effects of clover for nearly 70 years. On the ground, I could talk to a willing auditor long, if not wisely. I am getting tired of being misunderstood, and of having my statements doubted when I talk about clover as the great renovator of land. You preach agricultural truth, and the facts you would gather in this neighborhood are worth your knowing, and worth giving to the world. So come here and gather some facts about clover. All that I shall try to prove to you is, that the fact that clover and plaster are by far the cheaprst manures that can be had for our lands, has been demonstrated by many farmers beyond a doubt-so much cheaper than barn yard manure that the mere loading of and spreading costs more than 
the plaster and clover. Do not quote me as saying this, but come and see the farms hereabouts, and talk with our farmers."

Of course I went, and had a capital time. Mr. Gcddes has a magnificent farm of about 400 acres, some four miles from Syracuse. It is in high condition, and is continually improving, and this is due to growing large and frequent crops of clover, and to good, deep plowing, and clean and thorough culture.

We drove round-among the farmers. "Here is a man," said Mr. G., "who run in debt $\$ 45$ per acre for his farm. He has educated his family, paid off his debt, and reports his net profits at from $\$ 2,000$ to $\$ 2,500$ a year on a farm of 90 acres; and this is due to clover. You see he is building a new barn, and that does not look as though his land was running down under the system." The next farmcr we came to was also putting up a new barn, and another farmer was enlarging an old one. "Now, these farmers have never paid a dollar for manure of any kind except plaster, and their lands certainly do not deteriorate."

From Syracuse, I went to Geneva, to see our old friend John Johnston. "Why did you not tell me you were coming?" he said. "I would have met you at the cars. But I am right glat to see you. I want to show you my wheat, where I put on 250 lbs. of guano per acre last fall. People here don't know that I used it, and you must not mention it. It is grand."

I do not know that I ever saw a finer piece of wheat. It was the Diehl variety, sown 14th September, at the rate of $1 \frac{1}{4}$ bushels per acre. It was quite thick enough. One breadth of the drill was sown at the rate of two bushels per acre. This is earlier. "But," said Mr. J., "the other will have larger heads, and will yicld more." After examining the wheat, we went to look at the pilcs of muck and manure in the barn-yard, and from these to a splendid crop of timothy. "It will go $2 \frac{1}{2}$ tons of hay per acre," said Mr. J., " and now look at this adjoining field. It is just as good land naturally, and there is merely a fence between, and yet the grass and clover are so poor as hardly to be worth cutting."

"What makes the difference?" I asked.

Mr. Johnston, emphatically, "Manure."

The poor field did not belong to him!

Mr. Johnston's farm was originally a cold, wet, clayey soil. Mr. Geddes' land di 1 not need draining, or very little. Of course, land that needs draining, is richer after it is drained, than land that is 
naturally drained. And thourh Mr. Jo'nston w.s always a good farmer, yet he says he "never mate money until he commenced to drain." The accumulated fertility in the lan.l could then be made available by good tillage, and from that day to this, his land has been growing richer and richer. And, in fact, the same is true of Mr. Geddes' farm. It is richcr land to-day than when first plowed, while there is one field that for seventy years has had no manure applied to it, except plaster. How is this to be explained? Mr. Geddes would say it was due to clover and plaster. But this does not fully satisfy those who claim, (and truly), that "always taking out of the meal-tub and never putting in, soon comes to the bottom." The clover can add nothing to the land, that it did not get from the soil, except organis matter obtained from the atmosphere, and the plaster furnis'ses little or nothing except limo and sulp'suric acid. There are all thc other ingredients of plant-food to be accounted for-phosphoric acid, potash, soda, magnesia, etc. A crop of clover, or corn, or wheat, or barley, or oats, will not come to perfection unless every one of these elements is present in the soil in an available condition. Mr. Geddes has not furnished a single ounce of any one of them.

"Where do they come from?"

I answer, from the soil itself. There is probably enough of these elements in the soil to last ten thousand years; and if we return to the soil all the straw, chaff, and bran, and sell nothing but fine fiour, meat, butter, etc., there is probably enough to last a million years, and you and I need not trouble ourselves with speculations as to what will happen after that time. Nearly all our soils are practically inexhaustible. But of course these elements are not in an available condition. If they were, the rains would wash them all into the ocean. They are rendered available by a kind of fermentation. A manure-heap packed as hard and solid as a rock would not decay; but break it up, make it fine, turn it occasionally so as to expose it to the atmosphere, and with the proper degree of moisture and heat it will ferment rapidly, and all its clements will soon become available food for plants. Nothing has been created by the process. It was all there. We have simply made it avxilable. So it is with the soil. Break it up, make it fine, turn it occasionally, expose it to the atmosphere, and the clements it contains become available.

I do not think that Mr. Geddes' land is any better, naturally, than yours or mine. We can all raise fair crops by cultivating the land thoroughly, and by never allowing a weed to grow. On Mr. Lawes' experimental wheat-field, the plot that has never re- 
ceived a particle of minure, produces every year an average of about 15 bushels per acre. And the whole crop is removed-grain, straw, and chaff. Nothing is returned. And that the land is not remarkably rich, is evident from the fact that some of the farms in the neighborhood, produce, under the ordinary system of management, but little more wheat, once in four or five years than is raised every year on this experimental plot without any manure.

Why? Because these farmers do not half work their land, and the manure they make is little better than rotten straw. Mr. Lawes' wheat-field is plowed twice every year, and when I was there, the crop was hand-hoed two or three times in the spring. Not a wced is suffered to grow. And this is all there is to it.

Now, of course, instead of raising 15 bushels of wheat every year, it is a good deal better to raise a crop of 30 bushels every other year, and still better to raise 45 bushels every third year. And it is here that clover comes to our aid. It will enable us to do this very thing, and the land runs no greater risk of exhaustion than Mr. Lawes' unmanured wheat crop.

Mr. Geddes and I do not differ as much as you suppose. In fact, I do not believe that we differ at all. He has for years been an earnest advocate for growing clover as a renovating crop. $\mathrm{He}$ thinks it by far the cheapest manure that can be obtained in this section. I agree with him most fully in all these particulars. He formed his opinion from experience and observation. I derived mine from the Rothamsted experiments. And the more I see of practical farming, the more am I satisfied of their truth. Clover is, unquestionably, the great renovating crop of American agriculture. A crop of clover, equal to two toas of hay, when plowed under, will furnish more ammonia to the soil than twenty tons of straw-made manure, drawn out fresh and wet in the spring, or than twelve tons of our ordinary barn-yard manure. No wonder Mr. Geddes and other intelligent farmers recommend plowing under clover as manure. I differ from them in no respect exccpt this: that it is not absolutely essential to plow clover under in the green state in order to get its fertilizing effect; but, if made into hay, and this hay is fed to animals, and all the manure carefully saved, and returned to the land, there need be comparatively little loss. The animals will seldom take out more than from five to ten per cent of all the nitrogen furnished in the food-and less still of mineral matter. I advocate growing all the clover you possibly can-so does Mr. Geddes. He says, plow it under for manure. So say I-unless you can make more from feeding out the clover-bay, 
than will pay you for waiting a year, and for cutting and curing the clover and drawing back the manure. If you plow it under, you are sure of it. There is no loss. In feeding it out, you may lose more or less from leaching, and injurious fermentation. But, of course, you need not lose anythin's, except the little that is retained in the flesh, or wool, or milk, of the animals. As thing; are on many farms, it is perhaps best to plow under the clover for manure at once. As things ought to be, it is a most wasteful practice. If you know how to feed out the hay to advantage, and trke pains to save the manure (and to add to its value by feeding oil-cake, bran, etc., with it), it is far better to mow your clover, once for hay, and once for seed, than to plow it under. Buy oil-cake and bran with the money got from the seed, and growing clover-seed will not injure the land.

I am glad to hear that Mr. Geddes occasionally sells straw. I once sold 15 tons of straw to the puper-makers for $\$ 150$, they drawing it themselves, and some of my neighbors criticised me severely for doing so. It is not considered an orthodox practice. I do not advocate selling straw as a rule; but, if you have more than you can use to advantage, and it is bringing a good price, sell part of the straw and buy bran, oil-cake, etc., with the money. To feed nothing but straw to stock is poor economy; and to rot it down for manure is $\mathrm{n}$ ) better. Straw itself is not worth $\$ 3.00$ a ton for manure; and as one ton of straw, spread in an open yard to rot, will make, in spring, about four tons of so-called manure, and if it costs 50 cents a ton to draw out and spread it, the straw, even at this comparatively high estimate of its value, nets you, when fed out alone, or rotted down, only $\$ 1.00$ a ton.

I had about 30 tons of straw. Fed out alone or rotted down it would make 120 tons of m?nure. After deducting the expense of hauling, and spreading, it nets me on the land, $\$ 30$. Now sell half the straw for $\$ 150$, and buy three tons of oil-cake to feed out with the other half, and you would have about seventy tons of manure. The manure from the fifteen tons of straw is worth, say $\$ 45$, and from the three tons of oil-cake, $\$ 60$, or $\$ 105$. It will cost $\$ 35$ to draw and spread it, and will thus net on the land, $\$ 70$. So far as the manure question is concerned, therefore, it is far better to sell half your straw, and buy oil-cake with the money, than to feed it out alone-and I think it is also far better for the stock. Of course, it would be better for the farm, not to sell any of the straw, and to buy six tons of oil-cake to feed out with it; 
but those of us who are short of capital, must be content to bring up our land by slow degrees.

"I am at a loss to understand," wrote Mr. Geddes, "what you mean, when you say that a ton of straw will make, in the spring of the year, four tons of so-called manure. If you had said that four tons of straw would make one ton of manure, I should have thought nothing of it. But how you can turn one ton of straw into four tons of anything that anyboly will call manure, I cio not see. In a conversation I had with Hon. Lewis F. Allen, of Black Rock, more than a year ago, he told me that he had enquired of the man who furnished hay for feeding cattle at the Central Yards, in Buffalo, as to the loads of manure he sold, and though I can not now say the exact quantity to a ton of hay, I remember that it was very little-far less than I had before supposed. Please explain this straw-manure matter."

Boussingault, the great French chemist-farmer, repeatedly analyzed the manure from his barn-yard. "The animals which had produced this dung, were 30 horses, 30 oxen, and from 10 to 20 pigs. The absolute quantity of moisture was ascertained, by first drying in the air a considerable weight of dung, and after pounding, continuing and completing, the drying of a given quantity." No one can doubt the accuracy of the results. The dung made in the

Winter of $1837-8$, contained 79.6 per cent of water.
" " $1838-9$, " 77.8 " " "
Autumn " 1839,

Fresh solid cow-dung contains, according to the same authority, 90 per cent of water.

I have frequently seen manure drawn out in the spring, that had not been decomposed at all, and with more or less snow among it, and with water dripping from the wagon, while it was being loxded. It was, in fact, straw saturated with water, and discolored $b r$ the droppings of animals. Now, how much of such manure would a ton of dry straw make? If we should take 20 lbs. of straw, trample it down, and from time to time sprinkle it with water and snow, until we had got on $80 \mathrm{lbs}$., and then put on $20 \mathrm{lbs}$. more straw, and $80 \mathrm{lbs}$. more water, and keep on until we had used up a ton of straw, how much "so-called manure," should we have to draw out?

$20 \mathrm{lbs}$. of straw, and $80 \mathrm{lbs}$. water $=100 \mathrm{lbs}$. so-called manure. $2,000 \mathrm{lbs}$. of straw, and $8,000 \mathrm{lbs}$. water $=10,000 \mathrm{lbs}$. so-called manure.

In other words, we get five tons of such manure from one ton of 
straw. This is, perhaps, an extreme case, but there can be little doubt, that a ton of straw, trampled down by cattle, and sheep, in an open barn-yard, exposed to snow and rain, would weigh four toas when drawn out wet in the spring.

Yes, it is quite an argument in favor of manure cellars. I have always had a prejudice against them-probably, because the first one I saw was badly manuged. There is, however, no neccssity, even in an ordinary open barn-yard, with more or less sheds and stables, of having so much water in the manure when drawn out. Tue real point of my remarks, which so surprised Mr. Geddes, was this: We have to draw out so much water with our manure, under any circumstances, that we should try to have it as rich as possible. It is certainly true, that, if the manure from a ton of straw is worti $\$ 3$, that from a ton of clover-hay, is worth $\$ 10$. Aad it costs no more to draw out and spread the one than the other. I have never yet found a farmer who would believe that a ton of clover-hay, rotted down in the barn-yard, would make three or four tons of manure; but he would readily assent to the proposition, that it took four or five tons of green clover to make a ton of hay; and that if these four or five tons of green-clover were rotted in the yard, it would make three or four tons of manure. And yet, the only difference between the green-clover and the hay, is, that the latter has lost some 60 or 70 per cent of water in curing. Add that amount of water to the hay, and it will make as much manure as the green-clover from which the hay was inade.

\section{GYPSUM AND CLOVER AS MANURE.}

A good farmer came in while we were talking. "Nothing like plaster and clover," he said, "for keeping up a wheat-farm." And you will find this the general opinion of nearly all American w'seat-yrowers. It must be accepted as a fact. But the deductions drawn from the fact are as various as they are numerous.

Let us look first at the fact. And, if you like, we will take my own farm as an example. About 60 years ago, it was covered with the primeval forest. The trees, on the higher and drier land, were first cut down, and many of them burnt on the land. Wheat was sown among the stumps. The crop varied in different years, from 10 to 30 bushels per acre. When 30 bushels were grown, the fact was remembered. When 10 bushels only were grown, little was said about it in after years, until now there is a general impression that our wheat crops were formerly much larger per acre than now. I doubt it; but we will not discuss the point. One thing is 
certain, the land would produce good crops of cluver; and when this clover was plowed under for manure, we got better crops of wheat afterwards. This was the rule. Later, we commenced to use gypsum as a top-dressing on clover. The effect was of ten wonderful. Farmers will tell you that they sowed $200 \mathrm{lbs}$. of plaster per acre, on their young clover, in the spring, and it doubled the crop. This statement expresses an agricultural, and not an arithmetical fact. We do not know that the crop on the plastered portion was twice as heavy as on the unplastered. We know tinat it was larger, and more luxuriant. There was a greatcr, and more vigorous growth. And this extra growth was cause $l$ by the small top-dressing of powdered gypsum rock. It was a great fact in agriculture. I will call it fact, No. 1.

Then, when the clover was turned under, we usually got good wheat. This is fact, No. 2. On these two facts, hang many of our agricultural theories. We may state these facts in many ways. Still, it all comes to this: Clover is good for wheat ; plaster is good for clover.

There is another fact, whic' 1 is a matter of general observation and remark. You rarely find a good farmer who does not pay special attention to his clover-crop. When I was riding with $\mathrm{Mr}$. Geddes, among the farmers of Onondaga County, on passing a farm where everything loo'ed tinrifty-gool fences, good buillings, good garden, good stock, and the land clean and in good condition-I would ask who lived there, or some other question. No matter what. The answer was always the same. "Oh! he is another of our clover men." We will call this fact, No. 3.

And when, a year afterwards, Mr. Geddes returned my visit, and I drove him around among the farmers of Monroe County, he found precisely the same state of facts. All our good farmers were clover men. Among the good wheat-growers in Michigan, you will find the same state of things.

These are the facts. Let us not quarrel over them, 


\section{H A P T E R X X I V.}

\section{THE CHEAPEST MANURE A FARMER CAN USE.}

I do not know who first said, "The cheapest manure a farmer can use is-clover-seed," but the saying has become part of our agricultural literature, and deserves a passing remark.

I have heard good farmers in Western New York say, that if they had a field sown with wheat that they were going to plow the spring after the crop was harvested, they would sow $10 \mathrm{lbs}$. cf clover-seed on the wheat in the spring. They thought that the growth of the clover in the fall, after the wheat was cut, and the grow th the next spring, before the land was plowed, would afford manure worth much more than the cost of the clover-secd.

"I do not doubt it," said the Deacon; "but would it not be better to let the crop grow a few months longer, ard then plow it under?"

"But that is not the point," I remarked; "we sometimes adopt a rotation when Indian-corn follows a crop of wheat. In such a case, good farmers sometimes plow the land in the fall, and again the next spring, and then plant corn. This is one method. But I have known, as I said before, good farmers to seed down the wheat with clover; and the following spring, say the third week in May, plow under the young clover, and plant immediately on the furrow. If the land is warm, and in good condition, you will frequently get clover, by this time, a foot high, and will have two or three tons of succulent veretation to turn under; and the farmer who first recommended the practice to me, said that the cut-worms were so fond of this green-clover that they did not molest the young corn-plants. I once tried the plan myself, and found it to work well; but since then, I have kept so many pigs and sheep, that clover has been too useful to plow under. But we will not discuss this point at present.

"What I wanted to say is this: Here we have a ficld in wheat. Half of it (A) we seed down with 12 lbs. of clover-sced per acre; the other half (B) not. The clover-seed and sowing on A, cost, say, $\$ 2$ per acre. We plow B in the fall; this will cost us about as much as the clover-seed sown on $A$. In the spring, $A$ and $B$ are both plowed and planted to corn. Now, which half of the field will be in the cleanest and best condition, and which will produce the best corn, and the best barley, or oats, afterwards?" 
"I vote for A," said the Deacon.

"I vote for A," said the Doctor.

"I vote for A," said the Squire.

"I should think," modestly suggested Charley, " that it would depend somewhat on the soil," and Charley is right. On a clean, moderately rich piece of light, sandy soil, I should certainly expect much better corn, and better barley or oats, on $\mathbf{A}$, where the clover was grown, than on B. But if the field was a strong loam, that needed thorough cultivation to get it mellow enough for corn, I am inclined to think that B would come out ahead. At any rate, I am sure that on my own farm, moderately stiff land, if I was going to plant corn after wheat, I should not seed it down with clover. I would plow the wheat-stublle immediately after harvest, and harrow and cultivate it to kill the weeds, and then, six weeks or two months later, I would plow it again. I would draw out manure ia the winter, pile it up in the field to ferment, and the next spring spread it, and plow it under, and then-

"And then what ?" asked the Deacon.- "Why the truth is;" said I, "then I would not plant corn at all. I should either sow the field to barley, or drill in mangel-wurzel or Swede-turnips. But if I did plant corn, I should expect better corn than if I had sown clover with the wheat; and the land, if the corn was well cultivated, would be remarkably clean, and in fine condition; and the next time the land was seeded down with clover, we could reasonably expect a great crop."

The truth is, that clover-seed is sometimes a very cheap manure, and farmers are in no danger of sowing too much of it. I do not mean sowing too much seed per acre, but they are in no danger of sowing too many acres with clover. On this point, there is no difference of opinion. It is only when we come to explain the action of clover-when we draw deductions from the facts of the tie case-that we enter a field bristling all over with controversy.

"You have just finished threshing," said the Deacon, "and for my part, I would rather hear how your wheat turned out, than to listen to any of your chemical talk about nitrogen, phosphoric acid, and potash."

"The wheat," said I, " turned out full as well as I expected. Fourteen acres of it was after wheat, and eight acres of it after oats. Both these fields were seeded down with clover list year, but the clover failed, and there was nothing to be done but to risk them again with wheat. The remainder was after barley. In all, 
there was not quite 40 acres, and we had 954 bushels of Diehl wheat. This is not bad in the circumstances; but I shall not be content until I can average, taking one year with another, 35 to 40 businels per acre. If the land had been rich enough, there would unquestionably have been 40 bushels per acre this year. That is to say, the season was quite capable of producing this amount; and I think the mechancial condition of the land was also equal to it; all that was needed was sufficient available plantfood in the soil."

"I can see no reason," said the Doctor, "why you may not averare 40 bus'iels of wheat par acre in a good season."

"The field of 14 acres," said I, "where wheat followed wheat, yielded 23 bushels per acre. Last year it yielded 22 bushels pcr acre ; and so we got in the two years 45 bushels per acre."

This fiel 1 has had no manure of any kind for years. In fact, since th 3 land was cleared, 40 or 50 years ago, I presume that all the manure that has been applied would not, in the aggregate, be equal to more than a good crop of clover-hay. The available plant-food required to proluce these two crops of wheat came from tha soil itself, and from the rain, dews, and atmosphere. The land is now seeded down with clover, and with the aid of a bushel or two of plaster per acre, next spring, it is not improbable that, if mown twice for hay next year, it will yield in the two crops thrce tons of hay per acre.

Now, three tons of clover-hay contain about 33 lbs. of phosphoric acid, $90 \mathrm{lbs}$. of potash, and $150 \mathrm{lbs}$. of nitrogen.

The last crop of wheat, of 22 bushels per -acre, and say 1,500 lbs. of straw, would contain :

In the grain. In the straw. In total crop.

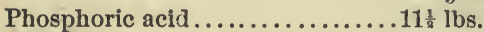

Potash...........................

Nitrogen...........................23 "

3 lbs.

"

$9 \frac{1}{8}$ “ $32 \frac{1}{8}$ "

It seems very unkind in the wheat-plants not to give me mors than 22 bushels per acre, when the clover-plants comiug after will find phosphoric acid enough for 40 bushels of wheat, and potash and nitrogen enough for nearly 100 bushels of wheat per acre. And these are the three important constituents of plant-food.

Why, then, did I get only 22 bushels of wheat per acre? I got 23 bus'aels on the same land the year previous, and it is not improbable that if I had sown the same land to wheat again this fall, I should get 12 or 15 bushels per acre again next year. But the clover will find plant-food enough for 40 bushels of wheat.

"There is not much doubt," said the Deacon, "that you will 
got a $\cong$ ood crop of clover, if you will keep the shcep off of the land this fall. But I do not see what you mean by the clover-piants finding food enough for 40 bushels of wheat, while in point of fact, if you had sown the field again to wheat this fall, you would not, as you say, probably get more tian 12 or 15 buslicls of wheat.

"He means t.ais," saill the Doctor. "If he had sown the land to wheat ihis fall, witbout manure, he would probably not ge over 15 bushels of whcat per acre, and yet you both agree that the land will, in all probability, produce next year, if mown twice, three tons of clover-hay per acre, without any manure.

"Now, if we admit that the clover gets no more nitrogen from the rain and dews, and from the atmosphere, than the wheat will get, then it follows that this soil, which will only produce 15 bushcls of wheat per acre, does, in point of fact, contain plant-foot enough for 40 bushels of wheat, and the usual proportion of straw.

"The two crops take up from the soil as follows:

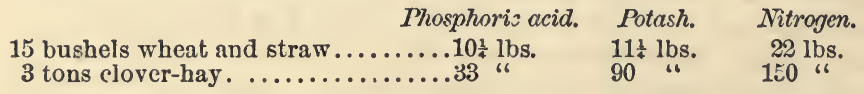

"These facts and figures," continued the Doctor, "are worth looking at and thinking about. Why can not the wheat get as much phosphoric acid out of the soil as the clover?"

"Because," said the Deacon, "the roots of the clover go down deeper into the subsoil than the roots of wheat."

"That is a very good reason, so far as it goes," said I, "but does not include all the facts. I have no sort of doubt, that if I had sown this land to wheat, and put on $75 \mathrm{lbs}$. of nitrogen per acre, I should have got a whent-crop containing, in grain and straw, 30 lbs. of phosphoric acid. And so the reason I got 15 bushels of wheat per acre, instead of 40 bushels, is not because the roots of wheat co not go deep enough to find sufficient soluble phosphoric acid."

"Possibly," said the Doctor, "the nitrogen you apply may render the phosphoric acid in the soil more soluble."

"That is true," said I; " and this was the answer Liebig gave to Mr. Lawes. Of which more at some future time. But this answer, like the Deacon's, does not cover all the facts of the case; for a supply of soluble phosphoric acid would not, in all probability, give me a large crop of wheat. I will give you some facts presently bearing on this point.

"What we want to find out is, why the clover can get so much more phosphoric acid, potesh, and nitrogen, than the wheat, from the same soil ?" 


\section{MORE ABOUT CLOVER.}

The Deacon seemed to think the Doctor was going to give a scientific answer to the question. "If the clover can get more nitrogen, phosphoric acid, and potash, from the same soil than wheat," said he, "why not accept the fact, and act accordingly? You scientific gentlemen want to explain everything, and sometimes make confusion worse confounded. We know that a sheep will grow fat in a pasture where a cow would starve."

"True," said the Doctor, "and that is because the cow gathers food with her tongue, and must have the grass long enough for her to get hold of it; while a sheep picks up the grass with her teeth and gums, and, consequently, the sheep can eat the grass down into the very ground."

"Very well," said the Deacon; "and how do you know but that the roots of the clover gather up their food sheep-fashion, while the wheat-roots eat like a cow?"

"That is not a very scientific way of putting it," said the Doctor; " but I am inclined to think the Deacon has the right idea."

"Perhaps, then," said I, "we had better let it go at that until we get more light on the subject. We must conclude that the wheat can not get food enough from the soil to yield a maximum crop, not because there is not food enough in the field, but the roots of t'he wheat are so constituted that they can not gather it up; while clover-roots, foraging in the same soil, can find all they want."

"Clover," said the Deacon, "is the scavenger of the farm; like a pig, it gathers up what would otherwise be wasted."

"Of course, these illustrations," said the Doctor, "do not give us any clear idea of how the clover-plants take up food. We must recollect tiat the roots of plants take up their food in solution; and il has just occurred to me that, possibly, Mr. Lawes' experiments on tha amount of water given off by plants during their growth, may throw some light on the subject we are discussing."

"Mr. Lawes found," continued the Doctor, " that a wheat-plant, from March 19 to June 28, or 101 days, evaporated through its leaves, etc., 45,713 grains of water; while a clover-plant, standing alongside, and in precisely similar condition, evaporated 55,093 grains. Tine clover was cut June 28, when in full bloom. The wheat-plant was allowed to grow until ripe, Sept. 7. From June 28 to Səpt. 7, or 72 days, the wheat-plant evaporated 67,814 grains."

"One moment," said the Deacon; " as I understand, the cloverplant evaporated more water than the wheat-plant, until the 28th of June, but that during the next 71 days, the wheat-plant evap. orated more watcr than it had during the previous 101 days." 
"Y̌es," said I, "and if these facts prove nothing else, they at least show that there is a great difference between wheat and clover. I was at Rothamsted when these experiments were made. During the first nine days of the experiment, the cloverplant evaporated 399.6 grains of water; while the wheat-plant, standing alongside, evaporated only 128.7 grains. In other words, the clover-plant evaporated three times as much water as the wheat-plant. During the next 31 days, the wheat-plant evaporated 1,267.8 grains, and the clover-plant 1,643.0 grains; but during the next 27 days, from April 28 to May 25, the wheat-plant evaporated 162.4 grains of water per day, while the clover-plant only evaporated 109.2 grains per day. During the next 34 days, from May 25 to June 28, the w'seat-plant evaporated 1,17\%.4 grains per day, and the cluver-plant 1,473.5 grains per day."

"In June," said the Deacon, "the (lover evaporates ten times as much water per day as it did in May. How much water would an acre of clover evaporate?"

"Let Charley figure it out," said the Doctor. "Suppose each plant occupies 10 square inches of land; there are 6,272,640 squars inches in an acre, and, consequently, there would be 627,264 clover-plants on an acre. Each plant evaporated 1,473.5 grains per day, and there are 7,000 grains in a pourd."

Charley made the calculation, and found that an acre of clover, from May 25 to June 28, evaporated 528,598 lbs. of water, or 15,547 lbs. per day.

A much more accurate way of ascertaining how much water an acre of clover evaporates is afforded us hy these experiments. After the plants were cut, they were weighed and analyzed; and it being known exactly how much water each plant had given off during its growth, we have all the facts necessary to tell us just how much a crop of a given weight would evaporate. In brief, it was found that for each pound of dry substance in the wheatplant, 247.4 lbs. of water had been evaporated; and for each pound in the clover-plant, $269.1 \mathrm{lbs}$.

An acre of wheat of 15 bushels per acre of grain, and an equal weight of straw, would exhale during the spring and summer $177 \frac{8}{4}$ tons of water, or calculated on 172 days, the duration of the experiment, 2,055 lbs. per day.

An acre of clover that would make two tons of hay, wruid pass off through its leaves, in 101 days, 430 tons of water, or 8,600 lbs. per day-more than four times as much as the wheat.

These figures show that, from an agricultural point of view, there is a great difference between wheat and clover; and yct I 
tnink the figures do not show the whole of the difference. The clover was cut just at the time when the wheat-plant was entering on its period of most rapid growth and exhalation, and, consequently, the figures given above probably exaggerate the amount of water given off by the wheat during the early part of the season. It is, at any rate, quite clear, and this is all I want to show, that an acre of good clover exhales a much larger amount of water from spring to hay-harvest than an acre of wheat.

"And what," said the Deacon, who was evidently getting tircd of the figures, "does all tinis prove?"

The figures prove that clover can drink a much greater quanlity of water during March, April, May, and June, than wheat; and, consequently, to get the same amount of food, it is not necessary that the clover should have as much nitrogen, phosphoric acid, potash, etc., in the water as the wheat-plant requires. I do not know that I make myself understood."

"You want to show," said the Dcacon, "that the wheat-plant requires richer food than clover."

Yes, I want to show that, though clover requires more food per day than wheat, yet the clover can drink such a large amount of water, that it is not necessary to make the "sap of the soil" so rich in nitrogen, phosphoric acid, and potash, for clover, as it is for wheat. I think this tells the whole story.

Clover is, or may be, the grandest renovating and enriching crop commonly grown on our farms. It owes its great value, not to any power it may or may not possess of getting nitrogen from the atmosphere, or phosphoric acid and potash from the subsoil, but principally, if not entir:ly, to the fact that the roots can drink up such a large amount of water, and live and thrive on very weak food.

\section{HOW TO MAKE A FARM RICH BY GROWING CLOVER.}

Not by growing the clover, and selling it. Nothing would exhaust the land so rapidly as such a practic?. We must either plow under the clover, let it rot on the surface, or pasture it, or use it for soiling, or make it into hay, feed it out to stock, and return the manure to the land. If clover got its nitrogen from the atmosphere, we might sell the clover, and depend on the roots left in the ground, to enrich the soil for the next crop. But if, as I have endeavored to show, clover gets its nitrogen from a weak solution in the soil, it is clear, that though for a year or two we might rais? good crops from the plant-food left in the clover-roots, yet we 
should soon find that growing a crop of clover, and leaving only the roots in the soil, is no way to pcrmaneitly enrich land.

I do not say that such a practice will "exhaust" the land. Fortunately, while it is an easy matter to impoverish land, we should have to call in the aid of the most advanced agricultural science, before we could "exhaust" land of its plant-food. The free use of Nitrate of Soda, or Sulphate of Ammonia, might enable us to do something in the way of exhausting our farms, but $i$. would reduce our balance at a bank, or send us to the poor-house, before we had fully robbed the land of its plant-food.

To exhaust land, by growing and selling clover, is an agricultural impossibility, for the simple reason that, long before the soil is exhausted, the clover would produce such a poverty-stricken crop, that we should give up the attempt.

We can make our land poor, by growing clover, and selling it ; or, we can make our land rich, by growing clover, and feeding it out on the farm. Or, rather, we can make our land rich, by draining it where needed, cultivating it thoroughly, so as to devclope the latent plant-food existing in the soil, and then by growing clover to take up and organize this plant-food. This is how to make land rich by growing clover. It is not, in one sense, the clover that makes the land rich; it is the draining and cultivation, that furnishes the food for the clover. The clover takes up this food and concentrates it. The clover does not create the plantfood; it merely saves it. It is the thorough cultivation that enriches the land, not ìhe clover.

"I wish," writes a distinguished New York gentleman, who has a farm of barren sand, "you would tell us whether it is best to let. clover ripen and rot on the surface, or plow it under when in blossom? I have heard that it gave more nitrogen to the land to let it ripen and rot on it, but as I am no chemist, I do not know."

If, instead of plowing unc'er the clover-say tlee last of June, it was left to grow a month longer, it is quite possible that the cloverroots and seed would contaiz mor nitrogen than they did a month earlier. It was formerly thougint that there was a loss of nitrogen during the ripening process, but the evi ence is not altogether conclusive on the point. Still, if I had a piece of sandy land that I wished to enrich by clover, I do not think I s'ould plow it under in June, on the one hand, or let it grow until maturity, and rot down, on the other. I should rather prefer to mow the crop just as it commenced to blossom, and let the clover lie, spread out on the land, as left by the machine. Tincre would, I think, be no loss of fertilizing elements by evaporation, while the clover-hay woild act 
as a mulch, and the second growth of clover would be encouraged by it. Mow this second crop again, about the first week in August. Then, unless it was desirable to continue the process another year, the land might be plowed up in two or three weeks, turning under the two previous crops of clover that are on the surface, together with the green-clover still growing. I believe this would be better than to let the clover exhaust itself by running to seed.

\section{H A P T E R X X V.}

\section{DR. VAELCKER'S EXPERIMENTS ON CLOVER.}

In the Journal of the Royal Agricultural Society of England, for 1.68, Dr. Vœlcker, the able chemist of the Society, and formerly Professor of Agricultural Chemistry, at the Royal Agricultural College at Cirencester, England, has given us a paper "On the Causes of the Benefits of Clover, as a preparatory Crop for Wheat." The paper has been repeatedly and extensively quoted in this country, but has not been as critically studied as the importance of the subject demands.

"Never mind all that," said the Deacon, "tell us what Dr. Vœlcker says." .

"Here is the paper," said I, " and Charley will read it to us." Charley read as follows:

"Agricultural chemists inform us, that in order to maintain the productive powers of the land unimpaired, we must restore to it the phosphoric acid, potash, nitrogen, and other substances, which enter into the composition of our farm crops; the constant removal of organic and inorganic soil constituents, by the crops usually sold off the farm, leading, as is well known, to more or less rapid deterioration and gradual exhaustion of the land. Even the best wheat soils of this and other countries, become more and more impoverished, and sustain a loss of wheat-yiclding power, when corncrops are grown in too rapid succession without manure. Hence, the universal practice of manuring, and that also of consuming oilcake, corn, and similar purchase 1 food on land naturally poor, or partially exhausted by previous cropping.

"Whilst, however, it holds good as a general rule, that no soil can be cropped for any length of time, without gradually becoming 
more and more infertile, if no manure be applied to it, or if the fertilizing elements removed by the crops grown thereon, be not by some means or other restored, it is, nevertheless, a fact, that after a heavy crop of clover carried off as hay, the land, far from being less fertile than before, is peculiarly well adapted, even without the adjition of manure, to bear a good crop of wheat in the following year, provided the season be favorable to its growth. This faet, indeed, is so well known, that many farmers justly regard the growth of clover as one of the hest preparatory operations which the land can undergo, in order to its producing an abundant crop of wheat in the following year. It has further been noticed, that clover mown twice, leaves the land in a better condition, as regards its wheat-producing capabilities, than when mown once only for hay, and the second crop fed off on the land by sbeep; for, notwithstanding that in the latter instance the fertilizing elements in the clover-crop are in part restored in the sheep excrements, yet, contrary to expectation, this partial restoration of the elements of fertility to the land has not the effect of producing more or better wheat in the following year, than is reaped on land from off which the whole clover-crop has been carried, and to which no manure whatever has been applied.

"Again, in the opinion of several good, practical agriculturists, with whom I have conversed on the subject, land whereon clover has been grown for seed in the preceding year, yields a better crop of wheat than it does when the clover is mown twice for hay, or even only once, and afterwards fed off by sheep."

"I do not think," said the Deacon, "that this agrees with our expəricnce here. A good crop of clover-seed is profitable, but it is thought to be rather hard on land."

"Such," said I, "is the opinion of John Johnston. He thinks allowing clover to go to seed, impoverishes the soil."

Charley, continued to read :

"Whatever may be the true explanation of the apparent anomalies connected with the growth and chemical history of the cloverplant, the facts just mentioned, having been noticed, not once or twice only, or by a solitary observer, but repeatedly, and by numbers of intelligent farmers, are certainly entitled to credit; and little wisdom, as it strikes me, is displayed by calling them into question, because they happen to contradict the prevailing theory, according to which a soil is said to become more or less impoverished, in proportion to the large or small amount of organic and mineral soil constituents carricd off in the produce." 
"That is well said," I remarked, " and rery truly ; but I will not interrupt the reading."

"In the course of a long residence," continues Dr. Vœlcker, "in a purely agricultural district, I have often been struck with the remarkably healthy appearince and good yield of wheat, on land from which a heavy crop of clover-hay was obtained in the preceding year. I have likewise had frequent opportunities of observing, that, as a rule, wheat grown on part of a field whercon clover has been twice mown for hay, is better than the produce of that on the part of the same field on which the clover has becn mown only once for hay, and aftcrwarts fed off by sheep. These observations, extending over a number of years, led me to inquirc into the reasons why clover is specially well fitted to prepare land for wheat; and in this paper, I shall endeavor, as the result of my experiments on the subject, to give an intelligible explanation of the fact, that clover is so excellent a preparatory crop for wheat, as it is practically known to be.

"By those taking a superficial view of the sulject, it may be suggested that any injury likely to be causcd by the removal of a ccrtain amount of fertilizing matter, is altogether insignificant, and more than compensated for, by the bencfit which results from the abundant growth of clover-roots, and the physical improvement in the soil, which takes place in their decomposition. Looking, however, more closely into the matter, it will be found that in a good crop of clover-hay, a very considerable amount of both mineral and organic substances is carried off the land, and that, if the total amount of such constituents in a crop had to be regarded exclusirely as a measure for determining the relative degrees in which different farm crops exhaust the soil, clover would have to be described as about the most exhausting crop in the entire rotation.

"Clover-hay, on an average, and in round numbers, contains in 100 parts :

Water

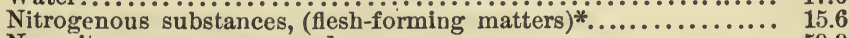

Non-nitrogenous compounds.......................... 59.9

Mineral matter, $($ ash $) \ldots \ldots \ldots \ldots \ldots \ldots \ldots \ldots \ldots \ldots \ldots \ldots \ldots \ldots \ldots \ldots \ldots \ldots \ldots, \quad 7.5$

* Containing nitrogen $\ldots \ldots \ldots \ldots \ldots \ldots \ldots \ldots \ldots \ldots \ldots \ldots, \frac{100.0}{2.5}$

" The mineral portion, or ash, in 100 parts of clover-hay, consists of : 
Phosphoric acid.................................... 7.5

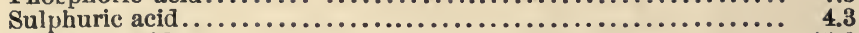

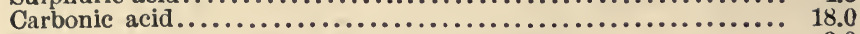

Silica.................................................... $\quad 3.0$

Lime.................................................. $\quad 30.0$

Magnesia............................................ 8.5

Potash................................................... 20.0

Soda, chloride of sodium, oxide of iron, sand, loss, etc.......... 8.7

"Let us suppose the land to have yielded four tons of clover-hay per acre. According to the preceding data, we find that such a crop includes $224 \mathrm{lbs}$. of nitrogen, equal to $272 \mathrm{lbs}$. of ammonia, and $672 \mathrm{lbs}$. of mineral matter or ash constituents.

In $672 \mathrm{lbs}$. of clover-ash, we find:

Phosphoric acid.................................. 51

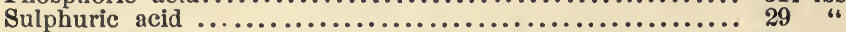

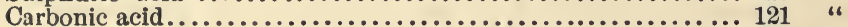

Silica............................................... "

Lime................................................... "

Magnesia.................................................. "

Potash...................................................... $134 \frac{1}{8}$ "

Soda, chloride of sodium, oxide of iron, sand, etc......... 58 "

"Four tons of clover-hay, the produce of one acre, thus contain a large amount of nitrogen, and remove from the soil an enormous quantity of mineral matters, abounding in lime and potash, and containing also a goo 1 deal of phosphoric acid.

"Leaving for a moment the question untouched, whether the nitrogen contained in the clover, is derived from the soil, or from the atmosphere, or partly from the one, and partly from the other, no question can arise as to the original source from which the mineral matters in the clover produce are derived. In relation, therefore, to the ash-constituents, clover must be regarded as one of the most exhausting crops usually cultivated in this country. This appears strikingly to be the case, when we compare the preceding figures with the quantity of mineral matters which an average crop of wheat removes from an acre of land.

"The grain and straw of wheat contain, in round numbers, in 100 parts:

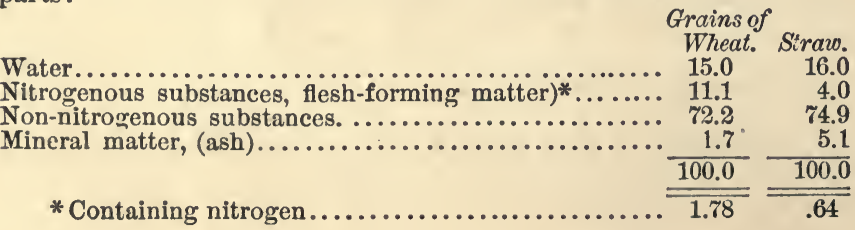


"The ash of wheat contains, in 100 parts :

\begin{tabular}{|c|c|c|}
\hline . & $\begin{array}{c}\text { Grain. } \\
50.0\end{array}$ & $\begin{array}{r}\text { Strawo. } \\
5.0\end{array}$ \\
\hline ...... & 0.5 & \\
\hline ...... & & \\
\hline 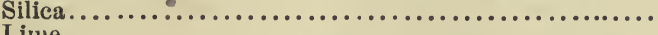 & 2.5 & \\
\hline 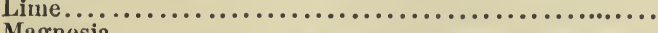 & 3.5 & \\
\hline 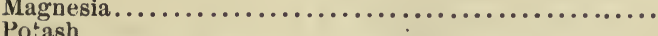 & 11.5 & \\
\hline 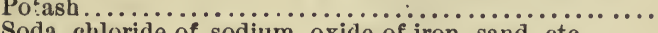 & 30.0 & 1 \\
\hline of sodiur & 20 & \\
\hline & & \\
\hline
\end{tabular}

"The mean produce of wheat, per acre, may be estimeted at 25 bushels, which, at $60 \mathrm{lbs}$. per bushel, gives 1,500 lbs.; and as the weight of the straw is generally twice that of the grain, its produce will be $3,000 \mathrm{lbs}$. According, therefore, to the preceding data, there will be carried away from the soil:

In 1,500 lbs. of the grain.. $25 \mathrm{lbs}$. of mineral food, (in round numbers). In $3,000 \mathrm{lbs}$. of the straw.. $150 \mathrm{lbs}$. of mineral food, (in round numbers).

Total............... $\overline{\mathbf{1 7 5}}$ lbs.

"On the average of the analyses, it will be found that the composition of these $175 \mathrm{lbs}$. is as follows:

\begin{tabular}{|c|c|c|c|}
\hline & $\begin{array}{l}\text { In the } \\
\text { grain. }\end{array}$ & $\begin{array}{l}\text { In the } \\
\text { straw. }\end{array}$ & Total. \\
\hline 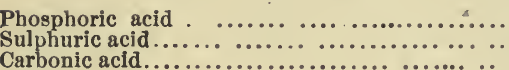 & $\begin{array}{c}12.5 \\
0.1\end{array}$ & $\begin{array}{l}7.5 \mathrm{lbs} . \\
4.0\end{array}$ & $\underset{4.1}{20.0 \mathrm{lbs}}$ \\
\hline 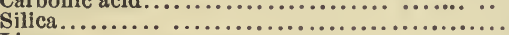 & 0.6 & 100.5 "6 & $101.1 “$ \\
\hline ........ & 0.96 & 8.2 " & 9.1 “ \\
\hline 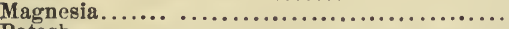 & 2.9 " & 3.0 & 5.9 \\
\hline \multirow{3}{*}{ Soda, chloride of sodium, oxide of iron, sand, etc. } & $7.5 \%$ & 19.5 " & 27.0 " \\
\hline & 0.5 & $7.3 \quad 6$ & $7.8 \quad 6$ \\
\hline & 25. $1 \mathrm{bs}$. & $150.1 \mathrm{bs}$. & $1^{\prime} / 5 . \mathrm{lbs}$. \\
\hline
\end{tabular}

" The total quantity of ash constituents carried off the land, in an average crop of wheat, thus amounts to only $175 \mathrm{lbs}$. per acre, whilst a good crop of clover removes as much as $672 \mathrm{lbs}$.

"Nearly two-thirds of the total amount of mineral in the grain and s'raw of one acre of wheat, consists of silica, of which there is an ample supply in almost every soil. The restoration of silica, therefore, need not trouble us in any way, especially as there is not a single instance on record, proving that silica, even in a soluble condition, has ever been applied to land, with the slightest advantage to corn, or grass-crops, which are rich in silica, and which, for this reason, may be assumed to be particularly grateful for it in a soluble state. Silica, indeed, if at all capable of producing a beneficial effect, ought to be useful to these crops, either by strengthening the straw, or stems of graminaceous plants, or otherwise benefting them; but, after deducting the amount of silica from the 
total amount of mineral matters in the wheat produced from one acre, only a triflng quantity of other and more valuable fe1 tilizing ash constituents oî plants will be left. On comparing tre Iclative amounts of phosphoric acid, and potash, in an avcrüge clep of wheat, and a good crop of clover-hay, it will be seen that one acre of clover-hay contains as much phosphoric acid, as two and onehalf acres of wheat, and as much potash as the produce from five acres of the same crop. Clover thus unqucsticnably removes from the land very much nore mineral matter than does wheat; wheat, notwithstanding, succecds remarkably well after clover.

"Four tons of clover-hay, or the produce of an acre, contains, as alrcady stated, $224 \mathrm{lbs}$. of nitrogen, or calculated as ammonia, 272 lbs.

"Assuming the grain of wheat to furnish 1.78 per cent of nitrogen, and wheat-straw, .64 per cent, and assuming also that 1,500 lbs. of corn, and 3,000 lbs. of straw, represent the average produce per acre, there will be in the grain of wheat, per acre, $26.7 \mathrm{lbs}$. of nitrogen, and in the straw, $19.2 \mathrm{lks}$., or in both together, $46 \mathrm{lbs}$. of nitrogen; in round numbers; equal to about $55 \mathrm{lbs}$. of ammonia, which is only about one-fift'. the quantity of nitrogen in the produce of an acre of clover. Wheat, it is well known, is specially benetited by the application of nitrogenous manures, and as clover carries off so large a quantity of nitrogen, it is ratural to expect the yield of whcat, after clover, to fall short of what the land might be presumed to produce without manure, before a crop of clover was taken from it. Experience, however, has proved the fallacy of this presumption, for the result is exactly the opposite, inasmuch as a better and heavier crop of wheat is produced than without the intercalation of clover. What, it may be asked, is the explanation of this apparent anomaly?

"In taking up this inquiry, I was led to pass in review the celebrated and highly important experiments, undertaken by Mr. Lawes and Dr. Gilbert, on the continued growth of wheat on the same soil, for a long succession of years, and to examine, likewise carefully, many points, to which attention is drawn, by the same authors in their memoirs on the growth of red clover by different manures, and on the Lois Weedon plan of growing wheat. Abundant and most convincing evidence is supplied by these indefatigable experimenters, that the wheat-producing powers of a soil are not increased in any sensible degree by the liberal supply of all the mineral matters, which enter into the crmposition of the ash of wheat, and that the abstraction of these mineril matters from the soil, in any much larger proportions than can possibly take place 
under ordinary cultivation, in no wise affects the yiel 3 of wheat, provided there be at the same time a liberal supply of available nitrogen within the soil itself. The amount of the litter, therefore, is regarded by Messrs. Lawes and Gilbert, as the measure of the increased produce of grain which a soil furnishes.

"In conformity with these views, the farmer, when be wishes to increase the yield of his wheat, finds it to his advantage to have recourse to ammoniacal, or other nitrogenous manures, and depends more or less entirely upon the soil, for the supply of the neccessary mineral or ash-constituents of wheat, having found such a supply to be amply sufficient for his requirements. As far, therefore, as the removal from the soil of a large amount of mineral soil-constituents, by the clover-crop, is concerned, the fact viewed in the light of the Rothamsted experiments, becomes at once intelligible; for, notwithstanding the abstraction of over $600 \mathrm{lbs}$. of mineral matter by a crop of clover, the succeeding wheat-crop does not suffer. Inasmuch, however, as we have seen, that not only much mineral matter is carried off the land in a crop of clover, but also much nitrog $3 n$, we might, in the absence of direct evidence to the contrary, be led to suspect that wheat, after clover, would not be a good crop; whereas, the fact is exactly the reverse.

"It is worthy of notice, that nitrogenous manures, which have such a marked and beneficial effect upon wheat, do no good, but in certain combinations, in some seasons, do positive harm to clover. Thus, Messrs. Lawes and Gilbert, in a series of experiments on the growth of red-clover, by different manures, obtained 14 tons of fresh green produce, equal to about three and threefourths tons of clover hay, from the unmanured portion of the experimental field; and where sulphates of potash, soda, and magnesia, or sulphate of potash and superphosphate of lime were employed, 17 to 18 tons, (equal to from ahout four and one-half to nearly five tons of hay), were obtained. When salts of ammonia were added to the mineral manures, the produce of clover-hay was, upon the whole, less than where the mineral manures were used alone. The wheat, grown after the clover, on the unmanured plot, gave, however, $29 \frac{1}{2}$ bushels of corn, whilst in the arjoining field, where wheat was grown after wheat, without manure, only $15 \frac{1}{2}$ bushels of corn per acre were obtained. Messrs. Lawes and Gilbert notice especiılly, that in the clover-crop of the preceding year, very much larger quantities, both of mineral matters and of nitrogen, were taken from the land, than were removed in the unmanured wheat-crop in the same year, in the adjoining field. Notwithstanding this, the soil from which the clover had been 
taken, was in a condition to yield 14 bushels more wheat, per acre, than that upon which wheat had been previously grown; the yield of wheat, after clover, in these experiments, being fully equal to that in another field, where large quantities of manure were used.

"Taking all these circumstances into account, is there not presumptive evidence, that, notwithstanding the removal of a large amount of nitrogen in the clover-hay, an abundant store of available nitrogen is left in the soil, and also that in its relations towards nitrogen in the soil, clover differs essentially from wheat? The results of our experience in the growth of the two crops, appear to indicate that, whereas the growth of the wheat rapidly exhausts the land of its available nitrogen, that of clover, on the contrary, tends somehow or other to accumulate nitrogen within the soil itself. If this can be shown to be the case, an intelligible explanation of the fact that clover is so useful as a preparatory crop for wheat, will be found in the circumstance, that, during the growth of clover, nitrogenous food, for which wheat is particularly grateful, is either stored up or rendered available in the soil.

"An explanation, however plausible, can hardly be accepted as correct, if based mainly on data, which, although highly probable, are not proved to be based on fact. In chemical inquirics, especially, nothing must be taken for granted, that has not becn proved by direct experiment. The following questions naturally suggest themselves in reference to this subject: What is the amount of nitrogen in soils of different characters? What is the a mount more particularly after a good, and after an indifferent crop of clover? Why is the amount of nitrogen in soils, larger after clover, than after wheat and other crops? Is the nitrogen present in a condition in which it is available and useful to wheat? And lastly, are there any other circumstances, apart from the supply cf nitrogenous matter in the soil, which help to account for the beneficial effects of clover as a preparatory crop for wheat ?

"In order to throw some light on these questions, and, if possible, to give distinct answers to at least some of them, I, years agi, when residing at Cirencester, began a scries of experiments; and more recently, I have been fortunate enough to obtain the cooperation of Mr. Robert Valentine, of Leighton Buzzard, who kindly undertook to supply me with materials for my analysis.

"My first experiments were made on a thin, calcareous, clay soil, resting on oolitic limestone, and producing generally a fair crop of red-clover. The clover-field formed the slope of a rather steep hillock, and varied much in depth. At the top of the hill, the soil became very stony at a depth of four inches, so that it could only 
with difficulty be excavated to a depth of six inches, when the bare limestone-rock made its appearance. At the bottom of the field the soil was much deeper, and tse clover stronger, than at the upper part. On the brow of the hill, where the clover appeared to be strong, a square yarl was measured out; and at a little distanee off, where the clover was very bad, a second square yard was measured; in both plots, the soil being taken up to a depth of six inches. The soil, where the clover was good, may be distinguished from the other, by being 'marked as No. 1, and that where it was bal, as No. 2.

\section{CLOVER-SOIL NO. 1. (GOOD CLOVER).}

"The roots having first been shaken out to free them as much as possible from the soil, were then washed once or twice with cold distilled water, and, after having been dried for a little while in the san, were weighed, when the square yarł produced $1 \mathrm{lb} .10 \frac{1}{2} \mathrm{oz}$. of ceaned clover-roots, in an air-dry state ; an acre of land, or 4,840 square yards, accordingly yielded, in a depth of six inches, 3.44 tons, or $3 \frac{1}{2}$ tons in round numbers, of clover-roots.

"Fully dried in a water-bath, the roots were found to contain altogether 44.67 per cent of water, and on being burnt in a platinum capsule, yiclded 6.089 of ash. A portion of the dried, finely powdered and well mixed roots, was burned with soda lime, in a combustion tube, and the nitrogen contained in the roots otherwise determined in the usual way. Accordingly, the following is the general composition of the roots from the soil No. 1:

Water............................................ 44.C75

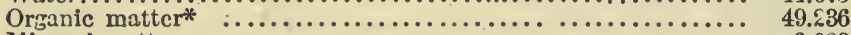

Mlineral matter........................................ 6.089

$\frac{\overline{100.000}}{=}$

* Containing nitrogen ............................ $1 . \AA 97$

Equal to ammonia.................................. 1.575

" $A$ ssuming the whole ficld to have produced $3 \frac{1}{2}$ tons of clover-

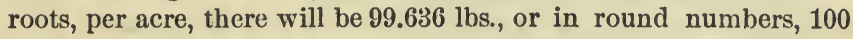
lbs. of nitrogen in the clover-roots from one acre; or, about twice as much nitrogen as is present in the average produce of an acre of wheat."

"That is a remarkable fact," said the Deaeon, "as I unclerstand nitrogen is the great thing needed by wheat, and yet the roots alone of the clover, contain twice as much nitrogen as an average crop of wheat. Go on Charlcy, it is quite intcresting."

"The soil," continues Dr. Vœlcker, "which had been scparated from the roots, was passed through a sieve to deprive it of any stones it might contai.ı. It was then pa:tiılly dried, and the nitro 
gen in it determined in the usual manner, by combustion with sodalime, when it yielted .313 p cr cent of nitrogen, equal to .38 of ammonia, in one combustion; and .373 per cent of nitrogen, equal t) .46 of ammonia, in a second determination.

"That the reader may have some idea of the character of this soil, it may be stated, that it was further submitted to a general analysis, according to which, it was found to have the following composition :

GENERAL COMPOSITION OF SOIL, NO. 1. (GOOD CLOVER).

MIoisture....................................... 18.73

Organic matter*........... $\ldots \ldots \ldots \ldots \ldots \ldots \ldots \ldots \ldots \ldots \ldots \ldots,{ }_{9.72}$

Oxide of iron and alumina.................................... 13.24

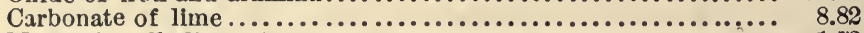

Magnesia, alkalies, etc...................................... 1.72

Insoluble silicious matter, (chiefly clay)................... 47.77

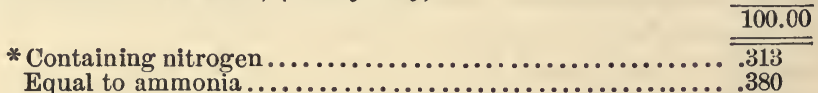

"The second square yard from the brow of the hill, where the clover was bad, produced 13 ounces of air-dry, and partially clean roots, or 1.75 tons per acre. On analysis, they were found to have the following composition:

CLOVER-ROOTS, NO. 2. (BAD CLOVER).

Water...................................... $\quad 55.732$

Or ranic matter*......................................... $\quad 39.408$

Mineral matter, $(a s h) \ldots \ldots \ldots \ldots \ldots \ldots \ldots \ldots \ldots \ldots \ldots \ldots \ldots \ldots, \quad 4.860$

* Containing nitrogen ........................... $=\frac{100.000}{.792}$

Equal to ammonia........................................

"The roots on the spot where the clover was very bad, yielded only $31 \mathrm{lbs}$. of nitrogen per acre, or scarcely one-third of the quantity which was obtained from the roots where the clover was good.

"The soil from the second square yard, on analysis, was found, when freed from stones by sifting, to contain in 100 parts: COMPOSITION OF SOIL, NO. 2. (BAD CLOVER):

Water .......................................... 17.24 Organic matter*........................................... 9.64

Oxide of iron and alumina $\ldots \ldots \ldots \ldots \ldots \ldots \ldots \ldots \ldots \ldots \ldots \ldots \ldots \ldots, 11.89$

Carbonate of lime.......................................... 14.50

Magnesia, alkalies, etc................................... 1.53

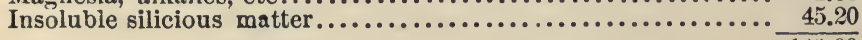

100.00

$2 d$ determination.

* Containing nitrogen...................... .306

Equal to ammonia............................ 
"Both portions of the clover-soil thus containel about the same percentage of orga.iic matter, and yielded nearly the same amount of nitrogeu.

"In addition, however, to the nitrogen in the clover-roots, a good deal of nitrogen, in the shape of root-fibres, decayed leaves, and similar organic matters, was disscminated throughout the fine soil in which it occurred, and from which it could not be separated; but unfortunately, I neglected to weigh the soil from a square yard, and am, therefore, unable to state how much nitrogen per acre was present in the shape of small root-fibres and other organic matters.

"Before mentioning the details of the experiments made in the next season, I will here give the composition of the ash of the partially cleaned clover-roots :

\section{COMPOSITION OF ASH OF CLOVER-ROOTS, (PARTIALLY}

\section{CLEANED).}

Oxide of iron and alumina.......................... 11. 73

Lime................................................. ${ }^{18.49}$

Magnesia.................................................. ${ }_{3.03}$

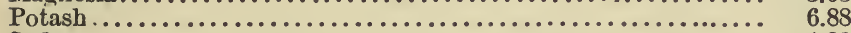

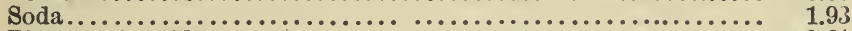

Phosphoric acid....................................... $\quad 3.61$

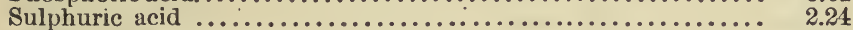

Soluble silica $\ldots \ldots \ldots \ldots \ldots \ldots \ldots \ldots \ldots \ldots \ldots \ldots \ldots \ldots \ldots \ldots \ldots \ldots \ldots \ldots, 19.01$

Insoluble silicious matter................................... 24.83

Carbonic acid, chlorine, and loss........................... $8 . \approx 5$

"This ash was obtained from c'over-roots, which yielded, when perfcctly dry, in round numbers, eight per cent of ash. Cloverroots, washed quitc clean, and separated from all soil, yield about five per cent of ash; but it is extremely difficult to clean a large quantity of fibrous roots from all dirt, and the preceding analysis distinctly shows, that the ash of the clover-roots, analyzed by mc, was mechanically mixed with a good deal of fine soil, for oxide of iron, and alumina, and insoluble silicious matter in any quantit-, are not normal constituents of plant-ashes. Making allowance for soil contamination, the ash of clover-roots, it will be noticed, contains much lime and potash, as well as an appreciable amount of phosphoric and sulphur.c aci:?. On the decay of the clover-roots, these and other mineral fertilizing matters are left in the surfaccsoil in a readily available cordition, and in considerable proportions, when the clover stands well. Although a crop of clover removes much mineral matter from the soil, it must be borne in mind, that its roots extract from the land, soluble mineral fert.liz- 
ing matters, which, on the decay of the ronts, remain in the land in a prepared and more readily available form, than that in which they originally occur. The benefits arising to wheat, from the growth of clover, may thus be due partly to this prepaiaiion and concentration of mineral food in the surface-soil.

"The clover on the hillside field, on the whole, turned out a very good crop; and, as the plant stood the winter well, and this field was left another season in clover, without being plowed up, I availed myself of the opportunity of making, during the following season, a number of experiments similar to those of the preceding year. This time, however, I selected for examination, a square yard of soil, from a spot on the brow of the hill, where the clover was thin, and the soil itself stony at a depth of four inches; and another plot of one square yard at the bottom of the hill, from a place where the clover was stronger than that on the brow of the hill, and the soil at a depth of six inches contained no large stones.

SOIL NO. 1. (CLOVER THIN), ON THE BROW OF THE HILL.

"The roots in a square yard, six inches deep, when picked out by hand, and cleaned as much as possible, weighed. in their natural state, 2 lbs. $11 \mathrm{oz}$; and when dried on the top of a water-bath, for the purpose of getting them brittle and fit for reduction into fine powder, $1 \mathrm{lb} .12 \mathrm{oz} .31$ grains. In this state they were submitted as before to analysis, when they yielded in 100 parts :

COMPOSITION OF CLOVER-ROOTS, NO. 1, (FROM BROW OF HILL).

Moisture............................................ 4.34

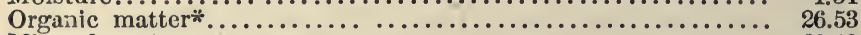

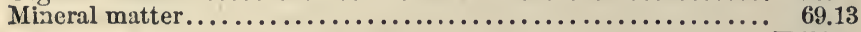

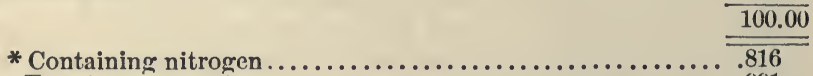

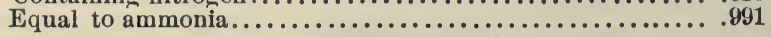

"According to thcse data, an acre of land will yield three tons $12 \mathrm{cwts}$. of nearly dry clover-roots, and in this quantity there will be about 66 llss. of nitrogen. The whole of the soil from which the roots have been picked out, was passed through a half-inch sieve. The stones left in the sieve weighed $141 \mathrm{lbs}$; the soil which passed through weighing $218 \mathrm{lbs}$.

"The soil was next dried by artificial heat, when the $218 \mathrm{lbs}$. became reduced to $185.487 \mathrm{lbs}$.

$\sim$ In this partially dried state it contained: 
Moisture ......................................... 4.21

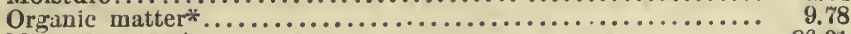

Mineral mattert............................................ 86.01

100.00

* Containing nitrogen ................................. 391

Equal to ammonia.......................................... .4

+ Including phosphoric acid................................. 261

"I also determined the phosphoric acid in the ash of the cloverroots. Calculated for the roots in a nearly dry state, the phosphoric acid amounts to .287 per cent.

"An acre of soil, according to the data, furnished by the six inches on the spot where the clover was thin, produced the following quantity of nitrogen:

Ton. Cwts. Lbs.

In the fine soil ............................ $111 \quad 33$

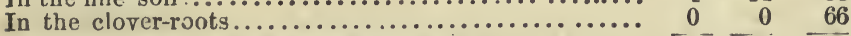

Total quantity of nitrogen per acre............

"The organic matter in an acre of this soil, which can not be picked out by hand, it will be seen, contains an enormous quantity of nitrogen; and although, probably, the greater part of the roots and other remains from the clover-crop may not be decomposed so thoronghly as to yield nitrogenous food to the succeeding wheat-crop, it can scarcely bs doubted that a considerable quantity of nitrogen will become available by the time the wheat is sown, and that one of the chief reasons why clover benefits the succeeding wheat-crop, is to be found in the abundant supply of available nitrogenous food furnished by the decaying clover-roots and leaves.

CLOVER-SOIL NO. 2, FROM THE BOTTOM OF THE HILI. (GOOD CLOVER.)

"A square yard of the soil from the bottom of the hill, where the clover was stronger than on the brow of the hill, produced 2 lbs. 8 oz. of fresh clover-roots; or $1 \mathrm{lb} .11 \mathrm{oz} .47$ grains of partially dried roots; $61 \mathrm{lbs} .9 \mathrm{oz}$. of limestones, and $239.96 \mathrm{lbs}$. of nearly dry soil.

"The partially dried rocts contained:

Moisture........................................... $\quad \mathbf{5 . 0 6}$

Organic matter*............................................... 31.91

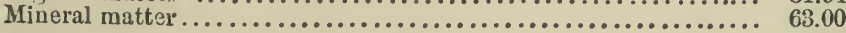

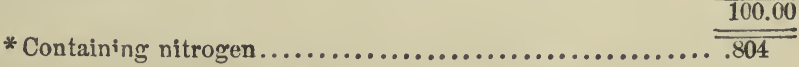

"An acre of this soil, six inches deep, produced 3 tons, $7 \mathrm{cw}$ 's. $65 \mathrm{lbs}$. of clover-roots, containing $61 \mathrm{lbs}$. of nitrogen; that is, there 
was very nearly the same quantity of roots and nitrogen in them, as that furnished in the soil from the brow of the hill.

'- 'The roots, moreover, yielded .365 per cent of phosphoric acid; or, calculaied per acre, $27 \mathrm{lbs}$.

" In rhe partiaily dried soil, I found:

Moisture............................................ $\quad 4.70$

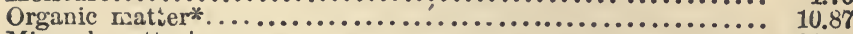

Miucral mattert...................................... 84.43

10.00

* Containing nitrogen ................................405

Equal to aumonia..................................491

†Including phosphoric acid................................ .321

"According to these determinations, an acre of soil from the bottom of the hill, contains:

Nitrogen in the Tons. Cwots. Lbs.

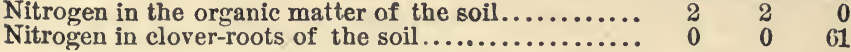

Total amount of nitrogen per acre.............. $\frac{2}{-}-\frac{2}{2}-61$

"Compared with the amount of nitrogen in the soil from the brow of the hill, about $11 \mathrm{cwt}$. more nitrogen was obtained in the soil and roots from the bottom of the hill, where the clover was more luxuriant.

"The increased amonnt of nitrogen occurred in fine root-fibres and other organic matters of the soil, and not in the coarser bits of roots which were picked out by the hand. It may be assumed that the finer particles of organic matter are more readily decomposed than the coarser roots; and as there was a larger amount of nitrogen in this than in the preceding soil, it may be expected that the land at the bottom of the hill, after removal of the clover, was in a better agricultural condition for wheat, t),an that on the brow of the hill. 


\section{H A P T E R X X I.}

\section{EXPERIMENTS ON CLOVER-SOILS FROM BURCOTT LODGE FARM, LEIGHTON BUZZARD.}

' The soils for the next experiments, were kindly supplied to me, - 1866, by Robert Valentine, of Burcott Lodge, who alsn sent me some notes respecting the growth and ricld of clover-hay and secd on this soil.

"Foreign seed, at the rate of 12 lbs. per acre, was sown with a crop of wheat, which yielded five quarters per acre the previous year.

it The first crop of clover was cut down on the 25th of June, 1866 , and carried on June 30th. The weather was very warm, from the time of cutting until the clover was carted, the thermometer standing at $80^{\circ}$ Fahr. every day. The clover was turned in the swath, on the second day after it was cut; on the fourth day, it was turned over and put into small heaps of about $10 \mathrm{lbs}$. each; and on the fifth day, these were collected into larger cocks, and then stacked.

"The best part of an 11-acre field, produced nearly three tons of clover-hay, sun-dried, per acre ; the whole ficld yielding on an average, $2 \frac{1}{3}$ tons per acre. This result was obtained by weighing the stack three months after the clover was carted. The second crop was cut on the 21st of August, and carried on the 27th, the weight being nearly $30 \mathrm{cwt}$. of hay per acre. Thus the two cuttings produced just about four tons of clover-hay per acre.

"The 11 acres were divided into two parts. Al,out one-half was mown for hay a second time, and the other part left for seed. The produce of the second half of the 11-acre field, was cut on the 8th of October, and carried on the 10th. It yielded in round numbers, 3 cwt. of clover-seed per acre, the scason being very unfavorable ' for clover-seed. The second crop of clover, mown for hay, was wather too ripe, and just beginning to show seed.

"A square foot of soil, 18 inches deep, was dug from the second portion of the land which produced the clover-hay and cloverseed.

SOIL FROM 'PART' OF 11-ACRE FIELD 'TWICE MOWN FOR HAY.

"The upper six inches of soil, one foot square, contained all the inain roots of 18 strong plants; the next six inches, only small root fibres, anc? in the third section, a six-inch slice cut down at a 
depth of 12 inches from the surface, no distinct fibres could be found. The soil was almost completely saturated with rain wuen it was dug up on the 13th of September, 1860:

Lbs.

The upper six inches of soil, one foot square, weighed........... $6 \dot{0}$

The second " " "

The third " " "

"These three portions of one foot of soil, 18 inches deep, were dried nearly completely, and weighed again; when the first six inches weighed $51 \frac{1}{4}$ lus.; the second six inches, $51 \mathrm{lbs} .5 \mathrm{oz}$.; and the third section, 54 lbs. $2 \mathrm{oz}$.

"Th? first six inches contained $3 \mathrm{lbs}$. of silicious stones, (flints), which were rejected in preparing a sample for analysis; in the two remaining sections there were no large sized stones. The soils were pounded down, and passed through a wire sieve.

"The three layers of soil, dried and reduced to powder, were mixed together, and a prepared average sample, when submitted to analysis, yielded the following results:

COMPOSITION OF CLOVER-SOIL, 18 INCHES DEEP, FROM PART OF 11-ACRE FIELD, TWICE MOWN FOR HAY.

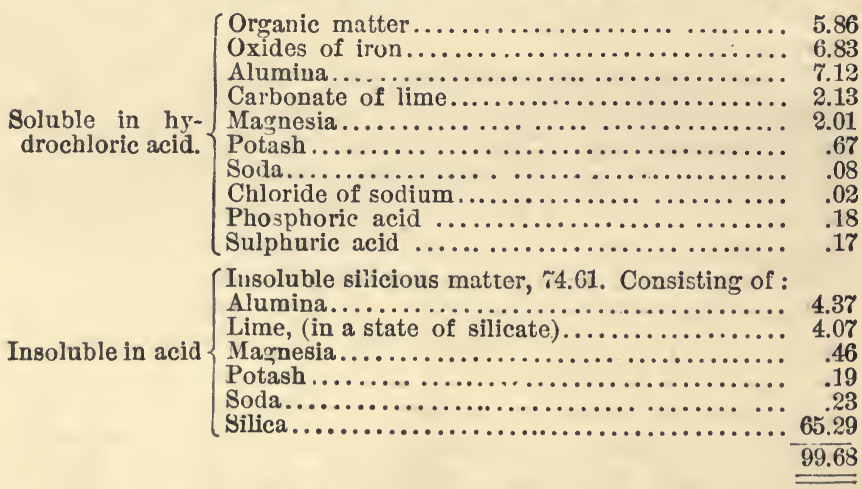

"This soil, it will be seen, contained, in appreciable quantities, not only potash and phosphoric acid, but all the elements of fertility which enter into the composition of good arable land. It may be briefly described as a stiff clay soil, containing a sufficiency of lime, potash, and phosphoric acid, to meet all the requirements of the clover-crop. Originally, rather unproductive, it has been much improved by deep culture; by being smashed up into rough clods, early in autumn, and by being exposed in this state to the crumbling effects of the air, it now yields good corn and forage crops. 
"In separate portions of the three layers of soil, the proportions of nitrogen and phosphoric acid contained in each layer of six inches, were determined and found to be as follows:

Soil dried at $212 \mathrm{deg}$. Fahr. 1ot sic iu six $3 a$ six inches. incties. inches.

Percentage of phosphoric acid.............. . .24y $\quad .144 \quad .172$

Nicrogen................................. $1.6 \%$. $1.692 \quad .064$

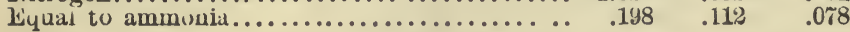

"In the upper six inches, as will be seen, the percentage of both phosphoric acid and nitrogen, was larger tian in the two following layers, while the proportion of nitrogen in the six inches of surface soil, was much larger than in the next six inches; and in the third section, containiug no visible particles of root-fibres, only very little nitrogen occurred.

"In their natural statc, the three layers of soil contained:

1 st six $2 d$ six $3 d$ six inches. inches. inches.

Moisture............................17.16 18.24 16.62

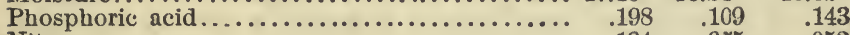

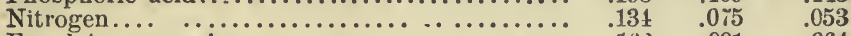

Equal to ammonia........................ .10.3 .091 .064

Weight of one foot square of soil............. $\quad 60 \quad 61 \quad 63$

"Calculated per acre, the absolute weight of one acre of this land, six inches deep, wcighs:

Lbs.

1st six inches.................................. 2,613,600

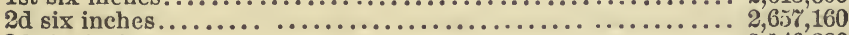

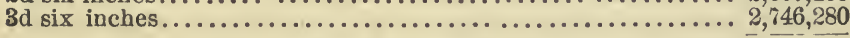

"No great error, thcrefore, will be made, if we assume in the subsequent calculations, that six inches of this soil weighs two and onc-half millions of pounds per acre.

"An acre of land, according to the preceling determinations, contains :

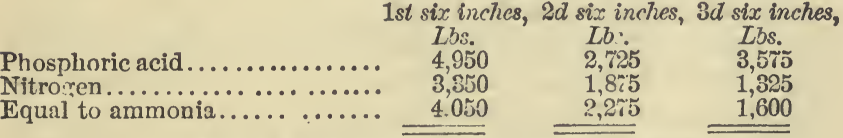

"The proportion of phosphoric arid in six inches of surface soil, it will be seen, amounted to about two-tenths per cent; a proportion of the whole soil, so small that it may appear insufficient for the production of a good corn-crop. However, when calculated to the acre, we find that six inches of surface soil in an acre of land, actually contain over two tons of phosphoric acid. An average crop of wheat, assumed to be $25^{\circ}$ bushels of grain, at $60 \mathrm{lbs}$. per 
bus'del, and 3,000 lbs. of straw, removes from the land on which it is grown, $20 \mathrm{lbs}$. of phosphoric acid. The clover-soil analyzed by me, consequently contains. an amount of phosphoric acid in a depti of ouly six inches, which is equal to that present in $247 \frac{1}{2}$ average crops of wheat; or supposing that, by good cultivation and in favorable suasons, the average yield of wheat could be doubled, and 50 bushels of grain, at $60 \mathrm{lbs}$. a bushel, and 6,000 lbs. of straw could be raised, 124 of such heavy wheat-crops would con- 1 tain no more phosphoric acid than aciually occurred in six inches of this clover-soil per acre.

"The mere presence of such an amount of phosphoric acid in a soil, however, by no mcans proves its sufficiency for the production of so many crops of wheat; for, in the first place, it can not be shown that the whole of the phosphoric acid found by analysis, occurs in the soil in a readily available combination; and, in the second place, it is quite certain that the root fibres of the wheatplant can not reach and pick up, so to speak, every particle of phosphoric acid, even supposing it to occur in the soil in a form most conducive to 'ready assimilation by the plant.'

"The calculation is not given in proof of a conclusion which would be manifestly absurd, but simply as an illustration of the enormous quantity in an acre of soil six inches decp, of a constituent forming the smaller proportions of the whole weight of an acre of soil of that limited dcpth. It shows the existence of a practically unlimited amount of the most important mineral constituents of plants, and clearly points out the propriety of rendering available to plants, the natural resources of the soil in plantfood; to draw, in fact, up the mineral wealth of the soil, by thoroughly working the land, and not leaving it unutilized as so much dead capital."

"Good," said the Deacon, "that is the right doctrine."

"The roots," continues Dr. Vœlcker, "from one square foot of soil were cleaned as much as possible, dried cumpletely at $212^{\circ}$, and in that state wcighed 240 grains. An acre corsequently contained $1,493 \frac{1}{2} \mathrm{lbs}$. of dried clover-roots.

"The clover-roots contained, dried at $212^{\circ} \mathrm{Fahr}$,

Organic matter*.................................... 81.33

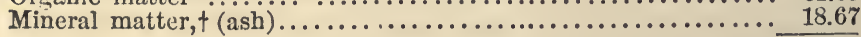

100.00

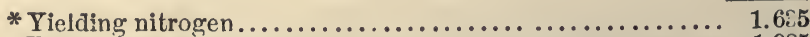

Equal to ammonia........................................ 1.985

+Including insoluble silicious matter, (clay and sand)....... 11.67 
"Acenrdingly the clover-roots in an acre of land furnished 241 lbs. of nitrogen. We have thus:

Lbs. of

ritrogen.

In the six inches of surface soil...................... 3,350

In large clover-roots................................ $24 \frac{1}{\frac{1}{8}}$

In second six inches of soil.................................... 1,875

Total amount of nitrogen in oue acre of soil 12 inches deep.... $5,249 \frac{2}{8}$

Equal to ammonia............................... $6,37 \mathbf{i}^{\frac{1}{2}}$

Or in round numbers, two tons six cwt. of nitrogen per acre; an enormous quantity, which must have a powerful influence in encouraging the luxuriant development of the succeeding wheatcrop, although only a fraction of the total amount of nitrogen in the clover remains may become sufficiently decomposed in time to be available to the young wheat-plants.

CLOVER-SOIL FROM PART OF 11-ACRE FIELD OF BURCOTT LODGE FARM, LEIGHTON BUZZARD, ONCE MOWN FOR HAY, AND LEFT AFTERWARDS FOR SEED.

"Produce $2 \frac{1}{2}$ tons of clover-hay, and 3 cwt. of seed per acre.

"This soil was obtained within a distance of five yards from the part of the field where the soil was dug up after the two cuttings of hay. After the seed there was some difficulty in finding a square foot containing the same number of large clover-roots, as that on the field twice mown; however, at last, in the beginning of November, a square foot containing exactly 18 strong roots, was found and dug up to a depth of 18 inches. The soil dug after the seed was much drier than that dug after the two cuttings of hay :

The upper six inches deep, one foot square, weighed......... 55 lbs. The next " The third "

"After drying by exposure to hot air, the threc layers of soil weighed :

The upper six inches, one foot square................ 49 lbs. The next The third

"Equal portions of the dried soil from each six-inch section were mixed together and reduced to a fine powder. An average sample thus prepared, on analysis, was found to have the following composition: 
COMPOSITION OF CLOVER-SOIL ONCE MOWN FOR HAY, AND AFTERWARDS LEFT FOR SEED. DRIED A'T $212^{\circ}$ FAHR.

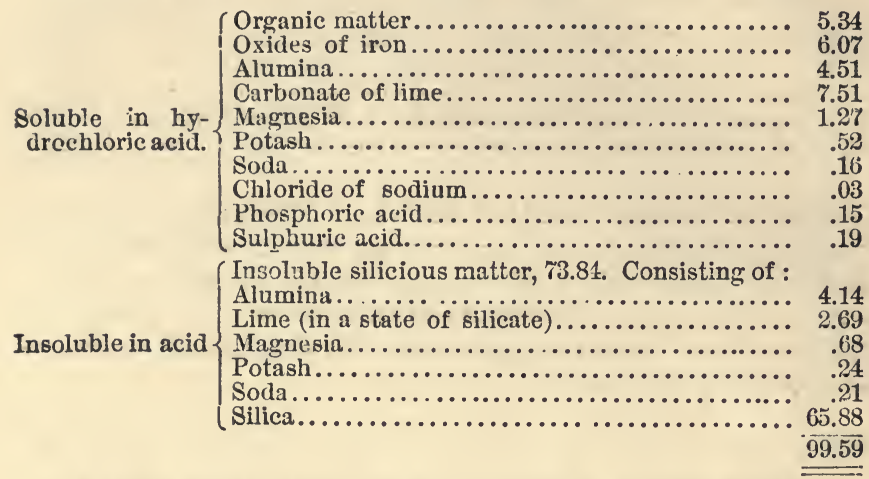

"The soil, it will be seen, in general character, resembles the preceding sample; it contains a good deal of potash and phosphoric acid, and may be presumed to be well suited to the growth of clover. It contains more carbonate of lime, and is somewhat lighter than the sample from the part of the field twice mown for hay, and may be termed heavy calcareous clay.

"An acre of this land, 18 inches deep, weighed, when very nearly dry:

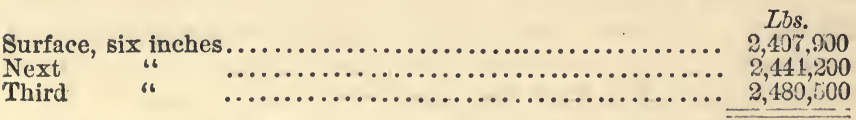

"Or in round numbers, every six inches of soil weimined per acre $2 \frac{1}{2}$ millions of pounds, which agrees tolerably well with the actual weight per acre of the prececing soil.

"The amount of phosphoric acid and nitrogen in each six-inch layer was determined separately as before, when the following results were obtained:

\section{IN DRIED SOIL.}

First Second Third six inches. six inches. six inches.

\begin{tabular}{|c|c|c|}
\hline & & \\
\hline & .199 & .160 \\
\hline Equal to ammonia.. & .229 & .162 \\
\hline
\end{tabular}

"An acre, according to these determinations, contains in the thrce senarate sections: 
First Second Thir d six inches. six inches. six inches.

Phosphoric acid .................. 3,975

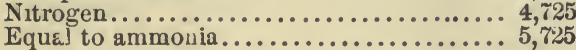

lbs.

$l b s$.

4,150

3,500

$3,350 \quad 2, \div 25$

$4,056 \quad 2,700$

"Here, again, as might naturally be expected, the proportion of nitrogen is largest in the surface, where all the decaying leaves dropped during the growth of the clover for seed are found, and wherein root-fibres are more abundant than in the lower strata. The first six inches of soil, it will be seen, contained in round numbers, $2 \frac{1}{2}$ tons of nitrogen per acre, that is, considerably more than was found in the same section of the soil where the clover was mown twice for hay; showing plainly, that during the ripening of the clover seed, the surface is much enriched by the n.trogenous matter in the dropping leaves of the clover-plant.

"Clover-roots.-The roots from one square foot of this soil, freed as much as possible from adhering soil, were dried at $212^{\circ}$, and when weighed and reckuced to a fine powder, gave, on analysis, the following results :

Oganic matter*................................ 64.76

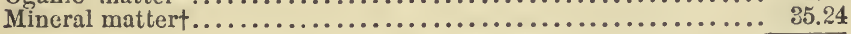

* Containing nitrogen............................

Equal to ammonia................................... 2.066

tIncluding clay and sand (insoluble silicious matter)........ 26.04

"A square foot of this soil produced 582 grains of dried cloverroots, consequently an acre yielded $3,622 \mathrm{lbs}$. of rosts, or more than twice the weight of roots obtained from the soil of the same fiel 1 where the clover was twice mown for hay.

"In round numbers, the $3,622 \mathrm{lbs}$. of clover-roots from the land mown once, and afterwards left for seed, contained $51 \frac{1}{2}$ lbs. of nitrogen.

"The roots from the soil after clover-seed, it will be noticed, were not so clean as the preceding sample, nevertheless, they yielded more nitrogen. In 64.76 of orgaric matter, we have here 1.702 of nitrogen, whereas, in the case of the roots from the part of the field where the clover was twice mown for hay, we have in 81.33 parts, that is, much more organic matter, and 1.635 , or rather less of nitrogen. It is evident, therefore, that the organic matter in the soil after clover-sced, occurs in a more advanced stage of decomposition, than found in the clover-roots from the part of the field twice mown. In the manure, in which the decay of such and similar organic remains proceeds, much of the non-nitrogeno"s, or carbonaceous matters, of which these remains chiefly, 
though not entirely, consist, is transformed into gaseous carbonic acid, and what remains behind, becnmes richer in nitrogen and mineral matters. A parallel case, showing the dissipation of carbonaceous matter, and the increase in the percentage of nitrogen and mineral matter in what is left behind, is prescnted to us in fresh and rotten dung; in long or fresh dung, the percentage of organic matter, consisting chiefly of very imperfertly decomposed straw, being larger, and that of nitrogen and mineral matter smaller, than in well-rotted dung.

"The roots from the field after clover-seed, it will be borne in mind, were dug up in November, whilst those obtained from the land twice mown, were dug up in September; the former, therefore, may be expected to be in a more advanced state of decay than the latter, and richer in nitrogen.

"In an acre of soil, after clover-seed, we have:

Nitrogen in first six icches of soil ....................... $\begin{aligned} & \text { Lbs. } \\ & 4,725\end{aligned}$

Nitrogen in roots..................................................

Nitrogen in second six inches of soil.......................... 3,350

Total amount of nitrogen, per acre, in twelve inches of soil...

"Equal to ammonia, 9,867 lbs. : or, in round numbers, 3 tons and $12 \frac{1}{2} \mathrm{cwts}$. of nitrogen per acrs; equal to 4 tons $8 \mathrm{cwts}$. of ammonia.

"This is a very much larger amount of nitrogen than occurred in the other soil, and shows plainly that the total amount of nitrogen accumulates especially in the surface-soil, when clover is grown for seed; thus explaining intelligibly, as it appears to me, why wheat, as stated by many practical men, succeeds better on land where clover is grown for seed, than where it is mown for hay.

"All the three layers of the soil, after clover-seed, are richer in nitrogen than the same sections of the soil where the clover was twice mown, as will be seen by the following comparative statement of results :

\begin{tabular}{|c|c|c|c|c|c|c|}
\hline & \multicolumn{3}{|c|}{$\begin{array}{l}\text { I. } \\
\text { Cloven-SOIL TWICE } \\
\text { MOW .: }\end{array}$} & \multicolumn{3}{|c|}{$\begin{array}{c}\text { П. } \\
\text { CLOVER-SOIL ONCE MOWX } \\
\text { AND THEN LEFT FOR BEED. }\end{array}$} \\
\hline & $\begin{array}{l}\text { Tpper } \\
\text { 6i.iches. }\end{array}$ & $\begin{array}{c}\text { Sccond } \\
6 \text { inches. }\end{array}$ & 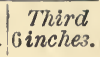 & $\begin{array}{l}\text { Upper } \\
6 \text { inches. }\end{array}$ & $\begin{array}{l}\text { Next } \\
6 \text { inches. }\end{array}$ & $\begin{array}{c}\text { Lowest } \\
\text { 'j inclies. }\end{array}$ \\
\hline $\begin{array}{l}\text { Percentage of nitrogen in } \\
\text { dried soil................ }\end{array}$ & .168 & .092 & .034 & .189 & .131 & .089 \\
\hline Equal to ammonia ......... & .198 & .112 & .078 & .229 & .182 & .108 \\
\hline
\end{tabular}

"This difference in the amount of accumulated nitrogen in clore:-land, appears still more strikingly on comparing the tote! 
amounts of nitrogen per acre in the different sections of the two portions of the 11-acre field.

\section{PERCENTAGE OF NITROGEN PER ACRE.}

First Second Third six inches, six inches, six inches.

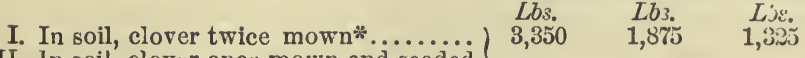

II. In soil, clover once mown and seeded

afterwardst................... 4,725

Equal to ammonia :

* I. Clover twice mown............ 4,053

†II. Clover seeded............... 5,725

$\frac{3,250}{2,2 \% 5} \begin{aligned} & \frac{2,225}{1,600} \\ & 4,050\end{aligned}$

I. Nitrots

I. Nitrogen in roots of clover twice mown............. $24 \frac{1}{4}$

II. Nitrogen in clover, once mown, and grown for seed after- $\}$

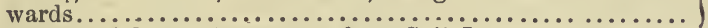

II. Weight of dry roots per acre from Soil II .......... 1,493

Total amount of nitrogen in 1 acre, 12 inches deep of Soil I*. $5,242 \frac{2}{2}$

Total amount of nitrogen in 1 acre, 12 inches deep of Soil II $\nmid$. $\} 8,129 \frac{1}{8}$

Excess of nitrogen in an acre of soil 12 inches deep, calculated

as ammonia in part of field, mown once and then seeded....

* Equal to ammonia.........................

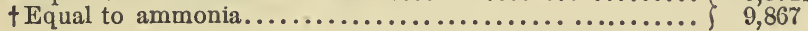

"It will be seen that not only was the amount of large cloverroots greater in the part where clover.was grown for seed, but that likewise the different layers of soil were in every instance richer in nitrogen after clover-seed, than after clover mown twice for hay.

"Reasons are given in the beginning of this paper which it is hoped will have convinced the reader, that the fertility of land is not so much measured by the amount of ash constituents of plants which it contains, as by the amount of nitrogen, which, tog:ther with an excess of such ash constituents, it contains in an available form. It has been shown likewise, that the removal from the soil of a large amount of mineral matter in a good clover-crop, in conformity with many direct field experiments, is not likely in any degree to affect the wheat-crop, and that the yield of wheat on soils under ordinary cultivation, according to the experience of many farmers, and the direct and numerous experiments of Messrs. Lawes and Gilbert, rises or falls, other circumstances being equal, with the supply of available nitrngenous food which is given to the wheat. This being the case, we can not doubt that the benefits arising from the growth of clover to the succeeding wheat, are mainly due to the fret that an immense amount of nitrogenous food accumulates in the soil during the growth of clover. 
"This accumulation of nitrogenous plant-food, specially useful to cereal crops, is, as shown in the preceding experiments, much greater when clover is grown for seed, than when it is made into hay. This affords an intelligible explanation of a fact long observed by good practical men, although denicd by other: who decline to accept their experience as resting upon trustworthy evidence, because, as they say, land cannot become more fertile when a crop is grown upon it for seed, which is carried off, than when that crop is cut down and the produce consumed on the land. The chemical points brought forward in the course of this inquiry, show plainly that mere speculation as to what can take place in a soil, and what not, do not much advance the true theory of certain agricultural practices. It is only by carefully investigating subjects like the one under consideration, that positive proofs are given, showing the correctness of intelligent observers in the fields. Many years ago, I made a great many experiments relative to the chemistry of farm-yard manure, and then showed, amongst other particulars, that manure, spread at once on the land, need not there and then be plowed in, inasmuch as neither a broiling sun, nor a sweeping and drying wind will cause the slightest loss of ammonia; and that, therefore, the old-fashioned farmer who carts his manure on the land as soon as he can, and spreads it at once, but who plows it in at his convenience, acts in perfect accordance with correct chemical principles involved in the management of farm-yard manure. On the present occasion, my main object has been to slow, not merely by reasoning on the subject, but by actual experiments, that the larger the amounts of nitrogen, potash, soda, lime, phosphoric acid, etc., which are removed from the land in a clorer-crop, the better it is, nevertheless, made thereby for producing in the succeeding year an abundant crop of wheat, other circumstances being favorable to its growth.

"Indeed, no kind of manure can be compared in point of efficacy for wheat, to the manuring which the land gets in a really good crop of clover. The farmer who wishes to derive the full benefit from his clover-lay, should plow it up for wheat as soon as possible in the autumn, and leave it in a rough state as long as is admissible, in order that the air may find free access into the land, and the organic remains left in so much abundance in a good crop of clover be changed into plant-food ; more especially, in other words, in order that the crude nitrogenous organic matter in the cloverroots and decaying leaves, may have time to become transformed into ammoniacal compounds, and these, in the course of time, into nitrates, which I am strongly inclined to think is the form in which 
nitrogen is assimilated, par excellence by cereal crops, and in which, at all events, it is more efficacious than in any other state of combination wherein it may be used as a fertilizer.

"When the clover-lay is plowed up early, the decay of the clover is sufficiently advanced by the time the young wheat-plant stands in need of readily available nitrogenous food, and this being uniformly distributed through the whole of the cultivated soil, is ready to benefit every single plant. This equal and abundant distribution of food, peculiarly valuable to cereals, is a great advantage, and speaks strongly in favor of clover as a preparatory crop for wheat.

"Nitrate of soda, an excellent spring top-dressing for wheat and cereals in general, in some seasons fails to produce as good an effect as in ot'sers. In very dry springs, the rainfall is not sufficient to wash it properly into the soil and to distribute it equally, and in very wet seasons it is apt to be washed either into the drains or into a stratum of the soil not accessible to the roots of the young wheat. As, therefore, the character of the approaching season can not usually be predicted, the application of nitrate of soda to whext is always attended with more or less uncertainty.

"The case is different, when a good crop of clover-hay has been obtained from the land on which wheat is intended to be grown afterwards. An enormous quantity of nitrogenous organic matter, as we have seen, is left in the land after the removal of the clovercrop; and these remains gradually decay and furnish ammonia, which at first and during the colder months of the year, is retained by the well known absorbing properties which all good wheatsoils possess. In spring, when warmer weather sets in, and the wheat begins to make a push, these ammonia compounds in the soil are by degrees oxidized into nitrates; and as this change into food peculiarly favorable to young cereal plants, proceeds slowly but steadily, we have in the soil itself, after clover, a source from which nitrates are continuously produced; so that it does not much affect the final yield of wheat, whether heavy rains remove some or all of the nitrate present in the soil. The clover remains thus afford a more continuous source from which nitrates are produced, and greater certainty for a good crop of wheat than when recourse is had to nitrogenous top-dressings in the spring.

\section{SUMMARY.}

"The following are some of the chief points of interest which I have endeavored fully to develope in the preceding pages:

"1. A good crop of clover removes from the soil more potash, 
phosphoric acid, lime, and other mineral matters, which enter into the composition of the ashes of our cultivated crops, than any other crop usually grown in this country.

"2. Tuere is fully thre: times as much nitrogen in a crop of clover as in the average produce of the grain and straw of wheat per acre.

"3. Notwithstanding the large amount of nitrogenous matter and of ash-constituents of plants, in the produce of an acre, clover is an excellent preparatory crop for wheat.

“4. During the growth of clover, a large amount of nitrogenous matter accumulates in the soil.

" 5 . This accumulation, which is greatest in the surface soil, is due to decrying leaves dropped during the growth of clover, and to an abundance of roots, containing, when dry, from one and three-fourths to two per cent of nitrogen.

" 6 . The clover-roots are stronger and more numerous, and more leaves fall on the ground when clover is grown for seed, than when it is mown for hay; in consequence, more nitrogen is left after clover-seed, than after hay, which accounts for wheat yielding a better crop after clover-seed than after hay.

“ 7 . The development of roots being checked, when the produce, in a green condition, is fed off by sheep, in all probability, leaves still less nitrogenous matter in the soil than when clover is allowed to get riper and is mown for hay ; thus, no doubt, accounting for the observation made by practical men, that, notwithstanding the return of the produce in the sheep excrements, wheat is generally stronger, and yields better, after clover mown for hay, than when the clover is fed off green by sheep.

" 8 . The nitrogenous matters in the clover remains, on their gradual decay, are finally transformed into nitrates, thus affording a continuous source of food on which cereal crops specially delight to grow.

"9. There is strong presumptive evidence that the nitrogen which exists in the air, in shape of ammonia and nitric acid, and descends, in these combinations, with the rain which falls on the ground, satisfies, under ordinary circumstances, the requirements of the clover-crop. This crop causes a large accumulation of nitrogenous matters, which are gradually changed in the soil into nitrates. The atmosphere thus furnishes nitrogenous food to the succeeding wheat indirectly, and, so to say, gratis.

"10. Clover not only provides abundance of nitrogenous food, but delivers this food in a readily available form (as nitrates), more gradually and continuously, and, consequently, with more cer- 
tainty of a good result, than such food can be applied to the land in the shape of nitrogenous spring top-dressings."

"Thank you Charley," said the Doctor, "that is the most remarkable paper I ever listened to. I do not quite know what to think of it. We shall have to examine it carefully."

"The first three propositions in the Summary," said I, "are unquestionably tiue. Proposition No. 4, is equally true, but we must be careful what meaning we attach torihe word 'accumulate.' The idea is, that clover gathers up the nitrogen in the soil. It does not increase the absolute amount of nitrogen. It accumulates it-brings it together."

"Proposition No. 5, will not be disputed; and I think we may accept No. 6, also, though we can not be sure that allowing clover to go to seed, had anything to do with the increased quantity of clover-roots."

"Proposition No. 7, may or may not be true. We have no proof, only a 'probability; ' and the same may be said in regard to propositions Nos. 8,9 , and 10."

The Deacon seemed uneasy. He did not like these remarks. He had got the impression, while Charley was reading, that much more was proved than Dr. Vœlckcr claims in his Summary.

"I thought," said he, "that on the part of the field where the clover was allowed to go to seed, Dr. Vœlcker found a great increase in the amount of nitrogen."

"That scems to be the general impression," said the Doctor, " but in point of fact, we have no proof that the growth of clover, either for hay or for seed, had anything to do with the quantity of nitrogen and phosphoric aciả found in the soil. The facts given by Dr. Vœlcker, are exceedingly interesting. Let us look at them:"

"A field of 11 acres was sown to winter-wheat, and seeded down in the spring, with $12 \mathrm{lbs}$. per acre of clover. The wheat yielded 40 bushels per acre. The next year, on the 25th of June, the clover was mown for hay. We are told that 'the best part of the ficld yielded three tons $(6,720 \mathrm{lbs}$.) of clover-hay per acre; the whole field averaging $2 \frac{1}{2}$ tons $(5,600$ lbs.) per acre.'"

"We are not informed how much land there was of the 'best part,' but assuming that it was half the field, the poorcr part must have yielded only $4,480 \mathrm{lbs}$. of hay per acre, or only twothirds as much as the other. This shows that there was considerable difference in the quality or condition of the land.

"After the ficld was mown for hay,it was divided into two parts: one part was mown again for hay, August 21st, and yielded about 
$30 \mathrm{cwt}$. (3,360 lbs.) of hay per acre; the other half was allowed to grow six or seven weeks longer, and was then (October 8th), cut for seed. The yield was a little over $5 \frac{1}{2}$ bushels of seed per acre. Whether the clover allowed to grow for seed, was on the richer or poorer half of the field, we are not informed.

" Dr. Vœlcker then analyzed tile soil. That from the part of the fisld mown twice for hay, contained per acre:

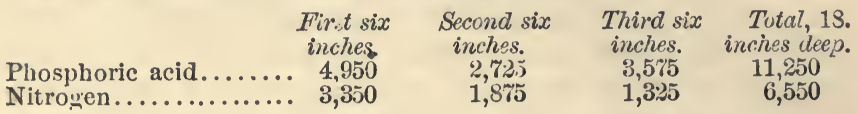

"The soil from the part monon once for hay, and then for seed, contained per acre:

\begin{tabular}{|c|c|c|c|c|}
\hline & $\begin{array}{c}\text { First s:x } \\
\text { inches. } \\
\quad 3,975 \\
. \quad 4,725\end{array}$ & $\begin{array}{c}\text { Second six } \\
\text { inches. } \\
4,150 \\
3,350\end{array}$ & $\begin{array}{c}\text { Third six } \\
\text { inches. } \\
3,500 \\
2, \div 20\end{array}$ & $\begin{array}{c}\text { Total, } 18 \\
\text { inches deep. } \\
11,62.5 \\
10,300\end{array}$ \\
\hline
\end{tabular}

"Dr. Vœlcker also ascertained the amount and composition of the clover-roots growing in the soil on the two parts of the field. On the part mozon twice for hay, the roots contained per acre $24 \frac{1}{2} \mathrm{lbs}$. of nitrogen. On the part mown once for hay, and then for seed, the roots contained $51 \frac{1}{2} \mathrm{lbs}$. of nitrogen per acre."

"Now," said the Doctor, "these facts are very interesting, but there is no sort of evidence tending to show that the clover has anything to do with increasing or decreasing the quantity of nitrogen or phosphoric acid found in the soil."

"There was more clover-roots per acre, where the clover was allowed to go to seed. But that may be because the soil happened to be richer on this part of the field. There was, in the first six inches of the soil, 3,350 lbs. of nitrogen per acre, on one-half of the field, and $4,725 \mathrm{lbs}$. on the other half; and it is not at all surprising that on the latter half there should be a greater grow th of clover and clover-roots. To supposo that during the six or seven weeks while the clover was maturing its seed, the clover-plants could accumulate $1,375 \mathrm{lbs}$. of nitrogen, is absurd."

"But Dr. Vœlcker," said the Deacon, "states, and states truly, that "more leaves fall on the ground when clover is grown for seed, than when it is mown for hay ; and, consequently, more nitrogen is left after clover-seed than after hay, which accounts for wheat yielding a better crop after clover-seed than after hay."

"This is all true," said the Doctor, "but we can not accept Dr. Vœlcker's analyses as proving it. To account in this way for the $1,375 \mathrm{lbs}$. of nitrogen, we should have to suppose that the cloverplants, in going to szed, s'ed one hundred tons of dry clover-leaves 
per acre! The truth of the matter seems to be, that the part of the field on which the clover was allowed to go to seed, was naturally much richer than the other part, and consequently produced a greater growth of clover and clover-roots."

We can not find anything in these experiments tending to show that we can make land rich by growing clover and selling the crop. The analyses of the soil show that in the first eighteen inches of the surface-soil, there was $6,550 \mathrm{lbs}$. of nitrogen per acre, on one part of the field, and 10,300 lbs. on the other part. The clover did not create this nitrogen, or bring it from the atmosphere. The wheat with which the clover was seeded down, yielded 40 bushels per acre. If the field had been sown to wheat again, it probably would not have yielded over 25 bushels per acre-and that for want of available nitrogen. And yet the clover got nitrogen enough for over four tons of clover-hay; or as much nitrogen as a crop of wheat of 125 bushels per acre, and $7 \frac{1}{2}$ tons of straw would remove from the land.

Now what does this prove? There was, in 18 inches of the soil on the poorest part of the field, 6,550 lbs. of nitrogen per acre. A crop of wheat of 50 bushels per acre, and twice that weight of straw, would require about $92 \mathrm{lbs}$. of nitrogen. But the wheat can not get this amount from the soil, while the clover can get double the quantity. And the only explantion I can give, is, that the cloverroots can take up nitrogen from a weaker solution in the soil than wheat-roots can.

"These experiments of Dr. Vœlcker," sa:d I, " give me great encouragement. Here is a soil, 'originally rather unproductive, but much improved by deep culture; by being smashed up into rough clods early in autumn, and by being exposed in this state to the crumbling effects of the air.' It now produces 40 bushels of wheat per acre, and part of the field yielded three tons of clover-hay, per acre, the first cutting, and $5 \frac{1}{2}$ bushels of clover-seed afterwards-and that in a very unfavorable season for clover-seed."

You will find that the farmers in England do not expect to make their land rich, by growing clover and selling the produce. After they have got their land rich, by good cultivation, and the libcral use of animal and artificial manures, they may expect a good crop of wheat from the roots of the clover. But they take good care to feed out the clover itself on the farm, in connection with turnips and oil-cake, and thus make rich manure. 
And so it is in this country. Much as we hear about the value of clover for manure, even those who extol it the highest do not depend upon it alone for bringing up and maintaining the fertility of their farms. The men who raise the largast crops and make the most money by farming, do not sell clover-hay. They do not look to the roots of the clover for making a poor soil rich. They are, to a man, good cultivators. They work their land thoroughly and kill the weeds. They keep good stock, and feed liberally, and make good manure. They use lime, ashes, and plaster, and are glad to draw manure from the cities and villages, and muck from the swamps, and not a few of them buy artificial manures. In the hands of such farmers, clover is a grand renovating crop. It gathers up the fertility of the soil, and the roots alone of a large crop, often furnish food enough for a good crop of corn, potatoes, or wheat. But if your land was not in good heart to start with, you would not get the large crop of clover; and if you depend on the clover-roots alone, the time is not far distant when your large crops of clover will be things of the past.

\section{AMOUNT OF ROOTS LEFT IN THE SOIL BY DIFFERENT CROPS.}

We have seen that Dr. Vœlcker made four separate determinations of the amount of clover-roots left in the soil to the depth of six inches. It may be well to tabulate the figures obtained:

CLOVER-ROOTS, IN SIX INCHES OF SOIL, PER ACRE.

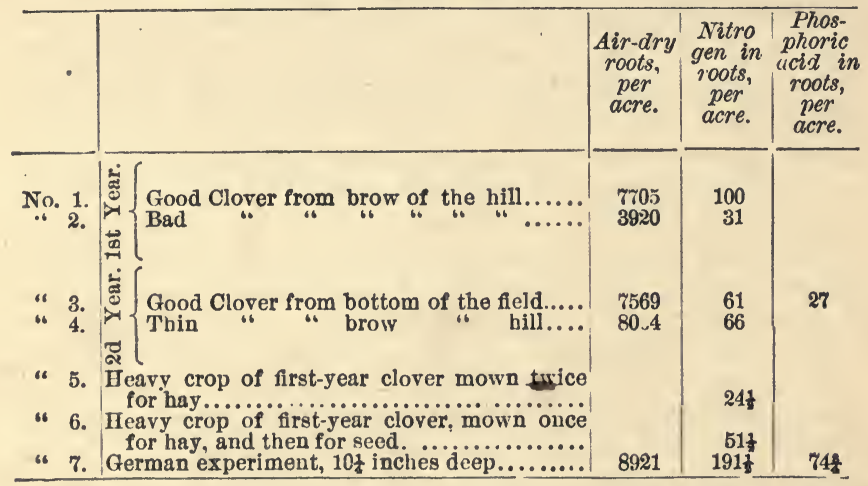

I have not much confidence in experiments of this kind. It is so easy to make a little mistake; and when you take only a square foot of land, as was the case with Nos. 5 and 6, the mistake is multiplied by 43,560 . Still, I give the table for what it is worth. 
Nos. 1 and 2 are from a one-year-old crop of clover. The field was a calcareous clay soil. It was somewhat hilly; or, perhaps, what we here, in Western New York, should call "rolling land." The soil on the brow of the hill, "was very stony at a depth of four inches, so that it could only with difficulty be excavated to " six inches, when the bare limestone-rock made its appearance."

A square yard was selected on this shallow soil, where the clover was good; and the roots, air-dried, weighed at the rate of $7,705 \mathrm{lbs}$. per acre, and contained 100 lbs. of nitrogen. A few yards distance, on the same soil, where the clover was bad, the acre of roots contained only $31 \mathrm{lbs}$. of nitrogen per acre.

So far, so good. We can well understand this result. Chemistry has little to do with it. There was a good stand of clover on the one plot, and a poor one on the other. And the conclusion to be drawn from it is, that it is well worth our while to try to secure a good catch of clover.

"But, suppose," said the Doctor, "No. 2 had happened to have been pastured by sheep, and No. 1 allowed to go to seed, what magic there would have been in the above figures!"

Nos. 3 and 4 are from the same field, the second year. No. 4 is from a square yard of thin clover on the brow of the hill, and No. 3, from the richer, deeper land towards the bottom of the hill.

There is very little difference between them. The roots of thin clover from the brow of the hill, contain five lbs. more nitrogen per acre, than the roots on the deeper soil.

If we can depend on the figures, we may conclude that on our poor stony "knolls," the clover has larger and longer roots than on the richer parts of the field. We know that ronts will run long distances and great depths in search of food and water.

Nos. 5 and 6 are from a heavy crop of one-year-old clover. No. 5 was mown twice for hay, producing, in the two cuttings, over four tons of hay per acre. No. 6 was in the same field, the only difference being that the clover, instead of being cut the second time for hay, was allowed to stand a few weeks longer to ripen its seed. You will see that the latter has more roots than the formcr.

There are $24 \frac{1}{2} \mathrm{lbs}$. of nitrogen per acre in the one case, and $51 \frac{1}{2}$ lb3. in the other. How far this is due to difference in the condition of the land, or to the clifficulties in the way of getting out all the roots from the square yard, is a matter of conjecture.

Truth to tell, I have very little confidence in any of these figures. It will be observed that I have put at the bottom of the table, the result of an examination made in Germany. In this case, the nitrogen in the roots of an acre of clover, amounted to $191 \frac{1}{2}$ lbs. per 
acre. If we can depend on the figures, we must conclude that there were nearly eight times as much clover-roots per acre in the German field, as in the remarkably heary crop of clover in the English field No. 5.

"Yes," said the Deacon, "but the one was $10 \frac{1}{4}$ inches deep, and the other only six inches deep; and besides, the German experiment includes the "stubble' with the roots."

The Deacon is right; and it will be well to give the complete table, as published in the American Agriculturist:

TABLE SHOWING THE AMOUNT OF ROOTS AND STUBBLE LEFT PER ACRE BY DIFFERENT CROPS, AND THE AMOUNT OF INGREDIENTS WHICH THEY CONTAIN PER ACRE.

\begin{tabular}{|c|c|c|c|}
\hline - & 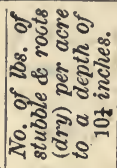 & 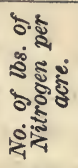 & 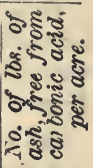 \\
\hline 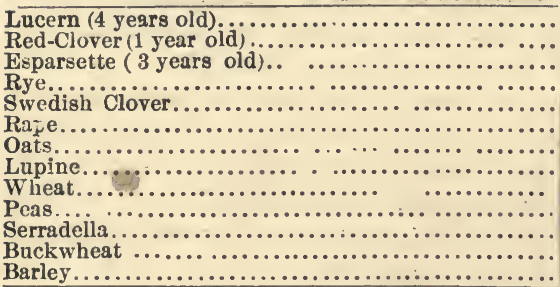 & $\begin{array}{l}9,678.1 \\
8,921.6 \\
5,930.9 \\
5,264.6 \\
5,004.3 \\
4,477 . \\
3,331.9 \\
3,520.9 \\
3,476 . \\
3.223 .5 \\
3.120 .1 \\
2,195.6 \\
1.9914\end{array}$ & $\begin{array}{r}136.4 \\
191.6 \\
123.2 \\
65.3 \\
102.3 \\
56.5 \\
26.6 \\
62.2 \\
28.5 \\
5.5 \\
64.6 \\
47.8 \\
22.8\end{array}$ & $\begin{array}{r}1,201.6 \\
1,919.9 \\
1,023.4 \\
1,747.8 \\
974.6 \\
622.3 \\
1,444.7 \\
550 . \\
1,089.8 \\
670.7 \\
545.6 \\
465.5 \\
391.1\end{array}$ \\
\hline
\end{tabular}

CONTENTS OF THE ASHES, IN POUNDS, PER ACR 3.

\begin{tabular}{|c|c|c|c|c|c|c|}
\hline & క్స్ & 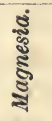 & 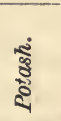 & ర్ & 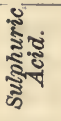 & 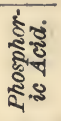 \\
\hline 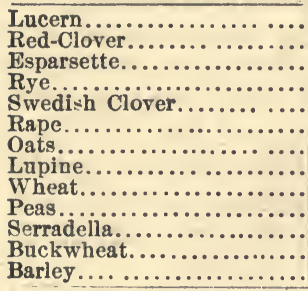 & $\begin{aligned} 197.7 \\
262.9 \\
132.8 \\
73.2 \\
136.1 \\
163.9 \\
85.5 \\
80.5 \\
76.7 \\
71.7 \\
79.8 \\
80 . \\
42.2 \\
\end{aligned}$ & $\begin{array}{r}24.2 \\
48.4 \\
287 \\
14.3 \\
17.6 \\
12.9 \\
11.2 \\
11.2 \\
10.1 \\
11 . \\
13.4 \\
7.2 \\
5.5\end{array}$ & $\begin{array}{l}36.7 \\
58.3 \\
42.6 \\
31.2 \\
2.5 .9 \\
34.7 \\
24.8 \\
16.5 \\
28.4 \\
11.2 \\
8.8 \\
8.8 \\
9.5 \\
\end{array}$ & $\begin{aligned} 26.4 \\
200 \\
13.8 \\
43.3 \\
5.7 \\
20.9 \\
18 . \\
3.5 \\
11 . \\
7 . \\
4.8 \\
4.2 \\
3.5\end{aligned}$ & $\begin{aligned} 18.7 \\
26.1 \\
20.6 \\
11.8 \\
13.2 \\
30.8 \\
8.8 \\
7.8 \\
7.4 \\
9.4 \\
9 . \\
6.6 \\
5.5\end{aligned}$ & $\begin{array}{l}38.5 \\
74.8 \\
29.7 \\
24.4 \\
24.2 \\
31.9 \\
29.9 \\
13.8 \\
11.8 \\
14.3 \\
=8.4 \\
11 . \\
11.2 \\
\end{array}$ \\
\hline
\end{tabular}

It may be presumed, that, while these figures are not absolutely, they are relatively, correct. In other words, we may conclude, that red-clover leaves more nitrogen, phosphoric acid, and potash, in the roots and stubble per acre, than any other of the crops named. 
The gross amount of dry substance in the roots, and the gross amouut of ash per acre, are considerably exaggerated, owing to the evidently large quantity of dirt attached to the roots and stubble. For instance, the gross amount of ash in Lucern is given as 1,201.6 lbs. per acre; while the total amount of lime, magnesia, potash, soda, sulphuric and phosphoric acids, is only $342.2 \mathrm{lbs}$. per acre, leaving $859.4 \mathrm{lbs}$. as sand, clay, iron, etc. Of the $1,919.9 \mathrm{lbs}$. of ash in the acre of clover-roots and stubble, there are 1,429.4 lbs. of sand, clay, etc. But even after deducting this amount of impurities from a gross total of dry matter per acre, we still have $7,492.2$ lbs. of dry roots and stubble per acre, or nearly $3 \frac{1}{4}$ tons of $d r y$ roots per acre. This is a very large quantity. It is as much dry matter as is contained in 13 tons of ordinary farm-yard, or stable-manure. And these $3 \frac{1}{4}$ tors of dry clover-roots contrin $191 \frac{1}{2}$ lbs. of nitrogen, which is as much as is contained in 19 tons of ordinary stable-manure. The clover roots also contain $74_{4}^{8} \mathrm{lbs}$. of phosphoric acid per acre, or as much as is contained in from 500 to $600 \mathrm{lbs}$. of No. 1 rectified Peruvian guano.

"But the phosphoric acid," said the Doctor, "is not soluble in the roots." True, but it was soluble when the roots gathered it up out of the soil.

"These figures," said the Deacon, "hare a very pleasant lozk. Those of us who have nearly one-quarter of our land in clover every year, ought to be making our farms very rich."

"It would seem, at any rate," said I, "that those of us who have gond, clean, well-drained, and well-worked land, that is now producing a good growth of clover, may reasonably expect a fair crop of wheat, barley, oats, corn, or potatoes, when we break it up and plow under all the roots, which are equal to 13 or 19 tons of stablemanure per acre. Whether we can or can not depend on these figures, one thing is clearly proven, both by the chemist and the farmer, that a good clover-sod, on well-worked soil, is a good preparation for corn and potatoes."

\section{MANURES FOR WHEAT.}

Probably nine-tenths of all the wheat grown in Western New York, or the "Genesee country," from the time the land was first cleared until 1870 , was raised without any manure being directly applied to the land for this crop. Tillage and clover were what the farmers depended on. There certainly has been no systematic manuring. The manure made during the winter, was drawn out in the spring, and plowed under for corn. Any manure made during the summer, in the yards, was, by the best farmers, scraped up and 
spread on portions of the land sown, or to be sown, with wheat. Even so good a farmer and wheat-grower as John Johnston. rarely used manure, (except lime, and latterly, a little guano), directly for wheat. Clover and summer-fallowing were for many years the dependence of the Western New York wheat-growers.

"One of the oldest and most experienced millers of Wastern New Yorik," remarked the Doctor, "once told me that "ever since our farmers began to manure their land, the wheat-crop had deteriorated, not only in the yield per acre, but in the quality and quantity of the flour obtained from it.' It seemed a strange remark to make; but when he explained that the farmers had given up summerfallowing and plowing in clover, and now sow spring crops, to be followed by winter wheat with an occasional dressing of poor manure, it is easy to see how it may be true."

"Yes," said I, "it is not the manure that hurts the wheat, but the growth of spring crops and weeds that rob the soil of far more plant-food than the poor, strawy manure can supply. We do not now, really, furnish the wheat-crop as much manure or plant-food as we formerly did when little or no manure was used, and when we depended on summer-fallowing and plowing in clover."

We must either give up the practice of sowing a spring crop, bəfore wheat, or we must make more and richer manure, or we must plow in more clover. The rotation, which many of us now adopt -corn, barley, wheat-is profitable, provided we can make our land rich enough to produce 75 bushels of shelled corn, 50 bushels of barley, and 35 bushels of wheat, per acre, in three years.

This can be done, but we shall either require a number of acres of rich low land, or irrigated meadow, the produce of which will make manure for the upland, or we shall have to purchase oilcake, bran, malt-combs, or refuse beans, to feed out with our straw and clover-hay, or we must purchase artificial manures. Unless this is done, we must summer-fallow more, on the heavier clay soils, sow less oats and barley; or we must, on the lighter soils, raise and plow under more clover, or feed it out on the farm, being careful to save and apply the manure.

"Botter do both," said the Doctor."

"How?" asked the Deacon.

"You had better make all the manure you can," continued the Doctor, " and buy artificial manures besides."

"The Doctor is right," said I, "and in point of fact, our best farmers are doing this very thing. They are making more manure and buying more manure than ever before; or, to state the matter correctly, they are buying artificial manures; and these increase the 
crops, and the extra quantity of straw, corn, and clover, so obtained, enables them to make more manure. They get cheated sometimes in their purchases; but, on the whole, the movement is a good one, and will result in a higher and better system of farming."

I am amused at the interest and enthusiasm manifested by some of our farmers who have used artificial manures for a year or two. They seem to regard me as a sad old fogy, because I am now depending almost entirely ou the manures made on the farm. Years ago, I was laughed at because I used guano and superphosphate. It was only yesterday, that a young farmer, who is the local agent of this neigbborhood, for a manure manufacturer, remarked to me, "You have never used superphosphate. We sowed it on our wheat last year, and could see to the very drill mark how far it went. I would like to tak? your order for a ton. I am sure it would pay."

"We are making manure cheaper than you can sell it to me, "I replied, "and besides, I do not think superphosphate is a good manure for wheat." - "Oh," he exclaimed, " you would not say so if you had ever used it."- "Why, my dear sir," said I, "I made tons of superphosphate, and used large quantities of guano before you were born; and if you will come into the house, I will show you a silver goblet I got for a prize essay on the use of superphosphate of lime, that I wrote more than a quarter of a century ago. I sent to New York for two tons of guano, and published the result of its use on this farm, before you were out of your cradle. And I had a ton or more of superphosphate made for me in 1856, and some before that. I have also used on this farm, many tons of superphosphate and other artificial manures from different.manufacturers, and one year I used 15 tons of bone-dust."

With rearly tact, he turned the tables on me by saying: "Now I can understand why your land is improving. It is because you have used superphosphate and bone-dust. Order a few tons."

By employing agents of this kind, the manufacturers have succeeded in selling the farmers of Western New York thousands of tons of superphosphate. Some farmers think it pays, and some that it does not. We are more likely to hear of the successes than of failures. Still there can be no doubt that superphosphate has, in many instances, proved a valuable and profitable manuie for wheat in Western New York.

From 200 to $300 \mathrm{lbs}$. are used per acre, and the evidence seems to show that it is far better to drill in the manure with the seed than to sow it broadcast. 
economical artificial manures that could be used for wheat. They contain too little nitrogen. Peruvian guano containing nitrogen equal to 10 per cent of ammonia, would be, I think, a much more effective and profitable manure. But before we discuss this question, it will be necessary to study tie results of actual experiments in the use of various fertilizers for wheat.

\section{$=\infty-$ \\ C H A P T E R X X V I I .}

\section{LAWES AND GILBERT'S EXPERIMENTS ON WHEAT.}

I hardly know how to commence an account of the wonderful experiments made at Rothamsted, England, by John Bennett Lawes, Esq., and Dr. Joseph H. Gilbert. Mr. Lawes' first systematic experiment on wheat, commenced in the autumn of 1843 . A field of 14 acres of rather heavy clay soil, resting on chalk, was selected for the purpose. Nineteen plots were accurately measured and staked off. 'The plots ran the long way of the field, and up a slight ascent. On each side of the field, alongside the plots, there was some land not included, the first year, in the experiment proper. This land was either left without manure, or a mixture of the manures used in the experiments was sown on it.

I have heard it said that Mr. Lawes, at this time, was a believer in what was called "Liebig's Mineral Manure Theory." Licbig had said that "The crops on a field, diminish or increase in exact proportion to the diminution or increase of the mineral substances conveyed to it in manure." And enthusiastic gentlemen have been known to tell farmers who were engaged in drawing out farm-yard manure to their land, that they were wasting their strength; all they needed was the mineral elements of the manure. "And you might," they said, "burn your manure, and sow the ashes, and thus save much time and labor. The ashes will do just as much good as the manure itself."

Whether Mr. Lawes did, or did not entertain such an opinion, I do not know. It looks as though the experiments the first year or two, were made with the expectation that mineral manures, or the ashes of plants, were what the wheat needed.

The following table gives the kind and quantities of manures used per acre, and the yield of wheat per acre, as carefully cleaned for market. Also the total weight of grain per acre, and the weight of straw and chaff per acre. 


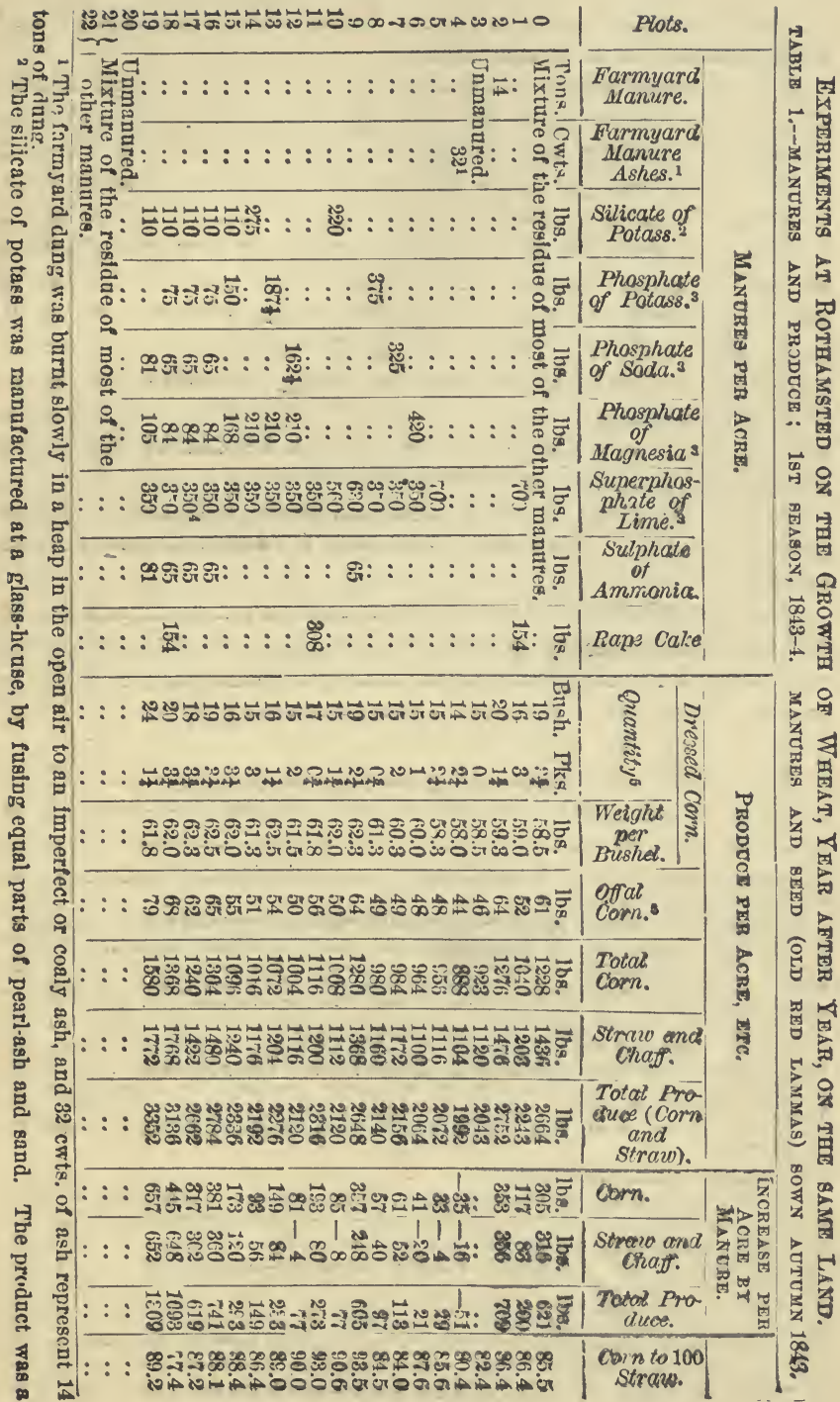


These were the resuits of the harvest of 1844. The first year of tilese since celebrated experiments.

If Mr. Lawes expected that the crops would be in proportion to the minerals supplied in the manure, he must have been greatly disuppoistel. The plot without manure of any kind, gave 15 bushels of wheat per acre; 700 ibs. of superphosphate of lime, made from burnt bones, produced only $33 \mathrm{lbs}$. or about half a bushel more grain per acre, and 4 lbs. less straw than was obtained without manure. $640 \mathrm{lbs}$. of superphosphate, and $65 \mathrm{lbs}$. of commercial sulphate of ammonia (equal to about $14 \mathrm{lbs}$. of ammonia), give a little over $19 \frac{1}{2}$ bushels of dressed wheat jer acre. As compared with the plot having $700 \mathrm{lbs}$. of superphosphate per acre, this $14 \mathrm{lbs}$. of available ammonia per acre, or, say $11 \frac{1}{2} \mathrm{lbs}$. nitrogen, gave an increase of 324 lbs. of grain, and $252 \mathrm{lbs}$. of straw, or a total increase of $576 \mathrm{lbs}$. of grain and straw.

On plot No. 19, $81 \mathrm{lbs}$. of sulphate ammonia, with minerals, produces $24 \frac{1}{4}$ bushels per acre. This yield is clearly due to the ammonia.

The rape-cake contains about 5 per cent of nitrogen, anã is also rich in minerals and cxrónaceous matter. It gives an increase, but not as large in proportion to the nitrogen furnished, as the sulp'sate of ammonia. And the same remarks apply to the 14 tons of farm-yard manure.

We siould have expected a greater increase from such a liberal dressing of barn-yard manure. I think the explanation is this:

transparent glass, slightly deliquescent in the air, which was ground to a powder under edge-stones.

3 The manures termed superphosphate of lime, phosphate of potass, phosphate of soda, and phosphate of magnesia, were made by acting upon bone-ash by means of sulphuric acid in the first instance, and in the case- of the alkali salts and the magnesian one neutralizing the compound thus obtained by means of cheap preparations of the respective bases. For the superpliosphate of lime, the proportions were 5 parts bone-ash, 3 parts water, and 3 parts sulphuric acid of sp. gr. 1.84; and for the phosphates of potass. soda, and magnesia, they were 4 parts bone-ash, water as needed, 3 parts sulphuric acid of sp. gr. 1.84, and equivalent amounts, respectively, of pearl-ash, soda-ash, or a mixture of 1 part medicinal carbonate of magnesia, and 4 parts magnesian limestone. The mixtures, of course, all lost weight considerably by the evolution of water and carbonic acid.

4 Made with unburnt bones.

- In this first season, neither the weight nor the measure of the offal corn was recorded separately; and in former papers, the bushels and pecks of total corn (including offal) have erroneously been given as dresseả corn. To bring the records more in conformity with those relating to the other years. 5 per cent, by weight, has been deducted from the total corn previously stated as dressed corn, and is recorded as offal corn; this being about the probable proportion, judging from the character of the season, the bulk of the crop, and the weight per bushel of the dressed ccrn. Aithough not strictly correct, the statements of dressed corn, as amended in this somewhat arbitrary way, will approximate more nearly to the truth, and be more comparable with those relating to other seasons, than those hitherto recosded. 
The manure had not been piled. It was probably taken out fresh from the yard (this, at any rate, was the case when I was at Rothamsted), and plowed under late in the season. And on this heavy land, manure will lie buried in the soil for months, or, if undisturbed, for years, without decomposition. In other words, while this 14 tons of barn-yard manure, contained at least $150 \mathrm{lbs}$. of nitrogen, and a large quantity of minerals and carbonaceous matter, it did not produce a bushel per acre more than a manure containing less than $12 \mathrm{lbs}$. of nitrogen. And on plot 19, a manure containing less than $15 \mathrm{lbs}$. of available nitrogen, produced nearly 4 bushels per acre more wheat than the barn-yard manure containing at least ten times as much nitrogen.

There can be but one explanation of this fact. The nitrogen in the manure lay dormant in this heavy soil. Had it been a light sandy soil, it would have decomposed more rapidly and produced a better effect.

As we have before stated, John Johnston finds, on his clay-land, a far greater effect from manure spread on the surface, where it decomposes rapidly, than when the manure is plowed under.

The Deacon was looking at the figures in the table, and not pay. ing much attention to our talk. "What could a man be thinking about," he said, " to burn 14 tons of good manure! It was a great waste, and I am glad the ashes did no sort of good."

After the wheat was harvested in 1844 , the land was immediately plowed, harrowed, etc.; and in a few weeks was plowed gain and sown to wheat, the different plots being kept separate, as before.

The following table shows the manures used this second year, and the yield per acre: 


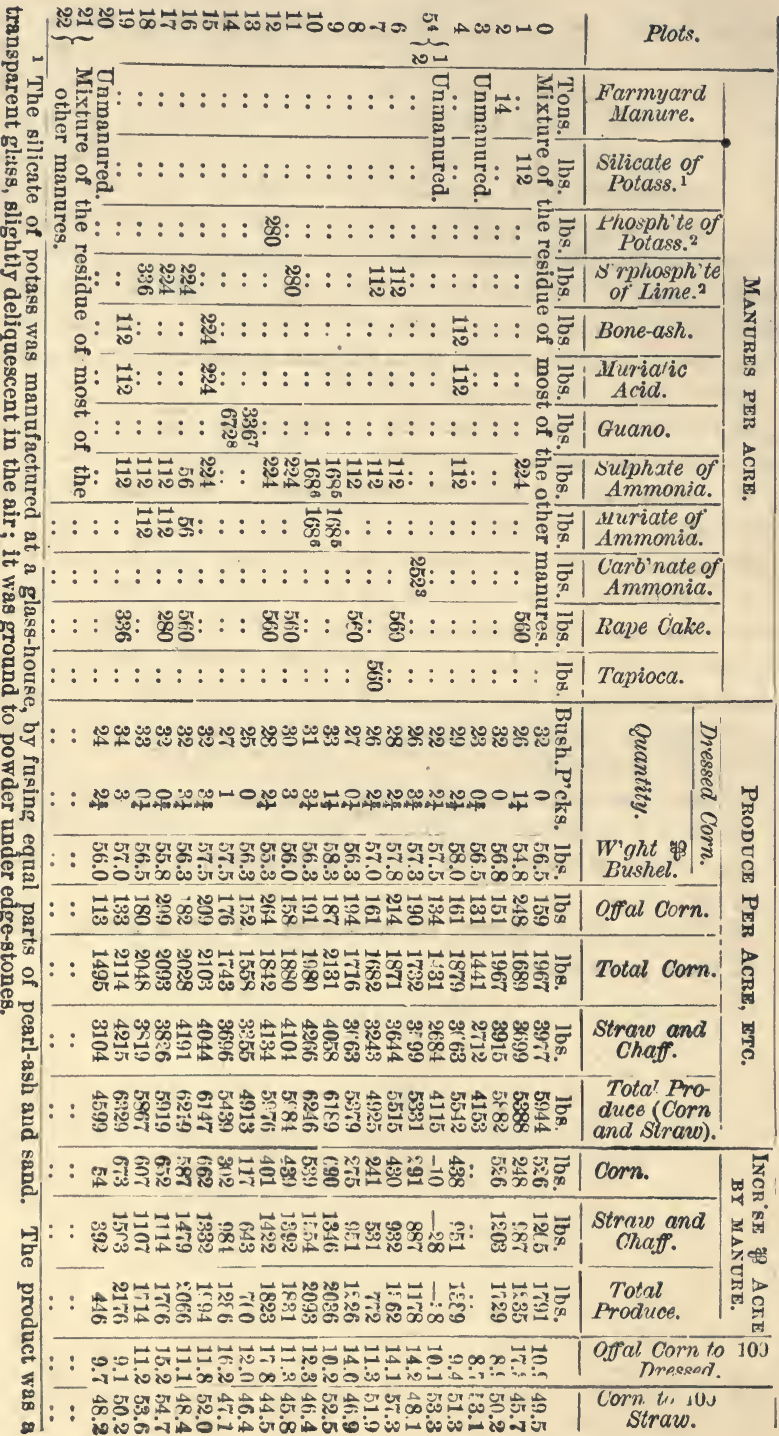


The season of 1845 was more farorable for wheat, than that of 1844 , and the crops on all the plots were better. On plot No. 3, which had no manure last year, or this, the yield is 23 bushels per acre, against 15 bushels last year.

Last year, the 14 tons of barn-yard manure gave an increase of only $5 \frac{1}{4}$ bushels per acre. This year it gives an increase of nearly 9 bushels per acre.

"Do you mean," said the Deacon, "that this plot, No. 2, had 14 tons of manure in 1844, and 14 tons of manure again in 1815 ?"

"Precisely that, Deacon," said 1, " and this same plot has received this amount of manure every year since, up to the present time -for these same experiments are still continued from year to year at Rothansted."

"It is porr farming," said the Deacon, "and I should think the land would get too rich to grow wheat."

"It is not so," said I, "and the fact is an interesting one, and teaches a most important lesson, of whicn, more hereafter."

Plot 5, last year, received $700 \mathrm{lbs}$. of superphosphate per acre. This year, this plot was divided; one half was left without ma. nure, and the other dressed with $252 \mathrm{lbs}$. of pure carbonate of ammonia per acre. The half without manure, $(5 a)$, did not produce quite as much grain and straw as the plot which had received no manure for two years in succession. But the wheat was of better quality, weighing $1 \mathrm{lb}$. more per bushel than the other. Still it is sufficiently evicient that superphosphate of lime did no good so far as increasing the grow th was concerned, either the first year it was applied, or the year following.

The carbonate of ammonia was dissolved in water and sprinkled over the growing wheat at three different times during the spring. You see this manure, which contains no mineral matter at all, gives an increase of nearly 4 bushels of grain per acre, and an increase of $887 \mathrm{lbs}$. of straw.

"Wait a moment," said the Deacon, "is not 887 lbs. of straw to

2 The mannres termed superphosphate of lime and phosnhate of potass, were made by acting upon bone-ash by means of sulphuric acid, and in the ca-e of the potass salt neutralizing the crimpound thus obtained, by means of pearl-ash. For the sunerphoshate of lime, the proportions were, 5 parts bone-ash. 3 parts water, and 3 parts snlphuric acid of sp. gr. 1.84: and for the phosphate of potass, 4 parts bone ash. water as needed, 3 parts snlphuric acid of sp. $g r .1 .84$; and an eqrivalent amonit of pearl-ash. The mixtires, of course, lost weight consider ably hy the evolntion of water and carhonic acid.

3 The medicinal carbonate of ammonia; it was dissolved in water and topdressed.

4 Plot 5 , was 2 lands wide (in after years, respectivelr, $5 a$ and $5 b$ ) : $5^{1}$ con isting of 2 aiternate one-fourth lengths across both lands, and $5^{2}$ of the 2 remaining one-fourth lengths.

Top-dressed at once. 6 Top-dressed at 4 intervals. ${ }^{7}$ Peruvian. ${ }^{8}$ Ichaboe. 
4 bushels of grain an unusually large proportion of straw to grain? I have heard you say that 100 lbs. of straw to each bushel of wheat is about the average. And according to this experiment, the carbonate of immonia produced over $200 \mathrm{lbs}$. of straw to a bushel of grain. How do you account for this."

"It is a general rule," said 1 , "that the heavier the crop, the greater is the proportion of straw to grain. On the no-manure plot, we have, this year, 118 lbs. of straw to a bushel of dressed grain. Taking this as the standard, you will find that the increase from manures is proportionally greater in straw than in grain. Thus in the increase of barn-yard manure, this year, we have about $133 \mathrm{lbs}$. of straw to a busiel of grain. I do not believe there is any manure that will give us a large crop of grain without a still larger crop of straw. There is considerable difference, in this respect, between diffcrent varietics of wheat. Still, I like to see a good growth of straw."

"It is curious," said the Doctor " that $3 \mathrm{cwt}$. of ammonia-salts alone on plots 9 and 10 should produce as much wheat as was obtained from plot 2, whcre 14 tons oi barn-yarl manure had been applied two years in succcssion. I notice that on one plot, the ammonia-salts were applied at once, in the spring, while on the other plot they were sown at four different times-and that the former gave the best results."

The only conclusion to be drawn from this, is, that it is desirable to apply the manure early in the spring-or better still, in the autumn.

"You are a great advocate of Peruviun guano," said the Deacon, "and yet $3 \mathrm{cwt}$ of Peruvian guano on Plot 13, only produced an increase of two bushels and $643 \mathrm{lbs}$. of straw per acre. The guano at $\$ 60$ per ton, would cost $\$ 9.00$ per acre. This will not pay."

This is an unusually small increas?. The reason, probably, is to be found in the fact that the manure and seed were not sown until March, instead of in the autumn. The salts of ammonia are quite soluble and act quickly; while the Peruvian guano has to decompose in the soil, and consequently needs to be applicd earlier, especially on clay land.

"I do not want you," said the Deacon, "to dodge the question why an application of 14 tons of farmyard-manure per acre, every year for over thirty years, does not make the land too rich for wheat."

"Possibly," said I, " on light, sandy soil, such an annual dressing of manure would in the course of a few years make the land too 
rich for wheat. But on a clayey soil, such is evidently not the case. And the fact is a very important one. When we apply manure, our object should be to make it as available as possible. Nature preserves or conserves the food of plants. The object of agriculture is to use the food of plants for our own advantage.

"Please be a little more definite," said the Deacon, "for I must confess I do not quite see the significance of your remarks."

"What he means," said the Doctor, "is this : If you put a quantity of soluble and available manure on land, and do not sow any crop, the manure will not be wasted. The soil will retain it. It will change it from a soluble into a comparatively insoluble form. Had a crop been sown the first year, the manure would do far more good than it will the next year, and yet it may be that none of the manure is lost. It is merely locked up in the soil in such a form as will prevent it from running to waste. If it was not for this principle, our lands would have been long ago exhausted of all their available plant-food."

"I think I understand," said the Deacon; "but if what you say is true, it upsets many of our old notions. We have thought it desirable to plow under manure, in order to prevent the ammonia from escaping. You claim, I believe, that there is little danger of any loss from spreading manure on the surface, and I suppose you would have us conclude that we make a mistake in plowing it under, as the soil renders it insoluble."

"It depends a good deal," said I, " on the character of the soil. A light, sandy soil will not preserve manure like a clay soil. But it is undoubtedly true that our aim in all cases should be to apply manure in such a form and to such a crop as will give us the greatest immediate benefit. Plowing under fresh manure every year for wheat is evidently not the best way to get the greatest benefit from it. But this is not the place to discuss this matter. Let us look at the result of Mr. Lawes' experiments on wheat the third year:" 
Experimants at Rothamsted on the Growth of

TABLE III.-MANURES $\triangle N D$ PRODUCE; 3RD SEASON, 1845-6.

\begin{tabular}{|c|c|c|c|c|c|c|c|c|c|c|c|c|c|c|}
\hline \multirow[b]{3}{*}{ 芯 } & \multicolumn{14}{|c|}{ ManuRes per ACre. } \\
\hline & \multirow{2}{*}{ 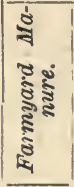 } & \multirow{2}{*}{ 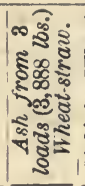 } & \multirow{2}{*}{ 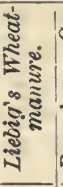 } & \multirow{2}{*}{ 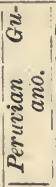 } & \multirow{2}{*}{ 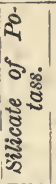 } & \multirow[b]{2}{*}{ 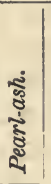 } & \multirow[b]{2}{*}{ 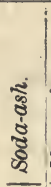 } & \multirow[b]{2}{*}{ 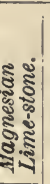 } & \multicolumn{3}{|c|}{$\begin{array}{l}\text { Superphosph te } \\
\text { of Lime. }\end{array}$} & \multirow{2}{*}{ 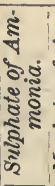 } & \multirow{2}{*}{ 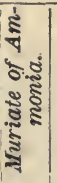 } & \multirow[b]{2}{*}{ 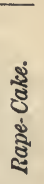 } \\
\hline & & & & & & & & & 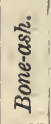 & 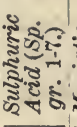 & 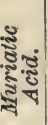 & & & \\
\hline & Tons. & & lbs. & lbs. & lbs. & lbs. & lbs. & 1 lbs. & $1 \mathrm{bs}$. & lbs. & lbs. & lbs. & lbs. & lbs. \\
\hline 0 & .. & . & . & 336 & .. & .. & .. & . & & . & 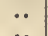 & .. & .. & .. \\
\hline $\begin{array}{l}1 \\
2\end{array}$ & ii & $\because$ & $\ddot{. .}$ & $\because$. & $\ddot{. .}$ & $\ddot{. .}$ & $\ddot{.}$ & $\ddot{. .}$ & $\begin{array}{l}224 \\
. .\end{array}$ & $\ddot{. .}$ & $\ddot{. .}$ & $\ddot{. .}$ & $\because$ & 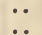 \\
\hline 3 & Unman & nured. & .. & .. & .. & .. & .. & .. & .. & - & .. & .. & .. & .. \\
\hline 4 & $\cdots$ & $\cdots$ & .. & $\therefore$ & - & $\cdots$ & $\cdots$ & - & 224 & -. & 224 & $224^{\circ}$ & .. & - \\
\hline $5 a\{1$ & .. & Straw & .. & $\because$ & $\cdots$ & . & $\because$ & $\because$ & *. & $\cdots$ & *. & 2011 & *. & $\cdots$ \\
\hline$\{1$ & $\ddot{.}$ & Ash. & .. & $\ddot{0}$ & $\ddot{. .}$ & .. & $\ddot{. .}$ & $\ddot{.}$ & .. & $\ddot{.}$ & ... & $\begin{array}{l}22 t^{2} \\
\ldots\end{array}$ & $\because$ & 449 \\
\hline $5 b\{2$ & $\because$. & & & .. & . & 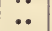 & . & .. & .. & . & .. & $224^{1}$ & $\because$ & 448 \\
\hline $6 a$ & .. & . & 448 & .. &.. & .. & .. & .. & .. & .. & .. & 119 & 110 & .. \\
\hline $7 a$ & .. & 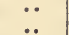 & $\begin{array}{l}418 \\
448\end{array}$ & $\ddot{0}$ & $\ddot{.}$ & $\because$ & $\ddot{\circ}$ & $\ddot{.}$ & $\ddot{~}$ & $\ddot{. .}$ & $\ddot{. .}$ & 112 & & $\ddot{4} \dot{48}$ \\
\hline $7 b$ & .. & .. & 448 & .. & .. & .. & .. & .. & .. & .. & .. & 112 & 112 & 448 \\
\hline $8 a$ & .. & .. & .. & .. & .. & . & . & .. & $2: 4$ & •. & .. & & & 448 \\
\hline $8 b$ & .. & 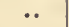 & •. & .. & .. & .. & .. & ・. & 224 & .. & .. & 112 & 112 & \\
\hline $9 a$ & ". & .. & .. & .. & . & . & . & .. & .. & .. & .. & $\ddot{\vartheta}$ & .. & 448 \\
\hline $10 x$ & • & 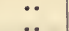 & :. & ... & 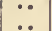 & $\because$ & $\because$ & $\ddot{.}$ & .. & .. & $\ddot{.}$ & 224 & $\because .$. & 448 \\
\hline $10 b$ & Unmaz & uared. & .. & .. & .. & .. & .. & .. & 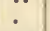 & .. & .. & $\ldots$ & .. & .. \\
\hline $11 a$ & .. & .. & .. & .. & .. & .. & .. & .. & 224 & 224 & .. & & & 448 \\
\hline $11 b$ & .. & •. & .. & .. & .. & .. & & .. & 224 & 224 & .. & 112 & 112 & \\
\hline $12 a$ & .. & .. & .. & .. & .. & • & 130 & .. & 224 & 224 & .. & 10 & ii & 448 \\
\hline & • & . & ? & .. & . & $\ddot{\circ}$ & 180 & .. & 224 & 224 & .. & 112 & 112 & 10 \\
\hline 13 & • & •. & . & .. & .. & $2 ! 0$ & .. & .. & 224 & 224 & .. & 10̈ & iiv & 448 \\
\hline & : & 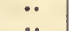 & $\ddot{0}$ & 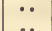 & $\ddot{*}$ & 250 & $\ddot{*}$ & 84 & 224 & $\begin{array}{l}224 \\
224\end{array}$ & *. & 112 & 112 & $\dddot{448}$ \\
\hline $14 b$ & $\ddot{. .}$ & ... & $\ddot{. .}$ & $\ddot{. .}$ & $\because$ & .. & $\ddot{0}$ & 81 & 224 & 224 & ・ & $1 \ddot{1}$ & 112 & .. \\
\hline Iria & .. & .. & .. & .. & & .. & .. & .. & 224 & .. & 224 & 224 & .. & 448 \\
\hline $10 ้ b$ & & $\because$ & 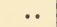 & .. & 224 & .. & .. & .. & 224 & .. & 224 & 224 & .. & 448 \\
\hline $16 a$ & .. & . & .. & .. & .. & 67 & 60 & 84 & 224 & 224 & & & • & 448 \\
\hline $16 \bar{b}$ & & 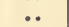 & - & 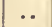 & 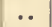 & 67 & 60 & 81 & 24 & 224 & .. & 224 & & 448 \\
\hline $17 a$ & . & .. & 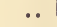 & .. & .. & 67 & c0 & 84 & 224 & 224 & .. & 112 & 112 & 448 \\
\hline $17 b$ & & .. & .. & .. & .. & 67 & 60 & 81 & $2 \approx 4$ & 224 & .. & 224 & 110 & .. \\
\hline 18 & . & .. & .. & .. & .. & 67 & 60 & 84 & 221 & 224 & .. & 112 & 112 & .. \\
\hline $18 b$ & & $\cdots$ & . & .. & .. & 67 & 60 & 84 & 224 & 224 & .. & .. & . & 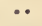 \\
\hline 19 & .. & 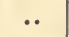 & .. & .. & .. & .. & .. & .. & 112 & .. & 112 & 112 & .. & 448 \\
\hline 21$\}$ & Mixt & of $t$ & resi & due & $\rho n$ & st & th & th & $\mathrm{n}$ & ures. & .. & .. & .. & •. \\
\hline
\end{tabular}

2 Top-dressed in the Spring. 
Wheat, Year after Year, on the same Land.

MANURES AND SEED (OLD RED LAMMAS), SOWN AUTUMN, 1845.

\begin{tabular}{|c|c|c|c|c|c|c|c|c|c|c|c|c|}
\hline \multirow[b]{3}{*}{$\underset{8}{\mathbb{8}}$} & \multicolumn{7}{|c|}{ Produce PER ACre, htC. } & \multicolumn{3}{|c|}{$\begin{array}{c}\text { INCREASE } \text { क् ACRE } \\
\text { BY MANURE. }\end{array}$} & \multirow{3}{*}{ 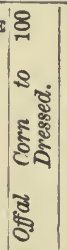 } & \multirow{3}{*}{$\begin{array}{l}\dot{3} \\
0 \\
0 \\
5 \\
0 \\
8 \\
0 \\
8 \\
5 \\
5 \\
8\end{array}$} \\
\hline & \multicolumn{3}{|c|}{ Dressed Corn. } & \multirow[b]{2}{*}{ 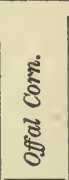 } & \multirow[b]{2}{*}{ 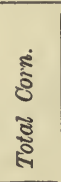 } & \multirow[b]{2}{*}{ 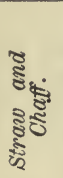 } & \multirow{2}{*}{ 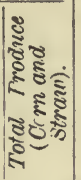 } & \multirow[b]{2}{*}{ हิ } & \multirow[b]{2}{*}{ 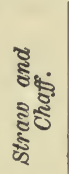 } & \multirow[b]{2}{*}{ 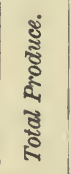 } & & \\
\hline & 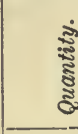 & & 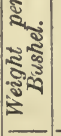 & & & & & & & & & \\
\hline $\begin{array}{l}0 \\
1 \\
2 \\
3\end{array}$ & $\begin{array}{c}\text { Bush. } \\
28 \\
22 \\
27 \\
17\end{array}$ & $\begin{array}{l}\text { "cks. } \\
18 \\
0 \% \\
\text { cis } \\
3 \frac{8}{4}\end{array}$ & $\begin{array}{l}\mathrm{lbs} . \\
62.3 \\
62.6 \\
63.0 \\
63.8\end{array}$ & $\begin{array}{c}\text { Jbs. } \\
134 \\
120 \\
113 \\
64\end{array}$ & $\begin{array}{l}\text { lbs. } \\
1906 \\
1509 \\
1826 \\
1207\end{array}$ & $\begin{array}{c}\text { lbs. } \\
2561 \\
1953 \\
2454 \\
1513\end{array}$ & $\begin{array}{l}\text { lbs. } \\
4467 \\
3462 \\
4 \AA 80 \\
2720\end{array}$ & $\begin{array}{c}\text { Ibs. } \\
699 \\
302 \\
619 \\
. .\end{array}$ & $\begin{array}{c}\text { lbs. } \\
1048 \\
440 \\
941 \\
. .\end{array}$ & $\begin{array}{c}\text { lbs. } \\
1 / 47 \\
742 \\
1560 \\
\ldots\end{array}$ & $\begin{array}{l}7.3 \\
8.1 \\
6.6 \\
7.4\end{array}$ & $\begin{array}{l}74.4 \\
77.3 \\
74.4 \\
79.7\end{array}$ \\
\hline 4 & 25 & $3 \frac{1}{4}$ & 63.5 & 130 & 1777 & 2390 & 4167 & 570 & 8.7 & 1447 & 7.8 & 74.3 \\
\hline 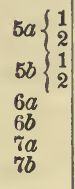 & $\begin{array}{l}19 \\
27 \\
23 \\
30 \\
20 \\
29 \\
22 \\
31\end{array}$ & $\begin{array}{l}0 \frac{1}{7} \\
0 \\
2 \frac{1}{2} \\
0 \frac{8}{4} \\
1 \frac{1}{8} \\
0 \frac{8}{4} \\
3 \frac{1}{4} \\
3\end{array}$ & \begin{tabular}{|l|}
63.7 \\
63.0 \\
63.4 \\
63.3 \\
63.7 \\
63.5 \\
63.0 \\
63.4
\end{tabular} & $\begin{array}{r}87 \\
126 \\
100 \\
165 \\
102 \\
114 \\
97 \\
150\end{array}$ & $\begin{array}{l}1305 \\
1827 \\
1598 \\
2076 \\
1400 \\
1967 \\
1534 \\
2163\end{array}$ & $\begin{array}{l}1541 \\
2309 \\
1721 \\
2901 \\
1676 \\
2571 \\
1968 \\
3007\end{array}$ & $\begin{array}{l}2846 \\
4136 \\
3319 \\
4977 \\
3076 \\
4 \div 38 \\
3502 \\
51 \div 0\end{array}$ & $\begin{array}{r}98 \\
620 \\
391 \\
869 \\
193 \\
760 \\
327 \\
956\end{array}$ & $\begin{array}{r}28 \\
796 \\
268 \\
1888 \\
163 \\
1058 \\
405 \\
1494\end{array}$ & $\begin{array}{r}126 \\
1416 \\
599 \\
2257 \\
356 \\
1818 \\
732 \\
2450\end{array}$ & $\begin{array}{c}. . \\
\ldots \\
\ddot{0} \\
7.0 \\
5.3 \\
6.8 \\
7.5\end{array}$ & $\begin{array}{l}84.6 \\
79.1 \\
92.8 \\
71.6 \\
83.6 \\
76.5 \\
77.9 \\
72.6\end{array}$ \\
\hline $\begin{array}{r}8 a \\
8 b \\
9 a \\
9 b \\
10 a \\
10 b\end{array}$ & $\begin{array}{l}22 \\
29 \\
23 \\
28 \\
27 \\
17\end{array}$ & $\begin{array}{l}3 \frac{1}{2} \\
0 \frac{8}{2} \\
2 \frac{1}{4} \\
2 \frac{1}{2} \\
1 \frac{1}{3} \\
2 \frac{1}{5}\end{array}$ & \begin{tabular}{|l|}
63.5 \\
63.6 \\
63.0 \\
63.3 \\
63.6 \\
63.8
\end{tabular} & $\begin{array}{r}101 \\
132 \\
122 \\
114 \\
109 \\
92\end{array}$ & $\begin{array}{l}1549 \\
1988 \\
1614 \\
1942 \\
1850 \\
1216\end{array}$ & $\begin{array}{l}1963 \\
2575 \\
203 ; \\
2603 \\
2244 \\
1455\end{array}$ & $\begin{array}{l}3512 \\
4563 \\
3647 \\
4545 \\
4094 \\
2671\end{array}$ & $\begin{array}{r}342 \\
781 \\
407 \\
735 \\
\mathbf{6 4 3} \\
\mathbf{9}\end{array}$ & $\begin{array}{r}450 \\
10 \nmid j 2 \\
520 \\
1090 \\
731 \\
-58\end{array}$ & $\begin{array}{r}792 \\
1843 \\
927 \\
1825 \\
1374 \\
-49\end{array}$ & $\begin{array}{l}7.1 \\
7.2 \\
7.9 \\
7.0 \\
6.4 \\
7.8\end{array}$ & $\begin{array}{l}78.9 \\
77.2 \\
79.4 \\
74.6 \\
82.4 \\
83.6\end{array}$ \\
\hline $\begin{array}{l}12 b \\
13 a \\
13 b \\
14 a \\
14 b\end{array}$ & $\begin{array}{l}23 \\
30 \\
24 \\
28 \\
24 \\
29 \\
23 \\
26\end{array}$ & 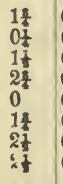 & \begin{tabular}{|l|}
63.3 \\
63.2 \\
63.0 \\
63.4 \\
63.5 \\
633.2 \\
63.0 \\
63.4
\end{tabular} & $\begin{array}{l}145 \\
155 \\
125 \\
136 \\
136 \\
138 \\
117 \\
124\end{array}$ & $\begin{array}{l}1628 \\
2055 \\
1661 \\
1955 \\
1660 \\
1998 \\
1605 \\
1812\end{array}$ & $\begin{array}{l}2133 \\
2715 \\
2163 \\
2554 \\
2327 \\
2755 \\
2031 \\
2534\end{array}$ & $\begin{array}{l}4770 \\
3824 \\
4509 \\
3987 \\
4753 \\
3636 \\
4356\end{array}$ & $\begin{array}{l}421 \\
848 \\
454 \\
748 \\
453 \\
791 \\
398 \\
605\end{array}$ & $\begin{array}{r}620 \\
1202 \\
650 \\
1041 \\
814 \\
1242 \\
519 \\
1021\end{array}$ & $\begin{array}{r}1041 \\
2050 \\
1104 \\
1789 \\
1267 \\
2033 \\
916 \\
1626\end{array}$ & $\begin{array}{l}9.8 \\
6.1 \\
7.9 \\
7.4 \\
9.1 \\
7.3 \\
7.7 \\
7.4\end{array}$ & $\begin{array}{l}76.3 \\
75.7 \\
76.8 \\
76.5 \\
71.3 \\
72.5 \\
79.0 \\
71.5\end{array}$ \\
\hline $\begin{array}{l}15 a \\
15 b\end{array}$ & $\begin{array}{l}31 \\
27\end{array}$ & $\begin{array}{l}1 \frac{8}{4} \\
2 \frac{8}{6}\end{array}$ & \begin{tabular}{|}
62.5 \\
63.0 \\
\end{tabular} & $\begin{array}{l}147 \\
117\end{array}$ & $\begin{array}{l}2112 \\
1861\end{array}$ & $\begin{array}{l}29: 36 \\
2513\end{array}$ & $\begin{array}{l}5048 \\
4374\end{array}$ & $\begin{array}{l}905 \\
654\end{array}$ & $\begin{array}{l}1423 \\
1600\end{array}$ & $\begin{array}{l}2328 \\
1654\end{array}$ & $\begin{array}{l}7.5 \\
5.9\end{array}$ & \begin{tabular}{|l|}
71.9 \\
74.0
\end{tabular} \\
\hline $\begin{array}{l}16 a \\
16 b \\
17 a \\
17 b \\
18 a \\
18 b\end{array}$ & $\begin{array}{l}23 \\
30 \\
33 \\
30 \\
31 \\
21\end{array}$ & $\begin{array}{l}3 \\
1 \\
24 \\
2 \\
0 \\
1\end{array}$ & $\begin{array}{l}62.5 \\
62.7 \\
62.8 \\
63.0 \\
62.8 \\
62.0\end{array}$ & $\begin{array}{l}108 \\
122 \\
129 \\
113 \\
103 \\
157\end{array}$ & $\begin{array}{l}1502 \\
2019 \\
2241 \\
2034 \\
2048 \\
1474\end{array}$ & $\begin{array}{l}2067 \\
2836 \\
3278 \\
2784 \\
2838 \\
1893\end{array}$ & $\begin{array}{l}3659 \\
4855 \\
5519 \\
4818 \\
4886 \\
3367\end{array}$ & $\begin{array}{r}385 \\
812 \\
1034 \\
827 \\
841 \\
267\end{array}$ & $\begin{array}{r}554 \\
1323 \\
1765 \\
1271 \\
1325 \\
380\end{array}$ & $\begin{array}{r}939 \\
2135 \\
2199 \\
2198 \\
2166 \\
647\end{array}$ & $\begin{array}{l}7.0 \\
6.6 \\
5.8 \\
5.9 \\
5.1 \\
6.6\end{array}$ & $\begin{array}{l}77.0 \\
71.2 \\
68.3 \\
73.0 \\
72.2 \\
77.1\end{array}$ \\
\hline $\left.\begin{array}{l}19 \\
20 \\
21 \\
22\end{array}\right\}$ & 28 & 3 & 62.0 & 107 & 1889 & 2425 & 4314 & 682 & 912 & 1594 & 5.8 & 77.9 \\
\hline
\end{tabular}


This year, the seed and manures wère sown in the autumn. And I want the Deacon to look at plot $0.3 \mathrm{cwt}$. of Peruvian guano here gives an increase of $10 \frac{1}{2}$ bushels of wheat, and 1,048 lbs. of straw per acre. This will pay well, even on the wheat aloie. But in addition to this, we may expect, in our ordinary rotation of crops, a far better crop of clover where the guano was used.

In regard to some of the results this year, Messrs. Lawes and Gilbert have the following concise and interesting remaris :

"At this third experimental harvest, we have on the continuously unmanured plot, namely, No. 3, not quite 18 bushels of dressed corn, as the normal produce of the season; and by its side we have on plot $10 b$-comprising one-half of the plot 10 of the previous years, and so highly manured by ammoniacal salts in 184i, but now unmanured-rather more than $17 \frac{1}{2}$ bushels. The near approach, again, to identity of result from the two unmanured plots, at once gives confidence in the accuracy of the experiments, and shows us how effectually the preceling crop had, in a practical point of view, reduced the plots, previously so differently circumstanced both as to manure and produce, to something like an uniform standard as regards their grain-producing qualiti s.

"Plot 2 has, as before, 11 tons of farm-yard manure, and the produce is $27 \frac{1}{4}$ bushels, or between 9 and 10 bushels more than without manure of any kind.

"On plot $10 a$, which in the previous year gave $\mathrm{ly}$ ammoniacal salts alone, a produce equal to that of the farm-yard manure, we have again a similar result: for two cwts. of sulphate of ammonia has now given $1,850 \mathrm{lbs}$. of total corn, instead of $1,826 \mathrm{lbs}$., which is the produce on plot 2. The straw of the latter, is, however, slightly heavier than that by the ammoniacal salt.

"Again, plot 5x, which was in the previous season unmanured, was now subdivided: on one-half of it (namely, $5 a^{1}$ ) we have the ashes of wheat-straw alone, by which there is an increase of rather more than one busk al per acre of dressed corn; on the other half (or $5 x^{2}$ ) we have, besides the straw-ashes, two cwts. of sulphate of ammonia put on as a top-dressing: two cwts. of su:phate of ammonia have, in this case, only increased the produce beyond that of $5 a^{1}$ by $7 \frac{7}{8}$ bushels of corn and $768 \mathrm{lbs}$. of straw, instead of by $9^{3} / 4$ bushels of corn and $789 \mathrm{lbs}$. of straw, which was the increase obtained by the same amount of ammoniacal salt on 10 $t$, as compared with $10 b$.

"It will be observed, however, that in the former case the ammoniacal salts were top-dressed, but in the latter they were drilled at the time of sowing the seed; and it will be remembered that in 
1815 the result was better as to corn on plot 9 , where the salts were sown earlier, than on plot 10, where the top-dressing extended far into the spring. We have had several direct instances of this kind in our experience, and we would give it as a s!iggestion, in most cases applicable, that manures for wheat, and especially ammoniacal ones, should be applied before or at the time the seed is sown; for, although the apparent luxuriance of the crop is greater, and the produce of straw really heavier, by spring rather than autumn sowings of Peruvian guano and other ammoniacal manures, yet we believe that that of the corn will not be increased in an equivalent degree. Indeed, the success of the crop undoubtedly depends very materially on the progress of the underground growth during the winter months; and this again, other things being equal, upon the quantity of available nitrogenous constituents within the soil, without a liberal provision of which, the range of the fibrous feeders of the plant will not be such, as to take up the minerals which the soil is competent to supply, and in such quantity as will be required during the after progress of tie plant for its healthy and favorable growth."

These remarks are very suggestive and deserve special attention.

"The next result to be noticed," continue Messrs. Lawes and Gilbert, "is that obtained on plot 6, now also divided into two equal portions designated respectively $6 a$ and $6 b$. Plot No. 6 had for the crop of 1844, superphosphate of lime and the phos hate of magnesia manure, and for that of 1845 , superphosphate of lime, rape-cake, and ammoniacal salts. For this, the third season, it was devoted to the trial of the wheat-manure manufactured undcr the sanction of Professor Liebig, and patented in this ccuntry.

"Upon plots 6 , four cwts. per acre of the patent wheat-manure were used, which gave $20 \frac{1}{4}$ bushels, or rather more than two bushels beyond the produce of the unmanured plot; but as tho manure contained, besides the minerals peculiar to it, some nitrogenous compounds, giving off a rery perceptible odor of ammori?, some, at least, of the increase would be due to that substance. On plot $6 b$, however, the further addition of one cwt. each of sulphate and muriate of ammonia to this so-called 'Mineral Manure,' giv s a produce of $29 \frac{1}{4}$ bushels. In other words, the addition of ammcriacal salt, to Liebiy's mineral manure has increased the produce by very nearly 9 bushels per acre beyond that of the mineral mantro alone, whilst the increase obtained over the unmanured plot, ly 1 t tons of farm-yard manure, was only $9 \frac{1}{4}$ bushels !

The following table gives the results of the experiments tine fourth year, 1846-7. 
Experiments at Rothamsted on the Growth of

TABLE IV.-MANURES AND PRODUCE ; 4TH SEASON, 18:6-7.

\begin{tabular}{|c|c|c|c|c|c|c|c|c|}
\hline \multirow[b]{3}{*}{ 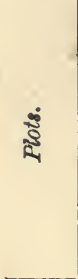 } & \multicolumn{8}{|c|}{ MANURes PER ACre. } \\
\hline & \multirow[b]{2}{*}{ 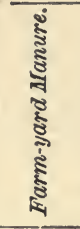 } & \multirow[b]{2}{*}{ 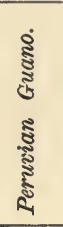 } & \multicolumn{3}{|c|}{ Superphosphate of Lime. } & \multirow[b]{2}{*}{ 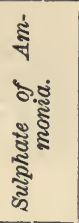 } & \multirow[b]{2}{*}{ 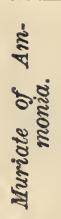 } & \multirow[b]{2}{*}{ ஓूँ } \\
\hline & & & 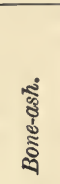 & 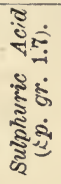 & 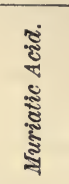 & & & \\
\hline \multirow{4}{*}{$\begin{array}{l}0 \\
1 \\
2 \\
3\end{array}$} & \multirow{4}{*}{\multicolumn{2}{|c|}{ 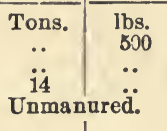 }} & lbs. & lbs. & lbs. & lbs. & lbs. & lts. \\
\hline & & & $\therefore 0 j$ & $\ddot{.}$ & $\check{200}$ & $3 \ddot{50}$ & $\ddot{50}$ & $\ddot{.}$ \\
\hline & & & .. & .. & .. & .. & .. & .. \\
\hline & & & 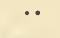 & 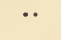 & $\cdots$ & *. & •. & *. \\
\hline 4 & $\cdots$ & - & $2 \cup 0$ & •. & 200 & 300 & 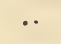 & .. \\
\hline \multirow{5}{*}{$\begin{array}{l}5 a \\
5 b \\
6 a \\
6 b \\
7 a \\
7 b\end{array}$} & .. & .. & 200 & 220 & .. & $1: 0$ & 150 & \multirow[b]{2}{*}{$50 \ddot{0}$} \\
\hline & •. & -. & 220 & 200 & .. & 150 & 150 & \\
\hline & $\ddot{.}$ & $\ddot{. .}$ & $\ddot{.}$ & $\ddot{0}$ & 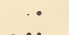 & $\begin{array}{l}150 \\
150\end{array}$ & $\begin{array}{l}150 \\
150\end{array}$ & $\because$ \\
\hline & $\ddot{.}$ & $\ddot{.}$ & $\ddot{.}$ & $\ddot{*}$ & $\ddot{\cdots}$ & 150 & 150 & $\ddot{. .}$ \\
\hline &.. & .. & $\because$. & $\ddot{. .}$ & $\ddot{.}$ & 150 & 110 & .. \\
\hline \multirow{2}{*}{$\begin{array}{l}8 a \\
8 b\end{array}$} & .. & .. & 200 & $2 c 0$ & .. & 150 & 150 & $5 \subseteq 0$ \\
\hline & $\cdots$ & .. & 200 & 200 & .. & 200 & 200 & \multirow{2}{*}{$\approx \ddot{4} \dot{0}$} \\
\hline $9 a\left\{\begin{array}{l}1 \\
2\end{array}\right\}$ & $\ddot{0}$ & $\dot{.}$ & $\ddot{0}$ & $\ddot{0}$ & $\ddot{m}$ & $1 \ddot{50}$ & $1 \ddot{0}$ & \\
\hline \multirow{3}{*}{$\begin{array}{c}9 b \\
1(c a \\
10 b\end{array}$} & $\ddot{\ddot{*}}$ & $\ddot{.}$ & $\ddot{.}$ & $\ddot{\ddot{*}}$ & $\ddot{\ddot{*}}$ & 150 & $\begin{array}{l}1.0 \\
150\end{array}$ & $\ddot{. .}$ \\
\hline & .. & .. & .. & .. & . & 150 & 150 & .. \\
\hline & $\cdots$ & $\cdots$ & $\cdots$ & $\cdots$ & $\cdots$ & 150 & 150 & $\cdot \cdot$ \\
\hline \multirow{7}{*}{$\begin{array}{l}11 a \\
11 b \\
12 x \\
11 b \\
13 a \\
13 b \\
14 a \\
14 b\end{array}$} & .. & .. & 100 & 100 & .. & 150 & 150 & .. \\
\hline & .. & .. & 160 & $10)$ & .. & 150 & 150 & .. \\
\hline & $\ddot{0}$ & 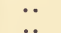 & 100 & 100 & 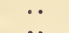 & 150 & 150 & 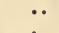 \\
\hline & $\ddot{0}$ & $\ddot{.}$ & 100 & 100 & $\ddot{0}$ & 150 & $\begin{array}{l}150 \\
1: 0\end{array}$ & .. \\
\hline & .. &.. & 100 & 100 & $\ddot{0}$ & 150 & 150 & $\ddot{0}$ \\
\hline & .. & .. & 160 & 100 & .. & 150 & 150 & .. \\
\hline & -. & .. & 100 & $1 \mathrm{CO}$ & .. & 150 & 150 & .. \\
\hline \multirow{2}{*}{$\begin{array}{l}15 a \\
15 b\end{array}$} & .. & .. & $2^{\wedge} 0$ & .. & 200 & 200 & .. & \multirow{2}{*}{$\begin{array}{l}\text { Exo } \\
\text { Exo }\end{array}$} \\
\hline & .. & $\cdots$ & $\Sigma 00$ & .. & $2 \mathrm{CO}$ & 300 & .. & \\
\hline \multirow{5}{*}{$\begin{array}{l}16 a \\
16 b \\
17 a \\
17 b \\
18 a \\
1 \varepsilon b\end{array}$} & .. & .. & 103 & 100 & .. & 150 & 150 & .. \\
\hline & .. & .. & 100 & 100 & .. & 150 & 150 & .. \\
\hline & .. & .. & 100 & 100 & .. & 150 & $1=0$ & .. \\
\hline & 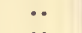 & . & 100 & $1 C 0$ & $\ddot{*}$ & 200 & 200 & $\ddot{*}$ \\
\hline & $\ddot{x}$ & $\ddot{.}$ & $\begin{array}{l}100 \\
100\end{array}$ & 100 & $\ddot{0}$ & $\begin{array}{l}150 \\
150\end{array}$ & $\begin{array}{l}150 \\
1: 0\end{array}$ & $\ddot{.}$ \\
\hline \multirow{3}{*}{$\left.\begin{array}{l}17 \\
20 \\
21 \\
22\end{array}\right\}$} & \multirow{2}{*}{\multicolumn{2}{|c|}{ Ūimanure d. }} & 100 & .. & 100 & $3 \mathrm{CO}$ & .. & 500 \\
\hline & & & .. & $\ddot{*}$ & . & .. & .. & .. \\
\hline & \multicolumn{7}{|c|}{ Mixture of the residue of most of the other manures. } & .. \\
\hline
\end{tabular}


Wheat, Year after Year, on the same Land.

MANURES $\triangle$ ND BEED (OLD RED LAMMAS), SOWN END OF OCTOBER, 1816.

\begin{tabular}{|c|c|c|c|c|c|c|c|c|c|c|c|c|}
\hline \multirow{3}{*}{ 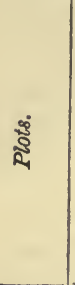 } & \multicolumn{7}{|c|}{ Prodtcr per ACre, \&C. } & \multicolumn{3}{|c|}{$\begin{array}{c}\text { INCREASE कृ ACRE } \\
\text { BY MANURE. }\end{array}$} & \multirow{3}{*}{ 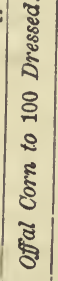 } & \multirow[b]{3}{*}{$\begin{array}{l}8 \\
0 \\
8 \\
8 \\
8 \\
8\end{array}$} \\
\hline & \multicolumn{3}{|c|}{ Dressed Corn. } & \multirow[b]{2}{*}{ 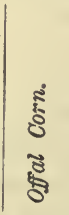 } & \multirow[b]{2}{*}{ 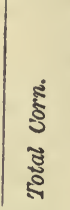 } & \multirow{2}{*}{ 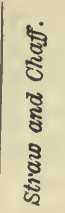 } & \multirow{2}{*}{ 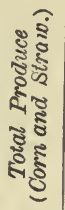 } & \multirow[b]{2}{*}{ క్రీ } & \multirow{2}{*}{ 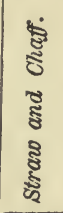 } & \multirow[b]{2}{*}{ 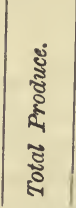 } & & \\
\hline & 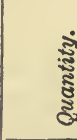 & & 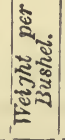 & & & & & & & & & \\
\hline $\begin{array}{l}0 \\
1 \\
2 \\
3\end{array}$ & $\begin{array}{c}\text { Bush.F } \\
33 \\
32 \\
23 \\
16\end{array}$ & $\begin{array}{c}\text { P'cis. } \\
\text { 'cis. } \\
1 \\
1 \\
34 \\
3 \frac{4}{4} \\
31\end{array}$ & $\mid \begin{array}{l}1 \mathrm{bs} . \\
61.1 \\
61.2 \\
62.3 \\
61.0\end{array}$ & \begin{tabular}{|c|}
$1 \mathrm{bs}$. \\
156 \\
147 \\
117 \\
95
\end{tabular} & \begin{tabular}{|l|} 
lbss. \\
2031 \\
2119 \\
1981 \\
1123
\end{tabular} & $\begin{array}{l}\text { lhs } \\
32 \% 7 \\
3735 \\
3628 \\
1902\end{array}$ & $\begin{array}{l}\text { lbs. } \\
\mathbf{5 3 0 8} \\
\mathbf{5} 554 \\
\mathbf{5} 003 \\
\mathbf{3 0 2 5}\end{array}$ & $\begin{array}{l}\text { lbs. } \\
908 \\
996 \\
858 \\
. .\end{array}$ & $\begin{array}{c}\text { lbs. } \\
1375 \\
1833 \\
1726 \\
. .\end{array}$ & $\begin{array}{c}\text { lbs. } \\
2 \approx 83 \\
28 \approx 9 \\
2584 \\
. .\end{array}$ & $\begin{array}{l}8.2 \\
7.2 \\
6.2 \\
8.9\end{array}$ & $\begin{array}{l}61.9 \\
56.7 \\
54.6 \\
59.0\end{array}$ \\
\hline 4 & 27 & $1 \frac{8}{6}$ & 61.9 & 82 & 1780 & 2948 & 4728 & 657 & 1046 & $1 \% 03$ & 4.7 & 60.3 \\
\hline $\begin{array}{l}5 a \\
5 b \\
6 a \\
6 b \\
7 a \\
7 b\end{array}$ & $\begin{array}{l}23 \\
32 \\
21 \\
21 \\
27 \\
25\end{array}$ & $\begin{array}{l}0 \\
2 \\
3 t \\
14 \\
3 \frac{1}{4} \\
1 \frac{1}{6}\end{array}$ & $\begin{array}{l}61.8 \\
61.4 \\
62.1 \\
61.6 \\
61.7 \\
61.5\end{array}$ & $\begin{array}{l}130 \\
136 \\
122 \\
127 \\
118 \\
125\end{array}$ & $\begin{array}{l}1921 \\
2132 \\
1663 \\
1632 \\
1834 \\
1682\end{array}$ & $\begin{array}{l}3412 \\
37: 21 \\
2786 \\
2303 \\
3151 \\
2953\end{array}$ & $\begin{array}{l}5333 \\
5833 \\
4449 \\
4435 \\
4935 \\
4035\end{array}$ & $\begin{array}{r}798 \\
1009 \\
540 \\
509 \\
711 \\
559\end{array}$ & $\begin{array}{r}1510 \\
1819 \\
884 \\
901 \\
1249 \\
1051\end{array}$ & $\begin{array}{l}2309 \\
2827 \\
1424 \\
1410 \\
1 \leq 63 \\
1010\end{array}$ & $\begin{array}{l}7.1 \\
6.6 \\
7.8 \\
8.2 \\
6.8 \\
7.9\end{array}$ & $\begin{array}{l}56.3 \\
5 \% .2 \\
5 \% .6 \\
58.2 \\
58.2 \\
56.9\end{array}$ \\
\hline $\begin{array}{c}8 a \\
83 \\
9 x\left\{\begin{array}{l}1 \\
2 \\
08 \\
10 x \\
103\end{array}\right.\end{array}$ & $\begin{array}{l}32 \\
35 \\
22 \\
2 j \\
26 \\
25 \\
25\end{array}$ & $\begin{array}{l}18 \\
3 \\
3 \\
2 \\
0 \\
3 \\
24\end{array}$ & $\begin{array}{l}62.1 \\
61.7 \\
63.5 \\
61.0 \\
61.3 \\
61.5 \\
61.2\end{array}$ & $\begin{array}{c}102 \\
123 \\
\ddot{0} \\
123 \\
118 \\
133\end{array}$ & $\begin{array}{l}2115 \\
2020 \\
1177 \\
1755 \\
1717 \\
1702 \\
1705\end{array}$ & $\begin{array}{l}3583 \\
3720 \\
2506 \\
3052 \\
2858 \\
2891 \\
2874\end{array}$ & $\begin{array}{l}\mathbf{5 7 9 8} \\
5743 \\
3983 \\
4807 \\
4575 \\
4503 \\
45 \div 9\end{array}$ & $\begin{array}{l}992 \\
897 \\
228 \\
632 \\
534 \\
5 \% 9 \\
582\end{array}$ & $\begin{array}{r}1781 \\
1818 \\
604 \\
1153 \\
956 \\
983 \\
972\end{array}$ & $\begin{array}{c}2773 \\
2715 \\
\because \\
1 \dot{5} 50 \\
1548 \\
15 \div 4\end{array}$ & $\begin{array}{c}5.5 \\
6.3 \\
\ddot{.} \\
\ddot{0} \\
\ddot{7.3} \\
8.2\end{array}$ & $\begin{array}{l}57.4 \\
54.3 \\
53.9 \\
57.5 \\
60.1 \\
58.8 \\
59.3\end{array}$ \\
\hline $\begin{array}{l}113 \\
113 \\
132 \\
123 \\
13 a \\
133 \\
1 ! 3 \\
11 b\end{array}$ & $\begin{array}{l}30 \\
23 \\
23 \\
27 \\
27 \\
27 \\
23 \\
28\end{array}$ & $\begin{array}{l}27 \\
18 \\
2 \\
04 \\
2 \frac{1}{8} \\
1 \frac{1}{4} \\
04 \\
3 \frac{8}{4}\end{array}$ & $\mid \begin{array}{l}61.6 \\
61.8 \\
62.0 \\
61.8 \\
63.5 \\
63.3 \\
32.8 \\
62.8\end{array}$ & $\begin{array}{r}142 \\
123 \\
124 \\
121 \\
108 \\
96 \\
175 \\
166\end{array}$ & $\begin{array}{l}2014 \\
1911 \\
1953 \\
1796 \\
1959 \\
1801 \\
1914 \\
1856\end{array}$ & $\begin{array}{l}3517 \\
3203 \\
3452 \\
3124 \\
3306 \\
3171 \\
3362 \\
3006\end{array}$ & $\begin{array}{l}5561 \\
5141 \\
5435 \\
4920 \\
52: 5 \\
4972 \\
5306 \\
4862\end{array}$ & $\begin{array}{l}921 \\
818 \\
830 \\
673 \\
836 \\
678 \\
821 \\
733\end{array}$ & $\begin{array}{l}1615 \\
1301 \\
1550 \\
1222 \\
1404 \\
1269 \\
1460 \\
1104\end{array}$ & $\begin{array}{l}2536 \\
2119 \\
2380 \\
1895 \\
2210 \\
1947 \\
2281 \\
1837\end{array}$ & $\begin{array}{l}6.3 \\
6.7 \\
6.6 \\
7.1 \\
5.5 \\
5.3 \\
9.7 \\
9.8\end{array}$ & $\begin{array}{l}59.5 \\
60.6 \\
57.1 \\
574 \\
57.3 \\
56.7 \\
59.5 \\
61.7\end{array}$ \\
\hline $\begin{array}{l}15 x \\
153\end{array}$ & $\begin{array}{l}32 \\
32\end{array}$ & $\begin{array}{l}3 \\
0\end{array}$ & $\begin{array}{l}63.0 \\
63.6\end{array}$ & $\begin{array}{l}151 \\
137\end{array}$ & $\begin{array}{l}2214 \\
2140\end{array}$ & $\begin{array}{l}3876 \\
3617\end{array}$ & $\begin{array}{l}6090 \\
5757\end{array}$ & $\begin{array}{l}1091 \\
1017\end{array}$ & $\begin{array}{l}1974 \\
1715\end{array}$ & $\begin{array}{l}3065 \\
2732\end{array}$ & $\begin{array}{l}7.2 \\
6.6\end{array}$ & $\begin{array}{l}57.1 \\
59.1\end{array}$ \\
\hline $\begin{array}{l}13 a \\
103 \\
17 z \\
17 b \\
13 z \\
13 b\end{array}$ & $\begin{array}{l}23 \\
34 \\
33 \\
35 \\
32 \\
29\end{array}$ & $\begin{array}{l}1 \frac{1}{6} \\
2 \frac{1}{4} \\
3 \\
1 \\
0 \frac{8}{4} \\
1 \frac{1}{8}\end{array}$ & $\begin{array}{l}62.3 \\
62.6 \\
62.3 \\
62.0 \\
62.7 \\
62.9\end{array}$ & $\begin{array}{l}132 \\
119 \\
119 \\
117 \\
142 \\
181\end{array}$ & $\begin{array}{l}1959 \\
2283 \\
2222 \\
2314 \\
2160 \\
2029\end{array}$ & $\begin{array}{l}3417 \\
4012 \\
4027 \\
4261 \\
3852 \\
4161\end{array}$ & $\begin{array}{l}5376 \\
6295 \\
6249 \\
6575 \\
6012 \\
6193\end{array}$ & $\begin{array}{r}896 \\
1160 \\
10^{\circ} 9 \\
1191 \\
1037 \\
906\end{array}$ & $\begin{array}{l}1515 \\
2110 \\
2195 \\
2159 \\
19 \% 0 \\
2262\end{array}$ & $\begin{array}{l}2351 \\
32 \% 0 \\
3224 \\
3550 \\
29 \div 7 \\
3168\end{array}$ & $\begin{array}{l}6.9 \\
5.2 \\
5.6 \\
6.4 \\
6.9 \\
9.7\end{array}$ & $\begin{array}{l}57.3 \\
56.9 \\
55.1 \\
54.3 \\
56.0 \\
48.7\end{array}$ \\
\hline $\left.\begin{array}{l}19 \\
20 \\
21 \\
22\end{array}\right\}$ & $\begin{array}{l}32 \\
20 \\
. .\end{array}$ & $\begin{array}{l}3 \\
c t \\
. .\end{array}$ & $\begin{array}{c}63.8 \\
63.5 \\
. .\end{array}$ & $\begin{array}{r}140 \\
70 \\
.\end{array}$ & $\begin{array}{c}2195 \\
13: 12 \\
. .\end{array}$ & $\begin{array}{c}4202 \\
2074 \\
. .\end{array}$ & $\begin{array}{c}6397 \\
3496 \\
. .\end{array}$ & $\begin{array}{c}10 \% 2 \\
209 \\
\ldots\end{array}$ & $\begin{array}{c}2300 \\
172 \\
.\end{array}$ & $\begin{array}{c}3372 \\
381 \\
\ldots\end{array}$ & $\begin{array}{c}6.7 \\
4.9 \\
. .\end{array}$ & $\begin{array}{l}52.2 \\
61.2 \\
\cdots\end{array}$ \\
\hline
\end{tabular}


Here again, I want the Deacon to look at plot 0, where 500 lbs. Peruvian guano, sown in October, gives an increase of nearly 14 bushels of dressed wheat and 1,375 lbs. of straw per acre. On plut 2 , where 14 tons of barn yard manure have now been applied four years in succession ( 56 tons in all), there is a little more straw, but not quite so much grain, as from the $500 \mathrm{lbs}$. of guano.

"But will the guano," said the Deacoz, "be as lasting as the manure?"

"Not for wheat," said I. "But if you seed the wheat down with clover, as would be the case in this section, we should get considerable benefit, probably, from the guano. If wheat was sown after the wheat, the guano applied the previous season would do little good on the second crop of wheat. And yet it is a matter of fact that there would be a considerable proportion of the guano left in the soil. The wheat cannot take it up. But the clover can. And we ali know that if we can grow good crops of clover, plowing it under, or feeding it out on the land, or making it into hay and saving the manure obtained from it, we shall thus be enabled to raise good crops of wheat, barley, oats, potatoes, and corn, and in this sense guano is a 'lasting' manure."

"Barnyard-manure," said the Doctor, "is altogether ton "lasting.' Here we have had 56 tons of manure on an acre of land in four years, and yet an acre dressed with $500 \mathrm{lbs}$. of guano produces just as good a crop. The manure contains far more plant-food, of all kinds, than the guano, but it is so 'lasting' that it does not do half as much good as its composition would lead us to expect. Its 'lasting' properties are a decided objection, rather than an advantage. If we could make it less lasting-in other words, if we could make it act quicker, it would produce a greater effect, and possess a greater value. In proportion to irs constituents, the barn-yard manure is far cheaper than the guano, but it has a less beneficial effect, because these constituents are not more completely decomposed and rendered available."

"That," said I, "opens up a very important question. We have more real value in manure than most of us are as yct able to brin? out and turn to good account. The sandy-land farmer has an advantage over the clay-land farmer in this respect. The latter has a naturally richer soil, but it costs him more to work it, and manure does not act so rapidly'. The clay-land farmer should use his best endeavors to decompose his manure."

"Yes," said the Doctor, " and, like John Johnston, he will probahly find it to his advantage to use it larcelv as a top-dressing on the suiface. Exposing manure to the atmosphere, spread out on 
the land for several months, and harrowing it occasionally, will do much to render its constituents available. But let us return to Mr. Lawes' wonderful experiments."

"On eight plots," suid I, " 300 lbs. of ammonia-salts were used without any other manures, and the average yield on these cight plots was nearly 26 bushels per acre, or an average increase of 9 bushels per acre. The same amount of ammonia-salts, with the addition of superphosphate of lime, gave an increase of 13 bushcis per acre. 400 lbs. ammonia salts, with superphosphate of lime, gave an increus of nearly $16^{\circ}$ bushels per acre, or three bushels per acre more than where 14 tons of barn-yard manure had be?n used four years in succession.

"I hope, after this, the Deacon will forgive me for dwelling on the value of available nitrozen or ammonia as a manure for wheat."

"I sec," said the Deacon, " that ground rice was used this year for manure; and in 1845 , tapioca was also used as a manure. The Connecticut Tobacco growers a few years since used corn-meal for manure, and you thought it a great waste of good food."

I think so still. But we will not discuss the matter now. Mr. Lawes wanted to ascertain whether carbonaceous mattcr was needed by the growing wheat-plants, or whether they could get a.l they needed from the soil and the atmosphere. The enormous quantities of carbonaceous matter supplied by the barn-yard manure, it is quite evident, are of little value as a manure for wheat. And the rice seems to have done very little more good than we shoul:l expect from the $22 \mathrm{lbs}$. of nitrogen which it contained. The large quantity of carbonaceous matter evidently did little good. Avail. able carbonaceous matter, such as starch, sugar, and oil, was intended as food for man and beast-not as food for wheat or tobacco.

The following table gives the results of the experiments the fifth year, 1847-8. 
EXPeriments at Rothamsted on the Growth of

TABLE V.-MANURES AND PRODUCE; 5TH SEASON, 1847-8.

\begin{tabular}{|c|c|c|c|c|c|c|c|c|c|c|c|}
\hline \multirow[b]{3}{*}{ 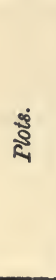 } & & \multicolumn{7}{|c|}{ Maliures Per Acre. } \\
\hline & \multirow[b]{2}{*}{ 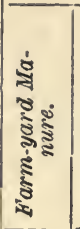 } & \multirow[b]{2}{*}{ 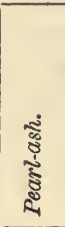 } & \multirow[b]{2}{*}{ 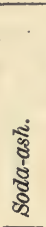 } & \multirow[b]{2}{*}{ 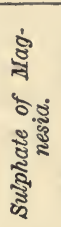 } & \multirow[b]{2}{*}{ 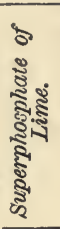 } & \multicolumn{3}{|c|}{$\begin{array}{c}\text { Superphosphate of } \\
\text { Lime. }\end{array}$} & \multirow{2}{*}{ 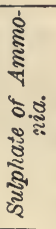 } & \multirow[b]{2}{*}{ 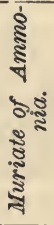 } & \multirow[b]{2}{*}{ 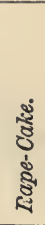 } \\
\hline & & & & & & 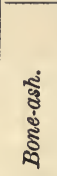 & 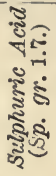 & 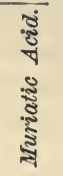 & & & \\
\hline & Tons. & $13 \mathrm{~s}$. & lbs. & lbs. & lbs. & lbs. & lbs. & lbs. & lbs. & lbs. & lbs. \\
\hline $\begin{array}{l}0 \\
1\end{array}$ & $\ddot{. .}$ & $\ddot{0}$ & $\begin{array}{l}\cdots \\
\ldots\end{array}$ & .. & $\begin{array}{c}2240 \\
. .\end{array}$ & $\ddot{0}$ & $\ddot{\ddot{*}}$ & $\ddot{0}$ & 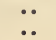 & $\ddot{0}$ & $\ddot{0}$ \\
\hline 2 & i4 & … & .. & .. & .. & .. & .. & .. & .. & .. & .. \\
\hline 3 & \multicolumn{2}{|c|}{ Unmanured. } & $\cdots$ & $\cdot \cdot$ & *. & $\cdots$ & 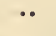 & $\cdot \cdot$ & $\bullet$ & $\cdots$ & • \\
\hline 4 & $\bullet$ & $\cdots$ & .. & .. & •. & 200 & .. & 200 & 300 & -. & •. \\
\hline $\begin{array}{l}5 a \\
5 b\end{array}$ & $\ddot{0}$ & $\begin{array}{l}300 \\
300\end{array}$ & $\begin{array}{l}200 \\
200\end{array}$ & $\begin{array}{l}100 \\
103\end{array}$ & 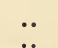 & $\begin{array}{l}200 \\
200\end{array}$ & $\begin{array}{l}150 \\
150\end{array}$ & . & $\begin{array}{l}250 \\
200\end{array}$ & $\begin{array}{l}250 \\
200\end{array}$ & $5 \ddot{000}$ \\
\hline $6 a$ & $\ddot{\ddot{*}}$ & .. & $\begin{array}{l}200 \\
\cdots\end{array}$ & .. & $\ddot{. .}$ & 400 & 300 & $\because$ & 200 & 200 & .000 \\
\hline $6 \check{0}$ & .. & .. & .. & .. & $\ddot{0}$ & 200 & 150 & $\ddot{\circ}$ & 200 & 200 & $\ddot{0}$ \\
\hline $7 a$ & .. & .. & .. & .. & .. & 400 & 200 & .. & 159 & 150 & Е00 \\
\hline & -. & •. & -. & .. & $\cdots$ & 200 & 150 & 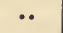 & 150 & 150 & \\
\hline $8 a$ & •. & 300 & 200 & 100 & .. & 200 & 150 & .. & .. & .. & .. \\
\hline $8 b$ & .. & 300 & 200 & 100 & .. & 200 & 150 & .. & . & .. & .. \\
\hline $\begin{array}{l}9 a \\
9 b\end{array}$ & .. & .. & $\bullet$ & .. & .. & 200 & 150 & . & $1 \ddot{50}$ & $\dot{\vec{r}} \dot{0}$ & •. \\
\hline $\begin{array}{r}10 a \\
10 a\end{array}$ & 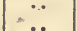 & .. & .. & .• & 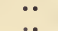 & & 100 & 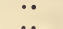 & $\begin{array}{l}150 \\
150\end{array}$ & $\begin{array}{l}100 \\
1=0\end{array}$ & $\ddot{\circ}$ \\
\hline $10 b$ & $\ddot{. .}$ & 300 & $\ddot{200}$ & $1 \ddot{00}$ & $\ddot{.}$ & $2 \ddot{00}$ & $1 \ddot{50}$ & $\ddot{.}$ & 150 & 150 & $\ddot{0}$ \\
\hline $11 a$ & .. & .. & •. & .. & .. & 200 & 150 & .. & 150 & 150 & 500 \\
\hline $11 b$ & .. & 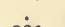 & .. & .. & .. & 200 & 150 & .. & $\approx 00$ & 203 & \\
\hline $12 a$ & $\therefore$ & 300 & .. & .. & .. & 200 & 150 & . & 159 & 150 & 500 \\
\hline $12 b$ & $\therefore$ & 300 & .. & .. & .. & 200 & 150 & .. & 200 & 200 & $\ddot{0}$ \\
\hline $13 a$ & .. & 300 & . & .. & .. & 200 & 150 & . & 150 & 150 & 500 \\
\hline $13 b$ & .. & 200 & .. & .. & .. & 200 & 150 & .. & 200 & 200 & $\ddot{0}$ \\
\hline $\begin{array}{l}14 a \\
14 b\end{array}$ & . & $\begin{array}{l}300 \\
300\end{array}$ & .. & .. & 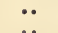 & $\begin{array}{l}200 \\
200\end{array}$ & $\begin{array}{l}150 \\
150\end{array}$ & $\ddot{0}$ & $\begin{array}{l}150 \\
200\end{array}$ & $\begin{array}{l}150 \\
200\end{array}$ & 500 \\
\hline & & & & & & & & & & & \\
\hline $\begin{array}{l}15 a \\
15 b\end{array}$ & . & 300 & 200 & 103 & .. & 200 & •. & 200 & 300 & .. & .. \\
\hline 150 & . & 300 & 200 & 100 & .. & 200 & •. & $\approx 00$ & 300 & •. & $\cdots$ \\
\hline $16 a$ & .. & 300 & 200 & 100 & .. & 200 & 150 & .. & 150 & 150 & $5 \simeq 0$ \\
\hline 160 & .. & 300 & 200 & 100 & & 200 & 150 & .. & 150 & $1: 0$ & $\Sigma 00$ \\
\hline $17 a$ & .. & 300 & 200 & 100 & .. & 200 & 150 & .. & 200 & 200 & .. \\
\hline 170 & .. & 300 & 200 & 100 & $\cdots$ & 200 & 150 & .. & 200 & 200 & .. \\
\hline $18 a$ & .. & 300 & 200 & 100 & . & 200 & 150 & .. & 150 & 150 & .. \\
\hline $18 b$ & $\cdots$ & 203 & 200 & 100 & .. & 200 & 150 & .. & 150 & 150 & .. \\
\hline 19 & & & .. & .. & .. & 200 & .. & 200 & 300 & .. & ธ0ग \\
\hline 20 & Unmar & aured. & .. & . & .. & - & .. & .. & .. & .. & .. \\
\hline $\begin{array}{l}21 \\
22\end{array}$ & .. & .. & .. & .. & .. & .. & .. & . & •. & .. & •. \\
\hline
\end{tabular}


Wheat, Year after Yeari, on the same Land.

MANURES AND SEED (OLD RED TAMMAS) SOWN AUTUMN, 1847.

\begin{tabular}{|c|c|c|c|c|c|c|c|c|c|c|c|c|}
\hline \multirow{3}{*}{ ڤ్ } & \multicolumn{7}{|c|}{ ProdUCE PER ACRE, ETC. } & \multicolumn{3}{|c|}{$\begin{array}{c}\text { INCREASE क्ष ACRE } \\
\text { BY MaNuRE. }\end{array}$} & \multirow{3}{*}{ 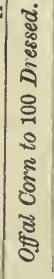 } & \multirow{3}{*}{ 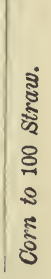 } \\
\hline & Dre & 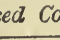 & & & & & & & & & & \\
\hline & 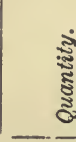 & & 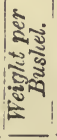 & 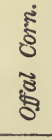 & 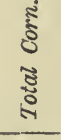 & 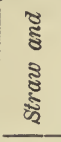 & 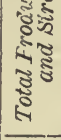 & हें & 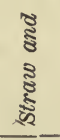 & 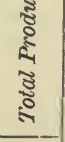 & & \\
\hline $\begin{array}{l}0 \\
1 \\
2 \\
3\end{array}$ & $\begin{array}{l}\text { ush. } \\
19 \\
16 \\
25 \\
14\end{array}$ & $\begin{array}{l}\text { Pks. } \\
0 \frac{8}{4} \\
0 \frac{8}{4} \\
2 \frac{8}{4} \\
3\end{array}$ & $\begin{array}{l}1 \mathrm{bs} . \\
53.4 \\
53.6 \\
53.2 \\
57.3\end{array}$ & $\begin{array}{l}\text { lbs. } \\
138 \\
160 \\
210 \\
106\end{array}$ & & & $\begin{array}{l}\text { lbs. } \\
3333 \\
2859 \\
4746 \\
2664\end{array}$ & $\begin{array}{l}1 \mathrm{bs} . \\
307 \\
1 \% 2 \\
753 \\
\cdots\end{array}$ & $\begin{array}{r}1 \mathrm{hs} . \\
362 \\
23 \\
1329 \\
. .\end{array}$ & $\begin{array}{c}1 \mathrm{bs} . \\
609 \\
195 \\
2082 \\
\cdots\end{array}$ & $\begin{array}{l}13.4 \\
16.3 \\
13.8 \\
12.1\end{array}$ & $\begin{array}{l}60.7 \\
64.7 \\
56.0 \\
55.6\end{array}$ \\
\hline 4 & 24 & $0 t$ & 3.5 & 172 & 1583 & $2 \% 13$ & 4296 & 631 & 1001 & 1632 & 12.0 & 58.3 \\
\hline $\begin{array}{l}5 a \\
5 b \\
6 a \\
6 b \\
7 a \\
7 b\end{array}$ & & $\begin{array}{l}3 \\
3 t \\
31 \\
6\end{array}$ & \begin{tabular}{|l}
59.2 \\
59.1 \\
53.8 \\
56.9 \\
59.4 \\
59.6
\end{tabular} & $\begin{array}{l}144 \\
107 \\
214 \\
216 \\
106 \\
187\end{array}$ & & $\begin{array}{l}3266 \\
3533 \\
2378 \\
2938 \\
3038 \\
3413\end{array}$ & $53 \pi 6$ & $\begin{array}{l}959 \\
983 \\
720 \\
735\end{array}$ & $\begin{array}{l}1554 \\
1821 \\
1166 \\
1256 \\
1376 \\
1701\end{array}$ & $\begin{array}{l}2513 \\
2801 \\
1866 \\
2041 \\
230^{\prime} 0 \\
2712\end{array}$ & $\begin{array}{r}7.9 \\
5.8 \\
14.6 \\
14.0 \\
5.9 \\
10.3\end{array}$ & $\begin{array}{l}62 . \\
5 \%\end{array}$ \\
\hline 9 & & $\begin{array}{l}3 \\
0 \frac{1}{6} \\
2 \frac{1}{2} \\
c \frac{1}{6} \\
1 \\
0 t\end{array}$ & $\begin{array}{l}56.2 \\
59.4 \\
56.7 \\
53.3 \\
53.1 \\
57.8\end{array}$ & $\begin{array}{l}154 \\
127 \\
125 \\
208 \\
215 \\
155\end{array}$ & & & & & $\begin{array}{r}605 \\
436 \\
233 \\
1206 \\
655 \\
1214\end{array}$ & $\begin{array}{r}916 \\
751 \\
462 \\
1923 \\
1037 \\
1866\end{array}$ & $\begin{array}{l}13.6 \\
11.1 \\
11.6 \\
13.9 \\
19.0 \\
10.6\end{array}$ & 51. \\
\hline & 25 & $2 \frac{1}{2}$ & $\begin{array}{l}53.4 \\
58.8 \\
58.5\end{array}$ & $\begin{array}{l}23 \\
207 \\
17 \\
16 \\
25 \\
22 \\
18 \\
227\end{array}$ & & & & $\begin{array}{r}1003 \\
7 \% 8 \\
882 \\
7 \% 4\end{array}$ & & 1959 & $\mid \begin{array}{r}13.1 \\
14.1 \\
9.3 \\
10.7 \\
14.7 \\
14.6 \\
11.1 \\
15.1\end{array}$ & 53. \\
\hline 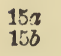 & & $\frac{2 \frac{1}{2}}{2 \frac{8}{8}}$ & $\begin{array}{l}59.1 \\
56.9\end{array}$ & & & & $46 \approx 3$ & $\begin{array}{l}619 \\
655\end{array}$ & $\begin{array}{l}1225 \\
1304\end{array}$ & 1959 & $\begin{array}{l}18.1 \\
14.1\end{array}$ & 58. \\
\hline $\begin{array}{l}15 a \\
16 b \\
17 a \\
17 b \\
18 a\end{array}$ & $\begin{array}{l}26 \\
26\end{array}$ & $\begin{array}{l}37 \\
12 \\
27 \\
27 \\
2 \frac{1}{2} \\
3 \\
28 \\
28\end{array}$ & \begin{tabular}{|l|}
60.0 \\
78.4 \\
59.7 \\
59.7 \\
59.2 \\
59.6
\end{tabular} & $\begin{array}{l}184 \\
171 \\
285 \\
222 \\
150 \\
215\end{array}$ & 1804 & $\begin{array}{l}2935 \\
3056\end{array}$ & $\begin{array}{l}4669 \\
4860\end{array}$ & $\begin{array}{r}1021 \\
976 \\
981 \\
994 \\
782 \\
852\end{array}$ & $\begin{array}{l}16: 58 \\
1581 \\
1612 \\
1223 \\
1344\end{array}$ & $\begin{array}{l}2005 \\
2196\end{array}$ & $\begin{array}{r}10.2 \\
9.4 \\
17.0 \\
12.6 \\
9.2 \\
13.3\end{array}$ & 59 \\
\hline $\begin{array}{l}19 \\
20 \\
21\end{array}$ & $\begin{array}{l}29 \\
16 \\
\text {.. }\end{array}$ & $\begin{array}{l}1 \frac{8}{4} \\
\text { Cक } \\
. .\end{array}$ & $\begin{array}{c}56.2 \\
58.3 \\
. .\end{array}$ & $\begin{array}{r}185 \\
111 \\
. .\end{array}$ & $\begin{array}{c}1050 \\
\cdots\end{array}$ & $\begin{array}{c}32^{225} \\
1721 \\
\ldots\end{array}$ & $\begin{array}{l}5123 \\
2771 \\
. .\end{array}$ & $\begin{array}{r}886 \\
98 \\
. .\end{array}$ & $\begin{array}{r}1583 \\
9 \\
. .\end{array}$ & $\begin{array}{c}2469 \\
107 \\
\ldots\end{array}$ & $\begin{array}{c}10.4 \\
11.3 \\
. .\end{array}$ & 61 . \\
\hline
\end{tabular}


This season was considered unfavorable for wheat. The continuously unmanured plot proluced $14 \frac{3}{4}$ bushels, and the plot receiving 14 tons of barn yard manure, 250 bushels per acre nearly.

$300 \mathrm{lbs}$. of ammonia-salts alone on plot $10 a$, gave $19 \frac{1}{4}$ busl:els per acre, while the same quantity of armonia, with superphosphate in addition, gave, on plot 93,25 bushels per acre.

The addition to the above manures of $300 \mathrm{lbs}$. of potash, $200 \mathrm{lks}$. soda, and $100 \mathrm{lbs}$. sulphate of magnesia, on plot 10b, gave precisely the same yicld per acre as the ammonia and the superphosphate alone. The potash, soda, and magnesia, therefore, did no good.

$400 \mathrm{lbs}$. of ammonia-salts, with superphosphate, potash, etc., gave, on plot $17 b$, nearly 29 bushels per acre, or $3 \frac{1}{2}$ bushels more than the plot which has now received 70 tons of barn-yard manure in five successive years.

"I see that, on plot 0 ," said the Deacon, " one ton of superphosphate was used per acre, and it gave only half a bushel per acre more than $350 \mathrm{lbs}$. on $9 a . "$

"This proves," said I, "that an excessive cose of superphosphate will do no harm. I am not sure that $100 \mathrm{lbs}$. of a good superphosphate drilled in with the seed, would not have done as much good as a ton per acre."

"You say," remarked the Deacon, "that the season was unfavorable for wheat. And yet the no-manure plot produced nearly 15 bushels of wheat per acre."

"That is all true," said I, " and yet the season was undoubtedly an unfavorable one. This is shown not only in the less yield, but in the inferior quality of the grain. The 'dressed corn' on the nomanure plot this year only weighed $57 \frac{1}{8} \mathrm{lbs}$. per bushel, while last year it weighed $61 \mathrm{lbs}$. per bushel."

"By the way," said the Doctor, "what do Messrs. Lawes and Gilbert mean by 'dressed corn' ?"

"By 'corn,", said I, " they mean wheat; and by 'dressed corn' they mean wheat that has been run through a fanning-mill until all the light and shrunken grain is blown or sieved out. In other words, 'dressed corn' is wheat carefully cleaned for market. The English farmers take more pains in cleaning their grain than we do. And this 'dressed corn' was as clean as a good fanning-mill could make it. You will observe that there was more 'cffal corn' this year than last. This also indicates an unfavorable season."

"It would have been very interesting," said the Doctor, "if Messrs. Lawes and Gilbert had analyzed the wheat produced by the different manures, so that we might have known sumething in rc- 
gard to the quality of the flour as influenced by the use of different fertilizers."

"They did that very thing," said I, "and not only that, but they made the wheat grown on different plots, into flour, and ascertained the yield of tlour from a given weight of wheat, and the amount of bran, middlings, etc., etc. They obtained some very interesting and importınt results. I was there at the time. But this is not the plac3 to discuss the question. I am often amused, however, at the remariss we often hear in regard to the inferior quality of our wheat as compared to what it was when the country was new. Many seem to think that 'there is something lacking in the soil'-some say potash, and some phosphates, and some this, and some that. I believe nothing of the kind. Depend upon it, the variety of the wheat and the soil and season have much more to do with the quality or strength of the flour, than the chemical composition of the manures applied to the land."

"At any rate," said the Doctor, "we may be satisfied that anything that will produce a vigorous, healthy growth of wheat is favorable to quality. We may use manures in excess, and thus produce over-luxuriance and an unhealthy growth, and have poor, shrunken grain. In this case, it is not the use, but the abuse of the manure that does the mischief. We must not manure higher than the season will bear. As yet, this question rarely troubles us. Hitherto, as a rule, our seasons are better than our farming. It may not always be so. We may find the liberal use of manure so profitable that we shall occasionally use it in excess. At present, however, the tendency is all the other way. We have more grain of inferior quality from lack of ferility than from an excess of plant-food."

"That may be true," said I, "but we have more poor, inferior wheat from lack of draining and good culture, than from lack of plant-food. Red-root, thistles, cockle, and chess, have done more to injure the reputation of 'Genesee Flour,' than any other one thing, and I should like to hear more said about thorough cultivation, and the destruction of weeds, and less about soil exhaustion."

The following table shows the results of the experiments the 8:xth year, 1848-9. 
Experinents at Rothamsted on the Growth of TABLE VI.-MANURES AND PRODUCE; 6TH SEA8ON, 1818-9.

\begin{tabular}{|c|c|c|c|c|c|c|c|c|c|c|}
\hline \multirow[b]{3}{*}{ 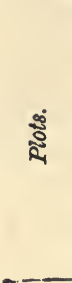 } & \multicolumn{10}{|c|}{ MANURES PER ACRE. } \\
\hline & \multirow[b]{2}{*}{ 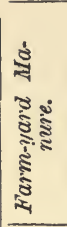 } & \multirow[b]{2}{*}{ 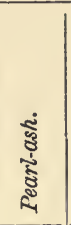 } & \multirow[b]{2}{*}{ 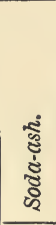 } & \multirow[b]{2}{*}{ 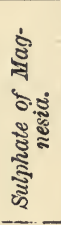 } & \multicolumn{3}{|c|}{ Superphosphate of Lime. } & \multirow[b]{2}{*}{ 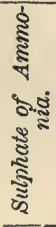 } & \multirow[b]{2}{*}{ 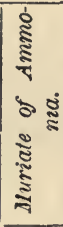 } & \multirow[b]{2}{*}{ 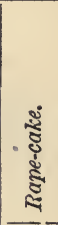 } \\
\hline & & & & & 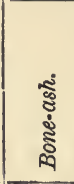 & 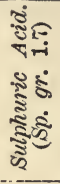 & 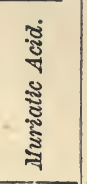 & & & \\
\hline & Tons. & lbs. & lbs. & lbs. & lbs: & $\begin{array}{l}1 b 8 . \\
450\end{array}$ & lbs. & lbs. & lbs. & lbs. \\
\hline $\begin{array}{l}0 \\
1\end{array}$ & $\ddot{0}$ & $60 \ddot{0}$ & $4 \ddot{00}$ & $2 \ddot{00}$ & $\begin{array}{c}\text { fovo } \\
. .\end{array}$ & $\begin{array}{c}450 \\
. .\end{array}$ & $\ddot{*}$ & $\ddot{*}$ & 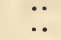 & $\ddot{x}$ \\
\hline 2 & 14 & ̈ㅜㅁ & 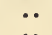 & $\ddot{*}$ & $\ddot{*}$ & $\ddot{*}$ & 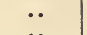 & .. & . & .. \\
\hline 3 & \multicolumn{2}{|c|}{ Unmanured. } & $\cdot \cdot$ & $\cdots$ & •• & 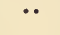 & 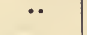 & 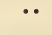 & •. & $\cdots$ \\
\hline 4 & $\cdots$ & $\cdots$ & •• & *. & 200 & $\cdots$ & 200 & 300 & $\cdots$ & $\cdots$ \\
\hline $5 a$ & $\cdots$ & 300 & 200 & 100 & 200 & 150 & .. & 250 & 250 & \\
\hline $5 b$ & .. & 300 & & 100 & & 150 & .. & $2 \mathrm{CO}$ & 200 & 500 \\
\hline $6 a$ & $\ddot{*}$ & $\begin{array}{l}3 \\
3\end{array}$ & $\begin{array}{l}200 \\
200\end{array}$ & 100 & 200 & $\begin{array}{l}150 \\
150\end{array}$ & 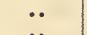 & $\begin{array}{l}200 \\
200\end{array}$ & 200 & $\ddot{*}$ \\
\hline $\begin{array}{l}60 \\
7 a\end{array}$ & $\ddot{*}$ & $\begin{array}{l}300 \\
300\end{array}$ & 200 & $\begin{array}{l}100 \\
100\end{array}$ & $\begin{array}{l}200 \\
200\end{array}$ & $\begin{array}{l}150 \\
150\end{array}$ & $\because$. & $\begin{array}{l}200 \\
200\end{array}$ & $\begin{array}{l}200 \\
200\end{array}$ & $\ddot{. .}$ \\
\hline $7 b$ & .. & 300 & $2 c 0$ & 100 & 200 & 150 & .. & 200 & 200 & .. \\
\hline $8 a$ & \multicolumn{2}{|c|}{ Unmanured. } & - & $\cdots$ & .. & $\cdots$ & •. & •. & .. & \\
\hline $8 b$ & 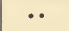 & -. & .. & $\cdots$ & •. & $\cdots$ & .. & .. & .. & 2000 \\
\hline $\begin{array}{l}9 a \\
0 b\end{array}$ & \multirow{2}{*}{\multicolumn{2}{|c|}{ Unmanured. }} & - & $\ddot{*}$ & 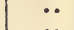 & $\cdots$ & $\because$ & 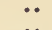 & .. & $2(0)$ \\
\hline $\begin{array}{r}90 \\
10 a\end{array}$ & & & 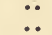 & $\ddot{.}$ & $\ddot{.}$ & $\ddot{0}$ & $\ddot{. .}$ & $\ddot{2} \ddot{0}$ & $2 \ddot{0} \dot{0}$ & $\ddot{. .}$ \\
\hline $10 b$ & $\ddot{0}$ & $\because$ & $\ddot{0}$ & 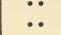 & $\ddot{0}$ & $\because$ & $\ddot{0}$ & 200 & 200 & $\ddot{0}$ \\
\hline $11 a$ & .. & 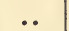 & .. & - & 200 & 150 & .. & 200 & 200 & .. \\
\hline $11 b$ & .. & & $\bullet$ & -. & & 150 & .. & 20 & 200 & .. \\
\hline $12 a$ & .. & 300 & & .. & 200 & 150 & .. & 20 & 200 & .. \\
\hline 12 & .. & 50 & . & .. & & 150 & .. & 20 & 200 & .. \\
\hline 13 & .. & 30 & & & 2 & 15 & .. & 20 & 200 & .. \\
\hline 13 & .. & & . & .. & & 150 & 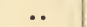 & $2^{n}$ & 20 & .. \\
\hline $14 a$ & .. & 3 & - & .. & 20 & 150 & .. & 20 & 20 & .. \\
\hline $14 b$ & .. & 300 & & & 200 & 150 & .. & 200 & 200 & . \\
\hline $15 a$ & .. & 300 & $2 r 0$ & 100 & 20 & .. & 200 & 300 & .. & \\
\hline $15 b$ & .. & 300 & 200 & 100 & 200 & .. & 200 & 300 & . & 500 \\
\hline $16 a$ & .. & 300 & 200 & 100 & 2 & $15 ?$ & $\bullet$ & 20 & 2,0 & .. \\
\hline $16 b$ & & & & 100 & & 150 & $\cdots$ & 200 & 200 & .. \\
\hline $17 x$ & .. & 300 & 200 & 109 & 20 & 150 & .. & 20 & 20 & .. \\
\hline $17 b$ & $\cdots$ & 300 & 20 & 10 & & 150 & & 20 & 20 & .. \\
\hline $18 a$ & .. & 300 & 21 & 100 & $2 n$ & 150 & .. & 20 & 20 & .. \\
\hline $18 b$ & & 300 & 200 & 100 & 200 & 150 & .. & 200 & 200 & .. \\
\hline 17 & & & & & 200 & .. & 200 & 300 & .. & 500 \\
\hline 20 & Unma & aured. & ." & .. & .. & .. & .. & .. & .. & .. \\
\hline $\left.\begin{array}{l}21 \\
28\end{array}\right\}$ & \multicolumn{8}{|c|}{ Mixture of the residue of most of the other manures. } & . & . \\
\hline
\end{tabular}


Wheat, Year after Year, on the same Land.

MANURES AND SEED (RED CLUSTFR), SOWN AUTUMN, 1818.

\begin{tabular}{|c|c|c|c|c|c|c|c|c|c|c|c|c|}
\hline \multirow{3}{*}{ ई̊ } & \multicolumn{7}{|c|}{ Produce per Acre, etc. } & \multicolumn{3}{|c|}{$\begin{array}{c}\text { INCREASE } \% \text { ACRE } \\
\text { BY MaNURE. }\end{array}$} & \multirow{3}{*}{ 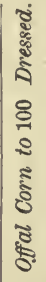 } & \multirow{3}{*}{ 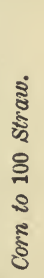 } \\
\hline & Dress & $\mathrm{ed} \mathrm{CO}$ & orn. & & & & & & & & & \\
\hline & 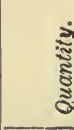 & & 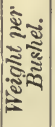 & 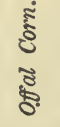 & 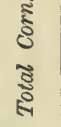 & 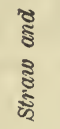 & 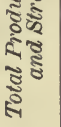 & క్ & 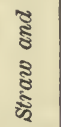 & 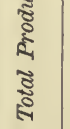 & & \\
\hline $\begin{array}{l}0 \\
1 \\
2 \\
3\end{array}$ & $\begin{array}{c}\text { Bush. } \\
. \\
\ddot{31} \\
19\end{array}$ & $\begin{array}{c}\text { Pks. } \\
\ddot{0} \\
\ddot{0} \\
1\end{array}$ & $\begin{array}{c}\mathrm{lbs} . \\
\ddot{0} \\
63.8 \\
61.4\end{array}$ & $\begin{array}{c}\text { lbs. } \\
\because \\
10 \dot{7} \\
47\end{array}$ & $\begin{array}{c}\text { lbs. } \\
\ddot{0} \\
20098 \\
12 \& 9\end{array}$ & $\begin{array}{c}1 \mathrm{bs} . \\
\ddot{0} \\
3029 \\
1614\end{array}$ & $\begin{array}{c}\text { lbs. } \\
\ddot{y} \\
\ddot{0} 0 \dot{9} 7 \\
2843\end{array}$ & $\begin{array}{l}\text { lbs. } \\
. . \\
\ddot{8} 99 \\
. .\end{array}$ & $\begin{array}{c}\text { lbs. } \\
\ldots \\
\text { 14i5 } \\
. .\end{array}$ & $\begin{array}{c}\text { Ibs. } \\
. . \\
2 \ddot{2} 54 \\
. .\end{array}$ & $\begin{array}{l}\ddot{7} \\
4.7 \\
3.9\end{array}$ & $\begin{array}{l}\ddot{6} \\
76.3 \\
76.1\end{array}$ \\
\hline 4 & 30 & 0 & 63.0 & 110 & 2063 & 2645 & 4708 & 834 & 1081 & 1865 & 5.6 & 78.0 \\
\hline $\begin{array}{l}5 a \\
5 b \\
6 a \\
6 b \\
7 a \\
7 b\end{array}$ & $\begin{array}{l}37 \\
39 \\
36 \\
37 \\
38 \\
37\end{array}$ & $\begin{array}{l}1 \frac{1}{4} \\
3 \frac{1}{7} \\
1 \frac{1}{8} \\
3 \frac{8}{4} \\
2 \frac{1}{4} \\
3 \frac{8}{4}\end{array}$ & \begin{tabular}{|l|}
63.1 \\
63.4 \\
63.0 \\
63.0 \\
631 \\
62.9
\end{tabular} & $\begin{array}{r}89 \\
97 \\
117 \\
94 \\
137 \\
141\end{array}$ & $\begin{array}{l}2446 \\
2651 \\
2410 \\
2484 \\
2576 \\
2531\end{array}$ & $\begin{array}{l}2589 \\
3824 \\
3072 \\
3516 \\
3584 \\
3396\end{array}$ & $\begin{array}{l}6035 \\
6475 \\
5482 \\
61 C 0 \\
6110 \\
5427\end{array}$ & $\begin{array}{l}1217 \\
1422 \\
1181 \\
1 \% 55 \\
1 £ 47 \\
13 C 2\end{array}$ & $\begin{array}{l}1575 \\
2210 \\
1 \leq 58 \\
1 ! 02 \\
1970 \\
1782\end{array}$ & $\begin{array}{l}3192 \\
3632 \\
2639 \\
3157 \\
3317 \\
8084\end{array}$ & $\begin{array}{l}3.7 \\
5.0 \\
5.1 \\
3.9 \\
5.6 \\
5.9\end{array}$ & $\begin{array}{l}68.1 \\
69.3 \\
78.4 \\
70.6 \\
71.9 \\
74.5\end{array}$ \\
\hline $\begin{array}{c}8 a \\
83 \\
9 a \\
9 b \\
10 a \\
10 b\end{array}$ & $\begin{array}{l}\mathbf{2 2} \\
\mathbf{3 1} \\
30 \\
\mathbf{2 2} \\
32 \\
\mathbf{3 2}\end{array}$ & $\begin{array}{l}3 \\
2 \frac{1}{8} \\
2 \frac{8}{4} \\
1 \frac{1}{4} \\
2 \frac{1}{4} \\
1 \frac{1}{6}\end{array}$ & \begin{tabular}{l|}
61.7 \\
63.0 \\
62.8 \\
62.3 \\
62.3 \\
63.3
\end{tabular} & $\begin{array}{r}76 \\
85 \\
111 \\
80 \\
112 \\
110\end{array}$ & $\begin{array}{l}1481 \\
2 C 80 \\
2 C 35 \\
1475 \\
2141 \\
2157\end{array}$ & $\begin{array}{l}1815 \\
3166 \\
2683 \\
1810 \\
2851 \\
2960\end{array}$ & $\begin{array}{l}3296 \\
5246 \\
4718 \\
3285 \\
4992 \\
5117\end{array}$ & $\begin{array}{l}252 \\
851 \\
806 \\
246 \\
912 \\
928\end{array}$ & $\begin{array}{r}201 \\
15: 2 \\
1069 \\
196 \\
1237 \\
1346\end{array}$ & $\begin{array}{r}453 \\
2403 \\
1875 \\
432 \\
2149 \\
2274\end{array}$ & $\begin{array}{l}5.3 \\
4.3 \\
5.8 \\
5.7 \\
5.5 \\
5.3\end{array}$ & $\begin{array}{l}81.6 \\
65.7 \\
75.8 \\
81.5 \\
75.1 \\
72.9\end{array}$ \\
\hline $\begin{array}{l}11 a \\
11 b \\
12 a \\
12 b \\
13 a \\
13 b \\
14 a \\
14 b\end{array}$ & $\begin{array}{l}35 \\
32 \\
35 \\
34 \\
34 \\
34 \\
34 \\
31\end{array}$ & $\begin{array}{l}C \frac{1}{3} \\
1 \frac{1}{4} \\
3 \frac{1}{4} \\
1 \frac{1}{4} \\
3 \frac{8}{2} \\
2 \frac{1}{4} \\
1 \frac{1}{4} \\
1 \frac{1}{6}\end{array}$ & \begin{tabular}{|l|}
62.6 \\
63.0 \\
64.3 \\
64.3 \\
64.1 \\
64.1 \\
64.3 \\
64.3
\end{tabular} & $\begin{array}{r}121 \\
112 \\
93 \\
71 \\
101 \\
129 \\
56 \\
112\end{array}$ & $\begin{array}{l}2317 \\
2149 \\
2396 \\
2267 \\
2340 \\
2346 \\
2266 \\
2123\end{array}$ & $\begin{array}{l}2892 \\
2942 \\
3371 \\
3300 \\
3286 \\
3246 \\
3211 \\
3218\end{array}$ & $\begin{array}{l}5209 \\
5091 \\
5 \% 67 \\
55 \% 7 \\
55 \% 6 \\
5592 \\
5477 \\
5341\end{array}$ & $\begin{array}{r}1088 \\
820 \\
1167 \\
1048 \\
1111 \\
1117 \\
1 C 37 \\
894\end{array}$ & $\begin{array}{l}1278 \\
1328 \\
1757 \\
1687 \\
1622 \\
1632 \\
1597 \\
1604\end{array}$ & $\begin{array}{l}2366 \\
2248 \\
2924 \\
2735 \\
2733 \\
2749 \\
2634 \\
2498\end{array}$ & $\begin{array}{l}5.6 \\
5.5 \\
4.1 \\
3.2 \\
4.5 \\
5.8 \\
2.5 \\
5.5\end{array}$ & $\begin{array}{l}80.1 \\
73.0 \\
71.1 \\
69.0 \\
72.3 \\
72.3 \\
70.6 \\
66.0\end{array}$ \\
\hline $\begin{array}{l}15 a \\
15 b\end{array}$ & $\begin{array}{l}31 \\
30\end{array}$ & $\begin{array}{l}31 \\
0 \frac{1}{4}\end{array}$ & $\begin{array}{l}64.2 \\
64.1\end{array}$ & $\begin{array}{l}65 \\
68\end{array}$ & $\begin{array}{l}2109 \\
2005\end{array}$ & $\begin{array}{l}3038 \\
3262\end{array}$ & $\begin{array}{l}5147 \\
5267\end{array}$ & $\begin{array}{l}880 \\
766\end{array}$ & $\begin{array}{l}1424 \\
1648\end{array}$ & $\begin{array}{l}2304 \\
2424\end{array}$ & $\begin{array}{l}3.2 \\
3.5\end{array}$ & $\begin{array}{l}694 \\
61.5\end{array}$ \\
\hline $\begin{array}{l}16 a \\
16 b \\
17 a \\
17 b \\
18 a \\
18 b\end{array}$ & $\begin{array}{l}33 \\
33 \\
34 \\
33 \\
32 \\
33\end{array}$ & $\begin{array}{l}11 \\
3 \frac{8}{4} \\
1 \\
1 \frac{1}{4} \\
1 \frac{4}{4} \\
2 \frac{1}{6}\end{array}$ & \begin{tabular}{|l|}
64.5 \\
64.6 \\
64.3 \\
64.4 \\
64.0 \\
64.0
\end{tabular} & $\begin{array}{r}101 \\
75 \\
111 \\
112 \\
93 \\
95\end{array}$ & $\begin{array}{l}2254 \\
2268 \\
2316 \\
2259 \\
2163 \\
2243\end{array}$ & $\begin{array}{l}3384 \\
3559 \\
3891 \\
3858 \\
3592 \\
3779\end{array}$ & $\begin{array}{l}5638 \\
5827 \\
6207 \\
6117 \\
5755 \\
6022\end{array}$ & $\begin{array}{r}1025 \\
1039 \\
1087 \\
1030 \\
934 \\
1014\end{array}$ & $\begin{array}{l}1770 \\
1945 \\
2277 \\
2244 \\
1978 \\
2165\end{array}$ & $\begin{array}{l}2795 \\
2 ! 84 \\
3864 \\
3264 \\
2912 \\
3179\end{array}$ & $\begin{array}{l}4.7 \\
3.4 \\
5.1 \\
5.2 \\
4.5 \\
4.4\end{array}$ & $\begin{array}{l}66.6 \\
63.7 \\
59.4 \\
5.5 \\
60.2 \\
59.3\end{array}$ \\
\hline $\left.\begin{array}{l}19 \\
20 \\
21 \\
22\end{array}\right\}$ & $\begin{array}{l}29 \\
\because . \\
\because .\end{array}$ & $\begin{array}{l}2 z \\
\because \\
\cdots\end{array}$ & $\begin{array}{c}63.9 \\
\cdots\end{array}$ & $\begin{array}{c}102 \\
\cdots \\
\cdots\end{array}$ & $\begin{array}{c}1991 \\
\because .\end{array}$ & $\begin{array}{c}3270 \\
\cdots\end{array}$ & $\begin{array}{c}5264 \\
\cdots\end{array}$ & $\begin{array}{l}765 \\
. \\
. .\end{array}$ & $\begin{array}{c}1656 \\
\cdots \\
\cdots\end{array}$ & $\begin{array}{c}2421 \\
\because \\
\because\end{array}$ & $\begin{array}{l}5.4 \\
\because . \\
\because .\end{array}$ & $\begin{array}{l}61.0 \\
\ddot{.}\end{array}$ \\
\hline
\end{tabular}


"This was my last year at Rotha!nsted," said I, "and I feel a peculiar interest in looking over the results after such a lapse of time. When this crop was growing, my father, a good practical farmer, but with little faith in chemical manures, paid me a visit. We vent to the experimental wheat-field. The first two plots, 0 and 1, had been dressed, the one with superphosphate, the other with potash, soda, and magnesia. My father did not seem much impressed with this kind of chemical manuring. Stepping to the next plot, where 14 tons of barn-yard manure had been used, he remarked, "this is good, what have you here?"

"Never mind," said I, "we have better crops farther on."

The next plot, No. 3, was the one continuously unmanured. "I can beat this myself," said he, and passed on to the next. "This is better," said he, "what have you here?"

"Superphosphate and sulphate of ammonia."

"Well, it is a good crop, and the straw is bright and stiff."-It turned out 30 bushels per acre, $63 \mathrm{lbs}$. to t'xe bushel.

The next six plots had received very heavy dressings of ammonia-salts, with superphosphate, potash, soda, and magnesia. He examined them with the greatest interest. "What have you here?" he asked, while he was examining $5 a$, which afterwards turned out $37 \frac{1}{4}$ bushels per acro.- " Potash, soda, epsom-salts, superphosphats, and ammonia-but it is the ammonia that does the grood."

He passed to the next plot, and was very enthusiastic over it. "What have you here?"-_Rape-cake and ammonia," said I. "It is a grand crop," said he, and after examining it with great interest, he passed to the next, $6 a$.- "What hare you here?""Ammonia," said I; and at 63 he asked the same question, and I rcplied "ammonia." At 7a, the same question and the same answer. Standing between $7 b$ and $8 a$, he was of course struck with the difference in the crop; $8 a$ was left this year without any manure, and though it had received a liberal supply of mineral manurcs the year before, and minerals and ammonia-salts, and rape-cake, the year previous, it only produced this year, $3 \frac{1}{2}$ bushels more than the plot continuously unmanured. The contrast between the wheat on this plot and the next one. might well interest a practical farmer. There was over 15 bushels per acre more wheat on the one plot than on the other, and 1,581 lbs. more straw.

Passing to the next plot, he exclaimed "this is hetter, but not so good as some that we have passed." - "It has had a heavy dressing of raps-cake," said I, "equal to about 100 lb3. of ammonia per acre, and the next plot was manured this year in the same way. Thz only difference being that one had superphosphate and potash, 
soda, and magnesia, the year before, while the other had superphosphate alone." It turned out, as you see from the table, that the potash, etc., only gave half a bushel more wheat per acre the year it was used, and this year, with $2,000 \mathrm{lbs}$. of rape-cake on each plut, there is only a bushel per acre in favor of the potash, soda, ard magnesia.

The next plot, $9 b$, "was also unmanured and was passed by my factser without comment. "Ah," said he, on coming to the two next plots, $10 x$ and $10 b$, "this is better, what have you here?""Nothing but ammonia," said I, "and I wish you would tell me which is the best of the two? Last year $10 b$ had a heavy dressing of minerals and superphosphate with ammonia, and $10 x$ the same quantity of ammonia alone, without superphosphate or other mineral manures. And this year both plots have had a dressing of $40 \mathrm{~J}$ lbs. each of ammonia-salts. Now, which is the best-the plot that had s iperphosphate an 1 minarals last year, or the one without?"- "Well," suid• he; "I can't see any difference. Both are good crops."

You will see from the table, that the plot which had the superphosphate, potash, etc., the year before, gives a peck less wheat this year than the other plot which had none. Practically, the yield is the same. Thare is an increase of 13 bushels of wheat per acreand this increase is clearly due to the ammonia-sxlts alone.

The next plot was also a splcndil crop.

"What have you Lere?"

"Superphosphate and ammonia."

This piot (11a), turned out 35 bushels per acre. The next plot, with phosphates and ammonia, was nearly as good. The next plot, with potash, phosphatez, and ammonia, equally grod, but no better than 11a. There was little or no benefit from the potash, except a little more straw. The next plot was good and I did not wait for the question, but simply said, "ammonia," and the next "ammonia," and the next "ammonia."- Standing still and looking at the wheat, my father asked, "Joe, where can I get this ammonia?" He had previously been a little skeptical as to the value of chemistry, and had not a bigh opinion of "book farmers," but that wheat-crop compelled him to admit "that perhaps, after all, there might be some good in it." At any rate, he wanted to know where be could get ammonia. And, now, as then, every good farmer asks the same question: "Where can I get ammonia?" Before we attempt to answer the question, let us look at the next year's experiments.-The following is the results of the experiments the seventh year, 1849-50. 


\section{EXPERIMENTS AT ROTHAMSTED ON THE Growth O\$T}

TABLE VIr.-MaNUR:is AND ProdUCE; 7TH SEASON. 1949-j0. AFTER THE 2 TO 3 FEET DEEP. MANURES AND SEED

\begin{tabular}{|c|c|c|c|c|c|c|c|c|c|c|}
\hline \multirow[b]{3}{*}{$\frac{\text { s. }}{\tilde{a}}$} & \multicolumn{10}{|c|}{ Manures per Acre. } \\
\hline & \multirow[b]{2}{*}{ 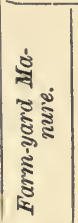 } & \multirow[b]{2}{*}{ 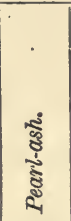 } & \multirow[b]{2}{*}{ 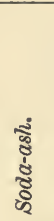 } & \multirow[b]{2}{*}{ 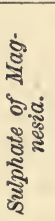 } & \multicolumn{3}{|c|}{ Superphosphate of Lime } & \multirow[b]{2}{*}{ 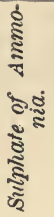 } & \multirow[b]{2}{*}{ 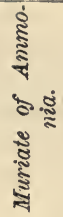 } & \multirow[b]{2}{*}{ 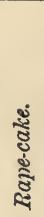 } \\
\hline & & & & & 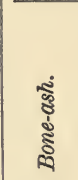 & 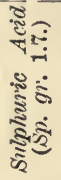 & 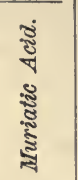 & & & \\
\hline & Tons. & lbs. & lbs. & lbs. & lbs. & lbs. & $\mathrm{lbs}$. & lbs. & lbs. & $\mathrm{lbs}$ \\
\hline $\begin{array}{l}0 \\
1\end{array}$ & $\ddot{r}$ & 6000 & $40 \ddot{0}$ & $\ddot{200}$ & 600 & 450 & .. & .. & $\cdots$ & .. \\
\hline 2 & $\ddot{14}$ & .. & .. & 200 & $\ddot{\circ}$ & 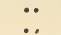 & $\cdots$ & $\ddot{*}$ & $\ddot{\ddot{n}}$ & $\because$ \\
\hline$\tilde{3}$ & \multicolumn{2}{|c|}{ Unmanured. } & $\because$ & $\ddot{. .}$ & $\ddot{0}$ & $\because$ & $\because$ & $\ddot{\cdots}$ & $\ddot{*}$ & $\ddot{\ddot{*}}$ \\
\hline 4 & .. & .. & .. & .. & 200 & .. & 200 & $\$ 00$ & .. & .. \\
\hline $5 a$ & .. & 300 & 200 & 100 & 200 & 150 & - & 250 & 250 & .. \\
\hline $5 b$ & .. & 300 & 200 & 103 & 200 & 150 & 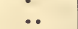 & $2: 0$ & 250 & .. \\
\hline $6 a$ & ... & 300 & 200 & $1 \mathrm{CO}$ & 200 & 150 & .. & 200 & 200 & $\ddot{0}$ \\
\hline $6 b$ & •. & 10 & 20 & 160 & 200 & 150 & .. & $\$ 00$ & 200 & $\ddot{0} \ddot{0}$ \\
\hline $\begin{array}{l}7 a \\
7 b\end{array}$ & $\ddot{\ddot{\prime}}$ & $\begin{array}{l}300 \\
300\end{array}$ & $\begin{array}{l}200 \\
200\end{array}$ & $\begin{array}{l}100 \\
100\end{array}$ & $\begin{array}{l}200 \\
200\end{array}$ & $\begin{array}{l}150 \\
150\end{array}$ & $\because$ & $\begin{array}{l}200 \\
200\end{array}$ & $\begin{array}{l}200 \\
200\end{array}$ & $\begin{array}{l}500 \\
500\end{array}$ \\
\hline $8 a$ & .. & .. & .. & .. & .. & .. & .. & 200 & 200 & 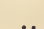 \\
\hline $8 b$ & .. & .. & .. & .. & .. & 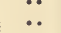 & $\ddot{0}$ & 200 & 200 & $\ddot{0}$ \\
\hline $9 x$ & .. & .. & .. & .. & .. & .. & .. & 200 & 200 & .. \\
\hline 93 & •. & .. & .. & .. & .. & .. & .. & 200 & 200 & .. \\
\hline $\begin{array}{l}10 a \\
10 b\end{array}$ & $\ddot{. .}$ & 300 & $2 \ddot{00}$ & $1 \ddot{00}$ & 200 & 150 & $\ddot{.}$ & 200 & 200 & 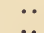 \\
\hline $11 a$ & & & & & & 150 & & 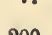 & 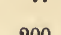 & $\cdots$ \\
\hline $11 b$ & $\ddot{0}$ & .. & $\ddot{.}$ & $\ddot{.}$ & $\begin{array}{l}200 \\
203\end{array}$ & $\begin{array}{l}150 \\
150\end{array}$ & $\bullet$ & 200 & 200 & .. \\
\hline $12 a$ & 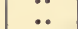 & 3000 & .. & $\ddot{.}$ & 20 & 150 & $\ddot{0}$ & 200 & 200 & $\ddot{\circ}$ \\
\hline $12 b$ & .. & 300 & .. & .. & 200 & 150 & $\ddot{.}$ & 200 & 200 & .. \\
\hline $13 a$ & .. & 300 & .. & .. & $20 J$ & 150 & .. & 200 & 200 & .. \\
\hline $13 b$ & .. & 300 & .. & .. & 203 & 150 & .. & 200 & 200 & .. \\
\hline $14 a$ & .. & 300 & .. & .. & 203 & 150 & .. & 200 & 200 & .. \\
\hline $14 b$ & .. & 300 & - & .. & 200 & 150 & .. & 200 & 200 & .. \\
\hline $15 a$ & .. & 300 & 200 & 100 & 200 & .. & 200 & 300 & .. & \\
\hline $15 b$ & .. & 300 & 200 & $10 \mathrm{~J}$ & 200 & .. & 200 & 300 & .. & 500 \\
\hline $16 u$ & & 300 & 200 & 100 & 200 & 150 & .. & 200 & 200 & .. \\
\hline $16 b$ & .. & 300 & 200 & 100 & 200 & 153 & .. & 200 & 200 & .. \\
\hline $17 a$ & .. & 300 & 200 & 10) & 200 & 150 & .. & 200 & 200 & .. \\
\hline $17 b$ & .. & 300 & 200 & 100 & $2^{\cap} 0$ & 150 & .. & 200 & 200 & .. \\
\hline $18 a$ & .. & 300 & 203 & 100 & 280 & $1 \div 0$ & .. & 200 & 200 & .. \\
\hline $18 b$ & 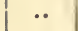 & 300 & 200 & 100 & 200 & 150 & .. & 200 & 200 & - \\
\hline 19 & & & & & 203 & .. & 200 & 300 & .. & 500 \\
\hline 20 & Unma & nured. & .. & .. & .. & .. & & .. & .. & . \\
\hline $\left.\begin{array}{l}21 \\
22\end{array}\right\}$ & \multicolumn{9}{|c|}{ Mixtare of the residue of most of the other manures. } & .. \\
\hline
\end{tabular}


Wheat, Year after Year, on the same Land.

HARVEST OF 1849 THE FIELD WAS TILE-DRAINED IN EVERT ALTERNATE FURROW, (RED CLUSTER), SOWN IN $\triangle$ UTUMN, 1849.

\begin{tabular}{|c|c|c|c|c|c|c|c|c|c|c|c|c|}
\hline \multirow{3}{*}{ 芯 } & \multicolumn{7}{|c|}{ Produce per Acre, etc. } & \multicolumn{3}{|c|}{$\begin{array}{l}\text { INCREASE } \% \text { ACRE } \\
\text { BX MANURE. }\end{array}$} & \multirow{3}{*}{ 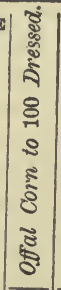 } & \multirow{3}{*}{ 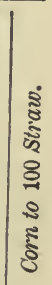 } \\
\hline & \multirow{2}{*}{\multicolumn{2}{|c|}{ 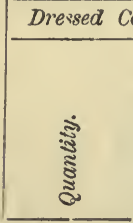 }} & orn. & & & & ह & & & & & \\
\hline & & & 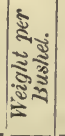 & 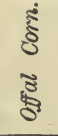 & 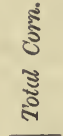 & 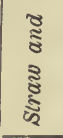 & 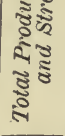 & ริ่ & 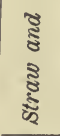 & 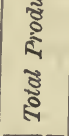 & & \\
\hline 0 & $\begin{array}{c}\text { Bush. } \\
19\end{array}$ & $\begin{array}{l}\text { Ylis. } \\
\text { 1t }\end{array}$ & $\begin{array}{l}1 \mathrm{bs} . \\
60.8\end{array}$ & $\underset{42}{\mathrm{Jbs} .}$ & $\begin{array}{l}\text { lbs. } \\
1220\end{array}$ & $\begin{array}{l}\text { lbs. } \\
2037\end{array}$ & $\begin{array}{l}1 \mathrm{bs} . \\
3257\end{array}$ & $\begin{array}{l}\text { lbs. } \\
218\end{array}$ & $\begin{array}{l}\mathrm{lbs} . \\
318\end{array}$ & $\mathrm{lbs}$. & 3.5 & 599 \\
\hline $\begin{array}{l}1 \\
2 \\
3\end{array}$ & $\begin{array}{l}\ddot{28} \\
15\end{array}$ & $\begin{array}{l}\ddot{2} \\
3 t\end{array}$ & $\begin{array}{l}61.9 \\
60.6\end{array}$ & $\begin{array}{l}\ddot{98} \\
41\end{array}$ & $\begin{array}{l}1 \ddot{861} \\
1002\end{array}$ & $\begin{array}{l}3 \ddot{4} 5 \\
1719\end{array}$ & $\begin{array}{l}5106 \\
2721\end{array}$ & $\begin{array}{l}\ddot{8} \dot{9} 9 \\
\cdots\end{array}$ & $\begin{array}{c}1 \ddot{5} \dot{2} 6 \\
.\end{array}$ & $\begin{array}{c}\ddot{2335} \\
\ldots\end{array}$ & $\begin{array}{l}5 . \ddot{4} \\
4.5\end{array}$ & $\begin{array}{l}5 \ddot{3} 3 \\
58.2\end{array}$ \\
\hline 4 & 27 & 3 & 61.2 & 87 & 1785 & 3312 & 5097 & 783 & 1593 & 2376 & 5.1 & 53.9 \\
\hline $\begin{array}{l}5 a \\
5 b \\
6 a \\
6 b \\
7 a \\
7 b\end{array}$ & $\begin{array}{l}29 \\
30 \\
37 \\
29 \\
32 \\
32\end{array}$ & $\begin{array}{l}3 \frac{1}{2} \\
3 \\
C \frac{1}{2} \\
3 \frac{1}{2} \\
1 \\
C t\end{array}$ & $\begin{array}{l}60.4 \\
60.4 \\
61.1 \\
61.3 \\
61.0 \\
61.2\end{array}$ & $\begin{array}{l}171 \\
160 \\
119 \\
148 \\
167 \\
150\end{array}$ & $\begin{array}{l}1974 \\
2018 \\
1939 \\
1930 \\
2134 \\
2112\end{array}$ & $\begin{array}{l}4504 \\
4379 \\
3327 \\
3959 \\
4485 \\
4230\end{array}$ & $\begin{array}{l}6479 \\
6397 \\
5887 \\
5939 \\
6619 \\
6392\end{array}$ & $\begin{array}{r}972 \\
1016 \\
958 \\
978 \\
1132 \\
1110\end{array}$ & $\begin{array}{l}2785 \\
2: j(00 \\
2238 \\
2210 \\
27 i 66 \\
2561\end{array}$ & $\begin{array}{l}3757 \\
3676 \\
3166 \\
3218 \\
3593 \\
3671\end{array}$ & $\begin{array}{l}9.5 \\
8.6 \\
6.3 \\
8.0 \\
8.4 \\
7.6\end{array}$ & $\begin{array}{l}43.8 \\
46.1 \\
49.9 \\
50.0 \\
47.9 \\
49.4\end{array}$ \\
\hline $\begin{array}{c}8 a \\
8 b \\
9 a \\
9 b \\
10 x \\
10 b\end{array}$ & $\begin{array}{l}23 \\
30 \\
30 \\
27 \\
26 \\
17\end{array}$ & $\begin{array}{l}3 \\
1 \\
1 \frac{1}{2} \\
2 \frac{8}{4} \\
3 \frac{4}{4} \\
3 \frac{8}{4}\end{array}$ & $\begin{array}{l}61.1 \\
61.0 \\
60.4 \\
60.8 \\
60.2 \\
61.1\end{array}$ & $\begin{array}{r}101 \\
103 \\
118 \\
80 \\
100 \\
76\end{array}$ & $\begin{array}{l}18.56 \\
1948 \\
1951 \\
1762 \\
1721 \\
1171\end{array}$ & $\begin{array}{l}3407 \\
3591 \\
3550 \\
3165 \\
3089 \\
1949\end{array}$ & $\begin{array}{l}5263 \\
5539 \\
5501 \\
4927 \\
4810 \\
3120\end{array}$ & $\begin{array}{l}854 \\
946 \\
91.9 \\
760 \\
719 \\
169\end{array}$ & $\begin{array}{r}16 \varsigma 8 \\
1872 \\
1831 \\
1416 \\
1370 \\
230\end{array}$ & $\begin{array}{r}2512 \\
2318 \\
2780 \\
2206 \\
2089 \\
399\end{array}$ & $\begin{array}{l}5.5 \\
5.6 \\
6.3 \\
4.7 \\
6.1 \\
6.8\end{array}$ & $\begin{array}{l}54.5 \\
54.2 \\
550 \\
55.7 \\
55.7 \\
60.1\end{array}$ \\
\hline $\begin{array}{l}11 a \\
11 b \\
12 \iota \\
12 b \\
13 \iota \\
133 \\
14 a \\
14 b\end{array}$ & $\begin{array}{l}30 \\
29 \\
29 \\
30 \\
31 \\
30 \\
31 \\
31\end{array}$ & $\begin{array}{l}37 \\
1 \frac{1}{8} \\
38 \\
38 \\
3 \frac{8}{4} \\
1 \frac{7}{8} \\
14 \\
1 \frac{8}{4}\end{array}$ & $\begin{array}{l}61.0 \\
61.1 \\
61.5 \\
61.4 \\
60.2 \\
61.0 \\
61.1 \\
61.5\end{array}$ & $\begin{array}{r}121 \\
14.5 \\
94 \\
115 \\
105 \\
111 \\
102 \\
65\end{array}$ & $\begin{array}{l}2001 \\
1940 \\
1935 \\
2013 \\
2027 \\
1964 \\
2023 \\
1995\end{array}$ & $\begin{array}{l}3306 \\
3741 \\
3921 \\
3975 \\
4023 \\
4008 \\
4052 \\
4015\end{array}$ & $\begin{array}{l}5807 \\
5681 \\
5856 \\
5918 \\
6.53 \\
5972 \\
6075 \\
6010\end{array}$ & $\begin{array}{r}999 \\
938 \\
933 \\
1011 \\
1025 \\
962 \\
1021 \\
9.13\end{array}$ & $\begin{array}{l}2057 \\
2022 \\
2202 \\
2186 \\
237 \% \\
2289 \\
2333 \\
2296\end{array}$ & $\begin{array}{l}3086 \\
2960 \\
3135 \\
3197 \\
333: 32 \\
3251 \\
3354 \\
3289\end{array}$ & $\begin{array}{l}6.4 \\
8.0 \\
5.1 \\
5.9 \\
5.4 \\
6.0 \\
5.3 \\
3.2\end{array}$ & $\begin{array}{l}52.6 \\
51.9 \\
49.4 \\
51.5 \\
50.3 \\
49.0 \\
49.9 \\
49.7\end{array}$ \\
\hline $\begin{array}{l}15 a \\
15 b\end{array}$ & $\begin{array}{l}26 \\
30\end{array}$ & $\begin{array}{l}01 \\
2 \frac{1}{3}\end{array}$ & $\begin{array}{l}61.5 \\
61.0\end{array}$ & $\begin{array}{l}99 \\
59\end{array}$ & $\begin{array}{l}1693 \\
1912\end{array}$ & $\begin{array}{l}3.321 \\
3.926\end{array}$ & $\begin{array}{l}5014 \\
5868\end{array}$ & $\begin{array}{l}6.21 \\
910\end{array}$ & $\begin{array}{l}1602 \\
2207\end{array}$ & $\begin{array}{l}2293 \\
3147\end{array}$ & $\begin{array}{l}5.7 \\
3.0\end{array}$ & $\begin{array}{l}51.0 \\
49.5\end{array}$ \\
\hline $\begin{array}{l}16 a \\
16 b \\
17 a \\
17 b \\
18 a \\
18^{3}\end{array}$ & $\begin{array}{l}33 \\
33 \\
31 \\
29 \\
29 \\
23\end{array}$ & $\begin{array}{l}2 \frac{1}{2} \\
3 \\
1 \\
2 \frac{1}{2} \\
3 \frac{1}{4} \\
2 \frac{1}{2}\end{array}$ & $\begin{array}{l}60.3 \\
69.4 \\
61.2 \\
61.5 \\
61.2 \\
60.9\end{array}$ & $\begin{array}{r}108 \\
122 \\
73 \\
139 \\
110 \\
103\end{array}$ & $\begin{array}{l}2134 \\
2159 \\
1985 \\
19 ' 11 \\
1931 \\
1845\end{array}$ & $\begin{array}{l}5103 \\
4615 \\
4126 \\
4031 \\
3927 \\
3344\end{array}$ & $\begin{array}{l}7937 \\
6774 \\
6111 \\
599.5 \\
5961 \\
5689\end{array}$ & $\begin{array}{r}1132 \\
1157 \\
983 \\
959 \\
932 \\
843\end{array}$ & $\begin{array}{l}3394 \\
28916 \\
2407 \\
2315 \\
2208 \\
2125\end{array}$ & $\begin{array}{l}4516 \\
4053 \\
3390 \\
3274 \\
3140 \\
2968\end{array}$ & $\begin{array}{l}5.3 \\
6.0 \\
3.8 \\
7.7 \\
6.1 \\
5.7\end{array}$ & $\begin{array}{l}41.8 \\
46.8 \\
48.1 \\
48.6 \\
49.3 \\
48.0\end{array}$ \\
\hline $\left.\begin{array}{l}19 \\
29 \\
21 \\
22\end{array}\right\}$ & $\begin{array}{l}29 \\
14 \\
\text {. }\end{array}$ & $\begin{array}{l}0 \\
0 \\
\cdots\end{array}$ & $\begin{array}{c}60.8 \\
59.1 \\
\mid \cdots\end{array}$ & $\begin{array}{l}88 \\
40 \\
.\end{array}$ & $\begin{array}{r}1850 \\
863 \\
\ldots\end{array}$ & $\begin{array}{c}3527 \\
1639 \\
.\end{array}$ & $\begin{array}{c}5377 \\
2507 \\
. .\end{array}$ & $\begin{array}{r}848 \\
-134 \\
. .\end{array}$ & $\begin{array}{c}1808 \\
-80 \\
\ldots\end{array}$ & $\begin{array}{c}2656 \\
-214 \\
.\end{array}$ & $\begin{array}{c}4.9 \\
4.5 \\
\cdots\end{array}$ & $\begin{array}{l}52.4 \\
53.0 \\
\end{array}$ \\
\hline
\end{tabular}


The summer of 1850 was unusually cool and unfavorable for wheat. It will be seen that on all the plots the yield of grain is considerably lower than last year, with a greater growth of straw.

You will notice that $10 b$, which last year gave, with ammonia-salts alone, $32 \frac{1}{4}$ bushels, this year, with superphosphate, potash, soda, and sulphate of magnesia, gives less than 18 bushels, while the adjo:ning plot, dressed with ammonia, gives nearly 27 bushcls. In other words, the ammonia alone gives 9 bushels per acre more than this large dressing of superphosphate, potash, etc.

On the three plots, $8 a, 8 b$ and $9 a$, a dressing of ammonia-sults alone gives in each case, a larger yield, both of grain and straw, then the 14 tons of barn-yard manure on plot 2. And recollect that this plot has now received 98 tons of manure in seven years.

"That," said the Doctor, "is certainly a very remarkable fact."

"It is so," said the Deacon.

"But what of it ?" asked the Squire, "even the Professor, here, does not advise the use of ammonia-salts for wheat."

"That is so," said 1, "but perhaps I am mistaken. Such facts as those just given, though I have been acquainted with them for many years, sometimes incline me to doubt the soundness of my conclusions. Still, on the whole, I think I am right."

"We all know," said the Deacon, "that you have great rcspcct for your own opinions."

"Never mind all that," said the Doctor, "but tell us just what you think on this subject."

"In hrief," said I, " my opinion is this. We need ammonia for wheat. But though ammonia-salts and nitrate of soda can often be used with decided profit, yct I feel sure that we can get ammonia or nitrogen at a less cost per lb. by buying bran, malt roots, cotton-seed-cake, and other foods, and using them for the double purpose of feeding stock and making manuro."

"I admit that such is the case," said the Doctor, "but here is a plot of land that has now had 14 tons of manure every year for seren years, and yet there is a plot along side, dressed with ammonia-salts furnishing less than half the ammonia contained in the 14 tons of manure, that produces a better yield of wheat."

"That," said I, "is simply because the nitrogen in the manure is not in an available condition. And the practical question is, how to make the nitrogen in our manure more immediately arailable. It is one of the most important questions which agricultur- 1 science is called upon to answer. Until we get more light, I fecl 
sure in saying that one of the best methods is, to feed our animals on richer and more casily digested food."

The following table gives the results of the eighth season of 1850-51. 
Experiments at Rothamsted on the Growth of TABLE VIIr.-MANURES AND PRODUCE; 8TH SEASON. 1850-51.

\begin{tabular}{|c|c|c|c|c|c|c|c|c|c|c|c|c|}
\hline \multirow[b]{3}{*}{ sి } & \multicolumn{12}{|c|}{ MANURES PER ACRE. } \\
\hline & \multirow{2}{*}{ 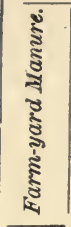 } & \multirow[b]{2}{*}{ 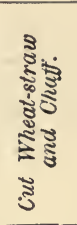 } & \multirow[b]{2}{*}{ 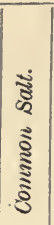 } & \multirow[b]{2}{*}{ 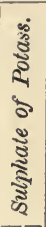 } & \multirow[b]{2}{*}{ 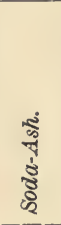 } & \multirow[b]{2}{*}{ 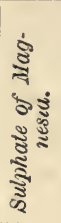 } & \multicolumn{3}{|c|}{$\begin{array}{l}\text { S'iperphosphate of } \\
\text { Lime. } \\
\end{array}$} & \multirow[b]{2}{*}{ 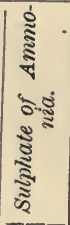 } & \multirow[b]{2}{*}{ 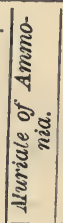 } & \multirow[b]{2}{*}{ 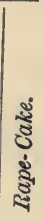 } \\
\hline & & & & & & & 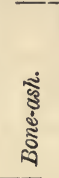 & 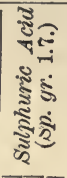 & 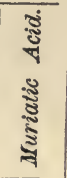 & & & \\
\hline 0 & Tons. & $\begin{array}{l}\text { lbs. } \\
\text {.. }\end{array}$ & lbs. & lbs. & lbs. & lbs. & lbs. & $\begin{array}{l}\text { lbs. } \\
45)\end{array}$ & Ibs. & lbs. & $\begin{array}{c}\text { lbs. } \\
\text {.. }\end{array}$ & Ibs. \\
\hline 1 & $\ddot{i s}$ & $\ddot{x}$ & $\because$ & $6 \ddot{0} 0$ & $4 \ddot{j}$ & $20 j$ & .. & .. & $\ddot{0}$ & $\ddot{.}$ & $\ddot{0}$ & $\ddot{0}$ \\
\hline $\begin{array}{l}2 \\
3\end{array}$ & 14 & $\ddot{0}$ & .. & .. & . & .. & .. & . & .. & .. & .. & .. \\
\hline & C.810 is & & .. & .. & .. & .. & • & $\cdots$ & $\cdot \cdot$ & 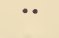 & .. & .. \\
\hline 4 & .. & .. & . & .. & . & . & 200 & .. & 200 & 400 & .. & .. \\
\hline $5 x$ & .. & . & .. & 393 & 200 & 100 & 290 & 150 & .. & 300 & 300 & .. \\
\hline $\begin{array}{l}53 \\
6 a\end{array}$ & .. & . & . & 393 & 2)0 & 103 & 230 & 150 & .. & 300 & 330 & .. \\
\hline $\begin{array}{l}6 a \\
63\end{array}$ & .. & 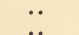 & $\because$ & 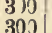 & $\begin{array}{l}230 \\
200\end{array}$ & $\begin{array}{l}109 \\
100\end{array}$ & $\begin{array}{l}200 \\
270\end{array}$ & 150 & . & 230 & $\begin{array}{l}230 \\
233\end{array}$ & 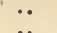 \\
\hline $7 x$ & $\ddot{0}$ & . & ‥ & 300 & 200 & 100 & 200 & 150 &. & $\begin{array}{l}200 \\
200\end{array}$ & 230 & 10i) \\
\hline $7 b$ & .. & $\because$ & 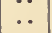 & $3>0$ & 203 & 100 & 200 & 150 & $\ddot{0}$ & 200 & 250 & $10 j 0$ \\
\hline $8 a$ & .. & 5000 & .. & & & & & & .. & & & .. \\
\hline 83 & .. & . & . & 300 & 200 & 100 & 200 & 150 & .. & 100 & 100 & . \\
\hline $\begin{array}{l}9 x \\
93\end{array}$ & . & $\ddot{.}$ & 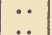 & $\because$ & 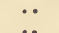 & $\cdots$ & .. & . & .. & 200 & 230 & . \\
\hline 10 i & .. & . & $\because$ & $\ddot{*}$ & $\ddot{0}$ & $\ddot{*}$ & $\ddot{.}$ & $\ddot{*}$ & $\ddot{.}$ & $\begin{array}{l}270 \\
200\end{array}$ & 2)0 & $\ddot{0}$ \\
\hline 103 & .. & .. & .. & .. & .. & .. & .. & .. & .. & 200 & 2) & .. \\
\hline $11 a$ & .. & . & $\cdots$ & $\cdots$ & . & .. & 230 & 150 & .. & 200 & 200 & • \\
\hline & .. & .. & .. & $\ddot{0}$ & $\ddot{0}$ & .. & 200 & 150 & .. & 207 & 2) & .. \\
\hline 1 ? & .. & .. & .. & 200 & 103 & .. & 200 & 150 & .. & 200 & 230 & .. \\
\hline 12 & .. & .. & .. & 200 & 100 & .. & 230 & 150 & .. & 203 & 270 & .. \\
\hline 13 & .. & .. & .. & 350 & .. & .. & 200 & 150 & .. & 270 & 230 & .. \\
\hline 13 & . & $\cdots$ & .. & 300 & .. & 10 & 200 & 153 & .. & 203 & 200 & .. \\
\hline 11 & .. & .. & .. & 200 & .. & 103 & 200 & 153 & .. & 270 & 230 & .. \\
\hline 11 & . & .. & .. & 200 & .. & 100 & 200 & $15)$ & .. & 200 & 230 & .. \\
\hline $15 x$ & . & .. & .. & 200 & 100 & 100 & 200 & .. & 200 & 400 & .. & : \\
\hline 15 & .. & . & .. & 200 & 100 & 100 & 200 & .. & 200 & 300 & .. & 5:0 \\
\hline $16 t$ & .. & .. & $333^{1}$ & 203 & 100 & 100 & 200 & 157 & .. & 3०0 & 300 & .. \\
\hline 163 & .. & & .. & 200 & 109 & 100 & 200 & 150 & . & 3 ) & 370 & 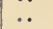 \\
\hline $17 a$ & .. & . & .. & 2) & 100 & 100 & 270 & 150 & .. & 270 & 200 & .. \\
\hline $17 b$ & .. & .. & . & 230 & 100 & 100 & 200 & 150 & .. & 2.10 & 200 & .. \\
\hline 133 & $\ddot{. .}$ & $\ddot{.}$ & $\ddot{. .}$ & .. & $\begin{array}{l}\ldots \\
\ldots\end{array}$ & $\because$ & 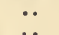 & 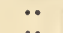 & 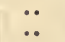 & $\begin{array}{l}230 \\
203\end{array}$ & $\begin{array}{l}200 \\
200\end{array}$ & 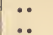 \\
\hline 19 & .. & .. & .. & .. & .. & .. & 200 & .. & 200 & 300 & .. & 500 \\
\hline 2) & Thn & 1 & .. & .. & .. & & $\cdots$ & 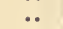 & .. & .. & .. & .. \\
\hline & & & $\because$. & $\because$ & .. & .. & .. & .. & .. & .. & .. & .. \\
\hline & & & & & .. & .. & .. & .. & .. & .. & . & 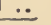 \\
\hline
\end{tabular}

1 Top-dressed in March, 1851. 
Wheat, Year after Year, on the same Land.

MANURES AND SEED (RED CLUSTER), SOWN AUTUMN, 1850.

\begin{tabular}{|c|c|c|c|c|c|c|c|c|c|c|c|c|}
\hline \multirow{3}{*}{ 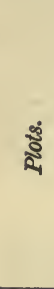 } & \multicolumn{7}{|c|}{ Produce per ACRE, etc. } & \multicolumn{3}{|c|}{$\begin{array}{l}\text { INCREASE } \text { is ACRE } \\
\text { BY MANURE. }\end{array}$} & \multirow{3}{*}{ 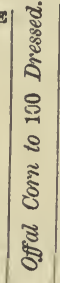 } & \multirow{3}{*}{ 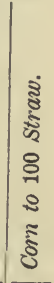 } \\
\hline & \multicolumn{3}{|c|}{ Dressed Corn. } & \multirow[b]{2}{*}{ 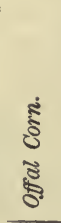 } & \multirow[b]{2}{*}{ 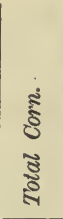 } & \multirow{2}{*}{ 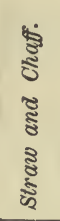 } & \multirow{2}{*}{ 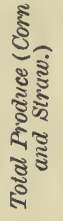 } & \multirow[b]{2}{*}{ క్త } & \multirow{2}{*}{ 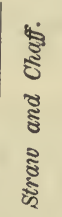 } & \multirow[b]{2}{*}{ 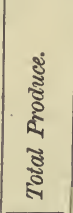 } & & \\
\hline & క్ & & 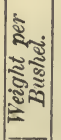 & & & & & & & & & \\
\hline $\begin{array}{l}0 \\
1 \\
2 \\
3\end{array}$ & $\begin{array}{c}\text { Bush. } \\
18 \\
18 \\
29 \\
15\end{array}$ & $\begin{array}{c}P^{\prime} \mathrm{ks} . \\
3 \frac{1}{4} \\
1 \frac{1}{4} \\
2 \frac{1}{3} \\
3 \frac{1}{4}\end{array}$ & $\begin{array}{l}\text { lbs. } \\
61.9 \\
61.7 \\
63.6 \\
61.1\end{array}$ & $\begin{array}{l}120 \\
124 \\
166 \\
114\end{array}$ & & & $\begin{array}{l}5143 \\
2710\end{array}$ & $\begin{array}{l}1 \mathrm{bs} . \\
213 \\
168 \\
966 \\
\ldots\end{array}$ & $\begin{array}{r}\text { lbs. } \\
235 \\
218 \\
1467\end{array}$ & $\begin{array}{r}\text { lbs. } \\
448 \\
386 \\
2433 \\
. .\end{array}$ & $\begin{array}{r}10.7 \\
11.0 \\
8.8 \\
11.8\end{array}$ & 06. \\
\hline 4 & 28 & $0 t$ & 2.6 & 159 & 1919 & 2919 & 4363 & 836 & 1322 & 2158 & 9.0 & 65. \\
\hline $\begin{array}{l}5 a \\
5 b \\
6 a \\
6 b \\
7 a \\
7 b\end{array}$ & & $\begin{array}{l}0 \\
38 \\
1 \frac{8}{4}\end{array}$ & $\mid$\begin{tabular}{|c|}
63.3 \\
63.3 \\
63.3 \\
63.3
\end{tabular} & & & & & $\begin{array}{l}1390 \\
1528 \\
1188 \\
1036 \\
1441 \\
1449\end{array}$ & $\begin{array}{l}2504 \\
2667 \\
1997 \\
1880 \\
2960 \\
2675\end{array}$ & & & 58. \\
\hline 80 & & 88 & & & & & & $\begin{array}{r}702 \\
780 \\
1059 \\
887 \\
883 \\
854\end{array}$ & & $\begin{array}{l}2684 \\
2202 \\
2326 \\
2275\end{array}$ & $\begin{array}{r}8.6 \\
7.9 \\
9.3 \\
9.5 \\
10.0 \\
8.3\end{array}$ & 8. \\
\hline & & $\begin{array}{l}28 \\
2 \frac{3}{24} \\
3 \\
21 \\
2 \frac{4}{4} \\
3 \frac{1}{4} \\
01\end{array}$ & $\begin{array}{l}.3 \\
.5 \\
.1 \\
.5 \\
.6 \\
.3 \\
.9 \\
.8\end{array}$ & & & & & & & & $\begin{array}{l}8.6 \\
8.4\end{array}$ & 59. \\
\hline 15 & & & & & & & & 994 & & 2799 & & 60.5 \\
\hline 18 & $\begin{array}{l}36 \\
36 \\
31 \\
30 \\
30 \\
31\end{array}$ & & & 143 & $\begin{array}{l}2083 \\
2090\end{array}$ & & & $\begin{array}{l}1010 \\
1007\end{array}$ & & $\begin{array}{l}4723 \\
4123 \\
3036 \\
2775 \\
2763 \\
2966\end{array}$ & $\begin{array}{l}6.5 \\
7.9 \\
7.2 \\
7.3\end{array}$ & 58.3 \\
\hline $\begin{array}{l}19 \\
20\end{array}$ & & 2 & & $\begin{array}{r}144 \\
89\end{array}$ & $\begin{array}{r}20: 31 \\
956\end{array}$ & 1609 & 2565 & $\begin{array}{r}918 \\
-127\end{array}$ & $\begin{array}{r}1721 \\
-18\end{array}$ & $\begin{array}{l}2669 \\
-145\end{array}$ & $\begin{array}{r}7.7 \\
10.2\end{array}$ & $\begin{array}{l}60.7 \\
59.4\end{array}$ \\
\hline & 17 & $3 t$ & 61.9 & 127 & 1232 & 1763 & 2995 & 149 & 136 & 285 & 11.5 & 69.9 \\
\hline
\end{tabular}


The plot continuously unmanured, gives about 16 bushels of wheat per acre.

The plot with barn-yard manure, nearly 30 bushels per acre.

$400 \mathrm{lbs}$. of ammonia-salts a'one, on plot $9 a, 31 \frac{1}{4}$ bushels ; on 96 , 29 bushels; on $10 a$ and $10 b$, nearly 29 bushels each. This is remarkable uniformity.

400 lbs. ammonia-salts and a large quantity of mineral manures in addition, on twelve different plots, average not quite 32 bushels per acre.

"The superphosphate and minerals," said the Deacon, "do not seem to do much good, that is a fact."

You will notice that $336 \mathrm{lbs}$. of common salt was sown on plot 16a. It does not seem to have done the slightest good. Where the salt was used, there is 2 lbs. less grain and 98 lbs. less straw than on the adjoining plot $16 b$, where no salt was used, but otherwise manured alikc. It would seem, however, that the quality of the grain was slightly improved by the sait. The salt was sown in March as a top-dressing.

"It would have been better," said the Deacon, " „o have sown it in autumn with the other manures."

"The Deacon is right," said I, "but it so happens that the next year and the year after, the salt was applied at the same time as the other manures. It gave an increase of $94 \mathrm{lbs}$. of grain and 61 lbs. of straw in 1851, but the following year the same quantity of salt used on the same plot cid more harm than good."

Before we leave the results of this year, it should be observed inat on $8 x, 5,000 \mathrm{lbs}$. of cut straw and chaff were used per acre. I do not recollect seeing anything in regard to it. And yet the result was very remarkable-so much so indeed, that it is a matter of regret that the experiment was not repeated.

This 5,000 lbs. of straw and chaff gave an increase of more than 10 bushels per acre over the continuously unmanured plot.

"Good," said the Deacon, "I have always told you that you under-estimated the value of straw, especially in regard to its mechanical action."

I did not reply to this remark of the good Deacon. I have nercr doubted the good effects of anything that lightens up a clay soil and renders it warmer and more porous. I suppose the great benefit derived from this application of straw must be attributed to its ameliorating action on the soil. The 5,000 lbs. of straw and chaff produced a crop within nearly 3 bushels per acre of the plot manured every year with 14 tons of barn-yard manure.

"I am surprised," said the Doctor, "that salt did no good. I 
have seen many instances in which it has had a wonderful effect on wheat."

"Yes," sai 1 I, " and our experienced friend, John Johnston, is very decidedly of the opinion that its use is highly profitable. He sows a barrel of salt per acre broadcast on the land at the time he sows his wheat, and I have myself seen it produce a decided improvement in the crop."

We have now given the results of the first eight years of the experiments. From this time forward, the sxme manures were used year after year on the same plot.

The results are given in the accompanying tables for the following twelve years-harvests for 18.52-53-54-55-56-57-58-59-6061-62 and 1863. Such another set of experiments are not to be found in the world, and they deserve and will receive the careful study of every intelligent American farmer

"I am with you there," said the Deacon. "You seem to think that I do not appreciate the labors of scientific men. I do. Such experiments as these we are examining command the respent of every intelligent farmer. I may not fully understand them, but I can see clearly enough that they are of great value." 
Experiments at Rothamsted on the Growth of Wheat, Ykar AFTER YeAR, ON THE SAME LAND.

Table IX.-Manures per Acre per Annum (with the exceptions explained in the Notes on p. 203), for 12 Years in succession-namely, for the 9 th, $10 \mathrm{hh}$, 11 th, 12th, 13th, 14th, 15th, 16th, 17t.., 18th, 19th, and 20th Seasons : that is, for the crops of Harvests 1852-53-54-55-56-57-58-59-60-61-62 and 1863.*

\begin{tabular}{|c|c|c|c|c|c|c|c|c|c|c|c|c|}
\hline \multirow{3}{*}{ 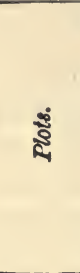 } & \multicolumn{12}{|c|}{$\begin{array}{c}\text { Manures per Acre per Annum for 12 Years, 1851-2 to 1862-3 inclusive, } \\
\text { except in the cases explained in the Notes on } p .203 .\end{array}$} \\
\hline & \multirow{2}{*}{ 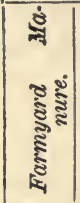 } & \multirow[b]{2}{*}{ 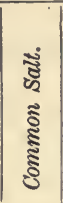 } & \multirow[b]{2}{*}{ 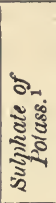 } & \multirow{2}{*}{ 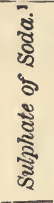 } & \multirow{2}{*}{ 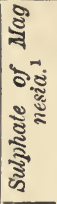 } & \multicolumn{3}{|c|}{$\begin{array}{l}\text { Superphosphate of } \\
\text { Lime. }\end{array}$} & \multirow{2}{*}{ 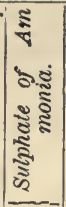 } & \multirow{2}{*}{ 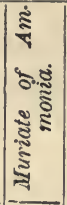 } & \multirow{2}{*}{ 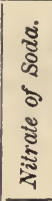 } & \multirow[b]{2}{*}{ 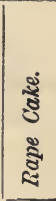 } \\
\hline & & & & & & 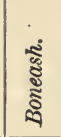 & 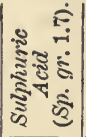 & : & & & & \\
\hline $\begin{array}{c}0 \\
1 \\
2 \\
3 \\
4 \\
5 a \\
5 b \\
6 a \\
6 b \\
7 a \\
7 b \\
8 a \\
8 b \\
9 a^{2} \\
9 b^{3} \\
10 a \\
10 b \\
11 a \\
11 b \\
12 a \\
12 b \\
13 a \\
13 b \\
14 a \\
14 b \\
15 a \\
15 b \\
16 a \\
16 b \\
\text { - }\left\{\begin{array}{l}17 a \\
17 b \\
18 a \\
18 b \\
19 \\
20 \\
21 \\
22\end{array}\right.\end{array}$ & 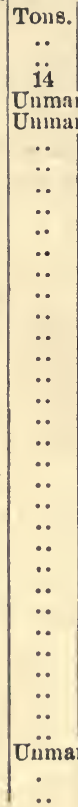 & 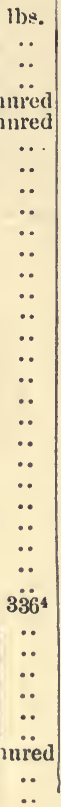 & $\begin{array}{l}1 \mathrm{bs} . \\
600 \\
. . \\
. \\
300 \\
300 \\
300 \\
300 \\
300 \\
300 \\
300 \\
300 \\
300 \\
. . \\
\because . \\
\therefore . \\
\because . \\
\because \\
300 \\
300 \\
. . \\
300 \\
300 \\
300 \\
300 \\
. \\
300 \\
300 \\
.0 \\
300 \\
300\end{array}$ & 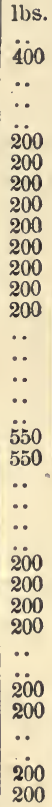 & 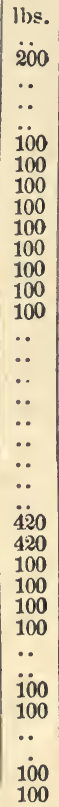 & 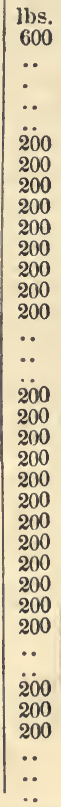 & 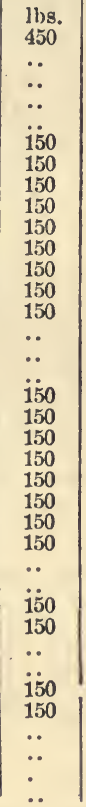 & 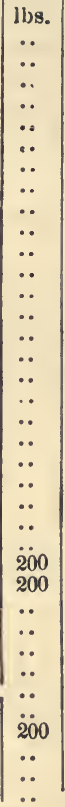 & \begin{tabular}{|c|}
$3 b s$. \\
.. \\
. \\
. \\
. \\
. \\
. \\
100 \\
100 \\
200 \\
200 \\
300 \\
300 \\
. \\
200 \\
200 \\
200 \\
200 \\
200 \\
200 \\
200 \\
200 \\
200 \\
200 \\
400 \\
300 \\
400 \\
400 \\
200 \\
200 \\
.0 \\
300 \\
.0 \\
100
\end{tabular} & \begin{tabular}{|c|} 
bs. \\
. \\
$\because$ \\
. \\
. \\
. \\
. \\
100 \\
100 \\
200 \\
200 \\
300 \\
300 \\
. \\
200 \\
200 \\
200 \\
200 \\
200 \\
200 \\
200 \\
200 \\
200 \\
200 \\
. \\
$\ddot{4}$ \\
400 \\
200 \\
200 \\
$\because$ \\
$\because$ \\
$\because$ \\
100 \\
..
\end{tabular} & 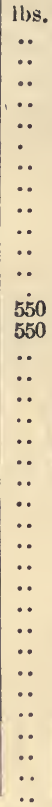 & 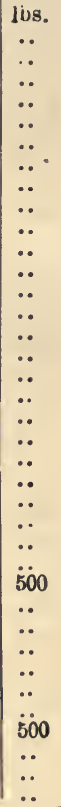 \\
\hline
\end{tabular}

* For the particnlars of the produce of each seyarate scason, see Tables X.-XXI. inclusive. 
NOTES TO TABLE IX. (p. 202.)

"For the 16 th and succeeding seasons-the sulphate of potass was reduced from 600 to 400 lbs. per acre per annum on Plot 1, and from 300 to $200 \mathrm{lbs}$. on all the other Plots where it was used; the sulphate of soda from 400 to $200 \mathrm{lbs}$. on Plot 1, to $100 \mathrm{lbs}$. on all the Plots on which $200 \mathrm{lbs}$. had previously been applied, and from 550 to $336 \frac{1}{2} \mathrm{lbs}$. (two-thirds the amount) on Plots $12 a$ and $12 b$; and the sulphate of magnesia from 420 to $280 \mathrm{lbs}$. (two-thirds the amount) on Plots $14 a$ and $14 b$.

2 Plot $9 a$-the sulphates of potass, soda, and magnesia, and the superphosphate of lime, were applied in the 12th and succeeding seasons, but not in the 9 th, 10 th, and 11 th ; and the amount of nitrate of soda was for the 9 th season only $475 \mathrm{lbs}$. per acre, and for the 10 th and 11 th seasons only $275 \mathrm{lbs}$.

3 Plot $9 b$-in the 9 th season only 475 lbs. of nitrate of soda were applied.

- Common salt-not applied after the 10th season.

- Plots $17 a$ and $17 b$, and $18 a$ and $18 b$-the manures on these plots alternate: that is, Plots 17 were manured with ammonia-salts in the 9 th season; with the sulphates of potass, soda, and magnesia, and superphosphate of lime, in the 10 th ; ammonia-salts again in the 11th; the sulphates of potass, soda, and magnesia, and superphosphate of lime, again in the 12th, and so on. Plots 18, on the other hand, had the sulphates of potass, soda, and magnesia, and superphosphate of lime, in the 9 th season; ammonia-salts in the 10th, and so on, alternately. 
Experiments at Rothamsted on the Growth of Wheat, Year after Year, on the same Land.

TabreX.-Pronuce of the 9tir Season, |Tabre XI.-Produce of the 10tu Sea1851-2. SEed (Red Cluster) sown November 7, 1851; Crop cut August 24, 1852.

\begin{tabular}{|c|c|c|c|c|c|}
\hline \multirow{3}{*}{ 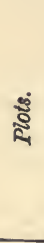 } & \multicolumn{5}{|c|}{$\begin{array}{l}\text { Produce PER ACRE, ETC. } \\
\text { (For the Mantures see pp. } 202 \\
\text { and 203.) }\end{array}$} \\
\hline & \multicolumn{3}{|c|}{ Dressed Corn. } & \multirow[b]{2}{*}{ 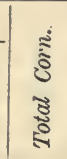 } & \multirow{2}{*}{ 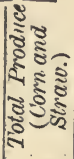 } \\
\hline & 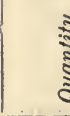 & 胥 & 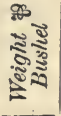 & & \\
\hline $\begin{array}{l}0 \\
1 \\
2 \\
3 \\
4\end{array}$ & $\begin{array}{c}\text { Bush. } \\
15 \\
13 \\
27 \\
13 \\
13\end{array}$ & $\begin{array}{l}\text { Pks. } \\
03 / 4 \\
1 \\
21 / 4 \\
31 / 4 \\
11 / 4\end{array}$ & $\begin{array}{l}\text { Jbs. } \\
55.8 \\
56.9 \\
58.2 \\
56.6 \\
57.3\end{array}$ & $\begin{array}{r}11) \times \\
919 \\
825 \\
1716 \\
860 \\
870\end{array}$ & $\begin{array}{l}\text { lbs. } \\
2625 \\
2322 \\
5173 \\
2157 \\
2411\end{array}$ \\
\hline $\begin{array}{l}5 a \\
5 b \\
6 a \\
6 b \\
7 a \\
7 b \\
8 a \\
8 b\end{array}$ & $\begin{array}{l}16 \\
17 \\
20 \\
20 \\
26 \\
26 \\
27 \\
27\end{array}$ & $\begin{array}{l}3 \\
01 / 4 \\
3 \\
31 / 2 \\
21 / 2 \\
33 / 2 \\
31 / 2 \\
01 / 2\end{array}$ & $\begin{array}{l}57.5 \\
57.3 \\
57.6 \\
57.5 \\
56.0 \\
55.8 \\
55.9 \\
55.9\end{array}$ & $\begin{array}{l}1039 \\
10655 \\
1238 \\
1300 \\
1615 \\
1613 \\
1699 \\
1651\end{array}$ & $\begin{array}{l}2341 \\
3097 \\
3365 \\
3931 \\
5455 \\
5115 \\
5505 \\
5433\end{array}$ \\
\hline $\begin{array}{l}9 a \\
9 b\end{array}$ & $\begin{array}{l}25 \\
24\end{array}$ & $\begin{array}{l}2 \\
13 / 4\end{array}$ & $\begin{array}{l}55.6 \\
55.3\end{array}$ & $\begin{array}{l}1591 \\
1509\end{array}$ & $\begin{array}{l}5305 \\
4833\end{array}$ \\
\hline $\begin{array}{l}10 a \\
10 b \\
11 a \\
11 b \\
12 a \\
12 b \\
13 a \\
13 b \\
14 a \\
14 b\end{array}$ & $\begin{array}{l}21 \\
22 \\
21 \\
24 \\
24 \\
24 \\
21 \\
23 \\
21 \\
25\end{array}$ & $\begin{array}{l}31 / 2 \\
01 / 4 \\
03 / 4 \\
11 / 2 \\
13 / 2 \\
11 / 4 \\
0 \\
33 / 4 \\
13 / 4 \\
01 / 4\end{array}$ & $\begin{array}{l}55.9 \\
57.3 \\
55.6 \\
55.9 \\
57.4 \\
57.3 \\
57.5 \\
57.1 \\
56.9 \\
56.7\end{array}$ & $\begin{array}{l}1320 \\
1313 \\
1472 \\
1387 \\
1503 \\
1492 \\
1480 \\
1476 \\
1507 \\
1530\end{array}$ & $\begin{array}{l}4107 \\
4162 \\
4553 \\
4233 \\
4760 \\
4721 \\
4792 \\
4765 \\
5054 \\
5137\end{array}$ \\
\hline $\begin{array}{l}15 a \\
15 b\end{array}$ & $\begin{array}{l}23 \\
25\end{array}$ & $\begin{array}{l}11 / 4 \\
04 / 2\end{array}$ & $\begin{array}{l}57.4 \\
56.8\end{array}$ & $\begin{array}{l}1451 \\
1520\end{array}$ & $\begin{array}{l}4663 \\
4941\end{array}$ \\
\hline $\begin{array}{l}16 a \\
16 b\end{array}$ & $\begin{array}{l}23 \\
28\end{array}$ & $\begin{array}{l}31 / 2 \\
0\end{array}$ & $\begin{array}{l}55.0 \\
54.5\end{array}$ & $\begin{array}{l}1794 \\
1700\end{array}$ & $\begin{array}{l}6471 \\
6316\end{array}$ \\
\hline $\begin{array}{l}17 a \\
17 b \\
18 a \\
18 b\end{array}$ & $\begin{array}{l}25 \\
21 \\
13 \\
14\end{array}$ & $\begin{array}{l}2 \\
11 / 2 \\
3 \\
33 / 4\end{array}$ & $\begin{array}{l}56.5 \\
56.9 \\
57.9 \\
56.7\end{array}$ & $\begin{array}{r}1577 \\
1520 \\
899 \\
921\end{array}$ & $\begin{array}{l}5311 \\
4986 \\
2550 \\
2685\end{array}$ \\
\hline 19 & 24 & $33 / 4$ & 561 & 1582 & $49 \% 9$ \\
\hline $\begin{array}{l}20 \\
21 \\
22\end{array}$ & $\begin{array}{l}14 \\
19 \\
19\end{array}$ & $\begin{array}{l}03 / 4 \\
13 / 4 \\
21 / 4\end{array}$ & $\begin{array}{l}56.6 \\
56.9 \\
55.9\end{array}$ & $\begin{array}{r}875 \\
1177 \\
1176\end{array}$ & $\begin{array}{l}2452 \\
3285 \\
3355\end{array}$ \\
\hline
\end{tabular}
RON. 1853. SEED (Red Rostock) suwn March 16; Crop cut September 10, and carted September 20, 1853.

Produce per Acre, etc.

(For the Manures see pp. 202 and 203).

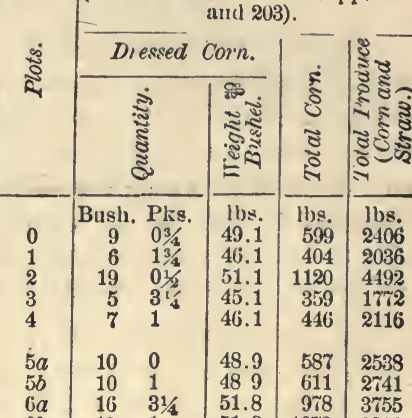

\begin{tabular}{r|rl|r|r|r}
$6 a$ & 16 & $31 / 4$ & 51.8 & 778 & 3755 \\
$6 b$ & 19 & 1 & 51.8 & 1072 & 3870 \\
\hline
\end{tabular}

\begin{tabular}{lll|l|l|l}
$7 a$ & 23 & $21 / 2$ & 52.2 & 1369 & 5110
\end{tabular}

\begin{tabular}{lll|l|l|l}
76 & 23 & $21 / 4$ & 51.1 & 1357 & 5091
\end{tabular}

\begin{tabular}{l|ll|l|l|l}
$8 a$ & 22 & $11 / 4$ & 51.1 & 1346 & 5312
\end{tabular}

\begin{tabular}{l|ll|l|l|l}
86 & 24 & $21 / 4$ & 51.1 & 1425 & 5352
\end{tabular}

\begin{tabular}{l|ll|l|l|l}
$9 a$ & 11 & 1 & 47.7 & 691 & 3090
\end{tabular}

\begin{tabular}{l|ll|l|l|l}
$9 b$ & 10 & $13 / 4$ & 46.1 & 649 & 2902
\end{tabular}

\begin{tabular}{l|ll|l|l|l}
$10 a$ & 9 & $33 / 4$ & 48.9 & 642 & 2691
\end{tabular}

\begin{tabular}{lllll|l|l}
$10 b$ & 15 & 2 & 49.8 & 896 & $35 \% 8$
\end{tabular}

\begin{tabular}{l|ll|l|r|r}
$11 a$ & 17 & 2 & 50.1 & 1015 & 3539
\end{tabular}

\begin{tabular}{lll|l|l|l}
$11 b$ & 18 & $23 / 4$ & 51.1 & $10 \pi 3$ & 3780
\end{tabular}

$\begin{array}{lllllll}12 a & 22 & 0 & 52.0 & 1283 & 4948\end{array}$

\begin{tabular}{lll|l|l|l}
$12 b$ & 23 & $31 / 4$ & 51.1 & $13 \%$ & 5079
\end{tabular}

\begin{tabular}{l|ll|l|l|l}
$13 a$ & 22 & $11 / 4$ & 52.1 & 1341 & 5045
\end{tabular}

\begin{tabular}{l|ll|l|l|l}
$13 b$ & 23 & $21 / 2$ & 51.1 & 1396 & 5308
\end{tabular}

$\begin{array}{lllllll}14 \pi & 21 & 2 & 51.2 & 1322 & 4793\end{array}$

\begin{tabular}{l|ll|l|l|l|l}
$14 b$ & 23 & $03 / 4$ & 52.6 & 1347 & 5108
\end{tabular}

\begin{tabular}{l|ll|ll|l}
$15 \pi$ & 19 & 0 & 51.1 & 1143 & 4504
\end{tabular}

\begin{tabular}{l|lll|ll|l}
$15 b$ & 23 & $21 / 3$ & 51.1 & 1351 & 5107
\end{tabular}

$\begin{array}{lllllll}16 n & 24 & 11 / 2 & 52.5 & 1496 & 6400\end{array}$

\begin{tabular}{l|ll|lll}
$16 b$ & 25 & $31 / 4$ & 52.5 & 1537 & 6556
\end{tabular}

\begin{tabular}{l|ll|l|l|l}
17 & 8 & 13 & 49.8 & 520 & 2516
\end{tabular}

\begin{tabular}{l|rr|rrr}
$17 b$ & 8 & $33 \%$ & 48.9 & 539 & $255 !$
\end{tabular}

$\begin{array}{llllll}18 x & 17 & 31 / 4 & 52.9 & 1111 & 4496\end{array}$

\begin{tabular}{l|ll|lll|l}
$18 b$ & 20 & 3 & 52.1 & 1256 & 5052
\end{tabular}

\begin{tabular}{l|ll|l|l|l}
19 & 19 & $11 / 4$ & 52.6 & 1160 & 4373
\end{tabular}

\begin{tabular}{l|ll|l|l|l|}
20 & 5 & $3 ' i$ & 47.8 & 425 & 2084
\end{tabular}

$\begin{array}{lllllll}21 & 12 & 33 & 50.4 & 753 & 2934\end{array}$

\begin{tabular}{llll|l|l|}
22 & 10 & 1 & 49.4 & 592,2452
\end{tabular}


Exper:ments at rothaustig on the Growth of Wheat, Year AFTER YEAR, ON THE SAME LAND.

Table XII.-Produce of the 11Th 'Table XIII.-Produce of the 12Th SEAson. 1S5:-4 SEED (Red Rustock) SEasun, 1854-5. SEed (Red Rosteck) sown Nivimber 12, 1853; Crop cht August 21, aisd curted Augrust 31, 1854. sown November 9, 1854; Cr(s) cut Allerust 26, and carted September 2, 1855 .

\begin{tabular}{|c|c|c|c|c|c|c|c|c|c|c|c|}
\hline \multirow{3}{*}{$\underset{\tilde{s}}{\stackrel{5}{s}}$} & \multicolumn{5}{|c|}{$\begin{array}{c}\text { Pawduce PEr ACre, ETC. } \\
\text { (For the Mamures sce pp. 20: } \\
\text { and } 203 \% \text {. }\end{array}$} & \multirow{3}{*}{$\dot{\vec{s}}$} & \multicolumn{5}{|c|}{$\begin{array}{c}\text { Produce PER Acre, E'TC. } \\
\text { (For the Mannres see pp. } 202 \\
\text { and } 20: 3) \text {. }\end{array}$} \\
\hline & \multicolumn{3}{|c|}{ Dressed Corn. } & \multirow[b]{2}{*}{ 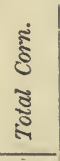 } & \multirow{2}{*}{ 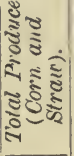 } & & \multicolumn{3}{|c|}{ Dressed Corn. } & \multirow[b]{2}{*}{ 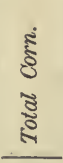 } & \multirow{2}{*}{ 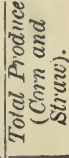 } \\
\hline & & & 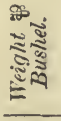 & & & & (2) & & 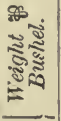 & & \\
\hline $\begin{array}{l}0 \\
1 \\
2 \\
3 \\
4\end{array}$ & $\begin{array}{c}\text { Bnsh. } \\
26 \\
24 \\
41 \\
21 \\
23\end{array}$ & $\begin{array}{l}\text { Pks. } \\
13 / 4 \\
11 / 2 \\
01 / 2 \\
01 / 4 \\
31 / 2\end{array}$ & $\begin{array}{l}\text { Ibs. } \\
61.0 \\
60.2 \\
62.5 \\
60.6 \\
61.1\end{array}$ & $\begin{array}{l}\text { Jis. } \\
1672 \\
1529 \\
2675 \\
1359 \\
1521\end{array}$ & $\begin{array}{l}\text { lbs. } \\
3786 \\
4060 \\
7125 \\
3496 \\
3859\end{array}$ & $\begin{array}{l}0 \\
1 \\
2 \\
3 \\
4\end{array}$ & $\begin{array}{c}\text { Bush. } \\
1 \% \\
18 \\
34 \\
17 \\
18\end{array}$ & $\begin{array}{l}\text { Plis. } \\
0 \\
2 \\
21 / 2 \\
0 \\
213\end{array}$ & $\begin{array}{l}\text { lbs. } \\
60.7 \\
60.5 \\
62.0 \\
59.2 \\
59.5\end{array}$ & $\begin{array}{l}\text { 1bs. } \\
1096 \\
1179 \\
2237 \\
1072 \\
1168\end{array}$ & $11 \mathrm{~s}$. \\
\hline $\begin{array}{l}5 a \\
5 b \\
6 a \\
6 b \\
7 a \\
7 b \\
8 a \\
8 b\end{array}$ & $\begin{array}{l}47 \\
49\end{array}$ & $\begin{array}{l}11 / 2 \\
0 \\
23 / 4 \\
21 / 4 \\
21 / 4 \\
11 / 2 \\
13 / 4 \\
21 / 2\end{array}$ & $\begin{array}{l}61.0 \\
61.6 \\
61.8 \\
61.8 \\
61-9\end{array}$ & $\begin{array}{l}1578 \\
1532 \\
2186 \\
2239 \\
2950 \\
2944 \\
30 C 5 \\
3208\end{array}$ & & 8 & $\begin{array}{l}18 \\
18 \\
27 \\
28 \\
22\end{array}$ & $\begin{array}{l}2 \\
01 / 2 \\
3 \\
1 \\
23 / 4 \\
11 / 4 \\
3 \\
03 / 4\end{array}$ & & $\begin{array}{l}1157 \\
1143 \\
1753 \\
1811 \\
2084 \\
2138 \\
1909 \\
2153\end{array}$ & \\
\hline $\begin{array}{l}9 a \\
9 b\end{array}$ & $\begin{array}{l}38 \\
38\end{array}$ & $\begin{array}{l}3 \\
3\end{array}$ & & & & & $\begin{array}{l}29 \\
25\end{array}$ & $\begin{array}{l}21 / 2 \\
11 / 2\end{array}$ & & $\begin{array}{l}1932 \\
1605\end{array}$ & \\
\hline $\begin{array}{l}14 \\
14\end{array}$ & 44 & $\begin{array}{l}11 / 2 \\
03 / 4 \\
2 \\
01 / 2 \\
31 / 4 \\
11 / 2 \\
01 / 3 \\
31 / 2 \\
11 / 4 \\
01 / 2\end{array}$ & & & $\begin{array}{l}5808 \\
7003 \\
8006\end{array}$ & & & $\begin{array}{l}33 / 4 \\
01 / 2 \\
3 \\
21 / 2 \\
01 / 4 \\
2\end{array}$ & & $\begin{array}{l}1907 \\
2158\end{array}$ & \\
\hline $\begin{array}{l}15 \\
15 t\end{array}$ & $\begin{array}{l}43 \\
43\end{array}$ & $1^{1 / 4}$ & & $\begin{array}{l}2801 \\
2810\end{array}$ & $\begin{array}{l}7699 \\
8083\end{array}$ & $\begin{array}{l}15 \pi \\
15 b\end{array}$ & $\begin{array}{l}31 \\
33\end{array}$ & $\begin{array}{l}31 / 4 \\
3\end{array}$ & $\begin{array}{l}60.0 \\
60.6\end{array}$ & $\begin{array}{l}2030 \\
2193\end{array}$ & 6415 \\
\hline 16 & $\begin{array}{l}49 \\
50\end{array}$ & $\begin{array}{l}21 / 4 \\
03 / 4\end{array}$ & $\begin{array}{l}61.7 \\
617\end{array}$ & $\begin{array}{l}3230 \\
3293\end{array}$ & $\begin{array}{l}99: 2 \\
99: 8\end{array}$ & $\begin{array}{l}16 a \\
16 b\end{array}$ & $\begin{array}{l}33 \\
32\end{array}$ & $2^{11 / 4}$ & $\begin{array}{l}58.2 \\
58.2\end{array}$ & $\begin{array}{l}2100 \\
2115\end{array}$ & 710 \\
\hline $\begin{array}{l}17 \\
17 \\
18 \\
18\end{array}$ & $\begin{array}{l}24 \\
23\end{array}$ & $\begin{array}{l}3 \\
21 / 4 \\
0 \\
23 / 4\end{array}$ & $\begin{array}{l}62.1 \\
62.2 \\
61.2 \\
61.0\end{array}$ & $\begin{array}{l}1526 \\
1511\end{array}$ & $\begin{array}{l}8218 \\
7629 \\
3944 \\
3888\end{array}$ & $\begin{array}{l}18 a \\
18 b\end{array}$ & 33 & $\begin{array}{l}33 / 2 \\
01 / 2 \\
33 / 2 \\
13 / 4\end{array}$ & 60.8 & $\begin{array}{l}1227 \\
1110 \\
2127 \\
2170\end{array}$ & \\
\hline 19 & 41 & $03 / 4$ & 61.7 & 2666 & 7343 & 19 & 30 & 0162 & 587 & $196 \%$ & 5818 \\
\hline $\begin{array}{l}20 \\
21 \\
22\end{array}$ & $\begin{array}{l}22 \\
32 \\
31\end{array}$ & $\begin{array}{l}3 \\
0^{\prime \prime} ; \\
3\end{array}$ & $\begin{array}{l}60.8 \\
61.2 \\
61.0\end{array}$ & $\begin{array}{l}1445 \\
2030 \\
1994\end{array}$ & $\begin{array}{l}3662 \\
5470 \\
5334\end{array}$ & $\begin{array}{l}20 \\
21 \\
22\end{array}$ & $\begin{array}{l}17 \\
24 \\
24\end{array}$ & $\begin{array}{l}21 / 2 \\
13 / 4 \\
21 / 2\end{array}$ & $\begin{array}{l}61.1 \\
60.8 \\
60.1\end{array}$ & $\begin{array}{l}1155 \\
1533 \\
1553\end{array}$ & \\
\hline
\end{tabular}




\section{Experiments at Rothamsted on the Growth of Wheat, Year}

\section{AFter Year, on the same LaNd.}

Table XIV.-Pronuce of the 13Th Table XV.-Produce of The 14th SEason, 1855-6. SEED (Red liostock) Skason, 1856-7. SEed (Red Rostock)

sown November 13, 1855; Crop cut, Anrủst 26, and carted September 3, 1856.

\begin{tabular}{|c|c|c|c|c|c|}
\hline \multirow{3}{*}{ ฉ্ } & \multicolumn{5}{|c|}{$\begin{array}{l}\text { Produck PEr Acre, ETc. } \\
\text { (For the Manmles see pp. } 202 \\
\text { and 203.) }\end{array}$} \\
\hline & \multicolumn{3}{|c|}{ Dressed Corn. } & \multirow[b]{2}{*}{ 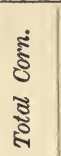 } & \multirow{2}{*}{ 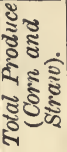 } \\
\hline & ปี & & 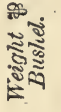 & & \\
\hline $\begin{array}{l}0 \\
1 \\
2 \\
3 \\
4\end{array}$ & $\begin{array}{c}\text { Bnsh. } \\
18 \\
17 \\
36 \\
14 \\
16\end{array}$ & $\begin{array}{l}\text { Pks. } \\
11 / 2 \\
03 / 4 \\
11 / 4 \\
21 \\
11 / 2\end{array}$ & $\begin{array}{l}\text { lbs. } \\
56.8 \\
56.3 \\
58.6 \\
54.3 \\
55.5\end{array}$ & $\begin{array}{r}\text { 1bs. } \\
1179 \\
1102 \\
2277 \\
892 \\
1026\end{array}$ & $\begin{array}{l}\text { lbs. } \\
3148 \\
3035 \\
6594 \\
2450 \\
2757\end{array}$ \\
\hline $\begin{array}{l}5 a \\
5 b \\
6 a \\
6 b \\
7 a \\
7 b \\
8 a \\
8 b\end{array}$ & $\begin{array}{l}18 \\
20 \\
27 \\
28 \\
37 \\
36 \\
40 \\
37\end{array}$ & $\begin{array}{l}31 / 4 \\
11 / 4 \\
11 / 4 \\
01 / 2 \\
1 \\
21 / 4 \\
01 / 2 \\
33 / 4\end{array}$ & $\begin{array}{l}\mathbf{5 6 . 5} \\
56.2 \\
\mathbf{5 8 . 2} \\
58.5 \\
58.0 \\
\mathbf{5 7 . 6} \\
\mathbf{5 6 . 8} \\
\mathbf{5 7 . 1}\end{array}$ & $\begin{array}{l}1167 \\
1247 \\
1717 \\
1755 \\
2312 \\
2244 \\
2507 \\
2400\end{array}$ & $\begin{array}{l}3179 \\
3369 \\
4767 \\
4848 \\
6872 \\
6642 \\
7689 \\
7489\end{array}$ \\
\hline $\begin{array}{l}9 a \\
9 b\end{array}$ & $\begin{array}{l}32 \\
26\end{array}$ & $\begin{array}{l}11 / 2 \\
0\end{array}$ & $\begin{array}{l}57.2 \\
56.3\end{array}$ & $\begin{array}{l}2019 \\
1679\end{array}$ & $\begin{array}{l}5894 \\
4831\end{array}$ \\
\hline $\begin{array}{l}10 a \\
10 b \\
11 a \\
11 b \\
12 a \\
12 b \\
13 a \\
13 b \\
14 a \\
14 b\end{array}$ & $\begin{array}{l}24 \\
27 \\
31 \\
30 \\
33 \\
32 \\
32 \\
30 \\
35 \\
34\end{array}$ & $\begin{array}{l}03 / 3 \\
23 / 4 \\
31 / 2 \\
21 / 2 \\
31 / 2 \\
31 / 2 \\
13 / 4 \\
31 / 4 \\
01 / 4 \\
03 / 4\end{array}$ & $\begin{array}{l}556 \\
\mathbf{5 7 . 2} \\
57.3 \\
57.5 \\
58.7 \\
58.8 \\
58.6 \\
58.9 \\
58.6 \\
59.0\end{array}$ & $\begin{array}{l}1505 \\
1727 \\
2001 \\
1946 \\
2102 \\
2079 \\
2036 \\
2008 \\
2195 \\
2162\end{array}$ & $\begin{array}{l}4323 \\
4895 \\
5518 \\
5389 \\
5949 \\
5804 \\
5779 \\
5659 \\
6397 \\
6279\end{array}$ \\
\hline $\begin{array}{l}15 a \\
15 b\end{array}$ & $\begin{array}{l}30 \\
32\end{array}$ & $\begin{array}{l}01 / 2 \\
0\end{array}$ & $\begin{array}{l}59.1 \\
59.4\end{array}$ & $\begin{array}{l}1923 \\
2045\end{array}$ & $\begin{array}{l}5444 \\
5797\end{array}$ \\
\hline $\begin{array}{l}16 a \\
16 b\end{array}$ & $\begin{array}{l}38 \\
37\end{array}$ & $\begin{array}{l}01 / 2 \\
3\end{array}$ & $\begin{array}{l}58.5 \\
58.7\end{array}$ & $\begin{array}{l}2426 \\
2450\end{array}$ & $\begin{array}{l}7955 \\
7917\end{array}$ \\
\hline $\begin{array}{l}17 a \\
17 b \\
18 a \\
18 b\end{array}$ & $\begin{array}{l}31 \\
30 \\
17 \\
18\end{array}$ & $\begin{array}{l}21 / 2 \\
11 / 2 \\
31 / 2 \\
0\end{array}$ & $\begin{array}{l}59.0 \\
59.1 \\
578 \\
57.7\end{array}$ & $\begin{array}{l}1983 \\
1935 \\
1140 \\
1131\end{array}$ & $\begin{array}{l}5541 \\
5400 \\
3152 \\
3069\end{array}$ \\
\hline 19 & 32 & 1 & 58.9 & 2059 & 5621 \\
\hline $\begin{array}{l}20 \\
21 \\
22\end{array}$ & $\begin{array}{l}17 \\
22 \\
21\end{array}$ & $\begin{array}{l}03 / 4 \\
11 / 2 \\
13 / 4\end{array}$ & $\begin{array}{l}57.7 \\
58.0 \\
57.8\end{array}$ & $\begin{array}{l}1075 \\
1398 \\
1351\end{array}$ & $\begin{array}{l}29633 \\
3927 \\
3849\end{array}$ \\
\hline
\end{tabular}

sown November 6, 1856 ; Crop cut August 13, and carted August 22, $185 \%$.

\begin{tabular}{|c|c|c|c|c|c|}
\hline \multirow{3}{*}{$\frac{\dot{0}}{\tilde{s}}$} & \multicolumn{5}{|c|}{$\begin{array}{c}\text { Propuce PER ACRE, ETC. } \\
\text { (For the Manures fee pp. } 202 \\
\text { and 203.) }\end{array}$} \\
\hline & \multicolumn{3}{|c|}{ Dressed Corn. } & \multirow[b]{2}{*}{ 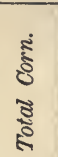 } & \multirow{2}{*}{ 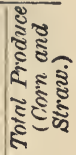 } \\
\hline & है & לू. & 产 & & \\
\hline $\begin{array}{l}0 \\
1 \\
2 \\
3 \\
4\end{array}$ & $\begin{array}{c}\text { Bush. } \\
18 \\
17 \\
41 \\
19 \\
22\end{array}$ & $\begin{array}{l}\text { Pks. } \\
21 / 4 \\
21 / 2 \\
03 / 4 \\
33 / 4 \\
13 / 4\end{array}$ & $\begin{array}{l}\text { lbs. } \\
59.0 \\
59.0 \\
60.4 \\
58.3 \\
58.8\end{array}$ & $\begin{array}{l}11 s . \\
1181 \\
1118 \\
2587 \\
1236 \\
1386\end{array}$ & $\begin{array}{c}\text { lbs. } \\
2726 \\
2650 \\
5910 \\
2813 \\
2958\end{array}$ \\
\hline $\begin{array}{l}5 a \\
5 b \\
6 a \\
6 b \\
7 a \\
7 b \\
8 a \\
8 b\end{array}$ & $\begin{array}{l}22 \\
24 \\
35 \\
35 \\
43 \\
46 \\
47 \\
48\end{array}$ & $\begin{array}{l}33 / 4 \\
21 / 4 \\
11 / 2 \\
11 / 4 \\
11 / 4 \\
116 \\
3 \\
31 / 4\end{array}$ & 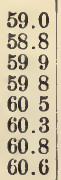 & $\begin{array}{l}1409 \\
1512 \\
2211 \\
2193 \\
2782 \\
2902 \\
3058 \\
3129\end{array}$ & $\begin{array}{l}3026 \\
3247 \\
4968 \\
4950 \\
6462 \\
6693 \\
7355 \\
7579\end{array}$ \\
\hline $\begin{array}{l}9 a \\
9 b\end{array}$ & $\begin{array}{l}43 \\
36\end{array}$ & $\begin{array}{l}3 \\
03 / 4\end{array}$ & $\begin{array}{l}60.1 \\
58.0\end{array}$ & $\begin{array}{l}2767 \\
2220\end{array}$ & $\begin{array}{l}6634 \\
5203\end{array}$ \\
\hline $\begin{array}{l}10 a \\
10 b \\
11 a \\
11 b \\
12 a \\
12 b \\
13 a \\
13 b \\
14 a \\
14 b\end{array}$ & $\begin{array}{l}29 \\
34 \\
39 \\
39 \\
43 \\
43 \\
42 \\
43 \\
43 \\
42\end{array}$ & $\begin{array}{l}01 / 2 \\
2 \\
0 \\
03 / 4 \\
31 / 2 \\
2 \\
3 \\
2 \\
3 \\
31 / 2\end{array}$ & $\begin{array}{l}58.0 \\
58.6 \\
58.5 \\
58.0 \\
604 \\
60.4 \\
60.6 \\
60.5 \\
60.5 \\
60.3\end{array}$ & $\begin{array}{l}1816 \\
2185 \\
2432 \\
2297 \\
2747 \\
2729 \\
2714 \\
2739 \\
2781 \\
2699\end{array}$ & $\begin{array}{l}4208 \\
5060 \\
5375 \\
5317 \\
6394 \\
6312 \\
6421 \\
6386 \\
6439 \\
6351\end{array}$ \\
\hline $\begin{array}{l}15 a \\
15 b\end{array}$ & $\begin{array}{l}42 \\
44\end{array}$ & $\begin{array}{l}11 / 4 \\
13 / 4\end{array}$ & $\begin{array}{l}60.4 \\
60.0\end{array}$ & $\begin{array}{l}2681 \\
2765\end{array}$ & $\begin{array}{l}6368 \\
6543\end{array}$ \\
\hline $\begin{array}{l}16 a \\
16 b\end{array}$ & $\begin{array}{l}48 \\
50\end{array}$ & $\begin{array}{l}31 / 4 \\
0\end{array}$ & $\begin{array}{l}60.5 \\
60.5\end{array}$ & $\begin{array}{l}3131 \\
3194\end{array}$ & $\begin{array}{l}7814 \\
7897\end{array}$ \\
\hline $\begin{array}{l}17 a \\
17 b \\
18 a \\
18 b\end{array}$ & $\begin{array}{l}26 \\
25 \\
41 \\
40\end{array}$ & $\begin{array}{l}23 / 4 \\
33 / 4 \\
01 / 4 \\
01 / 4\end{array}$ & $\begin{array}{l}59.1 \\
58.8 \\
59.7 \\
59.8\end{array}$ & $\begin{array}{l}1642 \\
1583 \\
2566 \\
2519\end{array}$ & $\begin{array}{l}3 \% 00 \\
3523 \\
6009 \\
5884\end{array}$ \\
\hline 19 & 41 & $21 / 2$ & 59.5 & 2600 & 5793 \\
\hline $\begin{array}{l}20 \\
21 \\
22\end{array}$ & $\begin{array}{l}19 \\
24 \\
23\end{array}$ & $\begin{array}{l}23 / 4 \\
0 \\
01 / 6\end{array}$ & $\begin{array}{l}58.4 \\
60.6 \\
60.6\end{array}$ & $\begin{array}{l}1213 \\
1528 \\
1491\end{array}$ & $\begin{array}{l}2777 \\
3353 \\
3298\end{array}$ \\
\hline
\end{tabular}


Experiments at Rothamsted on the Growti of Wheat, Year AFTER YeAR, ON THE SAME LAND.

Tabie XVI.-Pronuce of the 15Tru Table XVII.-Produce of the 16Th SEason, 1857-8. SEeD (Red Rosto. k) gown November 3 and 11, 1857; Crop) cut Angust 9, and carted August 20, 1858.

\begin{tabular}{|c|c|c|c|c|c|c|c|c|c|c|c|}
\hline \multirow{3}{*}{$\frac{\check{\Sigma}}{\tilde{\Sigma}}$} & \multicolumn{5}{|c|}{$\begin{array}{c}\text { Pizoduce PER ACRE, ETC. } \\
\text { (For the Maunres see pp. 202 } \\
\text { aud 203.) }\end{array}$} & \multirow{3}{*}{ 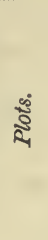 } & \multicolumn{5}{|c|}{$\begin{array}{c}\text { PRODUCE PER ACRE, ETC. } \\
\text { (For the Maunres see pp. } 202 \\
\text { and 203.) }\end{array}$} \\
\hline & \multicolumn{3}{|c|}{ Dressed Corn. } & \multirow[b]{2}{*}{ 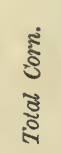 } & \multirow{2}{*}{ 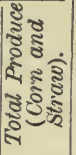 } & & \multicolumn{3}{|c|}{ Dressed Corn. } & \multirow[b]{2}{*}{$\begin{array}{l}\text { కే } \\
\text { కేँ } \\
\text { હี }\end{array}$} & \multirow{2}{*}{ 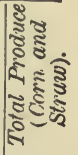 } \\
\hline & 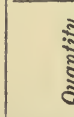 & گ్ & 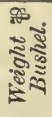 & & & & का & $\dot{3}$ & 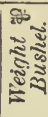 & & \\
\hline $\begin{array}{l}0 \\
1 \\
2 \\
3 \\
4\end{array}$ & $\begin{array}{c}\text { Bush. } \\
20 \\
16 \\
38 \\
18 \\
19\end{array}$ & $\begin{array}{l}\text { Plis. } \\
3 \\
11 / 4 \\
31 / 4 \\
0 \\
01 / 2\end{array}$ & $\begin{array}{l}\text { lbs. } \\
61.2 \\
60.7 \\
62.6 \\
60.4 \\
61.1\end{array}$ & $\begin{array}{c}\text { Ibs. } \\
.1332 \\
1055 \\
2512 . \\
1141 \\
1206\end{array}$ & $\begin{array}{l}\text { lbs. } \\
3234 \\
2685 \\
6319 \\
2811 \\
2879\end{array}$ & $\begin{array}{l}3 \\
4 \\
4\end{array}$ & $\begin{array}{l}\text { Buslı. } \\
21 \\
19 \\
36 \\
18 \\
19\end{array}$ & $\begin{array}{l}\text { Pks } \\
21 / 4 \\
3 \\
03 / 4 \\
11 / 4 \\
03 / 4\end{array}$ & $1 \mathrm{bs}$. & $\begin{array}{l}\text { lis. } \\
1254\end{array}$ & llis. \\
\hline $\begin{array}{l}5 a \\
5 b \\
6 a \\
6 b \\
7 a \\
7 b \\
8 a \\
8 b\end{array}$ & 18 & $\begin{array}{l}23 / 4 \\
1 \\
21 / 4 \\
01 / 2 \\
21 / 4 \\
21 / 4 \\
33 / 4 \\
31 / 4\end{array}$ & & $\begin{array}{l}1187 \\
1227 \\
1818 \\
1850 \\
2450 \\
2530 \\
2680 \\
2675\end{array}$ & $\begin{array}{l}2719 \\
2870 \\
4395 \\
4563 \\
6415 \\
6622 \\
7347 \\
7342\end{array}$ & $5 a$ & $\begin{array}{l}20 \\
20 \\
29 \\
30 \\
34 \\
34 \\
34 \\
34\end{array}$ & $\begin{array}{l}21 / 4 \\
21 / 2 \\
21 / 3 \\
01 / 2 \\
23 / 4 \\
21 / 2 \\
31 / 4 \\
03 / 4\end{array}$ & & 1277 & 7604 \\
\hline $\begin{array}{l}9 a \\
9 b\end{array}$ & $\begin{array}{l}37 \\
23\end{array}$ & $\begin{array}{l}21 / 6 \\
2\end{array}$ & $\begin{array}{l}60.8 \\
588\end{array}$ & $\begin{array}{l}2384 \\
1470\end{array}$ & $\begin{array}{l}6701 \\
4158\end{array}$ & & $\begin{array}{l}30 \\
24\end{array}$ & $\begin{array}{l}0 \\
2 \longleftarrow_{4}^{\prime}\end{array}$ & & $\begin{array}{l}180 \\
141\end{array}$ & $\begin{array}{l}70 \% 6 \\
5002\end{array}$ \\
\hline & 38 & $\begin{array}{l}31 / 2 . \\
3 \\
31 / 2 \\
01 / 4 \\
33 / 4 \\
03 / 4 \\
03 / 4 \\
03 / 4 \\
31 / 4 \\
11 / 4\end{array}$ & & & & & 34 & $\begin{array}{l}33 / 1 \\
2 \\
31 / 2 \\
31 / 4 \\
21 / 2 \\
31 / 2 \\
03 / 2\end{array}$ & & 200 & \\
\hline $\begin{array}{l}15 a \\
15 b\end{array}$ & $\begin{array}{l}35 \\
37\end{array}$ & $\begin{array}{l}11 / 2 \\
2\end{array}$ & & $\begin{array}{l}2285 \\
2436\end{array}$ & $\begin{array}{l}5800 \\
6134\end{array}$ & & $\begin{array}{l}34 \\
35\end{array}$ & $01 / 4$ & 550 & 2095 & 7088 \\
\hline $\begin{array}{l}16 a \\
16 b\end{array}$ & $\begin{array}{l}41 \\
42\end{array}$ & $\begin{array}{l}3 \\
0: / 3\end{array}$ & & & 7530 & & $\begin{array}{l}34 \\
34\end{array}$ & 13 & & 200 & $\begin{array}{r}7953 \\
7998\end{array}$ \\
\hline $\begin{array}{l}17 a \\
17 b \\
18 a \\
18 b\end{array}$ & $\begin{array}{l}22 \\
23\end{array}$ & $\begin{array}{l}11 / 4 \\
31 \% \\
33 / 4 \\
23 / 4\end{array}$ & $\begin{array}{l}62 . \\
62 . \\
62 . \\
62 .\end{array}$ & $\begin{array}{l}2150 \\
2181 \\
1472 \\
1338\end{array}$ & $\begin{array}{l}3480 \\
3305\end{array}$ & & $\begin{array}{l}21 \\
19 \\
32 \\
32\end{array}$ & $\begin{array}{l}3 y \\
2\end{array}$ & 56.0 & $\begin{array}{l}1247 \\
11(8 \\
19.3 \\
1980\end{array}$ & 6630 \\
\hline 19 & 33 & $11 / 4$ & 62.5 & 2177 & 5362 & 19 & 30 & 2 & .5 & 1903 & 5926 \\
\hline $\begin{array}{l}20 \\
21 \\
22\end{array}$ & $\begin{array}{l}17 \\
24 \\
22\end{array}$ & $\begin{array}{l}0 \\
13 / 4 \\
0\end{array}$ & $\begin{array}{l}60.3 \\
615 \\
61.5\end{array}$ & $\begin{array}{l}108 ? \\
1574 \\
1412\end{array}$ & $\begin{array}{l}3947 \\
3592\end{array}$ & $\begin{array}{l}21 \\
22\end{array}$ & $\begin{array}{l}17 \\
2 f \\
24\end{array}$ & $\begin{array}{l}11 \frac{2}{2} \\
03 / 4\end{array}$ & $\begin{array}{l}54.0 \\
53.0\end{array}$ & $\begin{array}{l}1589 \\
1460\end{array}$ & $\begin{array}{l}3256 \\
4783 \\
\mathbf{4 1 4 0}\end{array}$ \\
\hline
\end{tabular}
solvin November 4,1858 . Crop cut Angust 4, and carted Aurrist 20, 1859. 


\section{Experiments at Rothamsted on the Growti of Wheat, Year} AFTER YeAr, ON THE SAME LAND.

TABLE XVIII.-Produce of the 17TH 'TABI.E XIX.-Pronuce of the 18Tu SEASON. 1859-6). SEED (Red Rustocii) SEASON. 1860-1. SEeD (Red R intuck) sown Nove:mber 17, 1859; Crop cui September 17 and 19 , and cisted October 5,1860 .

\begin{tabular}{|c|c|c|c|c|c|c|c|c|c|c|c|}
\hline \multirow{3}{*}{$\frac{3}{0}$} & \multicolumn{5}{|c|}{$\begin{array}{l}\text { PioducE PER ACHE, ETC. } \\
\text { (For the Manures see pp. 2J2 } \\
\text { and 203.) }\end{array}$} & \multirow{3}{*}{ 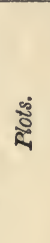 } & \multicolumn{5}{|c|}{$\begin{array}{c}\text { Produce PRn ACHE, ETC. } \\
\text { (Fur the Manures see pp. } 202 \\
\text { and 203.) }\end{array}$} \\
\hline & \multicolumn{3}{|c|}{ Dressed Corn. } & \multirow[b]{2}{*}{ 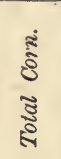 } & \multirow{2}{*}{ 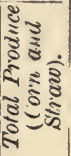 } & & Dies & ssed 0 & orn. & & \\
\hline & 胥 & & ॠँّ & & & & 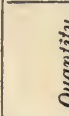 & $\overrightarrow{\mathrm{G}}$ & 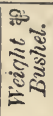 & $\begin{array}{l}\text { है } \\
\text { है } \\
\text { हี } \\
\text { है }\end{array}$ & 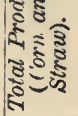 \\
\hline $\begin{array}{l}0 \\
1 \\
2 \\
3 \\
4\end{array}$ & $\begin{array}{c}\text { Bush. } \\
14 \\
12 \\
32 \\
12 \\
14\end{array}$ & $\begin{array}{l}\text { Pks. } \\
11 / 4 \\
13 / 4 \\
11 / 4 \\
31 / 2 \\
2\end{array}$ & $\begin{array}{l}11 \mathrm{~s} . \\
53.5 \\
52.8 \\
55.5 \\
52.6 \\
53.0\end{array}$ & $\begin{array}{r}1 \mathrm{lss} \\
826 \\
717 \\
1861 \\
738 \\
832\end{array}$ & $\begin{array}{l}11 \mathrm{~g} . \\
2271 \\
2097 \\
5304 \\
2197 \\
2352\end{array}$ & $\begin{array}{l}0 \\
1 \\
2 \\
3 \\
4\end{array}$ & $\begin{array}{c}\text { Bush. } \\
15 \\
12 \\
34 \\
11 \\
11\end{array}$ & $\begin{array}{l}\text { Pks. } \\
11 / 2 \\
33 / 4 \\
31 / 2 \\
11 / 4 \\
31 / 2\end{array}$ & $\begin{array}{l}116 . \\
57.6 \\
57.6 \\
60.5 \\
57.4 \\
58.0\end{array}$ & $\begin{array}{r}1 \text { bs } \\
1001 \\
828 \\
2202 \\
736 \\
863\end{array}$ & $\begin{array}{c}\text { lhs. } \\
2769 \\
2215 \\
5303 \\
1990 \\
2193\end{array}$ \\
\hline $\begin{array}{l}5 a \\
5 b \\
6 a \\
6 b \\
7 a \\
7 b \\
8 a \\
8 b\end{array}$ & $\begin{array}{l}15 \\
16 \\
21 \\
22 \\
27 \\
27 \\
30 \\
31\end{array}$ & $\begin{array}{l}23 / 4 \\
01 / 2 \\
01 / 2 \\
34,4 \\
31 / 2 \\
2 ! 4 \\
3 \\
23 / 4\end{array}$ & $\begin{array}{l}54.0 \\
53.1 \\
53.7 \\
54.2 \\
54.3 \\
51.3 \\
52.8 \\
52.3\end{array}$ & $\begin{array}{r}903 \\
935 \\
1210 \\
1326 \\
1612 \\
1597 \\
1759 \\
1787\end{array}$ & $\begin{array}{l}2483 \\
2595 \\
3393 \\
3719 \\
4615 \\
4734 \\
5639 \\
5600\end{array}$ & $\begin{array}{l}5 a \\
5 b \\
6 a \\
6 b \\
7 a \\
7 b \\
8 a \\
8 b\end{array}$ & $\begin{array}{l}15 \\
15 \\
27 \\
27 \\
35 \\
34 \\
36 \\
34\end{array}$ & $\begin{array}{l}13 / 4 \\
11 / 2 \\
114 \\
31 / 4 \\
21 / 4 \\
11 / 4 \\
0 \\
01 / 4\end{array}$ & $\begin{array}{l}59.1 \\
59.0 \\
59.5 \\
59.4 \\
59.0 \\
59.0 \\
58.3 \\
58.5\end{array}$ & $\begin{array}{l}1047 \\
1082 \\
1755 \\
1818 \\
2263 \\
2183 \\
2290 \\
2190\end{array}$ & $\begin{array}{l}2540 \\
2692 \\
4328 \\
4501 \\
5764 \\
5738 \\
6203 \\
5985\end{array}$ \\
\hline $\begin{array}{l}9 a \\
9 b\end{array}$ & $\begin{array}{l}32 \\
13\end{array}$ & $\begin{array}{l}2 / 2 \\
2 / 4 \\
2 / 4\end{array}$ & $\begin{array}{l}51.5 \\
48.5\end{array}$ & $\begin{array}{l}1858 \\
1155\end{array}$ & $\begin{array}{l}6635 \\
4285\end{array}$ & $\begin{array}{l}9 a \\
8 b\end{array}$ & $\begin{array}{l}33 \\
13\end{array}$ & $\begin{array}{l}3 \\
3\end{array}$ & $\begin{array}{l}56.8 \\
53.9\end{array}$ & $\begin{array}{r}2162 \\
909\end{array}$ & $\begin{array}{l}6607 \\
3079\end{array}$ \\
\hline $\begin{array}{l}10 a \\
10 b \\
11 a \\
11 b \\
12 a \\
12 b \\
13 a \\
13 b \\
14 a \\
14 b\end{array}$ & $\begin{array}{l}15 \\
18 \\
22 \\
22 \\
28 \\
26 \\
26 \\
27 \\
27 \\
27\end{array}$ & $\begin{array}{l}01 / 3 \\
21 / 2 \\
11 / 2 \\
11 / 2 \\
01 / 2 \\
21 / 2 \\
03 / 1 \\
01 / 2 \\
11 / 2 \\
01 / 4\end{array}$ & $\begin{array}{l}49.5 \\
51.0 \\
51.0 \\
51.2 \\
53.4 \\
53.5 \\
51.3 \\
53.8 \\
53.7 \\
53.2\end{array}$ & $\begin{array}{r}905 \\
11060 \\
1270 \\
1307 \\
1648 \\
1577 \\
15 i 5 \\
1600 \\
1583 \\
1563\end{array}$ & $\begin{array}{l}3118 \\
3120 \\
3: 73 \\
4000 \\
48 \% 8 \\
4664 \\
4.593 \\
4637 \\
46969 \\
4666\end{array}$ & $\begin{array}{l}10 a \\
10 b \\
11 a \\
11 b \\
12 a \\
12 b \\
13 a \\
13 b \\
14 a \\
14 b\end{array}$ & $\begin{array}{l}12 \\
15 \\
23 \\
25 \\
32 \\
33 \\
33 \\
35 \\
33 \\
33\end{array}$ & $\begin{array}{l}3 / 2 \\
3 \% / 4 \\
13 / 4 \\
03 / 4 \\
1: 4 \\
13 / 4 \\
11 / 4 \\
0 \\
01 / 4 \\
33 / 4\end{array}$ & $\begin{array}{l}55.0 \\
55.5 \\
55.3 \\
55.8 \\
58.1 \\
58.7 \\
53.9 \\
60.0 \\
59.1 \\
59.3\end{array}$ & $\begin{array}{r}854 \\
1033 \\
1455 \\
1578 \\
2009 \\
2144 \\
21 C 8 \\
23(14 \\
2125 \\
2173\end{array}$ & $\begin{array}{l}2784 \\
3196 \\
4032 \\
4223 \\
5201 \\
5481 \\
5486 \\
5794 \\
5 \div 02 \\
546\end{array}$ \\
\hline $\begin{array}{l}15 a \\
15 b\end{array}$ & $\begin{array}{l}25 \\
28\end{array}$ & $\begin{array}{l}11 / 8 \\
0\end{array}$ & $\begin{array}{l}5.38 \\
54.0\end{array}$ & $\begin{array}{l}1510 \\
1614\end{array}$ & $\begin{array}{l}4387 \\
470.1\end{array}$ & $\begin{array}{l}15 a \\
15 b\end{array}$ & $\begin{array}{l}34 \\
34\end{array}$ & $3^{11 / 4}$ & $\begin{array}{ll}60 & 0 \\
60 & 2\end{array}$ & $\begin{array}{l}2183 \\
2249\end{array}$ & $\begin{array}{l}5505 \\
5727\end{array}$ \\
\hline $\begin{array}{l}16 a \\
16 b\end{array}$ & $\begin{array}{l}32 \\
32\end{array}$ & $\begin{array}{l}2 \\
3\end{array}$ & $\begin{array}{l}520 \\
51.7\end{array}$ & $\begin{array}{l}1856 \\
1889\end{array}$ & $\begin{array}{l}5973 \\
6096\end{array}$ & $\begin{array}{l}16 a \\
16 b\end{array}$ & $\begin{array}{l}36 \\
37\end{array}$ & $\begin{array}{l}13 / 4 \\
2\end{array}$ & $\begin{array}{l}58.0 \\
53.6\end{array}$ & $\begin{array}{l}2338 \\
2132\end{array}$ & $\begin{array}{l}6761 \\
67750\end{array}$ \\
\hline $\begin{array}{l}17 a \\
17 b \\
13 a \\
18 b\end{array}$ & $\begin{array}{l}24 \\
26 \\
15 \\
16\end{array}$ & $\begin{array}{l}01 / 4 \\
11 / 2 \\
11 / 4 \\
114\end{array}$ & $\begin{array}{l}54.1 \\
51.3 \\
54.5 \\
54.6\end{array}$ & $\begin{array}{r}1409 \\
1 \breve{1} 18 \\
929 \\
963\end{array}$ & $\begin{array}{l}4103 \\
4518 \\
2649 \\
2706\end{array}$ & $\begin{array}{l}1 \% a \\
1 i b \\
18 a \\
18 b\end{array}$ & $\begin{array}{l}19 \\
18 \\
32 \\
33\end{array}$ & $\begin{array}{l}1 \\
03 / 4 \\
11 / 2 \\
11 / 2\end{array}$ & $\begin{array}{l}59.3 \\
59.1 \\
59.6 \\
59.5\end{array}$ & $\begin{array}{l}1229 \\
1166 \\
2050 \\
2122\end{array}$ & $\begin{array}{l}2982 \\
2829 \\
5144 \\
5446\end{array}$ \\
\hline 19 & 24 & $01 / 2$ & 53.0 & 1435 & 4178 & 19 & 32 & 2 & 58.8 & 2107 & 5345 \\
\hline $\begin{array}{l}20 \\
21 \\
22\end{array}$ & $\begin{array}{l}12 \\
15 \\
13\end{array}$ & $\begin{array}{l}0,4 \\
2 \\
3 ! 4\end{array}$ & $\begin{array}{l}51.5 \\
52.5 \\
53.8\end{array}$ & $\begin{array}{l}722 \\
893 \\
817\end{array}$ & $\begin{array}{l}2155 \\
2: 39 \\
2114\end{array}$ & $\begin{array}{l}20 \\
21 \\
22\end{array}$ & $\begin{array}{l}13 \\
16 \\
19\end{array}$ & $\begin{array}{l}03 \\
13 / 4 \\
23\end{array}$ & $\begin{array}{l}579 \\
58.2 \\
53.5\end{array}$ & $\begin{array}{r}872 \\
1109 \\
1306\end{array}$ & $\begin{array}{l}2340 \\
2749 \\
3243\end{array}$ \\
\hline
\end{tabular}

sown Noveluber 5, 1860; Crop cut Allurust 20, and cartod Angust 27, 1861 . 
Experinevts at Rotiamsted on the Growtil of Wheat, Year AFTER YeAr, ON THE SAME LaND.

Table XX.-Produce of the 19th Tabie XXI.-Promuge of the 20Th SEASON, 1ऽ61-2. SEED (Red Rostock) SEASON, 1S62-3. SEED (Rerl Rostock) sown O(tober 25, 18ti1; Crop cut Eown November 17, 18(i०); Crop cut Angust 29, and carted September 12, 186:2.

\begin{tabular}{|c|c|c|c|c|c|c|c|c|c|c|c|}
\hline \multirow{3}{*}{$\frac{\grave{\Omega}}{3}$} & \multicolumn{5}{|c|}{$\begin{array}{l}\text { Produce PER Acre, ETC. } \\
\text { (For the Manures see pp. 202 } \\
\text { uud 203.) }\end{array}$} & \multicolumn{6}{|c|}{$\begin{array}{c}\text { I'Rovuce PrR ACIE. ETC. } \\
\text { (For the Manures see l'p. } 202 \\
\text { and 203.) }\end{array}$} \\
\hline & \multicolumn{3}{|c|}{ Dressed Corn. } & \multirow[b]{2}{*}{ 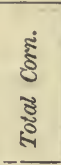 } & \multirow{2}{*}{ 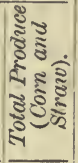 } & \multirow{2}{*}{$\frac{\dot{s}}{\tilde{E}}$} & \multicolumn{3}{|c|}{ Dressed rorn. } & \multirow[b]{2}{*}{ 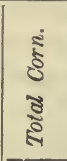 } & \multirow{2}{*}{ 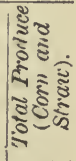 } \\
\hline & & 悹 & 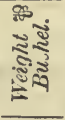 & & & & $\approx$ & & $\mid$ & & \\
\hline $\begin{array}{l}0 \\
1\end{array}$ & $\begin{array}{l}16 \\
16\end{array}$ & $\begin{array}{l}\text { Pks. } \\
31 / 2 \\
23 / 4 \\
11 / 2 \\
0 \\
21 / 2\end{array}$ & & & $\begin{array}{l}\text { lbs. } \\
32 \% 8 \\
27 \% 2 \\
6642 \\
2 \% 09 \\
2711\end{array}$ & 0 & 3nsh. & $\begin{array}{l}\text { Pliss. } \\
01 / 2 \\
3 \\
0 \\
1\end{array}$ & & $\begin{array}{l}\text { bs. } \\
429 \\
334 \\
886 \\
127 \\
303\end{array}$ & $\begin{array}{l}11,8 . \\
3,254 \\
3.1799 \\
7.165 \\
2,727 \\
2,957\end{array}$ \\
\hline $\begin{array}{l}5 a \\
5 b \\
6 a \\
6 b \\
7 a \\
7 b \\
8 a \\
8 b .\end{array}$ & & $\begin{array}{l}3 / 4 \\
31 / 2\end{array}$ & & & תרפט & $5 a$ & & 6 & & $\begin{array}{l}1283 \\
1296 \\
2522 \\
2534 \\
3477 \\
3507 \\
36 C 8 \\
3559\end{array}$ & $\begin{array}{r}2.970 \\
3.0644 \\
6.236 \\
6.250 \\
9.3: 10 \\
9.385 \\
10.283 \\
10.048\end{array}$ \\
\hline 9 & & $3 / 2$ & & & 4501 & & 41 & & & $27: 3$ & 6,92 \\
\hline & 32 & $\begin{array}{l}23 \\
01 / 4 \\
11 / 4 \\
03 / 1 \\
33 / 4 \\
23 \\
13 / 4 \\
0 \%\end{array}$ & & & & & 53 & $\begin{array}{l}1 \\
11 / 4 \\
13 / 4 \\
13\end{array}$ & & 3450 & 8,74 \\
\hline $\begin{array}{l}15 \\
15\end{array}$ & $\begin{array}{l}30 \\
32\end{array}$ & $\begin{array}{l}13 / 1 / 4 \\
23 / 4\end{array}$ & & $\begin{array}{l}1872 \\
2023\end{array}$ & & & $\begin{array}{l}49 \\
43\end{array}$ & $\begin{array}{l}1 ! \\
0\end{array}$ & & & 8.24 \\
\hline $\begin{array}{l}16 \\
16\end{array}$ & $\begin{array}{l}36 \\
36\end{array}$ & $\begin{array}{l}11 / 4 \\
01 / 2\end{array}$ & & $\begin{array}{l}2225 \\
2: 233\end{array}$ & & $\begin{array}{l}10 a \\
16 b\end{array}$ & $\begin{array}{l}56 \\
55\end{array}$ & $\begin{array}{l}23 / 4 \\
014\end{array}$ & $\begin{array}{l}62.4 \\
\text { c'2.3 }\end{array}$ & $\begin{array}{l}3710 \\
3607\end{array}$ & \\
\hline $\begin{array}{l}17 \\
17 \\
18 \\
18\end{array}$ & $\begin{array}{l}18 \\
18\end{array}$ & $\begin{array}{l}3 \\
2 \\
1 \\
2\end{array}$ & 585 & $\begin{array}{l}1168 \\
1195\end{array}$ & 3335 & & 46 & & $\begin{array}{l}62.6 \\
62.8\end{array}$ & $\begin{array}{l}13 \% 0 \\
1389 \\
3006 \\
3009\end{array}$ & $\begin{array}{l}7,8 \\
7,7\end{array}$ \\
\hline 13 & 23 & $11 / 2$ & 57.2 & 1479 & 4132 & 19 & 46 & $23 / 4$ & 62. & 3054 & 7,57 \\
\hline $\begin{array}{l}20 \\
21 \\
22\end{array}$ & $\begin{array}{l}12 \\
20 \\
20\end{array}$ & $\begin{array}{l}11 / 2 \\
01 / 4\end{array}$ & $\begin{array}{l}5: 1 \\
53.0\end{array}$ & $\begin{array}{r}818 \\
1273 \\
1270\end{array}$ & $\begin{array}{l}3465 \\
3430\end{array}$ & $\begin{array}{l}20 \\
21 \\
\text { 21 }\end{array}$ & $\begin{array}{l}17 \\
27 \\
\vdots 5\end{array}$ & $2^{1 / 2}$ & $\begin{array}{l}62.5 \\
62 \\
62.5 \\
02.4\end{array}$ & $\begin{array}{l}1137 \\
1596 \\
1 \mathrm{c} 7\end{array}$ & \\
\hline
\end{tabular}


The ninth season (1851--2), was unusually cold in June and wet in August. It will be seen that the wheat, both in quantity and quality, is the poorest since the commencement of the experiments. The unmanured plot gave less than 14 bushels of dressed grain per acre; the plot with barn-yard manure, less than 28 bushels, and the best yield in the whole serics was not quite 29 bushels per acre, and only weighed 55 lbs. per bushel. On the same plot, the year before, with precisely the same manure, the yield was nearly 37 bushels per acre, and the weight per bushel, $63 \frac{1}{2}$ lbs. So much for a favorable and an unfavorable season.

The tenth season (1852-3), was still more unfavorable. The autumn of 1852 was so wet that it was impossible to work the land and sow the wheat until the 16th of March 1853.

You will see that the produce on the unmanured plot was less than 6 bushels per acre. With barn-yard manure, 19 bushels, and with a heavy dressing of ammonia-salts and minerals, not quite 26 bushels per acre. With a heavy dressing of superphosphate, not quite $9 \frac{1}{4}$ bushels per acre, and with a full dressing of mixed mineral manures and superphosphate, 10 bushels per acre.

The weight per bushel on the unmanured plot was 45 lbs.; with mixed mineral manures, $48 \frac{1}{2} \mathrm{lbs}$. ; with ammonia-salts alone, $48 \frac{1}{2}$ lbs.; with barn-yard manure, 51 lbs.; and with ammonia-salts and mixed mineral manures, $52 \frac{1}{4}$ lbs.

Farmers are greatly dependent on the season, but the good farmer, who keeps up the ferulity of his land stands a better chance of making money (or of losing less), than the farmer who depends on the unaided products of the soil. The one gets 6 bushels per acre, and $1, \Delta 13 \mathrm{lbs}$. of straw of very inferior quality; the other gets 20 to 26 bushels per acre, and 5,000 lbs. of straw. And you must recollect that in an unfavorable season we are pretty certain to get high prices.

The eleventh season (1853-4,) gives us much more attractivelooking figures! We have over 21 bushels per acre on the plot which has grown eleven crops of wheat in eleven years without any manure.

With barn-yard manure, over 41 bushels per acre. With am. monia-salts alone $(17 a), 458$ bushels. With ammonia-salts and mixed minerals, $(16 b)$, over 50 bushels per acre, and 6,635 lbs. of straw. A total produce of nearly $5 \frac{1}{2}$ tons per acre.

The twolfth season (1854-5), gives us 17 bushels of wheat per acre on the continuously unmanured plot. Over $34 \frac{1}{2}$ bushels on the plot manured with barn-yard manure. And I think, for the first time since the commencement of the experiments, this plot pro- 
duces the largest yield of any plot in the field. And well it may, for it has now had, in twelve years, 168 tons of barn-yard manure per acre!

Several of the plots with ammonia-salts and mixed minerals, are nearly up to it in grain, and ahead of it in straw.

The itirteenth season (1850̃-6), gives $14 \frac{1}{2}$ bushels on the unmanured plot; over $3 \mathrm{C}_{\frac{1}{4}}$ bushels on the plot manured with barn-yard manure; and over 40 bushels on 8: , dressed with $600 \mathrm{lbs}$. ammoniasalts and mixed mineral manures. It will be noticed that $800 \mathrm{lbs}$. ammonia-salts does not give quite as large a yield this year as 600 lbs. I suppose 40 bushels per acre was all that the season was capable of producing, and an extra quantity of ammonia did no good. $400 \mathrm{lbs}$. of ammonia-salts, on $7 a$, produced $37 \frac{1}{4}$ bushels per acre, and $800 \mathrm{lbs}$. on $16 b$, only $3 \mathrm{r}^{\frac{3}{2}}$ bushels. That extra half bushel of wheat was produced at considerable cost.

The fourteenth season (1856-7), gives 20 bushels per acre on the unmanured plot, and 41 bushels on the piot with barn-yard manure. Mixed mineral manures alone on $5 a$ gives nearly 23 bushcls per acre. Mixed mineral manures and $200 \mathrm{lbs}$ ammoniasalts, on $6 a$, give $35 \frac{1}{4}$ bushels. In other words the ammonia gives us over 12 extra bushels of wheat, and 1,140 lbs. of straw. Mineral manures and 400 lbs. ammonia-salls, on $7 b$, give 461 busheis per acre. Mineral manures and $600 \mathrm{lbs}$. ammonia-salts, on 83 , give nearly 49 bushels per acre. Mineral manures and $800 \mathrm{lbs}$. of ammonia-salts, on 16b, give 50 bus'dels per acre, and 4,703 lbs. of straw.

"This cxceedingly heavy manuring," said the Deacon, "dnes rot pay. For instance,

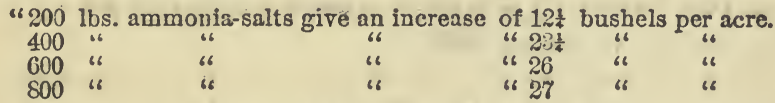

The Deacon is right, and Mr. Lawes and Dr. Gilbert call especial a tention to this point. The $200 \mathrm{lbs}$. of ammonia-salts contain about 50 lbs. of ammonia, and the 400 lbs., $100 \mathrm{lbs}$. of ammonia. And as I have said, $100 \mathrm{lbs}$. of ammonia per acre is an unusually heavy dressing. It is as much ammonia as is contained in 1,000 Ibs. of average Peruvian guano. We will recur to this subject.

The fifteenth scason $(1857-8$, gives a yield of 18 bushels of wheat per acre on the continuously unmanured plot, and nearly 39 bushels on the plot continuously manured with 14 tons of barnyard manure. Mixed mineral manures on $5 a$ and $5 b$, give a mean yield of less than 19 bushcls per acre. 
Mixed mineral manures and $100 \mathrm{lbs}$ ammonia-salts, on plots 21 and 22 , give $23 \frac{1}{4}$ bushels per acre. In other words :

25 lbs. ammonia (100 lbs. ammonia-salts), gives an increase of $4 \frac{1}{4}$ bush.

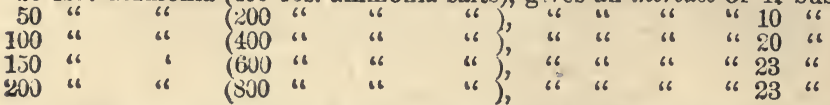

"It takes," said the Deacon, "about 5 lbs. of ammonia to produce a bushel of wheat. And according to this, 500 lbs. of Peruvian guano, guaranteed to contain 10 per cent of ammonia, would give an increase of 10 busicis of wheat."

"This is a very interesting matter," said I, "but we will not discuss it at present. Let us continue the examination of the subject. I do not propose to make many remarks on the tables. You must study them for yourself. I have spent hours and days and weeks making and pondering over these tables. The more you study them the more interesting and instructive they become."

The sixteenth seasnn (1858-9), gives us a little over $18 \frac{1}{4}$ bushels on the unmanured plot. On the plot manured with 14: tons farmyard manure, 361 bushels; and this is the highest yield this season in the wheat-field. Mixed mineral manures alone, (mean of plot $5 a$ and 55 ), give 201 bushels.

25 lbs. ammonia (100 lbs. ammonia-salts), and mixed minerals, give $25 \frac{1}{4}$ bushels, or an increase over minerals alone of $4 \frac{8}{4}$ bushels.

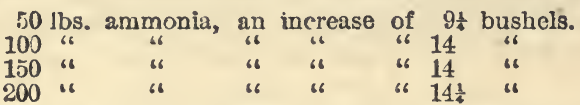

The season was an unfarorable one for excessive manuring. It was too wet and the crops of wheat when highly manured were much laid. The quality of the grain was inferior, as will be seen from the light weight per bushel.

The seventeenth season (1859--60,) gives less than 13 bushels per acre on the unmanured plot; and $32 \frac{1}{4}$ bushels on the plot manured with 14 tons farm-yard manure. This season (1860), was a miserable year for wheat in England. It was both cold and wet. Mixed mineral manures, on plots $5 a$ and $5 b$, gave nearly 16 bushels per acre. $25 \mathrm{lbs}$. ammonia, in addition to the above, gave less than 15 bushels. In other words it gave no increase at all.

\begin{tabular}{|c|c|c|c|c|c|c|c|}
\hline 50 lbs. & ammonia, & gave & an & increase & of & $\begin{array}{c}6 \\
11 \frac{9}{4}\end{array}$ & bushels. \\
\hline ;0 & "6 & \& & \&6 & 16 & "I & $15 \frac{1}{3}$ & 6 \\
\hline 66 & "6 & 66 & 6 & "6 & 16 & $16 t$ & 16 \\
\hline
\end{tabular}

It was a poor year for the wheat-grower, and that, whether he manured excessively, liverally, moderately, or not at all. 
"I do not quite see that," said the Deacon, "the farm-yard manure gave an increase of nearly 20 bushels per acre. And the quality of the grain must have been much better, as it weighed $3 \frac{1}{2} 1 \mathrm{bs}$. per bushel more than the plot unmanured. If the wheat cloubled in price, as it ought to do in such a poor year, I do not see but that the good farmer who had in previous years made his land rich, would come out ahead."

"Gool for the Deacon," said I. " "Is Saul also among the prophets?'” If the Deacon continues to study these experiments much longer, we shall have lim advocating chemical wanures and high farming!

The eighteenth season $(1860-1$,$) gave less than 11 \frac{1}{2}$ bushels per acre on the unmanured plot; and nearly 35 bushels on the manured plot.

The mixed mineral manures, gave nearly............151 bushels.

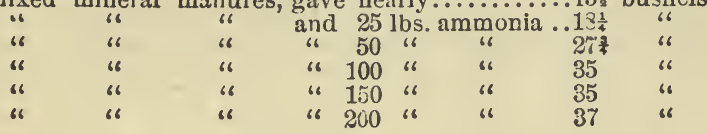

The nineteenth season (1861-2,) gave 16 bushcls per acre on the unmanured plot, and over $38_{\frac{1}{4}}$ bushels on the plot manured with farm-yard manure.

Mixed mineral manures, gave nearly..........18 bushels per acre.

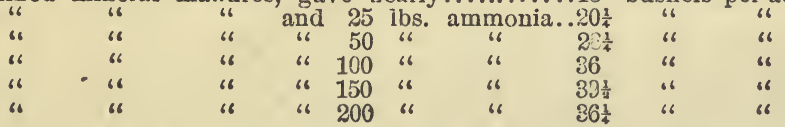

The twentieth season (1862-3), gave $17 \frac{1}{4}$ bushels on the unma: nured plot, and 44 bushels per acre on the manured plot.

M:xed mineral manures alone gave...........10 bushels per acre.

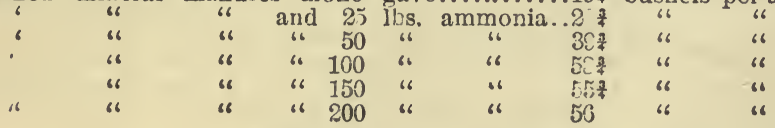

When we consider that this is the twentieth wheat-crop in succession on the same land, these figures are certainly remarkable.

"They are so," said the Deacon, "and what to me is the most surprising thing about the whole matter is, that the plot which has had no manure of any kind for 25 years, and has grown 20 wheat-srops in 20 successive years, should still produce a crop of wheat of $17 \frac{1}{4}$ bushels per acre. Many of our farmers do not average 10 bushels per acre. Mr. Lawes must either have very good land, or else the 
climate of England is better adapted for wheat-growing than Westerı New York."

"I do not think," said I, "that Mr. Lawes' land is any better than yours or mine; and I do not think the climate of England is any more favorable for growing wheat without manure tuan our climate. If there is any difference it is in our favor."

"Why, then," asked the Doctor, "do we not grow as much wheat per acre as Mr. Lawes gets from his continuously unmanured piot?"

This is a question not difficult to answer.

1st. We grow too many weeds. Mr. Lawes plowed the land twice every year; and the crop was hoed once or twice in the spring to kill the weels.

2u. We do not half work our heavy land. We do not plow it enough-do not cultivate, harrow, and roll enough. I have put wheat in on my own farm, and have secn others do the same thing, when the drill on the clay-spots could not deposit the seed an inch dcep. There is "plant-food" ezough in thcse "clay-spots" to give 17 bushels of wheat per acre-or perhaps 40 busheis-but we shall not get ten buslıcls. The wheat will not come up until late in the autumn-the plants will be weak and thin on the gro'und; and if they cscape the winter they will not get a fair hoid of the ground until April or May. You know tlie result. The straw is full of sup, and is almost sure to rust; the grain shrinks up, and we harvest the crop, not because it is worth the labor, but because we cannot cut the wheat with a machine on the better parts of the field without cutting these poor spots also. An acre or two of poor spots pull down the average yicld of the fiald below the average of Mr. Lawes' well-worked but unmanured land.

3d. Much of our wheat is seriously injured by stagnant water in the $s \circ \%$, a d standing water on the surface. I think we may safely siy that one-third the what-crop of this county (Monroe Co., N. $Y$.), is lost for want of better tillage and hetter draining-and yet we think we have as good wheat-land and are as good farmers as can be found in this country or any other!

Unless we drain land, where draingge is needed, and unless we work !and thoroughly that needs working, and unless we kill the weeds or check their excessive growth, it is poor economy to sow expensive manures on our wheat-crops.

But I do not think there is much danger of our falling into this error. The farmers who try artificial manures are the men who usually take the greatest pains to make the best and most manure 
from the animals kept on the farm. They know what manures cost and what they are worth. As a rule, too, such men are good farmers, and endeavor to work their land thoroughly and keep it clean. When this is the case, there can be little doubt that we can often use artificial manures to great advantage.

"You say," said the Deacon, who had been looking over the tables while I was taiking, "that mixed mineral manures and $50 \mathrm{lbs}$. of ammonia give $39 \frac{2}{4}$ bushcls per acre. Now these mixed mineral manures contain potash, soda, magnesia, and superphosphate. And I see where superphosphate was used without any potash, soda, and marnesia, but with the same amount of ammonia, the yield is nearly 46 bushels per acre. This does not say much in favor of potash, soda, and magnesia, as manures, for wheat. Again, I see, on plot $103,50 \mathrm{lbs}$. of ammonia, alone, gives over $43 \frac{1}{2}$ bushels per acre. On plot $11 b, 50 \mathrm{lbs}$. ammonia and superphosphate, give $46 \frac{1}{2}$ bushels. Like your father, I am inclined to ask, 'Where can I get this ammonia?""

\section{$\rightarrow$ \\ CHAPTER XXVIII.}

\section{LIME AS A MANURE.}

These careful, systematic, and long-continued experiments of Lawes and Gilbert seem to prove that if you have a piece of land well prepared for wheat, which will produce, without manure, say 15 bushels per acre, there is no way of making that land produce 30 bushels of wheat per acre, without directly or indirectly furnishing the soil with a liberal supply of available nitrogen or ammonia.

"What do you mean by directly or indirectly?" asked the Dercon.

"What I had in my mind," said I, "was the fact that I have seen a good dressing of lime double the yield of wheat. In such a case I suppose the lime decomposes the organic matter in the soil, or in some other way sets free the nitrogen or ammonia already in the soil; or the lime forms compounds in the soil which attract ammonia from the atmosphere. Be this as it may, the facts brought out by Mr. Lawes' experiments warrant us in concluding that the increased growth of wheat was connected in some way with an increased supply of available nitrogen or ammonia. 
My father used great quantities of lime as manure. He drew it a distance of 13 miles, and usually applied it on land intended for wheat, spreading it broad-cast, after the land had received its last plowing, and harrowing it in, a few days or weeks before sow. ing the wheat. He rarely applied less than 100 bushels of stonelime to the acre-renerally 150 bushels. He used to say that a small duse of lime did little or no good. He wanted to use enough to change the general character of the land-to make the light land firmer and the heary land lighter.

While I was with MIr. Lawes and Dr. Gilbert at Rothamsted, I went home on a visit. My father had a four-horse team drawing lime every day, and putting it in large heaps in the field to slake, before spreading it on the land for wheat.

"I do not believe it pays you to draw so much lime," said I, with the confidence which a young man who has learned a little of agricultural chemistry, is apt to feel in his newly acquired knowledge.

"Perhaps not," said my father, "but we have got to do somethin $r$ for the land, or the crops will be poor, and poor crops do not pay these times. What woull you use instead of lime ?"- "Lime is not a manure, strictly speaking," saill I; "a bushel to the acre woald furnish all the lime the crops require, even if there was not an abundant supply already in the soil. If you mix lime with guano, it sets free the ammonia; and when you mix lime with the soil it probably decomposes some compounds containing ammonia or the elements of ammozia, and thus furnishes a supply of ammonia for the plants. I think it would be cheaper to buy ammonia in the shape of Pcruvian guano."

After dinner, my father asked me to take a walk over the farm. We came to a field of barley. Standing at one end of the field, about the middle, he asked me if I could see any difference in the crop. "Oh, yes," I replied, "the barley on the right-hand is far better than on the left hand. The straw is stiffer and brighter, and the heads larger and heavier. I should think the right half of the field will be ten bushels per acre better than the other."

"So I think," he said, "and now can you tcll me why?""Probably you manured one half the field for turnips, and not the other half."-" No."- " You may have drawn off the turnips from half the field, and fed them off by sheep on the other half."-"No, both sides were treated precisely alike."-I gave it up - "Well," said he, "this half the ficld on the risht-hand was limed, thirty years ago, and that is the only reason I know for the difference. And now you need not tell me that lime does not pay."

I can well understand how this might happen. The system of 
rotation adopted was, 1 st clover, $2 \mathrm{~d}$ wheat, $3 \mathrm{~d}$ turnips, 4 th barley, seeded with clover.

Now, you put on, say 150 bushels of lime for wheat. After the wheat the land is manured and sown with turnips. The turnips are eaten off on the land by sheep; and it is reasonable to suppose that on the half of the field dressed with lime there would be a much heavier crop of turnips. These turnips being eaten off by the sheep would furnish more manure for this half than the other half. Then again, when the land was in grass or clover, tue limed half would afford more and sweeter grass and clover than the other half, and the sheep would remain on it longer. They would eat it close into the ground, going only on to the other half when they could not get enough to eat on the limed half. More of their droppings would be left on the limed half of the field. The lime, too, would continue to act for several years; but even after all direct benefit from the lime had ceased, it is easy to understand why the crops might he better for a long period of time.

"Do you think lime would do any good," asked the Deacon, " on our limestone land ?"-I certainly do. So far as I have seen, it does just as much good here in Western New York, as it did on my father's farm. I should use it very freely if we could get it cheap enough-but we are charged from 25 to $30 \mathrm{cts}$. a bushel for it, and I do not think at these rates it will pay to use it. Even gold may be bought to dear.

"You should burn your own lime," said the Deacon, "you have plenty of limestone on the farm, and could use up your down wood."-I believe it would pay me to do so, but one man cannot do everything. I think if farmers would use more lime for manure we should get it cheaper. The demand would increase with competition, and we should soon get it at its real value. At 10 to 15 cents a bushel, I feel sure that we could use lime as a manure with very great benefit.

"I was much interested some years ago," said the Doctor, "in the results of Prof. Way's investigations in regard to the absorp- : tive powers of soils."

His experiments, since repeated and confirmed by other chemists, formed a new epoch in agricultural chemistry. They afforded some new suggestions in regard to how lime may benefit land.

Prof. Way found that ordinary soils possessed the power of separating, from solution in water, the different earthy and alkaline substances presented to them in manure; thus, when solutions of salts of ammonia, of potash, magnesia, etc., were made to filter 
slowly through a hed of dry soil, five or six inches deep, arranged in a flower-pot, or other suitable vessel, it was observed that the liquid which ran tinrough, no longcr contained any of the ammonia or other salt employed. The soil had, in some form or other, retained the alkaline substance, while the water in which it was previously dissolved passed through.

Further, this power of the soil was found not to extend to the whole salt of ammonia or potash, but only to the alkali itself. If, for instance, sulphate of ammonis were the compound used in the experiments, the ammonia would be removed from solution, but the filtered liquid would contain sulphuric acid in abundancenot in the free or uncombined form, but united to lime; instead of sulphate of ammonia we should find sulphate of lime in the solution; and this result was obtaincd, whatever the acid of the salt experimented upon might be.

It was found, moreover, that the process of filtration was by no means necessary; hy the mere mixing of an akaline solution with a proper quautity of soil, as by shaking them together in a bottle, and allowing the soil to subside, the same rcsult was obtained. The action, therefore, was in no way referakle to any physical law brought into operation by the process of filtration.

It was also found that the combination between the soil and the alialine substance was rapid, if not instantaneous, partaking of the nature of the ordinary union between an acid and an alkali.

In the course of these experiments, several different soils wcre operated uron, and it was found that all soils capable of profitable cultivation possessed this property in a greater or less degeee.

Pure sand, it was found, dil not posscss this property. The organic matter of the soil, it was proved, had nothing to do with it. The addition of carbonate of lime to a soil ciid net incrcase its absorptive power, and indeed it was found that a soil in which carbonate of lime did not exist, possessed in a high degree the power of removing ammonia or potash from solution.

To what, tien, is the power of soils to arrest ammonia, potasb, magnesia, phosphoric acid, ctc., owing? The above experiments lead to the conclusion that it is due to the $c l x y$ which they contain. In the language of Prof. Way, however,

"It still remained to be considered, whether the whole clay tock any active part in these changes, or whether there existed in clay some chemical compound in small quantity to which the action was due. This question was to be decided by the extent to which clay was able to unite with ammonia, or other alkaline bases; and it soon became evident that the idea of the clay as a 
whole, neing the cause of the absorptive property, was inconsistent with all the ascert.tined laws of shemical combination."

- After a series of experiments, Prof. Way came to the conclusion that there is in clays a peculiar class of double silicates to which the absorptive properties of soil are due. He found that the double silicate of alumina and lime, or soda, whether found naturally in soils or produced artificially, would be decomposed when a salt of ammonia, or potash, etc., was mixed with it, the ammonia, or potash, taking the place of the lime or sola.

Prof. Way's discovery, then, is not that soils have "absorptive properties "-that has been long known-but that they absorb ammoaia, potash, phosphoric acid, etc., by virtue of the double silicate of alumina and soda, or lime, etc., which they contain.

Soils are also found to have the power of absorbing ammonia, or rather carbonate of ammonia, from the air.

" It has long been kn!wn," says Prof. Way, " that soils acquirc fertility by exposure to the influence of the atmosphere-bence one of the uses of fallows. * * I find that clay is so greedy of ammonia, that if air, charged with carbonate of ammonia, so as to be highly pungent, is passed through a tube filled with small fragments of dry clay, every particle of tha gus is arrested."

This power of the soil to absorb ammonia, is also due to the double silicates. But there is this remarkable difference, that while either the lime, soda, or potash silicate is capable of remoring the ammonia from solution, the lime silicate alone has ths power of ab. sorjing it from the air.

This is an important fact. Lime may act beneficially on many or most soils by convertin? the soda silicate into a lime silicata, or, in other words, converting a salt that wiil not absorb carboatate of ammonia froin the air, into a salt that has this important property.

There is no munure that has been so extensively used, and with such general success as lime, and yet, "who among us," remarks Prof. Way, "can say that he perfectly understancls the mode in which lime acts?" We are told that lime sweetens the soil, by neu'ralizing any acid charact?r t'iat it may possess; that it assists t'] 3 dacomposition of inert organic matters, and therefore increases the supply of vegetable food to plants: that it decomposes the remains of ancient rocks contrining potıs's, soda, marnesia, ctc., occurring in most soils, and that at the same time it liberates silica from these rocks; and lastly, that lime is one of the substances found unitormly and in considerable quantity in the ashes of plants, that therefore its application may be beneficial simply as furnıshing a material indispensable to the substance of a plant. 
These explanations are no doubt good as far as they go, but experience furnishes many facts which cannot ba explained by any one, or all, of these suppositions. Lime, we all know, does much good on soils abounding in organis matter, and so it frequently does on soils almost destitute of it. It may liberate potasn, soda, silica, etc., from clay soils, but the application of potash, soda, and silica has little beneficial effect on the soil, and therefore we cannot account for the actiun of lime on the supposition that it renders the potas', soda, etc., of the soil available to plants. Furthermore, lime effects great good on soils abounding in salts of lime, and therefore it cannot be that it operates as a source of lime for the striature of the plant.

None of the existing theories, therefore, satisfactorily account for the action of lime. Prof. Way's views are most consistent with the facts of practical experience; but they are confessedly hypothətical; and his more recent investigations do not confirm the idea that lime acts beneficially by converting the soda silicate into the lime silicate.

Thus, six soils were treated with lime water until they had absorbed from one and a half to two par cent of their weight of lime. This, supposing the soil to be six inches cleep, would be at the rate of about 300 bushels of lime per acre. The amount of ammonia in the soil was determined before liming, after liming, and then after being exposed to the fumes of carbonate ammonia until it had absorbed as much as it would. The following table exhibits the results:

\begin{tabular}{|c|c|c|c|c|c|c|}
\hline & No. 1. & No. 2. & No. 3. & No. 4. & No. 5. & No. 6 . \\
\hline $\begin{array}{l}\Delta \text { mmonia in } 1,0 j 0 \text { prains of natural } \\
\text { soil......... } \\
\text { Ammonia in } 1,00 j \text { grains of soil after }\end{array}$ & 0.293 & 0.181 & 0.035 & 0.109 & 0.127 & $0.0 \$ 3$ \\
\hline $\begin{array}{l}\text { Ammonia in } 1,000 \text { grains of soil after } \\
\text { liming } \ldots \ldots \ldots \ldots \ldots \ldots \ldots\end{array}$ & 0.169 & 0.102 & 0.040 & 0.050 & & 0.051 \\
\hline 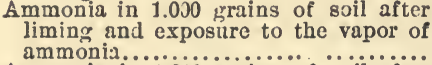 & 2.226 & 2.066 & 3.297 & 1.076 & 3.265 & 1.827 \\
\hline $\begin{array}{l}\text { Ammonia in } 1,0) 0 \text { grains of soil after } \\
\text { exposure to ammonia without liming. }\end{array}$ & 1.906 & 2.557 & 3.286 & 1.097 & 2.615 & 2.023 \\
\hline
\end{tabular}

No. 1. Surface soil of London clay.

No. 2. Same soil from $1 \frac{1}{2}$ to 2 feet below the surface.

No. 3. Same soil $\mathrm{z}$ feet below the surface.

No. 4. Loam of teritiary drift 4 feet below the surface.

No. 5. Gault clay - surface soil.

No. 6. Gault clay 4 feet bslow the surface.

It is evident that lime neither assisted nor interiered with the absorption of ammonia, and hence the beneficial effect of liming on such soils must be accounted for on some other supposition. This negative result, however, does not disprove the truth of Prof. Way's hypothesis, for it may be that the silicate salt in the natural soils was that of lime and not that of soda... Indeed, the extent to 
which the natural soils absorbed ammonia-equal, in No. 3, to about 7,000 lbs. of ammonia per acre, equivalent to the quantity contaiued in 700 tons of barn-yard manure-shows this to have been the case.

The lime liberated one-half the ammonia contained in the soil.

"This resu t," says Prof. Way, "is so nearly the same in all cases, that we are justifiel in believing it to be due to some special cause, and probably it arises from the existence of some compound silicates contxining ammonia, of which lime under the circumstances can replace one-dalf-forming, for instance, a double silicate of alumina, with half lime and half ammonia-such compounds are not unusual or new to the chemist."

This loss of ammonia from a heavy dressing of lime is very great. A soil five inches deep, weighs, in round numbers, 500 tons, or $1,000,000 \mathrm{lbs}$. The soil, No. 1, contained .0293 per cent of ammonia, or in an acre, five inches deep, $293 \mathrm{lbs}$. After liming, it contained .0169 per cent, or in an acre, five inches deep, $169 \mathrm{lbs}$. The loss by liming is $124 \mathrm{lbs}$. of ammonia per acre. This is equal to the quantity contained in $1200 \mathrm{lbs}$. of good Peruvian guano, or $12 \frac{1}{2}$ tons of barn-yarl manure.

In commenting on this great loss of ammonia from liming, Prof. Way observes:

"Is it not possible, that for the profitable agricultural use, the ammonia of the soil is too tightly locked up in it? Can we suppose that the very powers of ths soil to unite with and preserve the elements of manure are, however excellent a provision of nature, yet in some degree opposed to the growth of the abnormal crops whic' it is the business of the farmer to cultivate? There is no absolute reason why such should not be the case. A provision of nature must relate to natural circumstances; for instance, con pouzds of ammonia may be found ia the soil, capable of giving out to the agencies of water and air quite enough of ammonia for the growth of ordinary plants and the preservation of their species; but this supply may be totally inadequate to the necessities of man. * * Now it is not impossible that the laws which preserve the supply of vegetable nutrition in the soil, are too stringent for the requirements of an unusual and excessive vegetation, such as the cultivator must promote.

"In the case of ammonia lockel up in the soil, lime may be the remedy at the command of the farmer-his means of rendering immediately available stores of wealth, which can otherwise only slowly be brought into use.

"In this view, lime would well deserve the somewhat vague 
name that has been given it, namely, that of a 'stimulant'; for its application would be in some sort an application of ammonia, while its excessive application, by driving off ammonia, would lead to all the disastrous effects which are so justly attributed to it.

"I do not wish to push this assumption too far," says Prof. Way, in conclusion, "but if there be any truth in it, it points out the importance of employi ' $g$ lime in small quantities at short intervals, rather than in large doses once in many years."

"The Squire, last year," said the Deacon, "drew several hundred bushels of refuse lime from the kila, and mixed it with his manure. It made a powerful smell, and not an agreeable one, to the passers by. He put the mixture on a twenty-acre field of wheat, and he said he was going to beat you."

"Yes," said I, "so I understood-but he did not do it. If he had applied the lime and the manure separately, he would have stood a better chance; still, there are two sides to the question. I should not think of mixing lime with good, rich farm-yard manure; but with long, coarse, strawy manure, there would be less injury, and possibly some advantage."

"The Squire," said the Deacon," got one advantage. He had not much trouble in drawing the manure about the land. There was not much of it left."

Lime does not always decompose organic matter. In certain conditions, it will preserve vegetable substances. We do not want to mix lime with manure in order to preserve it; and if our object is to increase fermentation, we must be careful to mix sufficient soil with the manure to keep it moist enough to retain the liberated ammonia.

Many farmers who use lime for the first time on wheat, are apt to feel a little discouraged in the spring. I have frequently seen limed wheat in the spring look worse than where no lime was used. But wait a little, and you will see a change for the better, and at harvest, the lime will generally give a good account of itself.

There is one thing about lime which, if generally true, is an important matter to our wheat-growers. Lime is believed to hasten the maturity of the crop. "It is true of nearly all our cultivated crops," says the late Professor Johnston, "but especially of those of wheat, that their full growth is attained more speedily when the land is limed, and that they are ready for the harvest from ten to fourteen days earlier. This is the case even with buck- 
wheat, which becomes sooner ripe, though it yields no larger a return when lime is applied to the land on which it is grown."

In districts where the midge affects the wheat, it is exceedingly important to get a variety of wheat that ripens early; and if lime will favor early maturity, without checking the growth, it will be of great value.

A correspondent in Delaware writes: "I have used lime as a manure in various ways. For low land, the best way is, to sow it broadcast while the vegetation is in a green state, at the rate of 40 or 50 bushels to the acre; but if I can not use it before the frost kills the vegetation, I wait until the land is plowed in the spring, when I spread it on the plowed ground in about the same quantity as before. Last year, I tried it both ways, and the result was, my crop was increased at least fourfold in each instance, but that used on the vegetation was best. The soil is a low, black sand."

A farmer writes from New Jersey, that he has used over 6,000 bushels of lime on his farm, and also considerable guano and phosphates, but considers that the lime has paid the best. His farm has more than doubled in real value, and he attributes this principally to the use of lime.

"We lime," he says, "whenever it is convenient, but prefer to put it on at least one year before plowing the land. We spread from 25 to 40 bushels of lime on the sod in the fall; plant with corn the following summer; next spring, sow with oats and clover; and the next summer, plow under the clover, and sow with wheat and timothy. We have a variety of soils, from a sandy loam to a stiff clay, and are certain that lime will pay on all or any of them. Some of the best farmers in our County commenced liming when the lime cost $25 \mathrm{cts}$ a bushel, and their farms are ahead yet, more in value, I judge, than the lime cost. The man who first commences using lime, will get so far ahead, while his neighbors are looking on, that they will never catch up."

Another correspondent in Hunterdon Co., N. J., writes: "Experience has taught me that the best and most profitable mode of applying lime is on grass land. If the grass seed is sown in the fall with the wheat or rye, which is the common pructice with us in New Jersey, as soon as the harvest comes off the next year, we apply the lime with the least delay, and while fresh slacked and in a dry and mealy state. It can be spread more evenly on the ground, and is in a state to be more readily taken up by the fine roots of the plants, than if allowed to get wet and clammy. It is found most beneficial to keep it as near the surface of the ground 
as practicable, as the specific gravity or weight of this mineral manure is so great, that we soon find it too deep in the ground for the fibrous roots of plants to derive the greatest possible benefit from its use. With this method of application are connected several advantages. The line can be hauled in the fall, after the busy season is over, and when spread on the sod in this way, comcs in more immediate contact with the grass and grass-roots than wien the land is first plowed. In ficlds that have been limed in part in this manner, and then plowed, and lime applied to the remainder at the time of planting with corn, I always observe a great difierence in the corn-crop; and in plowing up the stubble the next season, the part limed on the sod is much mellower than that limed after the sod was broken, presenting a rici vegetable mould not observed in the other part of the ficld."

A farmer in Chester Co., Pa., also prefers to apply lime to newly. sceded grass or clover. He puts on 100 bushels of slaked lime per acre, either in the fall or in the spring, as most convenient. He limes one field every year, and as the farm is laid off into eleven fields, all the land receives a dressing of lime once in eleven years.

In some sections of the country, where lime has been used for many years, it is possible that part of the money might better be used in the purchase of guano, phosphates, fish-manure, etc.; while in this section, where we seldom use lime, we might find it greatly to our interest to give our land an occasional dressing of lime.

The value of quick-lime as a manure is not merely in supplying an actual constituent of the plant. If it was, a few pounds per acre would be sufficient. Its value consists in changing the chemical and physical character of the soil-in developing the latent mineral plant-food, and in decomposing and rendering available organic matter, and in forming compounds which attract ammonia from the atmosphere. It may be that we can purchase this ammonia and other plant-food cheaper than we can get it by using lime. It depends a good deal on the nature and composition of the soil. At present, this question can not be definitely settled, excent by actual trial on the farm. In England, where lime was formerly used in large quantities, the tendency for some time has been towards a more liberal and direct use of ammonia and phosphates in manures, rather than to develop them out of the soil by the use of lime. A judicious combination of the two systems will probably be found the most protitable.

Making composts with old sods, lime, and barn-yard manure, is 
a time-honored practice in Europe. I bave scen excellent results from the application of such a compost on meadow-land. The usual plan is, to select an old hedge-row or headland, which has lain waste for many years. Plow it up, and cart the soil, sods, etc., into a long, narrow heap. Mix lime with it, and let it lie six months or a year. Then turn it, and as soon as it is fine and mellow, draw it on to the land. I have assisted at making many a heap of this kind, but do not recollect the proportion of lime used; in fact, I question if we had any definite rule. If we wanted to use lime on the land, we put more in the heap; if not, less. The manure was usually put in when the heap was turned.

Dr. Vœlcker analyzed the dry earth used in the closets at the prison in Wakefield, England. He found that:

10 tons of dry earth before using

Nitro- Phosphor
gen. ic Acid.
62.lbs. $36 \mathrm{lbs}$.

10 tons of dry earth after being used once contained.... 74 " 50 "

10 tons of dry earth after being used twice contained.. 84 " 88 "

10 tons of dry earth after being used thrice contained.102 " 102 "

After looking at the above figures, the Deacon rcmarked: "You say 10 tons of dry earth before being used in the closet contained 62 lbs. of nitrogen. How much nitrogen does 10 tons of barnyard manure contain?"

"That depends a good deal on what food the animals eat. Ten tons of average fresh manure woulủ contain about $80 \mathrm{lbs}$. of nitrogen."

"Great are the mysteries of chemistry!" exclaimed the Deacon. "Ten tons of dry earth contain almost as much nitrogen as 10 tons of barn-yard manure, and yet you think that nitrogen is the most valuable thing in manure. What shall we be told next?"

"You will be told, Deacon, that the nitrogen in the soil is in such a form that the plants can take up only a small portion of it. But if you will plow such land in the fall, and expose it to the disintegrating effects of the frost, and plow it again in the spring, and let the sun and air act upon it, more or less of the organic matter in the soil will be decomposed, and the nitrogen rendered solulhle. And then if you sow this land to wheat after a guod summer-fallow, you will stand a chance of having a great crop."

This clry earth which Dr. Vœlcker analyzed appeared, he says, "to be ordinary garden soil, containing a considerable portion of clay." After it had been passed once through the closet, one ton of it was spread on an acre of grass-land, which produced 2 tons $8 \mathrm{cwt}$. of hay. In a second experiment, one ton, once passed through the closet, produced 2 tons $7 \mathrm{cwt}$. of hay per acre. We are not told how much hay the land produced without any dress- 
ing at all. Still we may infer that this top-dressing did considerable good. Of one thing, however, there can be no doubt. This one ton of earth manure contained only $1 \frac{1}{4} \mathrm{lb}$. more nitrogen and $1 \frac{1}{2} \mathrm{lb}$. more phosphoric acid than a ton of the dry earth itself. Why tien did it prove so valuable as a top-dressing for grass? I will not say that it was due solely to the decomposition of the nitrogenous matter and other plant-food in the earth, caused by the working over and sifting and exposure to the air, and to the action of the night-soil. Still it would seem that, so far as the bencficial effect was due to the supply of plant-food, we must attribute it to the earth itself rather than to the small amount of night-soil which it contained.

It is a very common thing in England, as I have said before, for farmers to make a compost of the sods and earth from an old hedge-row, ditch, or fence, and mix with it some lime or barnyard manurc. Then, after turning it once or twice, and allowing it to remain in the heap for a few months, to spread it on meadow-land. I have seen great benefit apparently derived from such a top-dressing. The young grass in the spring assumed a rich, dark green color. I have nbserved the same eff act where ccal-ashes were spread on grass-land; and I have thought that the apparent benefit was dus largely to the material acting as a kind of mulch, rather than to its supplying plant-food to the grass.

I doubt very much whether we can afford to make such a com- . post of earth with lime, ashes, or manure in this country. But I ieel sure that those of us having rich clay land containing, in an inert form, as much nitrogen and phosphoric acil as Dr. Volcker fornd in the soil to be used in the earth-closet at Wakefield, can well afford to stir it freely, and expose it to the disintegrating and decomposing action of the atmosphere.

An acre of dry soil six inches dcep weighs about 1,020 t.ns; and consequently an acre of such soil as we are talking about would contain $6,200 \mathrm{lbs}$. of nitrogen, and $3,600 \mathrm{lbs}$. of phosphoric acid. In other words, it contains th the depth of only six inclies as much nitrogen as would be furnished by 775 tons of commcn barn-yard manure, and as much phosphoric acid as 900 tons of manure. With such facts as these before us, am I to blame for urging farmers to cultivate their land more thoroughly? I do not know that my land or the Deacon's is as rich as this English scil; but, at any rate, I see no reason why such should not be the case. 


\section{H A P TER X X I X.}

\section{MANURES FOR BARLEY.}

Messrs. Lawes and Gilbert have published the results of experiments with different manures on barley grown annually on the same land for twenty years in succession. The experiments commenced in 1852 .

The soil is of the same general cliaracter as that in the field on the same farm where wheat was grown annually for so many years, and of which we have given such a full account. It is what we should call a calcareous clay loam. On my farm, we have what the men used to call "clay spots." These spots vary in size from two acres down to the tenth of an acre. They rarely produced even a fair crop of corn or potatoes, and the barley was seldom worth harvesting. Since I have drained the land and taken special pains to bestow extra care in plowing and working these hard and intractable portions of the fields, the "clay spots" have disappeared, and are now nothing more than good, rather stiff, clay loam, admirably adapted for wheat, barley, and oats, and capable of producing good crops of corn, potatoes, and mangel-wurzels.

The land on which Mr. Lawes' wheat and barley experiments were made is not dissimilar in general character from these "clay spots." If the land was only half-worked, we should call it clay; but being tioroughly cultivated, it is a good clay loam. Mr. Lawes describes it as "a somewhat heavy loam, with a sulsoil of raw, yellowish red clay, but resting in its turn upon chalk, which provides good natural drainage."

The part of the field devoted to the experiments was divided into 24 plots, about the fifth of an acre each.

Two plots were left without manure of any kind.

One plot was manured every year with 14 tons per acre of farmyard manure, and the other plots "with manures," to quote Dr. Gilbert, "which respectively supplied certain constituents of farmyard manure, separately or in combination."

In England, the best barley soils are usually lighter than the best wheat soils. This is probably due to the fact that barley usually follows a crop of turnips-more or less of which are catcn off on the land by sheep. The trampling of the sherp compresses the soil, and makes even a light, sandy one tirmer in texture.

In this country, our best wheat land is also our best barley land, provided it is in good heart, and is very thoroughly worked. 
It is no use sowing barley on heavy land half workec. It will do better on light soils; but if the clayey soils are made fine and mellow, they produce with us the best barley.

In chemical composition, barley is quite similar to wheat. $\mathrm{Mr}$. Lawes and Dr. Gilbert give the composition of a wheat-crop of 30 bushels per acre, 1,800 lbs. of grain, and $3,000 \mathrm{lbs}$. of straw; and of a crop of barley, 40 bushels per acre, $2,080 \mathrm{lbs}$. grain, and 2,500 lbs. of straw, as follows:

\begin{tabular}{|c|c|c|c|c|c|c|}
\hline & \multicolumn{2}{|c|}{ In Grain. } & \multicolumn{2}{|c|}{ In Straw. } & \multicolumn{2}{|c|}{ In Total Produce. } \\
\hline & Wheat. & Barley. & Wheat. & Barley. & Wheat. & Barley. \\
\hline 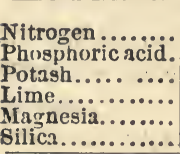 & $\begin{array}{l}\text { lbs. } \\
32 . \\
16 . \\
9.5 \\
1 . \\
3.5 \\
0.5\end{array}$ & $\begin{array}{l}\text { 1bs. } \\
33 . \\
17 . \\
11.5 \\
1.5 \\
4 . \\
12 .\end{array}$ & $\begin{array}{l}\text { lbs. } \\
13 . \\
7 . \\
20.5 \\
9 . \\
3 . \\
99.5\end{array}$ & $\begin{array}{l}\text { lbs. } \\
12 . \\
5 . \\
18.5 \\
10.5 \\
2.5 \\
63 .\end{array}$ & $\begin{array}{l}\text { lbs. } \\
45 . \\
2: 3 . \\
30 . \\
10 . \\
6.5 \\
100 .\end{array}$ & $\begin{array}{l}1 \mathrm{bs} . \\
45 . \\
22 . \\
30 . \\
12 . \\
6.5 \\
75 .\end{array}$ \\
\hline
\end{tabular}

A few years ago, when the midge destroyed our wheat, many farmers in Western New York raised "winter barley," instead of "winter wheat," and I have seen remarkably heavy crops of this winter barley. It is not now grown with us. The maltsters would not pay as much for it as for spring barley, and as the midge troubles us less, our farmers are raising winter wheat again.

Where, as with us, we raise winter wheat and spring barley, the difference between the two crops, taking the above estimate of yield and proportion of grain to straw, would be:

1st. Almost identical composition in regard to nitrogen, phosphoric acid, potash, lime, and magnesia; but as it has more straw, the wheat-crop removes a larger amount of silica than barley.

2d. The greatest difference is in the length of time the two crops are in the ground. We sow our winter wheat the last of August, or the first and sacond week in September. Before winter sets in, the wheat-plant often throws out a bunch of roots a foot in length. During the winter, though the thermometer goes down frequently to zero, and sometimes $10^{\circ}$ to $15^{\circ}$ below zero, yet if the land is well covered with snow, it is not improbable that the roots continue to absorb more or less food from the ground, and store it up for future use. In the spring, the wheat commences to grow before we can get the barley into the ground, though not to any considerable extent. I have several times sown barley as soon as the surface-soil was thawed out five or six inches deep, but with a bed of solid frozen earth beneath.

3 d. Two-rowed barley does not ripen as early as winter wheat, but our ordinary six-rowed barley is ready to harvest the samo time as our winter wheat. 
4th. We sow our barley usually in May, and harvest it in July. The barley, therefore, has to take up its food rapidly. If we ex. pect a good growth, we must provide a good supply of food, and have it in the proper condition for the roots to reach it and absorb it; in other words, the land must be not only rich, but it must be so well worked that the roots can spread out easily and rapidly in search of fuod and water. In this country, you will find ten good wheat-growers to one good barley grower.

"That is so," said the Deacon; "but tell us about Mr. Lawes' experiments. I have morc confidence in them than in your specnlations. And first of all what kind of land was the barley grown on?"

"It is," said I, "rather heavy land-as heavy as what the men call ' clay-spots,' on my farm."

"And on those clay-spots," sail the Deacon, "you either get very good barley, or a crop not worth harvesting."

"You have hit it exactly, Deacon," said I. "The best barley I have this year (1878) is on these clay-spots. And the reason is, that we gave them an extra plowing last fall with a three-1orso plow. That extra plowing has probably given me an extra 30 bushels of barley per acre. The barley on some of the lighter portions of the field will not yield over 25 bushels per acre. On the clay-spots, it looks now (June 13) as though there would be over 50 bushels per acre. It is all headed out handsomely on the clayspots, and has a strong, dark, luxuriant appearance, while on the sand, the crop is later and has a yellow, sickly look."

"You ought," said the Doctor, "to have top-dressed these poor, sandy parts of the field with a little superphosphate and nitrate of soda."

"It would have paid wondcrfully well," said I, "or, perhaps, more correctly speaking, the loss would hare bsen considerably less. We have recently been advised by a distinguished writer, to apply manure to our best land, and let the poor land take care of itself. But where the poor land is i. the same field with the good, we are obliged to plow, harrow, cultivate, sow, and harvest the poor spots, and the question is, whether we shall make them capable of producing a good crop by the application of manure, or be at all the labor and expense of putting in and harresting a crop of chicken-feed and weeds. Artificial manures give us a grand chance to make our crops more uniform."

"You are certainly right there," said the Doctor, "but let us examine the Rothamsted experiments on barley."

You will find the results in the following tables. The manures 
used, are in many respects the same as were adopted in the wheat experiments already given. The mineral or ash constituents were supplied as follows:

Potzsh-as sulphate of potash.

Soda-as sulphate of soda.

Magnesia - as sulphate of magnesia.

Lime-as sulphate, phosphate, and superphosphate.

Plosphoric acid-as bone-ash, mixed with sufficient sulphuric acid to convert most of the insoluble earthy phosphate of lime into sulphate and soluble superphosphate of lime.

Sulphuric acid-in the phosphatic mixture just mentioned; in sulphates of potash, soda, and magnesia; in sulphate of ammonia, etc.

Chlorine-in muriate of ammonia. Sitica-as artificial silicate of soda.

Other constituents were supplied as under:

Nitrogen-as sulphate and muriats of ammonia; as nitrate of soda: in farm-yard manure; in rape-cake.

Non-nitrogenous organic matter, yielding by decomposition, carbonic acid, and other products-in yard manure, in rape-cake. The artificial manure or mixture for each plot was ground up, or otherwise mixed, with a sufficient quantity of soil and turf-ashes to malie it up to a convenient measure for equal distribution over the land. The mixtures so prepared were, with proper precautions, sown broadcast by hand; as it has been found that the application of an exact amount of manure, to a limited area of land, can bo best accomplished in that way.

The same manures were used on the same plot cac's ycar. Any exceptions to this rule are mentioned in foot-notes. 
EXPERIMENTS ON THE GROWTH OF BARLEY, YEAR AFTER YEAR, ON THE SAME LAND, WITZOCT MANURE, AND WITH DIFFERENT IESCRIPTIONS of Mandre. Hoos Field, Rotiamsted, Exglaxd.

TABLE I.-SHOWING, taken together with the foot-notes, TuE DESCRIPTION AND QUANTITIES OF THE MAYURES APPLIED PER ACRP ON FACII PLOT, IN EACE YEAR OF THE TWENTY, 1852-18 11 INCLESIVE.

[N. B. This table has reference to all the sacceeding Tablcs].

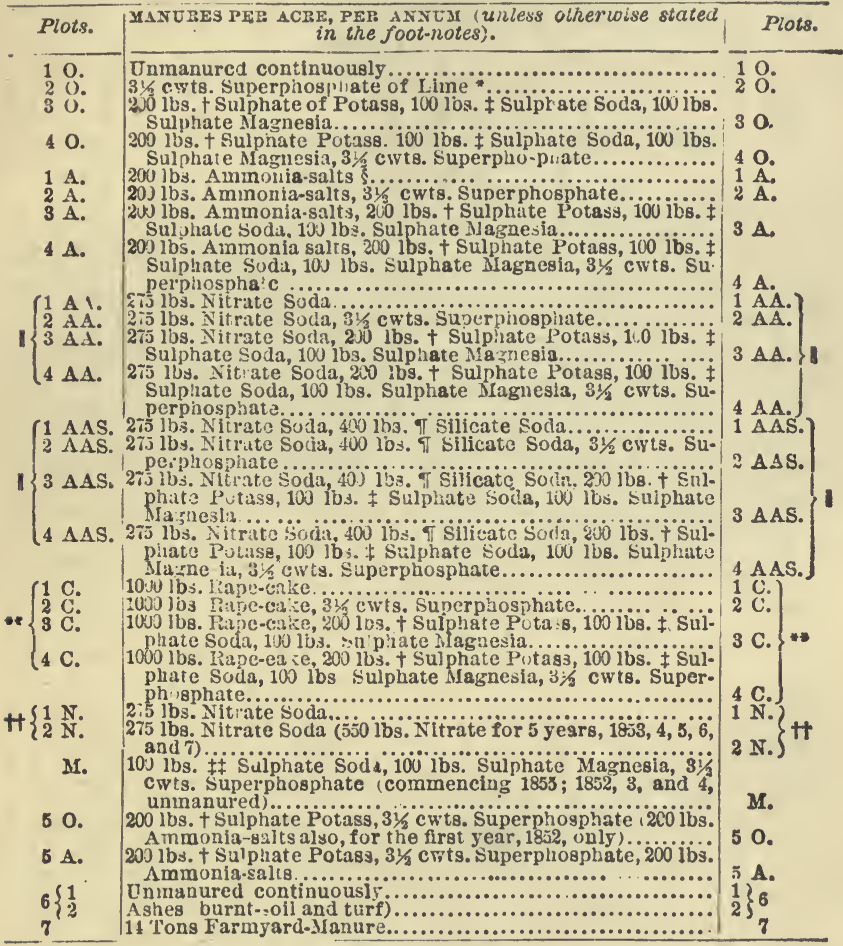

NOTÁS TO TABLE I.

* "31/3 cirts. Superphosphate of Lime" - in all cases, made from 200 lbs. Bone. ash, 150 ibs. Sulphuric acid sp. gr. 1.7 and water'

t Sulpliate Potass -3:0 lbs. per annum for the first 6 years, 1852-7.

$\$$ Sulphate Soda -200 lbs. per \&nnum for the first 6 ycars, 1852-7.

"The. Ammonia-salts "-in all cases cqual parts of Sulphate and Mariate of Am. monia of Cummerce.

"Plots"A 1 " and "AAS"-flrst 6 years, 1852-7, Instead of Nitrate of Eoda, 400 Ibs. Aminnnia-salts per annum; next 10 years, 1858-67, 200 lbs. Ammnnia-salts per annum ; 1868, and sinee, $275 \mathrm{Jbs}$. Kitrate of Sodaper annum. 275 Ibs. Nitratc of Suda is reckoned to c intain the same nimount of Nitrogen as 200 los. "Ammonia-salts."

- Plots "AAS"-the application of Silieates did not commence until 1861; in '64-5-6, and $7,200 \mathrm{lbs}$. Silicate of Soda and 200 lbs. Silicate of lime werc aiplicd per acre, but in 136\%, and since, $400 \mathrm{lbs}$. Silleate of Soda, and no Silicate of Lime. These plots eomprise, respectively, one half of the original "AA "plots, and, exceptilg the addition of the Sillicates, have been, and are, in other respects, manured in the same way as the "AA" plots.

**2000 lbs. Rape-cake per annum for the first 6 years, and $1000 \mathrm{lbs}$. only, each year gince. $t+30 \mathrm{~J}$ ibs. Sulphate Potass, and $31 / 2 \mathrm{cwts}$. Superphosphate of Lime, without Nitrate if Soda, the tirst year (1852); Nitrate alone each year since. $¥ \ddagger$ Sulphate Soda -200 lbs. per andum 1355,6 , and $\%$. 
Expebiments ox the Growth of Barlet, Year after Year, on tions of MaNule, Hoos

TABLE II.-DTESBED

[N.B. The double vertical lines show that there was a change in the descrip.

Table $I_{\text {. }}$, and foot-notes

\begin{tabular}{|c|c|c|c|c|c|c|c|c|c|c|c|c|}
\hline \multirow{2}{*}{ ङू } & \multicolumn{12}{|c|}{ HARVEBTS. } \\
\hline & 1852 & 1853 & 1854 & 1855 & 1856 & 1857 & 1858 & 1859 & 1860 & 1861 & 1862 & 1863 \\
\hline $\begin{array}{ll}1 & 0 . \\
2 & 0 . \\
3 & 0 . \\
4 & 0 .\end{array}$ & $\begin{array}{c}\text { bushels. } \\
2714 \\
235 / 8 \\
251 / 8 \\
323 / 4\end{array}$ & $\begin{array}{l}\text { bush. } \\
253 / 4 \\
331 / 2 \\
275 \% \\
35 \% 8\end{array}$ & $\begin{array}{l}\text { bush. } \\
35 \\
405 / 8 \\
361 / 2 \\
42\end{array}$ & $\mid$\begin{tabular}{l|} 
bus \\
31 \\
$361 / 4$ \\
$343 / 4$ \\
$371 / 8$
\end{tabular} & $\begin{array}{l}\text { bus } \\
137 / 8 \\
17 \% / 4 \\
16 \% / 8 \\
193 / 4\end{array}$ & $\begin{array}{l}\text { bush. } \\
261 / 8 \\
331 / 4 \\
3.2 \\
393 / 4\end{array}$ & $\begin{array}{l}\text { bush. } \\
211 / 8 \\
283 / 4 \\
241 / 4 \\
30 \%\end{array}$ & $\begin{array}{l}\text { bus } \\
131 / 2 \\
195 / 8 \\
157 / 8 \\
193 / 4\end{array}$ & $\begin{array}{l}\text { bus } \\
131 / 4 \\
153 / 4 \\
151 / 4 \\
18,4\end{array}$ & $\begin{array}{l}\text { bus } \\
161 / 4 \\
25 \\
187 / 8 \\
293 / 8\end{array}$ & $\begin{array}{l}\text { bus } \\
161 / 3 \\
211 / 8 \\
193 / 4 \\
251 / 8\end{array}$ & $\begin{array}{l}\text { bus } \\
227 / 8 \\
323 \% \\
27 \% \\
33\end{array}$ \\
\hline Means & $233 / 4$ & $30 \% / 8$ & $331 / 2$ & $343 / 6$ & 17 & $323 / 4$ & $261 / 4$ & $171 / 6$ & $15 \%$ & $223 \%$ & $20 \%$ & $28 \%$ \\
\hline $\begin{array}{ll}1 & A . \\
2 & A . \\
3 & A . \\
4 & A .\end{array}$ & $\begin{array}{l}337 / 8 \\
335 / 8 \\
36 \\
403 / 4\end{array}$ & $\begin{array}{l}395 / 8 \\
401 / 8 \\
361 / 2 \\
331 / 4\end{array}$ & $\begin{array}{l}473 / 4 \\
60 \% \\
50 \\
60 \% 8\end{array}$ & $\begin{array}{l}44 \% / 2 \\
473 / 2 \\
44 \% / 2 \\
43 \%\end{array}$ & \begin{tabular}{l|}
25 \\
$291 / 6$ \\
$283 / 8$ \\
$313 / 4$
\end{tabular} & $\begin{array}{l}387 / 8 \\
56 \% / 8 \\
423 / 8 \\
57 \%\end{array}$ & $\begin{array}{l}311 / 2 \\
513 / 8 \\
34 \text { ' } \\
51 \text { 多 }\end{array}$ & $\begin{array}{l}15 \% \\
34 \% \\
16 \% \\
34 \%\end{array}$ & $\begin{array}{l}265 / 8 \\
43 \% \\
28 \\
431 / 2\end{array}$ & $\begin{array}{l}301 / 2 \\
55 \\
323 / 4 \\
54 \% 8\end{array}$ & $\begin{array}{l}313 / 3 \\
485 / 3 \\
351 / 4 \\
475 \%\end{array}$ & $\begin{array}{l}425 / 8 \\
615 \% \\
48 \% 8 \\
55 \%\end{array}$ \\
\hline Means & $331 / 8$ & $33: 8$ & $513 / 4$ & $461 / 4$ & 2812 & $483 / 2$ & $421 / 8$ & $253 / 8$ & $35 \%$ & $43 \frac{1}{4}$ & $403 / 4$ & $521 / 8$ \\
\hline $\begin{array}{l}1 \text { AA. } \\
2 \text { AA. } \\
3 \text { AA. } \\
4 \text { AA. }\end{array}$ & $\begin{array}{l}41 / 2 \\
433 / 1 \\
413 / 2 \\
45 \% / 8 \\
\end{array}$ & $\begin{array}{l}403 / 4 \\
421 / 4 \\
41 \frac{4}{4} \\
4416 \\
\end{array}$ & $\begin{array}{l}563 / 8 \\
63 / 4 \\
511 / 2 \\
623 / 4 \\
\end{array}$ & \begin{tabular}{|l|}
48 \\
$503 / 8$ \\
$471 / 4$ \\
$495 \%$
\end{tabular} & $\begin{array}{l}361 / 4 \\
31 / 1 / 2 \\
2538 \\
37 \% \\
\end{array}$ & $\begin{array}{l}493 / 3 \\
66 \text { \%/ } \\
4978 \\
6478\end{array}$ & $\begin{array}{l}393 / 8 \\
561 / 4 \\
405 \% \\
56 \text { ' } \\
\end{array}$ & $\begin{array}{l}211 / 2 \\
35 \% \\
203 \% \\
353 / 4 \\
\end{array}$ & $\begin{array}{l}253 / 8 \\
431 / 4 \\
303 / 4 \\
461 / 4 \\
\end{array}$ & $\begin{array}{l}35 \\
553 / 4 \\
36 \% \\
55 \% \\
\end{array}$ & $\begin{array}{l}311 / 2 \\
51 \\
361 / 4 \\
483 \% \\
\end{array}$ & $\begin{array}{l}49 \\
601 / 2 \\
54 \\
591 / 2 \\
\end{array}$ \\
\hline Menns & $433 / 4$ & $421 / 8$ & $531 / 2$ & $48 \%$ & $32 \% / 8$ & $573 / 4$ & $481 / 8$ & $28 \%$ & $36 \%$ & $45 \%$ & $41 \%$ & $55 \%$ \\
\hline $\begin{array}{l}1 \text { AAS. } \\
2 \text { AAS. } \\
3 \text { AAS. } \\
4 \text { AAS. }\end{array}$ & & & & & & & & & & & & \\
\hline Means. & & & & & & & & & & & & \\
\hline $\begin{array}{ll}1 & \text { C. } \\
2 & C . \\
3 & C . \\
4 & C .\end{array}$ & $\begin{array}{l}3.1 / 3 \\
33 \% / 2 \\
3312 \\
33\end{array}$ & $\begin{array}{l}3.7 \% 8 \\
351 / 8 \\
351 / 4 \\
401 / 8\end{array}$ & $\begin{array}{l}60 \% / 4 \\
603 \% 8 \\
561 / 3 \\
60 \div 4\end{array}$ & $\begin{array}{l}481 / 3 \\
53 \% 4 \\
48 \% \\
513 / 4\end{array}$ & $\begin{array}{l}363 / 4 \\
371 / 8 \\
325 \% \\
35 \%\end{array}$ & $\begin{array}{l}641 / 8 \\
621 / 4 \\
601 / 4 \\
621 / 4\end{array}$ & $\begin{array}{l}5: 33 / 4 \\
573 \% 8 \\
52 \\
571 / 8\end{array}$ & $\begin{array}{l}383 / 4 \\
41 \\
341 / 8 \\
35\end{array}$ & $\begin{array}{l}313 / 4 \\
363 / 4 \\
354 \\
403 / 4\end{array}$ & $\begin{array}{l}561 / 3 \\
56 \% 3 \\
511 / 8 \\
53 \% 8\end{array}$ & $\begin{array}{l}41 \\
45 \\
36 \\
451 / 2\end{array}$ & $\begin{array}{l}51 \% \\
55 \\
531 / 8 \\
511 / 2\end{array}$ \\
\hline Means & $363 / 4$ & $37 \%$ & 5913 & 505 & $35:$ & $62 \div$ & 55 & $37 \div 4$ & $361 / 8$ & $541 / 3$ & $41 \%$ & 535 \\
\hline $\begin{array}{l}1 \mathrm{~N} . \\
2 \mathrm{~N} .\end{array}$ & \}$(25 \%)\{$ & $\begin{array}{l}313 / 8 \\
371 / 8\end{array}$ & $\begin{array}{l}493 / 8 \\
531 / 4\end{array}$ & $\begin{array}{l}50 \\
49 \%\end{array}$ & 293 & $\begin{array}{l}47 \% \\
58 \%\end{array}$ & $\begin{array}{l}873 / 4 \\
437 / 6\end{array}$ & $\begin{array}{l}217 \% \\
25 \%\end{array}$ & $27 \%$ & 381 & $\begin{array}{l}351 / 2 \\
38 \%\end{array}$ & $\begin{array}{l}511 / 2 \\
5378\end{array}$ \\
\hline $\begin{array}{ll} & \mathrm{M} . \\
5 & 0 . \\
5 & \mathrm{~A} .\end{array}$ & $\frac{(3318) 1}{35 \% 8}$ & $\begin{array}{l}271 / 2 \\
4018\end{array}$ & $\begin{array}{l}303 / 4 \\
51 \% / 8\end{array}$ & $\begin{array}{l}321 / 8 \\
3238 \\
47 \% 8\end{array}$ & $\begin{array}{l}183 / 4 \\
191 / 8 \\
331 / 8\end{array}$ & $\begin{array}{l}241 / \% \\
811 / 8 \\
B 1 \%\end{array}$ & $\begin{array}{l}257 \% \\
253 \% \\
481 \% 8\end{array}$ & $\begin{array}{l}192 / 6 \\
162 / 2 \\
33 \%\end{array}$ & $\begin{array}{l}10 \% \\
101 / 8 \\
39\end{array}$ & $\begin{array}{l}275 \% \\
28 \% 8 \\
49 \%\end{array}$ & $\begin{array}{l}235,8 \\
1738 \\
465\end{array}$ & $\begin{array}{l}281 / 8 \\
291 / 3 \\
511 / 2\end{array}$ \\
\hline $6\left\{\begin{array}{l}1 \\
2\end{array}\right.$ & 29 & $\begin{array}{l}281 / 4 \\
2738\end{array}$ & $\begin{array}{l}851 / 3 \\
83.4\end{array}$ & $\begin{array}{l}371 / 3 \\
361 / 4\end{array}$ & $\begin{array}{l}151 / 8 \\
15 \%\end{array}$ & $\begin{array}{l}84 \% / 3 \\
81 \frac{1}{8}\end{array}$ & $\begin{array}{l}261 / 3 \\
25 \% / 4\end{array}$ & $\begin{array}{l}171 / 8 \\
143 / 6\end{array}$ & $\begin{array}{l}121 / 4 \\
121 / 8\end{array}$ & $\begin{array}{l}16 \% \\
17 \%\end{array}$ & $\begin{array}{l}181 / 2 \\
19\end{array}$ & $\begin{array}{l}271 / 4 \\
28 \% / 8\end{array}$ \\
\hline 7 & 83 & $891 / 8$ & $563 / 6$ & $501 / 8$ & $821 / 8$ & $511 / 4$ & 55 & 40 & $41 \%$ & $54 \%$ & $493 / 4$ & $591 / 2$ \\
\hline
\end{tabular}

(1) Arerages of 4 years, 4 years, and 8 years. last 10 years, and total 17 years.

(1) Arerages 
the same LAND, Without MaNURE, AND With DIFferent DescripField, Rothamsted, Englaxd.

CORN PER ACRE-bushels.

tion, or quantity, of Mauure, at the period indicated, for particulars of which see thereto, p. 231.]

\begin{tabular}{|c|c|c|c|c|c|c|c|c|c|c|c|}
\hline & & . & HARV & Ts. & & & & AVEr. & $A G E A X$ & VNUAL. & \\
\hline 1864 & 1865 & 1866 & 1867 & 1868 & 1869 & 1870 & 1871 & 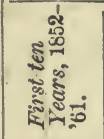 & 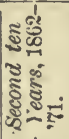 & 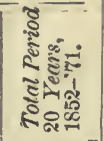 & $\frac{\dot{\Xi}}{\mathrm{s}}$ \\
\hline $\begin{array}{l}\text { bush. } \\
24 \\
301 / 4 \\
261 / 3 \\
331 / 4\end{array}$ & $\begin{array}{l}\text { bus } \\
18 \\
221 / 2 \\
2: 2 \\
243 / 8\end{array}$ & $\begin{array}{l}\text { bush. } \\
15 \% 8 \\
223 / 8 \\
191 / 8 \\
24\end{array}$ & \begin{tabular}{|l|} 
bus \\
$171 / 8$ \\
$24 \% 8$ \\
17 \\
$207 / 8$
\end{tabular} & $\begin{array}{l}\text { bush. } \\
155 / 8 \\
181 / 2 \\
141 / 4 \\
175 \%\end{array}$ & $\begin{array}{l}\text { bus } \\
151 / 8 \\
181 / 4 \\
18^{3} \\
221 / 4\end{array}$ & $\begin{array}{l}\text { bus } \\
131 / 2 \\
18 \\
163 / 4 \\
181 / 2\end{array}$ & \begin{tabular}{|l|} 
bus \\
$163 / 4$ \\
$231 / 3$ \\
$195 \%$ \\
25
\end{tabular} & $\begin{array}{r}\text { bushels. } \\
223 / 8 \\
27 \% 8 \\
243.4 \\
301 / 2\end{array}$ & $\begin{array}{l}\text { bush. } \\
171 / 3 \\
231 / 4 \\
201 / 3 \\
24 \%\end{array}$ & $\begin{array}{l}\text { bushels. } \\
20 \\
25 \frac{1 j}{2} \\
22 \% \\
271 / 2 \\
\end{array}$ & $\begin{array}{ll}1 & 0 . \\
2 & 0 \\
3 & 0 . \\
4 & 0 .\end{array}$ \\
\hline $283 / 3$ & $213 / 4$ & $20 \% / 8$ & $19 \gamma^{\prime}$ & $161 / 2$ & $18 \%$ & $16 \%$ & $21 \frac{1}{8}$ & 2636 & $21 \frac{1}{4}$ & $237 / 8$ & Means \\
\hline $\begin{array}{l}38 \% \\
581 / 2 \\
437 / 8 \\
55 \%\end{array}$ & $\begin{array}{l}29 \% \\
48 \% \frac{1}{3} \\
33 \% \frac{1}{4} \\
46 \%\end{array}$ & $\begin{array}{l}271 / 8 \\
501 / 2 \\
271 / 2 \\
47\end{array}$ & $\begin{array}{l}30 \% / 8 \\
44 \\
33 \\
43 \% \\
\end{array}$ & $\begin{array}{l}203 / 8 \\
37 \% 8 \\
25 \\
345 / 8\end{array}$ & $\begin{array}{l}27 \% / 8 \\
48 \\
343 / 4 \\
491 / 4 \\
\end{array}$ & $\begin{array}{l}273 / 4 \\
411 / 2 \\
307 / 8 \\
38\end{array}$ & $\begin{array}{l}36 \% \\
451 / 8 \\
381 / 2 \\
46 \%\end{array}$ & $\begin{array}{l}335 / 8 \\
45 \% / 8 \\
35 \\
461 / 8 \\
\end{array}$ & $\begin{array}{l}31 \% 4 \\
43 \% / 8 \\
35 \\
463 / 8 \\
\end{array}$ & $\begin{array}{l}321 / 2 \\
47 \\
35 \\
461 / 4 \\
\end{array}$ & $\begin{array}{l}1 \mathrm{~A} . \\
2 \mathrm{~A} . \\
3 \mathrm{~A} . \\
4 \mathrm{~A} .\end{array}$ \\
\hline $491 / 8$ & $3.21 / 2$ & $35^{1 / 3}$ & $37 \%$ & $293 / 3$ & $397 / 8$ & $341 / 2$ & $41 \frac{1}{1 / 2}$ & $401 / 2$ & $401 / 4$ & $401 / 4$ & Means \\
\hline $\begin{array}{l}413 / 4 \\
567 \% \\
44 \% 8 \\
563 \%\end{array}$ & \begin{tabular}{|l|}
$333 / 4$ \\
$471 / 2$ \\
$311 / 8$ \\
$437 / 8$
\end{tabular} & $\begin{array}{l}291 / 8 \\
507 / 8 \\
293 / 4 \\
507 \%\end{array}$ & \begin{tabular}{|l|}
293 \\
$44 \div$ \\
327 \\
45
\end{tabular} & $\begin{array}{l}27 \\
44 \\
271 / 2 \\
45 \%\end{array}$ & $\begin{array}{l}321 / 3 \\
481 / 4 \\
237 \\
4 ! 37 \\
8\end{array}$ & $\begin{array}{l}591 / 4 \\
461 / 4 \\
323 \% \\
441 / 2 \\
\end{array}$ & $\begin{array}{l}391 / 3 \\
461 / 2 \\
361 \% \\
46\end{array}$ & $\begin{array}{l}893 / 4 \\
4878 \\
385 \% \\
4978 \\
7 \%\end{array}$ & $\begin{array}{l}341 / 4 \\
495 / 3 \\
361 / 3 \\
491 / 2 \\
\end{array}$ & $\begin{array}{l}37 \\
494 \\
373,8 \\
493 / 4 \\
\end{array}$ & $\begin{array}{l}1 \mathrm{AA} . \\
2 \mathrm{AA} . \\
3 \mathrm{AA} . \\
4 \mathrm{AA} .\end{array}$ \\
\hline $49 \%$ & $411 / 8$ & $40 \%$ & 38 & 36 & 41 & $38 \%$ & 42 & $441 / 1 / 4$ & 423 & $433 / 8$ & Means \\
\hline $\begin{array}{l}411 / 8 \\
54 \% \\
50 \\
5 ! 1 / 8 \\
\end{array}$ & $\begin{array}{l}34 \% / 8 \\
471 / 4 \\
41 \\
501 / 2\end{array}$ & $\begin{array}{l}377 / 8 \\
511 / 8 \\
417 / 8 \\
50 \%\end{array}$ & $\begin{array}{l}321 / 4 \\
44 \\
391 / 2 \\
451 / 4 \\
\end{array}$ & $\mid \begin{array}{l}293 / 8 \\
447 / 8 \\
363 / 8 \\
465 \%\end{array}$ & $\begin{array}{l}343 / 4 \\
49 \% \\
40 \% / 2 \\
51 \frac{1}{3}\end{array}$ & $\begin{array}{l}35 \\
443 / 4 \\
423 / 4 \\
471 / 4 \\
\end{array}$ & $\begin{array}{l}481 / 6 \\
491 / 2 \\
483 / 8 \\
187 / 8\end{array}$ & (1) $\left\{\begin{array}{l}37 \% 4 \\
49 ! \\
431 / 3 \\
513\end{array}\right.$ & $\begin{array}{l}367 / 8 \\
471 / 4 \\
42 \\
485 / 3\end{array}$ & $\left.\begin{array}{l}37 \\
481 / 4 \\
425 \% \\
50\end{array}\right\}{ }^{(1)}$ & $\begin{array}{l}1 \text { AAS. } \\
2 \text { AAS. } \\
3 \text { AAS. } \\
4 \text { AAS. }\end{array}$ \\
\hline 52 & $4.3,3$ & $453 / 8$ & $401 / 4$ & $393 / 8$ & $441 / 4$ & $421 / 2$ & $483 / 4$ & $45 \frac{1}{4}$ & $43 \%$ & $44 \frac{1}{2}$ & Means \\
\hline $\begin{array}{l}481 / 8 \\
513 / 4 \\
493 / 8 \\
53^{3 / 3}\end{array}$ & \begin{tabular}{|l|}
45 \\
$461 / 8$ \\
$483 / 4$ \\
$4 S 1 / 8$
\end{tabular} & $\begin{array}{l}45 \% / 8 \\
47 \% / 2 \\
4378 \\
45 \% 8\end{array}$ & $\begin{array}{l}385 \% \\
451 / 2 \\
387 / 8 \\
425 \% 8\end{array}$ & $\begin{array}{l}37 \\
351 / 4 \\
351 \% \\
361 / 4\end{array}$ & $\begin{array}{l}421 / 2 \\
481 / 4 \\
43 \frac{1}{2} \\
521 / 3\end{array}$ & $\begin{array}{l}413 / 4 \\
413 / 4 \\
381 / 2 \\
433 / 4\end{array}$ & $\begin{array}{l}44 \\
413 / 4 \\
45^{3} / 8 \\
471 / 2\end{array}$ & $\begin{array}{l}47 \\
473 / 4 \\
44 \\
473 / 8\end{array}$ & $\begin{array}{l}435 / 8 \\
453 / 4 \\
43 ! 4 \\
471 / 4\end{array}$ & $\begin{array}{l}451 / 4 \\
463 / 4 \\
435 \% \\
473 \%\end{array}$ & $\begin{array}{ll}1 & \mathrm{C} . \\
2 & \mathrm{C} . \\
3 & \mathrm{C} . \\
4 & \mathrm{C} .\end{array}$ \\
\hline $501 / 2$ & 47 & $461 / 2$ & $413 / 8$ & $35 \%$ & $\overline{465 \%}$ & $411 / 2$ & $44 \frac{5}{\varepsilon}$ & $461 / 2$ & 45 & $453 / 4$ & Mcans \\
\hline $\begin{array}{l}403 / 1 \\
461 / 4\end{array}$ & $\begin{array}{l}37 \\
39 \%\end{array}$ & $\begin{array}{l}343 / 8 \\
41\end{array}$ & $\begin{array}{l}33 \\
36 \% 3\end{array}$ & $\begin{array}{l}2.51 / 2 \\
253 \%\end{array}$ & $\begin{array}{l}351 / 4 \\
35 \%\end{array}$ & $\begin{array}{l}343 / 4 \\
401 / 4\end{array}$ & $431 / 3$ & $\left.{ }^{2}\right)^{1}\left\{\begin{array}{l}375 \% \\
423 \%\end{array}\right.$ & $\begin{array}{l}3 \pi 1 / 3 \\
401 / 2\end{array}$ & $\left.\begin{array}{l}373 / 4 \\
41 \% 8\end{array}\right\}\left({ }^{2}\right)$ & $\begin{array}{l}1 \mathrm{~N} . \\
2 \mathrm{~N} .\end{array}$ \\
\hline $\begin{array}{l}25 \% \\
261 / 2 \\
50 \%\end{array}$ & $\begin{array}{l}193 / 4 \\
23 \\
43 ! 4\end{array}$ & $\begin{array}{l}19 \\
221 / 2 \\
43 \%\end{array}$ & $\begin{array}{l}201 / 2 \\
191 / 2 \\
34 \%\end{array}$ & $\begin{array}{l}143 / 4 \\
15 \\
361 / 3\end{array}$ & $\begin{array}{l}165 \% \\
23 \% 8 \\
497 \%\end{array}$ & $\begin{array}{l}16^{1 / 8} \\
141 / 2 \\
413\end{array}$ & $\begin{array}{l}221 / 8 \\
20 \\
441 / 4\end{array}$ & $\begin{array}{l}\text { (3) }\left(22^{5} / 8\right. \\
\left.\text { i }^{4}\right) \begin{array}{l}(2458 \\
43 \%\end{array} \\
433\end{array}$ & $\begin{array}{l}205 / 8 \\
211 / 8 \\
44 \% / 4\end{array}$ & $\begin{array}{ll}211 / 2) & (3) \\
223 & (4) \\
441 / 8 & (4) \\
4\end{array}$ & $\begin{array}{ll} & \mathrm{Mr} . \\
5 & \mathrm{O} . \\
5 & \mathrm{~A} .\end{array}$ \\
\hline $\begin{array}{l}251 / 8 \\
251 / 8\end{array}$ & $\begin{array}{l}21 \\
191 / 4\end{array}$ & $\begin{array}{l}161 / 2 \\
17 \% 4\end{array}$ & $\begin{array}{l}163 / 8 \\
193 \\
34\end{array}$ & $\begin{array}{l}15^{1 / 4} \\
157 / 8\end{array}$ & $\begin{array}{l}147 / 8 \\
153 / 8\end{array}$ & $15 \%$ & $\begin{array}{l}183 / 4 \\
21 / 4\end{array}$ & $\begin{array}{l}25 \\
237 / 8\end{array}$ & $\begin{array}{l}18 \% / 8 \\
20\end{array}$ & $\begin{array}{l}22 \\
21 \% / 8\end{array}$ & $\left.\begin{array}{l}1 \\
2\end{array}\right\} 6$ \\
\hline 62 & $523 / 4$ & $531 / 3$ & $45 \frac{5}{8}$ & $435 \%$ & $46 \%$ & $471 / 2$ & $541 / 4$ & 45 & $511 / 2$ & $481 / 4$ & 6 \\
\hline
\end{tabular}

(1853-'61), last 10 years, and total 19 years. of 9 years (1853-'61), last 10 years, and total 19 years. 
EXPeriments on the Growth of Barley, year after year, oN the MaNure. HoOs

TABLE III.-WEIGHT PER (N.B. The doukie vertical lines show that there was a change in the description, Talle $I$., and foot notes,

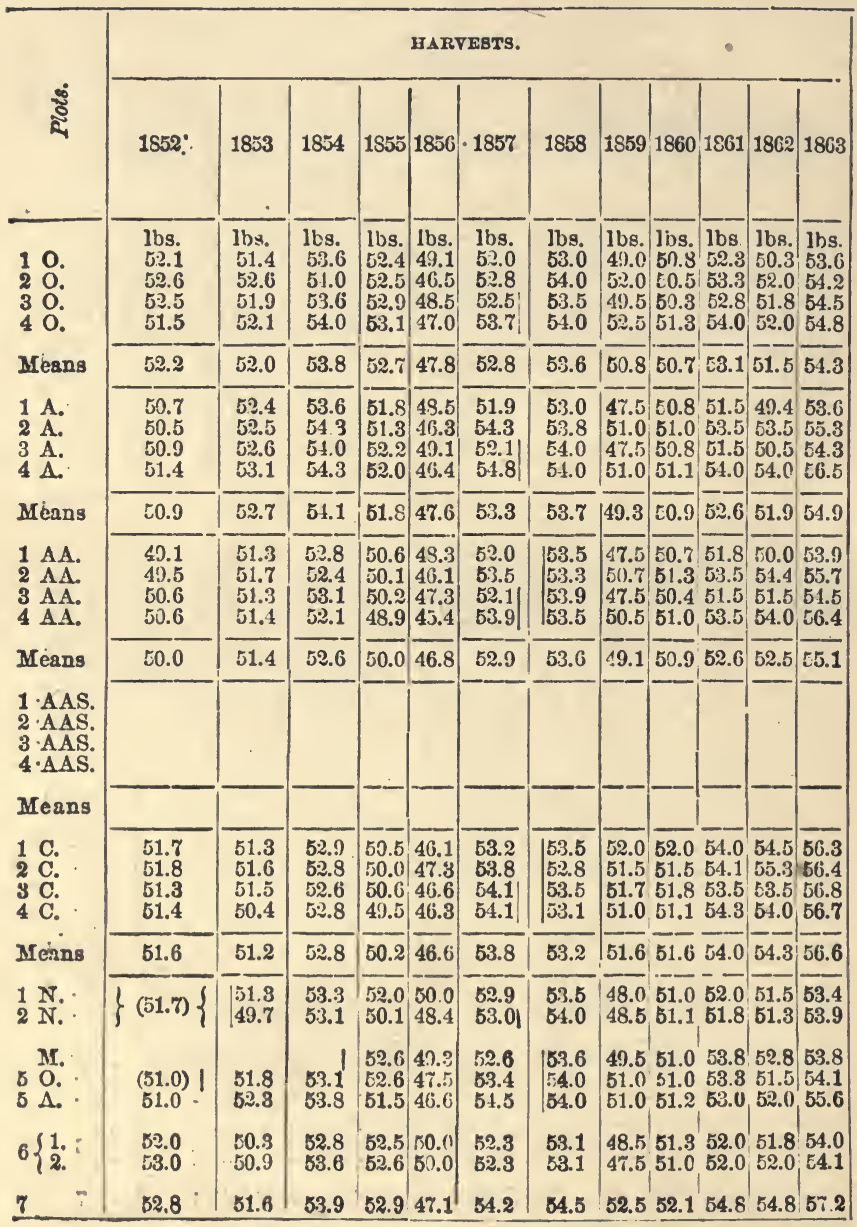

(1) Averages of 4 years, 4 years, and 8 years.

(2) Averages of 9 years last 10 years, and total 17 years.

(4) Average日 
SAME LAND, WITHOOT MANURE, AND WITE DIFFERENT DESCRIPTIONS OF FIELD, ROTHAMSTED.

BUSHEL OF DRESSED CORN-lbs.

or quantity, of Manure, at the period indicated, for particulars of which see t'sereto, p. 231.]

\begin{tabular}{|c|c|c|c|c|c|c|c|c|c|c|c|}
\hline \multicolumn{8}{|c|}{ HARVESTS. } & \multicolumn{3}{|c|}{ AVERAGE ANNUAL. } & \multirow[b]{2}{*}{ ฉి } \\
\hline 1851 & 1865 & 1836 & 1837 & 1868 & 1869 & 1870 & 1871 & 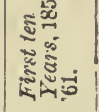 & 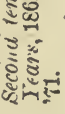 & 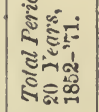 & \\
\hline $\begin{array}{l}1 \mathrm{bs} . \\
55.7 \\
56.8 \\
5 j .9 \\
57.3\end{array}$ & $\begin{array}{l}1 \mathrm{lbs} . \\
53.9 \\
53.8 \\
51.5 \\
54.0\end{array}$ & $\begin{array}{l}1 b s . \\
51.1 \\
53.2 \\
52.3 \\
52.7\end{array}$ & $\begin{array}{l}\text { lbs. } \\
51.8 \\
53.9 \\
52.9 \\
53.6\end{array}$ & $\begin{array}{l}\text { lbs. } \\
54.3 \\
55.8 \\
55.7 \\
55.3\end{array}$ & $\begin{array}{l}\text { lbs. } \\
52.4 \\
54.3 \\
54.7 \\
54.6\end{array}$ & $\begin{array}{l}\text { lbs. } \\
52.9 \\
53.6 \\
54.3 \\
65.6\end{array}$ & $\begin{array}{l}\text { lbs. } \\
55.0 \\
56.0 \\
55.4 \\
55.6\end{array}$ & $\begin{array}{r}\text { Hbs. } \\
51.6 \\
52.0 \\
51.8 \\
52.3\end{array}$ & $\begin{array}{l}\text { Jbs. } \\
53.1 \\
54.4 \\
54.3 \\
54.6\end{array}$ & $\begin{array}{l}\text { 1bs. } \\
52.3 \\
53.2 \\
53.0 \\
53.4\end{array}$ & $\begin{array}{ll}1 & 0 . \\
2 & 0 . \\
3 & 0 . \\
4 & 0 .\end{array}$ \\
\hline 56.7 & 51.1 & 52.3 & 53.1 & 53.3 & 54.0 & 54.1 & 55.5 & 52.0 & 54.1 & 53.0 & Means \\
\hline $\begin{array}{l}55.4 \\
57.0 \\
56.4 \\
57.6\end{array}$ & $\begin{array}{l}53.8 \\
52.7 \\
51.7 \\
53.5\end{array}$ & $\begin{array}{l}50.9 \\
51.4 \\
52.1 \\
54.7\end{array}$ & \begin{tabular}{|l|}
51.3 \\
54.1 \\
51.9 \\
51.3
\end{tabular} & $\begin{array}{l}53.3 \\
54.6 \\
51.8 \\
55.6 \\
\end{array}$ & $\begin{array}{r}52.4 \\
-57.0 \\
54.6 \\
57.4 \\
\end{array}$ & $\begin{array}{l}54.6 \\
57.2 \\
55.4 \\
57.1 \\
\end{array}$ & $\begin{array}{l}55.6 \\
55.0 \\
56.1 \\
56.5\end{array}$ & $\begin{array}{l}\mathbf{1 . 2} \\
\$ 1.8 \\
81.5 \\
\text { t.2.2 }\end{array}$ & $\begin{array}{l}53.0 \\
55.1 \\
54.1 \\
55.7\end{array}$ & $\begin{array}{l}52.1 \\
53.5 \\
52.8 \\
54.0 \\
\end{array}$ & 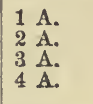 \\
\hline 56.6 & 53.7 & 530 & 52.9 & 51.6 & 55.4 & 56.1 & 55.8 & 51.6 & 54.5 & 53.1 & Means \\
\hline $\begin{array}{l}55.5 \\
57.2 \\
56.5 \\
56.6 \\
\end{array}$ & $\begin{array}{l}53.5 \\
53.3 \\
54.8 \\
53.3 \\
\end{array}$ & $\begin{array}{l}50.9 \\
55.0 \\
51.4 \\
55.4 \\
\end{array}$ & $\begin{array}{l}52.4 \\
51.1 \\
51.9 \\
51.6 \\
\end{array}$ & $\begin{array}{l}53.7 \\
55.6 \\
55.1 \\
56.0\end{array}$ & $\begin{array}{l}53.1 \\
57.2 \\
53.7 \\
57.1 \\
\end{array}$ & $\begin{array}{l}54.5 \\
56.9 \\
54.6 \\
57.1 \\
\end{array}$ & $\begin{array}{l}54.1 \\
55.9 \\
54.3 \\
56.3\end{array}$ & $\begin{array}{l}60.8 \\
51.2 \\
50.8 \\
51.1\end{array}$ & $\begin{array}{l}5.2 \\
55.4 \\
53.8 \\
55.8 \\
\end{array}$ & $\begin{array}{l}52.0 \\
53.3 \\
52.3 \\
63.4\end{array}$ & $\begin{array}{l}1 \text { AA. } \\
2 \text { AA. } \\
3 \text { AA. } \\
4 \text { AA. }\end{array}$ \\
\hline 56.7 & 53.5 & 53.2 & 53.3 & 55.1 & 55.3 & 55.8 & 55.2 & 51.0 & 54.6 & 52.8 & Means \\
\hline $\mid \begin{array}{l}56.1 \\
57.2 \\
57.2 \\
57.0\end{array}$ & $\begin{array}{l}51.2 \\
52.4 \\
51.8 \\
53.1 \\
\end{array}$ & $\begin{array}{l}51.8 \\
55.6 \\
52.5 \\
55.3 \\
\end{array}$ & \begin{tabular}{|l|}
53.5 \\
55.1 \\
53.0 \\
54.1
\end{tabular} & $\mid \begin{array}{l}54.2 \\
56.2 \\
55.5 \\
56.2\end{array}$ & $\begin{array}{l}54.8 \\
57.4 \\
56.6 \\
57.8\end{array}$ & $\begin{array}{l}55.0 \\
57.4 \\
55.9 \\
57.8 \\
\end{array}$ & $\begin{array}{l}54.6 \\
55.6 \\
53.8 \\
55.4\end{array}$ & (1) $\left\{\begin{array}{l}53.9 \\
55.1 \\
54.4 \\
54.9\end{array}\right.$ & $\begin{array}{l}54.6 \\
56.7 \\
55.5 \\
56.8\end{array}$ & $\left.\begin{array}{l}54.3 \\
55.9 \\
55.0 \\
55.8\end{array}\right\}{ }^{(1)}$ & $\begin{array}{l}1 \text { AAS. } \\
2 \text { AAS. } \\
3 \text { AAS. } \\
4 \text { AAS. }\end{array}$ \\
\hline 569 & $5: 3.6$ & 53.8 & 53.9 & 55.5 & 56.7 & 56.5 & 54.9 & 54.6 & 55.9 & 55.2 & Mcans \\
\hline $\begin{array}{l}57.1 \\
57.0 \\
57.3 \\
57.2\end{array}$ & $\begin{array}{l}538 \\
53.3 \\
53.3 \\
53.5\end{array}$ & $\begin{array}{l}55.1 \\
55.7 \\
55.3 \\
55.6 \\
\end{array}$ & \begin{tabular}{|l|}
51.4 \\
55.0 \\
51.7 \\
51.8
\end{tabular} & $\begin{array}{l}56.2 \\
56.1 \\
55.8 \\
55.4 \\
\end{array}$ & $\begin{array}{l}56.7 \\
57.1 \\
57.1 \\
57.4\end{array}$ & $\begin{array}{l}57.5 \\
57.8 \\
57.6 \\
58.0 \\
\end{array}$ & $\begin{array}{l}56.3 \\
56.4 \\
56.3 \\
56.4\end{array}$ & $\begin{array}{l}51.7 \\
51.7 \\
51.7 \\
51.4\end{array}$ & $\begin{array}{l}55.8 \\
56.0 \\
55.8 \\
55.9\end{array}$ & $\begin{array}{l}53.8 \\
53.9 \\
53.7 \\
33.6\end{array}$ & $\begin{array}{ll}1 & C . \\
2 & C . \\
3 & C . \\
4 & C .\end{array}$ \\
\hline 57.1 & 53.5 & 5.4 & 51.7 & 55.9 & 57.1 & 57.7 & 56.4 & 51.6 & 55.9 & 53.8 & Mreans \\
\hline $\begin{array}{l}56.0 \\
56.5\end{array}$ & $\begin{array}{l}51.1 \\
53.8\end{array}$ & $\begin{array}{r}52.0 \\
52.8\end{array}$ & $\begin{array}{l}52.9 \\
53.7\end{array}$ & $\begin{array}{l}52.8 \\
55.5\end{array}$ & $\begin{array}{l}54.3 \\
54.8\end{array}$ & $\begin{array}{l}55.6 \\
55.8\end{array}$ & $\begin{array}{l}54.6 \\
54.6\end{array}$ & $\left.{ }^{2}\right)\left\{\begin{array}{l}51.6 \\
51.1\end{array}\right.$ & $\begin{array}{l}53.1 \\
54.2\end{array}$ & $\left.\begin{array}{l}52.7 \\
52.7\end{array}\right\}(\%)$ & $\begin{array}{l}1 \mathrm{~N} . \\
2 \mathrm{~N} .\end{array}$ \\
\hline $\begin{array}{l}56.3 \\
57.11 \\
57.5\end{array}$ & $\begin{array}{l}51.4 \\
51.5 \\
51.1\end{array}$ & $\mid \begin{array}{l}53.9 \\
53.4 \\
51.8\end{array}$ & $\begin{array}{l}53.9 \\
51.0 \\
55.2\end{array}$ & $\begin{array}{l}51.0 \\
51.4 \\
57.5\end{array}$ & $\begin{array}{l}54.0 \\
55.6 \\
57.5\end{array}$ & $\begin{array}{l}55.3 \\
55.9 \\
57.3\end{array}$ & $\begin{array}{l}55.0 \\
55.1 \\
55.5\end{array}$ & $\begin{array}{ll}\text { (3) }^{(51.8} \\
\left({ }^{4}\right) & (52.0 \\
& 51.9\end{array}$ & $\begin{array}{l}54.2 \\
54.8 \\
55.7\end{array}$ & $\begin{array}{ll}5.3 .2) & (9) \\
\vdots 3.4) & (4) \\
53.3 & \end{array}$ & $\begin{array}{l}\text { A. } \\
5 \text { O. } \\
5 \text { A. }\end{array}$ \\
\hline $\begin{array}{l}56.0 \\
5.5 .3\end{array}$ & $\begin{array}{l}53.9 \\
53.9\end{array}$ & $\begin{array}{l}51.3 \\
51.8\end{array}$ & $\begin{array}{l}52.0 \\
52.5\end{array}$ & $\begin{array}{l}5.3 .5 \\
53.9\end{array}$ & $\begin{array}{l}52.8 \\
52.9\end{array}$ & $\begin{array}{l}54.0 \\
54.6\end{array}$ & $\begin{array}{l}55.4 \\
54.9\end{array}$ & $\begin{array}{l}51.5 \\
51.6\end{array}$ & $\begin{array}{l}53.5 \\
58.6\end{array}$ & $\begin{array}{l}52.5 \\
52.6\end{array}$ & $\left.\begin{array}{l}1 \\
2\end{array}\right\} 6$ \\
\hline 57.4 & 54.4 & 51.9 & $54.3^{\prime}$ & B7.1 & 564 & $5 \pi .1$ & 56.6 & 62.6 & $5 n ̃ .0$ & 54.3 & 7 \\
\hline
\end{tabular}




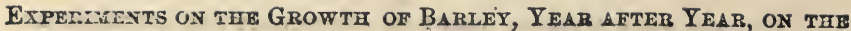
Manube. Hoos

TABLE IV. OFFAT.

[N.D. The double vertical lines show that there was a chsnge in the description, Talle I., and foot-notes

\begin{tabular}{|c|c|c|c|c|c|c|c|c|c|c|c|c|}
\hline \multirow[b]{2}{*}{ 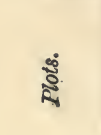 } & \multicolumn{12}{|c|}{ BARVESTS. } \\
\hline & 1852 & 1853 & 1854 & 1855 & 1856 & 1857 & 1858 & 1859 & 1860 & 1861 & 1862 & 1863 \\
\hline $\begin{array}{l}\text { 1. } 0 . \\
\text { 2. } 0 . \\
\text { 3. } 0 . \\
\text { 4. } 0 .\end{array}$ & $\begin{array}{l}\text { lbs. } \\
164 \\
100 \\
183 \\
136\end{array}$ & $\begin{array}{l}\text { lbs. } \\
225 \\
101 \\
151 \\
160\end{array}$ & $\begin{array}{c}\text { lbs. } \\
84 \\
101 \\
64 \\
105\end{array}$ & $\begin{array}{r}10 s . \\
144 \\
69 \\
76 \\
94\end{array}$ & \begin{tabular}{|r|}
$1 \mathrm{lbs}$. \\
131 \\
58 \\
129 \\
88
\end{tabular} & $\begin{array}{c}\mathrm{lbs} . \\
93 \\
106 \\
61 \\
53\end{array}$ & $\begin{array}{r}1 \text { lbs. } \\
86 \\
103 \\
96 \\
108\end{array}$ & $\begin{array}{l}\text { lbs. } \\
110 \\
159 \\
85 \\
160\end{array}$ & $\begin{array}{r}\text { lbs. } \\
78 \\
84 \\
78 \\
74\end{array}$ & $\begin{array}{r}1 \mathrm{bs} . \\
88 \\
78 \\
88 \\
58\end{array}$ & $\begin{array}{r}1 \mathrm{bs} . \\
64 \\
114 \\
73 \\
117\end{array}$ & $\begin{array}{r}1 \mathrm{bs} . \\
49 \\
58 \\
54 \\
57\end{array}$ \\
\hline Means & 146 & 159 & 89 & 96 & 102 & 78 & 93 & 129 & 78 & 178 & 92 & 55 \\
\hline $\begin{array}{l}\text { 1. A. } \\
\text { 2. A. } \\
\text { 3. A. } \\
\text { 4. A. }\end{array}$ & $\begin{array}{l}218 \\
260 \\
252 \\
273\end{array}$ & $\begin{array}{l}253 \\
244 \\
336 \\
274\end{array}$ & $\begin{array}{l}501 \\
1 \% 0 \\
197 \\
138\end{array}$ & $\begin{array}{l}138 \\
181 \\
177 \\
142\end{array}$ & $\begin{array}{l}219 \\
121 \\
189 \\
125\end{array}$ & $\begin{array}{r}113 \\
88 \\
91 \\
70\end{array}$ & $\begin{array}{r}98 \\
114 \\
96 \\
117\end{array}$ & $\begin{array}{l}184 \\
2 \% 4 \\
175 \\
253\end{array}$ & $\begin{array}{l}150 \\
159 \\
115 \\
150\end{array}$ & $\begin{array}{l}170 \\
130 \\
109 \\
110\end{array}$ & \begin{tabular}{|l|}
269 \\
191 \\
269 \\
150
\end{tabular} & $\begin{array}{r}116 \\
99 \\
108 \\
81\end{array}$ \\
\hline Means & 251 & 277 & $1 \% 2$ & 160 & 161 & 91 & 106 & 222 & 143 & 130 & 220 & 101 \\
\hline $\begin{array}{l}\text { 1. } \mathrm{AA} \text {. } \\
\text { 2. } \mathrm{A \Lambda} \text {. } \\
\text { 3. } \mathrm{AA} \text {. } \\
\text { 4. } \mathrm{AA} \text {. }\end{array}$ & $\begin{array}{l}2.9 \\
315 \\
318 \\
216\end{array}$ & $\begin{array}{l}303 \\
251 \\
236 \\
201\end{array}$ & $\begin{array}{l}326 \\
329 \\
3: 34 \\
273\end{array}$ & $\begin{array}{l}201 \\
181 \\
212 \\
150\end{array}$ & $\begin{array}{l}310 \\
233 \\
290 \\
176\end{array}$ & $\begin{array}{l}135 \\
133 \\
103 \\
183\end{array}$ & $\begin{array}{r}88 \\
134 \\
118 \\
143\end{array}$ & $\begin{array}{l}215 \\
320 \\
265 \\
285\end{array}$ & $\begin{array}{l}109 \\
118 \\
122 \\
141\end{array}$ & $\begin{array}{l}173 \\
190 \\
138 \\
179\end{array}$ & $\begin{array}{l}296 \\
133 \\
864 \\
191\end{array}$ & $\begin{array}{r}110 \\
143 \\
95 \\
66\end{array}$ \\
\hline Means & 231 & 273 & 316 & 187 & 252 & 140 & 121 & $2 \pi 1$ & 123 & 170 & 216 & 103 \\
\hline $\begin{array}{l}1 \text { AAS. } \\
2 \text { AAS. } \\
3 \text { A S } \\
4 \text { AAS. }\end{array}$ & & & & & & & & & & & & \\
\hline Means & & & & & & & & & & & & \\
\hline $\begin{array}{ll}1 & C . \\
2 & C . \\
3 & C . \\
4 & C .\end{array}$ & $\begin{array}{l}170 \\
16-1 \\
190 \\
144\end{array}$ & $\begin{array}{l}268 \\
376 \\
296 \\
217\end{array}$ & $\begin{array}{l}178 \\
238 \\
218 \\
227\end{array}$ & $\begin{array}{l}219 \\
195 \\
133 \\
222\end{array}$ & $\begin{array}{l}173 \\
161 \\
189 \\
205\end{array}$ & $\begin{array}{l}195 \\
169 \\
156 \\
168\end{array}$ & $\begin{array}{l}103 \\
148 \\
105 \\
125\end{array}$ & $\begin{array}{l}225 \\
171 \\
236 \\
330\end{array}$ & $\begin{array}{l}120 \\
156 \\
115 \\
153\end{array}$ & $\begin{array}{l}154 \\
151) \\
2(14 \\
201\end{array}$ & $\begin{array}{l}154 \\
128 \\
190 \\
174\end{array}$ & $\begin{array}{r}85 \\
109 \\
71 \\
66\end{array}$ \\
\hline Mcans & 167 & 301 & 223 & ¿0క & 183 & 157 & 120 & 246 & 136 & 178 & 161 & ह3 \\
\hline $\begin{array}{l}1 \mathrm{~N} . \\
2 \mathrm{~N} .\end{array}$ & \}$(94)\{$ & $\begin{array}{l}283 \\
223\end{array}$ & $\begin{array}{l}139 \\
256\end{array}$ & $\begin{array}{l}123 \\
224\end{array}$ & $\begin{array}{l}215 \\
103\end{array}$ & $\begin{array}{c}93 \\
151 \mid\end{array}$ & $\begin{array}{l}119 \\
110\end{array}$ & 205 & $\begin{array}{l}146 \\
179\end{array}$ & $\begin{array}{l}225 \\
190\end{array}$ & $\begin{array}{l}245 \\
216\end{array}$ & $\begin{array}{l}120 \\
114\end{array}$ \\
\hline $\begin{array}{ll} & \text { M. } \\
5 & 0 . \\
5 & 1 .\end{array}$ & $\begin{array}{c}(173) \mid \\
173\end{array}$ & $\begin{array}{r}68 \\
210\end{array}$ & ${ }_{170}^{113^{\mid}}$ & $\begin{array}{r}26 \\
50 \\
120\end{array}$ & $\begin{array}{r}94 \\
96 \\
151\end{array}$ & $\begin{array}{r}90 \\
101 \\
63\end{array}$ & $\begin{array}{r}84 \\
71 \\
151\end{array}$ & $\begin{array}{r}85 \\
110 \\
163\end{array}$ & $\begin{array}{r}75 \\
73 \\
193\end{array}$ & $\begin{array}{r}78 \\
73 \\
188\end{array}$ & $\begin{array}{l}108 \\
103 \\
210\end{array}$ & $\begin{array}{l}46 \\
41 \\
81\end{array}$ \\
\hline $6\left\{\begin{array}{l}1 \\
2\end{array}\right.$ & $\begin{array}{l}120 \\
118\end{array}$ & $\begin{array}{l}200 \\
161\end{array}$ & $\begin{array}{l}144 \\
110\end{array}$ & $\begin{array}{r}116 \\
73\end{array}$ & $\begin{array}{l}152 \\
125\end{array}$ & $\begin{array}{r}73 \\
105\end{array}$ & $\begin{array}{l}84 \\
81\end{array}$ & $\begin{array}{l}121 \\
127\end{array}$ & $\begin{array}{l}88 \\
95\end{array}$ & $\begin{array}{l}73 \\
67\end{array}$ & $\begin{array}{r}75 \\
134\end{array}$ & $\begin{array}{l}51 \\
65\end{array}$ \\
\hline$\theta$ & 101 & 267 & $\varepsilon 6$ & 103 & 141 & 131 & 121 & 260 & 147 & 193 & 208 & 60 \\
\hline
\end{tabular}

(1) Avcrages of 4 years, 4 years, and 8 years.

(2) Averages o'? rears last 10 years, and total 17 jears. ( $\left.{ }^{4}\right)$ Averages 
8AME LAND, WITHOUT MANURE, AND WITH DIFFGReNt DESORIPTIONS OF Field, Rothamsted.

CORN PET: $\triangle C R E-l b S$.

or quantity, of Manure, at t'ac period indicated, for particulars of which, see thereto, p. 231.]

\begin{tabular}{|c|c|c|c|c|c|c|c|c|c|c|c|}
\hline \multicolumn{8}{|c|}{ HARVESTS. } & \multicolumn{3}{|c|}{ AVERAGE ANNUAL. } & \multirow[b]{2}{*}{ 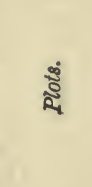 } \\
\hline 1864 & 1865 & 1866 & 1867 & 1868 & 1869 & $18 \% 0$ & 1871 & 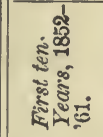 & 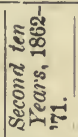 & 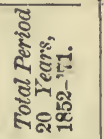 & \\
\hline $\begin{array}{c}1 \mathrm{bs} . \\
42 \\
69 \\
43 \\
41\end{array}$ & $\begin{array}{l}1 \mathrm{lbs} . \\
47 \\
38 \\
38 \\
28\end{array}$ & $\begin{array}{l}\text { lbs. } \\
41 \\
21 \\
33 \\
55\end{array}$ & $\begin{array}{l}1 \mathrm{bs} . \\
90 \\
53 \\
64 \\
60\end{array}$ & $\begin{array}{l}\text { lbs. } \\
21 \\
29 \\
27 \\
25\end{array}$ & $\begin{array}{c}1 \mathrm{bs} . \\
44 \\
89 \\
70 \\
69\end{array}$ & $\begin{array}{l}\text { lbs. } \\
31 \\
18 \\
18 \\
26\end{array}$ & $\begin{array}{l}\text { lbs. } \\
48 \\
33 \\
35 \\
48\end{array}$ & $\begin{array}{r}\text { lbs. } \\
120 \\
96 \\
101 \\
104\end{array}$ & $\begin{array}{l}\mathrm{Jbs} . \\
48 \\
52 \\
46 \\
53\end{array}$ & $\begin{array}{l}\text { lbs. } \\
84 \\
74 \\
74 \\
78\end{array}$ & $\begin{array}{ll}1 & 0 . \\
2 & 0 . \\
3 & 0 . \\
4 & 0 .\end{array}$ \\
\hline 49 & 88 & $\overline{39}$ & $\overline{6 r}$ & 25 & 63 & 23 & 41 & 105 & 50 & 78 & Mcans \\
\hline $\begin{array}{r}99 \\
63 \\
83 \\
110\end{array}$ & $\begin{array}{l}58 \\
81 \\
51 \\
60\end{array}$ & $\begin{array}{r}94 \\
64 \\
106 \\
63\end{array}$ & $\begin{array}{r}115 \\
76 \\
94 \\
71\end{array}$ & $\begin{array}{l}49 \\
39 \\
34 \\
50\end{array}$ & $\begin{array}{r}139 \\
113 \\
95 \\
21\end{array}$ & $\begin{array}{l}2: 3 \\
26 \\
24 \\
27\end{array}$ & $\begin{array}{r}105 \\
189 \\
189 \\
146\end{array}$ & $\begin{array}{l}174 \\
172 \\
173 \\
105\end{array}$ & $\begin{array}{r}107 \\
84 \\
95 \\
78\end{array}$ & $\begin{array}{l}141 \\
133 \\
134 \\
122\end{array}$ & $\begin{array}{l}1 \text { A. } \\
2 \text { A. } \\
3 \text { A. } \\
4 \text { A. }\end{array}$ \\
\hline 89 & 63 & 82 & 89 & 43 & 92 & 25 & 132 & 171 & 94 & 183 & Means \\
\hline $\begin{array}{r}110 \\
50 \\
76 \\
46\end{array}$ & $\begin{array}{r}64 \\
113 \\
48 \\
76\end{array}$ & $\begin{array}{l}149 \\
111 \\
10: 3 \\
133\end{array}$ & $\begin{array}{r}110 \\
60 \\
106 \\
119\end{array}$ & $\mid \begin{array}{l}46 \\
46 \\
59 \\
43\end{array}$ & \begin{tabular}{|r|}
64 \\
89 \\
111 \\
178 \\
\end{tabular} & $\begin{array}{l}33 \\
24 \\
86 \\
30\end{array}$ & $\begin{array}{r}133 \\
163 \\
133 \\
90\end{array}$ & $\begin{array}{l}216 \\
220 \\
214 \\
2 C 8\end{array}$ & $\begin{array}{r}111 \\
95 \\
113 \\
87\end{array}$ & $\begin{array}{l}164 \\
158 \\
164 \\
148\end{array}$ & $\begin{array}{l}1 \mathrm{AA} . \\
2 \mathrm{AA} . \\
3 \mathrm{AA} . \\
4 \mathrm{AA} .\end{array}$ \\
\hline 71 & 75 & 124 & 101 & 48 & 86 & 31 & 131 & 215 & 102 & 159 & Means \\
\hline \begin{tabular}{|l}
94 \\
53 \\
70 \\
93
\end{tabular} & $\begin{array}{l}55 \\
86 \\
50 \\
70\end{array}$ & $\begin{array}{r}88 \\
96 \\
141 \\
80 \\
\end{array}$ & $\begin{array}{l}85 \\
65 \\
79 \\
93\end{array}$ & $\mid \begin{array}{l}49 \\
64 \\
89 \\
46\end{array}$ & $\begin{array}{r}121 \\
60 \\
136 \\
125 \\
\end{array}$ & $\begin{array}{l}33 \\
23 \\
29 \\
26\end{array}$ & $\begin{array}{r}94 \\
153 \\
120 \\
175\end{array}$ & (1) $\left\{\begin{array}{l}81 \\
75 \\
85 \\
84\end{array}\right.$ & $\begin{array}{l}74 \\
75 \\
84 \\
93\end{array}$ & $\left.\begin{array}{l}77 \\
75 \\
85 \\
89\end{array}\right\}{ }^{(1)}$ & $\begin{array}{l}1 \text { AAS. } \\
2 \text { AAS. } \\
3 \text { AAS. } \\
4 \text { AAS. }\end{array}$ \\
\hline 77 & 65 & 101 & 81 & 50 & 111 & 28 & 128 & 81 & 82 & $8 ?$ & Means \\
\hline $\begin{array}{r}78 \\
92 \\
90 \\
123\end{array}$ & $\begin{array}{l}83 \\
44 \\
66 \\
69\end{array}$ & $\begin{array}{r}104 \\
89 \\
04 \\
128\end{array}$ & $\begin{array}{r}109 \\
89 \\
91 \\
72\end{array}$ & $\begin{array}{l}43 \\
61 \\
3 .) \\
42\end{array}$ & $\begin{array}{r}69 \\
111 \\
91 \\
67\end{array}$ & $\begin{array}{l}25 \\
24 \\
37 \\
28\end{array}$ & $\begin{array}{r}78 \\
88 \\
141 \\
1 \approx 4\end{array}$ & $\begin{array}{l}175 \\
1 \% 3 \\
192 \\
203\end{array}$ & $\begin{array}{l}83 \\
81 \\
91 \\
89\end{array}$ & $\begin{array}{l}129 \\
139 \\
1: 2 \\
1: 9\end{array}$ & $\begin{array}{ll}1 & C . \\
2 & C . \\
3 & c . \\
4 & C .\end{array}$ \\
\hline 26 & 66 & $\overline{104}$ & $\overline{90}$ & 47 & 85 & 28 & 109 & 192 & 87 & $1 \% 9$ & Means \\
\hline $\begin{array}{l}74 \\
85\end{array}$ & $\begin{array}{l}93 \\
84\end{array}$ & $\begin{array}{l}124 \\
104\end{array}$ & $\begin{array}{l}119 \\
83\end{array}$ & $\begin{array}{l}61 \\
35\end{array}$ & $\begin{array}{l}150 \\
93\end{array}$ & $\begin{array}{l}33 \\
3: 3\end{array}$ & $\begin{array}{r}99 \\
171\end{array}$ & (2) $\left\{\begin{array}{l}173 \\
199\end{array}\right.$ & $\begin{array}{l}112 \\
104\end{array}$ & $\left.\begin{array}{l}141 \\
149\end{array}\right\}\left(^{2}\right)$ & $\begin{array}{l}1 \mathrm{~N} . \\
2 \mathrm{~N} .\end{array}$ \\
\hline $\begin{array}{l}58 \\
79 \\
91\end{array}$ & $\begin{array}{l}69 \\
35 \\
94\end{array}$ & $\begin{array}{l}44 \\
48 \\
5: 3\end{array}$ & $\begin{array}{l}56 \\
56 \\
74\end{array}$ & $\begin{array}{l}23 \\
20 \\
33\end{array}$ & $\begin{array}{l}61 \\
75 \\
63\end{array}$ & $\begin{array}{l}25 \\
2: 3 \\
30\end{array}$ & $\begin{array}{r}58 \\
41 \\
144\end{array}$ & $\begin{array}{ll}\left(^{3}\right) & (77 \\
\left(^{4}\right) & (81 \\
& 160\end{array}$ & $\begin{array}{l}64 \\
61 \\
87\end{array}$ & $\begin{aligned}699) & (3) \\
72) & (4) \\
124 & \end{aligned}$ & $\begin{array}{ll} & \text { Mr. } \\
5 & \text { O. } \\
5 & \text { A. }\end{array}$ \\
\hline $\begin{array}{l}51 \\
51\end{array}$ & $\begin{array}{l}45 \\
47\end{array}$ & $\begin{array}{l}\tau 2 \\
51\end{array}$ & $\begin{array}{r}103 \\
83\end{array}$ & $\begin{array}{l}27 \\
21\end{array}$ & $\begin{array}{l}71 \\
57\end{array}$ & $\begin{array}{l}26 \\
23\end{array}$ & $\begin{array}{l}50 \\
41\end{array}$ & $\begin{array}{l}117 \\
107\end{array}$ & $\begin{array}{l}57 \\
61\end{array}$ & $\begin{array}{l}87 \\
85\end{array}$ & $\left.\begin{array}{l}1 \\
2\end{array}\right\} 6$ \\
\hline 117 & 56 & 148 & 111 & 49 & 100 & $2:)$ & 171 & 156 & 105 & $1^{\prime} 0$ & 7 \\
\hline
\end{tabular}

(1853-61), last 10 years, and total 19 years. ( $\left.{ }^{3}\right)$ Averages of 7 years (185j-'c1), of 9 years $(1853-61)$, last 10 years, and total 19 years. 
Espzriments on the Growth of Barley, Year after Year, on the Manure. Hoos TABLE V.-STRAW N.B. The double vertical lines show that there was a change in the descripT'uble 1. , and foot-notes

\begin{tabular}{|c|c|c|c|c|c|c|c|c|c|c|c|c|}
\hline \multirow{2}{*}{ ڤั่ } & \multicolumn{12}{|c|}{ HARVESTS. } \\
\hline & 1852 & 1853 & 1854 & 1855 & 1556 & 1857 & 1858 & 1859 & 1860 & 1861 & 1862 & $1 S 63$ \\
\hline $\begin{array}{ll}1 & 0 . \\
2 & 0 . \\
3 & 0 . \\
4 & 0 .\end{array}$ & $\begin{array}{l}\text { Cwts. } \\
16 \% / 8 \\
161 / 2 \\
161 / 3 \\
191 / 8\end{array}$ & $\begin{array}{l}\text { cwts. } \\
18 \\
171 / 3 \\
171 / 4 \\
201 / 2\end{array}$ & $\begin{array}{l}\text { cwts. } \\
213 / 4 \\
231 / 4 \\
207 / 8 \\
231 / 8\end{array}$ & $\begin{array}{l}\text { cwt } \\
17 \% 3 \\
17 \% / 4 \\
17 \% / 2 \\
13\end{array}$ & \begin{tabular}{|c|}
$c w t$ \\
$83 / 4$ \\
$83 / 4$ \\
$9 \% / 3$ \\
$93 / 2$
\end{tabular} & $\begin{array}{c}\text { cwts. } \\
123 / 4 \\
15 \% 8 \\
15 \\
171 / 8\end{array}$ & $\begin{array}{l}\text { cwts. } \\
10 \% 8 \\
147 / 8 \\
121 / 4 \\
161 / 8\end{array}$ & $\begin{array}{r}\text { cwt } \\
91 / 8 \\
121 / 4 \\
93 \\
121 / 4 \\
13\end{array}$ & $\begin{array}{l}\text { cwt } \\
71 / 3 \\
8 \% 8 \\
81 / 8 \\
91 / 3\end{array}$ & $\begin{array}{l}\text { cwt } \\
11 \\
131 / 4 \\
111 / 3 \\
153 / 8\end{array}$ & $\begin{array}{l}\text { cwt } \\
93 / 6 \\
127 / 8 \\
107 \\
13 \%\end{array}$ & $\begin{array}{l}\text { cwt } \\
11 \% 8 \\
15 \% 8 \\
13 \% 8 \\
15 \% 8\end{array}$ \\
\hline Means & $171 / 2$ & $181 / 4$ & 2214 & $\overline{17 \% / 8}$ & 9 & $1.51 / 8$ & $131 / 2$ & $105 / 8$ & $85 / 8$ & $123 / 4$ & $111 / 2$ & $137 / 8$ \\
\hline $\begin{array}{ll}1 & A . \\
2 & A . \\
3 & A . \\
4 & \text { A. }\end{array}$ & $\begin{array}{l}227 / 8 \\
26 \\
235 \% \\
27 \%\end{array}$ & $\begin{array}{l}233 / 4 \\
251 / 3 \\
251 / 8 \\
25 \% / 8\end{array}$ & $\begin{array}{l}30 \frac{1 / 4}{4} \\
407 / 8 \\
333 / 2 \\
401 / 2\end{array}$ & $\begin{array}{l}241 / 8 \\
2933 / 8 \\
2713 \\
31\end{array}$ & $\begin{array}{l}171 / 8 \\
211 / 2 \\
17 \% / 8 \\
211 \\
21 / 4\end{array}$ & $\begin{array}{l}1 \% 3 / 4 \\
263 / 4 \\
213 \% \\
277 / 8\end{array}$ & $\begin{array}{l}15 \% / 3 \\
283 / 4 \\
17 \% 3 \\
29 \% 8\end{array}$ & $\begin{array}{l}111 / 2 \\
247 \\
131 / 8 \\
27: 4\end{array}$ & $\begin{array}{l}1478 \\
2.5 \% 4 \\
16 \% \\
26 \% \\
20 \%\end{array}$ & $\begin{array}{l}195 / 8 \\
293 / 4 \\
2113 \\
301 / 2\end{array}$ & $\begin{array}{l}203 \\
323 \\
231 / 4 \\
31 \% \\
1 \%\end{array}$ & $\begin{array}{l}21318 \\
31 \\
2614 \\
32\end{array}$ \\
\hline Means & $251 / 3$ & $251 / 4$ & $363 / 8$ & 23 & $19 \%$ & 2313 & $221 / 8$ & $19 \frac{1}{4}$ & $30 \%$ & $253 / 1$ & 263 & $233 / 3$ \\
\hline $\begin{array}{l}1 \text { AA. } \\
2 \text { AA. } \\
3 \text { AA. } \\
4 \text { AA. }\end{array}$ & $\begin{array}{l}267 / 8 \\
28 \% 8 \\
26318 \\
283 \%\end{array}$ & $\begin{array}{l}251 / 3 \\
233 / 4 \\
271 / 4 \\
31 \% 8\end{array}$ & $\begin{array}{l}37 \% \frac{1}{48} \\
4433 \\
37^{3} / 8 \\
49\end{array}$ & $\begin{array}{l}321 / 8 \\
33 \% / 8 \\
31 \\
399^{7}\end{array}$ & $\begin{array}{l}241 / 2 \\
51^{5} \\
2(j 11 / 8 \\
33\end{array}$ & $\begin{array}{l}231 / 2 \\
322^{7} 8 \\
26 \\
361 / 4\end{array}$ & $\mid \begin{array}{l}2,1 / 8 \\
3325 / 8 \\
22 \% / 8 \\
353 / 4\end{array}$ & $\begin{array}{l}141 / 2 \\
26 \\
161 / 8 \\
30 \% 8\end{array}$ & $\begin{array}{l}131 / 2 \\
211,4 \\
18: \\
29\end{array}$ & $\begin{array}{l}22 \\
315 / 8 \\
241 / 8 \\
3358\end{array}$ & $\begin{array}{l}211 / 4 \\
311 \frac{2}{2} \\
24 \% / \\
331 / 8\end{array}$ & $\begin{array}{l}251 / 3 \\
321 / 3 \\
2 \tau 73 \\
31 ; 4\end{array}$ \\
\hline Mreans & $2 \pi / 2$ & $233 / 8$ & $42:{ }^{\prime}$ & $361 / 3$ & $283 / 4$ & $293 / 3$ & $271 / 2$ & $21 \%$ & $21 \frac{1}{1 / 2}$ & 2778 & $27 \%$ & 20 \\
\hline $\begin{array}{l}1 \text { AAS. } \\
2 \text { AAS. } \\
\text { i AAS. } \\
4 \text { AAS. }\end{array}$ & & & & & & & & & & & & \\
\hline Means & & & & & & & & & & & & \\
\hline $\begin{array}{ll}1 & C . \\
2 & C . \\
3 & C . \\
4 & C .\end{array}$ & $\begin{array}{l}215 / 8 \\
233 / 4 \\
217 / 8 \\
211 / 3\end{array}$ & $\begin{array}{l}267 / 8 \\
25 \% 3 \\
251 / 4 \\
27 \% / 3\end{array}$ & $\begin{array}{l}431 / 4 \\
411 / 8 \\
411 / 1 \\
421 / 3\end{array}$ & $\begin{array}{l}361 / 5 \\
361 / 8 \\
35 \% \\
37 \div 8\end{array}$ & $\begin{array}{l}26 \\
311 / 2 \\
261 / 3 \\
301 / 3\end{array}$ & 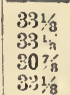 & $\mid \begin{array}{l}30 \% \frac{1}{3} \\
3378 \\
3034 \\
35\end{array}$ & $\begin{array}{l}26 ? ! \\
23 \% / 4 \\
255 / 8 \\
2 ! 313\end{array}$ & $\begin{array}{l}17 ? / 8 \\
205 / 8 \\
201 / 8 \\
223 / 2\end{array}$ & $\begin{array}{l}27 \% 8 \\
303 / 8 \\
303 / 4 \\
31\end{array}$ & $\begin{array}{l}26 \\
271 / 4 \\
23 \% / 8 \\
287 \%\end{array}$ & $\begin{array}{l}285 \% 8 \\
501 / 8 \\
2.7 \% \\
30 \%\end{array}$ \\
\hline Means & $231 / 2$ & $26^{\prime \prime}$ & $423 / 2$ & $361 / 2$ & $285 / 3$ & 325,8 & $325 / 6$ & $2 \pi 3 / 4$ & $203 / 13$ & 30 & $26 \times 2$ & $2 ! 1 \% 8$ \\
\hline $\begin{array}{l}1 \mathrm{~N} . \\
2 \mathrm{~N}\end{array}$ & \}$(15 / 4)\{$ & $\mid \begin{array}{l}231 / 8 \\
253 / 3\end{array}$ & $\begin{array}{l}333 / 3 \\
39 \cdot 4\end{array}$ & $\begin{array}{l}27 \\
331 / 4\end{array}$ & $\begin{array}{l}1958 \\
283 / 4\end{array}$ & $\begin{array}{l}245 \% \\
82,8\end{array}$ & $\begin{array}{l}201 / 3 \\
235 / 8\end{array}$ & $\begin{array}{l}183 / 1 \\
21 \frac{1}{1 / 4}\end{array}$ & $\begin{array}{l}16 \% / 2 \\
18 \% / 3\end{array}$ & $\begin{array}{l}271 / 1 \\
295 \%\end{array}$ & $\begin{array}{l}241 / 4 \\
21 \% / 4\end{array}$ & $\begin{array}{l}301 / 4 \\
297 / 8\end{array}$ \\
\hline $\begin{array}{l}\text { M. } \\
5 \text { O. } \\
5 \text { A. }\end{array}$ & $\begin{array}{c}(2516) \mid \\
251 / 3\end{array}$ & $\begin{array}{l}1.53 / 4 \\
21\end{array}$ & 2.) $1 \frac{1}{4}$ & $\begin{array}{l}15^{1} \\
14 ; \\
31\end{array}$ & $\begin{array}{l}105 / 3 \\
103 / 3 \\
223\end{array}$ & $\begin{array}{l}103 / 6 \\
13^{14} \\
27 \%\end{array}$ & $\mid \begin{array}{l}123 \% \\
12 \% / 2 \\
28 \%\end{array}$ & $\begin{array}{l}10 \% 8 \\
10 \% / 2 \\
261 / 8\end{array}$ & $\begin{array}{r}71 / 4 \\
67 \\
251 / 8\end{array}$ & $\begin{array}{l}151 / 3 \\
171 / 3 \\
317 \%\end{array}$ & $\begin{array}{l}141 / 2 \\
10 \% \\
31 \%\end{array}$ & $\begin{array}{l}191 / 2 \\
151 / 4 \\
3 !\end{array}$ \\
\hline $6\left\{\begin{array}{l}1 \\
2\end{array}\right.$ & $\begin{array}{l}171 / 8 \\
141 / 3\end{array}$ & $\begin{array}{l}16 \% / 3 \\
15 \% / 8\end{array}$ & $\begin{array}{l}221 / 3 \\
50 \% 4\end{array}$ & $\begin{array}{l}181 / 3 \\
163 / 4\end{array}$ & $\begin{array}{l}91 / 4 \\
91 / 3\end{array}$ & $\begin{array}{l}161 / 8 \\
14 \frac{5}{8}\end{array}$ & $\begin{array}{l}12 \\
11 \%\end{array}$ & $11 \frac{4}{10}$ & $\begin{array}{l}71 / 3 \\
73 / 4\end{array}$ & $10^{97 / 3}$ & $\begin{array}{l}103 / 8 \\
115 / 8\end{array}$ & $\begin{array}{l}131 / 2 \\
143 \%\end{array}$ \\
\hline .4 & 1813 & 223. & $S+1 / 4$ & $2 \pi 1 / 2$ & $19 \%$ & $235 / 3$ & $81^{3 / 11}$ & 2316 & $253 / 1$ & $315 /$ & $511 / 4$ & $3 ; 31 / 8$ \\
\hline
\end{tabular}

$\begin{array}{ll}\text { (1) Averages of } 4 \text { years, } 4 \text { years, and } 8 \text { years. } & \text { (2) Averages of } 9 \text { years }\end{array}$ last 10 years, and total 17 years.

(4) Averages 
8AME LAND, WITHOUT MANURE, AND WITH DIFFERENT DESCRIPTIONS OF Field, Rothamsted.

(AND CHAFF) PER ACRE-cwts.

tion, or quantity, of Manure, at the period indicated, for particulars of which see thereto, p. 2:31.]

\begin{tabular}{|c|c|c|c|c|c|c|c|c|c|c|c|}
\hline \multicolumn{8}{|c|}{ HARVESTS. } & \multicolumn{3}{|c|}{ AVERAGE ANNOAL. } & \multirow[b]{2}{*}{$\frac{\mathfrak{s}}{\stackrel{s}{k}}$} \\
\hline 1864 & 1865 & 1366 & 1867 & 1868 & 1869 & 1870 & $18 \pi 1$ & 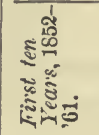 & 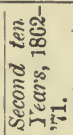 & 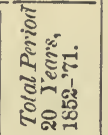 & \\
\hline $\begin{array}{l}\text { cwts. } \\
123 / 4 \\
15 \% \\
13 \% \\
163 \%\end{array}$ & $\mid \begin{array}{c}\text { cwt } \\
81 / 6 \\
91 / 8 \\
93 / 4 \\
10\end{array}$ & $\begin{array}{c}\text { cwts } \\
91 / 2 \\
125 / 8 \\
101 / 4 \\
12 \% / 8\end{array}$ & $\begin{array}{l}\text { cwt } \\
101 / 4 \\
121 / 4 \\
101 / 8 \\
12\end{array}$ & $\begin{array}{c}\text { cwts. } \\
11 \mathrm{~s} / 8 \\
93 \% \\
8 \% / 8 \\
101 / 8\end{array}$ & $\begin{array}{l}\text { cwt } \\
11 \\
103 / 8 \\
11 \\
127 / 8\end{array}$ & $\begin{array}{c}c w t \\
65 / 8 \\
8 \\
81 / 2 \\
93 \\
31 / 8\end{array}$ & $\begin{array}{l}c w t \\
11 \\
121 / 4 \\
111 / 4 \\
14\end{array}$ & $\begin{array}{r}\text { cwts. } \\
133 / 8 \\
147 / 8 \\
137 / 8 \\
161 / 8\end{array}$ & $\begin{array}{c}\text { cwts. } \\
101 / 4 \\
117 / 8 \\
103 / 4 \\
125 / 8\end{array}$ & $\begin{array}{l}\text { cwts. } \\
113 / 4 \\
133 / 8 \\
121 / 4 \\
143 / 8\end{array}$ & $\begin{array}{ll}1 & 0 . \\
2 & 0 . \\
3 & 0 . \\
4 & 0 .\end{array}$ \\
\hline $14 \% / 8$ & 91 & $111 / 4$ & $111 / 8$ & $97 / 8$ & $111 / 4$ & $\varepsilon 1 / 8$ & $121 / 8$ & $141 / 2$ & $113 / 8$ & $127 / 8$ & Means \\
\hline $\begin{array}{l}203 / 8 \\
321 / 2 \\
191 / 4 \\
347 / 8 \\
\end{array}$ & $\begin{array}{l}13 \\
215 / 8 \\
16 \\
221 / 2\end{array}$ & $\begin{array}{l}153 \% \\
281 / 8 \\
163 / 4 \\
273 / 8 \\
\end{array}$ & $\begin{array}{l}171 / 4 \\
285 \\
19 \% \\
25 \% / 2\end{array}$ & $\begin{array}{l}12 \% 3 \\
1938 \\
14 \% / 8 \\
50 \% 8 \\
5\end{array}$ & \begin{tabular}{|l|}
$181 / 4$ \\
32 \\
$603 / 4$ \\
$343 / 8$
\end{tabular} & $\begin{array}{l}123 / 2 \\
17 / 8 \\
15 \\
18 \% / 8\end{array}$ & $\begin{array}{l}231 / 3 \\
281 / 8 \\
253 / 8 \\
321 / 2\end{array}$ & $\begin{array}{l}193 / 4 \\
277 / 8 \\
217 / 8 \\
2878\end{array}$ & $\begin{array}{l}173 / 8 \\
271 / 2 \\
193 / 4 \\
29\end{array}$ & $\begin{array}{l}181 / 2 \\
275 / 8 \\
203 / 4 \\
281 / 2\end{array}$ & 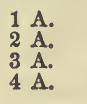 \\
\hline $263 / 1$ & $181 / 4$ & $213 / 4$ & $225 / 8$ & $163 / 2$ & $263 / 8$ & 16 & $2 \pi 1 / 4$ & $241 / 2$ & $23,1 / 8$ & $23 \frac{3}{4}$ & Means \\
\hline $\begin{array}{l}231 / 4 \\
33 \% / 8 \\
267 / 8 \\
371 / 4 \\
\end{array}$ & $\begin{array}{l}16 \\
23 \\
17 \\
247 / 8\end{array}$ & $\begin{array}{l}173 / 2 \\
281 / 8 \\
181 / 8 \\
281 / 4 \\
\end{array}$ & \begin{tabular}{|l|}
$171 / 8$ \\
$307 / 8$ \\
$203 / 4$ \\
$283 / 8$
\end{tabular} & $\mid \begin{array}{l}141 / 2 \\
217 / 8 \\
16 \frac{1}{4} \\
25 \% / 8\end{array}$ & $\begin{array}{l}211 / 2 \\
347 / 8 \\
223 / 4 \\
381 / 8\end{array}$ & $\begin{array}{l}17 \% 8 \\
233 / 4 \\
207 / 8 \\
181 / 4 \\
\end{array}$ & $\begin{array}{l}263 / 4 \\
321 / 8 \\
253 / 8 \\
32 \% 8\end{array}$ & $\begin{array}{l}24 \\
317 / 8 \\
253 / 4 \\
343 / 4 \\
\end{array}$ & $\begin{array}{l}201 / 8 \\
291 / 8 \\
221 / 4 \\
301 / 8\end{array}$ & $\begin{array}{l}301 / 2 \\
24 \\
323 / 8\end{array}$ & $\begin{array}{l}1 \text { AA. } \\
2 \text { AA. } \\
3 \text { AA. } \\
4 \text { AA. }\end{array}$ \\
\hline $30 \%$ & $201 / 4$ & $231 / 8$ & $24 \frac{1}{4}$ & $19 \%$ & $291 / 4$ & $201 / 4$ & $291 / 4$ & 29 & $253 / 8$ & $271 / 4$ & Means \\
\hline $\begin{array}{l}261 / 3 \\
331 / 2 \\
301 / 4 \\
40 \frac{3}{4}\end{array}$ & $\begin{array}{l}223 / 8 \\
231 / 4 \\
203 / 8 \\
251 / 2\end{array}$ & $\begin{array}{l}20 s / 8 \\
301 / 4 \\
25 \\
291 / 2 \\
\end{array}$ & \begin{tabular}{l|}
$181 / 2$ \\
$291 / 2$ \\
$233 / 8$ \\
$281 / 4$
\end{tabular} & $\begin{array}{l}167 / 8 \\
251 / 4 \\
22 \\
265 / 8\end{array}$ & $\begin{array}{l}233 / 1 \\
371 / 8 \\
305 / 8 \\
421 / 2\end{array}$ & $\begin{array}{l}17 \\
201 / 8 \\
201 / 2 \\
203 / 4\end{array}$ & \begin{tabular}{l|}
$293 / 4$ \\
$361 / 8$ \\
$311 / 8$ \\
38
\end{tabular} & (1) $\left\{\begin{array}{l}211 / 8 \\
291 / 8 \\
243 / 4 \\
31\end{array}\right.$ & $\begin{array}{l}21 \% \\
295 / 8 \\
201 / 8 \\
32\end{array}$ & $\left.\left.\begin{array}{l}21 / 8 \\
293 / 8 \\
253 / 8 \\
31 \frac{3}{3}\end{array}\right\}{ }^{1}\right)$ & $\begin{array}{l}2 \text { AAS. } \\
3 \text { AAS. } \\
4 \text { AAS. }\end{array}$ \\
\hline $325 / 8$ & $227 / 8$ & $263 / 8$ & $247 / 8$ & $225 / 8$ & $\overline{331 / 2}$ & $\overline{195 / 8}$ & $333 / 4$ & $26: 8$ & $273 / 3$ & 27 & Means \\
\hline $\begin{array}{l}261 / 8 \\
317 / 8 \\
31 / 8 \\
347 / 8 \\
\end{array}$ & $\begin{array}{l}211 / 2 \\
217 / 8 \\
22 \\
22\end{array}$ & $\begin{array}{l}241 / 8 \\
241 / 2 \\
243 / 8 \\
27 \% 8 \\
\end{array}$ & $\begin{array}{l}251 / 2 \\
255 / 8 \\
221 / 4 \\
241 / 4\end{array}$ & $\begin{array}{l}191 / 8 \\
195 / 8 \\
103 / 4 \\
211 / 8\end{array}$ & \begin{tabular}{l|}
27 \\
$331 / 1 / 3$ \\
$301 / 2$ \\
$351 / 3$
\end{tabular} & $\begin{array}{l}17 \% \frac{1}{17} \\
17 \% 8 \\
18 \% 8 \\
203 / 8\end{array}$ & $\begin{array}{l}2 \\
2 \\
3 \\
3\end{array}$ & $\begin{array}{l}293 / 8 \\
307 / 8 \\
287 / 8 \\
311 / 4\end{array}$ & $\begin{array}{l}241 / 4 \\
26 \\
251 / 4 \\
273 / 4\end{array}$ & $\begin{array}{l}267 \% \\
28 ? / 8 \\
271 / 8 \\
29 \%\end{array}$ & $\begin{array}{ll}2 & \mathrm{C} . \\
3 & \mathrm{C} . \\
4 & \mathrm{C} .\end{array}$ \\
\hline 31 & $217 / 8$ & $251 / 8$ & 24,6 & $197 / 8$ & $\overline{313 / 8}$ & $\overline{181 / 2}$ & 2958 & $301 / 8$ & $25 \% / 4$ & 28 & Means \\
\hline $\begin{array}{l}241 / 6 \\
2 \pi 3 / 4\end{array}$ & $\begin{array}{l}181 / 2 \\
211 / 2\end{array}$ & $\begin{array}{l}211 / 8 \\
237 / 8\end{array}$ & $\begin{array}{l}211 / 8 \\
213 / 4\end{array}$ & $\begin{array}{l}18 \% / 8 \\
1 \% 1 / 8\end{array}$ & $\begin{array}{l}24 \\
275 / 8\end{array}$ & $\begin{array}{l}131 / 4 \\
191 / 8\end{array}$ & $\begin{array}{l}291 / 4 \\
311 / 2\end{array}$ & $\left(^{2}\right)\left\{\begin{array}{l}233 / 8 \\
277 / 8\end{array}\right.$ & $\begin{array}{l}221 / 2 \\
241 / 2\end{array}$ & $\begin{array}{l}227 / 8 \\
261 / 8\}(2)\end{array}$ & $\begin{array}{l}1 \mathrm{~N} . \\
2 \mathrm{~N} .\end{array}$ \\
\hline $\begin{array}{l}137 / 8 \\
147 / 8 \\
337 / 8\end{array}$ & $\begin{array}{r}93 / 8 \\
103 / 2 \\
247 / 8\end{array}$ & $\begin{array}{l}123 / 8 \\
10 \% / 8 \\
28\end{array}$ & $\begin{array}{l}12 \\
103 / 8 \\
22 \% 8\end{array}$ & $\begin{array}{l}101 / 6 \\
81 / 2 \\
20 \% 9\end{array}$ & $\begin{array}{l}115 / 8 \\
151 / 2 \\
361 / 8\end{array}$ & $\begin{array}{r}-87 / 8 \\
43 / 8 \\
213 / 8\end{array}$ & $\begin{array}{l}143 / 4 \\
13 \frac{1}{8} \\
29 \% / 8\end{array}$ & $\begin{array}{r}\text { (3) }(113 / 4 \\
(4)(135 \% 8 \\
27 \% / 8\end{array}$ & $\begin{array}{l}123 / 4 \\
113 / 8 \\
28: 4\end{array}$ & $\begin{array}{l}123 / 8) \\
123 / 8) \\
28\end{array}$ & $\begin{array}{l}\text { M. } \\
5 \text { O. } \\
5 \text { A. }\end{array}$ \\
\hline $\begin{array}{l}135 / 8 \\
137 / 8\end{array}$ & $\begin{array}{l}83 / 4 \\
87 / 3\end{array}$ & $\begin{array}{r}101 / 2 \\
91 / 2\end{array}$ & $\begin{array}{r}93 / 8 \\
107 / 8\end{array}$ & $\begin{array}{l}10 \% / 2 \\
10 \% 8\end{array}$ & $\begin{array}{r}97 / 8 \\
103 / 8\end{array}$ & $\begin{array}{l}73 / 4 \\
77 / 8\end{array}$ & 13 & $\begin{array}{l}14 \\
13\end{array}$ & $\begin{array}{l}103 / 4 \\
11 \frac{1}{4}\end{array}$ & $\begin{array}{l}123 / 8 \\
121 / 8\end{array}$ & $\left.\begin{array}{l}1 \\
2\end{array}\right\} 6$ \\
\hline $3 / 8$ & $253 / 8$ & $31 \%$ & $271 / 8$ & $241 / 2$ & & & $371 / 8$ & $26 \%$ & $297 / 8$ & $20 \% 4$ & 7 \\
\hline
\end{tabular}

(1853-61), last 10 years. and total 19 years. of 9 years (1853-61), last 10 yeurs, and total 19 years. 
The produce of barley the first season (1852), was, per acre:

On the unmanured plot $\ldots \ldots \ldots \ldots \ldots \ldots \ldots \ldots \ldots \ldots \ldots \ldots \ldots$ bushels

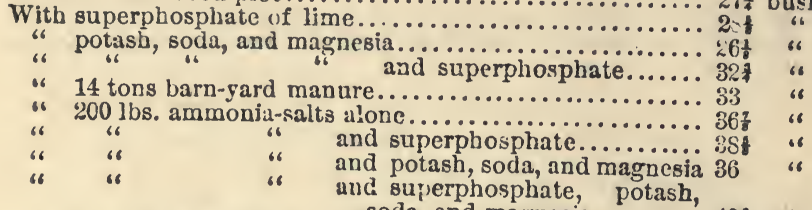
" 400 lbs. ammonia-salts alone, and magnesia......... 40 "

The $200 \mathrm{lbs}$. of ammonia-salts contain $50 \mathrm{lbs}$. of ammonia $=41$ lbs. nitrogen.

It will be seen that this 50 lbs. of ammonia alone, on plot $1 a$, gives an increase of neariy 10 bushels per acre, or to be more accurate, it gives an increase over the unmanured plot of $503 \mathrm{lbs}$. of grain, and 32:) lbs. of straw, while double the quantity of ammonis on plot 1a.a., gives an increase of $17 \frac{1}{4}$ bushels per acre-or an increase of $901 \mathrm{lbs}$. of grain, and 1,144 lbs. of straw.

"Put that fact in separate lines, side by side," said the Deacon, "so that we can see it."

\section{Total}

Grain Straw Produce.

50 lbs. of ammonia gives an increase of..... 503 lbs. 704 lbs. 1207 lbs.

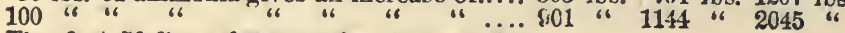

The first 50 lbs. of ammonia gives an $\ddot{i n}$ crease of ........................ 503 " 704 " 1207 "6

The second $50 \mathrm{lbs}$. of ammonia gives an increase of....................... 898 " 510 " 738 "

"That shows," said the Deacon, "that a dressing of 50 lbs. per acre pays better than a diressing of 100 lbs. per acre. I wish Mr. Lawes had sown 75 lbs. on one plot."

I wish so, too, but it is quite probable that in our climate, 50 Ibs. of available ammonia per acre is all that it will usually be profitable to apply per acre to the barley crop. It is equal to a cressing of $500 \mathrm{lbs}$. guarantced Peruvian guano, or $275 \mathrm{lbs}$. nitrate of soda.- "Or to how much manure?" asked the Deacon.

To about 5 tons of average stable-manure, or say three tons of good, well-rotted manure from grain-fed animals.

"And yet," said the Deacon, "Mr. Lawes put on 14 tons of yard manure per acre, and the yield of barley was not as much as from the $50 \mathrm{lbs}$. of ammonia alone. How do you account for that?"

Simply because the ammonia in the manure is not ammonia. It is what the chemists used to call "potential ammonia." $\mathbf{A}$ good deal of it is in the form of undigested straw and hay. The nitrogenous matter of the iood which bas been digested by the animal 
and thrown off in the liquid excrements, is in such a form that it will readily ferment and produce ammonia, while the nitrogenous matter in the undigested food and in the straw used for bedding, decomposcs slowly even under the most favorable conditions; and if buried while fresh in a clay soil, it probably would not all decompose in many years. But we will not discuss this at present.

"The superphosphate does not seem to have done much good," said the Deacon; " $3 \frac{1}{2} \mathrm{cwt}$. per acre gives an increase of less than two bushels per acre. And I suppose it was good superphosphate."

There need be no doubt on that point. Better superphosphate of lime cannot be made. But you must recollect that this is pure superphosphate made from burnt bones. It contains no ammonia or organic matter. Commercial superphosphates contain more or less ammonia, and had they been used in these experiments, they would have shown a better result than the pure article. They would have done good in proportion to the available nitrogen they contained. If these experiments prove anything, they clearly indicate that superphosphate alone is a very poor manure for either wheat or barley.

The second year, the unmanured plot gave $25 \frac{9}{4}$ bushels per acre. Potash, soda, and magnesia, (or what the Deacon calls "ashes,") 27. phate, nearly 36 bushels per acre.

50 lbs. of ammonia, alone, gives nearly 39 bushels, and ammonia and superphosphate together, 40 bushels.

The superphosphate and "ashes" give a better account of themselves this year; but it is remarkable that the ammonia alone, gives almost as good a crop as the ammonia and superphosphate, and a better crop than the ammonia and "ashes," or the ammonia, superphosphate, and ashes, together.

The 14 tons farm-yard manure gives over 36 bushels per acre. This plot has now had 28 tons of manure per acre, yet the $50 \mathrm{lbs}$. of ammonia alone, still gives a better yield than this heavy dressing of manure.

The third season (1854), was quite favorable for the ripening of wheat and barley. The seed on the experimental barley-field, was sown Feb. 24, and the harvest was late; so that the crop had an unusually long season for growth. It was one of the years when even poor land, if clean, gives a good crop. The unmanured plot, it will be seen, yielded over 35 bushels per acre of dressed grain, weighing over $53 \frac{1}{2}$ lbs. per bushel. The total weight of grain, was $1,963 \mathrm{lbs}$. This is over 40 bushels per acre, of $48 \mathrm{lbs}$. per bushel, which is the standard with us. 
The 14 tons of farm-yard manure produce nearly $56 \frac{1}{2}$ bushels per acre.

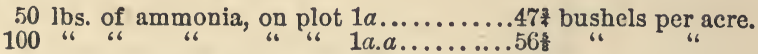

You will see, that though the plot which has received 42 tons of manure per acre, produced a splendid crop; the plot having nothing except $100 \mathrm{lbs}$. of ammonia per acre, produced a crop equally good. "How much increase do you get from 50 lbs. of ammonia," asked the Deacon, "and how much from 100 lbs. ?"

\section{Equal Amer.}

50 Train. Straw. Bushels.

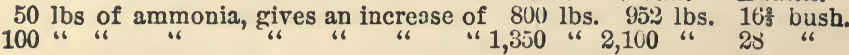

If you buy nitrate of soda at $3 \frac{8}{4}$ cents a 16 ., the ammonia will cost 20 cents a $1 \mathrm{~b}$. In the above experiment, $50 \mathrm{lbs}$. of ammonia, costing $\$ 10$, gives an increase of $16 \%$ bushels of barley, and nearly half a ton of straw. If the straw is worth $\$ 4.00$ per ton, the barley will cost 48 cents a bushel.

Double the quantity of manure, costing $\$ 20$, gives an increase of 28 bushels of barley, and over one ton of straw. In this case the extra barley costs 57 cents a bushel.

On plot $2 x$., $50 \mathrm{lbs}$. of ammonia and $3 \frac{1}{2} \mathrm{cwt}$. of superphosphate, give $3,437 \mathrm{lbs}$. of grain, equal to $71 \frac{1}{2}$ of our bushels per acre.

On plot 2a.r. $100 \mathrm{lbs}$. of ammonia and $3 \frac{1}{2} \mathrm{cwt}$. of superphos hate, give $3,643 \mathrm{lbs}$. of grain, which lacks only 5 lbs. of 76 bushels per acre, and nearly $2 \frac{1}{2}$ tons of straw.

"That will do," said the Dearon, "but I see that in 1857 , this same plot, with the same manure, produced $66 \frac{1}{2}$ bushels of dressed grain per acre, weighing $53 \frac{1}{2} \mathrm{lbs}$. to the bushel, or a total weight of 3,696 lbs., equal to just 77 of our bushels per acre."

"And yet," said the Doctor, "this same year, the plot which had 84 tons of farm-yard manure per acre, produced only 2,915 lbs. of grain, or less than 61 of our bushels of barley per acre."

The Squire happened in at this time, and heard the last remark. "What are you saying," he remarked, " about only 61 bushels of barley per acre. I should like to see such a crop. Last year, in this neighborhood, there were hundreds of acres of barley that did not yicld 20 bushels per acre, and very little of it would weigh 44 lbs. to the bushel."

This is true. And the maltsters find it almost impossible to get six-rowed barley weighing 48 lbs. per bushel. They told me, that they would pay $\$ 1.10$ per bushel for good bright barley weighing $48 \mathrm{lbs}$. per bushel, and for esch pound it weighed less than this, they deducted 10 cents a bushel from the price. In other words, 
they would pay $\$ 1.00$ a bushel for barley weighing 47 lbs. to the bushel; 90 cents for barley weighing $46 \mathrm{lbs}$; 80 cents for barley weighing $45 \mathrm{lbs}$., and 70 cents for barley weighing $44 \mathrm{lbs}$. -and at these figures they much preferred the heaviest barley.

It is certainly well worth our while, if we raise barley at all, to see if we cannot manage not only to raise larger crops per acre, but to produce barley of better quality. And these wonderful experiments of Mr. Lawes are well worth careful examination and study.

The Squire put on his spectacles and looked at the tables of figures.

"Like everybody else," said he, "you pick out the big figures, and to hear you talis, one would think you scientific gentlemen never have any poor crops, and yet I see that in 1860 , there are three different crops of only $12 \frac{1}{8}, 12 \frac{1}{4}$, and $13 \frac{1}{4}$ bushels per acre."

"Those," said I, "are the three plots which have grown barley every year without any manure, and you have selected the worst year of the whole twenty."

"Perhaps so," said the Squire, "but we have got to take the bad with the good, and I have often heard you say that a good farmer who has his land rich and clean makes more money in an unfarorable than in a favorable season. Now, this year 1860 , seems to have been an unfavorable one, and yet your pet manure, superphosphate, only gives an increase of $148 \mathrm{lbs}$. of barley-or three bushels and 4 lbs. Yet this plot has had a tremendous dressing of $3 \frac{1}{2} \mathrm{cwt}$. of superphosphate yearly since 1852 . I always told you you lost money in buying superphosphate."

"That depends on what you do with it. I use it for turnips, and tomatoes, cabbages, lettuce, melons, cucumbers, etc., and would not like to be without it; but $I$ have never recommended any one to use it on wheat, barley, oats, Indian corn, or potatoes, except as an experiment. What I have recommended you to get for barley is, nitrate of soda, and superphosphate, or Peruvian guano. And you will see that even in this decidedly unfavorable scason, the plot $2 a . n$., dressed with superphosphate and $275 \mathrm{lbs}$. of nitrate of soda, produced 2,338 lbs. of barley, or $48 \%$ bushels per acre. This is an increase over the unmanured plots of $33 \frac{1}{2}$ bushels per acre, and an increase of $1,872 \mathrm{lbs}$. of straw. And the plot dressed with superphosphate and $200 \mathrm{lbs}$. of salts of ammonia, gave equally as good results."

And this, mark you, is the ycar which the Squire selected as the one most likely to show that artificial manures did not pay.

"I never knew a man except you," said the Squire," who wanted unfavorable seasons." 
I have never said I wanted unfavorable seasons. I should not dare tu say so, or even to cherish the wish for one moment. But I do say, that when we have a season so favorable that even poorly worked land will produce a fair crop, we are almost certain to have prices below the average cost of production. But when we have an unfarorable season, such crops as barley, potatoes, and beans, of ten advance to extravagantly high prices, and the farmer who has gnod crops in such a season, gets something like adequate pay for his patient waiting, and for his efforts to improve his land.

"That sounds all very well," said the Squire," but will it pay to use these artificial manures ?"”

I do not wish to wander too much from the point, but would like to remark before I answer that question, that I am not a special advocate of artificial manures. I think we can often make manures on our farms far ch:aper than we can buy them. But as the Squire has asked the question, and as he has selected from Mr. Lawes' results, the year 1860 , I will meet him on his own ground. He has selected a season specially unfavorable for the growth of barley. Now, in such an unfavorable year in this country, barley would be likely to bring, at least, $\$ 1.25$ per bushel, and in a favorable season not over 75 cents a bushel.

Mr. Lawes keeps his land clean, which is more than can be said of many barley-growers. And in this unfavorable season of 1860 , h3 gets on his three unmanured plots an average of 730 lbs. of bariey, equal to $15 \frac{1}{4}$ bushels per acre, and not quite $800 \mathrm{lbs}$. of straw.

Many of our farmers frequently do no better than this. And you must recollect that in such careful experiments as those of Mr. Lawes and Dr. Gilbert, great pains would be taken to get all the barley that grew on the land. With us, barley is cut with a reaper, and admirable as our machines are, it is not an easy matter to cut a light, spindling crop of barley perfectly clean. Then, in pitching the crop and drawing it in, more or less barley is scattered, and even after we have been over the field two or three times with a steel-tooth rake, there is still considerable barley left on the ground. I think we may safely assume that at least as much barley is left on the ground as we usually sow-say two bushels per acre. And so, instead of having $15 \frac{1}{4}$ bushels per acre, as Mr. Lawes had, we should only harvest $13 \$$ bushels.

Of all our ordinary farm crops, barley is attended with the least labor and expense. We usually sow it after corn or potstoes. On such strong land as that of Mr. Lawes, we ought to plow the land 
in the autumn and again in the spring, or at least stir up the land thoroughly with a two or three-horse cultivator or gang-plow.

Let us say that the cost of plowing, harrowing, drilling, and rolling, is $\$ 5.00$ per ucre. Seed, $\$ 2.00$. Harvesting, $\$ 2.00$. Threshing, 6 cents a bushel.

Rieceipts :

$13 \frac{1}{4}$ bushels barley @ 1.25............. \$16.57

800 lbs. of straw @ \$4. per ton......... $\frac{1.60}{18.17}$

Putting in and harvesting the crop $\$ 9.00$

Threshing $13 \frac{1}{4}$ bushels $@ 6$ c...... $.80-9.80$

Rent and profit per acre............. \$ \$8.37

"That is a better showing than I expected," said the Squire, "and as barley occupies the land only a few months, and as we sow wheat after it, we cannot expect large profits."

"Very well," said I, "Now let us take the crop, this same unfavorable year, on plot 2a.a., dressed with superphosphate and nitrate of soda.

The expense of plowing, harrowing, drilling, rolling, seed, and harvesting, would be about the same, or we will say $\$ 2.00$ an acre more for extra labor in harvesting. And we will allow two bushels per acre for scatterings-though there is nothing like as much barley left on the ground when we have a good crop, as when we have a poor crop. But I want to be liberal.

The yield on plot 2a.a., was $48 \frac{8}{4}$ bushels per acre, and 2,715 lbs. of straw.

Receipts :

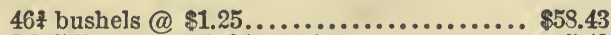

2,715 lbs. straw @ $\$ 4$. per ton.............. $\frac{5.43}{\$ 63.86}$

Putting in the crop and harvesting... \$11.00

Threshing $49+$ bushels @ 6 c......... 2.S0

2 2ั0 lbs. nitrate of soda @ 4 c......... 11.00

392 lbs. superphosphate @ 2 c........ 7.84

Rent and profit............................ \$31.22

In ordinary farm practice, I feel sure we can do better than this. Growing barley year after year on the same land, is not the most economical way of getting the full value of the manure. There is much nitrogen and phosphoric acid left in the land, which barley or even wheat does not seem capable of taking up, but which would prubably be of great benefit to the clover. 


\section{MANURE AND ROTATION OF CROPS.}

The old notion that there is any real chemical necessity for a rotation of crops is unfounded. Wheat can be grown after wheat, and barley after barley, and corn after corn, provided we use the necessary manures and get the soil clean and in the rigbt mechanical condition.

"What, then, do we gain by a rotation?" asked the Deacon.

Much every way. A good rotation enables us to clean the land. We can put in different crops at different seasons.

"So we could," broke in the Deacon, "if we sowed wheat after wheat, barley after barley, anci corn after corn."

True, but if we sowed winter-wheat after winter-wheat, there would not be time enough to clean the land.

"Just as much as when we sow wheat after oats, or peas, or barley."

"True again, Deacon," I replied, "but we are supposed to have cleaned the lanil while it was in corn the previous year. I say supposed, because in point of fact, many of our farmers do not half clean their land while it is in corn. It is the weak spot in our agriculture. If our land was as clean as it should be to start with, there is no rotation so convenient in this section, as corn the first year, barley, peas, or oats the second year, followed by winterwheat seeded down. But to carry out this rotation to the best advantage we need artificial manures."

"But will they pay?" asks the Deacon.

"They will pay well, provided we can get them at a fair price and get fair prices for our produce. If we could get a good superphosphate made from Charleston phosphates for $1 \frac{1}{2}$ cent per lb., and nitrate of soda for $3 \frac{1}{2}$ or 4 cents per lb., and the German potash-salts for $\frac{8}{4}$ cent per $1 \mathrm{~b}$., and could get on the average $\$ 1.25$ per bushel for barley, and $\$ 1.75$ for good white wheat, we could use these manures to great advantage."

"Nothing like barn-yard manure," says the Deacon.

No doubt on that point, provided it is good manure. Barn-yard manure, whether rich or poor, contains all the elements of plantfood, but there is a great difference between rich and poor manure. The rich manure contains twice or three times as much nitrogen and phosphoric acid as ordinary or poor manure. And this is the reason why artificial manures are valuable in proportion to the nitrogen and phosphoric acid that they contain in an available condition. When we use two or three hundred pounds per acre of a good artificial manure we in effect, directly or indirectly, convert 
poor manure into rich manure. There is manure in our soil, but it is poor. There is manure in our barn-yard, but it is poor also. Nitrogen and phosphoric acid will make these manures rich. This is the reason why a few pounds of a good artificial manure will produce as great an effect as tons of common manure. Depend upon it, the coming farmer will avail himself of the discoveries of science, and will use more artificial fertilizers.

But whether we use artificial fertilizers or farm-yard manure, we shall not get the full effect of the manures unless we adopt a judicious rotation of crops.

When we sow wheat after wheat, or barley after barley, or oats after oats, we certainly do not get the full effect of the manures used. Mr. Lawes' experiments afford conclusive evidence on this point. You will recollect that in 1846 , one of the plots of wheat $(10 b)$, which had received a liberal dressing of salts of ammonia the year previous, was left without manure, and the yield of wheat on this plot was no greater than on the plot which was continuously unmanured. In other words, the ammonia which was left in the soil from the previous year, had no effect on the wheat.

The following table shows the amount of nitrogen furnished by the manure, and the amount recovered in the crop, when wheat is grown after wheat for a series of years, and also when barley is grown after barley, and oats after oats. 
TALKS ON MANURES.
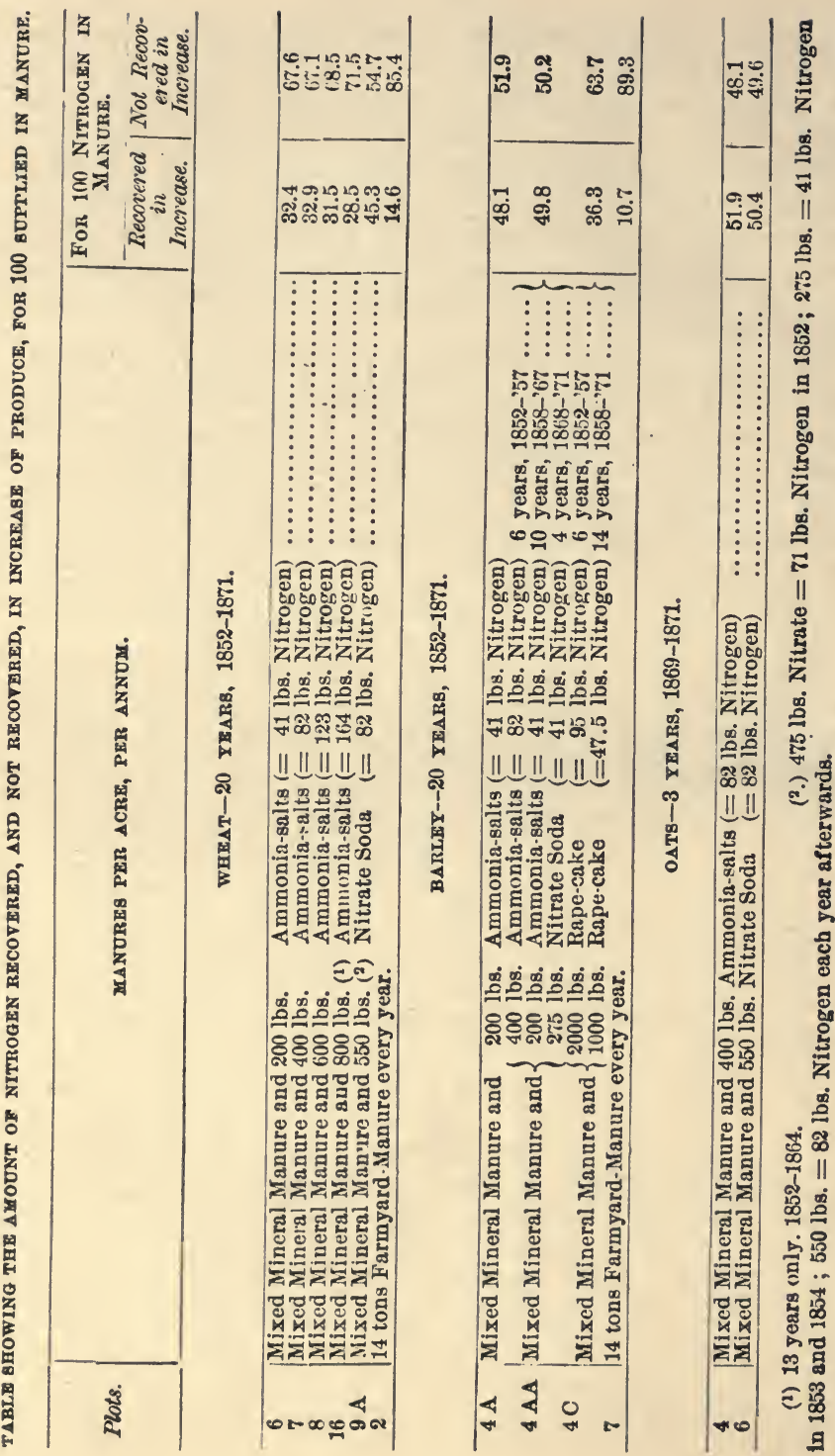
It is not necessary to make any comments on this table. It speaks for itself; but it does not tell half the story. For instance, in the case of wheat and barley, it gives the average result for 20 years. It shows that when $100 \mathrm{lbs}$. of nitrogen in a soluble and available form, are applied to wheat, about $68 \mathrm{lbs}$. are left in the suil. But you must recollect that $100 \mathrm{lbs}$. was applied again the next year, and no account is taken of the $68 \mathrm{lbs}$. left in the soiland so on for 20 years. In other words, on plot 8 , for instance, $2,460 \mathrm{lbs}$. of nitrogen have been applied, and only $77 \mathrm{~s}$ lbs. have been recovered in the total produce of grain, straw, and chaff, and $1,685 \mathrm{lbs}$. have been left in the soil.

Mr. Lawes estimates, from several analyses, that his farm-yard manure contains 0.637 per cent of nitrogen, 2.76 per cent of mineral matter, and 27.24 per cent of organic matter, and 70 per cent of water.

According to this, the plot dressed with 14 tons of manure every year, for 20 years, has received $3,995 \mathrm{lbs}$. of nitrogen, of which 5831 jbs. were recovered in the produce, and $3,411 \frac{8}{4} \mathrm{lbs}$. were left in the soil.

Iu the case of barley, 3,995 lbs. of nitrogen was applied during the 20 years to the plot dressed with farm-yard manure, of which $427 \frac{1}{2}$ lbs. were recovered in the crop, and $3,567 \frac{1}{2} \mathrm{lbs}$. left in the soil.

"I see," said the Deacon, "that barlcy gets less of the goodness out of farm-yard manure than wheat, but that it gets more out of the salts of ammonia and nitrate of soda. How do you account for that?"

"I surpose, because the manure for wheat was applied in the autumn, and the rains of winter and spring dissolved more of the plant-food than would be the case if the manure was applied in the spring. If the manure had been applied on the surface, instead of plowing it under, I believe the effect would have been still more in favor of the autumn-manuring."

When the nitrogen is in an available condition, spring barley can take up and utilize a larger proportion of the nitrogen than winter wheat. Neither the wheat nor the barley can get at and take up half what is applied, and this, notwithstanding the fact that a heavy dew or a slight rain furnishes water enough on an acre to dissolve a liberal dressing of nitrate of soda or sulphate and muriate of ammonia. The truth is, the soil is very conservative. It does not, fortunately for us, yield up all its plant-food in a year

We have seen that when wheat or barley is dressed with sol- 
uble ammonia-salts or nitrate of soda, a considerable amount of the nitrogen is left in the soil-an l yet this nitrogen is of comparatively littla benefit to the succeeding crops of wheat or barley, while a fresh dressing of ammonia-salts or nitrate of soda is of great benefit to the crop.

In other words, when wheat is sown after wheat, or barley after barley, we do not get half the benefit from the manure which it is theorstically capable of producing.

Now, the question is, whether by a judicious rotation of crops, we can avoid this great loss of manure ?

There was a time when it was thought that the growth of turnips enriched the soil. I have heard it said, again and again, that the reason English farmers grow larger crops of wheat and barley than we do, is because they grow so many acres of turnips.

"So I have often heard," said the Deacon, "and I supposed the broad turnip leaves absorbed nitrogen from the atmosphere."

There is no evidence that leaves have any such power; while there are many facts which point in an opposite direction. The following experiments of Lawes and Gilbert seem to show that the mere growth of turnips does not enrich land for grain crops.

Turnips were grown on the same land, year after year, for ten years. The land was then plowed and sown to barley for three years. The following table gives the results:

Three Years of Barley after Ten Years of Turnips.

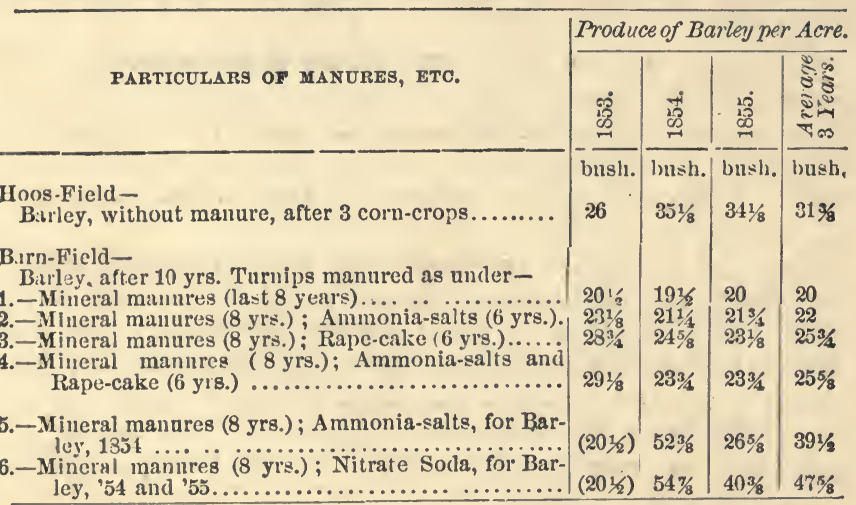

The yield of barley after turnips is less than it is after grain crops, and it is evident that this is due to a lack of available nitro- 
gen in the soil. In other words, the curnips leave less availuble nitrogen in the soil than grain crops.

After alluding to the facts given in the foregoing table, Messrs. Lawes and Gilbert say:

"There is evidence of another kind that may be cited as showing that it was of available nitrogen that the turnips had rendered the soil so deficient for the after-growth of barley. It may be assumed that, on the average, between 25 and $30 \mathrm{lbs}$. of nitrogen would be annually removed from the Rothamsted soil by wheat or barley grown year after year without nitrogenous manure. But it is estimated that from the mineral-manured turnip-plots there were, over the 10 years, more than $50 \mathrm{lbs}$. of nitrogen per acre per annum removed. As, however, on some of the plots, small quantities of ammonia-salts or rape-cake were applied in the first two years of the ten of turnips, it is, perhaps, more to the purpose to take the average over the last 8 years of turnips only; and this would show about $45 \mathrm{lbs}$. of nitrogen removed per acre per annum. An immaterial proportion of this might be due to the small amounts of nitrogenous manures applied in the first two years. Still, it may be assumed that about $1 \frac{1}{2}$ time as much nitrogen was removed from the land for 8 , if not for 10 years, in succession, as would have been taken in an equal number of crops of wheat or barley grown without nitrogenous manure. No wonder, then, that considerably less barley has been grown in 3 years after a series of mineral-manured turnip-crops, than was obtained in another field after a less number of corn-crops.

"The results obtained in Barn-field afford a striking illustration of the dependence of the turnip-plant on a supply of available nitrogen within the soil, and of its comparatively great power of exhausting it. They are also perfectly consistent with those in Hoos-field, in showing that mineral manures will not yield fair crops of barley, unless there be, within the soil, a liberal supply of available nitrogen. The results obtained under such very different conditions in the two fields are, in fact, strikingly mutually con. firmatory." 


\section{H A P T E R X X X}

\section{MIANURES FOR OATS.}

"What is the use of talking about manure for oats," said the Deacon, "if land is not rich enough to produce oats without manure, it certainly will not pay to manure them. We can use our manure on some crop that will pay better."

"That is precisely what we want tu know," said I. "Very likely you are right, but have you auy evidence ?"

"Evidence of what?"

"Have you any facts that show, for instance, that it will pay better to use manure for wheat or barley than for oats?"

"Can't say that I have, but I think manure will pay better on wheat than on oats."

Mr. Lawes is making a series of experiments on oats. Let us take a hasty glance at the results of the first two seasons :

Experiments on OAts at Rothamsted.

\begin{tabular}{|c|c|c|c|c|c|c|}
\hline \multirow[t]{2}{*}{ MANURES PER ACRE. } & \multicolumn{2}{|c|}{$\begin{array}{l}\text { Grain, in } \\
\text { bushels. }\end{array}$} & \multicolumn{2}{|c|}{ Straw, cuts. } & \multicolumn{2}{|c|}{$\begin{array}{l}\text { Weight per } \\
\text { bushel, lbs. }\end{array}$} \\
\hline & 1869. & 1870. & 1869. & 1870. & 1869. & $18 \% 0$. \\
\hline $\begin{array}{l}\text { 1.-No manure............. } \\
\text { 2.-Mixed Allialies and Superp }\end{array}$ & $36 \% / 8$ & $16 \%$ & $19 \frac{1}{4}$ & $91 / 8$ & $36 \%$ & 35 \\
\hline $\begin{array}{l}\text { of Lime.............................. } \\
\text { 3.-400 Ibs. Ammonialts } \\
\text { 4.-Mixed Alkalies and Superphosphate, }\end{array}$ & $\begin{array}{l}45 \\
561 / 8\end{array}$ & $\begin{array}{l}191 / 8 \\
371 / 2\end{array}$ & $\begin{array}{l}241 / 2 \\
367 / 8\end{array}$ & $\begin{array}{r}95 / 8 \\
17 \frac{1}{4}\end{array}$ & $\begin{array}{l}381 / 2 \\
371 / 2\end{array}$ & $\begin{array}{l}351 / 8 \\
34 \frac{1}{4}\end{array}$ \\
\hline $\begin{array}{l}\text { and } 400 \text { Tos. Ammonia-salts .......... } \\
\text { 5.-550 tos. Nitrate of Soda............. } \\
6 .- \text { Mixed Alkalies, Superphosphate, }\end{array}$ & $\begin{array}{l}751 / 4 \\
621 / 4\end{array}$ & $\begin{array}{l}505 / 8 \\
361 / 2\end{array}$ & $\begin{array}{l}54 \\
423 / 4\end{array}$ & $\begin{array}{l}285 / 8 \\
23\end{array}$ & $\begin{array}{l}391 / 4 \\
381 / 2\end{array}$ & $\begin{array}{l}36 \\
351 / 4\end{array}$ \\
\hline and 550 th & $693 / 8$ & 50 & $49 \% / 8$ & $283 / 4$ & $381 / 3$ & $35 \% / 2$ \\
\hline
\end{tabular}

It seems clear that, for oats, as for barley and wheat, what we most need in manure, is available nitrogen.

The first year, the no-manure plot produced 365 bushels of oats per acre, weighing $36:$ lbs. per bushel, and plot 3, with ammoniasalts alone, $56 \frac{1}{8}$ bushels, and with nitrate of soda alone, on plot 5 , $62 \frac{1}{4}$ bushels per acre, both weighing $38 \frac{1}{2} \mathrm{lbs}$. per bushel. In other words, 82 lbs. of available nitrogen in the salts of ammonia gave an increase of about 20 bushels per acre, and the same quantity of nitrogen in nitrate of soda an increase of 26 bushels per acre.

The next year, the season seems to have been a very unfavor- 
able one for oats. The no-manure plot produced less than 17 bushels per acre; and the "ashes" and superphosphate on plot 2, give an increase of less than 3 bushels per acre. But it will be seen that on plot 3 the ammonia-salts do as much good in this unfavorable season as in the favorable one. They give an increase of over 20 bushels per acre.

"A few such facts as this," said the Deacon, "would almost persuade me that you are right in contending that it is in the unfavorable saasons, when prices are sure to be high in this country, that a good farmer stands the best chance to make money."

"Where mixed alkalies and superphosphate," said the Doctor, " are added to the ammonia, the increase from the ammonia is far greater than where ammonia is used alone. In other words, by comparing plot 2 and plot 4 , you will see that the ammonia gives an increase of $30 \frac{1}{4}$ bushels por acre in 1869 , and $31 \frac{1}{2}$ bushels in $1870 . "$

The truth of the matter probably is this: $100 \mathrm{lbs}$. of available ammonia per acre is an excessive supply, when used alone. And in fuct Mr. Lawes himself only recommends about half this quantity.

Whether it will pay us to use artiâcial manures on oats depends on the price we are likely to get for the oats. When the price of oats per $l 3$. an 1 oat-straw is as high as barley and barley-straw per $l b$., then it will pay a littte better to use manure on oats than on barley. As a rule in this country, however, good barley is worth more per $\mathrm{lb}$. than good oats; and it will usually pay better to use artificial manures on barley than on oats.

Some years ago Mr. Bath, of Virginia, made some experiments on oats with the following results:

No. 1-200 lbs. Superphosphate...................22

Bushels of oats per acre.

No. $2-200$ lbs. Peruvian guano......................48

No. $3-100$ lbs. Peruvian guano ...........................

The oats were sown March 13, and the crop barvested July 4.

In 1860, I made some experiments with gypsum, superphosphate, and sulphate of ammonia as a top-dressing on oats.

The land was a clover-sod, plowed about the middle of May, and the oats sown May 20. On the 26th of May, just as the oats were coming up, the manures were sown broadcast. The oats were sown too late to obtain the best results. On another field, w here the oats were sown two weeks earlier, the crop was desidedly better. The oats were cut August 28.

The following is the result: 
ixperiments on Oats at Moreton Farm, Rochester, N. Y.

\begin{tabular}{|c|c|c|c|c|}
\hline Plots. & MANURES PER ACRE. & $\begin{array}{l}\text { Bushels } \\
\text { o, Oats } \\
\text { per ucre. }\end{array}$ & $\begin{array}{c}\text { Weight } \\
\text { per Bushel } \\
\text { in lbs. }\end{array}$ & $\begin{array}{l}\text { Straw } \\
\text { per acre } \\
\text { in los. }\end{array}$ \\
\hline $\begin{array}{r}\text { No. } 1 \\
2 \\
3 \\
4 \\
5\end{array}$ & 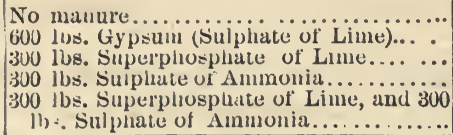 & $\begin{array}{l}36 \\
47 \\
50 \\
50 \\
51\end{array}$ & $\begin{array}{l}22 \\
26 \\
21 \\
22 \\
221 / 2\end{array}$ & $\begin{array}{l}1,958 \\
2,475 \\
2,475 \\
2,750 \\
2,575\end{array}$ \\
\hline
\end{tabular}

These experiments were made when my land was not as clean as it is now. I presume the weeds got more benefit from the ammonia than the oats. To top-dress foul land with expensive artificial manures is money thrown away. If the land had been plowed in the autumn, and the seed and manures could have been put in early in the spring, I presume we should have had more favorable results.

"Are you not ashamed to acknowledge," said the Deacon, " that you have ever raised oats weighing only 22 lbs. per bushel."

No. I have raised even worse crops than this-and so has the Deacon. But I made up my mind that such farming did not pay, and $I$ have been trying hard since then to clean my land and get it into better condition. And until this is done, it is useless to talk much of artificial manures.

The most striking result is the effect of the gypsum. It not only gave an increased yield of 11 bushels per acre, but the oats were of decidedly better quality, and there was nearly half a ton more straw per acre than on the plot alongside, where no manure was used.

The superphosphate was a good article, similar to that used in Mr. Lawes' experiments. 


\section{H A P T E R X X X I.}

\section{MANURES FOR POTATOES.}

Some time ago, a farmer in Pennsylvania wrote me that he wanted " to raise a first-rate crop of potatoes." I answered him as follows through the American Agriculturist:

"There are many ways of doing this. But as you only enter on the farm this spring, you will work to disadvantage. To obtain the best results, it is necessary to prepare for the crop two or three years beforehand. All that you can do this year is to select the best land on the farm, put on 400 lbs. of Peruvian guano, cultivate thoroughly, and suffer not a weed to grow. A two or threeyear-old clover-sod, on warm, rich, sandy loam, gives a good chance for potatoes. Do not plow until you are ready to plant. Sow the guano broadcast after plowing, and harrow it in, or apply a tablespoonful in each hill, and mix it with the soil. Mark out the rows, both ways, three feet apart, and drop a fair-sized potato in each hill. Start the cultivator as soon as the rows can be distinguished, and repeat every week or ten days until there is danger of disturbing the roots. We usually hill up a little, making a broad, flat hill. A tablespoonful of plaster, dusted on the young plants soon after they come up, will usually do gond. We recommend guano, because in our experience it does not increase the rot. But it is only fair to add, that we have not found even barn-yard manure, if thoroughly rotted and well mixed with the soil the fall previous, half so injurious as some people would have us suppose. If any one will put 25 loads per acre on our potato land, we will agree to plant and run the risk of the rot. But we would use some guano as well. The truth is, that it is useless to expect a large crop of potatoes, say 350 bushels per acre, without plenty of manure."

This was written before the potato-beetle made its appearance. But I think I should say the same thing now-only put it a little stronger. The truth is, it will not pay to "fight the bugs" on a poor crop of potatoes. We must select the best land we have and make it as rich as possible.

"But why do you recommend Peruvian guano," asked the Doctor, "rather than superphosphate or ashes? Potatoes contain a large amount of potash, and one would expect considerable benefit from an application of ashes."

"Ashes, plaster, and hen-dung," said the Judge, "will at any rate 
pay well on potatoes. I have tried this mixture again and again, and always with good effect."

"I believe in the hen-dung," said I, " and possibly in the plaster, but on my land, ashes do not seem to be specially beneficial on potatoes, while I have rarely used Peruvian guano without good effect; and sometimes it has proved wonderfully profitable, owing to the high price of potatoes."

Sometime ago, I had a visit from one of the most enterprising and successful farmers in Western New York.

"What I want to learn," he said, " is how to make manure enough to keep my land in good condition. I sell nothing but beans, potatoes, wheat, and apples. I feed out all my corn, oats, stalks, straw, and hay on the farm, and draw into the barn-yard the potato-vines and everything else that will rot into manure. I make a big pile of it. But the point with me is to find out what is the best stock to feed this straw, stalks, hay, oats, and corn to, so as to make the best manure and return the largest profit. Last year I, bought a lot of steers to feed in winter, and lost money. This fall I bought 68 head of cows to winter, intending to scll them in the spring."

"What did they cost you ?"

"I went into Wyoming and Cattaraugus Counties, and picked them up among the dairy farmers, and selected a very fair lot of cows at an average of $\$ 22$ per head. I expect to seli them as new milch cows in the spring. Such cows last spring would have been worth $\$ 60$ to $\$ 70$ each."

"That wili pay. But it is not often the grain-grower gets such a chance to feed out his straw, stalks, anit other fodder to advantage. It cannot be adopted as a permawent system. It is bad for the dairyman, and no real help to the grain-grower. The manure is not rich enough. Straw and stalks alone can not be fed to advantage. And when you winter cows to sell again in the spring, it will not pay to feed grain. If you were going to keep the cows it would pay well. The fat and flesh you put on in the winter would be returned in the form of butter and cheese next summer."

"Why is not the manure good? I am careful to save everything, and expect seven or eight hundred loads of manure in the spring."

"You had 60 acres of wheat that yielded 25 bushels per acre, and have probably about 50 tons of wheat straw. You had also 30 acres oats, that yielded 50 bushels per acre, say 35 tons of straw. Your 20 acres of corn produced 40 bushels of shelled corn per acre; say the stalks weigh 30 tons. And you have 60 tons of 
hay, half clover and half timothy. Let us see what your manure from this amount of grain and fodder is worth.

Manures from

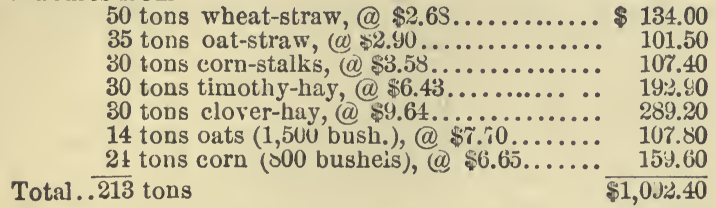

Total. . $\overline{213}$ tons

"This is the value of the manure on the land. Assuming that there are 600 loads, and that the labor of cleaning out the stables, piling, carting, and spreading the manure is worth 30 cents per load, or $\$ 180$, we have $\$ 912.40$ as the net value of the manure.

"Now, your 250-acre farm might be so managed that this amount of manure annually applied would snon greatly increase its fertility. But you do not think you can afford to summer-fallow, and you want to raise thirty or forty acres of pocatoes every year."

"I propose to do so," he replied. "Situated as I am, close to a good shipping station, no crop pays me better. My potatoes this year have averaged me over $\$ 100$ per acre."

"Very good. But it is perfectly clear to my mind that sooner or later, you must either farm slower or feed higher. And in your case, situated close to a village where you can get plenty of help, and with a good shipping station near by, you had better adopt the latter plan. You must feed higher, and make richer manure. You now feed out 213 tons of stuff, and make 600 loads of manure, worth $\$ 912.40$. By feeding out one third, or 71 tons more, you can more than double the value of the manure.

50 tons of bran or mill-feed would gire manure worth....... \$ $\$ 729.50$ 21 tons decorticated cotton-seed cake.................... $\quad 585.06$

$$
\$ 1,314.56
$$

"Buy and feed out this amount of bran and cake, and you would have 800 loads of manure, worth on the land $\$ 2,226.96$, or, estimating as before that it cost 30 cents a load to handle it, its net value would be $\$ 1,986.96 . "$

I am well aware that comparatively few farmers in this section can afford to adopt this plan of enriching their land. We want better stock. I do not know where I could buy a lot of steers that it would pay to fatten in the winter. Thозе farmers who raise good grade Shorthorn or Devon cattle are not the men to sell them half-fat at low rates. They can fatten them as well as I can. For some time to come, the farmer who proposes to feed liberally, 
will have to raise his own stock. He can rarely buy well-bred animals to fatten. A good farmer must be a good farmer throughout. He can not be good in spots. His land must be drained, wellworicd, and free from weeds. If he crops heavily he must manure heavily, and to do this he must feed liberally - and he can not afford to feed liberally unless he has good stock.

"I have, myself, no doubt but you are right on this point," said the Doctor, "but all this takes time. Suppose a farmer becomes satisfied that the manure he makes is not rich enough. To tell him, when he is anxious to raise a good crop of potatoes next rear, that he must go to work and improve his stock of cattle, sheep, and swine, and then buy bran and oil-cake to make richer manure, is somewhat tantalizing."

This is true, and in such a case, instead of adding nitrogen and phosphoric acid to his manure in the shape of bran, oil-cake, etc., he can buy nitrogen and phosphoric acid in guano or in nitrate of soda and superphosphate. This gives him richer manure; which is precisely what he wants for his potatoes. His poor manure is not so much deficient in potash as in nitrogen and phosphoric acid, and consequently it is nitrogen and phosphoric acid that he will probably need to make his soil capable of producing a large crop of potatoes.

I have seen Peruvian guano extensively used on potatoes, and almost always with good effect. My first experience with it in this country, was in 1852. Four acres of potatoes were planted on a two-year-old clover-sod, plowed in the spring. On two acres, Peruvian guano was sown broadcast at the rate of $300 \mathrm{lbs}$. per acre and harrowed in. The potatoes were planted May 10. On the other two acres no manure of any kind was used, though treated exactly alike in every other respect. The result was as follows:

No manure............................ 119 bushels per acre. 300 lbs. Peruvian guano...................... 205

The guano cost, here, about 3 cents a lb., and consequently nine dollars'worth of guano gave 84 bushels of potatoes. The potatocs were all sound and good, but where the guano was used, they were larger, with scarcely a small one amongst them.

In 1857, I made the following experiments on potatoes, in the same field on which the preceding experiment was made in 1852.

In this case, as before, the land was a two-year-old clover-sod. It was plowed about the first of May, and harrowed until it was in a good mellow condition. The potatoss were planted in hills $3 \frac{1}{2}$ 
feet apart each way. The following table shows the manures used and the yield of potatoes per acre.

Experiments on Potatoes at Moreton Farm.

\begin{tabular}{|c|c|c|c|}
\hline 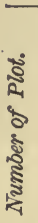 & $\begin{array}{l}\text { DESCRIPTION OF MANURES USED, AND QUANTITIES } \\
\text { APRLIED PER ACRE. }\end{array}$ & 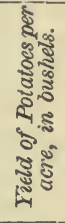 & 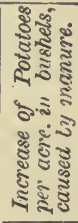 \\
\hline $\begin{array}{l}1 . \\
2 . \\
3 . \\
4 . \\
5 . \\
6 . \\
7 .\end{array}$ & 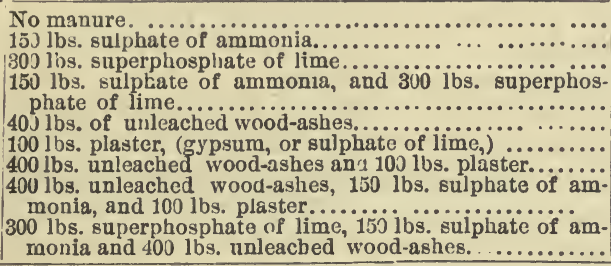 & $\begin{array}{r}95 \\
140 \\
132 \\
179 \\
100 \\
101 \\
110 \\
109\end{array}$ & $\begin{array}{r}45 \\
37 \\
84 \\
5 \\
6 \\
15 \\
14\end{array}$ \\
\hline
\end{tabular}

The superphosphate of lime was made expressly for experimental purposes, from calcined bones, ground fine, and mixed with sulphuric acid in the proper proportions to convert all the phosphate of lime of the bones into the soluble superphosphate. It was a purely minaral article, free from ammoni: and other organic matter. It cost about two and a half cents per pound.

The manures were deposited in the hill, covered with an inch or two of soil, and the seed then planted on the top. Where superphosphate of lime or sulphate of ammonia was used in conjunction with ashes, the ashes were first deposited in the hill and covered with a little soil, and then the superphosphate or sulphate of ammonia placed on the top and covered with soil before the seed was planted. Notwithstanding this precaution, the rain washed the sulphate of ammonia into the ashes, and decomposition, with loss of ammonia, was the result. This will account for the less yicld on plot 8 than on plot 2. It would have been better to have sown the asles broadcast, but some previous experiments with Peruvial guano on potatoes indicated that it was best to app!y guano in the hill, carefully covering it with soil to prevent it injuring the seed, than to sow it broadcast. It was for this reason, and for the greater convenience in sowing, that the manures were applied in the hill.

The ash of potatoes consists of about 50 per cent of potash, and this fact has induced many writers to recommend ashes as a manure for this crop." It will be seen, however, that in this instance, at 
least, they have very little effect, $400 \mathrm{lbs}$. giving an increase of only five bushels per acre. One hundred pounds of plaster per acre gave an increase of six bushels. Plaster and ashes combined, an increase per acre of 15 bushels.

One fact is clearly brought out by these experiments : that this soil, which has been under cultivation without manure for many years, is not, relatively to other constituents of crops, deficient in potash. Had such been the case, the sulphate of ammonia and superphosphate of lime-manures which contain no potash-would not have given an increase of 84 bushels of potatoes per acre. There was sufficient potash in the soil, in an available condition, for 179 bushels of potatoes per acre; and the reason why the soil without manure produced only 95 bushels per acre, was owing to a deficiency of ammonia and phosphates.

Since these experiments were made, Dr. Vœlcker and others have made similar ones in England. The results on the whole all point in one direction. They show that the manures most valuable for putatoes are those rich in nitrogen and phosphoric acid, and that occasionally potash is also a useful addition.

"There is one thing I should like to know," said the Doctor. "Admitting that nitrogen and phosphoric acid and potash are the most important elements of plant-food, how many bushels of potatoes should we be likely to get from a judicious application of these manures?"

"There is no way," said I, "of getting at this with any degree of certanty. The numerous experiments that have been made in England seem to show that a given quantity of manure will produce a larger increase on poor land than on land in better condition."

In England potatoes are rarely if ever planted without manure, and the land solected for this crop, even without manure, would usually be in better condition than the average potato land of this section, and consequently a given amount of manure, applied to potatoes here, would be likely to do more good, up to a certain point, than the same amount would in England.

Let us look at some of the experiments that have been made in England :-

In the Transactions of the Highland and Agricultural Society of Scotland for 1873 is a prize essay on "Experiments upon Potatoes, with Potash Salts, on Light Land," by Charles D. Hunter, F. C. S., made on the farm of William Lawson, in Cumberland. Mr. Hunter "was charged with the manuring of the farm and the purchasing of chemical manures to the annual value of $\$ 2,000$," or say $\$ 10,000$. 
"Potatoes," says Mr. Hunter, "were largely grown on the farm, and in the absence of a sufficiency of farm-yard manure, potash naturally suggested itself as a necessary constituent of a chemical potato-manure. The soil was light and gravelly, with an open subsoil, and the rainfall from 29 to 38 inches a year."

The first series of experiments was made in 1867. The following are some of the results :-

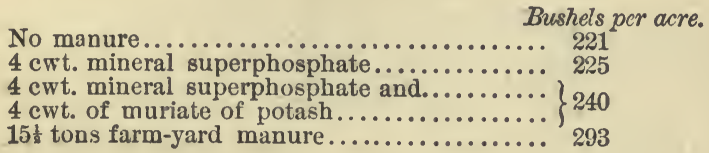

"That does not say much for potash ond superphosphate," said the Deacon. "The superphosphate only produced four bushels more than the no manure, and the potash and superphosphate only fifteen bushels more than the superphosphate alone."

It may be worth while mentioning that one of the experimental plots this year was on a head-land, "where the cattle frequently stand for shelter." This plot was dressed with only eight and a half tons of manure, and the crop was over 427 bushels per acre, while a plot alongside, without manure, produced only 163 bushels per acre.

"That shows the importance," said the Deacon, "of planting potatoes on rich land, rather than to plant on poor land aud try to make it rich by applying manure directly to the crop."

The following are some of the results in 1868:

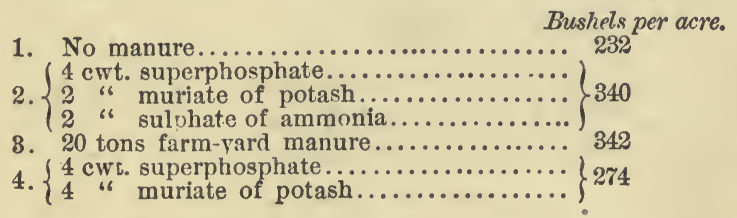

"Here again," said the Doctor, "superphosphate and potash alone give an increase of only forty-two bushels per acre, while on plot 2 , where two hundred weight of muriate of potash is substituted by two hundred weight of sulphate of ammonia, the increase is 108 bushels per acre. It certainly looks as though a manure for potatoes, so far as yield is concerned, should be rich in availalle nitrogen." 
The following are some of the results in 1869 :

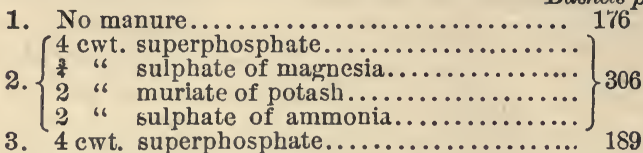
4. $\left.\left\{\begin{array}{l}4 \text { ewt. superphosphate } \ldots \ldots \ldots \ldots \ldots \ldots \ldots \ldots \ldots \ldots \ldots \ldots \ldots \ldots \\ 2\end{array}\right\}\right\}_{01}$

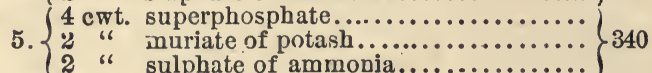

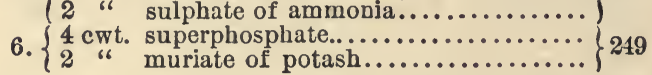

"This is a very interesting experiment," said the Doctor. "Superphosphate alone gives an increase of thirteen bushels. Superphosphate and potash an increase of seventy-three bushels. The potash, therefore, gives an increase of sixty bushels. Superphosphate and ammonia give twelve bushels more than superphosphate alone, and the reason it does not produce a better crop is owing to a deficiency of potash. When this is supplied the ammonia gives an increase (plots 5 and 6 ) of ninety-one bushels per acre."

In 1870 the above experiments were repeated on the same land, with the same general results.

In 1871 some experiments were made on a sharp, gravelly soil, which had been over-cropped, and was in poor condition. The following are the results :-

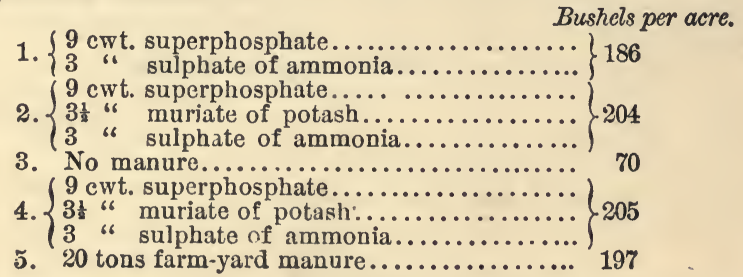

"On this poor soil," said the Doctor, "the ammonia and superphosphate gave an increase of 116 bushels per acre; and $3 \frac{1}{2}$ hundred weight of muriate of potash an increase, on one plot, of eighteen bishcls, and on the other nineteen bushels per acre."

In the same year, 1871, another set of experiments was made on a better and more loamy soil, which had been in grass for several years. In 1369 it was sown for hay, and in 1870 was broken up and sown to oats, and the next spring planted with potatoes. The following are some of the results: 
Bushels per acre.

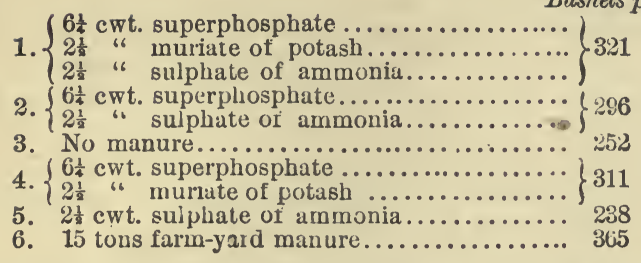

"It is curious," said the Doctor, "that the plot with sulphate of ammonia alone should produce less than the no-manure plot."

"The sulphate of ammonia," said I, "may have injured the seed, or it may have produced too luxuriant a growth of vine."

Another series of experiments was made on another portion of the sarne field in 1871. The "no-manure" plot prociuced 337 bushels per acre. Manures of various kinds were used, but the largest yield, 351 bushels per acre, was from superphosphate and sulphate of ammonia; fourteen tons barn-yard manure prod ce 340 busiels per acre; and Mr. Hunter remarks: "It is evident that, when the produce of the unmanured soil reaches nine tons [336 bushels] per acre, there is but little scope for manure of any kind."

"I do not see," said the Doctor, "that you have answered my question, but I suppose that, with potatoes at fifty cents a bushel, and wheat at $\$ 1.50$ per bushel, artificial manures can be more profitably used on potatoes than on wheat, and the same is probably true of oats, barley, corn, etc."

I have long been of the opinion that artificial manures can be applied to potatoes with more profit than to any other ordinary farm-crop, for the simple reason that, in this country, potatoes, on the average, command relatively high prices.

For instance, if average land, withont manure, will produce fifteen bushels of wheat per acre and 100 bushels of potatoes, and a given quantity of manure costing, say $\$ 25$, will double the crop, we have, in the one case, an increase of :-

15 bushels of wheat at $\$ 1.50 \ldots \ldots \ldots \ldots \ldots . . \$ 22.50$

$15 \mathrm{cwt}$. of straw......................

Cost of manure.................... 25.00

Profit from using manure............... $\$ 1.00$

And in the $o^{4}$ her:-

107 bushels of potatoes at 50 cents.......... $\$ 50.00$

Cost of manure......................... 25.00

Profit from using manure.............\$25.00 
The only question is, whether the same quantity of the right kind of manure is as likely to double the potato crop as to double the wheat crop, when both are raised on average land.

"It is not an easy matter," said the Deacon, " to double the yield of potatoes."

"Neither is it," said I, " to double the yield of wheat, but both can be done, provided you start low enuugh. If your land is clean, and well worked, and dry, and only produces ten bushels of wheat per acre, there is no difficulty in making it produce twenty bushels; and so of potatoes. If the land be dry and well cultivated, and, barring the bugs, produces without manure 75 bushels per acre, there ought to be no difficulty in making it produce 150 bushels.

"But if your land produces, without manure, 150 bushels, it is not always easy to make it produce 300 bushels. Fortunately, or unfortunately, our land is, in most cases, poor enough to start with, and we ought to be able to use manure on potatoes to great advantage."

"But will not the manure," asked the Deacon," injure the quality of the potatoes?"

I think not. So far as my experiments and experience go, the judicious use of good manure, on dry land, favors the perfect maturity of the tubers and the formation of starch. I never manured potatoes so highly as I did last year (1877), and never had potatoes of such high quality. They cook white, dry, and mealy. We made furrows two and a half feet apart, and spread rich, well-rotted manure in the furrows, and planted the potatoes on top of the manure, and covered them with a plow. In our climate, I am inclined to think, it would be better to apply the manure to the land for potatoes the autumn previous. If sod land, spread the manure on the surface, and let it lie exposed all winter. If stubble land, plow it in the fall, and then spread the manure in the fall or winter, and plow it under in the spring. 


\section{H A P T E R X X X I I.}

\section{WHAT CROPS SHOULD MANURE BE APPLIED :}

"It will not do any harm on any crop," said the Deacon, "but on my farm it seems to be most convenient to draw it out in the winter or spring, and plow it under for corn. I do not know any farmer except you who uses it on potatoes."

My own rule is to apply manure to those crops which require the most labor per acre. But I am well aware that this rule will have many exceptions. For instance, it will often pay well to use munure on barley, and yet barley requires far less labor than corn or potatoes.

People who let out, and those who work farms "on shares" seldom understand this matter clearly. I knew a farmer, who last year let out a field of good lind, that had been in corn the previous year, to a man to sow to barley, and afterwards to wheat on "the halves." Another part of the farm was taken by a man to plant corn and potatoes on similar terms, and another man put in several acres of cabbage, beets, carrots, and onions on halves. It never seemed to occur to either of them that the conditions were unequal. The expense of digging and harresting the potato-crop alone was greater than the whole cost of the barley-crop; while, after the barley was off, the land was plowed once, harrowed, and sowed to winter wheat; and nothing more has to be done to it until the next harvest. With the garden crops, the difference is even still more striking. The labor expended on one acre of onions or carrots would put in and harvest a ten-acre field of barley. If the tenant gets pay for his labor, the landlord would get say $\$ 5$ an acre for his barlcy land, and $\$ 50$ for his carrnt and onion land. I am pretty sure the tenants did not see the matter in this light, nor the farmer either.

Crops which require a large amount of labor can only be grown on very rich land. Our successful market-gardeners, seed-growers, and nurserymen understand this matter. They must get great crops or they cannot pay their labor bill. And the principle is applicable to ordinary farm crops. Some of them require much more labor than others, and should never be grown unless the land is 
capable of producing a maximum yield per acre, or a close approximation to it. As a rule, the least-paying crops are those which require the least labor per acre. Farmers are afrard to expend much money for labor. They are wise in this, unless all the conditions are favorable. But when they have land in a high state of cultivation-drained, clean, mellow, and rich-it would usually pay them well to grow crops which require the most labor.

And it should never be forgotten that, as compared with nearly all other countries, our labor is expensive. No matter how cheap our land may be, we can not afford to waste our labor. It is too costly. If men would work for nothing, and board themselves, there are localities where we could perhaps afford to keep sheep that shear two pounds of wool a year; or cows that make $75 \mathrm{lbs}$. of butter. We might make a profit out of a wheat crop of 8 bushels per acre, or a corn-crop of 15 bushels, or a potato-crop of 50 bushels. But it cannot be done with labor costing from $\$ 1.00$ to $\$ 1.25$ per day. And I do not believe labor will cost much less in our time. The only thing we can do is to employ it to the best advantage. Machinery will help us to some extent, but I can see no real escape from our difficulties in this matter, except to raise larger crops per acre.

In ordiuary farming, "larger crops per acre" means fewer acres planted or sown with grain. It means more summer fallow, more grass, clover, peas, mustard, coleseed, roots, and other crops that are consumed on the farm. It means more thorough cultivation. It means clean and rich land. It means husbanding the ammonia and nitric acid, which is brought to the soil, as well as that which is developed from the soil, or which the soil attracts from the atmosphere, and using it to grow a crop every second, third, or fourth year, instead of every year. If a piece of land will grow 25 bushels of corn every year, we should aim to so manage it, that it will grow 50 every other year, or 75 every third year, or, if the climate is capable of doing it, of raising 100 bushels per acre every fourth year.

Theoretically this can be done, and in one of Mr. Lawes' experiments he did it practically in the case of a summer-fallow for wheat, the one crop in two years giving a little more than two crops sown in succession. But on sandy land we should probably lose a portion of the liberated plant-food, unless we grew a crop of some kind every year. And the matter organized in the renovating crop could not be rendered completely available for the next crop. In the end, however, we ought to be able to get it with little or no loss. How best to accomplish this result, is one of the 
most interesting and important felds for scientific investigation and practical experiment. We know enough, however, to be sure that there is a great advantage in waiting until there is a sufficient accumulation of available plant-food in the soil to produce a large yield, before sowing a crop that requires much labor.

If we do not want to wait, we must apply manure. If we have no barn-yard or stable-manure, we must buy artificials.

\section{HOW AND WHEN MANURE SHOULD BE APPLIED.}

This is not a merely theoretical or chemical question. We must take into consideration the cost of application. Also, whether we apply it at a busy or a leisure season. I have seen it recommended, for instance, to spread manure on meaduw-land immediately after the hay-crop was removed. Now, I think this may be theoretically very good advice. But, on my farm, it would throw the work right into the midst of wheat and varley harvests; and I slould make the theory bend a little to my convenience. The meadows would have to wait until we had got in the crops-or until harvest operations were stopped by rain.

I mention this merely to show the complex character of this question. On my own farm, the most leisure season of the year, except the winter, is immediately after wheat harvest. And, as already stated, it is at this time that John Johnston draws out his manure and spreads it on grass-land intended to be plowed up the following spring for corn.

If the manure was free from weed-soeds, many of our best farm. ers, if they had some well-rotted manure like this of John Johnston's, would draw it out and spread it on their fields prepared for winter-wheat.

In this case, I should draw out the manure in heaps and then spread it carefully. Then harrow it, and if the harrow pulls the manure into heaps, spread them and harrow again. It is of the greatest importance to spread manure evenly and mix it thoroughly with the soil. If this work is well done, and the manure is well-rotted, it will not interfere with the drill. And the manure will be near the surface, where the young roots of the wheat can get hold of it.

"You must recollect," said the Doctor, "that the roots can only take up the manure when in solution."

"It must also be remembered," said I, "that a light rain of, say, only half an inch, pours down on to the manures spread on an acre of land about 14,000 gallons of water, or about 56 tons. If 
you have put on 8 tons of manure, half an inch of rain wonld furnish a g.ıllon of water to each pound of manure. It is not difficult to understand, therefore, how manure applied on the surface, or near the surface, can be taken up by the young roots."

"That puts the matter in a new light to me," said the Deacon. "If the manure was plowed under, five or six inches deep, it would require an abundant rain to reach the manure. And it is not one year in five that we get rain enough to thoroughly soak the soil for several weeks after sowing the wheat in August or September. And when it does come, the season is so far advanced that the wheat plants make little growth."

My own opinion is, that on clayey land, manure will act much quicker if applied on, or near the surface, than if plowed under. Clay mixed with manure arrests or checks decomposition. Sand has no sich effect. If anything, it favors a more active decomposition, and hence, manure acts much more rapidly on sandy land than on clay land. And I think, as a rule, where a farmer adrocates the application of manure on the surface, it will be found that he occupies clay land or a heavy loam; while those who oppose the practice, and think manure should be plowed under, ozcupy sandy land or sandy loam.

" J. J. Thomas," said I, "once gave me a new idea."

"Is that anything strange," remarked the Deacon. "Are ideas so scarce among you agricultural writers, that you can recollect who first suggested them ?"

"Be that as it may," said I, "this idea has had a decided influence on my farm practice. I will not say that the idea originated with Mr. Thomas, but at any rate, it was new to me. I had always been in the habit, when spading in manure in the garden, of putting the manure in the trench and covering it up; and in plowing it in, I thought it was desirable to put it at the bottom of the furrow where the next furrow would cover it up."

"Well," said the Deacon, "and what objection is there to the practice?"

"I am not objecting to the practice. I do not say that it is not a good plan. It may often be the only practicable method of applyin ; manure. But it is well to know that there is sometimes a better plan. The idea that Mr. Thomas gave me, was, that it was very desirable to break up the manure fine, spread it evenly, and thoroughly mix it with the soil.

"After the manure is spread on the soil," said Mr. Thomas, "and before plowing it in, great benefit is derived by thoroughly harrowing the top-soil, thus breaking finely both the manure and the soil, 
an 1 mixing them well together. Another way for the perfect diffusion of the manure among the particles of earth, is, to spread the manure in autumn, so that all the rains of this season may dissolve the soluble portions and carry them down among the particles, where they are absorbed and retained for the growing crop.

"In experiments," continues Mr. T'homas, "when the manure for corn was thus applied in autumn, has afiorded a yield of about r0 bushels per acre, when the same amount applied in spring, gave only 50 bushels. A thin coating of manure applied to winterwheat at the time of sowing, and was harrowed in, has increased the crop from 7 to 10 bushels per acre-and in addition to this, by the stronger growth it has caused, as well as by the protection it has afforded to the surface, it has not unfrequently saved the crop from partial or total winter-killing.

"In casez where it is necessary to apply coarse manures at once, much may be done in lessening the evils of coarseness by artificially grinding it into the soil. The instrument called the drag-1ollerwhich is like the common roller set stiff so as not to revolve-has been used to great advantage for this purpose, by passing it over the surface in connection with the harrow. We have known this treatment to effect a thorough intermixture, and to more than double the crop obtained by common management with common manure."

\section{TOP-DRESSING WITH MANURE.}

The term "top-dressing" usually refers to sowing or spreading manures on the growing crop. For instance, we top-dress pastures or meadows by spreading manure on the surface. If we sow nitrate of soda, or guano, on our winter-wheat in the spring, that would be top-dressing. We often sow gypsum on clover, and on barley, and peas, while the plants are growing in the spring, and this is top-dressing.

"If the gypsum was sown broadcast on the land before sowing the seed," said the Deacon," would not that be top-dressing also?"

Strictly speaking, I suppose that would not be top-dressing.

Top-dressing in the sense in which I understand the term, is sellom adopted, except on meadows and pastures as a regular system. It is an after-thought. We have sown wheat on a poor, sandy knoll, and we draw out some manure and spread on it in the winter or early spring; or we top-dress it with hen-manure, or guano, or nitrate of soda and superphosphate. I do not say that this is better than to apply the manure at the time of sowing the 
wheat, but if we neglect to do so, then top-dressing is a commendable practice.

Dr. Vœlcker reports the result of some experiments in top-dressing winter-wheat on the farm of the Royal Agricultural College at Cirencester, England. The manures were fircly sifted and mixed with about ten times their weight of fine soil, and sown broadcast on the growing wheat, March 22. A fine rain occurred the following day, and washed the manure into the soil. The following is the yield per acre:-

No manure. 27 bushels and 1984 lbs. of straw.

280 lbs. Peruvian guano............. 40

195 " nitrate of soda.............. 38

180 " nitrate of soda, and $168 \mathrm{lbs}$. of

common salt.................... 40 40 443 lbs. Proetor's wheat-manure....... $39 \frac{1}{2}$ 672 " " 4 tons chalk-marl..................27

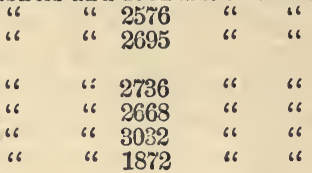

The manures in each case cost $\$ 7.80$ per acre, except the large dose of Proctor's wheat-manure, which cost $\$ 11.70$ per acre. The wheat was worth $\$ 1.26$ per bushel. Leaving the value of the straw out of the question, the profit from the use of the top-dressing was :

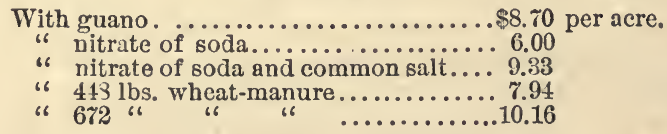

The marl did no good.

The nitrate of soda and common salt contained no phosphoric acid, and yet produced an excellent effect. The guano and the wheat-manure contained phosphoric acid as well as nitrogen, and the following crop of clover would be likely to get some benefit from it.

John Johnston wrote in 1863 , "I have used manure only as a top-dressing for the last 26 years, and I do think one load, used in that way, is worth far more than two loads plowed under on our sti. land." 


\section{H A P T E R X XIII.}

\section{MANURES ON PERMANENT MEADOWS AND PASTURES.}

In this country, where labor is comparatively high, and hay often commands a good price, a good, permanent meadow frequently affords as much real profit as any other portion of the farm. Now that we have good mowing-machines, tedders, rakes, and loading and unloading apparatus, the labor of hay-making is greatly lessened. The only difficulty is to keep up and increase the annual growth of good grass.

Numerous experiments on top-dressing meadows are reported frnm year to year. The results, of course, differ considerably, being influenced by the soil and season. The profit of the practice depends very much on the price of hay. In the Eastern States, hay generally co:nmands a higher relative price than grain, and it not unfrequently happens that we can use manure on grass to decided advantage.

The celebrated experiments of Messrs. Lawes \& Gilbert with "Manures on Permanent Meadow-land" were commenced in 1856, and have been continued on the same plots every year since that time.

"You need not be afraid, Deacon," said I, as the old gentleman commenced to button up his coat, "I am not going into the details of these wonderful experiments; but I am sure you will be interested in the results of the first six or seven years.

The following table explains itself: 


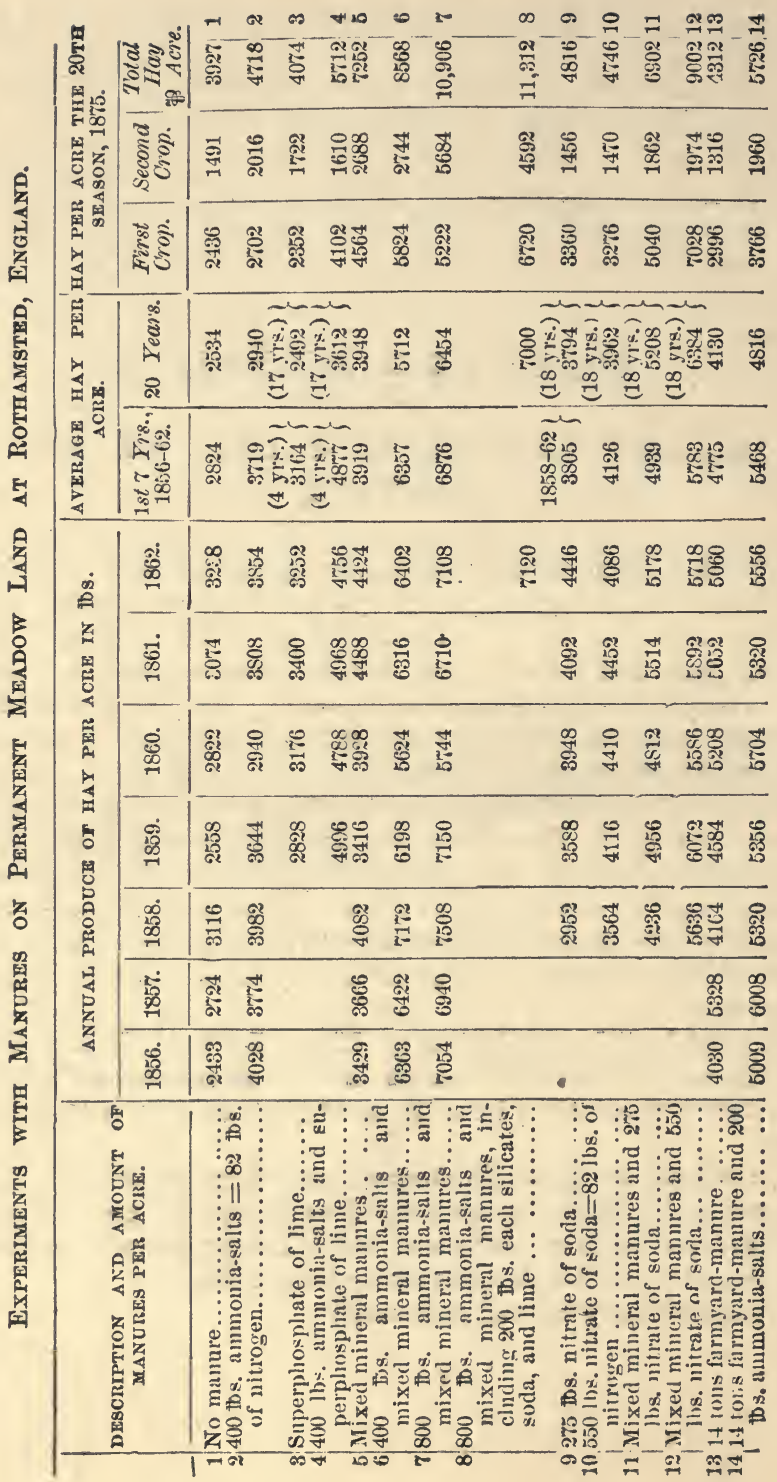


These are all the figures I will trouble you with. The "mixed mineral manures" consisted of superphosphate of lime (composed of $150 \mathrm{lbs}$. bone-ash and $150 \mathrm{lbs}$. sulphuric acid, sp. gr. 1.7), $500 \mathrm{lbs}$. sulphate of potash, $200 \mathrm{lbs}$. sulphate of soda, and $100 \mathrm{lbs}$. sulphate of magnesia. The ammonia-salts consisted of equal parts sulphate and muriate of ammonia, containing about 25 per cent. of ammonia. The manures were sown as early as possible in the spring, and, if the weather was suitable, sometimes in February. The farmyard-manure was spread on the land, in the first year, in the spring, afterwards in November or December. The hay was cut from the middle to the last of June; and the aftermath was pastured off by sheep in October.

" It is curious," said the Deacon, "that $400 \mathrm{lbs}$. of ammonia-salts should give as great an increase in the yield of hay the first year as 14 tons of farmyard-manure, but the second year the farmyardmanure comes out decidedly ahead."

"The farmyard-manure," said I, "was applied every year, at the rate of 14 gross tons per acre, for eight years-1853 to 1863. After 1863 , this plot waz left without manure of any kind. The average yield of this plot during the first 8 years was $4,800 \mathrm{lbs}$. of hay per acre.

On the plot dressed with 14 tons of farmyard-manure and 200 lbs. ammonia-salts, the average yield of hay for 8 years was 5,544 lbs. per acre. After the eighth year the farmyard-manure was discontinued, and during the next twelve years the yield of hay averaged $3,683 \mathrm{lbs}$, or $1,149 \mathrm{lbs}$. more than the continuously unmanured plot.

In 1859, superphosphate of lime was used alone on plot 3, and has been continued ever since. It seems clear that this land, which had been in pasture or meadow for a hundred years or more, was not deficient in phospluates.

"It does not seem," said the Deacon, " to have been deficient in anything. The twentieth crop, on the continuously unmanured plot was nearly $1 \frac{1}{4}$ ton per acre, the first cutting, and nearly $\frac{8}{4}$-ton the second cutting. And apparently the land was just as rich in 1875 , as it was in 1856 , and yet over 25 tons of hay had been cut and removed from the land, without any manure being returncd. And yet we are told that hay is a very exhausting crop."

"Superphosphate alone," said the Doctor, "did very little to increase the yield of hay, but superphosphate and ammonia produced the first year, 1859 , over a ton more hay per acre than the superphosphate alone, and when poiast is added to the manure, the yield is still further increased." 
"Answer me one question," said the Deacon, "and let us leave the subject. In the light of these and other experiments, what do you consider the cheapest and best manure to apply to a permanent meadow or pasture?"

"Rich, well-decomposed farmyard or stable manure," said I, "and if it is not rich, apply $200 \mathrm{lbs}$. of nitrate of soda per acre, in addition. This will make it rich. Poor manure, made from straw, corn-stalks, hay, etc., is poor in nitrogen, and comparatively rich in potash. The nitrate of soda will supply the deficiency of nitrogen. On the sea-shore fish-scrap is a cheaper source of nitrogen, and may be used instead of the nitrate of soda."

\section{$\rightarrow \infty$ \\ CHAPTER XXXIV. \\ MANURES FOR SPECIAL CROPS.}

\section{MANURES FOR HOPS.}

"For hops," suid the Doctor, "there is nothing better than rich, well-decomposed farmyard-manure-such manure as you are now making from your pigs that are bedded with stable-manure."

"That is so," said I, " and the better you feed your horses and pigs, the better will the manure be for hops. In England, Mr. Paine, of Surrey, made a series of experiments with different manures for hops, and, as the result of four years trial, reported that rape-calce, singly, or in combination, invariably proved the best manure for hops. In this country, cotton-seed, or cotton-seedcaks, would be a good substitute for the rape-cake. Whatever manure is used should be used liberally. Hops require a large amount of labor per acre, and it is, therefore, specially desirable to obtain a large yicld per acre. This can be accomplished only by the most lavish expenditure of manure. And all experience seems to show that it must be manure rich in nitrogen. In the hop districts of England, 25 tons of rich farmyard-manure are applied per acre ; and in addition to this, soot and rags, both rich iu nitrogen, have long been popular auxiliaries. The value of soot is due to the fact that it contains from 12 to 15 per cent of sulphate of am. monia, and the fact that it has been so long used with success as a manure for hops, secms to prove that sulp!rate of ammoni., which 
can now be readily ohtained, could be used to adrantage by our hop-growers-say at the rate, in addition to farm-yard manure, of 500 lbs. per acre, sown broadcast early in the spring.

\section{MANURES FOR TOBACCO.}

When tobacco is grown for wrappers, it is desirable to get a large, strong leaf. The richest land is selected for the crop, and large quantities of the richest and most stimulating manures are used.

Like cabbages, this crop requires a large amount of plant-food per acre; and, like them, it can only be grown by constant and ligh manuring. More manure must be used than the plants can take up out of the soil, and hence it is, that land which has been used for growing tobacco for some years, will be in high condition for ether crops without further manuring.

Farm-yard or stable-manure, must be the mainstay of the tobacco-planter. With this, he can use artificial fertilizers to advantage -such as fish-scrap, woollen-rags, Peruvian guano, dried blood, slaughter-house offal, sulphate of ammonia, nitrate of soda, etc.

For choice, high-flavored smoking-tobacco, the grower aims to get quality rather than quantity. This seems to depend more on the land and the climate than on the manures used. Superphosphate of lime would be likely to prove advantageous in favoring the early growth and maturity of the crop. And in raising tobacco-plants in the seed-bed, I should expect good results from the use of superphosphate, raked into the soil at the rate of three or four lbs. per square rod.

\section{MANURES FOR INDIAN CORN.}

We know less about the manurial requirements of Indian corn, than of almost any other crop we cultivate. We know that wheat, barley, oats, and grasses, require for their maximum growth a liberal supply of available nitrogen in the soil. And such facts and experiments as we have, seem to indicate that the same is also true of Indian corn. It is, at any rate, reasonable to suppose that, as Indian corn belongs to the same botanical order as wheat, barley, oats, rye, timothy, and other grasses, the general manurial requirements would be the same. Such, I presume, is the case; and yet there seem to be some facts that would incline us to place Indian corn with the leguminous plants, such as clover, peas, and beans, rather than with the cereals, wheat, barley, oats, etc.

"Why so," asked the Deacon, "Indian corn does not have much in common with beans, p:as, and clover?" 
As we have shown, clover can get more nitrogen out of the soil, than wheat, barley, and oats. And the same is true of beans and peas, though probably not to so great an extent.

Now, it would seem that Indian corn cגn got more nitrogen out of a soil, than wheat, barley, or oats-and to this extent, at least, we may consider Indian corn as a renovating crop. In other words, the Indian corn can get more nitrogen out of the soil, than wheat, barley, and oats-and when we feed out the corn and stalks on the farm, we have more food and more manure than if we raised and fed out a crop of oats, barley, or wheat. If this idea is correct, then Indian corn, when consumed on the farm, should not be classed with what the English farmers term "white crops," but rather with t'je "green crops." In other wor is, Indian corn is what cll writers used to call a "fallow crop"-or what we call a renovating crop.

If this is so, then the growth and consumption of Indian corn on the farm, as is the case with clover, should leave the farm richer for wheat, rather than poorer. I do not mean richer absolutely, but richer so far as the avaliable supply of plant-food is concorned.

"It may be that you are right," said the Doctor, "when corn is grown for fodder, but not when grown for the grain. It is the formation of the seed which exhausts the soil."

If I could bo sure that it was true of corn-fodder, I should have little doubt that it is true also of corn as ordinarily grown for crain and stalks. For, I think, it is clear that the grain is formed at the expease of the stulks, and not directly from the soil. The corn-fodder will take from the soil as much nitrogen and phosphoric acid as the crop of corn, and the more it will take, the more it approximates in character to clover and other renovating crops. If corn-fodider is a renovating crop, so is the ordinary corn-crop, also, provided it is consumed on the farm.

"But what makes you think," said the Deacon, "that corn can get more nitrogen from the soil, than wheat?"

"That is the real point, Deacon," said I, " and I will ask you this question. Suppose you had a field of wheat seeded down to clover, and the clover failed. After harvest, you plow up half of the field and sow it to wheat again, the other half of the field you plow in t'xe spring, and plant with Indian corn. Now, suppose you get 15 bushels of wheat to the acre, how mucb corn do you think you would be likely to get?"

"Well, that depends," said the Deacon, "but I should expect at least 30 bushels of shelled corn pər acre."

"Exactly, and I thin': most farmers would tell you the same; 
you get twice as much corn and stalks to the acre as you would of wheat and straw. In other words, while the wheat cannot find more nitrogen than is necessary to produce 15 bushels of wheat and straw, tie corn can find, and does find, take up, and organize, at least twice as much nitrogen as the wheat."

If these are facts, then the remarks we have made in regard to the value of clover as a fertilizing crop, are applicable in some degree to Indian corn. To grow clover and sell it, will in the end impoverish the soil ; to grow clover and fsed it out, will enrich the land. And the same will be true of Indian corn. It will gather up nitrogen that the wheat-crop can not appropriate; and when the corn and stalks are fed out, soms 90 per cent of the nitrogen will be left in the manure.

"You do not think, then," said the Doctor, "that nitrogen is such an important element in manure for corn, as it is in a manure for wheat."

I have not said that. If we want a large crop of corn, we shall usually need a liberal supply of availatle nitroren. But this is because a larger crop of corn means a much larger produce per acre, than a large crop of wheat. Forty bushols of wheat per acre is an unusually large crop with us; but 80 bushcls of shelled corn can be grown in a favorable season, and on rich, well-cultivated land. As the Deacon has said, 30 bushels of corn per acre can b3 grown as easily as 15 bushels of wheat; and it is quite probabls, in many cases, that a manure containing no nitrogen, might give us a crop of 35 or 40 bushels par acre. In other words, up to a certain point, manures containing mineral, or carbonaceous matter, might frequently, in orlinary agriculture, increase the yicld of Indian corn; while on similar land, such manures would have little effect on whest.

"That is so," said the Deacor, "we all know that plastcr frequently increases the growth of corn, waile it seldom does much good on wheat."

But, after you have got as large a crop as the land will produce, aided by plaster, ashes, and superphosphate, say 40 bushels of shelled corn per acre, then if you want to raise 70 bushels per acre, you must furnish tàe soil wit'i manuros containing sufficient available nitrogen.

Soms years ago, I made some careful experiments with artificial manures on Indian corn.

"Oh, yes," said the Deacon, "they were made on the south lot, 
in front of my house, and I recollect tinat the N. Y. State Ag. Suciety awarded you a prize of $\$ 75$ for them."

"And I recollect," s.iid I, "how you and some other neighbors langhed at me for spending so much time in measuring the land a.d applying the manures, and measuring the crop. But I wish I could bave afforded to continue them. A single experiment, however carefully made, can not be depended on. However, I will give the results for what they are worth, with some remarks made at the time:

"The soil on which the experiments were made, is a light, sandy loam. It has been under cultivation for upwards of twenty years, and so far as I can ascertain has never been manured. It has been somewhat impoverished by the growth of cereal crops, and it was thought that for this reason, and on account of its light texture and active character, which would cause the manures to act immediately, it was well adapted for the purpose of showing the effect of different manurial substances on the corn-crop.

"The land was clover-sod, two years old, pastured the previous summor. It was plowed early in the spring, and harrowed until in excellent condition. The corn was planted May 23 , in hills $3 \frac{1}{2}$ feet apart each way.

"The manures were applied in the hill immediately before the seed was planted.

"With superphosphate of lime, and. with plaster (gypsum, or sulphate of lime), the seed was placed directly on top of the manure, as it is well known that these manures do not injure the germinating principle of even the smallest sec.s.

"The ashes were dropped in the hill, and then covered with soil, and the seed planteci on the top, so that it should not come in contact wit' the ashes.

"Guano and sulphate of ammonia were treated in the same way.

"On the plots where ashes and guano, or ashes and sulphate of ammonia were both used, the ashes were first put in the hill, a"d covered with soil, and the guano or sulphate of ammonia placed on the top, and also covered with soil before the seed was planted. The ashes and superphosphate of lime was also treated in the same way. It is well known that unleached ashes, mixed either with guano, sulphate of ammonia, or superphosphate, mutually decompose each other, setting free the ammonia of the guano and sulphate of ammonia, and converting the soluble phosphate of the superphosphate of lime into the insoluble form in which it existed before treatment with sulphuric acid. All the plots were planted on the same day, and the manures weighed and applied under my 
own immediate supervision. Everytiing was done that was deemed necessary to secure accuracy.

"The following table gives the results of the experiments:

TABLF SHOWING THE RES:LTS OF EXPERIMENTS ON INDIAN CORN.

1. No manure ......................

2. 100 lbs. plaster (g. psum or sulphate of

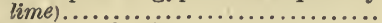

3. $400 \mathrm{lbs}$ unleached wood-ashes and 100 lbs. plaster (mixed)............

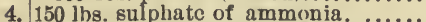

5. $300 \mathrm{lbs}$. superphosphate of lime......

6. $150 \mathrm{lbs}$. sulphate of ammonia and 300 lb $*$ superphosphatc of lime (mixed)

7. $400 \mathrm{lbs}$. unleached wood ashes, (uncertain) $\ldots \ldots \ldots \ldots \ldots \ldots \ldots \ldots$

8. $150 \mathrm{lbs}$. sulphate of ammonia and 400 lbs. unleached wood-ashes (sown

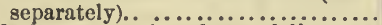

9. $300 \mathrm{lbs}$. superpho-phate of lime, 150 lbs. sulph. ammonia, and $400 \mathrm{lbs}$. unleached wood-ashes..............

10. $400 \mathrm{lhs}$, unleached wood-ashes........

11. $100 \mathrm{lbs}$. plaster. $4: 30 \mathrm{lbs}$. unleached wood-ashes, $300 \mathrm{lbs}$ superphos. phate of line, and $200 \mathrm{lbs}$. Peruvian gruano...........................

12. $75 \mathrm{lbs}$ sulphate of ammonia............

13. 200 lbs. Peruvian g ano..............

14. $400 \mathrm{lbs}$. unlcached wood-ashes, i0? lbs. plaster, and 500 lbs. Peruvian guano.........................

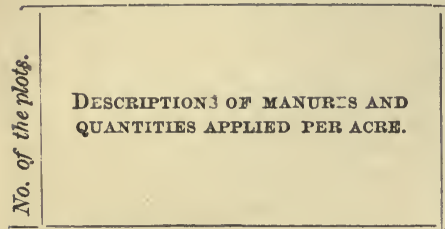

\begin{tabular}{|c|c|c|c|c|c|}
\hline 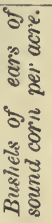 & 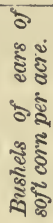 & 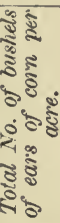 & 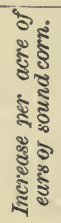 & 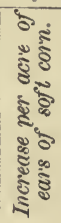 & 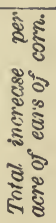 \\
\hline 60 & 7 & 67 & $\ldots \ldots$ & .. & .... \\
\hline 70 & 8 & 78 & 10 & 1 & 11 \\
\hline $\begin{array}{l}68 \\
90 \\
70\end{array}$ & $\begin{array}{r}10 \\
15 \\
8\end{array}$ & $\begin{array}{r}78 \\
105 \\
78\end{array}$ & $\begin{array}{r}8 \\
30 \\
10\end{array}$ & $\begin{array}{l}3 \\
8 \\
1\end{array}$ & $\begin{array}{l}11 \\
38 \\
11\end{array}$ \\
\hline 85 & 5 & 90 & 25 & $\cdots$ & 23 \\
\hline 60 & 12 & 72 & ....... & 5 & 5 \\
\hline 87 & 10 & 97 & 27 & 3 & $\varepsilon 0$ \\
\hline $\begin{array}{r}100 \\
60\end{array}$ & $\begin{array}{l}8 \\
8\end{array}$ & $\begin{array}{r}108 \\
68\end{array}$ & $\begin{array}{c}40 \\
\ldots . . .\end{array}$ & $\begin{array}{l}1 \\
1\end{array}$ & $\begin{array}{r}41 \\
1\end{array}$ \\
\hline $\begin{array}{l}93 \\
78 \\
88\end{array}$ & $\begin{array}{l}10 \\
10 \\
13\end{array}$ & $\begin{array}{r}105 \\
88 \\
101\end{array}$ & $\begin{array}{l}3.5 \\
18 \\
28\end{array}$ & $\begin{array}{l}3 \\
3 \\
6\end{array}$ & $\begin{array}{l}33 \\
21 \\
34\end{array}$ \\
\hline 111 & 14 & 125 & 51 & 7 & 58 \\
\hline
\end{tabular}

"The superphosphate of lime was made on purpose for these experiments, and was a pure mineral manure of superior quality, mad 3 from calcined bones; it cost abont $2 \frac{1}{2}$ cents per pound. Tle sulphate of ammonia was a good, commcrcial article, obtained from London, at a cost of ahout seven cents per pound. The ashes ware made from beech and hard maple (Acer sxccharinum) wood, and were sifted through a fine sieve before being weighed. The guano was the best Peruvian, costing about thrce cents per pound. It was crushed and sifted before using. In sowing the ashes on plot 7 , an error occurre 7 in their application, and for the purpose of checking the result, it was deemed advisable to repeat the experiment on plot 10 .

"On plot 5, with 300 lbs. of superphosphate of lime per acre, the plants came up first, and exhibted a healthy, dark-grcen appear- 
ance, which they rctained for some time. This result was not anticipated, though it is well known that superphosphate of lime has the effect of stimulating the germination of turnip-seed, and the early grow th of the plants to an astonishing degree; yet, as it has no such effect on wheat, it appeared probable that it would not produce this effect on Indian corn, which, in chemical composition, is very similar to wheat. The result shows how uncertain are all speculations in regard to the manurial requirements of plants. This immediate effect of superphosphate of lime on ccrn was so marked, that the men (who were, at the time of planting, somewhat inclined to he skeptical, in regard to the value of such small doses of manure), declared that 'superphosphate beats all creation for corn.' The difference in favor of superphosphate, at the time of hoeing, was very perceptible, even at some distance.

"Although every precaution was taken that was deemed necessary, to prevent the manures from mixing in the hill, or from injuring the seed, yet, it was found, that those plots dressed with ashes and guano, or with ashes and sulphate of ammonia, were injured to some extent. Shortly after the corn was planted, heavy rain set in, and washed the sulphate of ammonia and guano, down into the ashes, and mutual decomposition took place, with more or less loss of ammonia. In addition to this loss of ammonia, thes 3 manures came up to the surface of the ground in the form of an excrescence, so hard that the plants co:ll 1 with difficulty penctrate through it.

"It will be seen, by examining the table, that although tie superp'asphate of lime had a good effect during the early stages of the growth of the plants, yet the increase of ears of corn in the end did not come up to these early iadications. On plot 5, with $300 \mathrm{lbs}$. of superphosphate of lime per acre, the yield is precisely the same as on plot 2, with $100 \mathrm{lbs}$. of plaster (sulphate of lime), per acrc. Now, superphosphate of lime is composed necessarily of soluble phosphate of lime and plaster, or sulphate of lime, formcd from a combination of the sulphuric acid, employed in the manufacture of superphosphate, with the lime of the bones. In the 300 lts. of superphosphate of lime, sown on plot 5 , there would be about 100 lbs. of plaster; and as the effect of this dressing is no greater than was obtained from the $100 \mathrm{lbs}$. of plaster, sown on plot 2 , it follows, that the good effect of the superphosphate of lime was due to the plaster that it contained.

"A grain, on plot 4, with 150 lbs. of sulphate of ammonia per acre, we have 90 bushels of ears of sound corn, and 15 bushels of ears of soft corn, ('nubbins,') per acre ; or a total incrcass over the 
plot without manure, of 38 bushels. Now, the sulphate of ammo. nia contains no phosphate of lime, and the fact that such a manure gives a considerable increase of crop, confirms the conclusion wo have arrived at, from a comparison of the results on plots 2 and 5 ; that the increase from the superphosphate of lime, is not due to the phosphate of lime which it contains, unless we are to conclude tiat the sulphate of ammonia rendered the phosphate of lime in the soil more readily soluble, and thus furaished an increased quantity in an available form for assimilation by the plantsa conclusion, which the results with superphosphate alone, on plot 5, and with superphosphate and sulphate of ammonia, corrbined, on plot 6 , do not sustain.

"On plot 12 , half the quantity of sulp'sate of ammonia, was used as on plot 4 , and the incraas 3 is a little more than half what it is where double the quantity was used. Arain, on plot 13, $200 \mathrm{lbs}$. of Peruvian guano per acre, gives nearly as great an increase of sound corn, as the $150 \mathrm{lbs}$. of sulphate of ammovia. Now, $200 \mathrm{lbs}$. of Peruvian guano contains nearly as much ammonia as $150 \mathrm{lbs}$. sulphate of ammonia, and the increase in both cases is evidently due to the ammonia of these manures. Tse 200 los. of Peruvian guano, contained about 50 lbs. of phosphato of lime; but as the sulphate of ammonia, which contains no phospiate of lime, gives as great an increase as the guano, it follows, that the phosphate of lime in the guano, bad little, if any effect; a result precisely similar to that obtained with superphosphate of lime.

"We may conclude, therefore, that on this soil, which has never been manured, and which has been cultivated for many years with the Ceralia - or, in other words, with crops which remove a large quantity of phcsphate of lime from the soil-the phosphate of lime, relatively to the ammonia, is not deficient. If such was nct the case, an application of soluble phosphate of lime would have given an increase of crop, which we have shown was not the case in any one of these experiments.

"Plot 10, with 400 lbs. of unleached wood-ashes per acre, produces the same quantity of sound corn, with an extra bushel of 'nubbins' per acre, as plot 1, without any manure at all; ashes, therefore, applied alone, may be said to have had no effect whatever. On plot $3,400 \mathrm{lbs}$. of ashes, and $100 \mathrm{lbs}$. of plaster, give the same total number of bushels per acre, as plot 2, with $103 \mathrm{lbs}$. of plaster alone. Plot 8, with $400 \mathrm{lbs}$. ashes, and $150 \mathrm{lbs}$. of sulphate of ammonia, yields three bushels of sound corn, and five bushcls of 'nubbins' per acre, less than plot 4, with 150 lbs. sulphat? of 
ammonia alone. This result may be ascribed to the fact previously alluded to - the ashes dissipated some of the ammonia.

"Plot 11, with 100 lbs. of plaster, 400 lbs. ashes, 300 lbs. of superphosphate of lime, and $20 \mathrm{C}$ lbs. Peruvian guano (which contains about as much ammonia as $150 \mathrm{lbs}$. sulphate of ammonia), produced precisely the same number of total bushels per acre, as plot 4, with $150 \mathrm{lbs}$. sulphate of ammonia alone, and but 4 bushels more per acre, than plot 13, with $200 \mathrm{lbs}$. Peruvian guano alone. It is evident, from these results, that neither ashes nor phosphates had much effect on Indian corn, on this impoverished soil. Plot 14 received the largest dressing of ammonia (503 lbs. Peruvian guano), and produced much the largest crop; though the increase is not so great in proportion to the guano, as where smaller quantities were used.

"The manure which produced the most profitable result, was the $100 \mathrm{lbs}$. of plaster, on plot 2. The $200 \mathrm{lbs}$. of Peruvian guano, on plot 13 , and which cost about $\$ 6$, gave an increase of 14 bushels of shelled corn, and 6 bushels of 'nubbins.' This will pay at the present price of corn in Rochester, although the prufit is not very great. The superphosphate of lime, although a very superior article, and estimated at cost price, in no case paid for itself. The same is true of the ashes.

"But the object of the experiment was not so much to ascertain what manures will pay, but to ascertain, if possible, what constituents of manures are required, in greatest quantity, for the maximum growth of corn. * * Hitherto, no experiments have been made in this country, on Indian corn, that afforded any certain information on this point. Indeed, we believe no satisfactory experiments have been made on Indian corn, in any country, that throw any definite light on this interesting and important question. A few years ago, Mr. Lawes made similar experiments to those given above, on his farm, at Rothamsted, England; but owing to the coolness of the Englis' climate, the crop did not arrive at maturity.

"Numerous experiments have been made in this country, with guano and superphosphate of lime; but the superphosphates used were commercial articles, containing more or less ammonia, and if they are of any benefit to those crops to which they are applied, it is a matter of uncertainty whether the beneficial effect of the application is due to the soluble phosphate of lime, or to the ammonia. On the other hand, guano contains both ammonia and phosphate; and we are equally at a loss to determine, whether the effect is attributable to the ammonia or phosphate, or both. In order, therefore, to determine satisfactorily, which of the several ingredients 
of plants is required in greatest proportion, for the maximum growth of any particular crop, we must apply thes ingredients separately, or in such definite compounds, as will enable us to determine to what particular element or compounds the beneficial effect is to be ascribed. It was for this reason, that sulphate of ammonia, and a purely mineral superphnsphate of lime, were used in the above experiments. No one would think of using sulphate of ammonia at its price, [sulphate of ammonia is now cheaper, while Peruvian guano is more costly and less rich in ammonia], as an ordinary manure, for the reason, that the same quantity of ammonia can be obtained in other substances, such as barnyard-manure, Perurian guano, etc., at a much cheaper rate. But these manures contain all the elements of plants, and we can not know whether the effect produced by them is due to the ammonia, phosphates, or any other ingredients. For the purpose of experiment, therefore, we must use a manure that furnishes ammonia without any admixture of phosphates, potash, soda, lime, magnesia, etc., even though it cost much more than we could obtain the same amount of ammonia in other manures. I make these remarks in order to correct a very common opinion, that if experiments do not pay, they are useless. Tise ultimate object, indeed, is to ascertain the most profitable method of manuring; but the means of obtaining this information, can not in all cases be profitable.

"Similar experiments to those made on Indian corn, were made on soil of a similar character, on about an acre of Chinese sugarcane. I do not propose to give the results in detail, at this time, and allude to them merely to mention one very important fact, the superphosphate of lime had a very marled effect. This manure was applied in the hill on one plot (the twentieth of an acre,) at the rate of $400 \mathrm{lbs}$. per acre, and the plants on this plot came up first, and outgrew all the others from the start, and ultimately attained the height of about ten feet; while on the plot receiving no manure, the plants were not five feet high. This is a result entirely different from what I should have expected. It has been supposad, from the fact that superphosphate of lime had no effect on wheat, that it would probably have little effect on corn, or on the sugarcane, or other ceralia; and that, as ammonia is so beneficial for wheat, it would probably be beneficial for corn and sugar-cane. The above experiments indicate that such is the case, in regard to Indian corn, so far as the production of grain is concerned, though, as we have stated, it is not true in reference to the early growth of the plants. The superphosphate of limeon Indian corn, stimulated the growth of the plants, in a very decided manner at first, so 
much so, that we were led to su ppose, for some time, that it would give the largest crop; but at harvest, it was found that it produccd no more corn than plaster. These results seem to indicate, that superphosphate of lime stimulates the growth of stalks and icaves, and has little effect in increasing the production of seed. In raising Indian corn, for fodder or for soiling purposes, superphosphate of lime may be beneficial, as well as in growing the sorgium for sugarmaking purposes, or for foddder-though, perhaps, not for seed."

"In addition to the experiments given above, I also made the same season, on an adjoining field, another sat of experiments oir Indian corn, the results of which are given beiow.

"The land on which these experiments were made, is of a somewhat firmer texture than that on which the other set of experiments was made. It is situated about a mile from the barn-yard, and on this account, has seldom, if ever been manured. It has been cultivated for many years with ordinary farm crops. It was plowed early in the spring, and it was harrowed until quite mellow. The corn was planted May 33, 185\%. Each experiment occupied one-tenth of an acre, consisting of 4 rows $3 \frac{1}{2}$ feet apart, and the same distance between the hills in the rows, with one row without manure between each experimental plot.

"The manure was appliec in the hill, in the same manner as in the first set of experiments.

"The barnyard-manure was well-rotted, and consisted principally of cow-dung with a little horse-dung. Twenty two-horse wagon loals of this was applied per acre, and each load would probably veigh about one ton. It was put in the hill and covered with soil, and the seed then planted on the top.

"The following table gives the results of the experiments:

TABLE BHOWING THE RE ROCHESTER, N. Y, IN THE YeAR $135 \%$.

\begin{tabular}{|c|c|c|c|c|c|c|c|}
\hline & $\begin{array}{l}\text { DESCRIPTIONS OF MANURES, AND } \\
\text { QUANTITIES AFPLIED PE. } 3 \text { ACRE. }\end{array}$ & 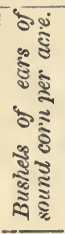 & 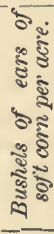 & $\frac{8}{2}$ & 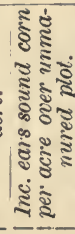 & 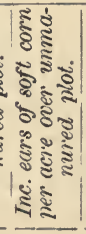 & 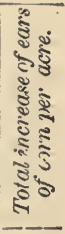 \\
\hline & 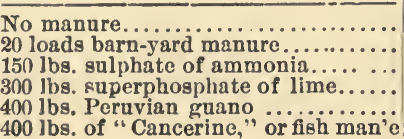 & $\begin{array}{l}75 \\
82 \frac{1}{2} \\
85 \\
88 \\
90 \\
85\end{array}$ & $\begin{array}{l}12 \\
10 \\
30 \\
10 \\
30 \\
20\end{array}$ & $\begin{array}{c}87 \\
927 \\
115 \\
93 \\
120 \\
105\end{array}$ & $\begin{array}{l}10 \\
11 \\
15 \\
10\end{array}$ & $\begin{array}{c}18 \\
38 \\
8\end{array}$ & $\begin{array}{l}23 \\
11\end{array}$ \\
\hline
\end{tabular}


* As before stated, the land was of a stronger nature than that on which the first set of experiments was made, and it was evi. dently in better condition, as the plot heving no manure proauced 20 bushels of ears of corn per acre more than the plot without manure in the other field.

"On plot 4, $300 \mathrm{lbs}$. of superphosphate of "ime gives a total increase of 11 buslicls of ears of corn per acre over the unmanured plot, agreeing exactly with the increase obtained from the same quantity of the same manure on plot 5, in the first set of experiments.

"Plot 3, dressed with 150 lbs. of sulphate of ammonia per acre, gives a total increase of 28 bushels of ears of corn per acre, over the unmanured plot; and an increase of $22 \frac{1}{2}$ bushels of ears per acre over plot 2 , which received 20 loads of good, well-rotted barnyard-dung per acre.

"Plot 5, with $400 \mathrm{lbs}$. of Peruvian guano per acre gives the best crop of this series viz : an increase of 33 bushels of corn per acre over the unmanured nlot, and $27 \frac{1}{2}$ over the plot manured with 20 loads of barnyard-dung. The $400 \mathrm{lbs}$. of 'Cancerine'-an artificial manure made in New Jersey from fish-gives a total increase of 18 bushels of ears per acre over the unmanured plot, and $12 \frac{1}{2}$ bushels more than that manured with barn-yard dung, though 5 bushels of ears of sound corn and 10 bushels of 'nubbins' per acre less tlian the same quantity of Peruvian guano."

\section{MANURES FOR TURNIPS.}

To raise a larg 3 crop of turaips, espacially of ruta-bagas, there is nothing better than a liberal application of rich, well-rotted farmyard-manure, and 250 to $300 \mathrm{lbs}$. of good superphosphate of lime per acre, drilled in with the seed.

I have seea capital crops of common turnips grown with no other manure except $300 \mathrm{lbs}$. of superphosphate per acre, drilled with th s sead. Superphosphate has a wonderful effect on the dovelopment of the roots of the turnip. And this is the secret of its great value for this crop. It increases the growth of the young plant, developing the formation of the roots, and when the turnip once gets full possession of the soil, it appropriates all the plantfood it can find. A turnip-crop grown with supcrpossphate, can get from the soil much more nitrogen than a crop of wheat. The turnip-crop, when supplied with superphosphate, is a good "scavenger." It will gather up an' orranize into good food the refuse plant-fcod left in the soil. It is to the surface soil, what clover is to the subsoil. 
To the markct gardener, or to a farmer who manures heavily. common turnips drille.l ia with superphospisate will prove a valuable crop. On such land no other manure will be needed. I cannot too earnestly recommend the use of superphospinate as a manure for turnips.

For Swede turnips or ruta-bagas, it will usually be necessary, in order to secure a maximum crop, to use a manure which, in addition to superphosphate, contuins available nitrogen. A gooà dressing of rich, well-rotted manure, spread on the land, and plowed under, and then $300 \mathrm{lbs}$. of superphosphate drilled in witi the seed, would be likely to give a good crop.

In the absence of manure, there is probably nothing better for the ruta-bagas than 300 lbs. of s()-called "rectified" Peruvian guano, that is, guano treated with sulphuric acid, to render the phosphates soluble. Such a guano is guiranteel to contain 10 per cent of ammonia, and 10 per cent of soluble phosphoric acid, and would be a good dressing for Swede turnips.

The best way to use gumno for turnips is to sow it broadcast on the land, and harrow it i:, and then either drill in the turnip-ssed on the flat, or on ridges. The latter is decidedly the better plan, provided you have the necessary implements to do the work expeditiously. A double mould-board plow will ridge up four acres a day, and the guano being previously sown on the surface, will be turned up with the mallow surface-soil into the ridge, where the seed is to be sown. The young plants get hold of it and grow so rapidly as to be soon out of danger from the turnip-beetle.

\section{MANURES FOR MANGEL-WURZEL OR SUGAR-BEETS.}

When sugar-beets are grown for feeding to stock, there is probably little or no difference in the manurial requirements of sugarbeets and mangel-wurzel. Our object is to get as large a growth as possible consistent with quality.

"Large roots," said the Deacon, "have been proved to contain less nutriment than small roots."

True, but it does not follow from this that rich land, or heavy manuring is the chief cause of this difference. It is much more likely to be due to the variety selected. The seed-growers have been breeding so'ely for size and shape. They have succeeded to such an extent that 84 gross tons of roots have been grown on an acre. This is equal to over 94 of our tons per acre. "That is an enormous crop," said the Deacon; "and it would require some labor to put 10 acres of them in a cellar."

"If they were as nutritious as ordinary mangels," said I, " that 
would be no argument against them. But such is not the case. In a letter just received from Mr. Lawes, (May, 1878,) he characterizes them as "bladders of water and salts."

Had the seed growers bred for qu $\iota l . t y$, the roots would have been of less size, but they would contain more nutriment.

What we want is a variety that has been bred with reference to quality; and when this is secured, we need not fear to make the land rich and otherwise aim to secure great growth and large-sized roots.

It certainly is not good economy to select a variety which has been bred for years to produce large-sized roots, and then sow this seed on poor land for the purpose of obtaining small-sized roots. Better take a variety bred for quality, and then make the land rich enough to produce a good crop.

We are not likely to err in making the land too rich for mangelwurzel or for sugar-beets grown for stock. When sugar-beets are grown for sugar, we must aim to use manures favorable for the production of sugar, or rather to avoid using those which are unfavorable. But where sugar-beets are grown for food, our aim is to get a large amount of nutriment to the acre. And it is by no means clear to my mind that there is much to be gained by selecting the sngar-beet instead of a good variety of mangel-wurzel. It is not a difficult matter, by selecting the largest roots for seed, and by liberal manuring, and continuously selecting the largest roots, to convert the sugar-beet into a mangel-wurzel.

When sugar-beets are grown for food, we may safely manure them as we would mangel-wurzel, and treat the two crops precisely alike.

I usually raise from ten to fiftcen acres of mangel-wurzel every year. I grow them in rotation with other crops, and not as the Hon. Harris Lewis and some others do, continuously on the same land. We manure liberally, but not extravagantly, and get a fair yield, and the land is left in admirable condition for future crops.

I mean by this, not that the land is specially rich, but that it is very clean and mellow.

"In 187\%," said the Deacon, "you had potatoes on the land where you grew mangels the previous year, and had the best crop in the neighborhood."

This is true, but still I do not think it a good rotation. A harley crop sceded with clover would be better, especially if the mangels were heavily manured. The clover would get the manure which had been washed into the subsoil, or left in such a condition that potatoes "s grain could not take it up. 
There is one thing in relation to my mangels of $18: 6$ which has escaped the Deacon. The whole piece was manured and well prepare 1 , and cibbled in with mangels, the rows being $2 \frac{1}{2}$ feet apart, and the seed dropped 15 inches apart in the rows. Owing to poor secd, the mangels failed on about three acres, and we plowed up the land and drilled in corn for fodder, in rows $2 \frac{1}{2}$ fect apart, and at the rate of over three bushels of seed per acre. We had a great crop of corn-fodder.

The next year, as I said before, the whole piece was planted with potatocs, and if it was true that mangels are an "enriching crop," while corn is an "exhausting" crop, we ought to have had much better potatoes after the mangels than after corn. This was certainly not the case; if there was any difference, it was in favor of the corn. But I do not place any confidence in an experiment of this kind, where the crops were not weighed and the results carefully ascertained.

Mr. Lawes has made some most thorough experiments with different manures on sugar-beets, and in 1876 he commenced a series of experiments with mangel-wurzel.

The land is a rather stiff clay loam, similar to that on which the wheat and barlcy experiments wers made. It is better suited to the growth of beets than of turnips.

"Why so," asked the Deacon, "I thought that black, bottom land was best for mangels."

"Not so, Deacon," said I, "we can, it is true, grow large crops of mangels on well-drained and well-manured swampy or bottom land, but the best soil for mangels, especially in regard to quality, is a gond, stiff, well-worked, and well-manurcd loam."

"And yet," said the Deacon, "you had a better crop last year on the lower and blacker portions of the field than on the heavy, clayey land."

In one sense, this is true. We had dry weather in the spring, and the mangel seed on the dry, clayey land did not come up as well as on the cooler and moister bottom-land. We had more plants to the acre, but the roots on the clayey land, when they once got fair hold of the soil and the manure, mrew larger and bettrr than on the lighter and moister land. The great point is to get this heary land into a fine, mellow condition.

But to Mr. Lawes' experiments. They are remarkably interesting and instructive. But it is not necessary to go into all the details. Suffice it to say that the experiments seem to prove, very conclusively, that beets require a liberal supply of available nitro- 
gen. Tinus, without manure, the yield of beets was about $7_{\frac{1}{2}}$ tons of bulbs per acre.

With $5 \tilde{5} 0 \mathrm{lbs}$. nitrate of soda per acre, the yield was a little over 2.2 tons per acre. With 14 tons of farmyard-manure, 18 tons per aeru. With 14 tons of farmyard manure and $550 \mathrm{lbs}$. nitrate of s. da, over $27 \frac{1}{2}$ tons per acre.

Superphosphate of lime, sulphates of potash, soda, and magnssia, and common salt, alone, or with other manures, had comparatively little effect.

Practically, when we want to grow a good crop of bects or mangels, these experiments prove that what we need is the richest kind of barnyard-manure.

If our manure is not rich, then we should use, in addition to the manure, a dressing of nitrate of soda-say 400 or 500 lbs. per aere.

If the land is in pretty gool condition, and we have no barnyard-manure, we may look for a fair crop from a dressing of nitrate of soda alone.

"I see," said the Deacon, "that $550 \mathrm{lbs}$. of nitrate of soda alone, gave an increase of $14 \frac{1}{2}$ tons par acro. And the folluwing year, on the same land, it gave an increase of $13 \frac{1}{2}$ tons; and the next year, on the same land, over 9 tons."

"Yes," said I, "the first three years of the experiments (1871-2-3), $550 \mathrm{lbs}$. of nitrate of soda alone, applied crery ycar, gave an average yield of $19 \frac{1}{4}$ tons of bulbs per acre. During the same three years, the plot dressed with 14 tons of barnyard-manure, gave an average yicld of 161 tons. But now mark. The next year (1874) all the plots were left without any manure, and the plot which had been previously dressed with nitrate of soda, alone, fell off to 3 tons per acre, while the plot which had been previously manured with barnyard-manure, produeed $10 \frac{s}{4}$ tons per acre."

"Good," said the Deaeon, "there is nothing like manure."

\section{MANURES FOR CABBAGE, PARSNIPS, CARROTS, LETTUCE, ONIONS, ETC.}

I class these plants together, because, though differing widely in many respects, they have one feature in common. They are all artificial productions.

A distinguished amateur horticulturist once said to me, "I do not sze why it is I have s) much trouble with lettuce. My land is rich, and the lettuce grow well, but do not head. They have a tendency to run up to seed, and soon get tough and bitter."

I advised him to raise his own seed from the best plants-and especially to reject all plants that showed any tendeney to go pro- 
maturely to seed. Furthermore, I told him I thought if he would sow a little superphosphate of lime with the seed, it would greatly stimulate the early grow th of the lettuce.

As I have said before, superphosphate, when drillel in with the seed, has a wonderful effect in developing the root-growtic of the young plants of turnips, and I thought it would have the same effect on lettuce, cabbage, cauliflowers, etc.

"But," said he, "it is not roots that I want, but heads."

"Exactly," said I, " you do not want the plants to follow out their natural disposition and run up to seed. You want to induce tiem to throw out a great abundance of tender leaves. In other words, you want them to 'head.' Just as in the turnip, you do not want them to run up to seed, but to produce an unnatural development of 'bulb.'"

Thirty years ago, Dr. Gilbert threw out the suggestion, that while it was evident that turnips required a larger proportion of soluble phosphates in the soil than wheat; while wheat required a larger proportion of available nitrogen in the soil, than turnips, it was quite probable, if we were growing turnips for seed, that then, turnips would require the same kind of manures as wheat.

We want exceedingly rich land for cabbage, especially for an early crop. This is not merely because a large crop of cabbage takes a large amount of plant-food out of the soil, but because . the cultivated cabbage is an artificial plant, that requires its food in a concentrated shape. In popular language, the plants have to be "forced."

According to the analyses of Dr. Anderson, the outsicle leaves of cabbage, contain, in round numbers, 91 per cent of water; and the heart leaves, $94 \frac{1}{2}$ per cent. In other words, the green leaves contain $3 \frac{1}{2}$ per cent more dry matter than the heart leaves.

Dr. Vœlcker, who analyzed more recently some "cattle-cabbage," found $89 \frac{1}{2}$ per cent of water in the green leaves, and $83 \frac{8}{4}$ per cent in the heart and inner leaves-thus confirming previous analyses, and showing also that the composition of cabbages varies considerably.

Dr. Volcker found much less water in the cabbage than Dr. Anderson.

The specimen analyzed by Dr. V., was grown on the farm of the Royal Ag. College of England, and I infer from some incidental remarks, that the crop was grown on rather poor land. And it is probably true that a large crop of cabbage grown on rich land, contains a higher percentage of water than cabbage grown on poorer 
land. On the poor land, the cabbage would not be likely to head. so well as on the rich land, and the grean leaves of cabbage contain more than half as much again ręal dry substance as the heart leaves.

The dry matter of the heart lcaves, however, contains more actual nutriment than the dry matter of the green leaves.

It would seem very desirable, therefore, whether we are raising cabbage for market or for home consumption, to make the land rich enough to grow good heads. Dr. Vœlcker says, "In ordinary seasons, the average produce of Swedes on our poorer fields is about 15 tons per acre. On weighing the produce of an acre of cabbage, grown under similar circumstances, I found that it amounted to $17 \frac{1}{2}$ tons per acre. On good, well-manured fields, however, we have had a much larger produce."

In a report on the "Cultivation of Cabbage, and its comparative Value for Feeding purposes," by J. M. M'Laren, of Scotland, the yield of Swede turnips, was 29 tons ton pere, and the yield of cabbage, $47 \frac{3}{4}$ tons per acre.

"It is very evident," said the Deacon, "that if you grow cabbage you should make the land rich enough to produce a good cropand I take it that is all you want to show."

"I want to show," I replied, " that our market gardeners have reason for applying such apparently excessive dressings of rich manure to the cabbage-crop. They find it safer to put far more manure into the land than the crop can possibly use, rather than run any risk of getting an inferior crop. An important practical question is, whether they can not grow some crop or crops after the cabbage, that can profitably take up the manure left in the soil."

Prof. E. Wolff, in the last edition of "Praktische Düngerlehre," gives the composition of cabbage. For the details of which, see Appendix, page 345 .

From this it appears that 50 tons of cabbage contain $240 \mathrm{lbs}$. of nitrogen, and 1,600 lbs. of ash. Included in the ash is $630 \mathrm{lbs}$. of potash; $90 \mathrm{lbs}$. of soda; $310 \mathrm{lbs}$. of lime; $60 \mathrm{lbs}$. of magnesia; 140 lbs. of phosphoric acid; 240 lbs. of sulphuric acid, and 20 lbs. of silica.

Henderson, in "Gardening for Profit," advises the application of 75 tons of stable or barn-yard manure per acre, for early cabbare. For late cabbage, after peas or early potatoes, he says about 10 tons per acre are used.

Brill, in "Farm Gardening and Seed Growing," also makes the same distinction in regard to the quantity of manure used for early 
and late cabbage. He speaks of 70 to 80 tons or more, per acre, of well-rotted stable-manure as not an unusual or excessive dressingr every year.

Now, according to Wolff's table, 75 tons of fres' stable-marure, with straw, contains $820 \mathrm{ll}$ s. of nitroge $\mathrm{s} ; 795 \mathrm{lbs}$. of potash ; 15 J lbs. soda ; $315 \mathrm{lbs}$. of lime ; $210 \mathrm{lbs}$. of magnesia ; $420 \mathrm{lbs}$. of phosphoric acid ; $105 \mathrm{lbs}$. sulphuric acid ; $2,65 \tilde{\mathrm{llus}}$. of silica, and $60 \mathrm{lbs}$. of chlorine.

"Put the figures sile by sile," said the Deacon, "so that we can compare them."

Here they are:

\begin{tabular}{|c|c|c|}
\hline & $\begin{array}{c}75 \text { tons } \\
\text { Freih Horse } \\
\text { manure. }\end{array}$ & $\begin{array}{l}50 \text { tons } \\
\text { C'ulbu'je. }\end{array}$ \\
\hline 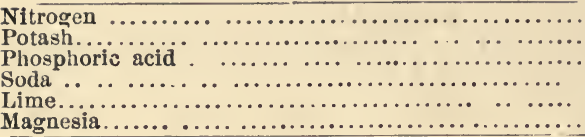 & 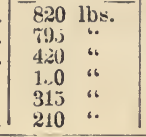 & 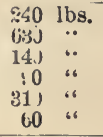 \\
\hline
\end{tabular}

"That is rather an interesting table," said the Doctor. "In the case of lime, the crop takes about all that this heavy dressing of manure supplies-but I suppose the soil is usually capable of furnishing a consider:able quantity."

"That may be so," said the Deacon, "but all the authorities on market gardening speak of the importance of either growing cal)bage on land containing lime, or else of applying lime as a manure. Quinn, who writes like a sensible man, says in h's book, 'Money in the Garden,' 'A top-drossing of lims every third year, thirty or forty bushels per acre, spread broadcast, and harrowed in, just before planting, pays handsomely.'"

Henderson thinks cabbage can only be grown successfully on land containing abundance of lime. He has used heavy dressings of lime on land which did not contain shells, and the result was satisf uctory for a time, but he found it too expensive.

Experience szems to show that to grow large crops of perfect cabbage, the scil must bs liberally furinished with manures rich in nitrogen and phosphoric acil.

In sa!ing this, I do not overlook the fact that cabbage require a large quantity of potash. I t'ink, however, that when large quantitics of stable or barn-yard manure is used, it will rarely be found that the soil lacks potash.

What we need to grow a large crop of cabbagc, is manure from well-fed animals. Such manure can rarely be purchased. Now, tive difference between rich manure and ordinary stabie or barn- 
yard-manure, consists principally in this: The rich manure contains more nitrogen and phosphoric acid than the ordinary stablemanure-and it is in a more available condition.

To eonvert common manure into rich manure, therefore, we must add nitrogen and phosphoric acid. In other words, we must use Peruvian guano, or nitrate of soda and superphosphate, or bonedust, or some other substance that will furnish available nitrogen and phosphoric acid.

Or it may well be, where stable-manure can be bought for $\$ 1.00$ per two-horse load, that it will be cheaper to use it in larger quantity rather than to try to make it rich. In this case, however, we must endeavor to follow the cabbage by some crop that has the power of taking up the large quantity of nitrogen and other plantfood that will be left in the soil.

The cabbage needs a large supply of nitrogen in the soil, but removes comparatively little of it. We see that when 75 tons of manure is used, a crop of 50 tons of cabbage takes out of the soil less than 30 per cent of the nitrogen. And yet, if you plant cabbarge on this land, the next ycar, without manure, you would get a small crop.

"It cannot be for want of nitrogen," said the Deacon.

"Yes it can," said I. " "The cabbage, especially the early kinds, must have in the soil a much larger quantity of available nitrogen t'ia: the plants can use."

I do not mean by this that a large crop of cabbage could be raised, year after year, if furnished only with a large supply of available nitrogen. In such a case, the soil would soon laek the necessary inorganic ingredients. But, what I mean, is this: Where land has been heavily manured for some years, we could often raise a gond crop of cabbage by a liberal dressing of available nitrogen, and still more frequently, if nitrogen and phosphoric acid were both used.

You may use what would be considered an excessive quantity of ordinary stable-manure, and grow a large crop of cabbare; but still, if you plant cabbage the next year, without manure of any kind, you will get a small crop; but dress it with a manure containing the necessary amount of nitrogen, and you will, so far as the sipply of plant-food is concerned, be likely to get a good crop.

In such circumstances, I think an application of 800 lbs. of nitrate of soda per acre, costing, say $\$ 32$, woul 1 be likely to afford a very handsome profit.

For lettuce, in addition to well prepared rich iand, I should sorv 3 lbs. of superphosplate to each square rod, scattered in the rows 
before drilling in the seed. It will favor the formation of fibrous roots and stimulate the growth of the young plants.

In raising onions from seed, we require an abundance of rich, well-rotted manure, clean land, and early sowing.

Onions are often raised year after year on the same land. That this entails a great waste of manure, is highly probable, but it is not an easy matter to get ordinary farm-land properly prepared for onions. It needs to be clean and free from stones and rubbish of all kinds, and when once it is in good condition, it is thought better to continue it in onions, even though it may entail more or less loss of fertility.

"What do you mean," asked the Deacon, "by loss of manure ?" "Simply this," said I. "We use a far greater amount of plantfood in the shape of manure than is removed by the crop of onions. And yet, notwithstanding this fact, it is found, as a matter of experience, that it is absolutely necessary, if we would raise a large and profitable crop, to manure it every ycar."

A few experiments would throw nuch light on this matter. I should expect, when land had been heavily dressed every year for a few years, with stable-manure, and annually sown to onions, that 800 lus. of sulphate of ammonia, or of nitrate of soda, or 1,200 lbs. of Peruvian guano would give as good a crop as 25 or 30 tons of manure. Or perhaps a better plan would be to apply 10 or 15 loads of manure, and $600 \mathrm{lbs}$. of guano, or $400 \mathrm{lbs}$. sulphate of am: monia.

\section{$\longrightarrow \infty-$ \\ C H A P T E R X X V.}

\section{MANURES FOR GARDENS AND ORCHARDS.}

\section{MANURE FOR MARKET-GARDENS.}

The chief dependence of the market-gardener must be on the stable-manure which he can obtain from the city or village. The chief defect of this manure is that it is sot rich enough in available aitrogen. The active nitrogen exists principally in the urine, and this in our city stables is largely lost. A ton of fresh, unmixed horse-dung contains about $9 \mathrm{lbs}$. of nitrogen. A ton of horse-urine, $31 \mathrm{lbs}$. But this does not tell the whole story. The nitrogen in the dung is contained in the crude, undigested portions of the food. It is to a large extent insoluble and unavailable, while the nitroger in the urine is soluble and active. 
The market-gardener, of course, has to take such manure as he can get, and the only points to be considered are (1), whether he had better continue to use an excessive quintity of the manure, or (2), to buy substances rich in available nitrogen, and either mix them with the manure, or apply them separately to the soil, or (3), whether he can use this horse-manure as bedding for pigs to be fed on rich nitrogenous food.

The latter plan I adopt on my own farm, and in this way I get a very rich and active manure. I get available nitrogen, phosphoric acid, and potash, at far cheaper rates than they can be purchased in the best commercial fertilizers.

Pigs void a large amount of urine, and as pigs are ordinarily kept, much of this liquid is lost for want of sufficient bedding to absorb it. With the market-gardener or nurseryman, who draws lurge quantities of horse-manure from the city, this need not be the case. The necessary buildings can be constructed at little cost. and the horse-manure can be used freely. The pigs should be fed on food rich in nitrogen, such as bran, malt-combs, brewers' grains, the refuse animal matter from the slaughter-houses or butcher's' stores, fish scrap, pea or lentil-meal, palin-nut cake, or such food as will furnish the most nitrogenous food, other things being equal, at the cheapest rate.

The market-gardener not only requires large quantities of rich manure, but he wants them to act quickly. The nurscryman who sets out a block of trees which will occupy the ground for three, four, or five years, may want a "lasting manure," but such is not the case with the gardener who grows crops which he takes off the land in a few months. As long as he continues to use horse or cow-manure freely, he nead not trouble himself to get a slow or lasting manure. His great aim should be to make the manure as active and available as possible. And this is especially the case if he occupies clayey or loamy land. On sandy land the manure will decompose more rapidly and act quicker.

"There are many facts," said the Doctor, "that show that an artificial application of water is equivalent to an application of manure. It has been shown that market-gardeners find it necessary to apply a much larger amount of plant food to the soil than the crops can take up. This they have to do year after year. And it may well be that, when a supply of water can be had at slight cost, it will be cheaper to irrigate the land, or water the plants, rather than to furnish such an excess of manure, as is now found necessary. Even with ordinary farm-crops, we know that they feel the effects of drouth far less on rich land than on poor land. In 
other words, a liberal supply of plant-food enables the crops to flourish with less water; and, on tie otier hand, a greater supply of water will enable the crops to flourish with a less supply of plant-food. The market-gardeners should look into this question of irrigation.

MANURES FOR SEED-GROWING FARMS.

In growing garden and vegetable seeds, much labor is necessarly employed per acre, and consequently it is of great importance to pavduce a good yield. The best and cleanest land ss necessary to start with, and then manures must be appropriately and freely used.

"But not too freely," said the Doctor, "for I am told it is quite possible to have land too rich for seed-growing."

It is not often that the land is too rich. Still, it may well be th:t for some crops too much stable-manure is used. But in nine cases out of ten, w'ien such manure gives too much growth and too little or too poor seed, the trouble is in the quality of the manure. It contains too much carbonaceous matter. In other words, it is so poor in nitrogen and phosphoric acid, that an excessive quantity has to be used.

The remedy consists in making richer manures and using a less quantity, or use half the quantity of stable-manure, and apply the rectified or prepared Peruvian guano, at the rate of $300 \mathrm{lbs}$. or 400 lbs. per acre, or say $200 \mathrm{lbs}$. superphosphate and $200 \mathrm{lbs}$. nitrate of soda per acre.

Where it is very important to have the seeds ripen early, a liberal dressing, say $400 \mathrm{lbs}$. per acre, of superphosphate of lime, will be likely to prove beneficial.

\section{MANURE FOR PRIVATE GARDENS.}

I once had a small garden in the city, and having no manure, I depended entirely on thorough cultivation and artificial fertilizers, such as superphosphate and sulphate of ammonia. It was cultivated not for profit, but for pleasure, but I never saw a more productive piece of land. I had in almost every case two crops a year on the same land, and on some plots three crops. No manure was used, except the superphosphate and sulphate of ammonia, and coal and wood ashes from the house.

About 5 lbs. of sulphate of ammonia was sown broadcast to the square rod, or worked into the soil very thoroughly in the rows where the seel was to be sown. Superphosphate was applied at the same rate, but instead of sowing it broadcast, I aimed to get it as near the seed or the roots of plants as possible. 
Half a teaspoonful of the mixture, consisting of equal parts of superphosphate and sulphate of ammonia, stirred into a large three gallon can of water, and sprinkled on to a bed of verbenas, seemed to have a remarkable effect on the size and brilliancy of the flowers.

Even to this day, although I have a good supply of rich barnyard-manure, I do not like to be without some good artificial manure for the garden.

\section{MANURE FOR HOT-BEDS.}

The best manure for hot-beds is horse or sheep-dung that has been used as bedding for pigs.

When fresh stable-manure is usad, great pains should be taken to save all the urine. In otiser words, you want the horse-dung ihorougaly saturated with urine.

The heat is prolueed principally from the carbon in the manure and straw, but you need active ritrocenous matter to stait the fire. And the richer the manure is in nitrogenous matter, and the more thoroughly this is distributed through the manure, the more reailily will it ferment. There is also another advantage in having rich manure, or manure well saturated with urine. You can make the lieap more compact. Poor manure has to be made in a loose beap, or it will not ferment; but such manure as we are talking about can be trodden down quite firm, and still ferment rapid enough to give out the necessary heat, and this compact heap will continue to ferment longer and give out a steadier heat, than the loose heap of poor manure.

\section{MANURE FOR NURSERYMEN.}

Our succcssful nurserymen purchase large quantitics of stable and other manures from the citics, drawing it as fast as it is made, and putting it in piles until wanted. They usually turn the piles once or twice, and often three times. This favors fermentation, greatly reducing it in bulk, and rendering the manure much more soluble and active. It also makes the manure in the heap more uniform in quality.

Messrs. Ellwanger \& Barry tell me that they often ferment the manure that they draw from the stables in the city, and make it so fine and rich, that they get but one load of rotted manure from three loads as drawn from the stables. For some crops, they use at least 20 loads of this rotted manure per acre, and they estimate that each load of this rotted manure costs at least $\$ 5.00$.

H. E. Hooker places the cost of manure equally high, but seems willing to use all he can get, and does not think we can profitably cinploy artificial manures as a substitute. 
In this I agree with him. But while I should not expect artificial manures, when used alone, to prove as cheap or as valuable as stable-manure at present prices, I think it may well be that a little nitrate of soda, sulphate of ammonia, and superphosphate of lime, or dissoived Peruvian guano, might be used as an auxiliary manure to great advantage.

Mr. H. E. Hooker, once sowed, at my suggुestion, some sulphate of ammonia and superphosphate on part of a block of nursery trees, and he could not perceive that these manures did any good. Ellwanger \& Barry also tried them, and reported the same negative result. This was several years ago, and I do not think any similar experiments have been made since.

"And yet," said the Deacon, "you used these self same manures on farm-crops, and they greatly increased the growth."

"There are several reasons," said the Doctor, "why these manures may have failed to produce any marked effect on the nursery trees. In the first place, there was considerable prejudice against them, and the nurserymen would hardly feel like relying on these manures alone. They probably sowed them on land already well manured; and I think they sowed them tos late in the seasun. I should like to see them fairly tried."

So would I. It scems to me that nitrate of soda, and superphosphate, or dissolved Peruvian guano, could be used with very great advantage and profit by the nurserymen. Of course, it would hardly be safe to depend upon them alone. They should be used either in connection with stable-manure, or on land that had previously been frequently dressed with stable-manure.

\section{MANURE FOR FRUIT-GROWERS.}

How to keep up the fertility of our apple-orchards, is becoming an important question, and is attracting considerable attention.

There are two methods generaliy recommended-I dare not say generally practised. The one, is to keep the orchard in bare-fallow ; the other, to keep it in grass, and top-dress with manure, and either eat the grass off on the land with sheep and pigs, or else mow it frequently, and let the grass rot on the surface, for mulch and manure.

"You are speaking now," said the Deacon, "of bearing appleorchards. No one recommends keeping a young orchard in grass. We all know that young apple trees do far better when the land is occupied with corn, potatoes, beans, or some other crop, which can be cultivated, than they do on land occupied with wheat, barley, oats, rye, buckwheat, or grass and clover. And even with bearing 
peach trees, I have seen a wonderful difference in an orchard, half of which was cultivated with corn, and the other half sown with wheat. The trees in the wheat were sickly-looking, and vore a small crop of inferior fruit, while the trees in the corn, grew vigorously and bore a fine crop of fruit. And the increased value of the crop of peaches on the cultivated land was far more than we can ever hope to get from a crop of wheat."

"And yet," said tire Ductur, "the crop of corn on the cultivated half of the peach-orchard removed far more plant-food from the soil, than the crop of wheat. And so it is evident that the difference is not due wholly to the supply of manure in the surface-soil. It may well be that the cultivation which the corn received favored the decomposition of organic matter in the soil, and the formation of nitrates, and when the rain came, it would penetrate decper into the loose soil than on the adjoining land occupied with wheat. The rain would carry the nitrogen down to the roots of the peach trees, and this will account for the dark green color of the leaves on the cultivated land, and the yellow, sickly-looking leaves on the trees among the wheat.

\section{HEN-MANURE, AND WHAT TO DO WITH IT.}

A bushel of corn fed to a hen would give no more nitrogen, phosphoric acid, and potash, in the shape of manure, than a bushel of corn fed to a pig. The manure from the pig, however, taking the urine and solid excrement together, contain 82 per cent of water, while that from the hen contains only 56 per cent of watcr. Morcover, hens pick up worms and insects, and tineir food in sicin case would contain more nitrogen than the usual food of pigs, and the manure would be correspondingly richer in nitrogen. Hence it happens that $100 \mathrm{lbs}$. of $d r y$ hen-manure would usually be richer in nitrogen than $100 \mathrm{lbs}$. of $d r y$ pig-manure. But feed pigs on peas, and hens on corn, and the dry pig-manure would be much richer in nitrogen than the dry hen-manure. The value of the manure, other things being equal, depends on the food and not on the animal.

Let no man think he is going to make his farm any richer by keeping hens, ducks, and gcese, than he will by keeping sheep, pigs, and horses.

"Why is it, then," asked the Deacon, "that hen-dung proves such a valuable manure. I would rather have a hundred lbs. of hen-dung than half a ton of barnyard-manure?"

"And I presume you are right," said I, " but you must recollect that your hen-manure is kept until it is almost chemically dry. Let 
us figure up what the half ton of manure and the $100 \mathrm{lbs}$. of henmanure would contain. Here are the figures, side by side:

\begin{tabular}{|c|c|c|}
\hline & $\begin{array}{l}100 \text { lbs. dry } \\
\text { Hen- Hla- } \\
\text { nure. }\end{array}$ & $\begin{array}{c}\text { Half to } \\
\text { Cow-Dung } \\
\text { with straw. }\end{array}$ \\
\hline 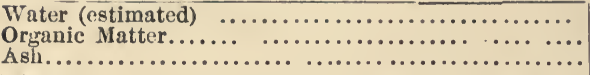 & $\begin{array}{ll}1: 2 & 1 b s . \\
51 & 6 \\
37 & 6\end{array}$ & $\begin{array}{rc}775 & 1 \mathrm{bs} . \\
203 & 6 \\
22 & 6\end{array}$ \\
\hline 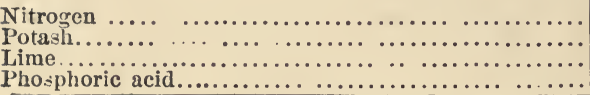 & $\begin{array}{ll}3 \frac{1}{2} & 6 \\
1 \frac{8}{2} & 6 \\
4 \frac{4}{4} & 6 \\
3 & 6\end{array}$ & $\begin{array}{l}22 / 56 \\
4 \\
3 \\
1166\end{array}$ \\
\hline
\end{tabular}

I would, myself, far rather have 100 lbs. of your dry hen-manure than half a ton of your farmyard-manure. Your hens are fed on richer food than your cows. The $100 \mathrm{lbs}$. of hen-manure, too, would act much more rapidly than the half ton of cow-manure. It would probably do twice as much good--possibly three or four times as much good, on the first crop, as the cow-manure. The nitrogen, being obtained from richer and more digestible food, is in a much more active and available condition than the nitrogen in the cow-dung.

"If you go on," said the Deacon, "I t'ain'r you will prove that I am right."

"I have never doubted," said I, "the great value of hen-dung, as compared with barnyard-manure. And all I wish to show is, that, notwithstanding its acknowledged value, the fact remains that a given quantity of the same kind of food will give no greater amount of fertilizing matter when fed to a hen than if fed to a pig."

I want those farmers who find so much benefit from an application of hen-manure, ashes, and plaster, to their corn and potatocs, to feel that if they would keep better cows, sheep, and pigs, and feed them better, they would get good pay for their feed, and the mazure would enable them to grow larger crops.

While we have been talking, the Deacon was looking over the tables. (See Appendix.) "I see," said he, "that wheat and rye contain more nitrogen than hen-manure, but less potash and plosphoric acid."

"This is true," said I, "but the way to compare them, in orler to see the effect of passing the wheat through the hen, is to look at the composition of the air-dried hen-dung. The fresh hen-dung, according to the table, contains 56 per cent of water, while wheat contains less than $14 \frac{1}{2}$ per cent."

Let us compare the composition of $1,000 \mathrm{lbs}$. air-dried hen-dung with 1,000 lbs. of air-dried wheat and rye, and also with bran, malt-combs, etc. 


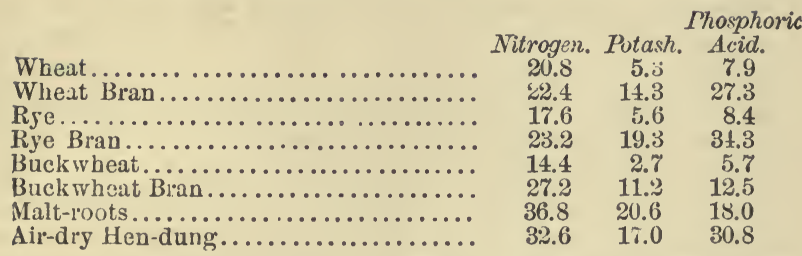

"That table," said the Doctor, "is well worth studying. You see, that when wheat is put through the process of milling, the miller takes out as much of the starch and gluten as he wants, and leaves you a product (bran), richer in phosphoric acid, potash, and nitrogen, than you gave him."

"And the same is true," continued the Doctor, "of the hen. Ynu gave her 2,000 grains of wheat, containing 41.6 grains of nitrogen. She puts this through the mill, together with some ashes, and bones, that she picks up, and she takes out all the starch and fat, and nitrogen, and phosphate of lime, that she needs to sustain life, and to produce flesh, bones, feathers, and eggs, and leaves you 1,000 grains of manure containing 32.6 grains of nitrogen, 17.0 grains of potash, and 30.8 grains of phosphoric acid. I do not say," continued the Doctor, "that it takes exactly 2,000 grains of wheat to make 1,000 grains of dry manure. I merely give these figures to enable the Deacon to understand why 1,000 lbs. of hen-dung is worth more for manure than $1,000 \mathrm{lb} 3$. of wheat."

"I must admit," said the Deacon, "that I always have been troubled to understand why wheat-bran was worth more for manure than the wheat itself. I see now-it is because there is less of it. It is for the same reason that boiled cider is richer than the cider from which it is made. The cider has lost water, and the bran has lost starch. What is left is richer in nitrogen, and potash, and phosphoric acid. And so it is with manure. The animals take out of the food the starch and fat, and leave the manure richer in nitrogen, phosphoric acid, and potash."

"Exactly," said I, "Mr. Lawes found by actual experiment, that if you feed $500 \mathrm{lbs}$. of barley-meal to a pig, containing $420 \mathrm{lbs}$. of dry substance, you get only 70 lbs. of dry substance in the manure. Of the $420 \mathrm{lbs}$. of dry substance, $276.2 \mathrm{lbs}$. are used to support respiration, etc.; $73.8 \mathrm{lbs}$. are found in the increase of the pig, and 70 lbs in the manure."

The food contains $52 \mathrm{lbs}$. of nitrogenous matter; the increase of pig contains $7 \mathrm{lbs}$, and consequently, if there is no loss, the ma- 
nure shou'd contain $45 \mathrm{lbs}$. of nitrogenous substance $=$ to $7.14 \mathrm{lbs}$. of nitrogen.

"In other words," said the Doctor, " the $70 \mathrm{lbs}$. of $d r y$ iiquid and solid pig-manure contains $7.14 \mathrm{lbs}$. of nitrogen, or $100 \mathrm{lbs}$. would contain $10.2 \mathrm{lbs}$. of nitrogen, which is more nitrogen than we now get in the very best samples of Peruvian guano."

"And thus it will be seen," said I, " that though corn-fed pigs, leaving out the bedding and water, produce a very small quantity of manure, it is exceedingly rich."

The table from which these facts were obtained, will be found in the Appendix-pages 342-3.

\section{$\longrightarrow$ \\ CHAPTER XXXV1.}

\section{DIFFERENT KINDS OF MANURE.}

\section{COW-MANURE, AND HOW TO USE IT.}

"It will do more good if termented," said a German farmer in the neighborhood, who is noted for raising good crops of cabbage, "but I like hog-manure better than cow-dung. The right way is to mix the hog-manure, cow-dung, and horse-manure together."

"No doubt about that," said I, "but when you have a good many cows, and few other animals, how would you manage the manure?"

"I would gather leaves and swamp-muck, and use them for bedding the cows and pigs. Leaves make splendid bedding, and they make rich manure, and the cow-dung and leaves, when made into a pile, will ferment readily, and make grand manure for--anything. I only wish I had all I could use."

There is no question but what cow-manure is better if fermented, but it is not always convenient to pile it during the winter in such a way that it will not freeze. And in this case it may be the better plan to draw it out on to the land, as opportunity offers.

"I have heard," said Charley, "that pig-manure was not good for cabbage, it produces 'fingers and toes,' or club-foot."

Possibly such is the case when there is a predisposition to the disease, but our German friend says he has never found any ill. effects from its use. 
"Cows," said the Doctor, "when giviag a !arre quantity of milk, make rather poor manure. The manure loses what the milk takes from the food."

"We have shown what that loss is," said I. "It amounts to less than I think is generally suppose 1 . And in the winter, when the cows are dry, the manure would be as rich as from oxen, provided both were fel alike. Sэe Appendix, page 342. It will there be seen that oxen take out only 4.1 lbs. of nitrogen from $100 \mathrm{lbs}$. of nitrogen consumed in the food. In other words, provided there is no loss, we should get in the liquid and solid excrements of the ox and dry cow 95.9 per cent. of the nitrogen furnished in the food, and a still higher per cent of the mineral matter.

\section{SHEEP-MANURE.}

According to Prof. Wolff's table of analyses, sheep-manure, both solid and liquid, contain less water than the manure from horses, cows, or swine. With the exception of swine, the solid dung is also the richest in nitrogen, while the urine of sheep is preeminently rich in nitrogen and potash.

These facts are in accordance with the general opinions of farmers. Shcep-manure is considered, next to hen-manure, the most valuable manure made on the farm.

I cio not think we have any satisfactory evidence to prove that 3 tons of clover-hay and a ton of corn fed to a lot of fatteningsheep will afford a quantity of manure containing any more plantfool than the same kind and amount of food fed to a lot of fattening-cattle. The experiments of Lawes \& Gilbert indicate that if there is any d:ffrence it is in favor of the ox. See Appendix, page 343. But it may $w 11$ be that it is much easier to save the manure from the sheep than from the cattle. And so, practically, s'heep may be better manure-makers than cattle-for the simple rexson that less of the urine is lost.

"As a rule," said the Doctor," the dung of sheep contains far less water than the dung of cattle, though when you slop your breeding ewes to make them give more milk, the dung differs but little in appearance from that of cows. Ordinarily, howcver. sheepdung is light and dry, and, like horse-dung, will ferment much more rapidiy than cow or pig-dung. In piling manure in the winter or spring, special pains should be used to mix the sheep and horse-manure with the cow and pig-manure. And it may be remarked that for any crop or for any purpose where stable-manure is dcemed desirable, sheep-manure would be a better substitute than cow or pig-manure." 


\section{MANURE FROM SWINE.}

The dry matter of hog-manure, especially the urine, is rich in nitrogen, but it is mixe.l with suc's a large quantity of water that a ton of hog-manure, as it is usually found in the pen, is less valuable than a ton of horse or sheep-manure, and only a little more valuable than a ton of cow-manure.

As I have before said, my own plan is to let the strre-hogs sleep in a basement-cellar, and bed them with horse and sheep-manure. I have this winter over 50 sows under the horse-stable, and the manure from 8 horses keeps them dry and comfortable, and we are not specially lavish wit' straw in bedding the horses.

During the summer we aim to keep the hogs out in the pastures and orchards as much as possible. This is not only good for the health of the pigs, but saves labor and straw in the management of the manure. It goes directly to the land. The pigs are good grazers and distribute the manure as evenly over the land as sheep - in fact, during hot weather, sieep are even more inclined to huddle together under the trees, and by the side of the fence, than nigs. This is particularly the case with the larger brceds of sheep.

In the winter it is not a difficult matter to save all the liquid and solid excrements from pigs, provided the pens are dry and no water comes in from the rain and snow. As pigs are often managed, this is the real difficulty. Pigs void an enormous quantity of water, especially when fed un slops from the house, whey, etc. If they are kept in a pen with a separate feeding and sleeping apartment, both.should be under cover, and the feeding apartment may be kept covered a foot or so thick with the soiled bedding from the sleeping apartment. When the pigs get up in a morning, they will go into the feeding apartment, and the liquid will be discharged on the mass of manure, straw, etc.

"Dried muck," said the Deacon, "comes in very handy about a pig-pen, for absorbing the liquid."

"Yes," said I, "and even dry earth can be used to great advantage, not merely to absorb the liquid, but to keep the pens swcet and healthy. The three chief points in saving manure from pigs aro: 1, To have the pens under cover; 2, to keep the feeding apartment or yard covered with a thick mass of strawy manure and refuse of any kind, and 3, to scatter plenty of dry earth or dry muck on the floor of the sleeping apartment, and on top of the manure in the feeding apartment."

"You $\mathrm{f}$ ed most of your pigs," said the Deacon, "out of doors in the yard, and they sleep in the pens or basement cellars, and it 
seems to me to be a good plan, as they get more fresh air and exercise than if confined."

"We do not lose much manure," said I, "by feeding in the yards. You let a dozen pigs sleep in a pen all nigut, and as soon as they hear you putting the food in the troughs outside, they come to the door of the pen, and there discharge the liquid and solid excrements on the mass of manure left ticre on purposs to receive and absorb them. I am well aware that as pigs are often managed, we lose at least half the value of their manure, but there is no neccssity for tiis. $\mathrm{A}$ little care and thought will save nearly the whole of it.

\section{BUTING MANURE BY MEASURE OR WEIGHT.}

The Deacon and I have just been weighing a bushel of differcet kinds of manure made on the farm. We made two weighings of each kind, one thrown in loose, and the other pressed down firm. The following is the result:

WEIGHT OF MANURE PER BUSHEL, AND PER LOAD OF 50 BUSHELS.

\begin{tabular}{|c|c|c|c|}
\hline No. & KIND AND CONDITION OF MANURES. & 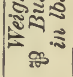 & 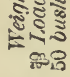 \\
\hline $\begin{array}{l}1 . \\
2 . \\
3 . \\
4 . \\
5 . \\
6 . \\
7 . \\
8 . \\
9 . \\
10 . \\
11 . \\
12 . \\
13 . \\
14 . \\
15 . \\
16 .\end{array}$ & 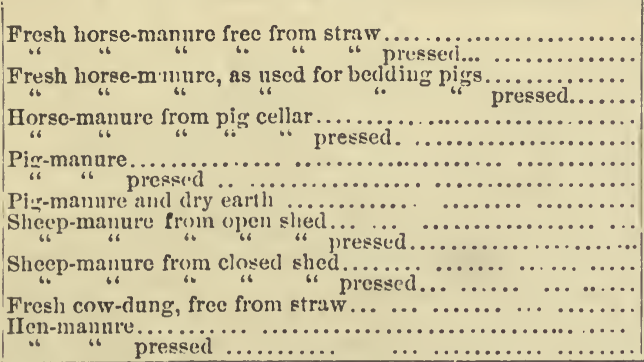 & \begin{tabular}{|l|}
$11) \mathrm{s}$ \\
$3 \%$. \\
55 \\
28 \\
46 \\
50 \\
72 \\
57 \\
75 \\
98 \\
42 \\
65 \\
28 \\
38 \\
87 \\
31 \\
$4 S$
\end{tabular} & $\begin{array}{l}16 \% \\
18 \% 5 \\
2 \% 50 \\
1400 \\
2300 \\
2500 \\
3600 \\
2850 \\
3 \% 5 \\
4 \% 00 \\
2100 \\
3250 \\
1400 \\
19 ; 0 \\
4350 \\
1700 \\
2400\end{array}$ \\
\hline
\end{tabular}

"In buying manure," said the Deacon, "it makes quite a differcnce whether the load is trod down solid or thrown loosely into the box. A load of fresh horse-manure, when trod clown, weighs half as much again as when thrown in loose."

"A load of horsc-manire," sail Charley, "after it has been used for bedding pigs, weighs $3,600 \mathrm{lbs}$, and only $2,300 \mathrm{lbs}$. when it is thrown into the pens, and I suppose a ton of the 'double-worked' manure is fuily as valuable as a ton of the fresh horse-manure. If so, 15 'loads' of the pig-pen manure is equal to 24 'loads' of the stable-manure." 
"A ton of fresh horse-manure," said the Doctor, "contains about 9 lbs. of nitrogen; a ton of fresh cow-dung about 6 lbs.; a ton of fresh sheep-dung, $11 \mathrm{lbs}$., and a ton of fresh pig-manure, 12 lbs. But if the Deacon and you weighed correctly, a 'load' or cord of cow-manure would contain more nitrogen tinan a load of pressed horse-manure. The figures are as follows:

A load of 50 bushels of fresh horse-dung, pressed

and free from straw contains.................. 12.37 lbs. nitrogen.

A load of fresh cow-dung....................... 13.05

" " $\quad \begin{aligned} & \text { sheep } \text { " } \\ & \text { " }\end{aligned}$

"These figures," said I, "show how necessary it is to look at this subject in all its aspects. If I was buying manures by veight, I would much prefer a ton of sheep-manure, if it had been made under cover, to any other manure except hen-dung, especially if it contained all the urine from the sheep. But if buying manure by the load or cord, that from a covered pig-pen would be preferable to any other."

\section{LIQUID MANURE ON THE FARM.}

I have never had any personal experience in the use of liquid manure to any crop except grass. At Rothamsted, Mr. Lawes used to draw out the liquid manure in a water-cart, and distribute it on grass land.

"What we want to know," said the Deacon, "is whether the liquid from our barn-yards will pay to draw out. If it will, the proper method of using it can be left to our ingenuity."

According to Prof. Wolff, a ton of urine from horses, cows, s'seep, and swine, contains the following amounts of nitrogen, p'osphoric acid, and potash, and, for the sake of comparison, I give the composition of drainage from the barn-yard, and also of fresh dung of the different animals :

TABLE SHOWING THE AMOUNT OF NITROGEN, PHOSPHORIC ACID, AND POTASH, IN ONE TON OF THE FRESH DUNG AND FIESH URINE OF DIFFERENT ANIMALS, AND ALSO OF THE DRALNAGE OF THE BATN-YARD.

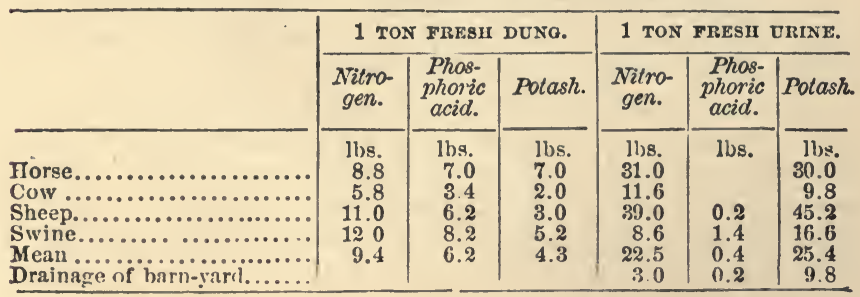


The drainage from a barn-yard, it will be seen, contains a little more than half as much nitrogen as cow-dung; and it is probahle that tue nitrogen in the liquid is in a much more available condition than that in the dung. It contains, also, nearly five times as much potash as the dung. It would seem, therefore, that with proper arrangements for pumping and distributing, this liquid could be drawn a short distance with profit.

But whether it will or will not pay to cart away the drainage, it, is obviously to our interest to prevcnt, as far as possible, any of the liquid from running to waste.

It is of still greater importance to guard against any loss of urine. It will be seen that, on the average, a ton of the urine of our domestic animals contains more than twice as much nitrogen as a ton of the dung.

Where straw, leaves, swamp-muck, or other absorbent materials are not sufficiently abundant to prevent any loss of urine, means should be used to drain it into a tank so located that the liquid can either be pumped back on to the manure when needed, or drawn away to the land.

"I do not see," said the Deacon, "why horse and sheep-urine should contain so much more nitrogen and potash than that from the cow and pig."

"The figures given by Prof. Wolf," said I, "are general averagcs. The composition of the urine varies greatly. The richer the food in digestible nitrogenous matter, the more nitrogen will there be in the dry matter of the urine. And, other things being equal, the less water the animal drinks, the richer will the urine be in nitrogen. The urins from a sheep fed solely on turnips would contain little or no more nitrogen than the urine of a cow fed on turnips. An ox or a dry cow fed on grass would probably void no more nor no poorer urine than a horse fed on grass. The urine that Mr. Lawes drew out in a cart on to his grass-land was made by sheep that had one ib. cach of oil-cake per day, and one $\mathrm{fb}$. of chaffed clover-hay, and all the turnips they would eat. They voided a large quantity of urine, but as the food was rich in nitrogen, the urine was doubtless nearly or quite as rich as that analyzed by Prof. Wolff, though that probably contained less water.

If I was going to draw out liquid manure, I should be very careful to spout all the buildings, and keep the animals and manure as much under cover as possible, an $\mathbf{l}$ also feed food rich in nitrogen. In such circumstances, it wocld doubtless pay to draw the urino full as well as to draw the solid manure. 


\section{NIGHTSOIL AND SEWAGE.}

The composition of human excrements, as compared with the mean composition of the excrements from horses, cows, sheep, and swine, so far as the nitrogen, phosphoric acid, and potash are concerned, is as follows :

TABLE SHOWING THE AMOUNT OF NITROGEN, PHOSPHORIC ACID, AND POTASH, IN ONE TON OF FRESH HUMAN EXCREMENTS, AND IN ONE TON OF FRESH EXCIEMENTS FHOM HORSES, COWS, SHCEP, AND SWINE.

\begin{tabular}{|c|c|c|c|c|c|c|}
\hline \multirow[b]{2}{*}{ One ton (2000 lbs). } & \multicolumn{3}{|c|}{ souns. } & \multicolumn{3}{|c|}{ URINE. } \\
\hline & $\begin{array}{l}\text { Nitro } \\
\text { gen. }\end{array}$ & $\begin{array}{c}\text { Phos- } \\
\text { phoric } \\
\text { acid. }\end{array}$ & Fotash. & $\begin{array}{l}\text { IVitro- } \\
\text { gen. }\end{array}$ & $\begin{array}{l}\text { Phos- } \\
\text { phoric } \\
\text { acid. }\end{array}$ & Potash. \\
\hline 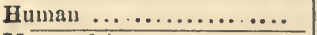 & $200 \mathrm{lbs}$. & $21.8 \mathrm{lbs}$. & 5.0 !lbs. & $12.0 \mathrm{Jbs}$. & $3.7 \mathrm{lbs}$. & $4.01 \mathrm{bs}$. \\
\hline $\begin{array}{r}\text { Mean of horse, cow, slseep, } \\
\text { and swine.... ............ }\end{array}$ & 9.4 ‘ & 6.26 & $4.3 "$ & 22.5 " & $0.4 “$ & $25.4 “$ \\
\hline
\end{tabular}

One ton of fresh fæces contains more than twice as much nitrogen, and more than three times as much phosphoric acid, as a ton of fresh mixed animal-dung. The nitrogen, too, is probably in a more available condition than that in common barnyard-dung; and we should not be far wrong in estimating 1 ton of fæces equal to $2 \frac{1}{2}$ tons of ordinary dung, or about equal in value to carefully preserved manure from liberally-fed sheep, swine, and fattening cattle.

"It is an unpleasant job," said the Deacon, "but it pays well to empty the vaults at least twice a year."

"If farmers," said the Doctor, "would only throw into the vaults from time to time some dry earth or coal ashcs, the contents of the vaults could be removed without any disagreeable smell."

"That is so," said I, "and even where a vault has been shamefully neglected, and is full of offensive matter, it can be cleaned out without difficulty and without smell. I have cleaned out a large vault in an hour. We were drawing manure from the yards with three teams and piling it in the field. We brought back a load of sand and threw balf of it into the vault, and put the other half on one side, to be used as required. The sand and frees were then, with a long-handled shovel, thrown into the wagon, and drawn to the pile of manure in the field, and threwn on to the pile, not more than two or three inches thick. The feam brought back a load of sand, and so we continued until the work was done. Sand or dry earth is cheap, and we used all that was necessary to prevent the escape of any unpleasant gases, and to keep the material from adhering to the shovels or the wagen.

"Human urine," said the Doctor, "is richer in phosphoric acid, 
but much poorer in nitrogen and potash than the urine from horses, cows, sheep, and swine."

"Some years ago," said the Deacon, "Mr. H. E. Hoolier, of Rochester, used to draw considerable quantities of urine from the city to his farm. It would pay better to draw out the urine from farm animals."

"The figures given above," said I, "showing the composition of suman excrements, are from Prof. Wolff, and probably are generally correct. But, of course, the composition of the excrements would vary greatly, according to the food."

It has been ascertained by Lawes and Gilbert that the amount of matter voided by an aduit male in the course of a year is-fæces, $95 \mathrm{lbs}$; urine, $1,049 \mathrm{lbs}$; total liquid and solid excrements in the pure state, 1,144 lbs. These contain :

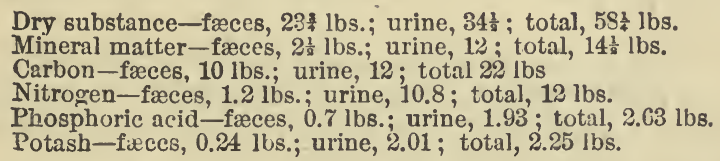

The amount of potash is given by Prof. E. Wolif, not by Lawes and Giibert.

The mixed solid and liquid excrements, in the condition they leave the body, contain about 95 per cent of water. It would require, therefore, 20 tons of fresh mixed excrements, to make one ton of $d r y$ nightsoil, or the entire amount voided by a mixed family of 43 persons in a year.

One hundred lbs. ot fresh fæces contain 75 lbs. of water, and 25 lbs. of dry substance.

One hundred lbs. of fresh urine contain $96 \frac{1}{2} \mathrm{lbs}$. of water, and $3 \frac{1}{2} \mathrm{lbs}$. of dry substance.

One hundred.lbs. of the dry substance of the fæces contain 5 lbs. of nitrogen, and $5 \frac{1}{2} \mathrm{lbs}$. of phosphates.

One hundred lbs. of the dry substance of the urine contain 27 "Is. of nitrogen, and 10a lbs. of phosphates.

'These figures are from Lawes and Gilbert, and may be taken as representing the composition of excrements from moderately wellfed persons.

According to Wolff, a ton of fresh human urine contains $12 \mathrm{log}$. of nitrogen. According to Lawes and Gilhert, $18 \mathrm{lbs}$.

The liquid carted from the city by Mr. Hooker was from well-fcd adu't males, and would doubtless be fully equal to the figures given by Lawes and Gilbert. If we call the nitrogen worth 20 cents a lb., 
and the phosphoric acid (soluble) worth $12 \frac{1}{2}$ cents, a ton of such urine would be worth, on the land, \$1.06.

"A ton of the fresh fæces," said the Deacon, "at the same estimate, would be worth ( $20 \mathrm{lbs}$. nitrogen, at 20 cents, $\$ 4 ; 21 \frac{8}{4}$ lbs. phosphoric acid, at $12 \frac{1}{2}$ cents, $\left.\$ 2.70\right)$, \$6.70."

"Not by a good deal," said the Doctor. "The nitrogen and phosphoric acid in the urine are both soluble, and would be immediately available. But the nitrogen and phosphoric acid in the freces would be mostly insoluble. We cannot estimate the nitrogen in the freces at over 15 cents a lb., and the phosphoric acid at 5 cents. This would make the value of a ton of fresh fæces, on the land, \$4.09."

"This makes the ton of fæces worth about the same as a ton of urine. But I would like to krow," said the Deacon, "if ycu really believe we could afford to pay $\$ 4$ per ton for the stuff delivered on the farm?"

"If we could get the genuine article," said the Doctor, "it would be worth $\$ 4$ a ton. But, as a rule, it is mixed with water, cnd dirt, and stones, and brisks, and rubbish of all kirds. Stili, it is unqu'stionably a valuable fertilizer."

"In the dry-earth closats," said I, "such a large cuantity of earth has to bo used to absorb the hquid, that the material, even if used several times, is not worth carting any considerable distancc. Dr. Gilbert found that 5 tons of absolutely dry earth, before usine; contained $16.7 \mathrm{lbs}$. of nitrogen.

Afte: being used once, ......5 tons of the dry earth contained 24.0 lbs.

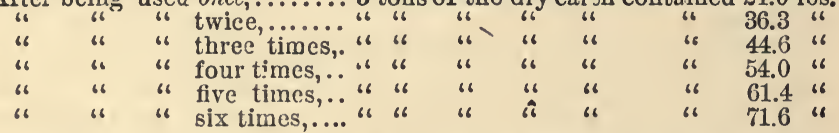

Dr. Vnelcker found that five tons of dry carth gained about $7 \mathrm{lbs}$. of n.trogen, and $11 \mathrm{lbs}$. of phosphoric acid, each time it was used in tie closets. If we consider each $1 b$. of nitrogen with the phosphori s acid worth 20 cents a lb., 5 tons of the dry earth, after bcing used once, would be worth $\$ 1.46$, or less than 30 cents a ton, and after it had been used six times, five tons of the material would be worti $\$ 11.98$, or about $\$ 2.40$ per ton.

In this calculation $I$ have not reckoned in the value of the nitrogen the soil contained before using. Soil, on a farm, is cheap.

It is clear from these facts that any earth-closet manure a farmer would be likely to purchase in the city has not a very high value. It is absurd to talk of making "guano" or any concentrated fertilizer out of the material from earth-closets. 
"It is rather a reflection on our seience and practical skill," said the Doctor, "but it looks at present as though the only plan to adopt in large eities is to use enormous quantities of water and wash the stuff into the rivers and oeeans for the use of aquatic plants and fishes. The nitrogen is not all lost. Some of it comes back to us in rains and dews. Of course, there are places where the sewage of our eities and villages ean be used for irrigating purposes. But when watcr is used as freely as it ought to be used for health, the sewage is so extremely poor in fertilizing matter, that it must be used in enormous quantities, to furnish a dressing equal to an application of 20 tons of stable-manure per aere."

"If," continued the Doetor, "the sewage is used merely as water for irrigating purposes, that is another question. The water itself may often be of great benefit. This aspect of the question has not received the attention it merits."

\section{PERUVIAN GUANO.}

Guano is the manure of birds that live prineipally on fish.

Fish eontain a high pereentage of nitrogen and phosphoric acid, and consequently when fish are digested and the carbon is burnt olit of them, the manure that is left contains a still higher percentage of nitrogen and phosphoric acid than the fish from which it was derived.

Guano is digested fish. If the guano, or the manure from the birds living on fish, has been preservel without loss, it would eontain not only a far higher percentage of nitrogen, but the nitrogen would be in a much more available condition, and eonsequently be more valuable than the fish from which the guano is made.

The differenee in the value of guano is largely due to a differenee in the elimate and loeality in which it is deposited by the birds. In a rainless and hot climate, where the bird-droprings would dry rapidly, little or no putrefaetion or fermentation would take place, and there would be no loss of nitrogen from the foriation and escape of ammonia.

In a damper elimate, or where there was more or lcss rain, the bird droppings would putrefy, and the ammonia would be liable to evaporate, or to be leached out by the rain.

Thirty years ago I saw a quantity of Peruvian guano that contained more than 18 per cent of nitrogen. It was remarkably light colored. You know that the white part of hen-droppings eonsists prineipally of uric aeid, whieh contains about 33 per eent of nitrogen.

For many years it was not difflcult to find guano eortaining 13 per cent of nitrogen, and genuine Peruvian guano was the chcap- 
est and best source of arailable nitrogen. But jatterly, not only has the price been advanced, but the quality of the guamo has deteriorated. It has contained less nitrogen and more phosphoric acid. Sie the Chapter on "Value of Fertilizers," Page £24.

\section{SALTS OF AMMONIA AND NITRATE OF SODA.}

"I wish," said the Deacon, "you would tell us something about the 'ammonia-salts' and nitrate of soda so long used in Lawes and Gilbert's experiments. I have never seen any of them."

"You could not invest a little money to better ac'vantage than to send for $a$ few bags of sulphate of ammonia and nitrate of soda. You would then sce what they are, and would learn more by using them, than I can tell you in a month. You use them just as you would common salt. As a rulc, the better plan is to sow them broadcast, and it is important to distribute them evenly. In sowing common salt, if you drop a handful in a place, it will kill the planis. $\Lambda$ nd so it is with nitrate of soda or sulphate of ammonia. Two or three pounds on a square rod will do good, but if you put half of it on a square yard, it will burn up the crop, and the other half will be applied in such a small quantity that you will see but little effect, and will conclude that it is a humbug. Judging from over thirty years' experience, I am safe in saying that not one man in ten can be trusted to sow these manures. They should be sown with as much care as you sow grass or clover-seed."

"The best plan," said the Doctor, "is to mix them with sifted coal-ashes, or with gypsum, or sifted carth."

"Perhaps so," said I, "though there is nothing gained by mixing earth or ashes with them, except in securing a more even distribution. And if I was going to sow them myself, I would much prefer sowing them unmixed. Any man who can sow wheat or barley can sow sulphate of ammonia or nitrate of soda."

"Lawes and Gilbert," said the Deacon, "used sulphate and muriate of ammonia, and in one or two instances the carbonate of ammonia. Which is the best?"

"The one that will furnish c mmonia or nitrogen at the cheapest rate," said the Doctor, "is the best to use. The muriate of ammonia contains the most ammonia, but the sulphate, in proportion to the ammonia, is cheaper than the muriate, and far cheaper than the carbonate.

Carbonate of ammonia contains $21 \frac{1}{2}$ per cent of ammonia.

Eu!phate of ammonia contains $255^{3}$ per cent of ammonia $=21^{1} / \mathrm{s}$ of nitrugen. 
Muriate of ammonia contains 31 per cent of ammonia $=25_{\frac{1}{2}}$ of nitrogen.

Nitrate of soda contains $16^{3} / 5$ per cent of nitrogen.

Nitrate of potash, 13⿱ㅗㄴ per cent of nitrogen.

From these figures you can ascertain, when you know the price of each, which is the cheapest source of nitrogen.

"True," said I, "but it must be understood that these figures represent the composition of a pure article. The commercial sulphate of ammonia, and nitrate of sodil, would usually contain 10 per cent of impurities. Lawes and Gilbert, who have certainly had much experience, and doubtless get the best commercial articles, state that a mixture of equal parts sulphate and muriate of ammonia contains about 25 per cent of ammonia. According to the figures given by the Doctor, the mixture would contain, if pure, over 28 per cent of ammonia. In other words, $90 \mathrm{lbs}$. of the pure article contains as much as $100 \mathrm{lbs}$. of the commercial article."

As to whether it is better, when you can buy nitrogen at the same price in nitrate of soda as you can in sulphate of ammonia, to use the one or the other will depend on circumstances. The nitrogen exists as nitric acid in the nitrate of soda, and as ammonia in the sulphate of ammonia. But there are good reasons to believe that before amnonia is used by the plants it is converted into nitric acid. If, therefore, we could apply the nitrate just where it is wanted by the growing crop, and when there is rain enough to thornughly distribute it through the soil to the depth of six or eight inches, there can be little doubt that the nitrate, in proportion to the nitrogen, would have a quicker and better effect than the sulphate of ammonia.

"There is another point to be considered," said the Doctor. "Nitric acid is much more easily washed out of the soil than ammonia. More or less of the ammonia enters into chemical combination with portions of the soil, and may be retained for months or years."

When we use nitrate of soda, we run the risk of losing more or less of it from leaching, while if we use ammonia, we lose, for the time being, more or less of it from its becoming locked up in insoluble combinations in the soil. For spring crops, such as barley or oats, or spring wheat, or for a meadow or lawn, or for topdressing winter-wheat in the spring, the nitrate of soda, provided it is sown early enough, or at any time in the spring, just previous to a heavy rain, is likely to produce a better effect than the sulphate of ammonia. But for sowing in the autumn on winter-wheat the ammonia is to be preferred. 
"Saltpetre, or nitrate of potash," said the Deacon, "does not contain as much nitrogen as nitrate of soda."

"And yet," said the Doctor, "if it could be purchased at the same price, it would be the cheaper manure. It contains $46 \frac{1}{2}$ per cent of potash, and on soils, or for crops where potash is needed, we may sometimes be able to purchase saltpetre to advantage."

"If I could come across a lot of damaged saltpetre," said I, " that could be got for what it is worth as manure, I should like to try it on my apple trees-one row with nitrate of soda, and one row with nitrate of potask. When we apply manure to apple trees, the ammonia, phosphoric acid, and potash, are largely retained in the first fev inches of surface soil, and the deeper roots get hold of only those portions which leach through the upper layer of earth. Nitric acid, however, is easily washed down into the subsoil, and would soon reach all the roots of the trees."

\section{$-$ \\ C H A P T E R XXXVII.}

\section{BONE-DUST AND SUPERPHOSPHATE OF LIME.}

Bone-dust is often spoken of as a phosphatic manure, and it has been supposed that the astonishing effect bone-dust sometimes produces on old pasture-land, is due to its furnishing phosphoric acid to the soil.

But it must be remembered that bone-dust furnishes nitrogen as well as phosphoric acid, and we are not warranted in ascribing the good effect of bones to phosphoric acid alone.

Bones differ considerably in composition. They consist essentially of gelatine and phosphate of lime. Bones from young animals, and the soft porous parts of all bones, contain more gelatine than the solid parts, or the bones from older animals. On the average, $1,000 \mathrm{lbs}$. of good commercial bone-dust contains $38 \mathrm{lbs}$. of nitrogen.

On the old dairy farms of Cheshire, where bone-dust produced such marked improvement in the quantity and quality of the pastures and meadows, it was usual to apply from 4,000 to 5,000 lbs per acre, and often mere. I other words, a dressing of bone-d $=s t$ 
frequently contained $200 \mathrm{lbs}$. of nitrogen per acre-equal to 20 or 25 tons of barn-yard manure.

"It has been supposed," said the Doctor, "that owing to the removal of so much phosphoric acid in the cheese sold from the farm, that the dairy pastures of Cheshire had been exhausted of phosphoric acid, and that the wonderful benefits following an application of bone-dust to these pastures, was due to its supplying phosphoric acid."

"I do not doubt," said I, "the value of phosphoric acid when applied in connection with nitrogen to old pasture lands, but I contend that the experience of the Cheshire dairymen with bonedust is no positive proof that their soils were particularly deficient in phosphoric acid. There are many instances given where the gelatine of the bones, alone, proved of great value to the grass. And I think it will be found that the Cheshire dairymen do not find as much benefit from superphosphate as they did from bone-dust. And the reason is, that the latter, in addition to the phosphoric acid, furnished a liberal dressing of nitrogen. Futhermore, it is not true that dairying specially robs the soil of phosphoric acid. Take one of these old dairy farms in Cheshire, where a dressing of bone-dust, according to a writer in the Journal of the Ruyal Agricultural Society, has caused 'a miserable corering of pink grass, rushes, and a variety of other noxious weeds, to give place to the most luxuriant herbage of wild clover, trefoil, and other succulent and nutritious grasses.' It is evident from this description of the pastures before the bones were used, that it would take at least three acres to keep a cow for a year.

"I have knuwn," says the same writer quoted above, "many a poor, honest, but half broken-hearted man raised from poverty to comparative independence, and many a sinking family saved from inevitable ruin by the help of this wonderful manure." And this writer not only spoke from observation and experience, but he showed his faith by his works, for he tells us that he had paid nearly $\$ 50,000$ for this manure.

Now, on one of these poor dairy farms, where it required 3 acres to keep a cow, and where the grass was of poor quality, it is not probable that the cows produced over $250 \mathrm{lbs}$. of cheese in a year. One thousand pounds of cheese contains, on the average, about $45 \frac{1}{2} \mathrm{lbs}$. of nitrogen; $2 \frac{1}{2} \mathrm{lbs}$. of potash. and $11 \frac{1}{2} \mathrm{lbs}$. of phosphoric acid. From this it follows, if $250 \mathrm{lbs}$. of cheese are sold annually from three acres of pasture, less than one $\mathrm{lb}$. of phosphoric acid per acre is exported from the farm in the cheese.

One ton of timothy-hay contains nearly $14 \frac{1}{2} \mathrm{lbs}$. of phosphoric 
acid. And so a farmer who raises a ton of timothy-hay per acre, and sells it, sends off as much phosphoric acid in one year as such a Cheshire dairyman as I have alluded to did in fourteen years.

What the dairymen want, and what furmers generally want, is nitrogen and phosphoric acid. Bone-dust furnishes both, and this was the reason of its wonderful effects.

It does not follow from this, that bone-dust is the cheapest and best manure we can use. It is an old and popular manure, and usually commands a good price. It sells for all it is worth. A dozen years ago, I bought ten tons of bone-dust at $\$ 18$ per ton. I have offered $\$ 25$ per ton since for a similar lot, but the manufacturers find a market in New York for all they can make.

Bone-dust, besides nitrogen, contains about 23 per cent of phosphoric acid.

"That does not give me," said the Deacon, "any idea of its value."

"Let us put it in another shape, then," said I. "One ton of good bone-dust contains about as much nitrogen as $8 \frac{1}{2}$ tons of fresh stable-manure, and as much plosphoric acid as 110 tons of fresh stable-manure. But one ton of manure contains more potash than 5 tons of bone-dust.

Bone-dust, like barnyard-manure, does not immediately yield up its nitrogen and phosphoric acid to plants. The bone phosphate of lime is insoluble in water, and but very slightly soluble in water containing carbonic acid. The gelatine of the bones would soon decompose in a moist, porous, warm soil, provided it was not protected by the oil and by the hard matter of the bones. Steaming, by removing the oil, removes one of the hindrances to decomposition. Reducing the bones as fine as possible is another means of increasing their availability.

Another gond method of increasing the availability of bone-dust is to mix it with barnyard-manure, and let both ferment together in a heap. I am inclined to think this the best, simplest, and most economical method of rendering bone-dust available. The bone-dust causes the heap of manure to ferment more readily, and the fermentation of the manure softens the bones. Both the manure and the bones are improved and rendered richer and more available by the process.

Another method of increasing the availability of bone-dust is by mixing it with sulphuric acid. 
The phosphate of lime in bones is insoluble in water, though rain water containing carbonic acid, and the water in soils, slowly dissolve it. By treating the bores with sulphuric acid, the phosphate of lime is decomposed and rendered soluble. Consequently, bone-dust treated with sulphuric acid will act much more rapidly than ordinary bone-dust. The sulphuric acid does not make it any richer in phosphoric acid or nitrogen. It simply renders them more available.

"And yet," said the Doctor, "the use of sulphuric acid for "dissolving' bones, or rather phosphate of lime, introduced a new era in agriculture. It is the grand agricultural fact of the nineteenth century."

"It is perhaps not necessary," said I, "to give any direction for treating bones with sulphuric acid. We have got beyond that. We can now buy superphosphate cheaper than we can make it from bones."

"But is it as good?" asked the Deacon.

"Soluble phosphate of lime," said I, "is soluble phosphate of lime, and it makes no difference whether it is made from burnt bones, or from phosphatic guano, or mineral phosphate. That question has been fully decided by the most satisfactory experiments."

"Before you and the Deacon discuss that subject," said the D=ctor, "it would be well to tell Charley what superphosphate is."

"I wish you would tell me," said Charley.

"Well," said the Doctor, " phosphate of lime, as it exists in bones, is composed of three atoms of lime and one atom of phosphoric acid. Chemists call it the tricalcic phosphate. It is also called the basic phosphaie of lime, and not unfrequently the 'bone-earth phosphate.' It is the ordinary or common form of phosphate of lime, as it exists in animals, and plants, and in the various forms of mineral phosphates.

"Then there is another phosphate of lime, called the dicalcic phosphate, or neutral phosphate of lime, or reverted phosphate of lime. It is composed of one atom of water, two atoms of lime, and one atom of phosphoric acid.

"Then we have what we call superphosphate, or acid phosphate of lime, or more properly monocalcic phosphate. It is composed of two atoms of water, one atom of lime, and one atom of phosphoric acid. This acid phosphate of line is soluble in noater.

"The manufacture of superphosphate of lime is based on these facts. The one-lime phosphate is soluh'e, the three-lime phosphate is insoluble. To convert the latter into the former, all we have to do is to take aroay trou atoms of lime. 
"Sulphuric acid has a stronger affinity for lime than phosphoric acid. And when you mix enough sulphuric acid with finely ground three-lime phosphate, to take away two atoms of lime, you get the phosphoric acid united with one atom of lime and two atoms of water."

"And what," asked the Deacon, "becomes of the two atoms of lime?"

"They unite with the sulphuric acid," said the Doctor, "and form plaster, gypsum, or sulphate of lime."

"The molecular weight of water," continued the Doctor, "is 18 ; of lime, 56 ; of sulphuric acid, 80 ; of phosphoric acid, 142.

"An average sample of commercial bone-dust," continued the Doctor, " contains about 50 per cent of phosphate of lime. If we take $620 \mathrm{lbs}$. of finely-ground bone-dust, containing $310 \mathrm{lbs}$. of three-lime phosphate, and mix with it $160 \mathrm{lbs}$. of sulphuric acid (say $240 \mathrm{tbs}$. common oil of vitriol, sp. gr. 1.7), the sulphuric acid will unite with $112 \mathrm{lbs}$. of lime, and leave the $142 \mathrm{lbs}$. of phosphoric acid united with the remaining 56 lbs. of lime."

"And that will give you," said the Deacon, "780 lbs. of "dissolved bones,' or superphosphate of lime."

"It will give you more than that," said the Doctor, "because, as I said before, the two atoms of lime $(112 \mathrm{lbs}$.) are replaced by two atoms (36 lbs.) of water. And, furthermore, the two atoms of sulphate of lime produced, contained two atoms (36 lbs.) of water. The mixture, therefore, contains, even when perfectly dry, 72 lbs. of water."

"Where does this water come from?" asked the Deacon.

"When I was at Rothamsted," said I, "the superphosphate which Mr. Lawes used in his experiments was made on the farm from animal charcoal, or burnt bonss, ground as fine as possiblethe finer the better. We took $40 \mathrm{lbs}$. of the meal, and mixed it with $20 \mathrm{lbs}$. of water, and then poured on $30 \mathrm{lbs}$. of common sulphuric acid (sp. g. 1.7), and stirred it up rapidly and thoroughly, and then threw it out of the vessel into a heap, on the earth-floor in the barn. Then mixed another portion, and so on, until we had the desired quantity, say two or three tons. The last year I was at Rothamsted, we mixed $40 \mathrm{lbs}$. bone-meal, $30 \mathrm{lbs}$. water, and 30 lbs. acid; and we thought the additional water enabled us to mix the acid and meal together easier and better."

"Dr. Habirshaw tells me," said the Doctor, "that in making the 'Rectified Peruvian Guano' no water is necessary, and none is used. The water in the guano and in the acid is sufficient to 
furnish the two atoms of water for the phosphate, and the two atoms for the sulphate of lime."

"Such is undoubtedly the case," said I, "and when large quantities of superphosphate are made, and the mixing is done by machinery, it is not necessary to use water. The advantage of using water is in the greater ease of mixing."

"Bone-dust," said the .Doctor, "cuntains about 6 per cent of water, and the sulphuric acid (sp. g. 1.7) contains about one-third its weight of water. So that, if you take $620 \mathrm{lbs}$. of bone-dust, and mix with it $240 \mathrm{lbs}$. of common sulphuric acid, you have in the mixture $117 \mathrm{lbs}$. of water, which is $45 \mathrm{lbs}$. more than is needed to furnish the water of combination."

"The superphosphate produced from $620 \mathrm{lbs}$. of bones, therefore," continued the Doctor, "would contain:

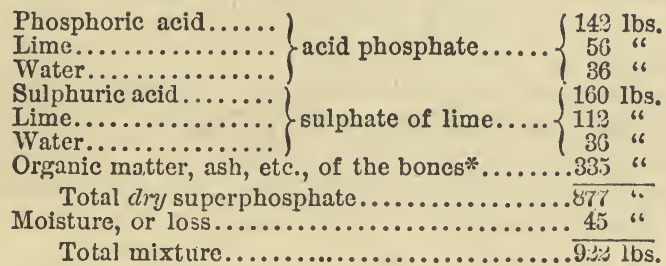

* Containing nitrogen, $23 \frac{1}{2} \mathrm{Dbs}$.

"There is a small quantity of carbonate of lime in the bones," said I, "which would take up a little of the acid, and you will have a remarkably good article if you calculate that the $620 \mathrm{lbs}$. of bone-dust furnish you half a ton $(1,000 \mathrm{lbs}$.) of superphosphate. It will be a better article than it is practically possible to make."

"Assuming that it made balf a ton," said the Doctor, "it would contain $14 \frac{1}{4}$ per cent of soluble phosphoric acid, and $2 \frac{1}{3}$ per cent of nitrogen."

"With nitrogen at 20 cents per lb., and soluble phosphoric acid at $12 \frac{1}{2}$ c. per $1 \mathrm{~b}$., this half ton of superphosphate, made from 620 lbs. of good bone-dust, would be worth $\$ 22.50$, or $\$ 45$ per ton."

"Or, to look at it in another light," continued the Doctor, "a ton of bone-dust, made into such a superphosphate as we are talling about, would be worth \$72.58."

"How much," asked the Descon, "would a ton of the bonc-dust be considered wortin before it was converted into superphosphate?"

"A ton of bone-dust," replied the Doctor, "contains 76 lbs. of nitrogen, worth, at 18 cents per ib., $\$ 13.68$, and 464 lbs. phosphoric acid, worth 7 cents per $1 b ., \$ 32.48$. In other words, a ton of bonedust, at the 'usual estimate, is worth $\$ 46.16 . "$ 
"And," said the Deacon, "after it is converted into superphos. phate, the same ton of bones is worth $\$ 72.58$. It thus appears that you pay $\$ 26.42$ per ton for simply making the phosphoric acid in a ton of bones soluble. Is'nt it paying a little too much for the whistle?"

"Pussibly such is the case," said I, "and in point of fact, I think bone-dust, especially from steamed or boiled bones, can be used with more economy in its natural state than in the form of superphosphate."

Superphosphate can be made more economically from mineral phosphates than from bones - the nitrogen, if clesired, being supplied from fish-scrap or from some other cheap source of nitrogen.

But for my own use I would prefer to buy a good article of superphosphate of lime, containing no nitrogen, provided it can be obtained cheap enough. I would buy the ammoniacal, or nitrogenous manure separately, and do my own mixing-unless the mixture could be bought at a less cost than the same weight of soluble phosphoric acid, and available nitrogen could be obtained separately.

$\Lambda$ pure superphosphate-and by pure I mean a-superphosphate containing no nitrogen-can be drilled in with the sced without injury, but I should be a little afraid of drilling in some of the ammoniacal or nitrogenous superphosphates with small seeds.

And then, again, the "nitrogen" in a superphosphate mixture may be in the form of nitric acid, or sulphate of ammonia, in one case, or, in another case, in the form of hair, wonllen rags, hide, or leatber. It is far more valuable as nitric acid or ammonia, because it will act quicker, and if I wanted hair, woollen rags, horn-shavings, etc., I would prefer to have them separate from the superphosphate.

\section{$\longrightarrow$

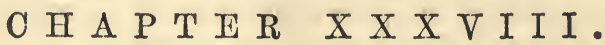

\section{SPECIAL MANURES.}

Twenty five to thirty years ago, much was said in regard to special zanurcs. Fertilizers were prepared for the different crops with special reference to the composition of the plants.

"But it was known then, as now," said the Doctor, "that all our agricultural plants were composed of the same elements."

"True, but what was claimed was this : Some crops contain, for 
instance, more phosphoric acid than other crops, and for thcse a manure rich in phosphoric acid was provided. Others contained a large proportion of potash, and these were called ' rotash crops,' and the manure prescribed for them was rich in potash. And so with the other ingredients of plants."

"I recollect it well," said the Doctor, " and, in truth, for several years I had much faith in the idea. It was advocated with consummate ability by the lamented Licbig, and in fact a patent was taken out by the Musgraves, of Liverpool, for the manufacture of Liebig's Special Manures, based on this theory. But the manures, though extensively used by the leading farmers of England, and endorsed by the highest authorities, did not in the end stand the test of actual farm practice, and their manufacture was abandoned. And I do not know of any experienced agricultural chemist who now advocates this doctrine of special manures.

"Dr. Vœlcker says: 'The ash-analyses of plants do not afford a sufticiently trustworthy guide to the practical farmer in selecting the kind of manure which is best applied to each crop.'"

"Never mind the authorities," said the Deacon; "what we want are facts."

"Well," replied the Doctor, "take the wheat and turnip crop as an illustration.

"We will suppose that there is twice the weight of wheat-straw as of grain; and that to 10 tons of bulbs there is 3 tons of turniptops. Now, $100 \mathrm{lbs}$. each of the ash of these two crops contain:

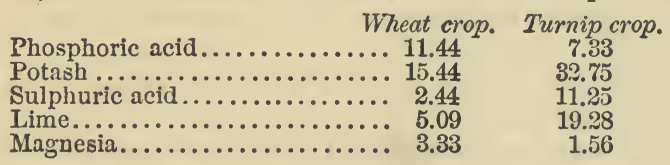

"There are other ingredients," continued the Doctcr, "but these are the most important.

"Now, if you were going to compound a manure for wheat, say 100 lbs., consisting of potash and phosphoric acid, what would be the proportions?"

The Deacon figured for a few moments, and then produced the following table:

100 LBS. SPECIAL MANURE FOR WHEAT AND TURNIPS.

Wheat manure. Turnip manure.

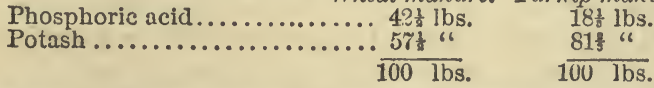

"Exactly," said the Doctor, " and yet the experiments of Lawes 
and Gilbert clearly prove that a soil neels to be richer in available phosphoric acid, to produce even a fair crop of turnips, than to produce a large crop of wheat. And the experience of farmers ererywhere tends in the same direction. England is the greatest turnip-growing country in the world, and you will find tnat where one farmer applies potash to turnips, or superphosphate to wheat, a hundred farmers use superphosphate as a special manure for the turnip crop."

"And we are certainly warranted in saying," continued the Doctor, " that the composition of a plant affords, in practical agriculture, and on ordinary cultivated soils, no sort of indication as to the composition of the manure it is best to apply to the crop."

"Again," continued the Doctor, "if the theory was a correct one, it would follow that those crops which contained the most nitrogen, would require the most nitrogen in the manure. Beans, peas, and clover would require a soil or a manure richer in available nitrogen than wheat, barley, or oats. We know that the very reverse is true-know it from actual, and repeated, and long-continued experiments like those of Lawes and Gilbert, and from the common experience of farmers everywhere."

"You need not get excited," said the Deacon, "the theory is a very plausible one, and while I cannot dispute your facts, I must confess I cannot see $20 h y$ it is not reasonable to suppose that a plant which contains a large amount of nitrogen should not want a manure specially rich in nitrogen; or why turnips which contain so much potash should not want a soil or manure specially rich in potash."

"Do you recollect," said I, " that crop of turnips I raised on a poor blowing-sand ?"

"Yes," said the Deacon, "it was the best crop of turnips I ercr saw grow."

"That crop of turnips," said I, "was due to a dressing of superphosphate of lime, with little or no potash in it."

"I know all thaî," said the Deacon. "I admit the fact that superphosphate is a good manure for turnips. What I want to know is the reason why superphosphate is better for turnips than for wheat?"

"Many reasons might be given," said the Doctor; "Prof. Volcker attributes it to the limited feeding range of the roots of turnips, as compared to wheat. 'The roots of wheat,' says Prof. Vœlcker, 'as is well known, penetrate the soil to a much greater depth than the more delicate feeding fibres of the roots of turnips. Wheat, remaining on the ground two or three months longer than 
turnips, can avail itself for a longer period of the resources of the soil; therefore in most cases the phosphoric acid disseminated through the soil is amply sufficient to meet the requirements of the wheat crop; whilst turinips, depending on a thinner depth of soil during their shorter period of growth, cannot assimilate sufficient phosphoric acid, to come to perfection. This is, I believe, the main reason why the direct supply of readily available phosphates is so beneficinl to root-crops, and not to wheat."

"This reason," said I, "has never been entirely satisfactory to me. If the roots of the turnip have such a limited range, how are they able to get such a large amount of potash?

"It is probable that the turnip, containing such a large relative amount of potash and so little phosphoric acid, has roots capable of absorbing potash from a very weak solution, but not so in regarü to phosphoric acil."

"There is another way of looking at this matter," said the Doctor. "You must recollect that, if turnips and wheat were growing in the same field, both plants get their food from the same solution. And instead of supposing that the wheat-plant has the power of taking up more phosphoric acid than the turnip-plant, we may suppose that the turnip has the power of rejecting or excluding a portion of plosphoric acid. It takes up no more potash than the wheal-plant, but it takes less phosphoric acid."

But it is not necessary to speculate on this matter. For the present we may accept the fact, that the proportion of potash, phosploric acid, and nitrogen in the crop is no indication of the proper proportion in which these ingredients should be applied to the soil for thes crops in manure.

It may well be that we should use special manurcs for special crops; but we must ascertain what thesc manures should bc, not from analyses of the crops to be grown, but from experiment and experience.

So far as present facts throw light on this subject, we should conclude that those crops which contain the least nitrogen are the most likely to be benefited by its artificial application; and the crops containing the most phosphoric acid, are the crops to which, in ordinary practical agriculture, it will be unprofitable to apply superphosphate of lime.

"That," said the Doctor, "may be stating the case a little too strong."

" "Perhaps so," said I, "but you must recollect I am now speaking of practical agriculture. If I wanted to raise a good crop of cabbage, I should not think of consulting a chemical analysis 
of the cabbage. If I set out cabbage on an acre of land, which, without manure, would produce 16 tons of cablage, does any one mean to tell me that if I put the amount of nitrogen, phosphoric acid and potash which 10 tons of cabbage contain, on an adjoining acre, that it would produce an extra grow th of 10 tons of cabbage. I car not believe it. The facts are all the other way. Plant growth is not such a siniple matter as the advocates of this theory, if there be any at this late day, would have us believe."

\section{$-$ \\ C H A P T E R X X X X}

\section{VALUE OF FERTILIZERS.}

In $185 \%$, Prof. S. W. Johnson, in his Report to the Connecticut Agricultural Society, adopted the following valuation:

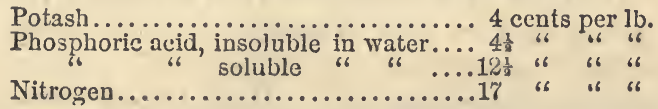

Analyses of many of the leading commercial fertilizers at that time showed that, when judged by this standard, the price charged was far above their actual value. In some cases, manures selling for $\$ 60$ per ton, contained nitrogen, phosphoric acid, and potash worth only from $\$ 20$ to $\$ 25$ per ton. And one well-known manure, which sold for $\$ 28$ per ton, was found to be worth only $\$ 2.33$ per ton. A Bone Fertilizer selling at $\$ 50$ per ton, was worth less than $\$ 14$ per ton.

"In 185.2," said the Doctor, "superphosphate of lime was manufactured by the New Jersey Zinc Co., and sold in New York at $\$ 50$ per ton of 2,000 lbs. At the same time, superphosphate of lime made from Coprolites, was selling in England for $\$ 24$ per ton of 2,240 lbs. The late Prof. Mapes commenced making "Im. proved Superphosphate of Lime," at Newark, N. J., in 1852, and Mr. De Burg, the same year, made a plain superphosphate of lime in Brooklyn, N. Y. The price, in proportion to value, was high, and, in fact, the same may be said of many of our superphos. phate manures, until within the last few years.

Notwithstanding the comparatively high price, and the uncertain quality of these commercial manures, the demand has been steadily on the increase. We have now many honorable and in- 
telligent men engaged in the manufacture and sale of these artificial manures, and owing to more definite knowledge on the part of the manufacturers and of the purchascrs, it is not a difficult matter to find manures well worth the money asked for them.

"A correct analysis," said I, "furnishes the only sure test of value. 'Testimonials' from farmers and others are pre-eminently unreliable. With over thirty years' experieuce in the use of these fertilizers, I would place far more confidence on a good and reliable analysis than on any actual trial I could make in the field. Testimonials to a patent fertilizer are about as reliable as testimonials to a patent-medicine. In buying a manure, we want to know what it contains, and the condition of the constituents."

In 1877, Prof. S. W. Johnson gives the following firures, showing "the trade-valucs, or cost in market, per pound, of the ordinary occurring forms of nitrogen, phosphoric acid, and potasi, as recently found in the New York and New England markets:

Nitrngen in ammonia and nitrates. "6 in Peruvian Guano, fine steamed bone, dried and fine ground blood, meat, and fish............. $\approx 0$

$"$ in fine ground bone, horn, and wooi-dust............ 13

" in coarse bone, horn-shavings, and fish-serap...... 1;

Phosphoric acid soluble in water..................... 1 1 $\frac{2}{8}$

" " "reverted," and in Peruvian Guino......... 9

" " insoluble, in fine bone and tish guano...... 7

" " " in coarse bone, bone-ash, and " " " in fine ground rock phosphate.... 5

Potash in high-grade sulphate............................ 9

" in kainit, as sulphate................................. $7 \frac{1}{2}$

" in muriate, or potassium chloride................. 6

"These 'estimated values," " says Prof. Johnson, " are not fixed, but vary with the state of the market, and are from time to time subject to revision. They are not exact to the cent or its fractions, because the same article sells cheaper at commercial or manufacturing centers than in country towns, cheaper in large lots than in small, cheaper for cash than on time. These values are high enough to do no injustice to the dealer, and accurate enough to serve the object of the consumer.

"By multiplying the per cent of Nitrogen, etc., by the tradevalue per pound, and then by 20 , we get the value per ton of the several ingredients, and adling the latter together, we obtain the total estimated value per ton.

"The uses of the 'Valuation' are, 1st, to show whether a given lot or brand of fertilizer is worth as a commodity of traje what it costs. If the selling price is no higher than the estimated value, 
the purcbaser may be quile sure that the price is reasonable. If the sclling price is but $\$ 2$ to $\$ 3$ per ton more than the estimated value, it may still be a fair price, but if the cost per ton is $\$ 5$ or more over the estimated value, it would be well to look further. 2a, Comparisons of the estimated values, and selling prices of a number of fertilizers will generally indicate fairly which is the best for the money. But the 'estimated value' is not to be too litcraily construed, for analysis cannot always decide accuratcly what is the form of nitrogen, etc., while the mechanical condition of a ferilizer is an item whose influence cannot always be rightly expressed or appreciated.

"The Agricultural value of a fertilizer is measured by the benefit reccived from its use, and depends upon its fertilizing effect, or crop-producing power. As a broad general rule it is true that Peruvian guano, superphosphates; fish-scraps, dried blood, potash salts, plaster, etc., have a high agricultural value which is related to their trade-value, and to a degree determines the latter value. But the rule has many cxceptions, and in particular instances the tradc-valuc cannot always be expected to fix or even to indicate the agricultural value. Fertilizing effect depends largeiy upon soil, crop, and weather, and as these vary from place to place, and from year to year, it cannot be foretold or estimated except by the results of past experience, and then only in a general and probable manner."

"It will be scen," said the Doctor, "that Prof. Johnson places a higher value on potash now than he did 20 years ago. He retains the same figures for soluble phosphoric acid, and makes a very just and proper discrimination between the different values of different forms of nitrogen and phosphoric acid."

"The prices," said I, "are full as high as farmers can afford to pay. But there is not much probability that we shall see them permanently reduced. The tendency is in the other direction. In a public address Mr. J. B. Lawes has recently remarked: 'A future generation of British farmers will doubtless hear with some surprise that, at the close of the manure season of 1876 , there were 40,000 tons of nitrate of soda in our docks, which could not find purchasers, although the price did not exceed $£ 12$ or $£ 13$ per ton.' "

"He cvidently thinks," said the Doctor, " that available nitrogen is cheaper now than it will be in ycars to come."

"Nitrate of soda," said I, "at the prices named, is only $2 \frac{1}{2}$ to $2 \frac{8}{4}$ cents per 1 ., and the nitrngen it contains would cost less than 18 cents per lb., instead of 24 cents, as given by Prof. Johnson."

"No. 1 Peruvian Guano, 'guaranteed,' is now sold," said the 
Doctor, "at a price per ton, to be determined by its composition, at the following rates:

Value per pound.

Nitrogen (ammonia, $\left.17 \frac{1}{2} c.\right) \ldots \ldots \ldots \ldots \ldots \ldots \ldots 1 \frac{1}{4} \mathrm{c}$.

Soluble phosphoric acid.................... $10 \mathrm{c}$.

Reverted " "

Insoluble " " $\quad$ "....................... $2 \mathrm{c}$.

Potash, as sulphate and phosphate........... $77_{\frac{1}{3}} \mathrm{c}$.

"The first cargo of Peruvian guano, sold under this guarantee, contained :

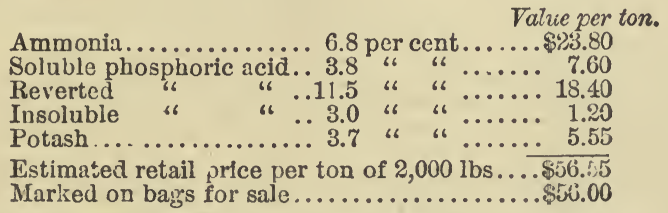

The second cargo, sold under this guarantee, contained:

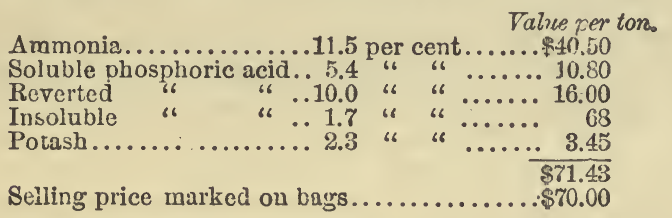

"It is interesting," said I, "to compare these analyses of Peruvian guano of to-day, with Peruvian guano brought to England twenty-nine or thirty years ago. I saw at Rothamsted thirty years ago a bag of guano that contained 22 per cent of ammonia. And farmers could then buy guano guaranteed by the dealers (not by the agents of the Peruvian Government), to contain 16 per cent of ammonia, and 10 per cent of phosphoric acid. Price, £9 5s. per ton of $2,240 \mathrm{lbs}$. - say $\$ 40$ per ton of $2,000 \mathrm{lbs}$.

The average composition of thirty-two cargoes of guano im. ported into England in 1849 was as follows :

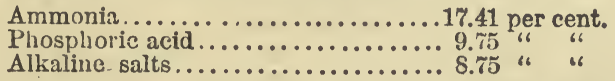

At the present valuation, adopted by the Agents of the Peruvian guano in New York, and estimating that 5 per cent of the phosphoric acid was soluble, and 4 per cent reverted, and that there was 2 lbs. of potash in the alkaline salts, this guano would bo worth : 
Value per ton of $2,000 \mathrm{lbs}$.

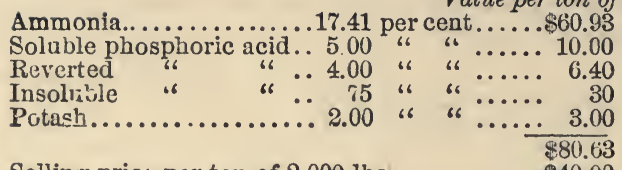

Selling price per ton of 2,000 lbs,..........\$40.00

Ichaboe guano, which was largely imported into England in 1844-5, and used extensively as a manure for turnips, contained, on the average, $7 \frac{1}{2}$ per cent of ammonia, and 14 per cent of phosphoric acid. Its value at the present rates we may estimate as follows :

Ammonia, $7 \frac{1}{2}$ per cent............................... \$26.25

Soluble Phosphoric acid, 4 per cent...................... 8.00

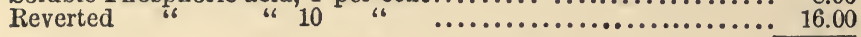

Selling price per ton of 2,000 lbs........................ \$21.80

The potash is not given, or this would probably add four or five dollars to its estimated value.

"All of which goes to show," said the Deacon, "that the Peruvian Government is asking, in proportion to value, from two to two and a half times as much for guano as was charged twenty. five or thirty years ago. That first cargo of guano, sold in New York under the new guarantee, in 1877 , for $\$ 56$ per ton, is worth no more than the Ichaboe guano sold in England in 1845, for less than $\$ 22$ per ton!

"And furthermore," continued the Deacon, "from all that I can learn, the guano of the present day is not only far ponrer in nitrogen than it was formerly, but the nitrogen is not as soluble, and consequently not so valuable, pound for pound. Much of the guano of the present day bears about the same relation to genuine old-fashioned guano, as leached ashes do to unleached, or as a ton of manure that has been leached in the barn-yard does to a ton that has been kept under cover."

"True, to a certain extent," said the Doctor, "but you must recollect that this 'guaranteed' guano is now sold by analysis. You pay for what you get and no more."

"Exactly," said the Deacon, "but what you get is not so good. A pound of nitrogen in the leached guano is not as available or as valuable as a pound of nitrogen in the unleached guano. An this fact ought to be understood."

"One thing," said I, "seems clear. The Peruvian Government is charging a considerably higher price for guano, in proportion to its actual value, than was charged 20 or 25 years ago. It may 
be, that the grano is still the cheapest manure in the market, but at any rate the price is higher than formerly-while there has been no corresponding advance in the price of produce in the markets of the world."

\section{POTASH AS A MANURE.}

On land where fish, fish-scrap, or guano, has been used frce!. for some years, and the crops exported from the farm, we may c:pect a relative deficiency of potash in the soil. In such a case, an application of unleached ashes or potash-salts will be likely to produce a decided benefit.

Clay or loamy land is usually richer in potash than soils of a more sandy or gravelly character. And on poor sandy land, the use of fish or of guano, if the crops are all sold, will be soon likely to prove of little benefit owing to a deficiency of potash in the soil. Ther may produce good crops for a few years, but the larger the crops produced and sold, the more would the soil become deficient in potash.

We have given the particulars of Lawes and Gilbert's experiments on barley. Mr. Lawes at a late meeting in London, stated that "he had grown 25 crops of barley one after the other with nitrogen, either as ammonia or nitrate of soda, but without potash, and that by the use of potash they had produced practically no better result. This year (187\%), for the first time, the potash had failed a little, and they had now produced 10 or 12 bushels more per acre with potash than without, showing that they were coming to the end of the available potash in the soil. This year (1877), they obtained 54 bushels of barley with potash, and 42 bushels without it. Of churse, this was to be expected, and they had expected it much sooner. The same with wheat; he expectcd the end would come in a few years, but they had now gone on bctween 30 and 40 years. When the end came they would not be sorry, because then they would have the knowledge they were seeking for."

Dr. Vœlcker, at the same mecting remarked: "Many soils contained from 11 to 2 per cent of available potash, and a still larger quantity locked up, in the shape of minerals, which only gradually came into play; but the quantity of potash carried off in crops did not exceed $2 \mathrm{cwt}$. per acre, if so much. Now 0.1 per cent of any constituent, calculated on a depth of six inches, was equivalent to one ton per acre. Therefore, if a soil contained only 0.1 per cent of potash, a ton of potash might be carried off from a 
depth of 6 inches. But you had not only 0.1 per cent, but something like $1 \frac{1}{2}$ per cent and upwards in many soils. It is quite true there were many soils from which you could not continuously take crops without restoring the potash."

"In all of which," said the Doctor, "there is nothing new. It does not help us to determine whether potash is or is not deficient in our soil."

"That," said I, "can be ascertained only by actual experiment. Put a little hen-manure on a row of corn, and on another row a little hen-manure and ashes, and on amother row, ashes alone, and leave one row without anything. On my farm I am satisfied that we need not buy potash-salts for manure. I do not say they would do no good, for they may do good on land not deficient in available potash, just as lime will do good on land containing large quantities of lime. But potash is not what my land needs to make it produce maximum crops. It needs available nitrogen, and possibly soluble phosphoric acid."

The system of farming adopted in this section, is much more likely to impoverish the soil of nitrogen and phosphoric acid than of potash.

If a soil is deficient in potash, the crop which will first indicate the deficiency, will probably be clover, or beans. Farmers who can grow large crops of red-clover, need not buy potash for manure.

On farms where grain is largely raised and sold, and where the straw, and corn-stalks, and hay, and the hay from clover-seed are retained on the farm, and this strawy manure returned to the land, the soil will become poor from the lack of nitrogen and phosphoric acid long before there would be any need of an artificial supply of potash.

On the other hand, if farmers should use fish, or guano, or superphosphate, or nitrate of soda, and sell all the hay, and straw, and potatoes, and root-crops, they could raise, many of our sandy soils would soon become poor in available potash. But even in this case the clover and beans would show the deficiency sooner than wheat or even potatoes.

"And yct we are told," said the Deacon," that potatoes contain no end of potash."

"And the same is true," said I, "of root-crops, such as mangelwurzel, turnips, etc., but the fact has no other significance than this: If you grow potatoes for many years on the same land and manure them with nitrogenous manures, the soil is likely to be speedily impoverished of potash."

"But suppose," said the Deacon, "that you grow potatoes on the 
same land without manure of any kind, would not the soil become equally poor in potash?"

"No," said I, " because you would, in such a case, get very small crops-small, not from lack of potash, but from lack of nitrogen. If I had land which had grown corn, potatoes, wheat, oats, and hay, for many years without manure, or an occasional dressing of our common barnyard-manure, and wanted it to produce a good crop of potatoes, I should nct expect to get it by simply applying potash. The soil might be poor in potash, but it is almost certain to be still poorer in nitrogen and phosphoric acid.

Land that has been manured with farm-yard or stable-manure for years, no malter how it has been cropped, is not likely to need potash. The manure is richer in potash than in vitrogen and phosphoric acid. And the same may be said of the soil.

If a farmer uses nitrogenous and phosphatic manures on his clayey or loamy land that is usually relatively rich in potash, and will apply his common manure to the sandy parts of the farm, he will rarely need to purchase manures containing potash. 


\section{H A P T E R X .}

\section{RESTORING FERTILITY TO THE SOIL.}

BY SIR J. B. LAWES, BART., LL.D., F.H.S., ROTHAMSTED, ENG.

$\Lambda$ relation of mine, who already possessed a very considerable estate, consisting of light land, about twenty years ago purchased a large property adjoining it at a very high price. These were days when farmers were flourishing, and they no more anticipated what was in store for them in the future, than the inhabitants of the earth in the days of Noah.

Times have changed since then, and bad seasons, low prices of wheat, and cattle-disease, have swept off the tenants from these two estates, so that my relation finds himself now in the position of being the unhappy owner and occupier of five or six farms, extending over several thousand acres-one farm alone occupying an area of two thousand four hundred acres. Fortunately for the owner, he possesses town property in addition to his landed estates, so that the question with him is not, as it is with many land ovners, how to find the necessary capital to cultivate the land, but, having found the capital, how to expend it in farming, so as to produce a proper return.

It is not very surprising that, under these circumstances, my opinion should have been asked. What, indeed, would have been the use of a relation, who not only spent all his time in agricultural experiments, but also pretended to teach our neighbors how to farm on the other side of the Atlantic, if he could not bring his science to bear on the land of an adjoining county! Here is the land-my relation might naturally sayhere is the money, and I have so much confidence in your capacity that I will give you carte-blanche to spend as much as you please-what am I to do?

An inspection of the property brought out the following facts - that all the land was very light, and that you might walk over the fresh plowed surface in the wettest weather without any clay sticking to your boots : still a portion of the soil was dark in color, and therefore probably contained a sufficient amount of fertility to make cultivation profitable, provided the management could be conducted with that care and economy which aro absolute essentials in a business where the expenditure is always pressing closely upon the income. 
Upon land of this description meat-making is the backbone of the system, which must be adopted, and a large breeding flock of sheep the first essential towards success.

Science can make very little improvement upon the fourcourse rotation-roots, barley, clover, and wheat, unless, perhaps, it may be by keeping the land in clover, or mixed grass and clover, for two or three years.

$\Lambda$ good deal of the land I was inspecting was so light, that, in fact, it was hardly more than sand, and for some years it had been left to grow anything that came up, undisturbed by the plow.

To a practised eye, the character of the natural vegetation is a sure indication of the fertility of the soil. Where herds of buffaloes are to be seen-their sides shaking with fat-it is quite evident that the pastures upon which they feed cannot be very bad; and in the same way, where a rank growth of weeds is found springing up upon land that has been abandoned, it may be taken for certain that the elements of food exist in the soil. This ground was covered with vegetation, but of the most impoverished description, even the "Quack" or "Couch-grass" could not form a regular carpet, but grew in small, detached bunches; everything, in fact, bore evidence of poverty.

Possibly, the first idea which might occur to any one, on seeing land in this state, might be: Why not grow the crops by the aid of artificial manures?

Let us look at the question from two points of view : first, in regard to the cost of the ingredients; and, secoridly, in regard to the growth of the crop.

We will begin with wheat. A crop of wheat, machine-reaped, contains, as carted to the stack, about six pounds of soil ingredients in every one hundred pounds; that is to say, each five pounds of mineral matter, and rather less than one pound of nitrogen, which the plant takes from the soil, will enable it to obtain ninety-four pounds of other substances from the atmosphere. To grow a crop of twenty bushels of grain and two thousand pounds of straw, would require one hundred and sixty pounds of minerals, and about thirty-two pounds of nitrogen; of the one hundred and sixty pounds of minerals, onehalf would be silica, of which the soil possesses already more than enough ; the remainder, consisting of about eighty pounds of potash and phosphate, could be furnished for from three to four dollars, and the thirty-two pounds of nitrogen could be purchased in nitrate of soda for six or eight dollars. 
The actual cost of the ingredients, therefore, in the crop of twenty bushels of wheat, would be about ten to twelve doilars. But as this manure would furnish the ingredients for the growth of both straw and grain, and it is customary to return the straw to the land, after the first crop, fully one-third of the cost of the manure might, in consequence, be deducted, which would make the ingredients of the twenty bushels amount to six dollars. Twenty bushels of wheat in England would sell for twenty-eight dollars; therefore, there would be twenty-twc dollars left for the cost of cultivation and profit.

A French writer on scientific agriculture has employed figures very similar to the above, to show how Fiench farmers may grow wheat at less than one dollar per bushel. At this price they might certainly defy the competition of the United States. It is one thing, however, to grow crops in a lecture room, and quite another to grow them in a field. In dealing with artificial manures, furnishing phosphoric acid, potash, and nitrogeir, we have substances which act upon the soil in very differents ways. Phosphate of lime is a very insoluble substance, and requires an enormous amount of vater to dissolve it. Salts of potash, on the other hand, are very soluble in water, but form very insoluble compounds with the soil. Salts of ammonia and nitrate of soda are perfectly soluble in water. When applied to the land, the ammonia of the former substance forms an insoluble compound with the soil, but in a very short time is converted into nitrate of lime; and with this salt and nitrate of soda, remains in solution in the soil water until they are either taken up by the plant or are washed away into the drains or rivers.

Crops evaporate a very large amount of water, and with this water they attract the soluble nitrate from all parts of the soil. Very favorable seasons are therefore those in which the soil is neither too dry nor too wet; as in one case the solution of nitrate becomes dried up in the soil, in the other it is either washed away, or the soil remains so wet that the plant cannot evaporate the water sufficiently to draw up the nitrates which it contains.

The amount of potash and phosphoric acid dissolved in the water is far too small to supply the requirements of the plant. and it is probable that what is required for this purpose is dissolved by some direct action of the roots of the plant on corning in contact with the insoluble phosphoric acid and potash is the soil. 
In support of this view, I may mention that we have clear evidence in some of our experiments of the wheat crop taking up both phosphates and potash that were applied to the land thirty years ago.

To suppose, therefore, that, if the ingredients which exist in twenty bushels of wheat and its straw, are simply applied to a barren soil, the crop will be able to come in contact with, and take up these substances, is to assumo what certainly will not take place.

I have often expressed an opinion that arable land, could not be cultivated profitably by means of artificial manures, unless the soil was capable of producing, from its own resources, a considerable amount of produce; still the question had never up to this time come before me in a distinct form as one upon which I had to decide one way or the other. I had, however, no hesitation in coming to the conclusion, that grain crops could never be grown at a profit upon my relation's land, and that consequently, for some years, it would ba better to give up the attempt, and try to improve the pasture.

After what I have said about the insolubility of potash and phosphoric acid, it may possibly be asked-why not give a good dose of these substances at once, as they do not wash out of the soil-say enough to grow sixty crops of grain, and apply the nitrate, or ammonia every year in just sufficient amounts to supply the wants of the crop?

The objections to this plan are as fcllows: assuming the most favorable conditions of climate, and the largest possible produce, the wheat could certainly not take up the whole of the thirty-two pounds of nitrogen applied, and the crop which requires nearly one pound of nitrogen in every one hundred pounds of gross produce, would be certainly less than three thousand two hundred pounds, if supplied with only thirty-two pounds of nitrogen. If we take the total produce of the best and worst wheat crop, grown during the forty years of our experiments, we shall arrive at a better understanding in the matter. The following are the figures :

Weight of Dry Produce of Wheat Per Acre.

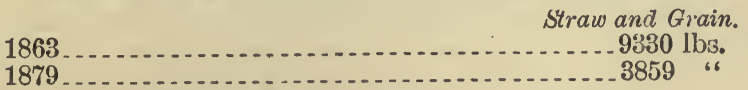

In order to ascertain the increase due to the nitrogen of the salts of ammonia or nitrate of soda, we must deduct from the 
crop the produce obtained, where mineral manuras without nitrogen were used. In 1863 this amount was three thousand pounds, and in 1879 it was ons thousand two hu.dred pounds. Deducting these amounts from the gross produce in each case, leaves sis thousand three hundred and thirty as the produce due to the nitrogen in the saason of 1833 , and two thousand six hundred and fifty-nine as the producs due to the nitrogen in 1879.

But in each case we applied the same amount of nitrogen, eighty-seven pounds; and as the amount of nitrogen in a wheat crop, as carted from the field, contains less than one per cent. of nitrogen, it is evident that if all that was contained in the manure had been taken up by the plant, the increased crop should have weighed ei ght thousand seven hundred pounds instead of six thousand thros hundred and thirty. Thus even in our best year, some of thə nitrogen applied failed to produce growth; and when we come to the bad year we find that only twenty-six and a half pounds were taken up out of the eightyseven pounds applied, thus leaving more than two-thirds of the whole unaccounted for.

Seasons are only occasionally either very bad or very good. What we call an average season does not differ very much from the mean of the best and worst years, which in this case would be represented by a crop of four thousand four hundred and ninety-four pounds, containing nearly forty-five pounds of nitrogen. I may say that, although I have employed one per cent. to aroid fractions in my calculations, strictly speaking three-quarters of a per cent. would more nearly represent the real quantity. If, however, on the average, we only obtain about forty-five pounds from an application of about eightyseven pounds of nitrogen, it is evident that not more than onehalf of the amount applied enters into the crop.

Now in dealing with a substance of so costly a nature as ammonia, or nitrate of soda-the nitrogen contained in which substances cannot cost much less than tweniy-five cents per pound by the time it is spread upon the land, it becomes a question of importance to know what becomes of the other half, or the residue whatever it may be, which has not been taken up by the crop. Part is undoubtedly taken up by the weeds which grow with the wheat, and after the wheat has bren cut. Part sinks into the sub-soil and is washed completely away during the winter.

I, myself, am disposed to think that the very great difference 
in the size of the Indian corn crops, as compared with the wheat crops in the States, is partly accounted for by their greater freelom from weeds, which are large consumers of nitric acid, and, in the case of the wheat crop, frequently reduce the yield by several bushels per acre. It must, however, be borne in mind that, though the wheat is robbed of its food where there are weeds, still if there were no weeds, the amount of nitric acid which the crop could not get hold of, woulrl, in all probabilty, be washed out of the soil during the ensuing winter. I come to the conclusion, therefore, that the nitrogen alone, which would be required to produce one bushel of wheat, would cost not much less than fifty cents; and that, in consequence, wheat-growing by means of artificial manures, will not pay upon very poor land.

I have said that the land, about which I was consulted, had not been plowed for several years, and that although nature had done all she could to clothe the soil with vegetation, the most disheartening feature in the case was, the poverty of the wceds. A thistle may be a giant or a dwarf. according to circumstances; here they were all dwarfs. The plaintain, which I believe is sometimos sown in these districts for.food, has a very deep root: here the plants were abundant, but the leaves were very small and lay so close to the ground, that, as the manager informed $m$, " the sheep were often injured from the amount of sand which they swallowed with the leares when feeding."

At Rothamsted, the analyses of the rain water passing through the ordinary soil of one of my fieids, which has been kept free from vegetation, have snown that the amount of nitric acid liberated in a soil, and washed out each year, is very large. Taking the ten years during which these special experiments have been in progress, I should think that the loss of nitrogen would be equal to, or possibly exceed, the amount of that substance removed by the average crops grown in the United States.

The results obtained hy the rain gaures, aro further com. pletely confirmed by those in an adjoining fiold, where wheat and fallow have been grown alternately for twenty-seven years. The liberation of nitric acid, during the year of rest, produced for a time a large growth of wheat, but it was clone at a very great waste of the fertility of the soil, and the produce is now, in proportion, considerably lower than that grown on the con. tinuously unmanured land. 
These results, if they are to be accepted as correct, must bring abuut a very considerable change in the generally received views in regard to fertility. We not only see more clearly the connection between a former vegetation and the stored up fertility in our suil, but we also see the importance of vegetation at the present day, as the only means by which tbe loss of nitric acid is prevented. The more completely the land is covered with vegetation, and the more growth there is, the greater will be the evaporation of water, and the less will be the loss of nitric acid by drainage.

I was not at all surprised to find, that the surface soil of a wood on my farm, was poorer in nitrogen than the soil of an old permanent pasture, to which no manure had been applied for twenty-five years, though during the whole period, the crop of hay had been removed every year from the land. The wood to which I refer is covered with oak, centuries old, and the foliage is so dense that but little underwood or other vegetation can grow beneath it. If both the wood and the pasture were put into arable cultivation, I have no doubt that the pasture would prove much more fertile than the wood land.

In our experiments on permanent pasture, it has been observed that the character of the herbage is mainly dependent on the food supplied. Weeds, and inferior grasses, can hold their own as long as poverty exists, but with a liberal supply of manure, the superior grasses overgrow and drive out the bad grasses and weeds. In consequence of the low price of wheat a good deal of land in England has been laid down to permanent pasture, and much money has been spent in cleaning the land preparatory to sowing the grass-seeds. I have on more occasions than one, suggested that the money employed in this process would be better expended in manure, by which the weeds would be "improved" off the face of the land. While walking over the abandoned portion of these estates I explained my views upon this point to the manager. They were, however, received with the usual skepticism, and the rejoinder that "there was only one way of getting rid of the weeds, which was by the plow and fire."

There is nothing that speaks to me so forcibly as color in vegetation; when travelling by rail, I do not require to be told that such a farm is, or is not, in high condition, or that we are passing through a fertile or infertile district. There is a peculiar green color in vegetation which is an unmistakable sign. that it is living upon the fat of the land. I need hardly say 
that, in this case, the color of the vegetation gave unmistakable signs of the poverty of the soil ; but in the midst of the dingy yellowish-green of the herbage, I came upon one square of bright green grass. In answer to my enquiry I was told that, a "lambing-fold had bəen there last year," and my informant added his opinion, "that the manure would be so strong that it would kill anything !" It had certainly killed the weeds, but in their place, some good grasses had taken possession of the soil.

The plan I proposed to adopt was, to spend no more money on tillare operations, but to endeavor to improve the pasture by giving to it the food necessary to grow good grasses, sowing at the same time a small quantity of the best seeds. I further suggested that a flock of sheep should be allowed to run over the whole of the land by day, and be folded there every night -about one pound of cotton-seed cake per head being allowed daily. By this means, as the fold would be moved every day, the amount of manure deposited on the soil could be estimated.

If there were a hundred sheep, receiving one pound of decorticated cotton-seed cake per head, daily, and the hurdles were arranged to enclose a space of twenty-five by twenty yards, in the course of ten days an acre of land would have received manure from one thousand pounds of cake; which amount would supply seventy-seven pounds of nitrogen, sixty-eight pounds of phosphate of lime, and thirty-two pounds of potash. This amount of cake would cost about sixteen dollars.

As regards the value of the cake as a food, it is somewhat difficult to form an estimate; but it takes nine or ten pounds of dry food-say roots, cake, and hay-to produce an increase of one pound of live weight in sheep. The cake has certainly a higher feeding value, than either hay or roots, but I will here give it only the same value, and consider that oze hundred and ten pounds of increase of the animal was obtained by the consumption of the one thousand pounds of cake. The value of the increase of the live weight would be in England fully eleven dollars, leaving five dollars as the cost of the manure. Now the cake furnished seventy-seven pounds of nit:ogen alone, which, if purchased in an artificial manure, would have cost nineteen dollars; and the other substances supplied by the cake, would have cost from four to five dollar: more. The manures required, therefore, would be obtained wuch more cheaply by this than by any other process. 
Labor would be saved by not cultivating the land. Manure would be saved by substituting veశ̧station which grows under or above ground, almost all th year ruald. And, by feeding the suock with cake, tha nacessary fertility would be obtained at the lowest possible cost.

It is probable that the land would require this treatment to bo repaated for several years, before there would be a fair growth of gr ss. The land might then bo broken up and one grain crop be taken, then it might again be laid dow. to grass.

Hitherto, I have considered a case where fertility is almo:t absent from the land, this, however, is an exception, as agriculture generally is carricd on upon soils which contain laige stores of fertility, though they may be very unequally distributed. By analysis of the soil we can measure the total amount of fertility which it contains, but we are left in ignorance in regard to the amount of the ingredients which are in such a form that the crops we cultivate can make use of them.

At Rothamsted, a!nong my experiments on the growth of continuous wheat, at the end of forty years, the soil supplied wili salts of ammonia has yielded, during the whole time, and still cointinues to yield, a larger produce than is obtained by a liberal supply of phosphates and alkaline salts without ammonia.

When we consider that every one hundred pounds of wheat crop, as carted to the stack, contains about five per cent. of mineral matter, and one per cent. of nitrogen, it is impossiblo to avoid the conclusion that my soil has a large available balance of mineral substances which the crop could not ma're us3 of for want of nitrogen. The crop which has received these mineral manures now amounts to from twelve to thirteen bushels per acre, and removes from the land about sixteen pounds of nitrogen every year.

Analyses of the soil show that, even after the removal of more than thirty crops in succession, without any application of manure containing ammonia, the soil still contains some t'r cusands of pounds of nitrogen. This nitrogen is in combinaiio_ with carbon; it is very insoluble in water, and until it be( ) 1 os separated from the carbon, and enters into combination with oxygen, does not appear to be of any use to the crop.

The combination of nitrogen with oxyg $\sim n$, is known as nitric acid. The nitric acid enters into combination with the lime of the soil, and in this form becomes the food of plants.

From its great importance in regard to the growth of plants, aitric asid might be called the main spring of agriculture, but 
being perfectly soluble in water, it is constanlly liable to bo washed out of the soil. In thə experiment to which I have rə- ferred above-where wheat is grown by mineral manures alone - we estimate that, of the amount of nitric acid liberated erch year, not much more than ono-half is taken up by the crop.

The wheat is ripe in July, at which time the land is tolerably free from weeds; several montlis, thcrefore, occur during which there is no vegetation to take up the nitric acid; and even when the wheat is sown at the enl of October, much nitric acid is liable to be washed away, as the power of the piant to take up food from the soil is very limited until the spring.

The formation of nitric acid, from the organic nitrogen in the soil, is due to the action of a minute plant, and goes on quite independent of the growth of our crops. We get, however, in the fact an explanation of the extremely different results obtained by the use of different manures. One farmer applies lime, or even ground limestone to a soil, and obtains an increase in his crops ; probably he has supplied the very substance which has enabled the nitrification of the organic nitrogen to increase; another applies potash, a third phosphates; if either of these are absont, the crops cannot make use of the nitric acid, however great may be the amount diffused through the soil.

It maJ possibly ba said that the use of mineral manures tends to exhaust the soil of its nitrogen; this may, or may not, be true; but even if the minerals enable the crop to take up a larger amount of the nitric acid found in the soil year by year, this does not increase the exhaustion, as the minerals only tend to arrest that which otherwise might be washed away.

We must look upon the organic nitrogen in the soil, as the main source of the nitrogen which grows our crops. Whatever may be the amount derived from the atmosphere, whether in rain, or dew ; or from condensation by the soil, or plants, it is probable that, where the land is in arable cultivation, the nitrogen so obtained, is less than the amount washed out of the soil in nitric acid. Upon land which is never stirred by the plow, there is much less waste and much less activity.

The large increase in the area of land laid down to permsnent pasture in Englaud, is not due alone to the fall in the price of grain. The reduction of fertility in many of the soils, which have been long under the plow, is beginning to be apparent. Undor these circumstances a less exhausting course of trcatment becomes necessary, and pasture, with the production of meat, milk, and butter, lakes the place of grain ficlds. 


\section{A P P E N D I X.}

LETTER FROM EDWARD JESSOP, YOKK, PA.

YoRk, PA., March 16, 1876.

Joseph Harris, Esq., Moreton Furm, Rochester, N. Y.:

DEAR SIR-Your favor of the 2:\%d of last month came safely to hand, and I am truly obliged to you for the reply to my question.-You ask, can I help you with facts or suggestions, on the subject of manure? I fear not much; but it may be useful to you to know what others need to know. I will look forward to the adrent of "Talks on Manures" with much interest, hoping to get new light on a subject second to none in importance to the farmcr.

I have done a little at composting for some years, and am now having a pile of about forty cords, made up of stable-manure and earth taken from the wash of higher lands, turned and fined. The labor of digging and hauling the earth, composting in thin layers with manure, turning, and fining, is so great, I doubt whether it pays for most farm cropsthis to be used for mangel-wurzel and market-garden.

The usual plan in this county is to keep the stable-manure made during winter, and the accumulation of the summer in the barn-yard, where it is soaked by rain, and trampled fine by cattle, and in August and Scptember is hauled upon ground to be seeded with wheat and grass-seeds. I do not think there is much piling and turning done.

My own conclusions, not based on accurate experiments, however, are, that the best manure I have ever applied was prepared in a covered pit on which cattle were allowed to run, and so kept well trampedsome drainage into a well, secured by pouring water upon it, when necessary, and the drainage pumped and distributed over the surface, at short intervals, particularly the parts not well tramped, and allowed to remain until it became a homogeneous mass, which it will do without having undergone so active a fermentation as to have thrown off a considerable amount of gas.

The ncxt best, composting it with earth, as above described, piled about five or six feet high, turned as often as convenient, and kept moist enough to secure fermentation.

Or, to throw all the manure as made into a covcred pit, until it is thoroughly mixed and made fine, by allowing hogs to run upon it and root at will ; and when prepared for even spreading, apply it as a topdressing on grass-land-at any convenient time.

As to how many loads of fresh manure it takes to make one of wellrotted manure, it may be answered approximatcly, three to one, but that would depend a good deal on the manner of doing it, and the amount of rough material in it. If well trodden by cattle under cover, and sufficient drainage poured over it, to prevcnt any violent fermentation, tho 
loss of weight, I think, would not be very great, nor the bulk lessened o ver one-half.

Many years ago an old and successful farmer said to me, "if you want to get the full benefit of manure, spread it as a top-dressing on some growing crop," and all my experience and observation since tend to confirm the correctness of his advice.

While on this subject, allow me to protest against the practice of naming the quantity of manure applied to a given space, as so many lyads, as altogether too indefinite. The bushel or cord is a definite quantity, which all can understand.

The average price of good livery stable horse-manure at this place bas beeu for several years four dollars a cord.

With two and a half miles to haul, I am trying whether keeping a flock of 50 breeding ewes, and feeding liberally with wheat bran, in addition to hay and pasture, will not procluce the needed manure more cheaply.

$$
\text { Respectfully yours, EDWARD JEsSOP. }
$$

P. S.-You ask for the arerage weight of a cord of manure, such as we pay four dollars for.

I had a cord of horse-stable manure from a livery stable in York which had been all the time under cover, with sevaral pigs running upon it, and was moist, without any excess of wet, loaded into a wagon-box holding an entire cord, or 123 cubic feet, tramped by the wagoner three times while loading.

The wagon was weighed at our hay-scales before loading, and then the wagou and load together, with a net result for the manure of $4,400 \mathrm{lbs}$. I considered this manure rather better than the averacc. I had another load, from a different place, which weighed over 5,000 lbs., but on examination it was found to contain a good deal of coal ashes. We never buy by the ton. Harrison Bros. \& Co., Manufacturing Chemists, Philadelphia, rate barnyard-manure as worth $\$ 5.77$ per ton, and say that would be about $\$ 7.21$ per cord, which would be less than $1 \frac{1}{2}$ tons to the cord. If thrown in loosely, and it happened to be very $d r y$, that might be possible.

Waring, in his " Handy Book of Husbandry," page 201, says, hз caused a cord of well-trodden livery stable manure containing the usual proportion of straw, to be carefully weighed, and that the cord weighed 7,080 lbs.

The load I had weighed, weighing $4,400 \mathrm{lbs}$., was considered by the wagoner and by myself as a fair sample of good manure. In view of these wide differences, furtber trials would be desirable. Dana, in his "Muck Manual," says a cord of green cow-dung, pure, as dropped, weighs $9,289 \mathrm{lbs}$.

Farmers here seldom draw manure with less than three, more generally with four horses or mules; loading is done by the purchaser. From the barn-yard, put on loose boards, from 40 to 60 bushels are about an average load.

In bauling frum town to a distance of three to five miles, farmers cenerally make two loads of a co:d each, a day's work. From the barn-yard, 
a very rariable number, per day. In my own case, two men with thrce horses have been hauling six and seven loads of sixty bushels, fine compost, a distance of from one-half to threc-fourths of a mile, up a long and rather steep hill, and spreading from the wagon, as hauled, upon grass-sod.

Our larger farmers often have one driver and his team, two wagons, one loading, while the other is drawn to the field; the driver slips off one of the side-boards, and with his dung-hook draws off piles at nearly equal distances, to be spre.$d$ as convenient.

EDWARD JESSOP.

LETTER FHOM Dr. E. L. STURTEVANT, SOUTI FRAMINGHAM, MASS.

Sodti Framingham, Mass., April 2, 1376.

Friend Harris-Manure about Boston is sold in various ways. First, according to the number of animals kept; price varying so much, that $I$ do not renture to name the figures. By the cord, to be trodden over while loading; never by weight, so far as I can lcarn-price from 0 to $\$ 12.00$ per cord, according to season, and rarious accidental circumstances. During the past winter, manurc has been given away in Boston. Handling, hauling to the railroad, and freight costing \$4 per cord for carrying 30 miles out. Market-gardeners usually haul manure as a return freight on their journeys to and from market. About South Framingham, price stiff at $\$ 8$ a cord in the cellar, and this may be considered the ruling suburban price. Very friendly yours,

E. Lewis Stcrtevant.

LETTER FROM M. C. WELD.

New York, Nov. 9, $13 \% 6$.

My Dear Harris-l don't know what I can write about manures, that would be of use. I have strong faith in humus, in ashes, leached and unlcached, in lime, gas-lime, plastcr, bones, ammonia ready formed, nitrates ready formed, not much in meat and blood, unless they are cheap. Nevertheless, they often are cheap, and produce splendid effects. I believe in sulphuric acid, with organic nitrogenous manures; the composting of meat, blood, hair, etc., with peat and muck, and wetting it down with dilute sulphuric acid. I bclieve in green-manuring, heartily, and in tillnge, tillage, tillage. Little faith in supcrphosphates and compounded manures, at selling prices. Habirshaw's guano is good enough. So much for my creed. Truly yours, M. C. WeLd.

LETTER FROM PETER HENDERSON.

New YoRr, Oct. §6, 1876.

Mr. Joseph Harris:

Dear Sir-If you will refer to my work "Gardening for Profit," New Edition, page 34, you will get about all the information 1 possess on Manures, except that I do not say anything about price. In a general way it might be safe to advise that whenever $a$ ton (it is always best to speak of manures by weight) of either cow, horse, hog, or other stablemanure can be laid on the ground for $\$ 3$, it is cheaper than commercial fertilizers of any kind at their usual market rates. This $\$ 3$ per ton, I 
think, would be about the average cost in New York, Boston, or Plihadclphia. We never haul it on the ground until we are ready to plow it in. If it has to be taken from the hog or cattle yards, we draw it out into large heaps, conrenient to where it is to be put on the land, turning it, to keep it from burning or "fire-fanging," if necessary. None of our farmers or market-gardeners here keep it under cover. The expense of such covering and the greater difficulties in getting at it, for the immensc quantities we use, would be greater than the benefits to be derived from keeping it under cover-benefits, in fact, which, I think, may be greatly overrated. Very truly yours,

Peter henderson.

LETTER FROM J. M. B. ANDERSON, ED. "CANADA FARMER," TORONTO. "Canada Farmer" Office, Toronto, March 29, $18 \% 6$.

J. IIarris, Esq.:

DEAR SiR-Yours of the 25th inst. is to hand, and I shall be most happy to render you any assistance in my power. The work you undcrtake is in able hands, and I have every confidence that, when completed, it will form an invaluable aequisition to the agrieultural literaturc of the day.

Manure in this city is usually sold by the two-horse load-about $1 \frac{1}{2}$ tons-at the rate of $\$ 1$ per load, or 63 cents per ton. The load contains just about a cord of manure, consequently a cord will weigh about $1 \frac{1}{1}$ tons.

With refcrence to the general management of manurc in Canada, I mag say that the system followed differs in no material respect from that of New York and the other Eastern States. It is usually kcpt over winter in the open barn yard (rarely under cover, I am sorry to say), laid out on the land about the time of disappearance of last snow, and plowed in. In some cases it is not carted out until the land is ready for immediate plowing. With some of our more advanced farmers, the system has lately been adopted of keeping manure under cover and sprinkling it thoroughly at intervals with plaster and other substances. Tanks arc also beeoming more common than formerly, for the prescrvation of licuid manure, which is usually applied by means of large, perforated hogsheads, after the manner of street-watering.

You ask, how the manure is managed at Bow Park, Brantford. That made during fall and winter is carefully kcpt in as small bulk as possible, to prevent exposure to the wcather. In February and March it is drawn out and put in heaps 8 feet square, and well packed, to prevent the esscape of ammonia. In spring, as soon as practicable, it is spread, and plowed under immediately. Manure madc in spring and summer is spread on the field at once, and plowed under with a good, deep furrow

Very truly yours,

J. M. B. Anderson, Ed. Canada Farmer.

MANURE STATISTICS OF LONG ISLAND.

TUE MANURE TRADE OF LONG ISLAND-LETTER FROM J. H. RUSTMMORE.

Old Westbery, Long Island, April 6, $18 \% 6$.

Jocenh Ilarris, Eiq. :

DeAr Sin-The great number of dealers in manure in New York pre- 
cludes accuracy, 5et Mr. Skidmore (who has been testifying voluminously before the New York Board of Health in relation to manure and street dirt), assures me that the accompanying figures are nearly correct. I enclose statement, from two roads, taken from their books, and the amount shipped uver the other road I obtained verbally from the General Freight Agent, and embody it in the sheet of statistics.

The Ash report I know is correct, as I had access to the books showing the business, for over ten years. I have made numerous applications, verbally, and by letter, to our largest market gardeners, but there scems to crist a general and strong disinclination to communieate anything worth knowing. I enclose the best of the replics received. Speaking for somc of our largest gardeners, I may say that they cultivate over one hundred acres, and use land sufficiently near to the city to enable them to dispense with railroad transportation in bringing manure to their places and marketing crops. I have noticed that one of the shrewdest gardeners invariably composts horn-shavings and bone-meal with horsemanure several months before expecting to usc it. A safe average of manure used per acre by gardeners, may be stated at ninety (90) tubs, and from two hundred to twenty hundred pounds of fertilizer in addition, according to its strength, and the kind of crop.

The following railroad manure statistics will give a gencr:lly correct idea of the age of manure, when used:

STATEMENT OF MANURE SENT FROM JAT. 1 TO DZC. :1, $18 \% 5$.

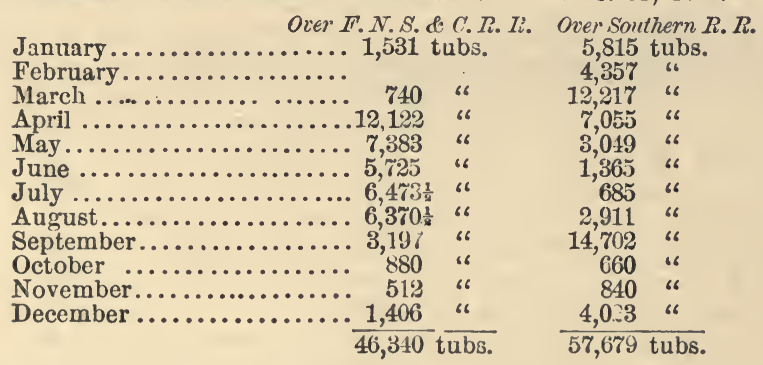

A tub is equal to 14 bushels.

Hobson, Hurtado \& Co. report the amount of Peruvian guano sold in this country last year at thirty thousand tons.

Estimated number of horses in New York city, 100,000.

Estimated produet of manure per horse. Four cords.

Estimated proportion of straw to pure excrement. One-half.

Amount shipped direet from stables. Nearly ail.

Amount shipped on vessels. One-half.

Length of time the unshipped manure remains in heaps. From three to four months.

Average cost per horse, annually. \$3.

Greatest distance of shipment. Virginia. 
Average amount shipped via L. I. R. R. 60,000 tubs.

Price of manure per tub delivered on cars or vessel. 80 cents. Average amount put on car. 40 tubs.

Statistics of Ash Trade.-Time when ashes are delivered. From middle of June to middle of October.

Places from which they are mostly shipped. Montreal, Belleville, anđ Toronto (Canada).

Method of transportation. Canal boats.

Average load per boat. About 8,000 bushels.

Average amount annually sold. 360,000 bushels.

Average cost delivered to farmers. $20 \frac{1}{8}$ cents per bushel.

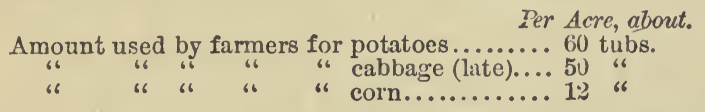

Amount of guano used on Long Island, as represented by the books of Chapman \& Vanwyck, and their estimate of sales by other firms, 5,000 tons.

The fertilizers used on the Island are bought almost exclusively by market gardeners or farmers, who do a little market gardening, as it is the general conviction that ordinary farm-crops will not give a compensating return for their applieation. Most market gardeners keep so little stock that the manure made on the place is very inconsiderable. Our dairy farmers either compost home-made manures with that from the city, spread it on the land for corn in the spring, or rot it separate, to use in the fall for wheat, on land that has been cropped with oats the same year. The manure put on for potatoes is generally estimated to enrich the land sufficient for it to produce one crop of winter grain, and from five to seven crops of grass, when it is again plowed and cultivated in rotation with, first, corn, second, potatoes or oats, and is reseeded in autumn of the same year.

Fish and fish guano are largely used on land bordering the water, and adjacent to the oil-works. The average price for guano in bulk at oiiworks is $\$ 12$ per ton. The average price for fish on wharf is $\$ 1.50$ per thousand, and it is estimated that, as a general average, 6,000 fish make a ton of guano. The fish, when applied to corn, are placed two at each hill, and plowed under at any time after the corn is large enough to cultivate. Seaweed is highly prized by all who use it, and it will produce a good crop of corn when spread thickly on the land previous to plowing. Very respectfully, J. H. RushMORE.

LETTER FROM JOHN E. BACKUS.

Newtown, Long Island, N. Y., March 2nd, 1876.

Mr. G. II. Rushmore:

DEAR SIr.-Some farmers and market-gardeners use more, and some less, manure, aceording to crops to be raised. I use about 30 gond twohorse wagon-loacis to the acre, to be applied in rows or broad-casted, as best for certain crups. I prefer old norse-dung for most all purposes. 
Guano, as a fertilizer, phosphate of bone and blood are vcry good; they act as a stimulant on plants and vegetation, and are highly beneficial to some vegetaticn-more valuable on poor soil than elsewhere, except to produce a thrifty growth in plants, and to insure a- large crop.

By giving you these few items they vary considerably on different parts of the-Island; judgment must be used in all cases and all business. Hoping these few lines may be of some avail to Mr. Harris and jourself, I remain, yours, etc., JoHN E. BACKUS.

\section{MANURE IN PHILADELPHIA.}

\section{LETTER FROM JOSEPH HEACOCK.}

\section{Jenkintown, Montgomery Co., Pa., April 18th, 1876.}

My DeAr Friend Harris.-Stable-manure in Philadelphia, costs by the single four-horse-load, about $\$ 9$ or $\$ 10$. Mostly, the farmers who haul much of it; have it engaged by the year, and then it can be had for from $\$ 7$ to $\$ 8$ per load. Mostly, four horses are used, though we frequently see two and three-horse teams, and occasionally, five or six horses are used. I have never seen any kind of dung hauled but that of liorses. Cow-manure would be thought too heavy to haul so long a distance. Sugar-liouse waste, spent hops, glue waste, etc, are hauled to a small extent. We live about 9 miles from the center of the city, and the road is very hilly, though otherwise a good one, bcing made of stone.

The loads vary from $2 \frac{1}{4}$ to $\mathrm{i}_{\frac{1}{4}}$ or 4 tons for four horses, according to the dryness of the manure. The wagons are made very strong, and weigh from $1,6 C 0 \mathrm{lbs}$. to 2,300 or $2,400 \mathrm{lbs}$, according to the number of horses that are to be used to them. I cannot say how many cords there are in an average load, but probably not less than two cords to four horses. One of my nei hbors has a stable engaged by the year. He pays $\$ 2.50$ per ton, and averages about three tons per load, and the distanee from the stable in the city to his place, can not be less than 12 miles. His team goes empty one way and of course can not haul more than a load a day. In fact, can not average that, as it would be too hard on his borses. The horses used for the purpose are large and strony. Fifteen or twenty years ago, there was kept on most farms of 75 to 100 acres, a team parposely for hauling manure from the city. But it is different now, many of the farmers using artificial manures, as it costs so much less; and others are keeping more stock, and so making their own manure. Still, there is a great deal hauled yet. And some of it to a aistance of 20 miles. Though when hauled to this distance, the teams are loaded both ways. For instance, they will start to the city with a load of hay ( 35 to $50 \mathrm{cwt}$.), on Monday afternoon (Tuesday is the day of the Hay Market); and when they have their load of hay off on Tuesday, they load their manure and drive out five or six miles and put up for the night. Next morning they start about $3 \mathrm{o}$ 'clock, arriving home before noou, having been away two days. On Thursday afternoon, they start ggain. You ean see that manuring in this way is very expensive. But farmers about here well know that if they do nct manure well they ruise 
but little. Probabiy about four loads are used per acre on the avarage. Each load is generally thrown off the wagon in one large heap near where wanted, and is allowed to lie until they use it. I can not tell how much it loses in bulk by lying in the heap.

As to what crops it is used on, farmers do not think that they could go amiss in applying it to anything except oats. But it is probably used more for top-dressing mowing land, and for potatoes, than for anything else.

The usual rotation is corn, potatoes, or oats, wheat seeded to clover and timothy, and then kept in grass from two to four years. Those who haul stable-manure, usuaily use bone-dust or superphosphate to a greater or less extent.

Last Deeember I built a pig-pen, $20 \mathrm{ft}: \times 40 \mathrm{ft}$., $1 \frac{1}{\frac{1}{3}}$ stories high. The upper story to be used for litter, ete. Therc is a four feet entry on the north side, running the length of the building. The remainder is civided into five pens, each $8 \mathrm{ft}$. $\mathrm{x} 16 \mathrm{ft}$. It is made so that in cold weather it can be closed up tight, while in warmer weather it can be madc as open as an out-shed. I am very much pleased with it. The pigs make a great deal of manure, and I believc that it can bc made much cheaper than it can be bought and hauled from Philadelphia.

Joseph Heacock, JR.

LETTER FROM HERMAN L. ROUTZAHN.

Middletown, Md., May 11th, 1876.

Joseph Harris, Esq. :

I herewith proeced to answer questions asked.

Wheat and corn are principal erops. Corn is fed now altogether to stock for the manure.

There is but little soiling done. The principal method of making manure is : Feeding all the corn raised, as well as hay, oats, and roots, to eattle; using wheat straw, weeds, etc., as bedding, throwing the manure in the yard (uncovered), and to cover the pile with plaster (by sowing broadcast), at least once a week. To this pile is added the manure from the hog-pens, hen-house, ete., and worked over thoroughly at least twice before using. It is then applied to corn by plowing under; to wheat, as a top-dressing. For corn it is usually hauled to the field, thrown off in heaps 25 fect each way, a cart-luad making two heaps. Spread just before the plow. For wheat, spread on directly after plowing, and thoroughly harrowed in. Applied broadeast for potatoes. Composts of different kinds are made and used same as in other localities, 1 presume. Artificial manures are going into disrepute (justly too). This is the plan now adopted by the farmers in this county (Frederick). Where woods are accessible, leaves and mould are hauled in and added to the manure-heap ; in fact, every substance that can be worked into the manure-heap is freely used. Well-rotted stable-manure is worth from $\$ 1.50$ to $\$ 2.50$ per cord, accurding to eondition and locality.

Very Respectfully Yours,

Herinan L. Routzahn. 
LETTER FROM PROF. E. M. SHELTON, PROF. OF AGRICULTURE, KANS28 STATE AGRICULTURAL COLLEGE.

\section{Kansas State Agricultural College, Manhattan, Kansas, May 5, 1876.}

DEAR SIR.-In reply to your first question, I would scy that stablemanure in this vicinity, is held in very light estimation. Indeed, by the householders of this city, and quite generally by the farmers, manure is regarded as one of those things-like drouth and grasshoppers-with which a mysterious Providence sees fit to clog the opcrations of the husbandman. The great bulk of the stable-manure made in this city is, every spring, carted into ravines and vacant lots-wherever, in short, with least expcnse it can bc put out of reach of the senses.

It must not be understood by this that manure has little influence on the growing crops in Kansas. Nowherc have I seen such excellent results froin application of home-made fertilizers, as in Kansas. For those sterile wastes known as "Alkali lands," and "Buffalo wallows," manure is a speedy and certain cure. During two years of severe drouth, I have noticed that wherever manure had been supplied, the crop withstood the effects of dry weather much better than where no application had bcen made. Four years ago, a strip across one of our fields was heavily manured; this year this field is into wheat, and a dark band that may be seen half a mile shows where this application was made.

These facts the better class of our farmers are beginning to appreciate. A few days ago, a neighbor, a very intelligent farmer, assurod me that from manuring eight to ten acres every year, his farm was now in better condition than when be broke up the prairie fifteen ycars ago.

I know of no analysis of stable or farmyard-manure made in Kansas. Concerning the weight of manures, I can give you a few facts, having had occasion during the past winter to weigh several loads used for experimental purposes. This manure was wheeled into the barnyard, chiefly from the cattle stalls, during the winter of 1874-5. It lay in the open yard until February last, when it was weighed and hauled to the fields. I found that a wagon-box, $1 \frac{1}{1} \times 3 \times 9$ feet, into which the manure was pitched, without treading, held with slight variations, when level full, one ton. At this rate a cord would weigh very close to three tons.

The greatest difficulty that we have to encounter in the management of manure grows out of our dry summers. During our summer months, unless sufficient moisture is obtained, the nanure dries out rapidly, becomes fire-fanged and practically worthless. My practice upon the College farm has been to give the bottom of the barn-yard a "dishing" form, so that it holds all the water that falls upon it. The manure I keep as flat as possible, taking pains to place it where the animals will keep it trod down solid. I have adopted this plan after having tried composting and piling the manure in the yards, and am satisfied that it is the only practical way to manage manures in this climate.

There is no particular crop to which manure is geterally applied 
in this State, unless, pcrhaps, wheat. The practice of applying manure as a top-dressing to winter-wheat, is rapicily gaining ground here. It is found that the manure thus applied, acting as a mulch, mitigates the effects of drouth, besides improving the quality of the wrain.

Very Respectfully Yours,

E. M. SHeltoN.

LETTER FROM PROF. W. H. BREWER, PROFESSOR OF AGRICULTURE IN SHEFFLELD SCIENTIFIC SCHOOL OF YALE COLLEGE.

Sheffield Scientific School of Yaile College, New Haven, Conn., April 14th, 1876.

Joseph Harris, Esa., Rochester, N. Y.:

MY DEAR Srr.-I have made inquiries relating to "the price of stablemanure in New Haven, and how far the farmers and gardencrs haul it, etc." I have not been to the horse-car stables, but I have to several livery stables, and they are all essentially the same.

They say that but little is sold by the cord or ton, or by any weight or measure. It is sold either "in the lump," "by the month," "by the year," or "per horse." Some sell it at a given sum per month for all their horses, on a general cstimatc of their horses-thus, one man says, "I get, this year, $\$ 25$ per month for all my manure, he to remove it as fast as it accumulates; say one, two, or three timcs per week. He hauls it about five miles and composts it all before using."

Another says, he sells per horse. "I get, this ycar, \$13 per horse, they to haul it." The price per horse ranges from $\$ 10$ to $\$ 15$ per year, the lattcr sum being high.

From the small or private stables, the manure is generally "lumped" by private contract, and is largely used about the city. It is hauled sometimes as much as 10 milcs, but usually much lcss.

But the larger stables often sell per shipment-it is sent by cars up the Connecticut Valley to Westficld, etc., where it is often haulcd several milcs from the railioad or rircr.

Much manuie is sent by bost from New York to the Connecticut Valley tobacco lands. Boats ("barges") are even loaded in Albany, go down the Hudson, up the Sound to Connccticut, to various places ncar Hartford, I am told. Two or three years ago, a man came here and exhibited to us pressed masses of manure-a patent had been taken out for pressing it, to send by R. R. (stable manure). I ncrer heard anything more about it-and he was confident and cnti usiastic about it.

Yours truly, WM. H. BREWER. 
FOOD, INCREASE, MANURE, ETC., OF FATTENING ANIMALS.

The following table is given by Mr. J. B. Lawes, of Rothamsted, England, showing the relation of the increase, manure, and loss by respirati sn, to the food consumed by different animals:

\section{OXEY.}

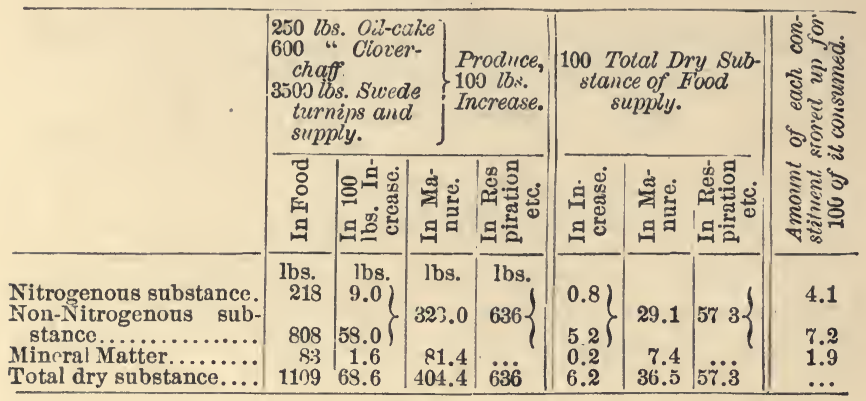

SHEEP.

\begin{tabular}{|c|c|c|c|c|c|c|c|c|}
\hline & \multicolumn{3}{|c|}{$\begin{array}{c}250 \text { lbs. Oil-cake } \\
300 \text {. Clover- } \\
\text { chaff. } \\
4000 \text { ibs. Swede } \\
\text { turnips and } \\
\text { supply. }\end{array}$} & $\begin{array}{l}\text { Produce. } \\
100 \text { lbs. } \\
\text { Increase. }\end{array}$ & \multicolumn{3}{|c|}{$\begin{array}{c}100 \text { Total Dry Sub- } \\
\text { stance of Food } \\
\text { supply. }\end{array}$} & \multirow{2}{*}{ 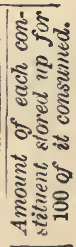 } \\
\hline & 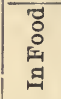 & 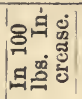 & 串方 & 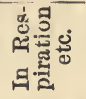 & 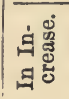 & 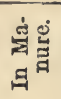 & 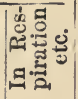 & \\
\hline Nitrogenous substan & $\begin{array}{l}\text { hss, } \\
177\end{array}$ & $\begin{array}{l}\text { lbs. } \\
7.5 j\end{array}$ & lbs. & lbs. & $0.8)$ & & & 4.2 \\
\hline $\begin{array}{l}\text { Non-Nitrogenous sub- } \\
\text { stance }\end{array}$ & & 1.0 & & 543.5\{ & 701 & 25.1 & 60.1\{ & 4 \\
\hline Mineral ma & 64 & 2.0 & (;) 2 & & 0.2 & 6. & & 8.1 \\
\hline Tro & 912 & 12 & 2)1 & 543.5 & 8.0 & 31.9 & 60.1 & \\
\hline
\end{tabular}

rias.

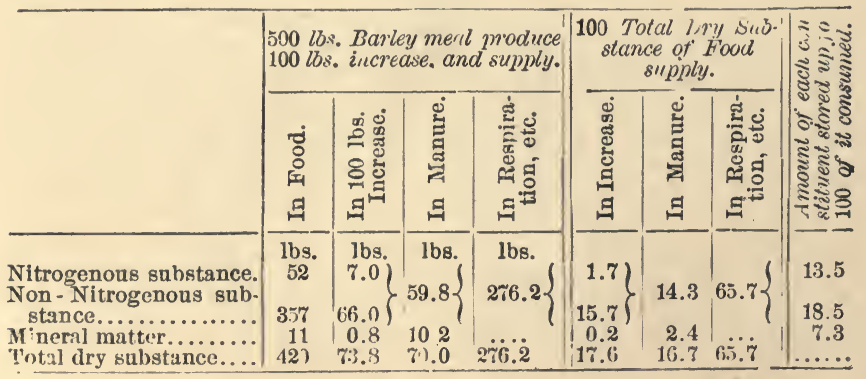


In the last edition of his hook on Manure, "Pralitische Düngerlehre," D:. Emil Wollf, gives the following tables:

Of $100 \mathrm{lbs}$. of dry substance in the food, there is found in the excrements :

\begin{tabular}{|c|c|c|c|c|c|}
\hline Dex Subetance. & Cow. & $0 x$ & Sheep. & Horse. & Irean. \\
\hline 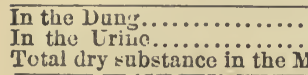 & $\begin{array}{l}38.01 \mathrm{lbs} \\
9.1 \% \\
97.1\end{array}$ & $\begin{array}{l}4.010 . \\
5.8 \% \\
51.4\end{array}$ & $\begin{array}{l}46.910 \mathrm{~s} . \\
63.6 \\
53.5\end{array}$ & $\begin{array}{l}4 \therefore 0: \mathrm{bs} . \\
3.6 \times \\
45.6\end{array}$ & 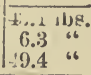 \\
\hline
\end{tabular}

Of $100 \mathrm{lbs}$. of organic substance in the food, there is found in the excrements :

\begin{tabular}{|c|c|c|c|c|c|}
\hline Organio Substancz. & Cow. & $O x$. & Sheep. & IIorse. & Mrean. \\
\hline 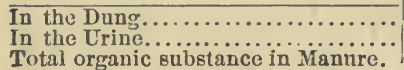 & $\begin{array}{l}36.5 \mathrm{Ibs} . \\
6.0 " 6 \\
42.5 " 6\end{array}$ & $\begin{array}{l}43.9108 . \\
3.2 " “ 6 \\
47.10\end{array}$ & 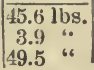 & $\mid \begin{array}{cc}8.2 & 168 . \\
2.5 & 6 \\
40.7 & \cdots\end{array}$ & $\begin{array}{l}71.0 \mathrm{lbs} . \\
3.9 " 6 \\
44.906\end{array}$ \\
\hline
\end{tabular}

Of $100 \mathrm{lbs}$. of nitrogen in the food, there is found in the excrements :

\begin{tabular}{|c|c|c|c|c|c|}
\hline Nitrogen. & Cow. & $0 x$. & Sheep. & Horse. & Mecn. \\
\hline $\begin{array}{l}\text { In the Dung................... } \\
\text { In the Urine... } \\
\text { Total Nitrogen in Manure }\end{array}$ & 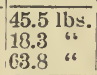 & 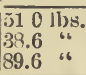 & $\begin{array}{l}33.71 \mathrm{lbs} . \\
51.8 \% \\
35.5 \%\end{array}$ & $\begin{array}{l}5(6.1 \mathrm{lbs} . \\
27.3 \\
83.4\end{array}$ & $\begin{array}{l}49.11 \mathrm{bs} \\
31.0 \\
83.1\end{array}$ \\
\hline
\end{tabular}

Oi 100 lbs. mincral matter in the food, there is found in the excrements :

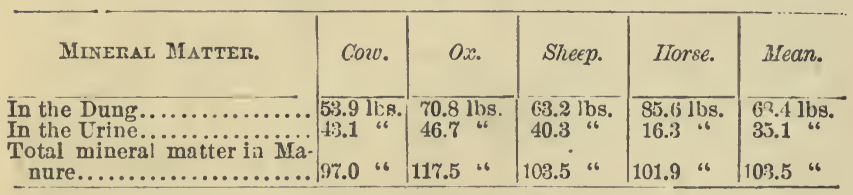

The excess of mineral matter is due to the mineral matter in the water dranik by the animals.

The following tables of analyses are copied in full from the last edition (1875), of Dr. Emil Wolft's Praltische Düngerlehre.

The figures differ matcrially in many cases from those previously published. They represent the average results of numerous reliable analyses, and are sufficiently accurate for all practical purposes connected with the subject of manures. In special cases, it will be we!l to consult actual analyses of the articles to be used. 


\section{I.-TABLES FOR CALCULATING THE EXHAUSTION AND EN- RICHING OF SOILS.}

A.-HARVEST PRODUCTS AND VARIOUS MANUFACTURED ARTICLES. Average quantity of water, nitrogen, and total ash, and the different ingredients of the ash in $1000 \mathrm{lbs}$. of fresh or air-dried substance.

\begin{tabular}{|c|c|c|c|c|c|c|c|c|c|c|}
\hline Substance. & $\stackrel{\Xi}{\Xi}$ & 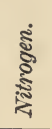 & ๙ึँ & $\frac{\widetilde{3}}{\widetilde{c}}$ & $\begin{array}{l}\text { हूँ } \\
\text { फू }\end{array}$ & 孞 & 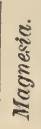 & 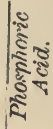 & 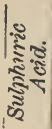 & 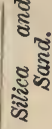 \\
\hline \multicolumn{11}{|l|}{ I. - HAY. } \\
\hline Ieadow Hay. . & 143 & 15.5 & 51.5 & 13.2 & 2.3 & 8.6 & 3.3 & 4.1 & 2.4 & 13.9 \\
\hline Rye Gruss............. & 143 & 16.3 & 58.2 & 20.2 & 2.0 & 4.3 & 1.3 & 6.2 & 2.3 & 18.5 \\
\hline Timothy.............. & 143 & 15.5 & 62.1 & 20.4 & 1.5 & 4.5 & 1.9 & 7.2 & 1.8 & 22.1 \\
\hline Moharhay ............. & 134 & $17 . \delta$ & 58.4 & 21.2 & 1.2 & 6.1 & 5.4 & 3.4 & 2.1 & 16.3 \\
\hline Red Clover.............. & 160 & 19.7 & 56.9 & 18.3 & 1.2 & 20.0 & 6.1 & 5.6 & 1.7 & 1.4 \\
\hline Red Clover, ripe....... & 150 & 12.5 & 44.0 & 9.8 & 1.4 & 15.6 & 6.8 & 4.3 & 1.3 & 3.0 \\
\hline White Clov & 165 & 23.2 & 59.8 & 10.1 & 4.5 & 19.3 & 6.0 & 8.4 & 4.9 & 2.5 \\
\hline Alsike Clover.... ...... & 160 & 24.0 & 39.7 & 110 & 1.2 & 12.5 & 5.0 & 4.0 & 1.6 & 1.6 \\
\hline Crimson Clov & 167 & 19.5 & 50.7 & 11.7 & 4.3 & 160.0 & 3.1 & 3.6 & 1.3 & 8.2 \\
\hline Lucern.... & 160 & 23.0 & 62.1 & 15.3 & 1.3 & 26.2 & 3.3 & 5.5 & 3.7 & 3.8 \\
\hline ette... & 167 & 21.3 & 45.8 & 13.0 & 1.5 & 16.8 & 3.0 & 4.6 & 1.4 & 3.7 \\
\hline Yellow Clover.......... & 167 & 22.1 & 55.7 & 11.9 & 1.3 & 82.6 & 2.1 & 4.3 & 1.0 & 1.5 \\
\hline Green Vetch Hay....... & 167 & 22.7 & 83.7 & & 5.6 & 22.8 & 5.4 & 10.7 & 2.8 & 4.9 \\
\hline Green Pea Нау........ & 167 & 22.9 & 62.4 & 23.2 & 2.3 & 15.6 & 6.3 & 6.8 & 5.1 & 0.9 \\
\hline $\begin{array}{c}\text { Spurry .............. } \\
\text { II.-Green FoDder. }\end{array}$ & 167 & 19.2 & 56.8 & 19.9 & 4.6 & 10.9 & 6.9 & 8.4 & 2.0 & 0.8 \\
\hline Ieadow G & 700 & 5.4 & 18.1 & 4.6 & 0.8 & 3.0 & 1.1 & 1.5 & 0.8 & 4.9 \\
\hline ass. & 800 & 5.6 & 20 & 11.6 & 0.4 & 2.2 & 0.6 & 2.2 & 0.8 & 2.1 \\
\hline rass. & 734 & 57 & 20) & 7.2 & 0.7 & 1.5 & 0.4 & 22 & 0.8 & 6.5 \\
\hline y Grass & 700 & 5.4 & 21 & 7.4 & 0.5 & 1.6 & 0.7 & 2.5 & 0.6 & 7.7 \\
\hline Rye-Fodder . ............ & 700 & 5.3 & 16.3 & 6.3 & 0.1 & 1.2 & 0.5 & 2.4 & 0.2 & 5.2 \\
\hline Oat & $\& 10$ & 3.7 & 15.8 & 7.5 & 0.6 & 1.2 & 0.6 & 1.7 & 0.6 & 5.7 \\
\hline Corn-Fodder.... & 822 & 1.9 & 12 & 4.3 & 0.5 & 1.6 & 1.4 & 1.3 & 0.4 & 17 \\
\hline 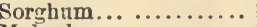 & กั 3 & 4.0 & 18 & 3.6 & 1. & 1.2 & 0.5 & 0.8 & 0.4 & 3.7 \\
\hline M1 & 730 & 5.9 & 13 & 5.0 & 0. & 1.4 & 1.3 & 0.8 & 0.5 & 3.9 \\
\hline lo:=om & 780 & 5.1 & $1:$ & 4.4 & 0.3 & 48 & 1.5 & 1.4 & 0.4 & 0.3 \\
\hline before ' & 830 & 5. & 14. & 5.3 & 0.3 & 4.2 & 1.5 & 1.7 & 0.3 & 04 \\
\hline White Clov & 8.3.5 & 5.6 & 13 & 2.3 & 1.0 & 4.4 & 1.4 & 1.9 & 1.1 & 0.6 \\
\hline ze Clove & $8 £ 0$ & 5.3 & 8 & 2.4 & 0.3 & 3.0 & 1.1 & 0.9 & 0.4 & 0.4 \\
\hline on Clover... & 815 & 4.3 & 12 & 2.8 & 1.0 & 3.8 & 0.7 & 0.9 & 0.3 & 2.0 \\
\hline Luce & 740 & 7.2 & 18 & 4.6 & 0.4 & 7.9 & 1.0 & 1.6 & 1.1 & 1.1 \\
\hline & 807 & 5. & 12 & 3.4 & 0. & 4 & 0.8 & 1.2 & 0.4 & 1.0 \\
\hline Yellow Cl & 830 & 4. & & & & & 0.6 & 1.1 & 0.3 & 0.4 \\
\hline Green Vetc & 820 & 5.1 & 18 & 6.1 & 1. & 4.9 & 1.2 & 2.3 & 0.6 & 1.1 \\
\hline Pea & 81 & 5. & & & 0 & ร. 5 & 1.4 & 1.5 & 1.1 & 0.2 \\
\hline Rape. & 870 & 4. & 12 & 4.0 & 04 & 2.7 & 0.5 & 1.4 & 1.7 & 0.6 \\
\hline 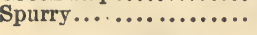 & 800 & 3.7 & 122 & 4.3 & 1.0 & 2.3 & 1.5 & 1.8 & 0.4 & 0.2 \\
\hline III.-Root Crops. & & & & & & & & & & \\
\hline Potatoe & 750 & 3.4 & 9 & 5.7 & 0.2 & 0.2 & 0.4 & 1.6 & 0.6 & .2 \\
\hline & & & & & & & 0.3 & 1.4 & 0.5 & \\
\hline Zel. & 880 & 1.8 & 7. & 4.1 & 1.2 & 0.3 & 0.3 & 0.6 & 0.2 & 0.2 \\
\hline & 815 & 1.6 & & 3.9 & 0.7 & 0.4 & 0.5 & 0.8 & 0.3 & 0.1 \\
\hline 3... & 920 & 1. & 7. & 3.3 & 0.7 & 0.8 & 0.3 & 0.9 & 0.8 & 0.1 \\
\hline & 850 & 2.2 & 7 & 2.8 & 1.7 & 0.9 & 0.4 & 1.0 & 0.5 & 0.2 \\
\hline Turnips. & 87 & 2.7 & 11. & 4.7 & 1.2 & 1.3 & 0.3 & 1.7 & 1.5 & 0.1 \\
\hline ry........ & 800 & 2.5 & 6.7 & 2.6 & 1.1 & 0.5 & 0.3 & 0.8 & 0.5 & 0.3 \\
\hline $\begin{array}{l}\text { Sugar Bec } \\
\text { of root. }\end{array}$ & & 2.0 & 9.6 & 2.8 & 2.3 & 0.9 & 1.2 & 1.2 & 0.7 & 0.2 \\
\hline
\end{tabular}




\begin{tabular}{|c|c|c|c|c|c|c|c|c|c|c|}
\hline SUB & हैं & 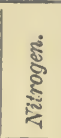 & 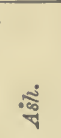 & ईूँ & క్ & હ્ડ & 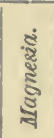 & 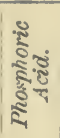 & & క్స్ई \\
\hline \multicolumn{11}{|l|}{$\begin{array}{l}\text { IV.-LEaves \& Stgus } \\
\text { of RoOT Crops. }\end{array}$} \\
\hline $\begin{array}{l}\text { Potato Vines, } \\
\text { ripe......... }\end{array}$ & 770 & 4.9 & 19.7 & 4.3 & 0.4 & 6.4 & 3.3 & 1.6 & 1.3 & \\
\hline Pot & 825 & 6.3 & 16.5 & 4.4 & 0.3 & & 2.4 & 1.2 & 0.8 & \\
\hline & 800 & 5.3 & 14 & 3.1 & & 5.0 & 1.3 & 0.7 & 0.2 & \\
\hline ....... & 905 & 3.0 & 14.1 & 4. & & & 1.3 & 0.8 & 0.8 & 0.5 \\
\hline$\bullet$ & $89 \%$ & 3.0 & 18.1 & 6. & & & 2.7 & 1.3 & 0.9 & 0.7 \\
\hline Tur ips.. & 893 & 3.0 & 11.9 & 2.8 & 1.1 & 3.9 & 0.5 & 0.9 & 1.1 & 0.5 \\
\hline .. & 82.2 & 51 & & 2. & & & 0.9 & 1.2 & 2.0 & 2. \\
\hline$\ldots$ & 850 & 3.5 & 16.5 & 4.3 & 2.9 & 3.2 & 0.4 & 1.0 & 1.4 & \\
\hline$\ldots$ & 850 & 4.6 & & 3.7 & 1.0 & 8.4 & 10 & 2.6 & 3.0 & 2. \\
\hline ....... & 890 & 2.4 & 16.0 & 6.3 & 0.9 & 3.1 & 0.6 & 1.4 & 2.4 & \\
\hline Cabbage St & 820 & 1.8 & 11.6 & 5.1 & 0.6 & 1.3 & 0.5 & 2.4 & .9 & \\
\hline \multicolumn{11}{|l|}{$\begin{array}{l}\text { V.-Manufactured } \\
\text { Products \& ReFuse. }\end{array}$} \\
\hline Wheat Bran. & 131 & 22.4 & 53.5 & 14.3 & 0.2 & 1.7 & 88 & 27.3 & 0.1 & 0. \\
\hline & & 000 & & & & 2.5 & 11.3 & 31.3 & & \\
\hline arl & 120 & 23.7 & 484 & 1 & 0 . & 1.8 & 3.0 & 8.9 & 0.9 & 23. \\
\hline at & 140 & $\cdots$ & 34.7 & 49 & 0. & 1.4 & 10 & 1.6 & 1.3 & 22.3 \\
\hline Pes & 140 & & 22.7 & 10.3 & & 4.1 & 2.2 & 3.1 & 0.9 & 0.9 \\
\hline an. & 140 & 27.2 & 34.6 & 11.2 & 0 . & 3.4 & 4.6 & 12.5 & 1.0 & 0. \\
\hline & & 18.9 & & & & 0. & 0.4 & 3.7 & (1) & \\
\hline$\ldots$ & 112 & 16.8 & 16 & & & 0. & 1. & 8.5 & & \\
\hline & 14) & 15.0 & & 5 . & & 0. & 2. & 9.5 & 0.6 & \\
\hline Cur & $1+0$ & .16 .0 & & 1. & 0 & 0. & 0. & 2.6 & & \\
\hline 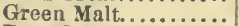 & 475 & 104 & & & & 0. & & 5.3 & & \\
\hline (n...... & 75 & 16.0 & & 4 & & & 2. & 9.7 & & \\
\hline r's Grains..... & 766 & 7.8 & & 0 & 0.1 & & 1. & 4.1 & & \\
\hline 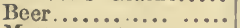 & & & & & 0.6 & & 0. & 2.0 & 0.2 & 0. \\
\hline $\mathbf{M} a$ & U & 36.8 & & 20. & 1 & & & 18.0 & 2.9 & 14.7 \\
\hline $\mathrm{Po}$ & 850 & 1.3 & & 0 & & & & 0.4 & & \\
\hline & & & & & & 0. & & 1.0 & 4 & 0.2 \\
\hline & & 2.9 & & & & & & 11 & 4 & \\
\hline$\ldots$ & & 0 & & & 0. & & 0. & 0.2 & & \\
\hline & & 12.8 & & & 10. & 4. & 0.3 & 0.5 & 7 & 0. \\
\hline. & & & & & & 0 . & & 0.1 & & \\
\hline & & 48 & & & & & 7. & 19. & & \\
\hline . & & & & 1 & & & 8 & 1 & & \\
\hline & & & & & & 97 & & 2 & 9 & \\
\hline & & & & & 4.6 & 13 & & & 6 & \\
\hline & & & & & $\ldots$ & 3 & & 27.2 & 6 & \\
\hline 1 & & & & & & & & 1 & & \\
\hline (1 & & & & 22. & $\ddot{1.3}$ & 2. & 1.6 & 14.9 & 2.1 & \\
\hline Palm-oil-cake...... & 100 & 25.9 & 26.1 & 5.0 & 0.2 & 3.1 & 4.5 & 11.0 & 0.5 & \\
\hline \multicolumn{11}{|l|}{ VI.-STRAW. } \\
\hline & & 4 & & & 0.6 & & 1. & 2. & 1. & \\
\hline & & & & & & 2 . & & 2. & 1.2 & \\
\hline & 1 & 4. & & & 0 & & & & & \\
\hline$\cdots$ & & & & 11.0 & 1.0 & & & 2. & 1.2 & 1 \\
\hline & & & & & & & & & 1.2 & \\
\hline o & 14 & 6. & & 9. & 1. & 3. & 1. & & & 21 \\
\hline & 1 & & & & & & & & & \\
\hline alks. & 15 & A & & & & 4. & & 5. & 1.2 & 11.7 \\
\hline & i & 13 & & & 1 & 9 & & 6. & 2.7 & 2.9 \\
\hline & 16 & & & & 1.8 & 16.2 & 3. & 3.5 & 2.7 & \\
\hline a bean. & 160 & 16.3 & & 18.5 & 1.1 & 9.8 & 3.3 & 3.2 & 1.6 & 8 \\
\hline ommon Vetch & 160 & & & $\begin{array}{r}12.8 \\
6.8\end{array}$ & $\begin{array}{l}3.2 \\
69\end{array}$ & & 2.5 & 3.9 & 1.7 & \\
\hline & & & & & & & & & & \\
\hline
\end{tabular}




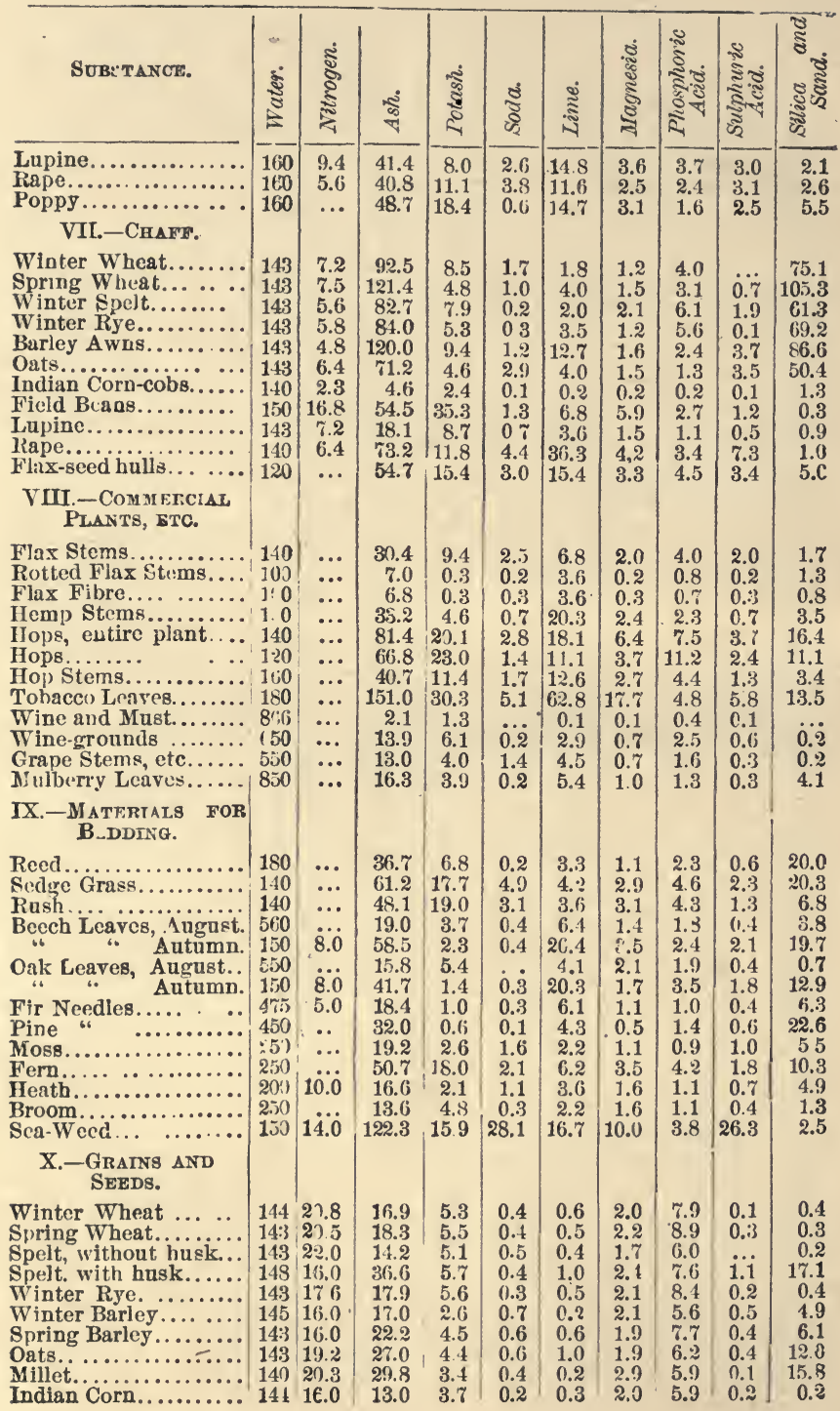




\begin{tabular}{|c|c|c|c|c|c|c|c|c|c|c|}
\hline SubstancE. & 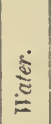 & 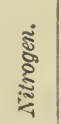 & वं & 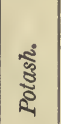 & ర్ & ฐ๊̃ & 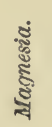 & 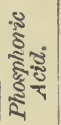 & के & 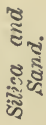 \\
\hline Sorghum. & 140 & & 16.0 & 3.3 & 0.5 & 0.2 & 2.4 & 8.1 & & 1.2 \\
\hline Buckwheat.. & 140 & 14.4 & 11.8 & 2.7 & 0.7 & 0.5 & 1.5 & 5.7 & $\ddot{0} \ddot{2}$ & 0.1 \\
\hline$\ldots \ldots, \ldots \ldots, \ldots$ & 143 & 35.8 & 23.5 & 9.8 & 0.2 & 1.2 & 1.9 & 8.6 & 0.8 & 0.2 \\
\hline Ficld Beaus...... . . . & 145 & 40.8 & 30.7 & 13.1 & 04 & 1.5 & $2 . \approx$ & 11.9 & 0.8 & 0.2 \\
\hline Garden Beans......... & 150 & 39.0 & 27.4 & 12.0 & 0.4 & 1.8 & ¿.0 & 9.7 & 1.1 & 0.2 \\
\hline Vetch... & 143 & $|44.0|$ & 26.8 & 8.1 & 2.1 & 2.1 & 2.4 & $|10.0|$ & 1.0 & 0.3 \\
\hline Lupine. & 130 & 56.6 & 341 & 10.2 & 0.1 & 30 & 4.0 & 14.3 & 1.5 & 0.2 \\
\hline S & 150 & 30.5 & 38.3 & 13.5 & 0.4 & 2. & 4.9 & 14.5 & 0.9 & 0.5 \\
\hline White Clo & 150 & $\cdots$ & 33.8 & 12.3 & 0.2 & 2.5 & 3.9 & 116 & 1.6 & 0.8 \\
\hline Esp. rsette .. & 160 & ... & 8.4 & 11.0 & 1.1 & 12.3 & 2.6 & 9.2 & 1.2 & 0.3 \\
\hline Ruta baga «.... & 140 & .. & 48.8 & 9.1 & 8.5 & 7.6 & 8.6 & 7.6 & 2.1 & 1.1 \\
\hline Sugar-Beet ............ & 146 & .. & 45.3 & 11.1 & 4.2 & 10.2 & 78 & 7.5 & 2.0 & 0.8 \\
\hline Carrots................ & 120 & & 748 & 14.8 & 3.5 & 29.1 & 5.0 & 11.8 & 4.2 & 4.0 \\
\hline n......... & 130 & .. & 54 & 6.5 & 4.6 & 17.3 & 5.9 & 16.5 & 24 & 0.6 \\
\hline Turnips............... & 125 & & 34.6 & 7.6 & 0.4 & 6.1 & 3.1 & 14.0 & 2.5 & 0.2 \\
\hline Rape.... & 118 & 31.2 & 39 & 8.6 & 0.6 & 5. & 4.6 & 16.5 & 0.9 & 0.5 \\
\hline Summer-Rape....... & 120 & & 34. & 7.7 & & & 4.7 & 14.9 & 2.3 & \\
\hline Mustard. & 130 & & is & 5.9 & 2.0 & 7.0 & 3.7 & 146 & 1.8 & 09 \\
\hline Popıy. & 117 & $28.0 \mid$ & 528 & 7.2 & 0.5 & 18.7 & 50 & 16.6 & 1.0 & 1.7 \\
\hline Linseed. & 118 & 32.8 & 32.6 & 10.0 & 0.7 & 2.6 & 4.7 & 13.5 & 08 & 0 \\
\hline Hemp... & 122 & 26.1 & 45.3 & 9.4 & 0.4 & 10.9 & 2.6 & $\mathbf{1 6 . 9}$ & 0.1 & 5.5 \\
\hline & 110 & & & 7.2 & & 8. & 2.1 & 6.0 & 0.6 & \\
\hline Horse-chestnuts, fresh & 492 & 10.2 & 12 & 7.1 & & 1. & 0.1 & 2.7 & 0.3 & \\
\hline Acorns, fresi.... ..... & $5 j 0$ & $\cdots$ & 9.6 & 6.2 & 0.1 & 0.7 & 0.5 & 1.4 & 0.4 & 0.1 \\
\hline \multicolumn{11}{|l|}{$\begin{array}{c}\text { XI.-VAriods Animat } \\
\text { Products. }\end{array}$} \\
\hline Cows' Milk. & 875 & 51 & 6.2 & 1.5 & 0.6 & 1.3 & 0.2 & 1.7 & & \\
\hline Sheep & 860 & 5.5 & & & 0.3 & 2. & 0.1 & 3.0 & 0.1 & 02 \\
\hline C & 450 & 4.5 .3 & 67.4 & 2.5 & 26.6 & 6.9 & 0.2 & 11.5 & & \\
\hline & 790 & 32.0 & 7. & 0.6 & 3.4 & 0.1 & 0.1 & 04 & 0.2 & 0.1 \\
\hline & 809 & 29.0 & 7.1. & 0.8 & 2.9 & 0.1 & 0.1 & 0.6 & 0.1 & $\cdots$ \\
\hline & 790 & 320 & 7. & 0.5 & 3.3 & 0. & 01 & 0.4 & 0.1 & $\cdots$ \\
\hline S & 800 & 29.0 & 7.1 & 1.5 & 2.2 & 0.1 & 0.1 & 0.9 & 0.1 & \\
\hline & 770 & 36.0 & 12.6 & 52 & & 0.2 & 0.4 & 4.3 & 0.4 & 0.3 \\
\hline C & 780 & 34.9 & 12.0 & 4.1 & 1.0 & 0.2 & 0.2 & 5.8 & - & 0.1 \\
\hline fl & 740 & 34.7 & 10.4 & 3.9 & 0.5 & 0.8 & 0.5 & $\begin{array}{r}46 \\
18\end{array}$ & ... & \\
\hline & 597 & 26.6 & & 1.7 & 1.4 & 20.8 & 0.6 & 18.6 & ... & \\
\hline$\tilde{L}$ & 662 & 25.0 & 38. & 24 & 0.6 & 16.3 & 0.5 & 13.8 & ... & 0.1 \\
\hline Li & 591 & 22.4 & 31. & 1.5 & 1.4 & 13.2 & 0.4 & 12.3 & ... & 0.2 \\
\hline Swine.. & 528 & 200 & 21.6 & 1.8 & 0.2 & 9.2 & 0.4 & 8.8 & & \\
\hline & 672 & 218 & 61.8 & 1.5 & 1.4 & 54.0 & 1.0 & 8. 7 & 0.1 & 0.1 \\
\hline , wa & is & 94.4 & 9 & 1.8 & 0 & 2. & 0.6 & 0.3 & & 2.5 \\
\hline Wool, unwashed..... & 150 & 04.0 & 98.8 & 74.6 & 1.9 & 4.2 & 1.6 & 1.1 & 40 & 30 \\
\hline
\end{tabular}




\section{B.-AVERAGE COMPOSITION OF VARIOUS MANURES.}

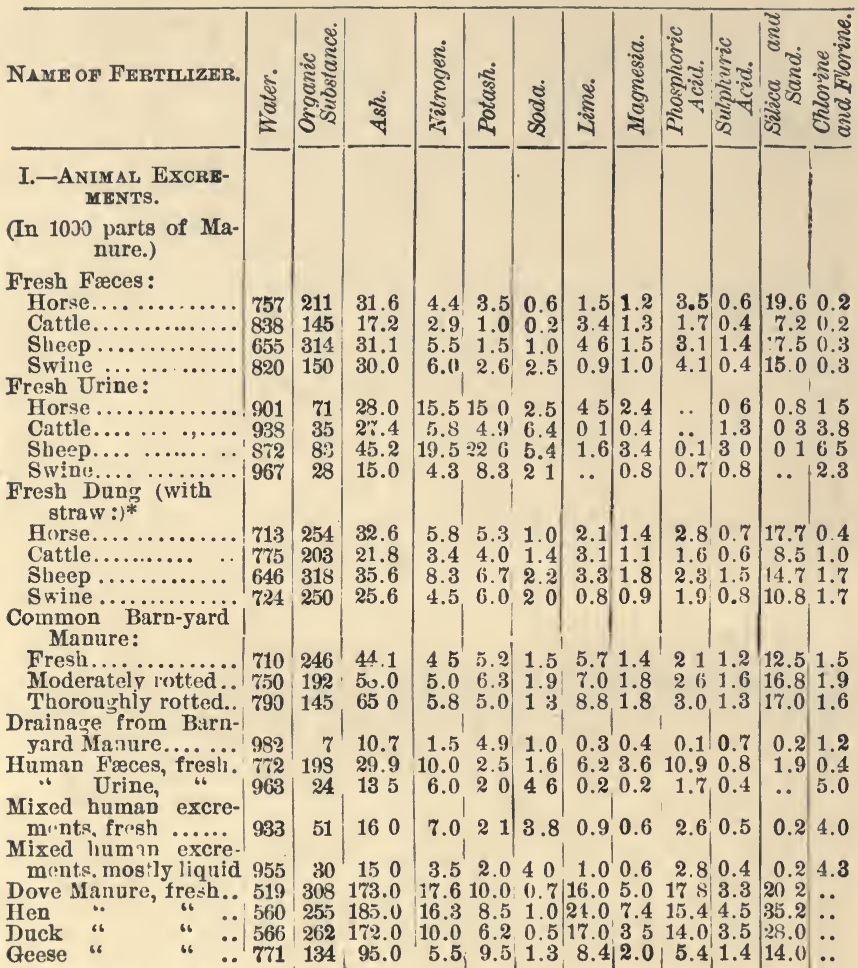

II.-Commercial MaNURES.

(In 100 parts of Fertilizer.)

Peruvian Guano...... 14.851.4

Norway Fish-Guano.. 12.6 53.4

Poudrette.........24.0 27.0

Pulverized Dead Änimals.............. 5.756.9

Flesh-Meal.......... $27.856 .6 \quad 15.6$

Dried Blood .......... 14079.0

Horn-Meal and Shav-

ings.................

8.568 .5

6.033 .3 $\begin{array}{lllllllllllllll}33.8 & 13.0 & 2.3 & 1 & 4 & 11.0 & 1.2 & 13 & 0 & 1.0 & 1.7 & 1.3\end{array}$ $\begin{array}{lllllllllllllll}34.0 & 9.0 & 0.3 & 0 & 9 & 15 & 4 & 0.6 & 13.5 & 0 & 3 & 1.6 & 1.1\end{array}$ \begin{tabular}{lll|l|l|l|l|l|l|l}
49.0 & 2.0 & 0.9 & 1.0 & 18.6 & 0.5 & 2.1 & 1.0 & 5.4 & 1
\end{tabular} $\begin{array}{lllllllllllllll}37.4 & 6.5 & 0.3 & 0 & 8 & 18.2 & 0.4 & 13 & 9 & 1.0 & 1.7 & 0.2\end{array}$

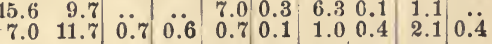
\begin{tabular}{rr|r|r|r|r|r|r|r}
25.0 & 10.2 & $\ldots$ & $\ldots$ & 6.6 & 0.3 & 5.5 & 0.9 & 11.0
\end{tabular}

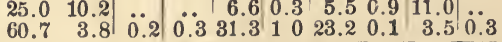

* It is estimated that in the case of horses, cattle, and swine, one-third of the nrine drains away. The following is the amount of wheat-straw used daily as bedding for each animal. Horse, $6 \mathrm{lbs}$.; Cattle, $8 \mathrm{lbs}$.; Swine, $4 \mathrm{lbs}$., and sheep, $0.6 \mathrm{lbs}$. 
NAME OF FrRTHIZER.

(In 100 parts.)

Bone-Meal from solid

parts............. parts..... $\dddot{\text { before }}$

ussd...............

Bon -bick, spent.....

Bonc ast..............

Baker Guano $\ldots . . . .$.

Jarvis Guano

Jak.... 11.8 8.2 80.0

Sombrero Phosphate.

Navassa Phosphate...

Nassau Phosphorite, rich..

Nassau Phospliorite, medium..........

Westphalian Phosphorite ............

Coprolites............

Sulphate of Ammonia.

Nitrate of Soda ......

Wool-dust and offal ..

Lime-cake........... 6.5 $47.0 \quad 46.5$

Whalc-oil refuse...... 23.0 $68.4 \quad 8.6$

Common Salt......... 5.0 .. 9.0

Gypsum or Flaster.... 20.0 $\quad . .80 .8$

Gas-lime............ 7.0 i.3 91.7

Sugar-House Scum.... $34524.5 \quad 41.0$

Leached wood ashes.. $20.0 \quad 5.0 \quad 75.0$

Wond-soot.... ...... $5.071 .8 \quad 232$

Coal-soot............. 5.0702248

Ashes from Deciduous trees...............

Ashes f:om Evergreen trees.

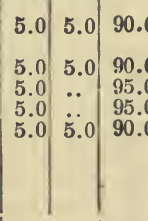

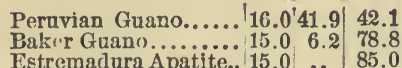

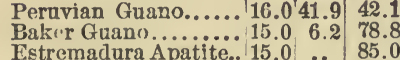

Estremadura Apatite.. $15.0 \quad$.. $\quad 85.0$

\begin{tabular}{ll|l|l} 
Sombrero Pho phate. & 15.0 & $\ldots$ & 85.0 \\
Navassa Phosphate... & 15.0 & $\ddot{2} .5$ & 82.5
\end{tabular}

Nassau Phosphorite, \begin{tabular}{ll|l|l|} 
rich............... 15.0 &.. & 85.0
\end{tabular}

Nassau Phosphorite, medium ............ 12.0 .. 88.0

Bone-black............ $15.0 \quad 8.0 \quad 77.0$ Bonc-Mcal............. 13.023 .863 .2 Phospho-guano

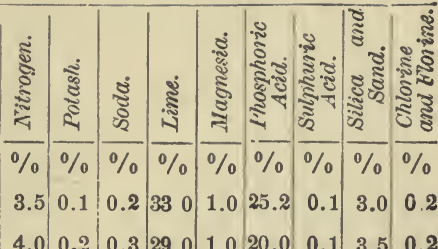

\begin{tabular}{ll|l|l|l|l|l|l|l}
4.0 & 0.2 & 0.3 & 29.0 & 1.0 & 20.0 & 0.1 & 3.5 & 0.2
\end{tabular} \begin{tabular}{ll|l|l|llllllll}
1.0 & 0.1 & 0.3 & 43 & 0 & 1.1 & 32 & 0 & 0.4 & 5.0 & $\ldots$
\end{tabular} $\begin{array}{lllllllllllll}0.5 & 0.1 & 0.2 & 37.0 & 1.1 & 26.0 & 0 & 4 & 15.0 & \ldots\end{array}$ $\begin{array}{lllllllllll} & \cdots & 0.3 & 0.6 & 46.0 & 1.2 & 35.4 & 0.4 & 6.5 & \ldots\end{array}$

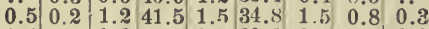
\begin{tabular}{l|l|l|l|l|l|l|l|l|l|l|l|l|l}
0.4 & 0.4 & 0.3 & 39.1 & 0 & 5 & 20.6 & 18.0 & 0.5 & 0.2
\end{tabular} \begin{tabular}{ll|lllllllll}
0.4 & 0.7 & 0.3 & 48.1 & 0.1 & 37.6 & 0.2 & 9.0 & 1.5
\end{tabular} $\begin{array}{lllllllllll}0 & 1 & . . & 0.8 & 43.5 & 0.6 & 35.0 & 0.5 & 1.0 & 0.6\end{array}$ $\begin{array}{llllllllll}0.1 & \ldots & \ldots & 37.5 & 0.6 & 33.2 & 0.5 & 5.0 & 0.1\end{array}$ $\begin{array}{llllllllllll}\text {.. } & 0.8 & 0.4 & 45.1 & 0.2 & 33.0 & 0.3 & 5.5 & 3.1\end{array}$ \begin{tabular}{lll|l|l|l|l|l|l|l}
.. & 0.7 & 0.4 & 40.1 & 0.2 & 24.1 & $\ldots$ & 20.8 & 1.5
\end{tabular} $\begin{array}{lllllllllll}\ldots & \ldots & \ldots & 21.8 & 0.9 & 19.7 & 1.0 & 22.0 & 1.6\end{array}$ $\begin{array}{llllllllll} & . & \ldots & \ldots & 37.2 & 0.2 & 29.2 & 0.5 & 3.3 & 1.5\end{array}$

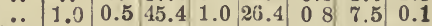

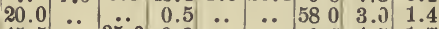
$\begin{array}{rllllllllll}15 & 5 & . & 35.0 & 0.2 & \ldots & & . & 0.7 & 1.5 & 1.7\end{array}$ $\begin{array}{lllllllllll}5.2 & 0.3 & 0.1 & 1 & 4 & 0.3 & 1.3 & 0.5 & 29 & 0 & 0.2\end{array}$ $\begin{array}{llllllllll}3.1 & . . & . . & 20.5 & 2.4 & 3.0 & \text {. } & 8.0 & \text {.. }\end{array}$ $\begin{array}{lllllllllll}5.7 & \ldots & \ldots & 3.0 & 0.2 & 2.3 & \ldots & 3.0 & \ldots\end{array}$ $\begin{array}{llllllllll} & . & \ldots & 44.3 & 1.2 & 0.2 & \ldots & 1.4 & 2.0 & 18.2\end{array}$ $\begin{array}{llllllllllll} & . & . & & . & 31.0 & 0.1 & . . & 44.0 & 4.0 & \ldots\end{array}$ $\begin{array}{llllllllllll}0 & 4 & 0.2 & \ldots & 64.5 & 1.5 & . & 12.5 & 3.0 & \ldots\end{array}$ $\begin{array}{llllllllll}1.2 & 0.2 & 0.6 & 20.7 & 0.3 & \ddot{1} .5 & 0.3 & 9.1 & 0.1\end{array}$ $\begin{array}{llllllllll} & & 2.5 & 1.3 & 24.5 & 2.5 & 6.0 & 0.8 & 20.0 & \text {.. }\end{array}$ $\begin{array}{llllllllll}1.3 & 2.4 & 0.5 & 10.0 & 1.5 & 0.4 & 0.3 & 4.0 & \text {.. }\end{array}$ $\begin{array}{llllllllll}2.5 & 0.1 & \text {.. } & 4.0 & 1.5 & \text {.. } & 1.7 & 16.0 & \text {.. }\end{array}$ $\begin{array}{llllllllllll}\text {.. } & 10.0 & 2.5 & 30.0 & 5.0 & 6.5 & 1.6 & 18.0 & 0.3\end{array}$ $\begin{array}{lllllllllll}\text {.. } & 6.0 & 2.0 & 35.0 & 6.0 & 4.5 & 1.6 & 18.0 & 0.3\end{array}$ \begin{tabular}{l|l|l|l|l|l|l|l|l|l|l}
$\because-$ & 1.5 & 0 & 8 & $?$ & 1.5 & 0.6 & 1.3 & $?$ & 0.2
\end{tabular} $\because \begin{array}{llllllllll}\cdots & 0.5 & 0.4 & ? & 3.2 & 0.2 & 8.5 & ? & \cdots\end{array}$ \begin{tabular}{ll|l|l|llllll}
$\because$ & 0.1 & 0.1 & $?$ & 3.0 & 0.1 & 5.0 & $?$ & $\ldots$
\end{tabular}

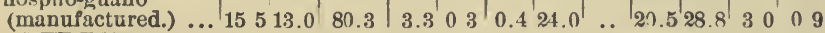


2.-TABLE SHOWING THE DISTRIBUTION OF INGREDIENTS IN SOME MANUFACTURING PROCESSES.

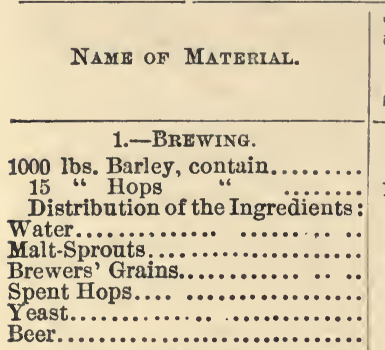

2.-Distillery.

a. 1000 lbs. Potatons, contain.... 40 “" Kiln-Malt............ 20 "Yeast-Malt...........

The Slrimp, contains............ (b.) Grain Spirits.

$800 \mathrm{lbs}$. Rye, contain .............

200 "Kiln-Malt, contain........

50 "Yeast-Malt,

The Slump,

\section{3.-Yeast Manufacture.}

700 lbs. bruised Rye, contain..... 300 " Barley-Nialt, " 0 istribution of the Ingredicnts: Yeast ........................

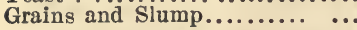

4.-Starch Manufacture.

1000 lbs. Potatoes, contain........

The remains in the Fibre... ....

\section{5.-MILLING.}

1000 lbs. Wheat, erntain..........

Distribution of the Ingredients: Flour $\quad 77.5$ per cent).

Mill-feed ( 6.5 " 3 .............

Bran (16.0 " $\quad \cdots . . . \cdots$

6.-Cheese-Making.

1000 lbs. Milk, contain..........

Distribution of the Ingredients:

Checse........................

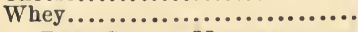

7.-Beet-Sugar Manufacture.

1000 Ins. Rosts, contain..........

Tops and Tails (12 per cent of

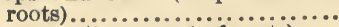

Pomace (15 per cent of roots).....

Skirnmings (4 per cent of roots)..

Molasses (3 per cent of roote)....

Sugar and loss..................

8.-Flax Dressing.

1000 lbs. Flax-Stalks, contain...

Distribution of the Ingredients:

In the Water..................

Stems or Husks.................

Flax and Tow..................

\begin{tabular}{|c|c|c|c|c|c|c|}
\hline : & 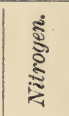 & 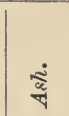 & $\frac{\tilde{\Sigma}}{\tilde{\Xi}}$ & ईั & 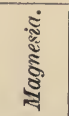 & 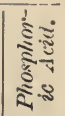 \\
\hline $\begin{array}{l}\text { lbs. } \\
855 \\
3.2\end{array}$ & $\begin{array}{l}\text { Ibs. } \\
15.2\end{array}$ & \begin{tabular}{|c}
$\mathrm{lbs}$ \\
2223 \\
1.00
\end{tabular} & $\begin{array}{l}\text { lbs. } \\
4.48 \\
0.345\end{array}$ & $\begin{array}{l}\text { lbs. } \\
0.58 \\
0.167\end{array}$ & $\begin{array}{c}\text { lbs. } \\
1.92 \\
0.056\end{array}$ & $\begin{array}{c}\text { los. } \\
7.71 \\
0.168\end{array}$ \\
\hline $\begin{array}{r}33 \\
263 \\
9 \\
30\end{array}$ & $\begin{array}{l}1.33 \\
8.74 \\
\dddot{2.94} \\
2.14\end{array}$ & $\begin{array}{r}1.23 \\
2.43 \\
13.08 \\
0.54 \\
2.27 \\
3.65\end{array}$ & $\begin{array}{l}0.852 \\
0.749 \\
0.580 \\
0.023 \\
0.643 \\
1.998\end{array}$ & $\begin{array}{c}0.039 \\
0.069 \\
1.474 \\
0.160 \\
0.097 \\
\ldots \ldots\end{array}$ & $\begin{array}{l}0.045 \\
0.0665 \\
1.134 \\
0.055 \\
0.185 \\
0.484\end{array}$ & $\begin{array}{l}0.234 \\
0.653 \\
3.631 \\
0.062 \\
1.319 \\
0.939\end{array}$ \\
\hline $\begin{array}{r}250 \\
37 \\
18.5 \\
125\end{array}$ & $\begin{array}{l}3.2 \\
056 \\
0.28 \\
4.04\end{array}$ & $\begin{array}{r}9.43 \\
1.06 \\
0.53 \\
11.02\end{array}$ & $\begin{array}{l}5.69 \\
0.184 \\
0.092 \\
5.966\end{array}$ & $\begin{array}{l}0.24 \\
0 . \mathrm{C} 40 \\
0 \\
0.300\end{array}$ & $\begin{array}{l}0.44 \\
0.688 \\
0.044 \\
0.572\end{array}$ & $\begin{array}{l}1.63 \\
0.368 \\
0.194 \\
2.212\end{array}$ \\
\hline $\begin{array}{r}681 \\
184 \\
46 \\
443\end{array}$ & $\begin{array}{r}14.08 \\
2.82 \\
0.71 \\
17.61\end{array}$ & $\begin{array}{r}14.32 \\
5.12 \\
1.23 \\
20.72\end{array}$ & \begin{tabular}{|ll}
4 & .501 \\
0 & 883 \\
0 & 221 \\
5 & 605
\end{tabular} & $\begin{array}{l}0.376 \\
0.195 \\
0.049 \\
0.620\end{array}$ & $\begin{array}{l}1648 \\
0.429 \\
0.107 \\
2.184\end{array}$ & $\begin{array}{l}1.5: 6 \\
0.382 \\
8.618\end{array}$ \\
\hline $\begin{array}{l}599 \\
276\end{array}$ & $\begin{array}{r}12.32 \\
4.23\end{array}$ & $\begin{array}{r}12.53 \\
7.67\end{array}$ & $\begin{array}{l}3.941 \\
1325\end{array}$ & $\begin{array}{l}0.329 \\
0.293\end{array}$ & $\begin{array}{l}1444 \\
0.643\end{array}$ & $\begin{array}{l}5.876 \\
\approx .801\end{array}$ \\
\hline $\begin{array}{r}45 \\
325\end{array}$ & $\begin{array}{r}4.67 \\
11.95\end{array}$ & $\begin{array}{r}3.41 \\
: 6.79\end{array}$ & $\begin{array}{l}\text { 1.273 } \\
3.973\end{array}$ & $\begin{array}{l}0.192 \\
0.430\end{array}$ & $\begin{array}{l}0.367 \\
1.720\end{array}$ & $6.06 \mathrm{~J}$ \\
\hline $\begin{array}{r}250 \\
75 \\
45\end{array}$ & $\begin{array}{l}3.20 \\
0.00 \\
2.6 j\end{array}$ & $\begin{array}{l}9.43 \\
0.54 \\
8.89\end{array}$ & $\begin{array}{l}5.69 \\
0.086 \\
5.604\end{array}$ & $\begin{array}{l}0.24 \\
0.266 \\
\ldots .\end{array}$ & $\begin{array}{l}0.44 \\
0.1142 \\
0.398\end{array}$ & $\begin{array}{l}1.63 \\
0.333 \\
1.497\end{array}$ \\
\hline 857 & 20.80 & $=6.39$ & 5.26 & 0.57 & .2 .02 & ๘.94 \\
\hline $\begin{array}{r}664 \\
58 \\
135\end{array}$ & \begin{tabular}{|}
14.65 \\
1.64 \\
4.51
\end{tabular} & $\begin{array}{l}5.50 \\
187 \\
9.60\end{array}$ & $\begin{array}{l}1.980 \\
0.048 \\
2.672\end{array}$ & $\begin{array}{l}0.154 \\
0.051) \\
0.396\end{array}$ & $\begin{array}{l}0.458 \\
0.148 \\
1.394\end{array}$ & $\begin{array}{l}2.862 \\
0.926 \\
4.102\end{array}$ \\
\hline 125 & 4.80 & 6.10 & 1.505 & 1.333 & 0.186 & 1.735 \\
\hline $\begin{array}{l}65 \\
60\end{array}$ & $\begin{array}{l}4.53 \\
0.27\end{array}$ & $\begin{array}{l}2.84 \\
3.26\end{array}$ & $\begin{array}{l}0.247 \\
1.258\end{array}$ & $\begin{array}{l}0.687 \\
0.646\end{array}$ & $\begin{array}{l}0.028 \\
0.158\end{array}$ & $\begin{array}{l}1.151 \\
0.581\end{array}$ \\
\hline 184 & 1.60 & 7.10 & 3.914 & 0.379 & 0.536 & 0.780 \\
\hline 85 & $\begin{array}{l}0.24 \\
0.44 \\
0.60 \\
0.32 \\
\ldots . .\end{array}$ & $\begin{array}{l}1.15 \\
1.71 \\
1.20 \\
2.47 \\
0.57\end{array}$ & $\begin{array}{l}0.336 \\
0.585 \\
0.380 \\
1.741 \\
0.872\end{array}$ & \begin{tabular}{|c|}
0.108 \\
0.390 \\
8.640 \\
0.141 \\
$\ldots$.
\end{tabular} & $\begin{array}{l}0.132 \\
0.105 \\
0.240 \\
0.009 \\
0.040\end{array}$ & $\begin{array}{l}0.144 \\
0.165 \\
0.381 \\
0.015 \\
0.6^{\prime} 2\end{array}$ \\
\hline 860 & & 30.36 & 9.426 & 6.751 & 1.995 & 3990 \\
\hline & $\ldots$ & $\begin{array}{r}25.15 \\
4.03 \\
1.22\end{array}$ & $\begin{array}{l}9.175 \\
0.171 \\
0.051\end{array}$ & $\begin{array}{l}4.100 \\
2 .(152 \\
0648\end{array}$ & $\begin{array}{l}1.850 \\
0.026 \\
0.054\end{array}$ & $\begin{array}{l}0.474 \\
0.126\end{array}$ \\
\hline
\end{tabular}




\section{N D E X.}

Absorptive Powers of Soils

Ammonia Absorbed by Soil frum

the Atmosphere ...............213

Ammonia and Superphosphate.....2 12

and Weeds.............25t

Converted into Nitric

Acid in the Soil.......313

for Oats............253-25t

for Potatoes............261

for Wheat........... $19:-213$

in Fresh Horse-dung.... $90^{\circ}$

in Limed and Unlimea

Soils...............220

in the Soil Liberated by

Lime..............221

- " Locked Üp in the Soil...221

" Loss of by Fermenting Manure............ 98 on Grass Land... ........273

Potential............... 31

Quantity of to Produce

One Bushel of Wheat, 211-212

، Required to Producs a

Bushel of Barley..240-212

Retained by the Snil.....213

Salts, Composition of....312 "How to Apply,

66 dens......... 297

A ¡derson, J. M. B., Letter from... 345 Animals, Composition of Manure

from Different..........306

" What They Remove from th: Food..... ..... 301

Apple Trees, Nitrate of Soda for...314 Artincial Manures, Will They Pay..214

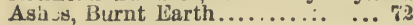

" Cual.................... 72

" for Barley............. 241

" for Indian Corn ............2\%

" for Oats...................

" for Potatoes..............2

" of Manure for Wheat.......173

" on Long Island............346

“ Plaster aad Heu-dung for

Potatoes..................255

" Wood ..............................

Barley After Ten Crops of Turnips. 250

* a Large Yield of ...........242

" and Clover after a heavily-

manured Root-crop. ......287

" Best Soil for................227

"6 Cost of Raising With and

Without Manure..........245

361
Barley, Lawes' and Gilbert's Experi-

ments oll.............. 227

"6. Potash Increases the Crop of at Rothamsted ...........3 329

" Profits of Raising in Po $r$

seasons...............243

" Quality and Price of........242

" Yield Per Acre............. 11

Barn-yard Manure, Difference in

Quality of .... ..............246

Be un-straw for Manure.......... 48 Bects, Sugar, Lawes' and Gilbert's

Experiments on...288

Blood................286

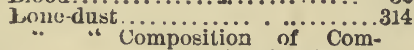
pared with Stable Manure..............316

. " Fermented with Manure.310

" i Made into Superphosphate............. 319

" " on Dairy Farms.......... 315

Fones as Minure.................. 102

Bra.......................... 33

. for Manurs.................

"Richer in Plant-food than

Wheat... .............301

Brewer, Prof. W. H., Letter from..3i1

Cabjage and Barn-yard Manure,
Composition of .........2!2
" Composition of ........29j-292
"Ilog and Cow Manure for.32
" Lime for..............2?
“ MIanure for.......... $\dddot{2} \% \mathbf{\%}-290$
"IIanure for Earjy and
Late.................

" Nreds a Large Supply if Nitrogen in the Soil, Thongh it Removes but Little.............. 93

" Potash for..................

. Special Manure for.........323

" Yield of per Acre.........291

Cattle vs. Sheep as Manure-makers.303

Chense, from a Ton of Hay.........111

"6 Plant-food in...............101

" versus Beef.................110

Clay Retains Ammonia... $\ldots \ldots \ldots \ldots .219$

Clover and Indian Corn............275

". as a Renovating and Ex-

hausting Crop.............277

"6 as Manure ..............119-122

“ as Manure for Wheat.........158

" Does it Get Nitrogen from the Atmosphere... ....133-138 
Clover, Dr. Vœlcker's Experiments

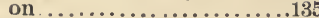

" for Wheat................. 126 " Gathers Up Manure from the Sub-soil..............237 " Hay, Composition of........... “Hay, English and German, for Manure.............47 "How to Make a Farm Rich by Growing..........133-163 " Letting it Rot on the Surface as Maunre............134 " Nitrogen as a Manure for....141 " Pasturing by Sheep versus Mowing for Hay...........137

" Plowing Uncer versus Feeding Out................. 123

" Routs, Amuunt of per Acre, 143-144-155

"Roots, Composition of..14.)-147 "Seed, Amount of Roots per Acre....................162

"Water Evaporated by.............

. Why it Euriches Land........131

Coal-a-hes to Mix with Artificial Manures..................312 Composting Cow-manure wit'? Muek. Leaves, ete... ........... 392 Compost of Stable-manure and Earth................. . 34

Corn, as a Renovating Crop..........275 " Ashes for ............. 2\%

"Barn-yard Manure for.........2

" Cost of Raising............. 9

" Crop, Composition of........25

‘ Experiments on............2\%

‘ Guano for............

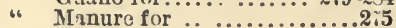

" Meal for Manur $3 . . . . . . . . . . . .185$

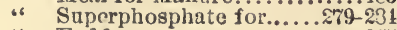

". Fodder.................. 2i5

"6 "6 vs. Màgel-ivirzcis...238

6: "6 Plasterfor. ........

" "6 vs. Wheat, Yield per acre.............. $2^{\prime}$

Crops Best to Apply Manure to....2.5

". How to Get Larger......... is-36

" Raised and Sold from the

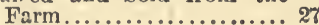

" Rotation of ...............

"We Must Raise Larger per

Acre....................266

"6 Why su puor................. 28

Cotton-sced C.ke... . . . . . . . 43-339

Cow-manure.................86-100 "6 "and Ḧow to Üse it....302

" " Composition of ....... $3^{\prime} 6$

Cows, Fecding Grain to.........110-113 Feeding in Winter for $\mathrm{Ma}$ nure..................256 Dairy Farms, Bone-dust on..........315 Drainage from Barn-yard............3.6 Dry Earth for Pig Pens..............204 Earth-closet Manure ...............310

Fallow, Fall... .............. " for Wheat, $\ddot{H}$ oy to $-\ddot{M} \ddot{r}$.

Lawes' Experiments..... 35

"Summer, for Wheat......15-34
Farm Dair $\vec{j}$, Reecipts and Expenses of ..................... 103 " Hon. George Geddes' ............. "6 Hon. Juseph Shull's............

4. John Johnston's ..... .

" Mr. Dewey's.............. \& 9

" Mr. Joseph O. Shcidon's. .. 15

"to Restore a Worn Out...... si

Farming, a Poor Business.......... 9

Difference Between Hig.l and Good ............. 11

" Faith in Good.............. 14

‘. Good Does Not Lead to

Over Produetion....... 14

"6 Slow Work............ 17 Fermenting Manure to Kill WeedSeeds.................. . 97

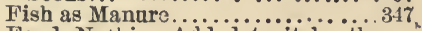
Food, Nothing Added to it by the

Animal...................... 42

Gardens, Manure for Private.......... $89^{\prime}$

Geddes, Hon. George.............17-117 Grains, Malt, English and German. 47 Grass a Saving's Bank .........4 41 .. Importance of Rich ...........113

" M:tuure for.............. 120

Guano as a Top-dressing for Wheat.270 “f f:r Barley................210

6 f.r Oats................253

" $\quad$ fi:r I'cas.................. 17

"6 for Potatoes........... 255-258

". on TVheat........... 1 0 0-180-184

“. Pcrnvian, Ccriposition of..311

6 "6 for Onions.......254

"6 Pricsand Cumpo aition of No:

"6 s) Rectified for Turnjps...........286

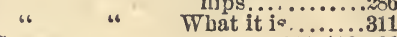

Gspsum................. liv-116-1£6

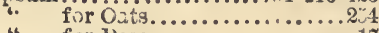

" for 1'cas................. 17

" for Pouaioes.............

Tarison, T. L., Letter frum.........

Lay, $\mathrm{B}_{3}$ st Manure for ............ 4

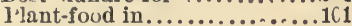

Teacoek, Jos"ph, Letter from... . . 318 1-enderson, Peter, Letter fro:-.....344 Hen Manure..............43-104-(1 Hich Farming for Potatoes... .......55 High Farming............ Tops, Manure for............. IJorse-manure, Composition of. ....sc5 Ilot-beds, Manure for .............2;7 IInman Excrements, Composition

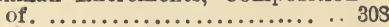

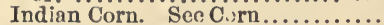

Irrigation on Market Gardi............295 Jessup, Edward, Letter from.........342 Johnson, Prof. S. W., on the Value of Fertilizers.................. 324

Lawes' and Gilbert's Experiments on Barley................... 226

Lawes' and Gilbert's Experiments on Oats.......................252

Lawes' and Gilbert's Exveriments on Permanent Meadows..........271 
Lawes' and Gilbert's Experiments on the Amount of Excrements Voided by Man.

Lawes' and Gilbert's Experiments on Sugar beets and Maugel-wurzels........................288

Lawes' and Gilbert's Experiments on Wheat....................170

Lawes' aud Gilbert's Experiments, Potash Beneficial for barley...... 323

Lawes' Table, Showng C، imposition and Value of Fouds......... 45

Leituce, Manure for...............289 Superphosphate tor...290-293

Lewis, Hon. Harris, Letter from....103 Liebis's Special Manures...........321 Lime as Manure..................210 - Beneficial Effect of for Thirty

Years....................216

" Changes the Chemical and Physical Character of the suil. .................224 “ Composting with $0 . d$ sods...224 " for Cabbage...............292 “ Iiastens tne Maturity of the Crop ...................222

"Impoverishes the Soil.......222

in Connecticut..............221

in Delaware..................2

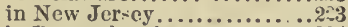

in Pennsylvania..............224

líised with Barn-yard Manure.... ............222

rn Grass Land............... 223

on Lime-stone Land............217

Quantity per Acre...........216

Sets Free Ammonia in the

Soil...................221

“ Silicate Äbsorbs Ämmonia

from Atmosp!ere. .......219

" When to Apply..............223

"Why Beneticial................220

Liquid Manure...................30is

Lowland, Draining.................. 30

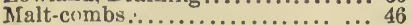

Mangel-wurzels for Manure......... 48

$$
\text { " } \text { Manure foric } 3-\approx 86-288
$$

" " " Yield per Acre..... 11

Manure Absoroing Liquid...........115 Lmount from Feed and Bedding .............. 73 Azount Made by a Horse

" " Made by Horses, Cows, Sheep, and Pigs... 51 Amount Made on a 250-acre

Farm.................257 Amount of Rain Required

to Dissolve..............267 Amolnt of Straiv in Horse. 346 and Rotatir $n$ of Crops.....246 Applying Artificial.........312 Applying Near the Surface.267 Applying on the Surface...173 as Top-dressing.............2 Barn-yard for Barley.......210 Barn-yard v8. Artificial for

Indian Corn ... ........284

66
Mannre Best for Kay............2\%

Bone-dust.............s14-316

Brings in Red clover...... 82

Buying ...............306 Buying by Measure or Weight................305

Buying by the Load or Ton.306

Cellar...................114

Cheapesta Farmer Can Use.127

Clover as.............119-122

Clover-seed as.............127

Comes from the Land.. .... 42

Common Salt as...........200

Composition of Fresh Barn. yard.................. 51

Composition of from Dipferent Animals... .......306

Composition of Heap at Ditferent Periods........ 57

Corn-meal for............. 185

Cost of Hauling............. 342

Cost of Loading and Drawing.................... is

Cow................. si-1c

Dairy-farm, How to Save and Apply.............114

Dr. Vœlcker's Experiments on ................. 51

Drawing Oat to the Field.. 89

English Plan of Keeping... (6)

Equivalent to Water.......24\%

Farm-yard for Potatoes ...261

Fermenting in W inter. 85-92.93

Fermenting, Shrinkage in..11ti

Fire-fang................. $8_{1-i} 8$

Fish. as, on Long Islaid.. 3.7

Foods which Make Ricl..... 45

for Cabbage, Parsuips, Onions, Carrots, Lettuce,

etc.................. 89

for Corn............... 80

fi.r Grass................ 82

for Hops...............274

for Hot-beds...............297

for Indian Coin...........275

fer Mangel-wuizels aild

Sugar-bects............ $\approx 87$

for Market Gardens .. . .... 2!4

for Oats................. $2 t 2$

for Potatoes............ 255

for Seed-urowing $\mathrm{F}$ arms... . 296

for Sorghum or Chinese Sugar-cane................

for Tubaccu........... ${ }_{2} ; 5$

for Turnips........... $585-3: 2$

for Wheat.................

from Cows..............20

from Earth-c.oset...........310

from Oxen .............308

from Pigs, Mr. Lawes Experiments... . .........301

frum Sheep................ . 303

Grain Farms, Managemeut of ................117

Guano. Price of Now and

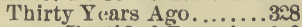

Guano, Rectified Peruvian.319

Gypsum and Clover as.....125

llcap, Changes in... ......6 67 
Ianure II 3 , Fermantirg........ ¿3

" in Winter " " Piling in Field..83-89-90 " " Turning............8 83 " IIen............. 43-101-801 " Ilorse $\ldots . . . \ldots \ldots \ldots . .32-8$ 'j " Horse and Farm-yard...... 50 c. How and When it Should be Applied... ..........257 How John Jolinston M inages it............... $\% 6$ How Made and Üsed in Maryland .............. 349 How the Deacon Makes it.. 74 How to Make........... 41 How to Make More.......25j IIow to Make More and Better on Dairy Farms.......10 How to Make Poor, Rich, 274-293

How to Make Richer.......25 Ho: Much it Sbrinks by Fermentation............342 How Much Nitrogen in a Load of ...............303 in Kansas....................310 in Philadelphia, Interesting Ficts..............333

Keeping Under Cover...... 5) Iime as..............215 Liquid............... 36 Management of in Canada.33j Mr. Lawes' Experiments with ................. 95

Loss from Leachi:ig......... 99 Management of ............. 94 Market Value of ..............104 Mixed with Lime..........222 Natural................. 23 Night-soil as..............303 Nitrate of Soda as..........13t Not Available.............. 95 on Dairy Farm..............101 on Permanent Meadows

and Pastures.............2\%1

Preserved by the Suil.......177 Pigs'................... 86 Piling.......................116 Potasn a3............... 329 Price of in Boston...........3 4 "6 Maryland.......333. " " New Haven....3i1 " " New York......3 " per Horse in $\mathrm{New}$ York .......336 Quantity Made on a Farm.. 12 Quantity of Used on Long Island. Interesting Statistic.3.

Reduced by Fermentation. 2.7 Richer in Plant-food than the Food from which it is Derived .................. $3^{\urcorner 1}$ Sheep................... \&6 Should he Broken Üp Fine. 268 Soluble Phosphates in..... 72 $140-320$
Nanure, Specific Gravity of from Ditferent Animali....... 305 Spread in Open Yard ......6 63 Stable, Managument......... Straw and C.duff as...........2\%0 Superpauspuate, liow Made..................317 Swamp-Nucs as............29 'I'unk.....................115 the Author's Plin of Minaging.................. 83 Tillage as........... $3 ;-12 i-225$ Tup-dressiug for Wheat in

" to What Crops Sıould it be Appiicd.................265 " Value of ................. 78

" Value of Depends on the Food, Not on tic Animal. 43 Sea-weed as..................... Special.
Value of Straw as........123

Water in .................124

TVeeds as..................24

Weight of .............343-350

Well-rotted, Cumposition of ....................6 65 Well-rotted, Loss from Leaching............... 65

"6 What is it? ............. 19-22

"Why Do We Ferment?... 94

I.Injket Gardens, Irrigution in......295

.6 " Manure for....... 294

" 6 Pig-manure ö... 295

Meadows, Manure fur .............271

Night soil ...................

Nitrate of Soda.....................134

" "Acts Quicker tia...

64 Ammonia ..... 813

" " as a Top-dressing

for Wheat.......270

"6 "C.mposition of....3 2

" " 6 fur Appls Trees....314

" " "for Bariey.........2.213

" " 6 for O.ts............

" " f r Onions..... 291

" " for Surar-Bcets....2?

" " 6 for Wheat........159

" " How to Apply......312

Nitric Acid.....................241 Nitrosen, Amount per Acre in the

Soil...............28-16?

as Manure................ 28

in Soils.......106-226-336-341

Makes Poor Man:Ir:

Rich.................. 46

Nurservmn, Manure for. ...........

Cats, Experiments on in Virginia... 253

" Experiments on at Moreto:1

Farm..................254

"L Lawes' and Gilbert's Experi-

ments on .................252

“. Manures for ....................2

Oil-cake for Sheen................ 76

Onions, Manure for.................294

Peas for Pigs....................... i7

Pea-straw for Manure............. 48
Nitrate of Potash..................... 
Peat, Composition of ............. 31

Phosphates.... $\quad \ldots . \ldots \ldots \ldots \ldots . . .27$ Exhanstion of on Dairy

Farms.............101 “ Soluble in Barn-yard Manure............. 72

Phosphoric Acid in Soils........ 106-2 246

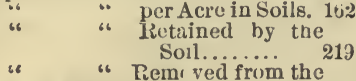

Farm by Hay, and by Milc I Cows.316

Pig Manure................... $43-803$

. Compusition of..........3

" " for Cabbage.......... 302

Pigs as Manure-Makers for Market

Gardeners......................2ว

Pigs' Bedảing ................... 31

- for Euriching Pasture-Land....30t

" How to Save Manare from. ..3at4

" Minure from. ............ $01-i, 01$

Piling Manure............... $! 7$

l'lant-food.....................21-105

. " Amount of in an Aere.24-3j " " in New and Cultivated Land.................

Plaster for indian Corn. ........27 Plowing in the Fall.... .......17 Potash, Amount of in the Soil $25-329$

- as Manure.

"6 as Manure for Wheat..... 215

" for Cabbages.............2!)

" for Potatoes...........255-26J

“ for Putatues aud Ruot-

Civps..................330

(6) Eow to Assertain when the

Soil Needs...........30

“ in Nitrate of Potasi.......314

" Not a Special Manura for

Turnus

" on Grass Land.............2.3

- our Soils not so likely to be

Deficient in, as of Nitro-

gen and Phosphorie Aci i. $3: 0$

“ Retained by the Soil......219

“Value of in Artificiul Ma-

nures.....

Potatoes, after Rout-Crops.......27

6. Ammonia for............2 1

" Cost of Raising........... 10

"Experiments on at More-

ton Farm .............259

"6 for Manure ............ 48

"6 How to Raise a Large

“ Manures for.................255

" Mr. Hunter's Experiments on in England........2 260

" on Rich Land............263

“ Profts of Using Artificial Manures on.........253

“ Will Manure Injurt Qual ity of ................. 864

Rape-cake

a ianure for Hops $\cdots{ }_{274}^{46}$

Roots, Amount of Left in Soil by

Different Crops....................164

Ront-erops.......................... 17

Rotation of Crops and Manures..... 16
T.u3iımore, J. H., Letter from.... .345

Routzahn. H. L., Letter from......349

Salt as a Manure for Wheat........270

- Common as Manure for Wheat. 200

" for Mangel-wurzels............104

Saw-dust for Bedding.............. 103

Season, a Ponr, Protitable for Good

Farmers...............213

" and Manure for Oat......253

Influence of on the Growth

of Wheat..............210

" Profit in Raising Uats $n$ a

Poor ...............253

" Protit in Raising Bariej in

a Poor................213

Seasons. Influenee on Crops.........21

Seed Growers, Mannres for........29;

Sewage....................... 308

Sheep-Manure..............303-i33; 303

. " Composition of .. ..506

"vs. Oxen as Manure Makers.303

Shelton, Prof. E. M., Letter from.. 350

Soil, Composition of...........144-150

". Exbaustion of ..........2, $27-3,2$

" from Earth-closet............225

" Nitrogen and Phosphoric Acid

in .....................2 $2 \mathbb{0}$

“ Plant-food in.....................

" Weight of per Ac e............

Soils Absorb Ammonia frim Atmos-

phere...................219

"A Aeorptive Powers of ....217

Sorrhum, Manures for......... .283

S pccial Mlanures ............... $3: 0$

Straw..................... $\varepsilon_{6}$

.. Amount of Manure from......124

" and Chaff for Manure.......200

- for Á́anures.................. 48

.. on Grain Farms.................. 118

“ Selling... ..................123

Sturtevant, Dr. E. L., Letter from 314

Superphospliate............... 116

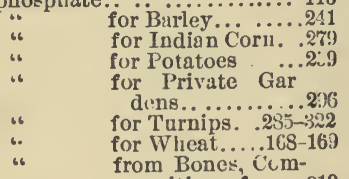

position of... 319

from Mincrul

Phospliaies.. $3: 0$

How Applied... 320

(1) Dairy Ferms . 315

on Gruss L: nd ...273

Valite of $a=$ Com

pared witu Bone-

Dust ............319

66

What Cropis Best

for...........243

Superphnspate of Lime Doctor

Telis How it is Made... .... 317 Superphosphate of Limi. $\dddot{W}$ hen

First Made in the United States 324

Surface Application of Manure. .70.268

Swamp-muek................ 29

" "Composi.ion of...... 31

Swine, see Pigs.................. 
Thomas, J. J., Temar's on t':c $\Lambda$ pplication of Manures............ 209 Tillage is Manure.......32-121-163-2.5 Tobacco, Manure for.............. 275 Top dressing with Manure.... . ...269 Turnips, Du They Absorb Nitrogen from the Atmosphere...25j " Impoverish the Soil More than Grain............250

" Masure fcr.............2 55 " and Wheat, Special Ma nures for.............321

Urine from Farm Animals Richer than Human...............309 " vs. Solid Manure... ........294 Valuation of Fertilizers............321 Water, Amount Given Off by Plants During Their Growth...........131

Water Equivalent to Manure.......2!6 Weeds...................15-41-189

Weed-seeds in Manure............ . 97 Weld, Col. M. C., Letter from...... 344 Wheat, Ammonia for.............192 "Artificial Manures for Should be Drilled in with Seed..................168-169
Wheat, Common salt as Manure for 5 CO ". Crop, Composition of... $26-1 \div 6$ $138-310$

"Effect of Manure on, in Poor Season...............213

" Intluence of Season on...... $\approx 10$

" is it Deteriorating ?..........18:)

" Larger Crops per Acre.......12?

" Lawes' and Gilbcrt's Experiments on .......140-170-333

" Manures for................167

"6 Mr. Lawes' Experiments on.122

" Nitrogen as Mauure for ...141

. Plant-food in...............

" Potash as Manure for ... ...210

" Straw and Chaff as a Maunre

for.................200

" Summer Fallowing for...35-168

" the 20th Crop on Same Land.213

" Top-dressing for ......2

" vs. Corn, Comparative

" Tield of .................2 276

"Well-rotted Manuri for......267

"W Why Our Crops are so Poor.214

" Yield per Acre............. 11 


\section{SENT FREE ON APPLICATION.}

\section{DESCRIPTIVE CATALOGUE}

-: of :-

\section{RURAL}

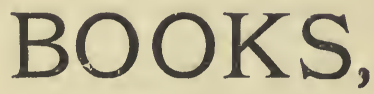

Containing II6 8vo pages, profusely illustrated, and giving full descriptions of nearly 600 works on the following subjects:

Farm and Garden,

Fruits, Flowers, Etc.,

Cattle, Sheep, and Swine,

Dogs, Etc., Horses, Riding, Etc.,

Poultry, Pigeons, and Bees,

Angling and Fishing,

Boating, Canoeing, and Sailing,

Field Sports and Natural History,

Hunting, Shooting, Etc,

Architecture and Building,

Landscape Gardening,

Household and Miscellaneous.

PUBLISHERS AND IMPORTERS.

ORANGE JUDD COMPANY, $52 \& 54$ Lafayette Place, New York. 


\section{Minshrooms. How to Grow Them.}

For home use iresh Mushrooms are a delicious, highly nutritious and wholesome delicacy; and for market they are less bulky than eggs, and, when properly handled, no crop is more remunerative. Anyone who has an ordinary house cellar, woodshed, or barn can grow Mushrooms. This is the most practical work on the subject ever written, and the only book on growing Mushrooms ever pubished in America. The whole subject is treated in detail, minutely and plainly, as only a practical man, actively engaged in Mushroom growing, can handle it. The author describes bow lie himself grows Mushrooms, and how they are grown for profit by the leading market gardeners, and for home use by the most successful private growers. The book is amply and pointedly illustrated, with engravings drawn from nature expressly for this work. By Wm. Falconer. Is nicely printed and bound in cloth. Price, post-paid.

\section{Allen's New American Farm Book.}

The very best work on the subject; comprising all that can be condensed into an available volume. Originally by Richard L. Allen. Revised and greatly enlarged by Lewis F. Allen. Cloth, 12mo... 2.50

\section{Henderson's Gardening for Profit.}

By Peter Henderson. New edition. Entirely rewritten and greatly enlarged. The standard work on Market and Family Gardening. The successful experience of the author for more than thirty years, and his willingness to tell, as he does in this work, the seeret of his success for the benefit of others, enables him to give most valuable information. The book is profusely illustrated. Cloth, 12mo.-- 2.00

\section{Fuller's Practical Forestry.}

A Treatise on the Propagation, Planting, and Cultivation, with a description and the botanical and proper names of all the indigenous trees of the United States, both Evergreen and Deciduous, with Notes on a large number of the most valuable Exotic Species. By Andrew S. Fuller, author of "Grape Culturist," "Small Fruit Culturist," etc.

\section{The Dairyman's Manual.}

By Henry Stewart, author of "The Shepherd's Manual," "Irrigation," etc. A useful and practical work by a writer who is well known as thoroughly familiar with the subject of which he writes.

Cloth, 12mo..

\section{Truck Farming at the South.}

A work giving the experience of a successful grower of vegetables or "grain truck" for Northern markets. Essential to any one who contemplates entering this promising field of Agriculture. By A. Oemler, of Georgia. Illustrated. Cloth, 12mo ...............

\section{Harris on the Pig.}

New edition. Revised and enlarged by the author. The points of the ₹arious English and American breeds are thoroughly discussed, and the great advantage of using thoroughbred males clearly slown. Tho work is equally valuable to the farmer who keeps but few pigs, and to the breeder on an extensive scale. By Joseph Harris. Illustrated. Cloth, 12mo ........... 1.50

\section{Jones's Peanut Plant-Its Cultivation and Uses.}

A practical Book, iustructing the beginner how to raise goc $^{*}$ crops of Pcanuts. By B. IV. Jones, Surry Co., Va. Paper Cover,.... .50 


\section{Barry's Fruit Garden.}

By P. Barry. A standard work on fruit and fruit-trees; the author having had over thirty years' practical experience at the head of one of the largest nurseries in this country. New edition, revised up to date. Invaluable to all fruit-growers. Illustrated. Cloth, 12mo. "2.c0

\section{The Propagation of Plants.}

By Andrew S. Fuller. Illustrated with numerous engravings. \&n eminently practical and useful work. Describing the process of hybidizing and crossing species and varieties, and also the many difierent modes by which cultivated plants may be propagated and multi-

piied. Cloth, 12mo ......... 1.50

\section{Stewart's Shopherd's Manual.}

A Valuable Practical Treatise on the Sheep, for American farmer's and sheep growers. It is so plain that a farmer, or a farmer's son, who has never kept a sheep. may learn from its pages how to manage a flock suceessfully, and yet so complete that even the experienced shepherd may gather many suggestions from it. The results of personal experience of somc years with the characters of the various moderı breeds of sheep, and the sheep-raising capabilities of many portions of our extensive territory and that of Canada-and the careful study of the diseases to which our sheep are chiefly subject, with those by which they may eventually be afflicted through unforeseen accidents-as well as the methods of management called for under our circumstances, are here gaihered. BJ Henry Stewart. Illustrated. Cloth, 12mo.... 1.50

\section{Allen's American Cattle.}

Their History, Breeding, and Management. By Lewis F. Allen. This Book will be considered indispensable by erery breeder of live stock. The large experience of the author in improving the character of American herds adds to the weight of his observations, and has enabled him to produce a work which will at once make good his claims as a standard authority on the subject. New and revised edition. Illustrated. Cloth, I2mo..... 250

\section{Fuller's Grape Culturist.}

By. A. S. Fuller. This is one of the very best of works on the culture of the hardy grapes, with full directions for all departments of propagation, culture, etc., with 150 excellent engravings, illustrating planting, training, grafting, etc. Cloth, 12mo_... 1.50

\section{White's Cranberry Culture.}

Contents :-Natural History.-History of Cultivation.-Choice of Location.-Preparing the Ground.-Planting the Vines.-Management of Meadows.-Flooding-Enemies and Difficulties Overcome.-Picking.-Keeping,- Profit and Loss.-Letters from Practical Gruwers. Insects Injurious to the Cranberry. By Joseph J. White. A practical grower. Illustrated. Cloth, 12mo. New and revised editicn - 1.25

\section{Herbert's Hints to Horse-Keepers.}

This is one of the best and most popular works on the Horse in this country. A Complete Manual for Horsemen, embracing: How to Breed a Horse; How to Buy a Horse; How to Break a Horse; How to Use a Horse; How to Feed a Horse ; How to Physic a Horse (Allopathy or Homœenthy); How to Groom a Horse; How to Drive a Horse; How to Ride a Horse, etc. By the late Henry William Herbert (Frank Forester). Beautifully Illustrated. Cloth, 12mo... 1.75 
\& Valnable Periodical for egerybody in City, Village, and Country.

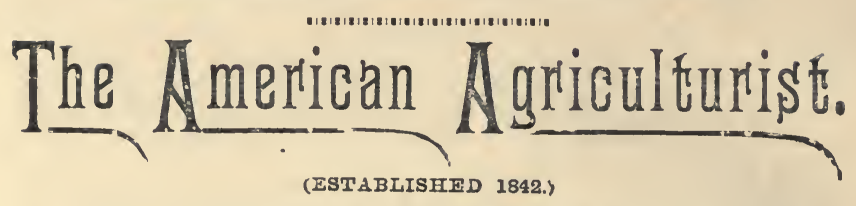

IHE LEADING INTERNATIONAL PUBLICATION FOR THE

FARM, GARDEN, AND HOUSEHOLD,
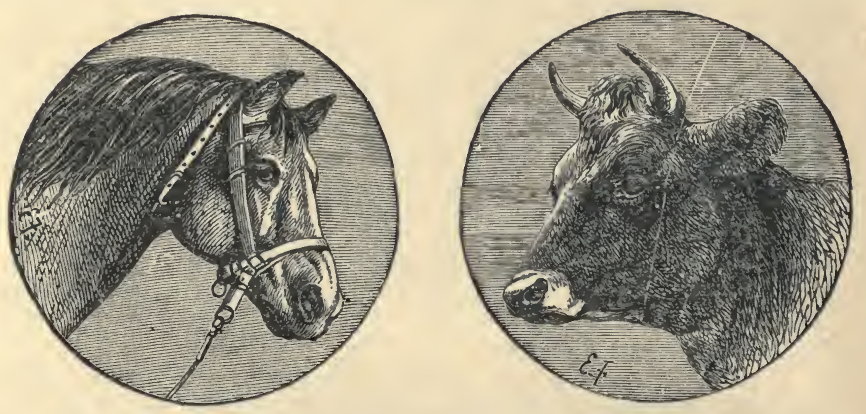

A MONTHLY MAGAZINE of from 48 to 64 pages in each number, containing in each volume upward of 700 pages and over 1000 original engravings of typical and prize-winning Horses, Cattle, Sheep, Swine, and Fowls: New Fruits, Vegetables, and Flowers; House and Barn Plans; New Implements and Labor-saving Contrivances; and many pleasing and instructive pictures for young and old.

THE STANDARD AUTHORITY in all matters pertaining to Agriculture, Horticulture, and Rural Arts, and the oldest and most ably edited periodical of its class in the world.

\section{BEST RURAL PERIODICAL IN THE WORLD.}

The thousands of hints and suggestions given in every volume are prepared by practical, intelligent farmers. who know what they write about.

The Household Department is valuable to every housekeeper, affording very many useful hints and directions calculated to lighten and facilitate indoor work.

The Department for Children and Youth is prepared with special care, to furnish not only amusement, but also to inculcate knowledge and sound moral principles.

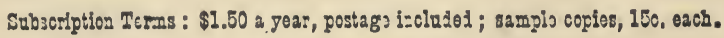

IrEY IT A THAX:

Address,

AMERICAN AGRICULTURIST,

52 \& 54 Lafayette Place, New York. 








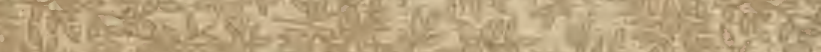

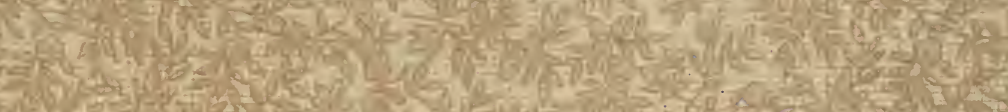

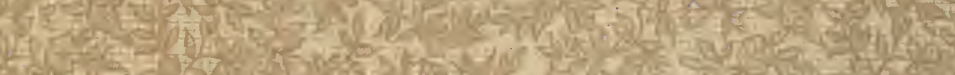

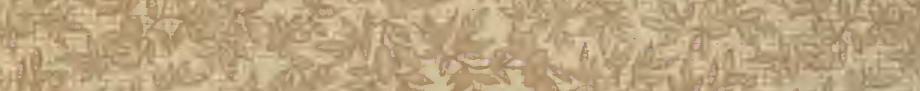

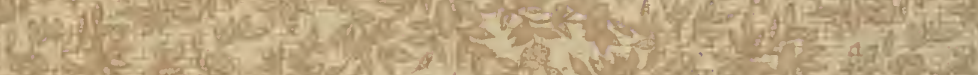

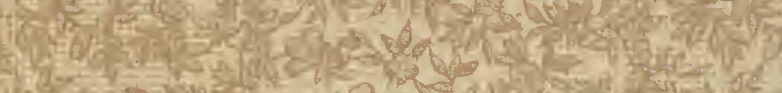

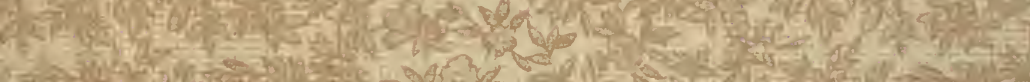

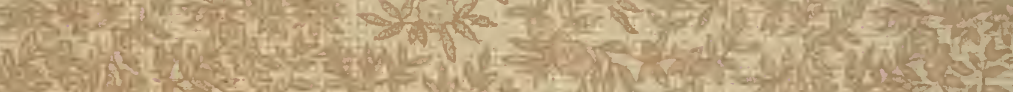
A a. (5)

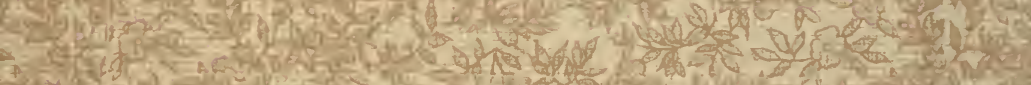
P. 2)

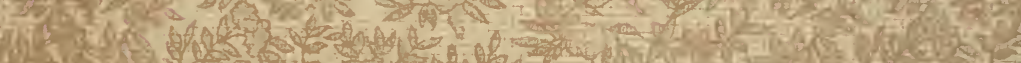
W y 5.70. 2 .

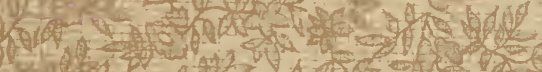

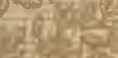
(8)

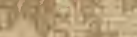




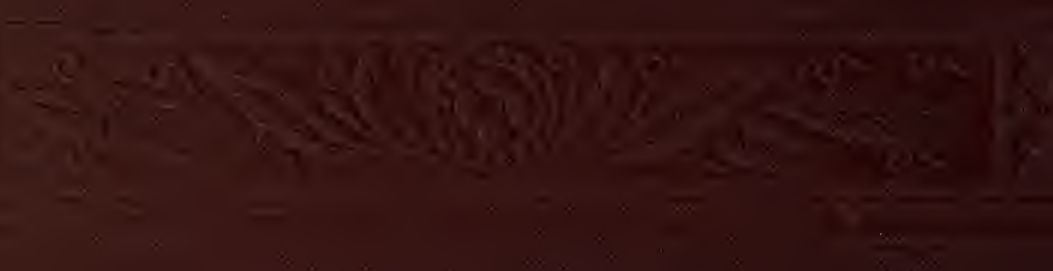

